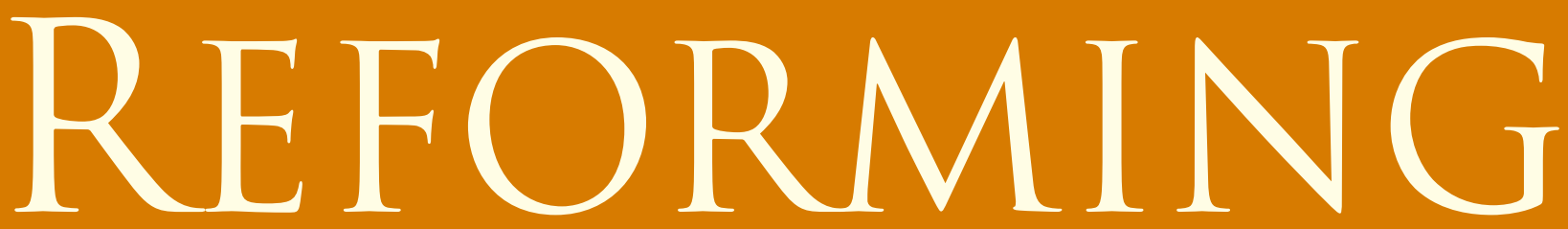

\title{
PAYMENTS AND SECURITIES
}

SETTLEMENT SYSTEMS IN

LATIN AMERICA ${ }_{\mathrm{THE}}^{\mathrm{N} D}$ CARIBBEAN

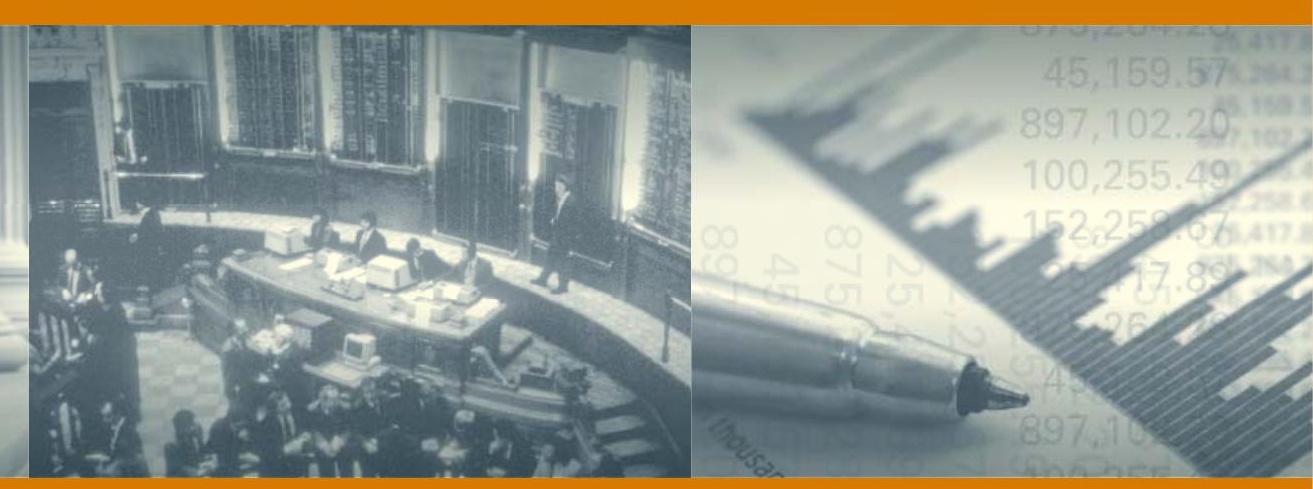



Reforming Payments and Securities Settlement Systems in Latin America and the Caribbean 

Reforming Payments and Securities Settlement Systems in Latin America and the Caribbean

MASSIMO CIRASINO

JOSÉ ANTONIO GARCÍA
MARIO GUADAMILLAS

FERNANDO MONTES-NEGRET 
(C)2007 The International Bank for Reconstruction and Development / The World Bank

1818 H Street NW

Washington DC 20433

Telephone: 202-473-1000

Internet: www.worldbank.org

E-mail: feedback@worldbank.org

All rights reserved

\section{7}

This volume is a product of the staff of the International Bank for Reconstruction and Development / The World Bank. The findings, interpretations, and conclusions expressed in this volume do not necessarily reflect the views of the Executive Directors of The World Bank or the governments they represent.

The World Bank does not guarantee the accuracy of the data included in this work. The boundaries, colors, denominations, and other information shown on any map in this work do not imply any judgement on the part of The World Bank concerning the legal status of any territory or the endorsement or acceptance of such boundaries.

Rights and Permissions

The material in this publication is copyrighted. Copying and/or transmitting portions or all of this work without permission may be a violation of applicable law. The International Bank for Reconstruction and Development / The World Bank encourages dissemination of its work and will normally grant permission to reproduce portions of the work promptly.

For permission to photocopy or reprint any part of this work, please send a request with complete information to the Copyright Clearance Center Inc., 222 Rosewood Drive, Danvers, MA 01923, USA; telephone: 978-750-8400; fax: 978-750-4470; Internet: www.copyright.com.

All other queries on rights and licenses, including subsidiary rights, should be addressed to the Office of the Publisher, The World Bank, 1818 H Street NW, Washington, DC 20433, USA; fax: 202-522-2422; e-mail: pubrights@worldbank.org.

ISBN-10: 0-8213-6635-1

ISBN-13: 978-0-8213-6635-6

eISBN: 0-8213-6637-8

DOI: $10.1596 / 978-0-8213-6635-6$

Cover design: Rock Creek Creative, Inc.

Library of Congress Cataloging-in-Publication Data has been applied for. 


\section{Contents}

Preface vii

Contributors ix

Acknowledgments $\quad$ xi

Abbreviations xii

CHAPTER

Introduction 1

Major Trends in Payments and Securities Settlement Systems 5

Assessment Tools $\quad 21$

Payments Systems Assessment Findings in Latin America

and the Caribbean 27

5 Securities Settlement Systems Assessment Findings in Latin America and the Caribbean 105

Transparency, Oversight, and Cooperation in Payments Systems 185

Implementing Payments and Securities Settlement Systems Reforms

Concluding Remarks $\quad 215$ 
APPENDIX

Main Statistics of Payments and Securities Settlement Systems in Selected Latin America and the Caribbean Countries

Scope, Elements, Participants, and Processes of Securities

Settlement Systems 239

CPSS Core Principles for Systemically Important Payment Systems

CPSS-IOSCO Recommendations for Securities Settlement Systems

CPSS-IOSCO Recommendations for Central Counterparties

CPSS General Guidance for National Payments System Development

Recommendations of the Financial Action Task Force

on Money Laundering 255

Systemically Important Payment Systems in Latin America and the Caribbean: Results of the Self-Assessment Exercises

References

Index 


\section{Preface}

he exponential growth in values transferred through the payment systems within national and across international borders, as well as the inherent risks in the clearing and settlement processes, have increased central and commercial banks' - as well as securities commissions'-attention to payment and securities settlement systems and their influence on the stability and efficiency of financial intermediation. As a result, payment systems issues have moved up the list of public policy priorities and have moved from the backroom to the boardroom of financial institutions.

In the 1970s and 1980s, central banks focused mainly on the influence of payment systems in the transmission of monetary policy, but in recent years their attention has broadened to deal more systematically with the goals of efficiency, integrity, security, reliability, and accessibility. An efficient, secure, and reliable payment system reduces the cost of exchanging goods, securities, and services, and is an essential tool for the effective implementation of monetary policy and the smooth functioning of money and capital markets. Although payment systems have traditionally focused on fund transfers, value is also exchanged by means of securities trading. Consequently, recent trends in payment system development have resulted in new initiatives leading to increasing convergence and interoperability of banking, payment, and securities infrastructures.

Payments systems are considered critical for the safe and effective functioning of the financial system. Safe systems are, therefore, a key element for maintaining and promoting financial stability. Poorly designed systems or technical and operational failures, combined with the increasing interdependence of financial intermediaries, could generate contagion and severe systemic disruptions in financial markets. Moreover, rapid technological changes, accompanied by evolving user needs, have transformed the role of payment systems in the delivery and efficient provision of financial services. The ongoing revolution in payment systems has increased the opportunities to market participants and end users.

International organizations, national authorities, and, in general, payment system stakeholders have recently looked more carefully into payments and securities settlement issues. The first set of important standards came with the release in 1989 of the Group of Thirty recommendations regarding securities clearance and settlement and the 1990 Lamfalussy Report recommending minimum standards. Since then, many different organizations have issued international standards, principles, recommendations, and codified best practices. At the end of the 1990s and the beginning of the 2000s, a consensus emerged within the Committee on Payments and Settlement Systems (CPSS) of the Bank for International Settlements (BIS) to introduce new standards known as the core principles for systemically important payments systems, followed by the joint CPSS-International Organization of Securities Commissions (IOSCO) recommendations for securities settlement systems. Furthermore, the work of international institutions is going beyond payments and securities settlement systems assessment to advice on how to effectively implement a reform. The World Bank Regional Initiatives on Payments and Securities Settlement Systems and the CPSS's "General Guidance for National Payments System Development," published in its final version in January 2006, are clear examples of these efforts. 
In the Latin America and Caribbean (LAC) region, the World Bank started efforts as early as 1995 to raise the awareness of the importance of modernizing national payments systems and of setting up a regional forum for the exchange of information. Such efforts further evolved with the request of regional finance ministers for the World Bank to launch a regional initiative to foster such a process of transformation. The latter initiative was formalized in 1999 into the Western Hemisphere Payments and Securities Clearance and Settlement Initiative (WHI) and converted in 2003 into a regional Western Hemisphere Payments and Securities Clearance and Settlement Forum (WHF), dedicated to the assessment of and exchange of information on payments and securities settlement systems in the LAC countries.

The WHI has been a coordinated effort supported by central banks and securities commissions inside and outside the region, as well as international financial and standard-setting institutions. In addition to the World Bank and the Centro de Estudios Monetarios Latinoamericanos, other institutions have supported the WHI, such as the Council of Securities Regulators of the Americas and an International Advisory Council, the latter comprising highly experienced institutions dealing with clearance and settlement of payments and securities.

Under the WHI, 23 country assessments were undertaken between May 1999 and December 2005. Country assessments are prepared jointly by an international team and their local counterparts. The so-called Yellow Book typically consists of a comprehensive description providing a brief background of the economic and financial conditions in the country, key institutional aspects related to the operation of the payments and securities settlement infrastructure-including the legal and regulatory frameworks and the oversight role of the central bank in coordination with other governmental organizations - and details on the major characteristics of both payments and securities settlement systems. In addition, a confidential report is delivered exclusively to the country authorities. This report includes an assessment of the risks and improvement opportunities as a contribution to the development of an action plan for the reforms deemed necessary in experts' views. In several cases, follow-up activities have been undertaken to discuss the way in which the recommendations might be implemented. The overall objective of the WHI - that is, the development of more secure and efficient payments and securities clearance and settlement systems in the respective member country, systems that are capable of satisfying the needs of the local, regional, and international markets-has been fostered by the work undertaken over the past seven years. Moreover, the WHI has led to the establishment of a high-level regional policy forum for the discussion of payments and securities settlement issues, which can be invaluable to foster increased cooperation as the $\mathrm{LAC}$ region becomes more integrated. The WHI-WHF has also significantly contributed to the joint World Bank-International Monetary Fund (IMF) Financial Sector Assessment Program.

This book intends to extract the main lessons and experiences of WHI-WHF from the assessments to the implementation of the reforms. It benefited from the numerous country assessments, as well as from followup work undertaken by the World Bank in the reform of payments and securities settlement systems in the LAC region. The book describes major trends in payments and securities settlement systems worldwide and presents the assessment tools used in preparing the country reports under WHI-WHF. In addition, the book provides a detailed summary of the main findings of the WHIWHF assessments in the payments and securities settlement areas for each country in the following fields: (1) legal and regulatory framework, (2) main characteristics of the interbank exchange and settlement circuits, (3) retail settlement systems, (4) the role of the government as a major participant in the payments system, (5) foreign exchange and cross-border settlement, (6) the operation of the interbank money market, (7) aspects related to securities settlement such as the legal framework, clearance and settlement processes, settlement risks, operational reliability, custody, depositories' organizational arrangements, cross-border links, and (8) the oversight role of the central bank, coordination with the regulatory and supervisory role over securities settlement, and cooperation with the private sector.

Finally, the purpose of this book is not only to indicate the situation derived from the assessments, but also to propose practical observations regarding the implementation of payments and securities settlement systems reforms in the LAC region. In some cases, these observations are also based on the experience gained through the World Bank's lending operations and technical assistance projects in this area. 


\section{Contributors}

\section{Massimo Cirasino}

Senior Financial Sector Specialist

Financial Sector Operations and Policy Department

Massimo Cirasino joined the World Bank in July 1998. He plays a leading role in the Financial Sector Operations and Policy Department and has participated in many of the group's country and regional interventions. He coordinates regional initiatives (including the Western Hemisphere Payments and Securities Clearance and Settlement Initiative and the Western Hemisphere Credit and Loan Reporting Initiative) for the improvement of financial infrastructure and has led several country studies. In 2004, Mr. Cirasino launched similar regional initiatives for the Commonwealth of Independent States and the Middle East. Mr. Cirasino represents the World Bank on the BIS-CPSS task force, which developed the core principles for systemically important payments systems; the CPSS-IOSCO task force, which created the assessment methodology for systemically important payments systems; and the CPSS-IOSCO task forces, which developed recommendations for central counterparties and guidelines for national payment system development. Mr. Cirasino is also the co-chair of the World Bank-CPSS task force, which drafted the General Principles for International Remittance Systems. Additionally, he is the primary World Bank contact for the assessment of payments and securities settlement systems in the context of the IMF-World Bank Financial Sector Assessment Program, and is responsible for World Bank training activities in payment and securities systems. Mr. Cirasino worked at Banca d'Italia from 1993-96 in the Payment
System Department and, later on, in the Representative Office in New York. Prior to joining Banca d'Italia, he worked in Brazil as a journalist and a researcher in monetary economics.

\section{José Antonio García \\ Financial Sector Specialist \\ Financial Sector Operations and Policy Department}

José Antonio García joined the World Bank in March 2004. In his current position, he provides technical and conceptual advice to World Bank financial sector operations and research, and coordinates regional initiatives for the improvement of financial infrastructure in Latin America and the Caribbean, the Commonwealth of Independent States, and the Middle East and North Africa. He has also led several country studies. Mr. García is a member of the secretariat of the joint World Bank-CPSS task force, which drafted the General Principles for International Remittance Systems. Prior to joining the World Bank, he was a senior economist at the Centro de Estudios Monetarios Latinoamericanos, where he acted as the World Bank's counterparty for management of the WHI, and served as technical secretary of the Working Group on Payment System Issues of Latin America and the Caribbean. From 1997-2000, he worked in the corporate credit department of Banco Inbursa in Mexico City, and from 1992-97 as technical consultant in banking supervision at Centro de Estudios Monetarios Latinoamericanos. Mr. García received a B.A. in Economics and an M.A. in Business Economics from Universidad Anahuac in Mexico City. 


\section{Mario Guadamillas}

Senior Financial Economist

Finance, Private Sector, and Infrastructure

Latin America and the Caribbean Region

Mario Guadamillas has worked for the World Bank since 1998. In his current position, he provides technical and conceptual advice to World Bank financial sector operations and research on the region. He coordinates regional initiatives for the improvement of financial infrastructure, including the WHI for payment systems and the Western Hemisphere Credit and Loan Reporting Initiative for credit reporting systems, and has led several country studies. He is also involved in the IMF-World Bank Financial Sector Assessment Program and represented the World Bank on the BIS-CPSS task force, which developed guidelines for national payment system development; the CPSSIOSCO task force, which developed the assessment methodology for the Securities Settlement System Recommendations; and the World Bank-CPSS task force, which drafted General Principles for International Remittance Systems. Prior to joining the World Bank, Mr. Guadamillas was an economist in the Ministry of Finance of Spain. He also worked for the central bank of Spain as an economic and financial analyst. From 1992-98, he lectured at Universidad Autónoma, Universidad San Pablo CEU, Universidad Alfonso X, Universidad Europea de Estudios Superiores, and Universidad Nacional de Educación a Distancia, all in Madrid. Mr. Guadamillas earned an M.A. in business at Universidad Complutense, and a Ph.D. in economics at Universidad Nacional de Educación a Distancia in Madrid.

\section{Fernando Montes-Negret \\ Sector Director \\ Finance and Private Sector Development \\ Europe and Central Asia Region}

Fernando Montes-Negret is in charge of defining and implementing the Bank's strategy for the development of the financial and private sectors of client countries in Europe and Central Asia. He joined the World Bank in October 1984 as an economist in the LAC region, where he worked on industrial development and finance projects in Argentina, Chile, and Costa Rica. From 1986-89, he served as deputy governor of the Banco de la República (Colombia's central bank). After returning to the Bank in June 1989, he held positions as senior economist in the East Asia and Pacific region (as country economist for China), the Europe and Central Asia region, and the Financial Sector Development Department. In April 1994, he was promoted to principal financial economist. In August 1997, he transferred to the LAC region and became sector leader in Mexico City. He became sector manager in the finance cluster of the Finance, Private Sector, and Infrastructure Sector Management Unit in October 1999, and was appointed sector director in April 2004. Mr. Montes-Negret is a graduate of the Universidad de los Andes, Wisconsin University, and Rice University. Prior to joining the Bank, he held various posts in Colombia, including undersecretary of finance, advisor to the Monetary Board, and advisor to the Minister of Development of Colombia. 


\section{Acknowledgments}

he ideas presented in this book are those of the authors and do not represent the World Bank's position, the WHI's position, or the position of any institution participating in the WHI. However, the authors are grateful for the contribution of WHI International Advisory Council members, country authorities (central banks and securities regulators) from the LAC region, staff of private institutions who the authors visited to study the WHI, and especially the members of the Working Group on Payments System Issues of LAC. We are especially grateful to the reviewers-Robert Keppler (World Bank), Jeff Stehm (Federal Reserve Board), and Joaquín Bernal (Banco de la República, Colombia) - for their very useful comments. We also want to thank our colleagues in the World BankMahktar Diop, Marilou Uy, and Susan G. Goldmarkfor their support in the review process and the publication phase of this book.

The successful experience of the WHI could have not been possible without the excellent contribution of our regional partner, the Centro de Estudios Monetarios Latinoamericanos. We are especially grateful to Kenneth Coates (director general) and Luis Giorgio (former deputy director general) for their enthusiasm and support of the project. We also want to thank other colleagues and friends for their very useful comments: Carlos Andrade (Banco Central del Ecuador), Augusto de la Torre (World Bank), Gustavo da Matta Machado (Brazilian Mercantile \& Futures Exchange), Caramae Farmer (Central Bank of Trinidad and Tobago), Catiana García (Consejo Monetario Centroamericano consultant), José Manuel Garrido (Banco Central de Chile), Patricia Guajardo (Banco Central de Chile), Francisco Guiñez (Depósito Central de Valores, Chile), Jim Hanson (World Bank), Gerson Larios (Banco Central de Reserva del Salvador), Jose Antonio Marciano (Banco Central do Brasil), Carlos Melegatti (Banco Central de Costa Rica), Gloria Moya (Comisión Nacional de Bancos y Seguros de Honduras), María Inés Ordoñez (Superintendencia Financiera, Colombia), Byron Sagastume (Banco de Guatemala), Francis Stenning (Caja de Valores de Lima, Peru), and Fernando Yañez (Depósito Central de Valores, Chile). Finally, we want to thank Ana Laura Sibaja (CEMLA) for statistics compilation and Santiago Pombo Bejarano (World Bank) and Dana Vorisek (World Bank) for their support in the publication process. 


\section{Abbreviations}

\begin{tabular}{|c|c|c|c|}
\hline $\mathbf{A C H}$ & automated clearinghouse & BVDN & Bolsa de Valores de Nicaragua \\
\hline ADRs & American depositary receipts & BvdNA & Bank van de Nederlandse Antillen \\
\hline \multirow[t]{2}{*}{ AFP } & Administradoras de Fondos de & BVG & Bolsa de Valores Global (Guatemala) \\
\hline & Pensiones & BVL & Bolsa de Valores de Lima \\
\hline ALADI & Asociación Latinoamericana de Integración & BVM & Bolsa de Valores de Montevideo \\
\hline AMF & Arab Monetary Fund & BVN & Bolsa de Valores Nacional (Guatemala) \\
\hline ASIGNA & Asigna Compensación y Liquidación & BVP & Bolsa de Valores de Panamá \\
\hline ASOBAN & Asociación Bancaria & BVPASA & Bolsa de Valores y Productos de Asunción \\
\hline ATM & automated teller machine & CARICOM & Caribbean Common Market \\
\hline BACEN & Banco Central do Brasil & CAVALI & Caja de Valores de Lima \\
\hline BANGUAT & Banco de Guatemala & CBLC & Companhia Brasileira de Liquidação \\
\hline BBV & Bolsa Boliviana de Valores & & e Custodia \\
\hline BCB & Banco Central de Bolivia & СВOB & Central Bank of The Bahamas \\
\hline BCBA & Bolsa de Comercio de Buenos Aires & CBTT & Central Bank of Trinidad and Tobago \\
\hline ВCCH & Banco Central de Chile & CCAV & Cámara de Compensación de Pagos de \\
\hline BCCR & Banco Central de Costa Rica & & Alto Valor (Chile) \\
\hline BCE & Banco Central del Ecuador & CCE & Cámara de Compensación Electrónica \\
\hline ВCH & Banco Central de Honduras & & (Peru) \\
\hline $\mathrm{BCN}$ & Banco Central de Nicaragua & $\mathbf{C C P}$ & central counterparty \\
\hline BCP & Banco Central del Paraguay & CD/DD & Créditos Directos/Debitos Directos \\
\hline BCR & Banco Central de Reserva de El Salvador & & (Costa Rica) \\
\hline BCRA & Banco Central de la República Argentina & CDs & certificates of deposit \\
\hline BCRD & Banco Central de la República Dominicana & CECOBAN & Centro de Compensación Bancaria \\
\hline BCRP & Banco Central de Reserva del Perú & & (Mexico) \\
\hline BCU & Banco Central del Uruguay & CEDEC & Cámara Electrónica de Compensación \\
\hline BCV & Banco Central de Venezuela & & (Colombia) \\
\hline $\mathrm{BCV}$ & Bolsa Centroamericana de Valores & CEDEVAL & Central de Depósito de Valores del Salvador \\
\hline & (Honduras) & CEMLA & Centro de Estudios Monetarios \\
\hline BEVSA & Bolsa Electrónica de Valores (Uruguay) & & Latinoamericanos \\
\hline BGP & border gateway protocol & CENIT & Sistema de Compensación Electrónica \\
\hline BHV & Bolsa Hondureña de Valores & & Nacional Internbancaria (Colombia) \\
\hline BIS & Bank for International Settlements & CENIVAL & Central Nicaragüense de Valores \\
\hline BISS & Bahamas Interbank Settlement System & CENTRAL & Centralclearing de Compensação \\
\hline BISX & Bahamas International Stock Exchange & & e Liquidação (Brazil) \\
\hline BITF & $\begin{array}{l}\text { Sistema Interbancario de Transferencia } \\
\text { de Fondos }\end{array}$ & CEPROBAN & $\begin{array}{l}\text { Centro de Procesamiento Bancario } \\
\text { (Honduras) }\end{array}$ \\
\hline BM\&F & Bolsa de Mercadorias e Futuros & CETIP & Central de Custódia e de Liquidação \\
\hline BMV & Bolsa Mexicana de Valores & & Financeira de Títulos (Brazil) \\
\hline BNP & Banco Nacional de Panamá & CEVAL & Central de Valores de la Bolsa Nacional \\
\hline BNV & Bolsa Nacional de Valores (Costa Rica) & & de Valores S.A. (Costa Rica) \\
\hline BOJ & Bank of Jamaica & CEVALDOM & Central de Valores Dominicana \\
\hline BOVESPA & Bolsa de Valores de São Paulo & CHIPS & Clearing House Interbank Payments System \\
\hline $\mathbf{B R}$ & Banco de la República (Colombia) & CIFTS & Customer Inquiry and Funds Transfer \\
\hline BROU & Banco de la República Oriental del Uruguay & & System (Jamaica) \\
\hline BVC & Bolsa de Valores de Caracas & CII & Cámara de Intercambio de Imágenes \\
\hline BVC & Bolsa de Valores de Colombia & & (Mexico) \\
\hline
\end{tabular}


CIP

CLC

CLS

CLS Bank

CM

CMCA

CMN

CNBS

CNBV

CNMV

CNV

CNV

CNV

CNV

CNV

COELSA

COMPE

CONASEV

CONASSIF

COSRA

CPSIPS

CPSS

CRYL

CSD

CUD

CVM

CVV

DCV

DCV

DECEVAL

DECEVALE Depósito Centralizado de Valores

DIAN Dirección de Impuestos y Aduanas

DNS

DPN

DTC

DvP

ECCB

ECCSD

ECCU

ECH

ECNs de Ecuador

Nacionales

Cámara Interbancaria de Pagamentos (Brazil)

Compensación y Liquidación de Cheques y

Otros Valores (Costa Rica)

continuous linked settlement

Continuous Linked Settlement Bank

clearing members

Consejo Monetario Centroamericano

Conselho Monetário Nacional (Brazil)

Comisión Nacional de Bancos y Seguros

(Honduras)

Comisión Nacional Bancaria y de Valores

(Mexico)

Comisión Nacional del Mercado de Valores

(Spain)

Comisión Nacional de Valores (Argentina)

Consejo Nacional de Valores (Ecuador)

Comisión Nacional de Valores (Panama)

Comisión Nacional de Valores (Paraguay)

Comisión Nacional de Valores (Venezuela)

Compensadora Electrónica S.A. (Argentina)

Centralizadora da Compensação de

Cheques é Outros Papéis (Brazil)

Consejo Nacional de Supervision

del Sistema Financiero (Costa Rica)

Council of Securities Regulators of the

Americas

core principles for systemically important

payment systems

Committee on Payment and Settlement

Systems

(Argentina)

central securities depository

(Colombia)

Comissão de Valores Mobiliários (Brazil)

Caja Venezolana de Valores

Depósito Central de Valores (Chile)

Depósito Central de Valores (Colombia)

Depósito Centralizado de Valores de

Colombia

deferred net settlement

Deuda Pública Nacional

Depository Trust Company

delivery versus payment

Eastern Caribbean Central Bank

Eastern Caribbean Central Securities

Depository

Eastern Caribbean Currency Union

electronic clearinghouse

electronic communication networks
ECOFIN European Union's Economic and Finance

Ministers

ECSE Eastern Caribbean Securities Exchange

ECSM Eastern Caribbean Securities Market

ECSRC Eastern Caribbean Securities Regulatory

Commission

EDV Empresa Depositaria de Valores (Bolivia)

EFTPOS electronic funds transfer at the point of sale

EMC

EMI

ESCB

EU

FATF

FDI

FDvP

Fedwire

FIAB

FIBV

FIFO

FIU

FRBNY

FSAP

FSC

FSF

FX

G-7

G-8

G-10

G-30

GEM

IAC

IADB

ICSD

IFIs

ILI

IMF Emerging Markets Committee

European Monetary Institute

European System of Central Banks

European Union

Financial Action Task Force on

Money Laundering

foreign direct investments

final delivery versus payment

Fedwire Funds Service

Federación Iberoamericana de Bolsas

de Valores

Federation Internationale des Bourses

de Valeurs

first in, first out

Financial Intelligence Units

Federal Reserve Bank of New York

Financial Sector Assessment Program

(World Bank-IMF)

Financial Services Commission (Jamaica)

Financial Stability Forum

foreign exchange

Group of Seven

Group of Eight

Group of Ten

Group of Thirty

Global Equity Market

International Advisory Council

Inter-American Development Bank

International Central Securities Depository

international financial institutions

Información y Liquidación de Impuestos

International Monetary Fund

INDEVAL Instituto para el Depósito de Valores

(Mexico)

INVERLACE Sistema de Registro, Información y

Transacciones (Colombia)

IOSCO International Organization of Securities

Commissions

ISD Investment Services Directive

ISIN International Securities Identification

Number

ISL Infolink Services Limited (Trinidad

and Tobago)

ISSA International Services Securities

Association

JCSD Jamaica Central Securities Depository

JETS Jamaica Electronic Transfers System

JSE Jamaica Stock Exchange

LAC Latin America and the Caribbean

LATINCLEAR Central Latinoamericana de Valores

(Panama) 
LBTR Sistema de Liquidación Bruta en Tiempo Rea

LGB Ley General de Bancos (Chile)

LGTOC Ley General de Títulos y Operaciones de Crédito (Mexico)

LGTOC Ley General de Títulos y Operaciones de Crédito (Mexico)

LINX Infolink Services Limited (Trinidad and Tobago)

LMF Ley Monetaria y Financiera (Dominican Republic)

LSE Liquidación de Servicios Externos (Costa Rica)

LVPS

MAE

MEC

MEP

MERVAL

MEXDER

MICR

MIT

MPLS

NACHA

NACS

NPS

NPSSC

OAL

OECD

OECS

OTC

PAC

PKI

POS

PROSA

PSSS

PvP

RG

RGSM

RTGS

SADC

SBL

SBOIF

SCC

SCT

SEBRA

SEC

SEDEC

SELIC

SEN large-value payments systems

Mercado Abierto Electrónico (Argentina)

Mercado Electrónico de Colombia

Medio Electrónico de Pago (Argentina)

Mercado de Valores de Buenos Aires

Mercado Mexicano de Derivados

magnetic ink character recognition

Mecanismo Interbancario de Transferencias

(Guatemala)

multiprotocol label switching

National Clearinghouse Association

(United States)

Netherlands Antilles Clearing System

national payment system

National Payments and Securities

Settlement Council

Obligación Adicional de Liquidación

(Mexico)

Organisation for Economic Co-operation

and Development

Organization of Eastern Caribbean States

over-the-counter

Pago Automático de Cuentas (Chile)

public key infrastructure

point of sale

Promoción y Operación S.A. (Mexico)

payments and securities settlement system

payment versus payment

general resolution

Regional Government Securities Market

(Eastern Caribbean)

real-time gross settlement system

Southern African Development Community

Sistema Bancario en Línea

Superintendencia de Bancos y Otras

Instituciones Financieras (Nicaragua)

Sistema de Cámaras de Compensación

(Ecuador)

Sistema de Custodia de Títulos

Sistema Electrónico del Banco de la

República (Colombia)

Securities and Exchange Commission

Sistema Electrónico de Comunicaciones

(Uruguay)

Servico Especial de Liquidação e Custodia

(Brazil)

Sistema Electrónico de Negociación

(Colombia)

SENDI
SEP
SEPA
SEPSA
SERPRO
SET

SFC

SHCP

SIAC

SIBE

SICAM

SICET

SICOF

SIDV

SIGALC

SILOC

SIMA

SINAC

SINACOFI

SINE

SINEDI

SINPE

SIPAV

SIPS

SISTRE

SITE

SITRAF

SLE

SML

SN-BVDN

SPEI

SPEUA

SPI

SPI

SPID

SPVS

SRO
Sistema Electrónico de Negociación de Divisas (Honduras)

Sistema de Ejecución Presupuestal single European payment area Sistema Electrónico de Pagos (Argentina)

Soluções para um Brasil de Todos Sistema Electrónico de Transferencia de Fondos para Préstamos Interbancarios (Venezuela, R. B. de)

Superintendencia Financiera de Colombia Secretaría de Hacienda y Crédito Público (Mexico)

Sistema de Atención a Cuentahabientes (Mexico)

Sistema Integrado Bursátil Electrónico

Sistema de Cámaras (Mexico)

Sistema de Custodia Electrónica de Títulos

(Venezuela, R. B. de)

Sistema de Información Contable y Financiera

Sistema Interactivo para el Depósito de Valores

Sistema Integrado de Garantías y Líneas de Crédito (Venezuela, R. B. de)

Sistema de Liquidação Diferida de Ordens de Crédito Interbancárias (Brazil)

Sistema Integrado de Mercado Abierto

(Venezuela, R. B. de)

Sistema Integrado de Negociación Asistida por Computador (Argentina)

Sistema Nacional de Comunicaciones

Financieras (Chile)

Sistema Integrado de Negociaciones Electrónicas

Sistema de Negociación de Divisas

Sistema de Negociación y Pagos

Electrónicos (Costa Rica)

Sistema de Pagos de Alto Valor (Bolivia)

systemically important payment system

Sistema de Tasas Referenciales

(Venezuela, R. B. de)

Sistema de Transferencias Electrónicas

(Bolivia)

Sistema de Transferéncia de Fundos (Brazil)

Sistema de Liquidación y Ejecución

(Ecuador)

Securities Market Law

Sistema de Negociación de la BVDN

Sistema de Pagos Electrónicos

Interbancarios (Mexico)

Sistema de Pagos Electrónicos de Uso

Ampliado (Mexico)

Sistema de Pagos Interbancarios (Ecuador)

Sistema de Pagos Interbancarios

(Venezuela, R. B. de)

Sistema de Pagos Interbancarios

para Divisas

Superintendencia de Pensiones, Valores

y Seguros (Bolivia)

self-regulatory organization 
Superintendencia del Sistema Financiero (El Salvador)

SSS

STP securities settlement system straight-through processing Sistema de Transferência de Reservas (Brazil)

SUGEVAL Superintendencia General de Valores (Costa Rica)

SV

Superintendencia de Valores (Bolivia)

SV Superintendencia de Valores (Colombia)

SVS Superintendencia de Valores y Seguros (Chile)

SWIFT Society for Worldwide Interbank Financial Telecommunication

TEBEL online trading system in Costa Rica

TECBAN Tecnología Bancária (Brazil)

TEF
Transferencia Electrónica de Fondos (Mexico)
TT

TTCD

TTS

TTSE

USD

VALPRE

VAR

WGPS

WGPS-LAC

WHCRI

WHF

WHI
Sistema de Transferencias Interbancarias (Costa Rica)

Transferencia de Terceros (Costa Rica) Trinidad and Tobago Central Depository Transferencia Telefónica Segura (Nicaragua) Trinidad and Tobago Stock Exchange U.S. dollar

Préstamo de Valores (Mexico) value at risk

Working Group on Payment System Issues Working Group on Payment System Issues of LAC

Western Hemisphere Credit and Loan Reporting Initiative

Western Hemisphere Payments and Securities Clearance and Settlement Forum Western Hemisphere Payments and Securities Clearance and Settlement Initiative 



\section{Introduction}

o the extent that expanding production and exchange in a market economy requires an increasing interconnection of various, and usually anonymous, decisional units, economic development rests crucially on infrastructure that makes those interconnections efficient, stable, and reliable. This infrastructure includes the whole complex of technical systems, actors, rules, and procedures that define the field of action where agents negotiate and perform commercial and financial transactions.

In contexts where many decisions are taken by multitudes of heterogeneous agents, an efficient, stable, and reliable infrastructure is necessary to ensure that transactions are carried out on the terms and conditions agreed on by their originating counterparts. Interconnecting the elements of infrastructure becomes even more essential as modern communication and information technologies make markets independent of specific physical locations. Especially where exchange involves agent commitments to future obligations - as is typically the case with financial contracts-elements of infrastructure such as the legal system and contract enforcement mechanisms must be in place to provide trading counterparts with sufficient reassurance that commitments are fulfilled in accordance with their agreed-on terms and conditions. ${ }^{1}$

The payments and securities settlement system is the infrastructure (comprising institutions, instruments, rules, procedures, standards, and technical means) established to effect the transfer of monetary value between parties discharging mutual obligations. A securities clearance

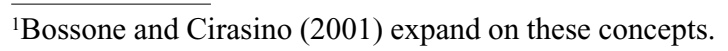

and settlement system can be considered as part of the overall payment mechanisms of a country, in that it satisfies the main features of this overall definition. In this case, the exchange of financial value consists of both the exchange of securities (equity, fixed income, or derivatives) and the exchange of liquid funds (usually sight deposits). The soundness and efficiency of a payments system determines the efficiency with which transaction money is used in the economy, and the risks associated with its use. An efficient system reduces the cost of exchanging goods and services, and it is indispensable to the functioning of the interbank, money, and capital markets. A weak payments and securities settlement system may severely drag on the stability and developmental capacity of an economy; its failures can result in inefficient use of financial resources, inequitable risk sharing among agents, actual losses for participants, and - at the extreme-loss of confidence in the financial system and in the very use of money. ${ }^{2}$

Many countries are embarking on projects to reform and modernize their payments and securities settlement systems, and domestic policy makers are faced with the formidable task of designing payment system infrastructures in fast-changing technological and institutional environments. These tasks become increasingly complex because competition and innovation require an alwayschanging combination of efficiency, reliability, safety, and system stability in the provision of payment services to larger numbers of individual users and institutions.

${ }^{2}$ Listfield and Montes-Negret (1994) discuss how an efficient payment system contributes to the development of modern, marketbased financial institutions and markets. 
Historically, payment systems have been at the heart of banking. As more and more countries in the nineteenth and early twentieth centuries started to centralize moneyissuing activities in single banking institutions, or central banks, the liabilities of these institutions became for most commercial banks the instrument to settle their interbank payment obligations. It became natural for central banks to provide clearing and settlement services for the payments delivered by commercial banks. As a consequence, the promotion of the efficiency and safety of payment arrangements became one of the raisons d'être of central banks (Padoa-Schioppa 1999). Yet in the middle of the twentieth century, as payment technology had settled down, payment system issues were considered less important than other aspects of the financial system, and were seen mostly as technical matters to be dealt with by subunits of IT departments in the central and commercial banks.

It was not until the mid-1980s that the debate on payment system reform policies took on greater weight in the countries with more advanced financial systems. Financial market liberalization led private sector agents and national regulators to identify technical and institutional solutions to serve the increasing demand for new payment services, while protecting the economy from the risks originating from rapidly growing volumes of financial transactions. Also, the internationalization of financial markets and episodes of severe financial crisis around the world fostered closer cooperation among industrial countries - and among industrial countries and emerging economies - on how to set up and enforce standards to improve payment system performance in terms of risk control and shock resilience.

Due to their historical involvement in payment systems and the implications for an effective monetary policy of a sound payment system, the central banks of the leading industrial countries have been the main actors in moving the policy debate forward and in taking concrete steps to improve domestic and cross-border payment system performance. It takes only a cursory look at the list of studies and reports under the aegis of the Committee on Payment and Settlement Systems (CPSS) of the Group of Ten central banks to see the intensifying cooperative effort under way and its results to date. ${ }^{3}$ In practice, the specific role filled by central banks in the payment system

${ }^{3}$ See the Bank for International Settlements' Web site at $<$ www.bis. org/publ/index.htm>. differs from country to country, and can include the provision of special purpose large-value, time-critical, funds transfer systems; bulk low-value electronic systems, including automated clearing house services; and government securities clearance and settlement services and settlement agent for other payment systems. In addition, central banks increasingly perform the functions of regulation and oversight of payment systems and services (Padoa-Schioppa 1999).

The private sector, in contrast, has traditionally provided most of the payment services to end users. In addition, the private sector is normally involved in retail clearing services and clearance and settlement of nongovernmental securities. In this latter regard, in some countries - especially countries in the early stages of capital markets development - comprehensive and rigorous attention to regulatory issues is sometimes lacking as initial major emphasis is placed, quite naturally, on matters relating to operational efficiency and cost.

Today, securities clearance and settlement systems are recognized as having the same inherent risks as those associated with systemically important payment mechanisms. Both the efficiency and the safety and soundness aspects of these systems are now receiving closer attention from domestic securities regulators as well as international organizations. ${ }^{4}$ In essence, the initial prominent role played by the private sector in the implementation and operation of securities systems is now being replaced by a combination of roles shared by the private and public sectors, with specific and well-defined roles being assigned to the securities regulator.

In sum, a national payments system encompasses "the entire matrix of institutional and infrastructure arrangements and processes in a country for initiating and transferring monetary claims in the form of commercial bank and central bank liabilities." ${ }^{5}$ As such, payment systems

\footnotetext{
${ }^{4}$ These concepts include speed of settlement, certainty of settlement (correct amount, correct party, correct date, clear understanding when finality occurs), reliability (availability, in accordance with rules and regulations), safety and soundness (to ensure against fraud, credit and systemic risk, privacy), convenience (easy access, consistent with technological capabilities), cost (realistic, consistent with the service provided), and universality (equitable basis by all financial institutions, interface with other systems).

${ }^{5}$ In this book, a broad interpretation of a national payments system is used to include both payments and securities settlement systems (CPSS 2006).
} 
are at the core of a country's monetary and financial system. This system evolves continuously, reflecting the changing needs of its stakeholders and the increasing number of options offered by rapid technological development. Such evolution can at times take the form of incremental change aimed at gradually improving the system's safety and efficiency. In other cases, countries embark in major revolutionary reforms that lead to quantum leaps in the design and components of the national payments system.

As a result of the growing international interest in issues related to payments and securities settlement systems, the World Bank and the International Monetary Fund have increased their involvement in this area by assisting member countries in setting up standards and in enforcing their implementation. In this respect, both institutions operate through a variety of instruments, including technical assistance, project assistance, and, recently, the assessment of payment system vulnerabilities in individual member countries as part of the joint International Monetary Fund-World Bank financial sector assessment program (FSAP).

In the Latin America and the Caribbean (LAC) region, efforts to raise the awareness of the importance of modernizing national payments systems and setting up a regional forum for the exchange of information were started by the World Bank as early as 1995. Such efforts further evolved with the request of regional finance ministers to the World Bank to launch a regional initiative to foster such a process of transformation. The latter initiative was formalized in 1999 into the Western Hemisphere Payments and Securities Clearance and Settlement Initiative (WHI), later converted in 2003 into a regional Western Hemisphere Payments and Securities Settlement Forum (WHF), dedicated to the assessment of and exchange of information on payments and securities settlement systems in the LAC countries.

The WHI has been a coordinated effort supported by central banks and securities commissions inside and outside the region, as well as international financial and standard-setting institutions. Besides the World Bank and the Center for Latin American Monetary Studies, other institutions have supported the WHI, such as the Council of Securities Regulators of the Americas and an International Advisory Council, the latter comprising highly experienced institutions dealing with clearance and settlement of payments and securities.
Under the WHI, 23 country assessments were undertaken between May 1999 and December 2005. Country assessments are prepared jointly by an international team and their local counterparts.

The purpose of this book is to (1) extract the main lessons and experiences of the WHI-WHF regarding the implementation of various reforms; (2) describe status of and major trends in payments and securities settlement systems worldwide and their implications for the LAC region; (3) summarize the detailed assessment findings for each LAC country; ${ }^{6}$ and (4) propose practical observations regarding the implementation of payments and securities settlement system reforms in the LAC region.

\section{ORGANIZATION OF THE BOOK}

The rest of the chapters of this book are organized as follows: Chapter 2 indicates some of the major trends worldwide in the area of payments and securities settlement systems. The chapter analyzes the importance of adopting an integrated approach in reforming payment systems and describes the latest debate and evolution in issues such as large-value payment systems, the use of the central bank's money, the direction of advances in retail payments systems, the growing flow of remittances and new players in the foreign exchange and cross-border transactions such as the Continuous Linked Settlement (CLS) Bank. In the area of securities settlement systems, the chapter indicates the closer attention paid to those issues and a broader approach through the evolution of international standards. It also includes the current debate about market infrastructure, globalization, and the new challenges for securities settlement systems. Finally, it covers the need for strengthening the oversight function of the central bank over payments systems.

Chapter 3 describes the tools used for the WHI assessments. They include working papers (especially Working Papers 2 and 3) produced by the WHI-WHF, the CPSS core principles for systemically important payment systems, the International Monetary Fund-World Bank

\footnotetext{
${ }^{6}$ The information included is based on the WHI-WHF findings and subsequent updates. However, payments and securities settlement systems are continuously evolving. Thus, information should be checked with country authorities to ensure accuracy.
} 
guidance note for assessing observance of core principles for systemically important payment systems, the CPSSInternational Organization of Securities Commissions (IOSCO) recommendations for securities settlement systems, the CPSS-IOSCO methodology for the securities settlement systems, and the CPSS-IOSCO recommendations for central counterparties.

Chapter 4 covers the main findings of the WHI-WHF country assessments in the area of payment systems. Twenty-three countries have been assessed under the WHI-WHF. The issues covered include the legal basis, interbank exchange settlement circuits, retail payment systems, government payments, foreign exchange and cross-border settlement systems, and the functioning and settlement of the interbank money market.

Chapter 5 analyzes the main findings of the WHI-WHF country assessments in the area of securities settlement systems. The issues covered are the legal basis, clearing and settlement processes, settlement risk, settlement asset, operational issues, custody risk, depositories' organizational arrangements, regulatory and oversight framework, and cross-border settlement.

Chapter 6 indicates the main issues related to the oversight role of the central bank, the coordination with other regulators, and cooperation with the private sector. The chapter covers the legal foundations of the oversight function; transparency and dissemination of information; objectives, scope, instruments, pricing, and access; and organizational arrangements and cooperation.

For chapters 4, 5 and 6, the book follows a systematized approach for each issue covered. First, it includes a brief context in which the main areas, normally identified through international standards and best practices, are described. Second, a status subsection is included describing the facts identified for each of the 23 countries covered. Finally, the observations subsections summarize the findings often encountered in the systems analyzed or that, even if not identified in many systems, are important due to their relevance (for example, issues related to dollarized systems).

Chapter 7 goes beyond the assessment exercise to indicate some practical steps in the way forward for a payments system reform. The chapter starts on how to use the assessment as a starting point for the reform effort, and then covers issues such as the role of a national payments and securities settlement system, the different institutional roles in a reform, how to engage the private sector in the effort, and finally the preparation and implementation of the reform.

Finally, chapter 8 presents the concluding remarks. 


\section{Major Trends in Payments and Securities Settlement Systems}

any trends can be identified in payment and securities settlement systems over the past few years. Many of the trends are captured in recent publications from the Committee on Payment and Settlement Systems (CPSS), leading central banks, international financial institutions such as the World Bank and the International Monetary Fund, and payment system specialists. This chapter highlights the most visible of these trends. ${ }^{1}$

\section{BROADENING THE SCOPE OF THE PAYMENTS SYSTEMS}

The concept of payment systems has changed, or at least the payment systems area of influence has widened. A payment system can be defined as the collection of institutions, instruments, rules, procedures, standards, and technical means used to exchange financial value between two parties discharging an obligation (Listfield and Montes-Negret 1994). Traditionally, payment systems have focused on funds transfer systems. However, value can be transferred also by means of securities. Government securities traditionally have received close attention from central banks due to the role that they play as the government's bank as well as the government's agent with regard to public debt management. However, private securities have normally been outside the influence of central bank regulation and oversight. Today, securities clearance and settlement systems are recog-

${ }^{1}$ For an analysis of change drivers in the payment systems area see Montes-Negret (2006). nized as having the same inherent risks as those associated with systemically important payment mechanisms. International organizations consider both payments and securities settlement as a joint area of analysis; the private sector also looks at this issue as a unique area. Some new terminology incorporating concepts for payments and securities settlement has emerged.

Payments and securities settlement systems also have important interrelations with other areas of the financial sector. Examples are bank-troubled resolution schemes (unwinding mainly in cheque systems that still settle large-value payments) and credit information systems.

\section{ADOPTING AN INTEGRATED APPROACH TO PAYMENT SYSTEM REFORM}

Recognizing the importance of an integrated approach to payment system reform, the CPSS published a report containing general guidance for national payment system development. The report acknowledges that there is no single recipe for effective payment system development, but the questions that countries undergoing a reform process ask themselves are largely similar. For example, who should be involved and who should initiate the process? What are the priorities in which to invest and are they based on a solid understanding of the payment system? What are the different infrastructures needed and what are their supporting institutional arrangements?

The CPSS report provides expertise in payment systems and the consensus view of central banks and international financial institutions. However, the priorities of CPSS member countries need not be the same as those of other countries. Indeed, reform priorities differ from 
country to country based on each country's needs and capabilities. Drawing on a comparison with the transportation system, buying the most expensive technology to build an airport would be pointless if the rest of the system were not sufficiently developed to make effective use of that airport. Alternatively, the airport may provide only a modest contribution to the overall transport system if most people still use ground transportation. Indeed, the objective of the payment system, just like that of the transportation system, should be to develop an appropriate mix of infrastructures and an institutional framework to connect people in an efficient and safe way.

The CPSS report aims to give assistance in and advice on the planning and implementation of reforms in the payment system as a whole. It underlines that the central bank is always a driving force in the development of the national payment system. However, reforms in this field depend on a parallel development of the banking system, and should therefore be a cooperative effort, involving stakeholders from, for example, the banking sector and regulatory agencies. An adequate understanding of the different infrastructures and their institutional framework is needed and is indispensable for getting the priorities right.

The report includes 14 guidelines (see appendix 6) and accompanying explanatory text on payment system development. The report also includes implementation sections, which illustrate the guidelines with practical examples, issues, and possible approaches to implementation. In preparing the report, the CPSS drew on the contribution of a working group, which consisted of a broad range of central bank experts from industrial and developing countries around the world, as well as from the International Monetary Fund and the World Bank.

\section{DEVELOPMENTS IN LARGE-VALUE PAYMENT SYSTEMS}

Large-value payment systems (LVPS) play a key role in the financial infrastructure by discharging payment obligations between banks. The 1990s experienced a major transformation in the design of these systems: from deferred net settlement systems, which settled only at the end of the day, to real-time gross settlement (RTGS) systems, which settle on a continuous basis. This revolution was largely due to the possibilities offered by information and communication technology and to the measures taken by central banks to reduce systemic risks in these systems. The CPSS of the central banks of the Group of Ten (G-10) countries reflected these changes by publishing the report Real-Time Gross Settlement Systems in 1997 (CPSS 1997b).

The purpose of a new report by the CPSS, published in May 2005, is to present the state of the art in LVPS, taking stock of the developments that have taken place since the 1997 report. It is written to be free standing and does not require reference to previous reports. The central message of the report is that interbank payments today settle faster, with a lower amount of liquidity (mainly, central bank money), and at a lower cost. Indeed, whereas the key achievements in the 1990s were speed and safety of payments, the focus since the turn of the century has been to reduce liquidity costs and to provide users with more flexible intraday liquidity management.

In parallel, new systems have emerged to meet an expanding demand for cross-border payments. The primary example is Continuous Linked Settlement Bank, which was established to reduce credit risk in the settlement of foreign exchange (FX) transactions (see below). Another example is the emergence of new infrastructures in countries where a foreign currency plays an important role. Standardized arrangements have been established that enable financial institutions to settle foreign currency transactions through a correspondent bank while using the same system design as the local RTGS system.

While certain trade-offs exist between achieving lower risks and achieving lower costs, recent developments in LVPS design allow more flexibility in addressing various risk and cost trade-offs than were available in traditional architectures. Central banks, on their side, have continued to seek a balance between more stringent risk controls and the need for systems to be cost efficient. ${ }^{2}$

The analysis in the new CPSS report shows that the complexity of trade-offs between risks and costs implies a wide range of possibilities for the design of an LVPS. There is therefore no single solution fitting all markets

${ }^{2}$ For an interesting analysis on the practical implications in terms of liquidity in an RTGS system and some measures to reduce the liquidity pressure and increase liquidity distribution, see Bernal and Merlano (2006). 
and all participants' preferences. Hence, the report does not prescribe the adoption of any specific feature or design element introduced in a given LVPS in the CPSS countries. It is the responsibility of the owner of each LVPS to come up with the design that best fits the user's needs, and achieve an optimal balance of risks and costs, while meeting the relevant policy objectives.

\section{THE USE OF CENTRAL BANK MONEY}

As a result of the launch of RTGS systems in many countries around the world, there is a growing use of central bank's money to settle transactions, in particular of large value. However, the role of central bank money in payment systems raises a number of questions. Industrial economies have complex and interdependent payment arrangements in which there is a combination of competition and cooperation between the many institutions involved. The use of central bank money is thus part of the underlying issue of the balance between the services provided by central banks and those provided by commercial banks in the payment system. Given the widespread and fundamental changes that have occurred over the past decade or so and that continue today, it is useful to consider whether an appropriate balance is being maintained and how the composite use of both monies can best be achieved.

A 2004 CPSS report looks at a range of practical policy questions. For example, which institutions should have accounts at the central bank? What services should central banks provide to meet the needs of account holders? When should central banks insist that payment or securities settlement systems settle in central bank money or - when this is not practicable - what sufficiently safe alternatives exist to mitigate credit and liquidity risks? What are the possible benefits and risks of the concentration of payments through a few large banks, and how might central banks approach this issue? Finally, to what extent can the supply of central bank money, normally confined to the area of jurisdiction of the central bank, meet the demands of global players who are active in multiple currencies?

The report shows that there is much common ground among CPSS central banks in their objectives as well as in the main tenets of their policy concerning the role of central bank money in payment systems. These collective views and practices are presented in the form of 10 propo- sitions. At the same time, however, there are often differences when it comes to the implementation of policy.

\section{UNCLEAR DIRECTIONS REGARDING THE USE OF RETAIL PAYMENT INSTRUMENTS}

Around the world, retail payment instruments are diverse, both within and between countries. The diverse nature of the transaction types, counterparties, and payment volumes and values has given rise to several different payment instruments. For example, in G-10 countries, although all the countries use all the noncash retail payment instruments to some extent, they fall into one of two groups that rely heavily on a particular class of noncash instrument: Many European countries and Japan rely mostly on credit transfers, whereas Australia, Canada, the United States, and a few European countries depend heavily on cheque payments.

The most significant trends in retail payments common to the selected countries are the continued primacy of cash (in volume terms) for face-to-face payments, despite a long-standing movement toward noncash payments; growth in payment cards, primarily for face-to-face payments; increased use of direct funds transfers, especially direct debit transfers, for remote payments; and substantial changes in the market arrangements for providing and pricing the retail payment instruments and services delivered to end users.

Retail payments in the selected countries are experiencing an increased pace of experimentation and innovation. Although the most recently emerging payment technology and its specific applications have not yet been adopted as core payment methods, research and development, and market experimentation continue. At the same time, more traditional forms of payment instruments, technology, and banking arrangements are evolving. Over the long term, some of these market developments may well alter traditional payment practices and contribute to increased efficiency and convenience in retail payment systems.

\section{GROWING FLOWS OF REMITTANCES}

International remittances initiated by migrant workers are an important source of family income in many developing economies as well as a significant share of the recipient's GDP. Originators of such remittances throughout the world generally comprise low-income migrants 
who regularly send money to family members in laborexporting countries. Often, beneficiaries depend on remittance income to cover day-to-day living expenses, and remittances provide a cushion to mitigate the shocks associated with emergencies, and in some cases to create investment in sustainable employment opportunities.

Remittance payments are cross-border retail payments with particular access requirements on both the paying and the receiving sides. Remitters and recipients frequently do not have access to banks as payment agents, and instead rely on systems set up by non-bank remittance service providers, with service agents as intermediaries. Therefore, remittance systems may differ from other payment systems in that, normally, there will be a multitude of international remittance systems operating in a country. Whereas a LVPS frequently will include all operators that process large-value transactions, remittance systems tend to be proprietary with a limited set of operators, which again provide a limited number of products. Remittance systems typically do not entail systemic risk, but they have a great impact on the welfare of consumers and, potentially, on the development of countries.

Because remittance services are a subset of the broader retail payment systems, to ensure that remittance transfers provide the best value and certainty to the end users there is a need for regulations for remittance service providers and appropriate minimum standards for the provision of these services. To ensure compliance with the standards, there is a need for a framework to guide oversight practices in areas such as supervision, monitoring, inspection, enforcement, cooperation, information sharing, disclosure, and system and service requirements.

In January 2004, the presidents of the Americas in the Declaration of Nuevo León, Mexico, stated, "We recognize that remittances are an important source of capital in many countries of the Hemisphere. We commit to take concrete actions to promote the establishment, as soon as possible, of necessary conditions, in order to achieve the goal of reducing by at least half the regional average cost of these transfers no later than 2008 and report on progress achieved at the next Summit of the Americas in Argentina in 2005. We will adopt, as needed or appropriate, measures such as: the promotion of competition between the providers of these services, the elimination of regulatory obstacles and other restrictive measures that affect the cost of these transfers, as well as the use of new technologies, while maintaining effective financial oversight."

Furthermore, at their meetings in Boca Raton, Florida, in February 2004, the general statement from the Group of Seven finance ministers and central bank governors included the commitment, "We aim to reduce the impediments that raise the cost of sending remittances."

During the Group of Eight Summit in the United States, in June 2004, Group of Eight countries stated the following: ${ }^{3}$

"G8 [Group of Eight] countries will work with the World Bank, IMF, and other bodies to improve data on remittance flows and to develop standards for data collection in both sending and receiving countries. G8 countries will also lead an international effort to help reduce the cost of sending remittances. The developmental impact of these flows may be fostered by increasing financial options for the recipients of these flows. The G8 programs will:

(i) Make it easier for people in sending and receiving countries to engage in financial transactions through formal financial systems, including by providing access to financial literacy programs, where appropriate, and by working with the private sector to extend the range and reach of these services.

(ii) Reduce the cost of remittance services through the promotion of competition, the use of innovative payment instruments, and by enhancing access to formal financial systems in sending and receiving countries. In some cases, remittance costs between sending and receiving countries have been reduced by up to 50 percent or more. G8 countries believe that similar reductions of high costs could be realized in the case of other countries.

(iii) Promote better coherence and coordination of international organizations that are working to enhance remittance services and heighten the developmental impact of remittance receipts in developing countries.

(iv) Encourage cooperation between remittance service providers and local financial institutions, including micro-

${ }^{3}$ G8 Action Plan: Applying the Power of Entrepreneurship to the Eradication of Poverty, Sea Island, June 9, 2004. 
finance entities and credit unions, in ways that strengthen local financial markets and improve access by recipients to financial services.

(v) Encourage the creation, where appropriate, of market-oriented local development funds and credit unions that give remittance-receiving families more options and incentives for productively investing remittance flows.

(vi) Support dialogue with governments, civil society, and the private sector to address specific infrastructure and regulatory impediments. For example, governments should ensure non-discriminatory access to payment systems for the private sector, consistent with strong supervisory standards, and work together to modernize overall financial infrastructure."

Against this background, the World Bank and the CPSS convened a task force in November 2004 to address the needs of international policy coordination for remittance systems.

Following its mandate, in March 2006 the task force published for public comments some general principles on remittances describing key features and functions that should be satisfied by remittance systems, providers, and financial intermediaries. These principles are intended to be clear and universally applicable international standards; the principles' main focus being to identify the main characteristics of sending and receiving remittances and the related infrastructures, with a view to improving them.

The task force pursued the following streams of work:

- Mapped and compared the remittance market in different countries, as well as the respective cross-border arrangements in these countries in the form of country reports. This analysis allowed the task force to define stylized structures of remittance systems and to determine principles that could be applied.

- Identified principles to ensure an appropriate level of consumer protection and transparency.

- Discussed the appropriate level of access to payment systems infrastructure preserving the safety and integrity of the infrastructure. Appropriate mechanisms for educating the remittance agents and operators will also be considered.
- Defined the appropriate regulatory framework for the remittance market.

- Discussed the role of authorities and remittance service providers' bank in the application of the principles.

The task force, in addition to CPSS and World Bank representatives, comprised representatives from central banks of both sending and receiving countries, as well as from multilateral institutions such as the International Monetary Fund, development banks, and the Arab Monetary Fund. The task force benefited from the work carried out by several institutions worldwide, and constantly pursues coordination with other international fora involved on this matter.

\section{AN INCREASING ATTENTION TO OPERATIONAL RELIABILITY, RESILIENCE, AND INTEGRITY OF SETTLEMENT SYSTEMS}

Responses to disaster risk involve the adoption of measures that would allow continuous operation in a sufficiently controlled environment at a level that will permit the ongoing management of existing positions and payments. To make this possible, robust contingency plans need to be prepared and tested, including establishing backup computer centers, frequent updating of backup data, backup power sources, and so on. After the September 11, 2001, disaster important vulnerabilities were identified in liquidity management caused by operational and telecom problems among major financial institutions and their customers, resulting in important bottlenecks for several days. This happened despite the resilience shown by the U.S. payment system thanks to the Federal Reserve's market participants' extraordinary cooperation. Lost and disrupted transactions caused uncertainty. As a result, U.S. regulatory agencies and industry participants learned important lessons, pointing to the fundamental flaw that continuity plans were developed at the level of individual institutions, in general, with a focus on singlesite outage scenarios.

As a result of the disruption of all services to lower Manhattan from the 9/11 terrorist attacks, major players must now recast their plans to deal with the potential for wide area disruptions, making evident the importance of geographical diversification and focusing more on desired outcomes than on specific scenarios. There also is a new emphasis on availability of critical staff and distribution of business and technical expertise. The 9/11 crisis made 
clear the importance of testing within and across institutions, with emphasis on ongoing communications during a crisis (governance during emergencies), the risks of geographical concentration of service providers and key staff, as well as the need to better understand the web of interdependencies between market participants and clients, banks, utility companies, and so on.

One of the main conclusions of the ongoing review is the need to coordinate plans across the industry, domestically and even internationally, more closely than previously anticipated. The regulatory response has been fast in providing a number of initiatives to identify sound practices for business continuity. These initiatives are contained in two reports: the "Interagency White Paper on Sound Practices to Strengthen Resilience of the U.S. Financial System," and the "Interagency White Paper on Structural Change in the Settlement of Government Securities: Issues and Options." Other work include the new guidelines from the Payments Risk Committee, enhanced contingency testing of Fedwire Funds Service and the Clearing House Interbank Payments System, and further enhancement of Fedwire funds and securities services. Extensive work in these areas has been carried out also by U.K. authorities.

Obviously, emphasis needs to be put on the market infrastructure and the larger institutions that can create systemic risk. ${ }^{4}$ Proper focus has been given to the resilience and continuity of critical markets and firms that play significant roles in those markets beyond the national borders of major financial centers. ${ }^{5}$

${ }^{4}$ It is interesting to note the huge increase in liquidity support following the $9 / 11$ events. Commercial bank borrowings from the Federal Reserve discount window rose from \$200 million to about $\$ 45$ billion on September 14, 2001, with daylight overdrafts peaking at $\$ 150$ billion on September 14, the highest level ever and more than 60 percent the usual level.

${ }^{5}$ In the United States, critical markets have been defined to encompass the operation of the federal funds market, the FX and commercial paper markets, as well as the government, corporate, and mortgagebacked securities markets. Although "core clearing and settlement organizations" consist of market utilities that provide critical clearing and settlement services for financial markets and large payment system operators, "firms that play significant roles in critical financial markets" are those that participate in sufficient volume or value such that their failure to perform critical activities by the end of the business day could present systemic risk. See U.S. Securities and Exchange Commission (2002).
Setting higher standards for security and recovery of core settlement systems is having major cost implications for banks and other financial participants. Major investments in what is known as "high availability architecture" (which might include "synchronous mirroring," that is, the simultaneous copying of transactions at primary and recovery centers to avoid any loss of data; data mirroring, clustering, data replication, load balancing between processing centers, and so on) are under way. ${ }^{6}$

In summary, the response to geographic diversification is being built around a capability model with three components: (1) split operations in an active-active mode (White Paper recommendations); (2) splitting of operations in such a manner that they take place in two distinct geographic areas; and (3) traditional backup recovery capabilities. $^{7}$

Operational risks must be dealt with not only at the level of payment system operators, but also at the level of system participants. In this regard, within Basle II a new emphasis on operational risk is focusing the attention of boards, bank managers, and bank regulators. The Basle Committee on Banking Supervision defines this risk as "the risk of direct or indirect loss resulting from inadequate or failed internal processes, people, or systems or from external events." Operational risk is also defined as the "risk that deficiencies in information systems or internal controls will result in unexpected loss: fraud, non-deliberate incorrect information, disaster risk and personnel risk" (CPSS 2003c).

Finally, in October 2004, the Financial Action Task Force on Money Laundering revised the 40 recommendations and introduced nine special recommendations (see appendix 3), all aimed at fighting money laundering and terrorist financing. The Financial Action Task Force on Money Laundering comprises a broad spectrum of international authorities, including financial intelligence units, central banks, and law enforcement entities. For more information, see http://www.fatf-gafi.org.

\footnotetext{
${ }^{6}$ Monks (2003). This technology is still limited to distances of no more than 100 kilometers (60 miles) between the recovery center and the primary center.

${ }^{7}$ For an interesting discussion of some private sector perspectives, see ECB-CPSS (2003).
} 


\section{A NEW APPROACH TO FX AND CROSS-BORDER TRANSACTIONS: THE LAUNCH OF THE CLS}

A broad definition would regard a cross-border payment as a transaction that involves individuals, corporations, settlement institutions, central banks, or a combination thereof in at least two different countries. Following this definition, at least three major categories of crossborder payment transactions can be identified:

- Payments that originate in some country and for which the destination (that is, the final beneficiary) is some other country. Major examples in this category would be the payments (typically made by corporations) associated with the international trade of goods and services, as well as the unilateral transfers from an individual residing in country $\mathrm{X}$ to an individual resident of country Y (that is, personal remittances). This type of payments is what most people would regard as a "payments of a cross-border nature."

- Payment transactions in which the origin and destination are both in the same country, but which use the payments infrastructure of at least some other country for settlement. For example, two banks operating in the same country and that make trades in the local FX market usually settle the foreign currency leg through foreign bank correspondents. Another example in this category could be the payments a resident of country $\mathrm{X}$ makes with a credit or debit card (issued in country X) while traveling in country Y. As far as the payer and the payee are concerned, the transaction would be domestic in nature, although the payments infrastructure of at least these two countries would be used to process and settle the payment.

- Cash payments. Major examples here are the payments made by a resident of country $X$ in country $Y$ with the legal tender of the latter, or payments made through some remittances companies in which the originator gives cash in country $\mathrm{X}$ to be paid to a beneficiary (typically in cash) in country $\mathrm{Y}^{8}$

${ }^{8}$ Resident of country $\mathrm{X}$ could be carrying cash all the way or could withdraw cash with a card issued in country $X$ from an ATM in country $Y$ to make payments in this latter country. According to the definition given above, one could even think of including the cash payments made between residents of the same country with the legal tender issued by some other country.
Literature on cross-border payment systems is relatively recent and in most cases the attention has been centered in the risk features of these transactions. Not surprisingly, much of the systematic work carried out in recent years by policy makers and international institutions has focused on cross-border payments associated with transactions in financial markets, because this particular type of crossborder transactions is regarded as having the potential of producing systemic risk effects due to their largevalue nature.

Particularly relevant in this area is the work of the CPSS of the G-10 countries. Two of the specific topics studied by the CPSS have been cross-border securities settlements and settlement risk in FX transactions (CPSS 1995, 1996a). In particular, as a result of the work in the latter area, commonly known as the Allsopp Report, in 1996 the G-10 central bank governors launched a comprehensive strategy to reduce the systemic risks in settling FX transactions. ${ }^{9}$ In Latin America and the Caribbean, settlement risks in the FX domestic markets, which are the most relevant in the region in terms of their cross-border implications, are currently being studied by Latin America and the Caribbean central banks in the context of the Working Group on Payment System Issues of Latin America and the Caribbean.

In particular, when in 1996 governors of the central banks of the G-10 countries endorsed a comprehensive strategy to reduce risks, particularly systemic risks, in settling FX transactions, they agreed on a three-track strategy providing for

- Action by individual banks to control FX settlement exposures;

- Action by industry groups to provide risk-reducing multicurrency services; and

- Action by central banks to induce rapid private sector progress.

The most important action, which can be considered a revolution in the world of FX and cross-border market was the launch, in September 2002, of the Continuous Link Settlement Bank (CLS Bank). CLS Bank started its

\footnotetext{
${ }^{9} \mathrm{~A}$ progress report on this issue was produced in July 1998. See CPSS (1998a).
} 
CLS, settling FX transactions in seven currencies (the Australian dollar, the Canadian dollar, the U.S. dollar, the euro, the Swiss franc, the Japanese yen, and the British pound) on a payment versus payment basis on the books of the seven respective central banks. At the time of its launch, CLS had 66 of the world's largest financial institutions participating as shareholders. In 2005, FX deals with a total of 15 currencies (the former plus the Danish krone, the Norwegian krone, the Swedish krona, the Hong Kong dollar, the Korean won, the Singapore dollar, the South African rand, and the New Zealand dollar) were being settled through the CLS Bank. By the end of 2005, the CLS Bank had a total of 56 member banks (shareholders, with settlement accounts) and 674 member customers (third parties sponsored by a member bank), and nearly 80 percent of total member volume was being settled through it. The CLS Bank is subject to the cooperative oversight of central banks involved and it is under the direct oversight of the U.S. Federal Reserve.

Some of the most relevant features of the CLS service follow:

- Counterparty risk is eliminated through a form of payment versus payment, although liquidity risk is not eliminated.

- Settlement members hold accounts at the CLS Bank. - Single multicurrency account on CLS Bank's books.

- Individual currency balances calculated, monitored.

- FX trades settle gross on CLS Bank's books.

- Final, simultaneous debits and credits to Settlement Member's accounts: Achieves payment versus payment.

- Pay-ins and pay-outs are via CLS Bank accounts and RTGS systems.

- CLS Bank holds accounts at central bank of issue.

- Participants' funding and defunding of these accounts is on the basis of the net amounts in each currency of the trades they are settling that day.

\section{INCREASING IMPLEMENTATION OF INTEGRATED INITIATIVES IN PAYMENT AND SECURITIES SETTLEMENT SYSTEMS}

In addition to the CLS Bank, industry groups and government agencies have launched or are studying several important global initiatives that have the potential to increase efficiency or reduce payment risks, or both. Such new networks and vehicles are having an important impact on the operation of banking and non-banking institutions. Some examples are cited below:

- In Europe, authorities and market players are struggling to achieve the Single European Payment Area and interesting efforts to integrate financial systems and capital markets, including settlement and depository institutions are taking place. The launch of the Trans-European Automated Real-Time Gross Settlement Express Transfer System 2 (TARGET 2) is also moving in the same direction of rationalization of the payment infrastructure.

- In Central America, a project is under way to integrate the LVPSs of Costa Rica, Dominican Republic, Honduras, Guatemala, and Nicaragua.

- In the securities area, there are also a number of global initiatives. The projected Global Equity Market initiative of the New York Stock Exchange to establish a common stock market among 10 major countries, including Brazil and Mexico, would allow 24-hour trading around the world.

"The automation of trading systems, led by the European Exchanges and US 'electronic communication networks' (or ECNs), combined with the growth of online trading, has led to significant declines in trading costs, massive increases in turnover, internationalization of trading and settlement systems' operations, and a major reform in the structure and governance of securities exchanges. Reductions in trading costs lowered the cost of raising equity capital and shifted issuance of trading activity to lower cost centers" (IMF 2003, 131).

The same concern about the fragmentation of the banks' liquidity applies to the use of their collateral: "Large banks want to be able to approach several markets from a single access point enabling them to make the most efficient use of collateral and to minimize costs" (Sabatini 2003). Within the Trans-European Automated Real-Time Gross Settlement Express Transfer System 2 this concern will be reduced, because there will be less need for collateral movements.

Cross-border issues in payments and securities trading are being studied by a Cross-Border Collateral Task Force established by the New York Payments Risk 
Committee. ${ }^{10}$ One of the task force's recommendations contains a request to the G-10 central banks to "expand the range of acceptable collateral to include (more) foreign denominated collateral." 11 Within the EU, central banks began accepting securities collateral from any of the other EU markets in two eligible currencies (the euro and the U.K. pound) provided that agreeable custodian or collateral arrangements are put in place. As international central securities depositories develop, we will see further changes in this area.

On the retail side of the payments system, some integration initiatives are taking place, in particular in Europe (for example, STEP2), ${ }^{12}$ or links between different domestic automated clearinghouses (for example, the link between the Mexico and U.S. automated clearinghouses).

\section{CLOSER AND BROADER ATTENTION TO SECURITIES SETTLEMENT SYSTEMS THROUGH THE EVOLUTION OF INTERNATIONAL STANDARDS}

In the area of securities settlement systems (SSSs), there has been an important process of consolidation and generalization of international accepted standards worldwide. The first set of internationally recognized standards was included in the document, "Group of Thirty Recommendations Regarding Securities Clearance and Settlement," published in 1989 and targeted to "reducing risk, improving efficiency and promoting greater standardization in international settlement." "13 Soon after and throughout the decade of the 1990s this document became a key refer-

\footnotetext{
${ }^{10}$ The Payments Risk Committee is a private sector group of senior managers from U.S.-resident banks (domestic and foreign) that is sponsored by the Federal Reserve Bank of New York. The committee identifies and analyzes issues of mutual interest related to risk in payments and settlement systems. It also seeks to foster broader industry awareness and discussion, and to develop input on public and private sector initiatives.

${ }^{11}$ See http://www.newyorkfed.org/prc/PRCGlobalPaymentLiquidity. pdf

${ }^{12}$ The first pan-European automated clearing house (PE-ACH) is the STEP 2 system, which the Euro Banking Association launched in April 2003.

${ }^{13} \mathrm{G}-30$ (1989). A year before, in 1988, the International Securities Services Association issued a publication with four recommendations that helped to pave the way for many of the G-30 recommendations.
}

ence for the assessment of SSSs. Major SSSs around the world were assessed against these recommendations and some upgraded in order to observe with the recommendations included in this document. The Group of Thirty (G-30) report focused on the areas of trade comparison, trade confirmation/affirmation, central securities depositories, netting schemes, delivery versus payment, ${ }^{14}$ sameday-funds, rolling settlement cycle, securities lending, and common message standard. In addition, the Lamfalussy Minimum Standards (CPSS 1990) issued for the purpose of cross-border and multicurrency netting and settlement schemes were not only relevant for payments settlement systems (PSSs), as mentioned before, but also for SSSs. These six standards refer to the legal basis, financial risks, management of credit and liquidity risks, admission criteria, and operational reliability of netting schemes.

In 1990, the technical committee of the International Organization of Securities Commissions (IOSCO) issued a report on clearing and settlement. Its objective is to "contribute to the process of creating an efficient central securities depository from a national regulatory point of view and, at the international level, offering views on how to create links in accordance to the recommendations issued on the subject." The report is intended to be applicable for both spot and derivatives markets. The report deals with a broad range of issues related to securities settlement, mainly regulatory (including the role of selfregulatory organizations), liquidity risk, and industry organizational arrangements and operational reliability. In addition, it endorses the $\mathrm{G}-30$ recommendations as practical, feasible, short-term goals and supports its prompt implementation.

In 1995, the International Securities Services Association amended the G-30 recommendations. The main amendments included trade comparison in $\mathrm{T}+0$ instead of $\mathrm{T}+1$; positive affirmation of trade details by indirect market participants by $\mathrm{T}+1$; explicit reference to immobilization and dematerialization and rules when several central securities depositories operate in a country, in order to allow for use of funds and cross-collateral; and choice

\footnotetext{
${ }^{14}$ This concept was introduced in CPSS (BIS), September 1992, Delivery versus Payment in Securities Settlement Systems.
} 
between an RTGS or Lamfalussy Recommendationscompliant netting system for funds settlement.

Progress in technology had driven most systems to centralized and computerized book-entry custody, as well as clearance and settlement. However, in some emerging markets, the legal framework was still based on delivery of physical securities. Thus, the Emerging Markets Committee of IOSCO was given the mandate to conduct a study on the legal and regulatory framework for clearing and settlement in emerging markets. The aim was to conduct a comparative study of the legal regulatory framework of participating countries, ${ }^{15}$ identify and discuss similarities in developing their respective central depository systems and provide guidelines for the development of policies in relation to the legal and regulatory framework. Thus, in November 1997, the document "Towards a Legal Framework for Clearing and Settlement in Emerging Markets" was released.

In 1998, IOSCO set up 30 principles of securities regulation in the document "Objectives and Principles of Securities Regulation." The principles were based on three main objectives of securities regulation: protecting investors, ensuring that markets are fair, efficient, and transparent; and reducing systemic risk. The principles are grouped into eight categories; one of them, Principle 30 , in the secondary market category, indicates that SSSs should be subject to regulatory oversight; should be designed to ensure that they are fair, effective, and efficient; and should reduce systemic risk.

In 1999, the International Federation of Stock Exchanges released the document, "Clearing and Settlement Best Practices Report." 16 The objective of the report was "to enable FIVB members and their respective clearing and settlement organizations individually to score their performance against benchmarks and best practices, and to identify areas in their processes where improvements should be considered." The report examines main findings in the areas of settlement cycles, settlement success rates, processing cycles, asset lockup periods, market systems integration, delivery versus payment, indirect

\footnotetext{
${ }^{15}$ The participating countries were Brazil, the Republic of Korea, Malaysia, Mauritius, South Africa, Sri Lanka, and Thailand.

${ }^{16}$ This report was the continuation of an effort initiated with the International Federation of Stock Exchanges (FIBV 1996).
}

trade confirmation, securities lending, management practices, and management systems and unit costing. The report ended with some recommendations about business plans, the custodians and fail rates, the global standard settlement cycle, management information, netting, the Code of Good Practice, and future surveys.

In 2000, International Securities Services Association issued new recommendations in order to tackle key risks in current clearance and settlement arrangements throughout the world. Special attention was given to governance of infrastructure, the appropriate use of technology, and the management of technology risks and user requirements in cross-border transactions.

Despite all these efforts from public and private sector institutions that have fundamentally helped to drive the upgrade and modernization of SSSs around the world, a comprehensive set of public sector endorsed recommendations was lacking. This task was undertaken by central banks and securities regulators through a CPSS-IOSCO task force with the publication in November 2001 of the document "Recommendations for Securities Settlement Systems." This document has been included by the Financial Stability Forum, in its seventh meeting, held in Hong Kong, China, as one of the key standards that international organizations use for the assessment of financial systems. ${ }^{17}$ The objective of this report is "to promote implementation by SSSs of measures that can enhance international financial stability, reduce risks, increase efficiency and provide safeguards for investors by developing recommendations for the design, operation and oversight of such systems." The 19 recommendations are designed to identify minimum standards that systems should meet. They constitute the most comprehensive set of SSSs recommendations, including a broad range of topics (see appendix 4).

\footnotetext{
${ }^{17}$ The Financial Stability Forum was established in Washington on April 14, 1999. Its objective is to assess financial system vulnerabilities, identify corrective actions to attack these vulnerabilities, and improve cooperation and information exchange among financial system authorities. It comprises 40 members, including national authorities responsible for financial stability in significant international financial centers, international financial institutions, sectorspecific international groupings of regulators and supervisors, and committees of central bank experts. For a more detailed explanation, see http://www.fsforum.org/.
} 


\section{Figure 2.1. Evolution of International Standards for Securities Settlement Systems}

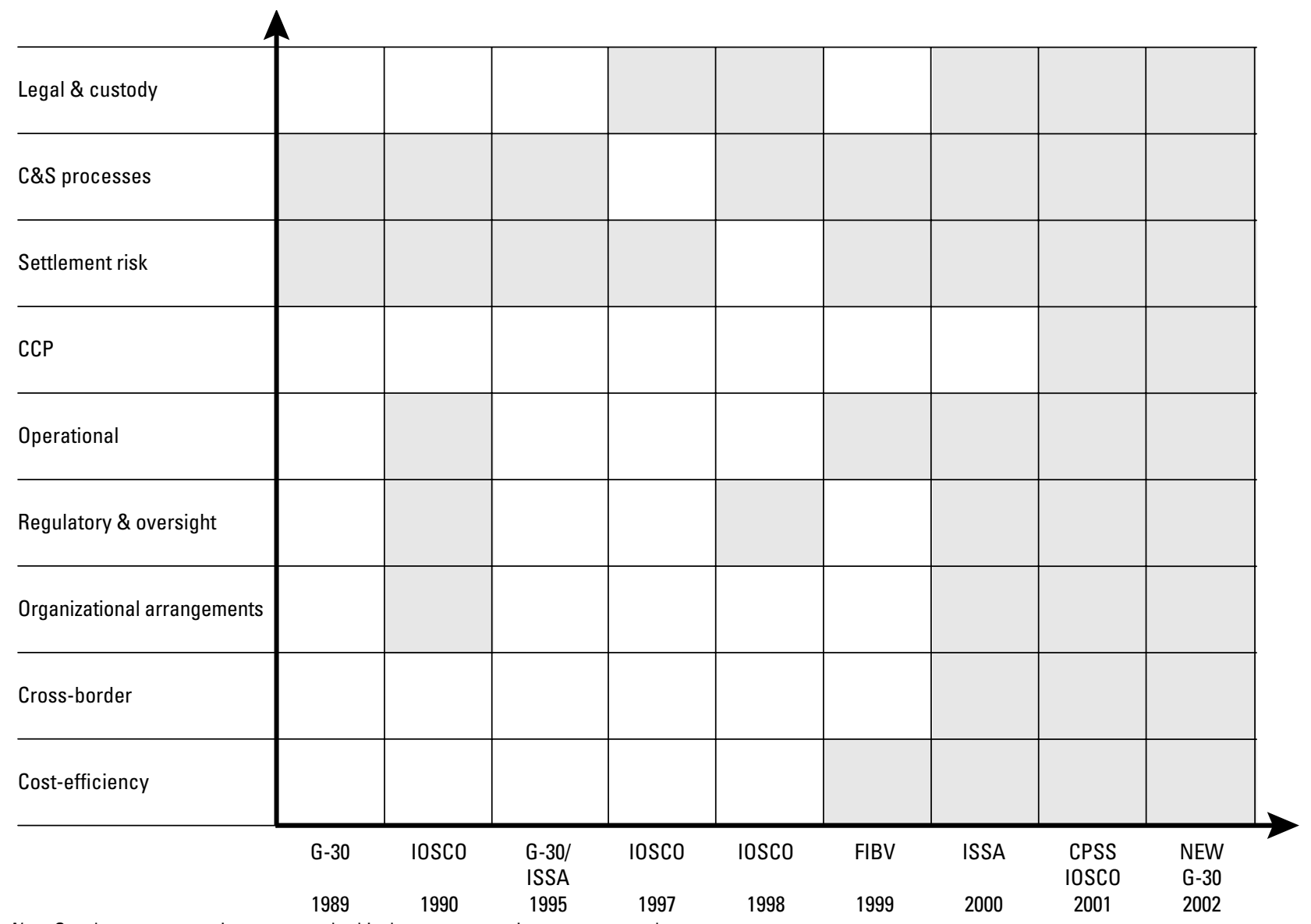

Note: Gray boxes represent issues covered; white boxes represent issues not covered.

In any case, at the private level, the effort to contribute to the upgrading and modernization of SSSs has continued, and the G-30 has issued a set of new recommendations focused on the cross-border and international context. These recommendations go beyond minimum standards and try to identify best practices. Thus, public policy makers may first wish to assess and ensure observance of CPSS-IOSCO minimum standards while encouraging to strive for G-30 best practices where the market is more mature, or for specific issues that are relevant for the SSSs assessed. The report focuses on three main areas of reform: building a strengthened, interoperable global network; strengthening network safety and stability; and improving governance.

Figure 2.1 summarizes the evolution of international standards in more than a decade, and shows how atten- tion has evolved from the core process issues to increasingly consider other elements such as legal, operational, regulation, and oversight.

In November 2004, the CPSS-IOSCO Task Force issued the document "Recommendations for Central Counterparties (CCPs)" that includes detailed international standards for CCPs' risk management. ${ }^{18}$ The CCPs' large and

\footnotetext{
${ }^{18} \mathrm{~A}$ central counterparty interposes itself between counterparties to financial contracts traded in one or more markets, becoming the buyer to every seller and the seller to every buyer. Central counterparties have long been used by derivatives exchanges and a few securities exchanges and trading systems. In recent years, they have been introduced by many more securities exchanges and have begun to provide their services to over-the-counter markets, including markets for securities repurchase agreements and derivatives.
} 
growing role in SSSs and the potential for risk management failures could disrupt markets and payment and SSSs. For that reason and to increase use of CCPs for securities settlement, the CPSS and IOSCO established the task force to come up with international standards for CCPs' risk management.

In January 2006, the CPSS published the report on crossborder collateral arrangements. There are important liquidity issues arising from commercial banks' use of payment systems. Because collateral plays an important role in securing the credit extended by a central bank, these liquidity issues are deeply interrelated with policies stipulating the terms and conditions under which a central bank accepts collateral. During the past few years, with the globalization of financial markets and the increasing use of collateral to mitigate counterparty risks in financial market transactions, the banking community has discussed the potential use of collateral in one country or currency to obtain liquidity in another. The report analyzes these factors.

At the European regional level, in November 1997, the European Monetary Institute endorsed a report entitled, "Standards for the use of EU Securities Settlement Systems in ECSB Credit Operations," which laid down the nine standards for assessing the soundness of SSSs seeking to qualify for involvement in monetary policy and intraday credit operations. These standards refer to legal soundness, settlement in central bank money, no undue custody risks, regulation or control by competent authorities, transparency of risks, and conditions for participation in a system, risk management procedures, intraday finality of settlement, operating hours and days and operational reliability of technical systems, and availability of adequate back-up facilities.

The European Union's Economic and Finance Ministers (July 17, 2000) defined the terms of reference for a report on the regulation of European securities markets to be produced by the Committee of Wise Men. ${ }^{19}$ Its target was to refine regulatory proposals and produce operational recommendations. The final report included a section regarding clearing and settlement. The committee focused in the process of consolidation for an efficient pan-

\footnotetext{
${ }^{19}$ The chair of this committee was Alexandre Lamfalussy, and included Cornelius Herströter, Luis Angel Rojo, Bengt Ryden, Luigi Spaventa, Norbert Walter, and Nigel Wicks.
}

European clearing and settlement system, and the private and public sector roles in building it. It indicated that the public role would come through the Investment Services Directive review and the work of the Giovannini Group.

The Giovannini Group conducted a comprehensive analysis on cross-border clearing and settlement arrangements for equities, fixed income securities, and derivatives with three main goals: ${ }^{20}$

- To analyze the current situation of cross-border clearing and settlement in the market concerned;

- To consider the requirements against which the efficiency of possible alternatives for clearing, settlement, and depository services can be assessed; and

- To identify some possible alternative arrangements for clearing, settlement, and depository services.

The group identified 15 barriers to efficient cross-border clearing and settlement regarding technical requirements and market practice, national differences in tax procedures, and issues relating to legal certainty. Those impose higher costs to the clearing and settlement process through increased direct costs in the form of higher fees for the services provided, indirect costs due to extra back-office facilities needed to complete the settlement process, and opportunity costs because of the inefficient use of collateral and a higher incidence of failed trades.

In Latin America and the Caribbean, the Council of Securities Regulators of the Americas published in 1996 the document, "COSRA Principles of Securities Clearance and Settlement" and in 2001 the document, "Delivery versus Payment and Settlement Assurance."

\section{MARKET INFRASTRUCTURE, GLOBALIZATION, AND CHALLENGES IN SSSS}

From a securities services perspective, the "customer" includes asset managers, insurance companies, and individuals. The banks, broker-dealers, and nonbank financial institutions provide them with products and market

\footnotetext{
${ }^{20}$ The Giovannini Group consists of financial market participants, and the chair is Alberto Giovannini (deputy general manager of Banca di Roma). It advises the European Commission on financial market issues. The group was formed in 1996 and has focused its work on identifying inefficiencies in the European Union financial markets and proposing practical solutions to improve market integration. The commission's Directorate-General for Economic and Financial Affairs provides the secretariat for the Giovannini Group.
} 
access. The securities value chain from the investment decision to the settlement and added-value services is represented in figure 2.2 .

Clearing and settlement is a key element to determine the infrastructure quality of capital markets. The core clearing and settlement services (shadowed area in figure 2.2) have been normally delimited by the confirmation, clearing, and settlement and banking services associated with the settlement of the securities transactions. Other services were established outside the borderline of clearing and settlement systems. Today, it is difficult to distinguish core clearing and settlement services from the rest, or to define the borderline clearly. Other services such as investment decisions, execution, asset servicing, and other value-added services are provided by the same institutions that provide clearing and settlement services.

In the near future, important changes are expected in the demand and supply of capital that, at the same time, will drive to changes in investors' behavior. Thus, the demand and supply of capital will be influenced by the following:

- Demographics: evolution in the population ratio between prime savers (40-59) and dissavers $(60+)$ could imply a surplus or deficit in capital supply. Aging savers will accumulate surplus capital. The capital they supply will probably exceed what is required to fund global GDP growth.

- Economics: GDP per capita growth in emerging markets will increase capital demand.

In addition, it will produce the following:

- Asset reallocation: the investors and their intermediaries will reallocate assets in the search of increased predictability of returns.
- Higher specialization: the need to respond to a more differentiated demand. Customer demands from the securities services industry will change. There is a move toward a world of differentiation, not a world where "one size fits all."

The most pressing needs extend beyond clearing and settlement. They arise also at the beginning and end of the securities value chain.

The industrial market population will undergo a major change in the next few decades. Figure 2.3 shows the percent of the population by age group for Europe and the United States over a 60-year period. "Prime savers" (ages 40 to 59) are at or near a 100-year peak. Older dissavers will outnumber prime savers in Europe and the United States; the problem is acute in countries such as Italy and Japan, with a ratio of prime savers to dissavers of $2: 1$. In contrast, in the cases of China and India the trend is an increase of prime savers as a percentage of the population.

Changes in the investment strategy will imply:

- More attention to best execution and low fees; and

- Outperformance in emerging markets.

Differentiated needs from investors will imply:

- Increased speed and expandable capacity;

- "Functional flexibility" in the securitized and structured products area;

- A large investor segment interested in "one size fits all" solution, despite the specialized need; and

- Market segments interested in enhanced market transparency and investor protection.

In addition, securities markets are increasingly globalized on trading, but the consolidation of national clearing

Figure 2.2. Securities Services Value Chain

\begin{tabular}{|lllllll}
\hline $\begin{array}{l}\text { Investment } \\
\text { decision }\end{array}$ & Execution & Confimation & $\begin{array}{l}\text { Clearing and } \\
\text { settlement }\end{array}$ & $\begin{array}{l}\text { Banking and } \\
\text { finance }\end{array}$ & $\begin{array}{l}\text { Asset } \\
\text { servicing }\end{array}$ & $\begin{array}{l}\text { Value-added } \\
\text { services }\end{array}$ \\
\hline Transparency & $\begin{array}{l}\text { Indication of } \\
\text { interest }\end{array}$ & Allocation & Clearance & $\begin{array}{l}\text { Credit and cash } \\
\text { management }\end{array}$ & $\begin{array}{l}\text { Income } \\
\text { collection }\end{array}$ \\
Research & Execution & Affirmation & Delivery & $\begin{array}{l}\text { Securities } \\
\text { lending }\end{array}$ & $\begin{array}{l}\text { Corporate } \\
\text { actions }\end{array}$ \\
$\begin{array}{l}\text { Buy-sell } \\
\text { decision }\end{array}$ & Notification & Instructions & Payment & Margin & Tax reclaim \\
finance & Performace \\
reporting
\end{tabular}




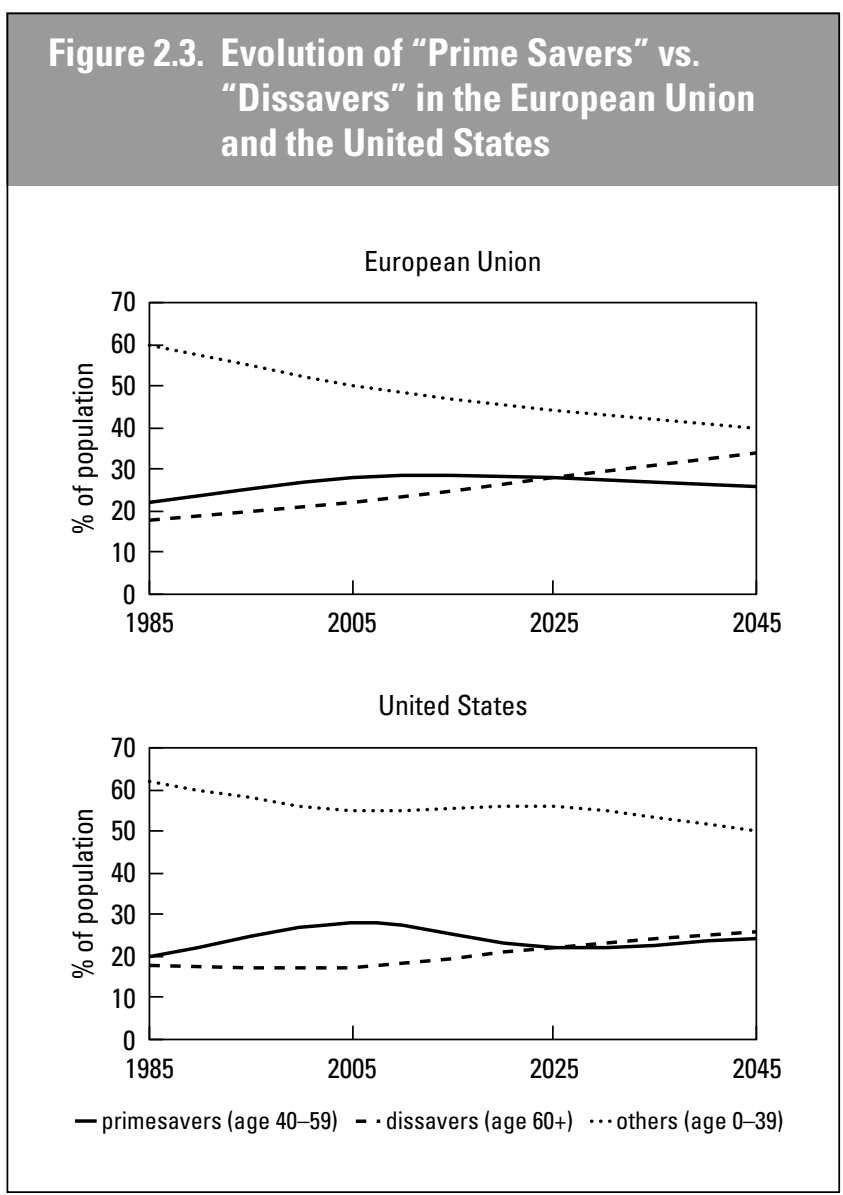

and settlement infrastructures is still an obstacle for market integration. This is especially the case for such regions (for example, Europe) that are in a process of financial markets integration. This consolidation requires a common regulatory approach and a set of governance rules that prevent any natural monopoly position by service providers. But market developments have still not resulted in a clear picture on how and when to achieve that final stage, nor what it ultimately will look like. The objectives are better risk management, reduction of operating costs, achievement of efficiency gains, and maintenance of competitive service offerings and provider choice.

In this environment, what are some of the key issues to give attention in order to provide more efficient and secure clearing and settlement services?:
- Lower cost
- Reduced operational risk
- Straight-through processing
- Fully interoperable markets

- Harmonized regulations

- Fair market access

- Adequate oversight of the systems

- Uniform, consistent supervision of market participants

Chapter 5 of this book analyzes in detail how the countries in Latin America and the Caribbean have faced the challenges described above through the recent reforms of their SSSs.

\section{STRENGTHENING THE OVERSIGHT FUNCTION OF CENTRAL BANKS}

There is an emerging consensus within the international central banking community on the need to ensure the smooth functioning of domestic and cross-border payment systems through appropriate oversight. ${ }^{21}$

The oversight function should be developed and strengthened with a view to ensuring the financial and technical integrity of the payment system; its robustness against shocks; and its overall efficiency through rules, standards, monitoring, and enforcement. In this regard, the CPSS has produced important guidelines on payment system design and, lately, it has laid out the core principles for systemically important payment systems, or systems handling large transaction volumes in relation to the size of their participants..$^{22}$ In addition to the core principles for systemically important payment systems, the CPSS task force identified four central bank responsibilities in applying the core principles, in effect laying out the main features of central banks' oversight of the payments system.

In May 2005, the CPSS published a report on oversight, which starts from the observation that central banks have always had a close interest in the safety and efficiency of payment and settlement systems. One of the principal functions of central banks is to be the guardian of public confidence in money, and this confidence depends crucially on the ability of economic agents to transmit money and financial instruments smoothly and securely through payment and settlement systems. The systems must therefore be strong and reliable, available even when the markets around them are in crisis, and never themselves be the source of such crisis.

\footnotetext{
${ }^{21}$ Central banks in many countries are currently engaged in an effort to clarify their role as payment system overseer. For a recent example, see Bank of England (2000).

${ }^{22}$ For a discussion of the problems relating to compliance with the core principles, see Johnson (2000)
} 
Central banks have traditionally influenced payment and settlement systems primarily by being banks that provide a variety of payment and settlement services to other banks. As such, central banks provide a safe settlement asset, and, in most cases, they operate systems that allow for the transfer of that settlement asset. It is only relatively recently that oversight has become a function that is more formal and systematic - namely a function whereby the objectives of safety and efficiency are promoted by monitoring existing and planned systems, assessing them against these objectives, and, where necessary, inducing change. However, although recent, this development in the nature of oversight has been rapid and the function has now come to be generally recognized as a core responsibility of central banks.

Given the importance of the subject, and the experience that has been gained over the years, the CPSS felt it would be useful to set out publicly what has been learned about effective oversight. Most of this report is both descriptive and analytical, explaining why and how central banks oversee payment and settlement systems. It looks at the need for oversight, the source of central banks' responsibilities for oversight, the scope of oversight, and the activities that oversight involves. In addition, it looks at cooperative oversight, where more than one central bank or other authority has responsibilities for a system. However, in addition to this description and analysis, the report includes 10 principles for effective oversight, each with explanatory text. Five of the principles are generally applicable to oversight arrangements, while the other five are specifically for cooperative oversight arrangements.

As discussed in chapter 6, many central banks beyond the $\mathrm{G}-10$ are involved in the process of establishing the payment system oversight function. 



\section{Assessment Tools}

everal assessment tools were used in the evaluation of the payments and securities settlement systems (SSSs) in each country. In addition to those listed below, mention should be made of the discussions that took place in the working group that prepared the Committee on Payment and Settlement Systems (CPSS) report on guidance on national payment system development (see chapter 2). Some of the authors participated actively in this project and brought to the attention of the international community the experience gained in the different country assessments, which is captured in this book. In addition, they gained from other working group members new perspectives that became an important tool in the assessment exercise, in particular in moving from the assessment to reforms.

\section{WORKING PAPERS 2 AND 3 OF THE WHI (AND WHF)}

Working Paper 3 of the Western Hemisphere Payments and Securities Clearance and Settlement Initiative (and Western Hemisphere Payments and Securities Clearance and Settlement Forum) presents a model for the confidential report, "Assessment and Observations on the Payments Clearance and Settlement System of Country X," which was delivered to each participating central bank at the end of the international team's work, and which was deployed on the field in the context of the Western Hemisphere Payments and Securities Settlement Forum. ${ }^{1}$

${ }^{1}$ This document was prepared by Massimo Cirasino (World Bank) and has benefited from comments by José Antonio García (World Bank), Mario Guadamillas (World Bank), Robert Keppler (World Bank),
Similarly, Working Paper 2 describes the methodology used for the assessment of the securities clearance and settlement systems in the same context. ${ }^{2}$

Another important reference for the assessment is the table of contents and methodology for the Latin America and the Caribbean descriptive reports ("Yellow Books") and statistical tables. ${ }^{3}$ The tables of contents and statistical tables have built on the models of the Group of Ten countries' reports ("Red Books"), and the models of European Union countries ("Blue Books"). ${ }^{4}$

It needs to be noted that at the moment of the preparation of the first draft of these documents, which coincided with the beginning of the activities of the Western Hemisphere Payments and Securities Clearance and Settlement Initiative, most of the other assessment tools presented in this chapter were not available and, therefore, these documents have been particularly useful in carrying out this exercise.

Fernando Montes-Negret (World Bank), and all colleagues participating in the Western Hemisphere Payments and Securities Settlement Forum missions. This tool is constantly being revised as a result of international developments, comments received, and new experience gained from country assessments under the Western Hemisphere Payments and Securities Clearance and Settlement Initiative.

${ }^{2}$ This document was prepared by Mario Guadamillas (World Bank) and has benefited from comments by Massimo Cirasino (World Bank), José Antonio García (World Bank), Robert Keppler (World Bank), and Fernando Montes-Negret (World Bank).

${ }^{3}$ See www.ipho-whpi.org.

${ }^{4}$ See www.bis.org. 


\section{THE CPSS CORE PRINCIPLES FOR SYSTEMICALLY IMPORTANT PAYMENT SYSTEMS}

The CPSS established a task force on payment system principles and practices in May 1998, to consider what principles should govern the design and operation of payment systems in all countries. The task force has developed an international consensus on such principles. It comprised representatives not only from the Group of Ten central banks and the European Central Bank, but also from 11 other national central banks of countries in different stages of economic development from all over the world, and from representatives from the International Monetary Fund and the World Bank. In developing universal principles, it consulted groups of central banks in Africa, the Americas, Asia, the Pacific Rim, and Europe.

In December 1999, the Bank for International Settlements published a draft of the CPSS core principles for comment from the wider financial community. From the responses, it was clear that there is strong and widespread international support for the core principles. It was also clear from the written and oral comments that many readers would value more detail on how to interpret and implement the core principles. Accordingly, the task force developed a second part of this report, which provides such guidance. Public comments were sought once again on a draft of the second part, and the responses demonstrated continuing extensive support for the exercise and its results. The final report was published in January 2001.

The core principles are expressed deliberately in a general way to help ensure that they will be useful in all countries, and that they will be durable. They do not represent a blueprint for the design or operation of any individual system, but rather suggest the key characteristics that all systemically important payment systems (SIPS) should satisfy. The second part of the report therefore discusses in more depth the interpretation of the core principles, by giving more-detailed examples of issues to be addressed in complying with the core principles, and of ways in which these issues have been tackled in some particular contexts. It does not and cannot provide a single model for every practical application of the core principles. It is already apparent that the core principles and the explanatory second part of the report are being used widely to analyze payment systems and to guide oversight and reform. That was the purpose of the exercise; the authors hope that the report will continue to prove helpful for many years to come.

\section{THE INTERNATIONAL MONETARY FUND-WORLD BANK GUIDANCE NOTE FOR ASSESSING OBSERVANCE OF CORE PRINCIPLES FOR SIPS}

This document provides guidelines for assessing CPSS core principles for SIPS (CPSIPS) under the financial sector assessment program. ${ }^{5}$ The CPSIPS apply to individual payment systems that are considered of systemic importance. The assessment also covers the central bank responsibilities in applying the core principles both as operator of a SIPS and as overseer of SIPS run privately.

The most direct application of the CPSIPS is for systems that involve only fund transfers, but CPSIPS also apply to payment systems in which transfers of funds related to other financial assets, such as securities, are settled. In fact, a relevant factor to determine whether a system is systemically important is the nature and origin of the payments it handles, including the cash leg of securities markets transactions. It is widely recognized that there is a strong interrelationship between payments and SSSs. The assessment of both payments and securities clearance systems and SSSs should be highly coordinated.

The following factors are considered relevant to the assessment process:

1. Objective of Assessment. The primary objective of an assessment should be the identification of the nature and extent of any weaknesses in individual SIPS and their observance of the CPSIPS. The assessment should not solely focus on deficiencies, but also highlight relevant strengths. This

\footnotetext{
${ }^{5}$ The first version of the guidance note was published August 2001, in Washington, DC. The guidance note was prepared by a team comprising Kai Barvell and Udaibir Das (International Monetary Fund), and Massimo Cirasino and Mario Guadamillas (World Bank). Charlie Garrigues and Robert Keppler (World Bank) also contributed to the drafting process. The paper benefited from the comments of the CPSS of the Bank for International Settlements, and in particular from Gregor Heinrich and Robert Lindley (CPSS Secretariat), Rita Brizi (Banca d'Italia), Daniel Heller (Swiss National Bank), Jeffrey Marquardt (Board of Governors of the Federal Reserve System), and Elke Wunstorf (European Central Bank). The Guidance Note can also be used for self-assessment or for peer review purposes.
} 
approach will provide a more accurate measure of overall observance with the CPSIPS. The assessments should identify systemically relevant weaknesses of a payment system and recommend actions and priorities for the improvements needed to achieve observance with the CPSIPS. In addition, the assessment should focus on the central bank responsibilities in applying the CPSIPS and, in case of shortcomings, identify the appropriate measures to be taken.

2. Cooperation. A detailed assessment of CPSIPS cannot be performed without the full cooperation of the payment system operator and relevant authorities, which includes primarily the central bank in relation to its role and responsibilities as overseer of the private payments system or as operator of its own SIPS.

3. Access to Information. When conducting an assessment, the assessors must have access to all relevant information and persons. The required information may include not only published documents such as the relevant laws, regulations, rules, and administrative policies, but also more sensitive information, such as self-assessments and operational guidelines used by or compiled by the operator or overseer. ${ }^{6}$ During the mission, the assessor will need to meet with various individuals and organizations. Typically, these could include the payment system overseer and other supervisory authorities, relevant government ministries, payment system participants, other financial sector institutions, and auditors. Special note should be made when any required information is not provided; note should also be made of the impact this might have on the accuracy of the assessment.

4. Assessment by Experts. The assessment of a payment system should be conducted only by persons with sound experience of payment system mechanisms. The assessment process requires judgmental weighing of numerous elements that only qualified assessors - who have practical, relevant experience-can normally make.

5. Comprehensiveness. The assessment must be conducted in sufficient depth to allow judgment to be

${ }^{6}$ Self-assessments are strongly encouraged in the financial sector assessment program process. exercised as to whether assessment criteria are fulfilled in practice, and not just in form. In this regard full cognizance should be given to payment system reforms that are under way. The assessor must be aware of cross-linkages with the banking and securities sectors, and must integrate assessment findings with the assessments of the banking, securities, and core principles and practices of transparency.

6. Assessment of Enforcement. Strong emphasis is to be laid on the actual practice and enforcement of the core principles to ensure the safety and soundness of the payment system. Assessors should evaluate not only the legal and regulatory framework and the rules of the payment system, but also the way in which such rules and legislation are applied in practice and are enforced. If, for example, different kinds of risks in the settlement process are not controlled or properly mitigated due to a lack of enforcement, then this point should be noted via a clarifying comment.

7. Assessment Criteria. In order to achieve full observance with a standard, the assessment criteria must generally be met without any significant shortcomings. These criteria have been taken from the implementation summary for each core principles mentioned in the CPSS report. There may be instances where one can demonstrate that the core principles have been observed through different means other than these criteria. Conversely, due to the specific conditions in individual countries, the assessment criteria identified in this document may not always be sufficient to achieve the objective of the specific standard, and therefore additional elements may have to be taken into account. Examples of these elements have also been included in the assessment criteria under each core principle.

8. Assessment Preparation. Prior to the mission, the assessor will review the self-assessments undertaken by the authorities. A questionnaire has been prepared to be used in instances when a self-assessment is not available or contains significant information gaps. The questionnaire should be sent to the central bank of the country in its capacity as payment system overseer. Response should be obtained well in advance of the field mission. The assessor should also review relevant laws, regulations, instructions, and other documentation (responses to the financial sector assessment program questionnaire, reports, 
studies, public statements, Web sites, and nonpublished guidelines, directives, and assessments). Prior to the mission, the assessor will also need to discuss with the mission chief and agree with relevant authorities on a comprehensive agenda of meetings and interviews with stakeholders in the payments system. These stakeholders include the central bank, other domestic authorities, and any relevant governmental and private sector entities (including bankers associations, card companies, clearinghouses, securities market operators, and so on).

9. Assessment Counterparts. In most countries, at least one SIPS is operated by the central bank, and the assessment work is subsequently conducted by discussing issues with central bank officials, to a large extent.

- In countries where a SIPS is privately operated, the central bank, as the overseer of payment systems, should have made an assessment of the system's observance of the core principles. In such cases, the assessor should primarily discuss the assessment with the central bank, but should also meet with the system operator.

- In case the central bank has not made any assessment of the privately operated system, the assessor should primarily meet with the system operator, but also discuss the result of the assessment with the central bank. It may be the case that in such a situation the central bank would like to attend the assessor's meeting with the system operator, and this would be acceptable. However, in all of the assessor's other interviews, he or she should avoid having someone from the authorities attending the meeting, as this could hamper the dialogue.

10. Assessment Obstacles. The assessor will identify any factors that facilitated or impaired the assessment, with particular reference to the degree of cooperation encountered in carrying out the analysis, and will indicate the extent to which these factors may have affected the objectivity of the assessment.

\section{THE CPSS-INTERNATIONAL ORGANIZATION OF SECURITIES COMMISSIONS RECOMMENDATIONS FOR SSSS}

The CPSS and the technical committee of the International Organization of Securities Commissions (IOSCO) issued recommendations for SSSs in November 2001.
The recommendations were developed by the task force on SSSs that the CPSS and the technical committee of IOSCO created in December 1999. The task force comprises 28 central bankers and securities regulators from 18 countries and regions, and from the European Union. The task force's work has benefited greatly from input from other central bankers and securities regulators, and from operators of, and participants in, SSSs. In January 2000, the task force received input from central bankers and securities regulators - who together represented about 30 countries - as well as from representatives of the International Monetary Fund and the World Bank. In January 2001, the CPSS and the technical committee of IOSCO released a version of this report for public comment. Nearly 90 comments were received, coming from a wide variety of interested parties. Most parties were in Europe, but some were also from Asia, Africa, and the Americas. As a result of these comments, several recommendations have been changed significantly and a new recommendation on cross-border links between settlement systems has been added.

The 19 recommendations and accompanying explanatory texts identify minimum standards that SSSs should meet. The recommendations are designed to cover systems for all types of securities, for securities issued in both industrial and developing countries, and for domestic as well as cross-border trades.

National authorities responsible for the regulation and oversight of SSSs are expected to assess whether markets in their jurisdiction have implemented the recommendations and to develop action plans for implementation where necessary. As an important first step towards establishing a comprehensive methodology for assessing implementation, the report includes key questions pertaining to each of the recommendations, answers to which would form the basis for assessments.

\section{THE ASSESSMENT METHODOLOGY FOR THE SSSS}

As mentioned above, in November 2001 the CPSSIOSCO recommendations for SSSs were published. These recommendations have been included in the key standards for sound financial systems highlighted by the Financial Stability Forum. The CPSS and the technical committee of IOSCO encourage national authorities 
responsible for the regulation and oversight of SSSs to assess whether markets in their jurisdiction have implemented the recommendations and to develop action plans for implementation where necessary.

The assessment methodology, released by the CPSSIOSCO task force in November 2002, aims to set out a clear and comprehensive framework for use in these assessments. The methodology is primarily intended for use in self-assessments by national authorities or in peer reviews of such self-assessments. It is also intended to serve as guidance for the international financial institutions (that is, the International Monetary Fund and the World Bank) undertaking their financial sector assessments, and for other forms of technical assistance, possibly including financing of reforms by the World Bank. In this regard, international financial institutions took part in developing this assessment methodology. Furthermore, the methodology may also prove useful to private market participants who may be conducting their own assessments of the safety and efficiency of SSSs on the basis of the SSSs' observance of the recommendations.

\section{CPSS-IOSCO RECOMMENDATIONS FOR CENTRAL COUNTERPARTIES}

The CPSS-IOSCO recommendations for central counterparties (CCPs), released in March 2004, aim to set out comprehensive standards for risk management of a CCP. CCPs occupy an important place in SSSs. A CCP interposes itself between counterparties to financial transactions, becoming the buyer to the seller and the seller to the buyer. A well-designed CCP with appropriate risk management arrangements reduces the risks faced by SSS participants and contributes to the goal of financial stability. CCPs have long been used by derivatives exchanges and a few securities exchanges. In recent years, they have been introduced into many more securities markets, including cash markets and over-the-counter markets. Although a CCP has the potential to reduce risks to market participants significantly, it also concentrates risks and responsibilities for risk management. Therefore, the effectiveness of a CCP's risk control and the adequacy of its financial resources are critical aspects of the infrastructure of the markets it serves. In light of the growing interest in developing CCPs and expanding the scope of their services, the CPSS and the technical committee of IOSCO concluded that international standards for CCP risk management are a critical element in promoting the safety of financial markets.

The report has 15 headline recommendations and accompanying explanatory text. The recommendations cover the major types of risks CCPs face. The report sets out the intended scope of application of these recommendations and their relationship with the task force report on recommendations for SSSs. The report also includes a methodology for assessing implementation of the recommendations, which identifies key issues and key questions and provides guidance on the assignment of an assessment category.

The CPSS and the technical committee of IOSCO encourage CCPs to conduct a self-assessment of their observance of the recommendations and to utilize the answers to the key questions as a basis for their public disclosure. National authorities responsible for the regulation and oversight of the CCPs are also expected to assess whether the CCPs in their jurisdiction have implemented the recommendations and to develop plans for implementation where necessary. 



\section{Payments Systems Assessment Findings in Latin America and the Caribbean}

his chapter covers the main findings of the Western Hemisphere Payments and Securities Clearance and Settlement Initiative on-the-field assessments in the area of payment systems. The countries assessed are Argentina, The Bahamas, Bolivia, Brazil, Chile, Colombia, Costa Rica, the Dominican Republic, Ecuador, El Salvador, Guatemala, Honduras, Jamaica, Mexico, the Netherlands Antilles, Nicaragua, the Organization of Eastern Caribbean States (OECS), Panama, Paraguay, Peru, Trinidad and Tobago, Uruguay, and the República Bolivariana de Venezuela. ${ }^{1}$ Table 4.1 indicates the date of the original assessment. Updates to these assessments have been included in the information presented in this chapter for most countries.

The assessments took place following the methodology described in chapter 3 . Areas covered in this chapter are legal basis; interbank exchange settlement circuits; retail payment systems; government payments; foreign exchange (FX) and cross-border settlement systems; and the functioning and settlement of the interbank money market.

The chapter is organized as follows: Section 2 deals with issues related to the legal framework, section 3 includes an analysis of large-value payment systems (LVPS), section 4 describes the retail payments systems, section 5 covers the government payments, and section 6 discusses FX and cross-border settlement mechanisms. Section 7

${ }^{1}$ OECS comprises Anguilla, Antigua and Barbuda, the Commonwealth of Dominica, Grenada, Montserrat, St. Lucia, St. Kitts and Nevis, and St. Vincent and the Grenadines.

\section{Table 4.1 Dates of Country Assessments}

\begin{tabular}{l|l}
\hline Country & \multicolumn{1}{|c}{ Date } \\
\hline Argentina & July 1999 \\
Bahamas, The & May 2001 \\
Bolivia & October 2004 \\
Brazil & November 2000 \\
\hline Chile & December 1999 \\
Colombia & February 2001 \\
Costa Rica & June 2001 \\
Dominican Republic & January 2002 \\
Ecuador & August 2002 \\
El Salvador & February 2000 \\
Guatemala & February 2004 \\
Honduras & October 2002 \\
Jamaica & June 2002 \\
Mexico & March 2001 \\
Netherlands Antilles & December 2002 \\
Nicaragua & December 2003 \\
OECS & April 2000 \\
Panama & January 2005 \\
Paraguay & April 2004 \\
Peru & June 1999 \\
Trinidad and Tobago & February 2000 \\
Uruguay & May 2005 \\
Venezuela, R.B. de & November 2002 \\
\hline
\end{tabular}

Source: Authors' elaboration. 
describes the functioning and settlement of interbank money markets, in which the link between funds transfers and securities settlement is explicit.

Each section follows a systematic approach for each issue covered. First, it includes a brief context in which the main areas, normally identified through international standards and best practices, are described. Second, a status in the region subsection box describes the main facts identified for each of the countries in the specific issue covered. Finally, the observations subsections summarize the findings that are often encountered in the systems analyzed.

\section{LEGAL FRAMEWORK}

This section includes context, status in the region, and observations regarding the legal framework.

\section{Context}

A sound and appropriate legal framework is generally considered the basis for a sound and efficient payments system. The legal environment should include (1) laws and regulations of broad applicability that address issues such as insolvency and contractual relations between parties; (2) laws and regulations that have specific applicability to payment systems (such as legislation on elec- tronic signature, validation of netting, and settlement finality); and (3) the rules, standards, and procedures agreed by the participants of a payment system. The legal infrastructure should also cover other activities carried out by both public and private sector entities. For example, the legislative framework may establish clear responsibilities for the central bank or other regulatory bodies such as oversight of the payments system or the provision of liquidity to participants in these systems. Finally, relevant pieces of legislation that have impact on the soundness of the legal framework on the payments system include law on transparency and security of payment instruments, terms, and conditions; antitrust legislation for the supply of payment services; and legislation on privacy (see table 4.2). While laws are normally the appropriate means to enforce a general objective in the payments field, in some cases regulation by the overseers might be an efficient way to react to a rapidly changing environment. In other cases, specific agreements among participants might be adequate; in this case, an appropriate professional assessment of the enforceability of these arrangements is usually required. Finally, because the payments system typically includes participants incorporated in foreign jurisdictions, or the payments system might operate with multiple currencies or across borders, in some cases it may be necessary to address issues associated with foreign jurisdictions.

\section{Status in the Region}

\section{Table 4.2 Main Legal Issues in Individual Latin America and the Caribbean Countries ${ }^{a}$}

\section{Country \\ Legal Issues}

Argentina

Regulatory and Oversight Powers of the Central Bank

The legal framework for payments consists primarily of the Financial Institutions Law of 1997, the Charter of the Banco Central de la República Argentina (BCRA), the Cheques Law of 1995 (amended by Law 24, 760 on December 11, 1996), and the bylaws issued by the BCRA. The BCRA's authority over clearinghouses and similar entities that perform payment settlement functions stems indirectly from the Financial Institutions Law, and is formalized in the BCRA's charter.

Payment Instruments

Two kinds of cheques are recognized by the Cheques Law: ordinary and postdated. The BCRA is authorized by law to regulate the terms and requirements for the opening and closing of accounts with ordinary and postdated cheques, regulate cheque forms, and decide on matters concerning effective rendering of clearing services, including the rejection of cheques, accounts denominated in foreign currency, and the operation of electronic clearing systems.

\section{Settlement Finality and Zero-Hour Rule}

There are no provisions at the level of the law to clarify when settlement is to be considered final, or if zero-hour rules could be applicable. 


\section{Table 4.2 Main Legal Issues in Individual Latin America and the Caribbean Countries ${ }^{\mathrm{a}}$ (Continued)}

\begin{tabular}{|c|c|}
\hline Country & Legal Issues \\
\hline $\begin{array}{l}\text { Argentina } \\
\text { (Continued) }\end{array}$ & $\begin{array}{l}\text { According to the Circular } 2534 \text { of the BCRA, in order to participate in the BCRA's real-time gross settlement } \\
\text { (RTGS), the Medio Electrónico de Pagos (MEP), financial entities must sign an agreement with the former. } \\
\text { This agreement covers all transactions that are settled in the MEP. Article } 3 \text { of the agreement establishes } \\
\text { that all messages issued by financial institutions to move their funds deposited at the BCRA have the nature } \\
\text { of irrevocable payment instructions. }\end{array}$ \\
\hline & $\begin{array}{l}\text { In addition, Article } 4 \text { of the agreement states that the accounts are debited when there are sufficient funds } \\
\text { and as long as there is no judicial order that mandates otherwise (for example, in case of bankruptcy). This } \\
\text { implies that when the BCRA has received notice of the court order, it applies that court order immediately } \\
\text { without any retroactive effect. In this case, therefore, the zero-hour rule does not apply. }\end{array}$ \\
\hline
\end{tabular}

\section{Netting Arrangements}

Although netting is used on a broad scale for the settlement of large-value and retail payments, there is no explicit legal recognition of the netting arrangements.

\section{Electronic Payments, Messages, and Signatures}

Regarding electronic payments, the BCRA only has legal authority, under the Cheques Law, to regulate the operations of electronic cheque-clearing systems. The operation of electronic payment systems is governed by a number of circulars issued by the BCRA. Private clearinghouses have their own rules and procedures, which are based on the provisions contained in BCRA circulars.

\section{Bahamas, The}

\section{Regulatory and Oversight Powers of the Central Bank}

In the Central Bank of the Bahamas (CBOB) Act of 2000, the only explicit mention to payment systems is in Section $\mathrm{VI}$, Article 25, which states that the CBOB may promote the establishment of a bank-clearing system and provide facilities therefore.

\section{Settlement Finality and Zero-Hour Rule}

There is no clear definition at the level of the law of intraday finality for accounting entries in the CBOB's books or in the books of the banks that initiate transfers for their own account or for the accounts of their customers.

\section{Netting Arrangements}

There is no legal definition regarding the validity of multilateral netting schemes.

\section{Electronic Payments, Messages, and Signatures}

Three relevant legal pieces are the Data Protection Act, the Electronic Communications and Transactions Act, and the Computer Misuse Act. Key references to these acts have been incorporated into documented agreements among the clearing banks, and between the latter and the CBOB.

\section{Other Relevant Laws and Provisions}

The operations of the cheque clearinghouse are governed by the Bahamas Clearing Arrangement, which is signed by the seven clearing banks. This agreement covers the clearing process; operational issues; times of the clearing; and treatment of out-station cheques, dishonored cheques, and returns and settlement.

\section{Bolivia}

\section{Regulatory and Oversight Powers of the Central Bank}

Article 3 of the Legal Statute of the Banco Central de Bolivia (BCB) provides a general basis for the oversight function over the payment systems.

\section{Settlement Finality and Zero-Hour Rule}

Although included in the clearinghouses regulation (Article 25.4) and Sistema de Pagos de Alto Valor regulation (Articles 35 and 36 ), the concepts of acceptance, irrevocability, or settlement finality of an order to be processed by the system and the possible implications these concepts may have in different circumstances are not recognized at the level of the law. 


\section{Table 4.2 Main Legal Issues in Individual Latin America and the Caribbean Countries ${ }^{\text {(Continued) }}$}

\begin{tabular}{l|l}
\hline Country & \multicolumn{1}{c}{ Legal Issues } \\
\hline $\begin{array}{l}\text { Bolivia } \\
\text { (Continued) }\end{array}$ & Netting Arrangements \\
Although netting is used on a broad scale for the settlement of large-value and retail payments, there is no \\
explicit legal recognition of the netting arrangements used in financial transactions. \\
Collateral and Repos \\
Article 8 of the BCB Statute and Articles 85 and 131 of the banking law seem to provide enough legal protec- \\
tion to collateral pledged to BCB under repos and reserve requirements (the so-called Fondo RAL). However, \\
Article 128, which establishes the liabilities priority in case of a bank resolution process, only assigns a \\
second-degree priority to liabilities with the BCB. This is a key issue for the envisaged mechanisms for the \\
intraday credit mechanism in the Sistema de Pagos de Alto Valor. \\
Although the repo is regulated in a BCB resolution and the internal rules of the stock exchange, a clear legal \\
definition (ownership transfer) is neither included in the mentioned regulations nor in any law. In the case of \\
the pledge, the general legal basis is included in the civil code, but there is no specific legal framework for \\
the securities used as collateral in financial market transactions.
\end{tabular}

\section{Brazil}

\section{Regulatory and Oversight Powers of the Central Bank}

The general responsibilities of the central bank (Banco Central do Brasil [BACEN]) are stated in its legal statute, Law 4,595, of December 1964.

The Payment System Law of 2001 defines the scope of the Brazilian payments system. This law sets out the specific responsibilities of the BACEN toward payment systems. In particular, it reinforces the BACEN'S broad mandate, stated in Law 4,595, to regulate payment and securities clearance and settlement systems.

Resolution 2,882 of 2001 of the National Monetary Council (Conselho Monetário Nacional) states the payments system objectives of the BACEN. It also defines the scope of application of BACEN's rules and interventions, namely all clearinghouses and system operators that handle interbank transfers and settle among at least three direct participants. Nine general rules with which system operators must comply are the core of this resolution. In general, these rules resemble the Committee on Payment and Settlement Systems (CPSS) core principles for systemically important payment systems.

Furthermore, according to this resolution, the BACEN will conduct oversight on a continuous basis over payment systems; to this purpose, it is entitled to regulate the activities of system operators, authorize the functioning of the systems, and apply sanctions. The resolution also specifies that the BACEN may apply specific provisions to those systems that are considered systemically important, and the resolution clarifies the role of the securities regulator and the cooperative framework between it and the BACEN. Finally, it states that the BACEN will only operate payment systems that settle on a gross basis, in real time.

Following up on this resolution, in August 31, 2001, the BACEN issued Circular 3,057. This circular contains the detailed regulation of the functioning of clearinghouses and other payment system operators, and defines several features with which these entities must comply, including capital requirements, transparency standards, risk control measures, operational requirements, and so on. All these elements had to be submitted to the BACEN for their revision and approval. The annex to the circular also defines a formula to determine whether a system is systemically important, based on the average value of the largest transaction or the aggregate value, or both, over a six-month period.

\section{Settlement Finality and Zero-Hour Rule; Collateral and Repos; Netting Arrangements}

The legal framework established by the payment system law also grants private clearinghouses important legal rights and protections. These are (1) legal rights to seize the collateral pledged by bankrupt participants, (2) protection of the payments system against the implications of a zero-hour rule, and (3) legal recognition of multilateral netting schemes. This legal framework also clarifies specific responsibilities for the clearinghouses: Those that are designated as systemically important by the BACEN must act as central counterparties and guarantee final settlement of the transactions they accept for clearance and settlement. 


\section{Table 4.2 Main Legal Issues in Individual Latin America and the Caribbean Countries ${ }^{\text {(Continued) }}$}

\begin{tabular}{|c|c|}
\hline Country & Legal Issues \\
\hline \multirow[t]{3}{*}{$\begin{array}{l}\text { Brazil } \\
\text { (Continued) }\end{array}$} & $\begin{array}{l}\text { These clearinghouses are subject to sanctions similar to those that are applicable to financial institutions. A } \\
\text { specific restriction is that the net assets of a clearinghouse cannot be used as pledged collateral for any } \\
\text { loans sought by the clearinghouse. }\end{array}$ \\
\hline & Electronic Payments, Messages, and Signatures \\
\hline & $\begin{array}{l}\text { The electronic signature is protected legally. However, some issues regarding the certification authority for } \\
\text { cryptography are still open. }\end{array}$ \\
\hline \multirow[t]{8}{*}{ Chile } & Regulatory and Oversight Powers of the Central Bank \\
\hline & $\begin{array}{l}\text { Article } 3 \text { of the Legal Statute of the central bank (Banco Central de Chile [BCCH]) of } 1989 \text { establishes its main } \\
\text { responsibilities and powers, among which the } \mathrm{BCCH} \text { is responsible for safeguarding currency stability and } \\
\text { the smooth functioning of domestic and foreign payments. According to this law, it is the BCCH's duty to } \\
\text { authorize the creation and regulate the operation of cheque and other clearinghouses in which banks and } \\
\text { financial companies participate. In addition, Article } 35 \text { establishes the duties of the BCCH towards companies } \\
\text { whose line of business is to issue or operate credit cards or any other similar system. The BCCH is empowered } \\
\text { to issue the rules to which such companies must abide. Besides, these companies are subject to monitoring } \\
\text { by the banking supervisory agency. }\end{array}$ \\
\hline & Payment Instruments \\
\hline & $\begin{array}{l}\text { The law on credit transactions and other monetary liabilities generally regulates monetary and credit } \\
\text { transactions, either in local or foreign currency. }\end{array}$ \\
\hline & The Bank Current Accounts and Cheques Law of 1982 regulates the operation and use of cheques. \\
\hline & Other Relevant Laws and Provisions \\
\hline & $\begin{array}{l}\text { The General Banking Law (Ley General de Bancos) of } 1997 \text { groups some relevant provisions for the payments } \\
\text { system in Chile. Among others, the Ley General de Bancos includes the rules that regulate the BCCH's system } \\
\text { to guarantee demand deposits in the case of the failure of a bank. The Ley General de Bancos also regulates } \\
\text { the creation of auxiliary banking institutions by banks, the creation of essential instruments for specific payment } \\
\text { system functions such as clearinghouses, the establishment of automated teller machine (ATM) networks, } \\
\text { and the operation of credit cards. }\end{array}$ \\
\hline & $\begin{array}{l}\text { Finally, the compendium of central bank financial regulations includes, among other provisions, those } \\
\text { related to the large value and retail payments system, such as the operational rules for the RTGS; the } \\
\text { operational rules for the cheque clearinghouse; liquidity credit lines regulations for banks and finance } \\
\text { companies; the required legal reserve; technical reserve regulations; payment cards services; BCCH } \\
\text { transactions with financial instruments; and so on. }\end{array}$ \\
\hline
\end{tabular}

\section{Colombia}

\section{Regulatory and Oversight Powers of the Central Bank}

The central bank does not have a clear empowerment over payment system oversight. The legal foundation for central bank intervention in the system is included in Article 16 of the Central Bank Law 31 de 1992 (Ley Orgánica del Banco de la República [BR]). In describing the central bank functions, the article states that the central bank should study and adopt monetary, credit, and FX measures to regulate monetary circulation and, in general, the liquidity of the financial system, and the smooth functioning of the domestic and international payment system. When the central bank directly provides payment services, it meets its regulatory objectives by means of subscription by participants of bilateral contracts in which all obligations and responsibilities of participants are established, as well as the rules for their operations, service pricing, and the sanctions for noncompliance.

The Law 795/2003 (Estatuto Orgánico del Sistema Financiero) states that the Superintendencia Financiera de Colombia will regulate the payments systems and related activities that are not under the responsibility of the central bank. This activity will be executed with prior consultation to the BR board of directors (Article 6j). In addition, Article 71, paragraph 1, indicates that the Superintendencia Financiera de Colombia will supervise, monitor, and inspect, following general guidelines issued by the national government, the entities administering credit and debit cards or payment and settlement systems. 


\section{Table 4.2 Main Legal Issues in Individual Latin America and the Caribbean Countries ${ }^{\text {(Continued) }}$}

\begin{tabular}{|c|c|}
\hline Country & Legal Issues \\
\hline \multirow{2}{*}{$\begin{array}{l}\text { Colombia } \\
\text { (Continued) }\end{array}$} & Payment Instruments \\
\hline & $\begin{array}{l}\text { The cheque in Colombia is considered as a credit vehicle, and as such is regulated by general norms in } \\
\text { the Commercial Code (Articles } 619 \text { to } 821 \text { ). It is also subject to special provisions of the Commercial Code } \\
\text { (Articles } 712 \text { to } 751 \text { ) and the Single Accounting Circular of the Superintendencia Financiera de Colombia } \\
\text { (Title III, Chapter I). Banking current accounts are governed in general by the Commercial Code (Articles } 1382 \\
\text { to 1392) and by Superintendencia Financiera de Colombia regulations, although the corresponding contracts } \\
\text { are deemed bilateral and consensual. }\end{array}$ \\
\hline
\end{tabular}

\section{Settlement Finality and Zero-Hour Rule}

The laws for liquidation of companies do not explicitly contain any provisions on this area. Nonetheless, Article 2490 of the Civil Code contains a rule applicable to creditors' payments when an individual is in bankruptcy. Following this rule, creditors have the right to demand, following a judicial procedure, the cancellation of any businesses carried out by the debtor against their interests, provided there is fraud of the debtor and its counterpart.

\section{Netting Arrangements}

Regarding the recognition of netting arrangements, under Colombian law bilateral netting is explicitly seen as a way to extinguish obligations when two persons present reciprocal debit positions. Multilateral netting is permitted in cases where multiple and reciprocal entities hold debit and credit positions and participate in a payment system, and where there is an agreement among them, also provided that the agreement respects the provisions of the law. Thus, in Colombia, netting is legally recognized and operates automatically without explicit solicitation of the counterparties between themselves or a third party.

The Colombian Civil Code (Articles 1687 to 1710) rules the legal figure of novation.

\section{Electronic Payments, Messages, and Signatures}

Law 527 of 1999 allows data messages to be used as a means to both offer and accept contracts. In this context, data messages are referred to as the information originated, received, organized, or communicated by electronic, optical, or similar means, such as the electronic data interchange, Internet, and electronic mail. Data messages bases can be admitted as evidence before court proceedings. ${ }^{c}$

In this regard, the signature in a data message is an important element to determine its integrity. When the message contains an electronic signature, the law presumes that the subscriber has the intention of validating the message and of being linked to its content. The use of the digital signature has the same force as the physical signature, as long as it complies with the set of attributes established in the law.

\section{Costa Rica} Regulatory and Oversight Powers of the Central Bank

Law 7558 of 1995 (Organic Law of the Banco Central de Costa Rica [BCCR]) prescribes as one of the basic objectives of the central bank "to promote the efficiency of the internal and external payment system and to maintain its smooth functioning" (Article 2) and as one of its main functions to establish, operate and oversee clearing systems.

Law 7558 also empowers the board of directors of the BCCR to organize and regulate the functioning of the payment system. However, Article 69 of this law seems to limit the BCCR's responsibilities to services provided by the central bank itself; for that reason, it is unclear who is in charge of regulating and overseeing payment systems operated by other entities.

\section{Settlement Finality and Zero-Hour Rule}

There is no explicit mention in any law on when settlement becomes final. The Costa Rican laws do not contain explicit references to the zero-hour rule.

\section{Netting Arrangements}

Neither the civil code nor the commercial code has explicit provisions for netting arrangements. Article 130 of the Securities Markets Law implicitly admits this arrangement for securities clearance and settlement, even though in case of insolvency the court may rule the arrangement as invalid. The principles of netting are not well known outside the payment and securities area. 


\section{Table 4.2 Main Legal Issues in Individual Latin America and the Caribbean Countries ${ }^{\mathrm{a}}$ (Continued)}

Country Legal lssues

(Continued)
Costa Rica

\section{Collateral and Repos}

Articles 49 and 50 of the Securities Markets Law indicate that ownership of the securities is transferred by means of a repo.

\section{Electronic Payments, Messages, and Signatures}

The Securities Markets Law (Article 180) recognizes electronic or magnetic transmission and data-storage media as official proof in a court of law.

A law on digital signatures and digital certificates was issued in 2001. Digital signatures have the same legal validity and effectiveness as written signatures.

\section{Dominican Republic}

In November 2002, the Monetary and Financial Law (Ley Monetaria y Financiera [LMF]) was approved. This law establishes all aspects related to the financial sector as well as the monetary and exchange regimes of the nation. The LMF is a framework law, and the principles contained in it are applied through regulations issued by the monetary board; those regulations have a ranking similar to laws.

Article 27 of the LMF states that the payments system, cheques clearance, and other payment means are a public service whose exclusive regulator is the Banco Central de la República Dominicana (BCRD). As such, the BCRD has to act as the supervisor and final settlement agent of these services. The monetary board is responsible for regulating the organization and functioning of the payment systems to ensure the smooth functioning of payment flows and of the interbank market.

The LMF explicitly prohibits the organization of alternative multilateral settlement systems, although the service could be provided by a private institution if explicitly authorized by the monetary board.

\section{Payment Instruments}

Cheques are ruled by the Cheque Law of 1951, modified by Law 62-2000 of August 2000. This law contains rules regarding the form and creation of the cheque, and the endorsement and the conditions that, if not complied with, make the cheque void. Credit cards are regulated by various resolutions of the monetary board; the last such resolution was issued in February 1988.

\section{Settlement Finality and Zero-Hour Rule}

For the various payment systems there are no explicit legal dispositions dealing with payment finality. Moreover, there is no explicit zero-hour rule.

\section{Netting Arrangements}

Payment system concepts such as bilateral netting and novation are considered only in a general sense in civil legislation. There is no explicit legal base for multilateral netting. However, the LMF states that the monetary board, in order to regulate the functioning of the payments system, may establish different subsystems using the international standards as a reference.

\section{Electronic Payments, Messages, and Signatures}

An electronic trade, documents, and digital signatures law (Ley de Comercio Electrónico, Documentos y Firmas Digitales, No. 126-2002) was approved in 2002, and a draft version of its regulation was being discussed in January 2003. The main purpose of this law is to regulate the identification of the individuals or entities participating in an electronic trade transaction.

\section{Ecuador}

\section{Regulatory and Oversight Powers of the Central Bank}

The Central Bank of Ecuador (Banco Central del Ecuador [BCE]) is empowered under the Monetary Regime and State Bank Law (Ley de Régimen Monetario y Banco del Estado), which is considered as the BCE's legal statute, to establish the monetary policy and to apply financial and exchange rate policies. This law states that the BCE is the official depository of public sector funds and of the banking reserve requirements. Thus, the BCE is the financial and fiduciary agent for the government and is responsible for managing the current accounts held by financial and nonfinancial entities. In this role, it must provide all the necessary facilities 


\section{Table 4.2 Main Legal Issues in Individual Latin America and the Caribbean Countries ${ }^{\text {(Continued) }}$}

\begin{tabular}{l|l} 
Country & \multicolumn{1}{c}{ Legal Issues } \\
$\begin{array}{l}\text { Ecuador } \\
\text { (Continued) }\end{array}$ & $\begin{array}{l}\text { for the proper, timely, and safe execution of the transactions over these accounts; at the same time, it must } \\
\text { control the overall risks in the system. } \\
\text { The regulations code of the BCE sets and regulates its operational responsibilities toward the national clearing } \\
\text { system, the reserve requirement, interbank transactions, public sector current accounts and conventional } \\
\text { payment instruments. There are no legal or regulatory dispositions dealing with the oversight powers of the } \\
\text { central bank over the payments system. }\end{array}$
\end{tabular}

\section{Payment Instruments}

A Cheque Law and its regulation were approved in 1975. The BCE codified regulations rules the BCE operational responsibilities regarding the national clearance and settlement system, the legal reserves ratio, the interbank money market operations, the public sector accounts, and conventional payment media.

\section{Settlement Finality and Zero-Hour Rule}

The Cheque Law explicitly states the timing of settlement finality. There is no such definition for other payment systems. There are no explicit references to the zero-hour rule.

\section{Netting Arrangements}

Netting arrangements are not recognized explicitly in the Ecuadoran laws.

\section{Collateral and Repos}

Repurchase agreements are not defined in Ecuadoran laws. There is however, a National Securities Commission regulation for exchange-traded repos, which entitles the stock exchange to seize the guarantees posted by the selling party.

\section{Electronic Payments, Messages, and Signatures}

A law on electronic trade, electronic signatures, and messages (Ley de Comercio Electrónico, Firmas y Mensajes de Datos) was approved in 2002. It rules data messages, electronic signatures, and certification services, among other issues. Under this law, for all legal purposes data messages have the same validity as paper documents, and electronic signatures have the same validity as written signatures. Annexed messages through a direct electronic link are also legally valid.

\section{El Salvador}

\section{Regulatory and Oversight Powers of the Central Bank}

The legal and regulatory framework that governs the nation's payment system is provided, in a limited way, through the banking law, the commercial code, and Banco Central de Reservas (BCR) regulations. The BCR has responsibility for maintaining the legal reserve requirements established by its board of directors on the daily balances of deposits of commercial banks. The BCR also has the authority to regulate the payment system and provide clearing and settlement services for payment transactions, with settlement taking place through the commercial banks' dedicated reserve accounts. The Superintendence of the Financial Sector supervises banks and other financial institutions.

Finally, the BCR is authorized to issue regulations regarding the payment system. In general, it would appear that the BCR leaves the proposal of new regulations largely to the commercial banks.

\section{Payment Instruments}

There is a relatively old Cheque Law that contains the usual provisions.

\section{Settlement Finality and Zero-Hour Rule}

The timing of settlement finality is not mentioned explicitly in any law. There are no explicit references to the zero-hour rule.

\section{Netting Arrangements}

Netting arrangements are not recognized explicitly in the laws. 


\section{Table 4.2 Main Legal Issues in Individual Latin America and the Caribbean Countries ${ }^{\text {(Continued) }}$}

\begin{tabular}{l|l}
\hline Country & \\
\hline $\begin{array}{l}\text { El Salvador } \\
\text { (Continued) }\end{array}$ & Other Relevant Laws and Provisions \\
In December 2000, a new law (Ley de Integración Monetaria) was passed by congress that introduced, \\
de facto, the dollarization in the country, effective since January 2001. All accounts are denominated in \\
U.S. dollars and the local currency (colón) is currently present only for physical transactions in banknotes \\
and coins. The dollarization has introduced several implications for the payments system in El Salvador. \\
For example, the law states that after a transition period of two years banks will be allowed to maintain \\
their reserve requirements abroad.
\end{tabular}

\section{Guatemala Regulatory and Oversight Powers of the Central Bank}

The Legal Statute of the Banco de Guatemala (Ley Orgánica del Banco de Guatemala [BANGUAT]) dated May 10, 2002, and published in the official gazette on May 13,2002, includes as a basic function of the BANGUAT "to provide for a smooth functioning of the payment system" (Article 4c). Thus, the law is not specific about the role of the central bank in payments systems, but it establishes the basis for its regulatory and oversight powers and, if necessary, for the operation of some systems. In addition, the law empowers the monetary council to regulate the clearinghouse or any other instrument with similar goals (Article 26d). This law also regulates the reserve requirements (Article 43 and 44 ) as the basis for payments settlement in central bank money (Article 70), and in open market operations (Article 46).

\section{Payment Instruments}

Cheques are regulated by the Regulation of the Cheque Clearinghouse, 2003, which also includes the rules for cheque standardization.

\section{Settlement Finality and Zero-Hour Rule}

In the law, there is no provision regarding the concepts of acceptance, irrevocability, or settlement finality of an order to be processed by the system and the possible implications these concepts may have in different circumstances.

\section{Netting Arrangements}

Although netting is used on a broad scale for the settlement of large-value and retail payments, there is no explicit legal recognition of the multilateral netting arrangements, and therefore it is unclear what would be the court's interpretation in case of an insolvency procedure.

\section{Collateral and Repos}

The Civil Law (Article 744) and the Operations Manual of the Stock Exchange Trading Floor (Article 20) include the definition of repo transactions. In both, a repo transaction is defined as the ownership transfer of securities by an agreed price with the commitment, after an agreed period, to transfer back the ownership of fungible securities. The repurchase operation takes place under a contractual arrangement between the counterparties.

\section{Electronic Payments, Messages, and Signatures}

There is no law or regulation thereof with reference to electronic documents and signatures. There is only an explicit authorization of the monetary council to the BANGUAT to operate the systems using electronic records.

\section{Regulatory and Oversight Powers of the Central Bank}

The general empowerment of the central bank regarding payment systems emanates from Article 2 of the Central Bank (Banco Central de Honduras [BCH]) Law. The BCH is responsible for the stability of the internal and external value of the domestic currency and the normal functioning of the payments system. Article 16 includes as one of the functions of the $\mathrm{BCH}$ board the responsibility over the adequate functioning of the financial and payments systems in the country. In terms of liquidity provision by the BCH, Articles 38 and 39 regulate central bank liquidity provision under normal and exceptional circumstances, respectively. Government payments are regulated in Article 56. Chapter IV, Section II, establishes the reserve ratio regulation, and Article 54 specifically states that the reserve ratio funds serve as a basis for the cheque clearinghouse, which only operates in domestic currency. 


\section{Table 4.2 Main Legal Issues in Individual Latin America and the Caribbean Countries ${ }^{\text {(Continued) }}$}

\begin{tabular}{l|l}
\hline Country & \multicolumn{1}{c}{ Legal lssues } \\
\hline $\begin{array}{l}\text { Honduras } \\
\text { (Continued) }\end{array}$ & $\begin{array}{l}\text { Payment Instruments } \\
\text { There is a law and regulation of credit cards. } \\
\text { The Commercial Law (Articles } 595 \text { to } 631 \text { ) regulates cheque clearing. The operation of the electronic cheque } \\
\text { clearinghouse (ECH) is based on an agreement (Convenio Especial para la Administración del Proceso Elec- } \\
\text { trónico de la Cámara de Compensación Nacional) between the bankers' association and the BCH. The agree- } \\
\text { ment indicates that the rules of the system are to be issued by the central bank, and that the operations } \\
\text { settled through the system are under the supervision of the Banking Superintendence. Actually, the BCH has } \\
\text { issued two regulations for the cheque clearinghouse: one for cheque standardization and the other, the } \\
\text { operational rules of the clearinghouse. }\end{array}$ \\
\hline
\end{tabular}

\section{Settlement Finality and Zero-Hour Rule}

There is no explicit zero-hour rule. There is no clarity about the timing of final settlement and, in any case, there is legal uncertainty about the settlement finality of multilateral net debit positions of the cheque clearinghouse.

\section{Netting Arrangements}

There is no legal recognition of netting arrangements.

\section{Collateral and Repos}

The Commercial Law (Articles 1289 to 1307) provides the legal basis for the pledge. Article 1298 regulates securities pledge and the different ways it can be constituted. However, the methods to constitute a pledge of securities are applicable only to securities issued on physical form and, thus, because almost all securities are dematerialized and no central securities depository exists there is no efficient and secure way to constitute a pledge on securities.

Regarding the central bank's (Bank of Jamaica [BOJ]) powers over the payments system, the BOJ Act only contains a reference (Provision 27) to the promotion, by the BOJ, of clearance and settlement facilities for banks. It does not contain any provisions on the powers or the role of the BOJ as payment systems overseer.

As for the payment systems operated by the BOJ, not all of them have detailed rules. Rules are available to the participants, but not to the public.

\section{Settlement Finality and Zero-Hour Rule}

There is no definition of settlement finality at the law level, nor is there a definition of specific triggers for the intervention of a financial institution. ${ }^{d}$

\section{Netting Arrangements}

Netting - in particular, multilateral netting -is not explicitly recognized by law. The only relevant reference is in the bankruptcy law, which allows for the offsetting of the obligations with the bankrupt party.

\section{Electronic Payments, Messages, and Signatures}

In terms of electronic documents and signatures, there is no specific law; there is only an article in the evidence law. So far, that article has been tested positively only in contexts other than the payments system.

\section{Mexico} Regulatory and Oversight Powers of the Central Bank

Article 2 of the Central Bank Law (Ley del Banco de México) of 1993, establishes fostering a well-functioning payments system as one of the primary tasks of the Banco de México. Article 3 defines the central bank's functions, some of which include to regulate the issuance and circulation of currency and of the payments system, and to operate with credit institutions as the reserve bank and as lender of last resort. Article 15 details the requirements and exceptions for financing that the Banco de México may grant to credit institutions in order to avoid problems in the payments system, and details the operations the Banco de México can make as the lender of last resort. Article 24 establishes the central bank's ability to issue regulations for the payments system and to impose sanctions. Article 31 establishes the central bank's ability to regulate the transfer of funds through banks. 


\section{Table 4.2 Main Legal Issues in Individual Latin America and the Caribbean Countries ${ }^{\text {(Continued) }}$}

\begin{tabular}{l|l}
\hline Country & \multicolumn{1}{c}{ Legal Issues } \\
\hline $\begin{array}{l}\text { Mexico } \\
\text { (Continued) }\end{array}$ & $\begin{array}{l}\text { Before November 2002, the interpretation of these powers was that the Banco de México was responsible } \\
\text { for regulating, organizing, and controlling its own payment systems, as well as for overseeing self-regulated } \\
\text { private systems in order to guarantee the continuous, appropriate, efficient, and safe provision of financial } \\
\text { services in a competitive environment of free access. In November 2002, the Mexican Congress enacted the } \\
\text { Payment System Law, granting the Banco de México clear and full powers to oversee all payment systems } \\
\text { and to impose sanctions. }\end{array}$
\end{tabular}

\section{Payment Instruments}

The General Law of Credit Certificates and Transactions (Ley General de Títulos y Operaciones de Crédito) regulates paper-based payment instruments such as cheques, money orders, and bills. A June 2001 reform to the Banking Law authorized banks to provide clients with direct debit or preauthorized charge services.

\section{Settlement Finality and Zero-Hour Rule}

The Payment System Law also clarified the timing of settlement finality in systemically important payment systems, and gave explicit protection to collateral pledged in such systems from any insolvency procedures. Additionally, in the Mexican legislation there are no specific references to the zero-hour rule.

\section{Netting Arrangements}

The Federal Civil Code (Fifth Title, Book 4, Articles 2185 to 2205) contains the legal underpinning for netting arrangements. However, there is no explicit recognition of multilateral netting arrangements. This same code also contains general legal dispositions for novation (Fifth Title, Book 4, Articles 2213 to 2223).

\section{Collateral and Repos}

As for collateralization, in Mexico there are two basic legal frameworks: the pledge, and securities safekeeping (caución bursátil). A relevant feature of securities safekeeping is that the extrajudicial sale of pledged securities may be agreed, as long as the specific execution procedure described in the law is followed.

Ownership of securities is transferred through repurchase agreements, which are regulated in the Ley General de Títulos y Operaciones de Crédito.

\section{Electronic Payments, Messages, and Signatures}

Regarding electronic documents and signatures, the commercial code contains a section on electronic commerce. Article 89 establishes that, for purposes of the code, electronic and optic media and any other technology may be used in commercial activities. Information created, sent, received, filed, or communicated through these media is called a data message. It is presumed (Article 90) that a data message comes from the issuer if a means of identification such as a user name and password has been used, or if the message is received through an automated information system programmed either by the issuer or on his behalf. Article 1298-A establishes that data messages are accepted as proof in a court of law.

On July 5, 2002, the Banco de México issued Circular 19/2002, known as the Circular on Extended Infrastructure. This circular allows the Banco de México to authorize commercial banks to issue digital certificates to their clients for operational purposes and to register and process such certificates through the extended infrastructure.

\section{Netherlands Antilles Regulatory and Oversight Powers of the Central Bank}

In the statutes of the central bank (Bank van de Nederlandse Antillen [BvdNA]) of 1985, there are no provisions regarding the powers of the BvdNA to promote the efficiency of payments and to regulate the security of payment instruments and products, neither are there provisions regarding the oversight powers of the central bank over payment and securities settlement systems. Finally, there are no formal provisions regulating the activities of the BvdNA in offering facilities to the banking sector for the settlement of payments or of securities trades.

\section{Payment Instruments}

In the Code of Commerce (Wetboek of Koophandel), only specific arrangements are given with respect to cheques and bills of exchange. 


\section{Table 4.2 Main Legal Issues in Individual Latin America and the Caribbean Countries ${ }^{\text {(Continued) }}$}

\begin{tabular}{|c|c|}
\hline Country & Legal Issues \\
\hline \multirow{6}{*}{$\begin{array}{l}\text { Netherlands Antilles } \\
\text { (Continued) }\end{array}$} & Settlement Finality and Zero-Hour Rule; Netting Arrangements \\
\hline & $\begin{array}{l}\text { The legal framework is incomplete or nonexistent regarding basic concepts such as settlement finality, the } \\
\text { legal recognition of bilateral or multilateral netting arrangements of payments, and the prevention of possible } \\
\text { conflicts of laws in case a foreign bank with branches in the Netherlands Antilles goes bankrupt. In particular, } \\
\text { it is not certain whether the finality of payments made at the BvdNA's RTGS occurs immediately once a } \\
\text { payment is settled, and that it cannot be revoked or made void, for instance due to the existence of the } \\
\text { so-called zero-hour rule. }\end{array}$ \\
\hline & Collateral and Repos \\
\hline & There is no legal basis for repos or standardized repo contract. \\
\hline & Electronic Payments, Messages, and Signatures \\
\hline & $\begin{array}{l}\text { Regarding electronic means of payment, in } 2000 \text { the parliament enacted a law dealing with the conduct } \\
\text { of contracts via electronic channels and the electronic signature. An e-signature has now the same legal } \\
\text { force as a written one, and there are no judicial hinders to citing electronic documentation or data in a } \\
\text { court of law. }\end{array}$ \\
\hline
\end{tabular}

Nicaragua

Regulatory and Oversight Powers of the Central Bank

The basic legal framework is included in the Banco Central de Nicaragua (BCN) Organic Law. Article 3 of this law articulates BCN's general responsibilities regarding payment systems. Article 38 empowers the BCN to provide cheque-clearing services, mentioning that the reserve requirement can be used as basis for cheque clearing. Government payments are regulated in Article 48.

\section{Settlement Finality and Zero-Hour Rule}

There is no explicit zero-hour rule. There is no clarity about the timing of final settlement and, in any case, there is legal uncertainty about the settlement finality of multilateral net debit positions of the cheque clearinghouse.

\section{Netting Arrangements}

There is no legal recognition of netting arrangements.

\section{Electronic Payments, Messages, and Signatures}

Despite Article 119 of the banking law, which contains several operational rules for the use of information technology in banking operations, the legal framework for the recognition of electronic documents and signatures is not complete. The article could serve as a basis for regulation of these issues, but currently no specific regulation has been issued with respect to payments system.

\section{OECS}

\section{Regulatory and Oversight Powers of the Central Bank}

The legal framework in the OECS is heavily affected by the multiterritorial structure of the organization where eight independent jurisdictions coexist.

On the one hand, the regulatory powers conferred on the Eastern Caribbean Central Bank (ECCB) by the agreement that established it in 1983 have not been used to date. ${ }^{e}$ On the other hand, there is a banking legislation common to all of the member states, collectively referred to as the Uniform Banking Act. The Uniform Banking Act recognizes the ECCB as the region's central bank with responsibility for the supervision of the financial system. Regulatory orders drawn under this law also have the force of law and provide a significant degree of flexibility to the monetary authorities.

The Clearing House Rules establish the ECCB clearinghouse in accordance with the ECCB agreement. The rules and procedures deal with the management of the system, clearing arrangements, settlement, returned items, missing instruments, and general provisions such as endorsement of cheques.

The Procedural Guidelines for Operations between the Commercial Banks and the ECCB explain, among other things, the procedures and time schedules that should be followed to request and utilize the banking services the ECCB avails to the commercial banks, whereas the Procedural Guidelines for Operations 


\section{Table 4.2 Main Legal Issues in Individual Latin America and the Caribbean Countries ${ }^{\text {a }}$ (Continued)}

\begin{tabular}{l|l} 
Country & \multicolumn{1}{c}{ Legal lssues } \\
$\begin{array}{l}\text { OECS } \\
\text { (Continued) }\end{array}$ & $\begin{array}{l}\text { between Participating Governments and the ECCB explain the procedures and time schedules the ECCB } \\
\text { uses in effecting its role as banker to the member governments. }\end{array}$
\end{tabular}

\section{Payment Instruments}

The Bills of Exchange Act (1987) regulates cheques and deals with the legal rules applicable to bills of exchange such as negotiability; the effect of forgery; delivery; acceptance; endorsements; dishonor; alteration and cancellation; presentment; conflict of laws; liability of acceptor, drawer, or endorser; definition and presentment of cheques; promissory notes; signatures; and other related matters.

The legal framework for the clearance and settlement of (intra-island) cheques is to be found in the clearinghouse rules. These rules were issued in 1990 by the ECCB, but the rules were not published in the official gazettes of the territories and they only have a contractual nature.

\section{Settlement Finality and Zero-Hour Rule}

There is no clear definition of intraday finality for accounting entries in the ECCB's books or in the books of the banks that initiate transfers for their own account or for the accounts of their customers.

\section{Netting Arrangements}

There is no legal definition regarding the validity of multilateral netting schemes.

\section{Electronic Payments, Messages, and Signatures}

There is no specific legal framework regarding the acceptability of electronic signatures or of bank computer records as evidence in a court of law.

\section{Other Relevant Laws and Provisions}

Draft Payments Code and General Banking and Payments Rules were completed in September 2003.

\section{Panama}

\section{Regulatory and Oversight Powers of the Central Bank}

The U.S. dollar is legal tender in Panama and there is no central bank. The legal and regulatory framework that governs the Panamanian payment system is provided by the Banking Law (Decree-Law 9, 1998), the fiscal code, the commercial code (Law 57, 1917), the law of the Banco Nacional de Panamá (BNP; Law 20, 1975) and others.

The BNP, a state-owned commercial bank, is authorized to open accounts to any other bank operating in Panama. Government agencies, mixed or government enterprises, and municipalities are obliged to maintain their deposit accounts in the BNP. The clearinghouse of the banking system also functions under the direction and responsibility of the BNP, whose board of directors issues regulations concerning the functioning of the clearing process for cheques, the Automated Clearing House (ACH), debit and credit cards, and oversees compliance with those cards by the banks. The BNP is also authorized to open settlement-only accounts to nonbank payments providers such as Telered (in charge of clearing $\mathrm{ACH}$, debit, and credit cards) and Latinclear (the central securities depository).

Given the special characteristics of the Panamanian monetary and payments system, the payment systems oversight function is not regulated. Some specific regulations in this area are contained in the Banking Law and in the law of the BNP.

\section{Settlement Finality and Zero-Hour Rule}

No specific legal provisions are identified protecting finality and irrevocability of payments and netting. Article 126 of the banking law, however, ranks obligations resulting from the clearing process at the BNP among the top priorities to be honored in case of an insolvency process.

There is no explicit zero-hour rule, nor is there complete certainty as to whether a judge in liquidation proceedings might have the power to revoke obligations against a defaulting financial institution pending settlement. 


\section{Table 4.2 Main Legal Issues in Individual Latin America and the Caribbean Countries ${ }^{\text {(Continued) }}$}

\begin{tabular}{|c|c|}
\hline Country & Legal Issues \\
\hline \multirow{6}{*}{$\begin{array}{l}\text { Panama } \\
\text { (Continued) }\end{array}$} & Netting Arrangements \\
\hline & $\begin{array}{l}\text { No explicit regulations are in place for bilateral or multilateral netting of transactions exclusively related to } \\
\text { the payments system. }\end{array}$ \\
\hline & Collateral and Repos \\
\hline & $\begin{array}{l}\text { The Securities Market Law is clear in protecting securities pledged against any third party claim even in } \\
\text { case of insolvency. Pledged securities therefore, can be executed in a bankruptcy case without the need of } \\
\text { a court order. }\end{array}$ \\
\hline & Electronic Payments, Messages, and Signatures \\
\hline & $\begin{array}{l}\text { A legal framework (Law 43, 2001) supports electronic processing of payments (signature, recording, legal } \\
\text { proof, and so on). }\end{array}$ \\
\hline
\end{tabular}

The Legal Statute of the Central Bank (Ley 489/95-Carta Orgánica del Banco Central de Paraguay [BCP]) describes the authority of the BCP to supervise payment systems. Article 45 indicates that the BCP is responsible for the efficiency and smooth functioning of the payments system. To this purpose, the BCP may adopt measures to develop and upgrade payment systems and may create payment clearinghouses. Article 5 articulates the BCP regulatory authority for the development of its functions. Article 45 also describes the type of instruments that may be settled in the clearinghouse, and Article 64 provides the legal basis for the opening of current accounts of financial institutions at the central bank as well as for the operation of clearinghouses by the BCP. This law also regulates the reserve requirements and the management of public funds by the BCP.

Article 45 provides a general basis for the payment systems oversight function and for the operation of clearinghouses. However, there is no regulation developing in more detail the procedures on which oversight activities are to be based.

Other relevant laws include the Banking Law (Ley 861/96 de Bancos, Financieras y Otras Entidades de Crédito); the Deposit Insurance Law (Ley 2334/2003 de Garantía de Depósitos), and the Bankruptcy Law (Ley 154/70 de Quiebras). Particularly relevant are Articles 13 and 26 of the Deposit Insurance Law, which describe, respectively, the bank resolution causes, and the creditors' priority in case of a bankruptcy, making no mention of any payment system's final settlement balances.

\section{Payment Instruments}

The Cheques Law (Ley 805/96 de Cheques) regulates all aspects related to cheques and their use both as payment instruments and as credit instruments.

\section{Settlement Finality and Zero-Hour Rule}

There are no provisions regarding the concepts of acceptance, irrevocability, or settlement finality of an order to be processed by the system and their possible implications in different circumstances. In fact, the Bankruptcy Law includes cases in which transactions can be revoked after one year (see Article 61).

\section{Netting Arrangements}

There is no explicit legal recognition of multilateral netting arrangements.

\section{Collateral and Repos}

The legal basis for the repo, included in the civil code, is uncertain. Although the legal basis for the pledge is included in the civil code, there is no specific legal framework for the securities used as collateral in financial market transactions.

\section{Electronic Payments, Messages, and Signatures}

There is no legal support to make electronic documents and signatures legally valid. 
Table 4.2 Main Legal Issues in Individual Latin America and the Caribbean Countries ${ }^{\text {(Continued) }}$

\begin{tabular}{l|l}
\hline Country & Regulatory and Oversight Powers of the Central Bank \\
\hline Peru & In Peru, the legal framework that empowers the central bank (Banco Central de Reserva del Perú \\
[BCRP]) to regulate and oversee payment systems stems from its objective to preserve monetary \\
stability. The Organic Law of the BCRP specifies the powers and duties related to its functions as a \\
monetary authority. \\
The BCRP's legal authority is specific and clear in the case of low-value transactions. In this regard, \\
Article 68 of the Organic Law specifies that the regulation of clearinghouses is a competence of the \\
BCRP. In addition, the recently modified Securities Law (Ley de Títulos-Valores, October 2000) empowers \\
the BCRP to issue regulations regarding electronic clearing and settlement of cheques and securities. \\
The banking supervisory agency, however, is the one that grants authorization to parties interested in \\
operating a clearinghouse. \\
This legal empowerment for the BCRP is not present in the case of large-value systems. Thus, although \\
the BCRP has issued regulations for the operation of the central bank-operated RTGS system, legal \\
shortcomings and uncertainties have been solved through the incorporation of adherence agreements \\
(Convenios de Adhesión). Based on them, the participants in the system agree to the conditions \\
established in those agreements.
\end{tabular}

\section{Settlement Finality and Zero-Hour Rule}

There is no provision regarding the concepts of acceptance, irrevocability, or settlement finality at the law level. These concepts have only been included in the operational regulation of the RTGS (Article 7) and in the electronic clearinghouse (ECH) general regulation (Article 12).

In case of insolvency, the so-called zero-hour rule is not applicable in Peru. In case of a bank intervention, the banking supervisory agency decides, on the day of the intervention, if the relevant bank has enough funds to cover its net debit position in the cheque clearinghouse. If the banking supervisory agency decides that the intervened bank will cover its position, the Banking Law (Article 118) states that this debit position should be considered senior debt.

\section{Netting Arrangements}

Multilateral netting is not recognized at the law level, although it is recognized in some regulations (Article 13 of the ECH general regulations). Novation is recognized in the Civil Code (Articles 1277 to 1288), but is only effective when the parties explicitly state their intention to novate.

\section{Collateral and Repos}

It is not clear whether security interests provided under collateral arrangements may be enforced efficiently and in all relevant circumstances.

\section{Electronic Payments, Messages, and Signatures}

In June and July 2000, regulations for the legal recognition of electronic signatures and documents were issued, supporting the electronic processing of payments. Law No. 27291 modified the civil code to adapt its provisions to the use of electronic documents. Law No. 27269 regulates electronic signatures. In addition, Law No. 27309 incorporates the information technology offences in the criminal code.

Trinidad and Tobago

\section{Regulatory and Oversight Powers of the Central Bank}

The Central Bank Law empowers the Central Bank of Trinidad and Tobago (CBTT) the right to issue notes and coins to be regarded as legal tender. The CBTT is also empowered to establish and maintain a clearinghouse for commercial banks operating in the country. The law also specifies other functions of the CBTT in the payment system area, which include (1) issuing demand drafts and other kinds of remittances; and (2) opening accounts for and accepting deposits from the government, local government authorities and statutory bodies, other public authorities, commercial banks, and nonbank financial institutions. 


\section{Table 4.2 Main Legal Issues in Individual Latin America and the Caribbean Countries ${ }^{\text {a }}$ (Continued)}

\section{Country \\ Legal Issues}

Trinidad and Tobago (Continued)
The Central Bank Act and the Financial Institutions Act have been amended to give explicit powers for oversight of the payments system to the central bank. The Financial Institutions Act will cover the treatment of orders for transfer of funds on the commencement of external administration, as well as the validity and enforceability of financial collateral and close-out netting arrangements.

\section{Payment Instruments}

The Bills of Exchange Act states that the law recognizes three types of cheques: ordinary, postdated, and antedated cheques. The Dishonored Cheques Act of 1998 refers to cheques that cannot be covered due to insufficient funds, and makes it illegal for a person to acquire goods or services by use of a dishonored cheque.

\section{Settlement Finality and Zero-Hour Rule}

Currently, there is no specific legislation that addresses issues related to payments and securities clearance and settlement such as acceptance, finality, or revocability.

\section{Netting Arrangements}

There is no explicit legal recognition of multilateral netting arrangements.

\section{Electronic Payments, Messages, and Signatures}

As part of the reform package to modernize legislation with respect to electronic commerce draft policies on electronic funds transfer and data protection were published by the Ministry of Public Administration and Information for Public Comment.

\section{Uruguay}

Regulatory and Oversight Powers of the Central Bank
The Legal Statute of the Central Bank (Banco Central del Uruguay [BCU]) of 1995 includes as a basic function of the BCU "to ensure a smooth functioning of the domestic and foreign payments" (Article 3b). Thus, the law is specific about the role of the central bank in payments systems, but it establishes the basis for its regulatory and oversight powers (although not explicitly) and, if necessary, for the operation of some systems. Articles 6 and 26 regulate the issue of currency. The law also empowers the BCU to establish arrangements with private and public institutions regarding payments and settlement (Article 29). This law also regulates the reserve requirements (Article 27), open market operations, and financial assistance (Articles 27, 36 and 37). Article 55 refers to the securities issued by the central bank.

Article 3 and 7 of the legal statute of BCU provides a general, although not explicit, basis for the oversight function over the payment systems. There is, however, no regulation developing the oversight function and the implications of this activity for the participants in the payments system.

\section{Settlement Finality and Zero-Hour Rule}

There is no provision at the law level regarding the concepts of acceptance, irrevocability, or settlement finality of a payment order to be processed by the system.

\section{Netting Arrangements}

There is no explicit legal recognition of netting arrangements.

\section{Collateral and Repos}

Although the repo is included in a BCU regulation (Title I, Chapter 7, Book 3, Article 182.1) and Communications (2004/110, 111, and 344), a clear legal definition (ownership transfer) is not included either in the regulations or in any law. This BCU Regulation only includes an operational definition and related procedures.

\section{Electronic Payments, Messages, and Signatures}

The legal basis for electronic signatures and documents is included in only a limited way. Article 694 of the Budget Law (Ley de Presupuestos) of 1998 and Decree 65/1998 of March 1998, include these concepts but only for activities related to public administration (for example, public documents). 


\section{Table 4.2 Main Legal Issues in Individual Latin America and the Caribbean Countries ${ }^{\text {a }}$ (Continued)}

\section{Country Legal Issues}

Venezuela, R.B. de

Regulatory and Oversight Powers of the Central Bank

The law of the Banco Central de Venezuela (BCV) dated October 3, 2001, includes as a basic function of the $\mathrm{BCV}$ "to care for the smooth functioning of the payment system of Venezuela and to establish its operating rules" (Article 7, Item 7). The law also empowers the BCV to oversee and regulate the functioning of the different payment systems in the country, whether or not they are operated by the BCV, in order to guarantee that those systems work in an efficient way and within the highest levels of security for the systems participants and for the public (Article 21, paragraph 17).

\section{Payment Instruments}

The legal framework to be applied for cheques is the Commerce Code of Venezuela (El Código de Comercio de Venezuela). The cheques could be drawn al portador (bearer form); two types of cheques exist: a la vista (cash) and a término (term).

Currently, the legal framework for cheques clearing and settlement is the regulation of the system of clearinghouses, issued by the BCV.

\section{Settlement Finality and Zero-Hour Rule}

There are no provisions regarding the concepts of acceptance, irrevocability, or settlement finality of an order to be processed by the system and the possible implications these concepts may have under different circumstances.

There is no explicit zero-hour rule.

\section{Netting Arrangements}

There is no explicit legal recognition of netting arrangements.

\section{Collateral and Repos}

The Banking Law (Article 46) and the Securities Market Law (Article 79) include the definition of repo transactions. In both, a repo transaction is defined as the ownership transfer of securities by an agreed price with the commitment, after an agreed period, to transfer back the ownership of fungible securities. In case the underlying securities of repo transactions are constituted by shares, the ownership transfer must occur at the issuer's registry.

The legal basis for the pledge is included in the civil code but the pledge, as a tool for collateralized financial transactions, is not regulated.

\section{Electronic Payments, Messages, and Signatures}

An electronic documents and signature decree law was approved in February 2001. It regulates signatures and electronic data messages so they are accepted as proof in a court of law. It specifically assigns to the electronic signature the same validity as the autograph signature (see Article 16). In any case, this legal basis is still to be customized for the different settlement systems in the country through their specific regulations and rules.

\section{Source: Authors' elaboration.}

a. The description of legal issues contained in this table is derived from the experience of country missions. The analysis of legal framework of individual countries is particularly complex. Therefore, it is possible that some important elements are omitted and that the description is incomplete. For this reason, the organization of information in the table differs slightly from country to country.

b. See also Table 6.1 .

c. Nonetheless, for the validation of data messages as evidence, elements taken into account are the form in which the data message was generated, archived, and communicated; the form in which the integrity of the information in the message was preserved; and the form in which its initiator was identified. d. At present the BOJ applies a policy of unlimited current account overdrafts, for which reason the legal finality issue is less relevant in practice. If the BOJ decides to limit its credit exposure, this issue will become crucial.

e. Regulations were issued only informally and were never published in the Official Gazettes of the territories, thus not acquiring the legal strength envisaged by the Agreement. 


\section{Observations}

Some of the specific problems identified in the legal and regulatory framework follow:

- In general, there is no regulation developing the oversight function and its implications for the participants of the systems. Nevertheless, central bank laws usually recognize somehow, implicitly in most cases, that the oversight of payment systems is among central banks' functions.

- In general, there is a lack of provisions regarding the concepts of acceptance, irrevocability, or settlement finality of an order to be processed by the system and their possible implications in different circumstances. These concepts are especially important in the case when an insolvency proceeding is opened; the definition of these concepts could limit potential problems. Especially in netting systems, the legal definition of these concepts would reduce uncertainties and curtail the possibility of any unwinding procedures resulting in serious liquidity risk that could derive in systemic risk. Similarly, and although in general there are no explicit zero-hour rules, there is uncertainty on whether the judicial courts may revoke pending or already executed operations made by the defaulting institution.

- Related to the lack of rules on settlement finality, many legal frameworks in the region fail to define specific triggers for the intervention of financial institutions, creating uncertainty about the effective daily closing of the systems or central bank credit risk exposure. ${ }^{2}$

- In countries where the legal framework is more advanced, there is still the possibility that settlement finality is negatively affected because of bankruptcy proceedings through which fraudulent transactions may be reversed several days before the participant is declared bankrupt. However, the impact in case of RTGS systems is likely to be negligible due to the gross nature of the system. Also, some problems of interpretation may arise because, generally, settlement finality is regulated in detail only in system regulations, which have a lower hierarchy than the bankruptcy laws. Initiatives to engage the judicial system in this debate are worth pursuing.

- Normally, there is no explicit legal recognition of the multilateral netting arrangements and therefore it is

\footnotetext{
${ }^{2}$ In case the central bank grants uncollateralized loans or allows current account overdrafts.
}

unclear what would be the interpretation of a court in case of an insolvency proceeding. Because netting is used on a very broad scale for cheque clearing, other retail payments, and even for the settlement of securities transactions, this constitutes a serious legal risk. It may also hamper further development of financial instruments such as derivatives. It is important to protect netting schemes from potentially disruptive insolvency laws so that even if a system participant fails during the day, a liquidator cannot unwind settlement occurring on a net basis later in the day. ${ }^{3}$

- Few countries have enacted a payment system law that covers, among other topics, settlement finality, the protection of systems against bankruptcy proceedings, and the specific oversight powers of the central bank. A similar approach could prove beneficial for other countries, because current legal provisions are generally spread in several laws, and in many cases lack clarity or the required level of specificity.

- On some occasions, the provisions stated in the central bank law have not been developed in specific regulations dealing with the various processes associated with the operation of the different settlement systems. Not all the systems have detailed rules. Thus, participants cannot be aware of the different risks they incur when participating in the systems and the implications of applicable procedures and compromises in all circumstances. This situation, however, is changing rapidly in countries that are introducing new systems, especially those introducing RTGS systems. In other cases, there is also a lack of clarity regarding the sanctions policies and the procedures and conditions for removing participants from the system.

- Although there is a general legal definition for the pledge, in most cases the implications when used to guarantee operations to be processed in a payments system are unclear. The legal basis for the pledge is normally included in the civil code, but the pledge as a tool for collateralized operations is not regulated. Furthermore, there are no rules regarding the procedures for the execution of those guarantees in case of a default. This creates an important impediment for central banks granting or wishing to grant collateralized intraday credit for the purpose of payment settlement.

\footnotetext{
${ }^{3}$ See, for instance, the EU Directive on Settlement Finality in Payment and Securities Settlement Systems (CPSS 2001, p. 19).
} 
- Many countries have recently approved laws for electronic documents and signatures. These need to be completed with the corresponding changes in regulations and rules of settlement systems in order to make effective the legal basis already created in this area and to make clear that the laws also apply to the electronic exchange of messages within the payment systems operated by the central bank or other organizations, or both.

- In general, there is no public or private body responsible for the resolution of potential conflicts arising from the operation of the systems. There is no provision regarding the responsibility of the operator in case of malfunctioning of the system, and therefore there is no rule dealing with a possible compensation for those events.

- Plans to educate the judicial system on the specific legal needs of the financial sector and on the systemic implications of the application of certain laws should be put in place as soon as an exhaustive assessment of the legal framework for the payment system has been completed.

- In sum, country authorities, and, in particular, the committees managing payments systems reform projects, need to review the legal framework with particular attention to the irrevocability of final settlement, adequate protection of the systems against the effects of bankruptcy proceedings, the legal definition of a repo operation, the legal recognition of multilateral netting arrangements, and the legal definition and the regulation of oversight powers of the central bank. Other legal issues to be considered from a developmental point of view include the legal basis for the collateral pledge and securities lending. Due to the variety and extreme importance of these legal aspects, some countries should consider if the importance and number of legal changes required could justify a payments system law. In any case, these topics should be dealt with at the level of a law.

\section{LARGE-VALUE PAYMENT SYSTEMS (LVPS)}

This section includes context, status in the region, and observations regarding LVPSs.

\section{Context}

LVPSs are the most significant components of national payments systems. This is because they are able to generate and transmit disturbances of a systemic nature to the financial sector. In order to cope with these systemic risks, several measures are adopted, depending on the nature of the LVPS. If the system is characterized by a deferred net settlement of payment transactions, risk control measures include the introduction of bilateral and multilateral caps, the implementation of loss-sharing agreements, and the pledging of collateral to cope with the inability of one or more participants to pay. In contrast, the development of RTGS systems is one response to the growing awareness of the need for sound risk management in large-value funds transfer systems. RTGS systems can offer a powerful mechanism for limiting settlement and systemic risks in the interbank settlement process because they can effect final settlement of individual funds transfers on a continuous basis during the processing day. In addition, RTGS systems can contribute to the reduction of settlement risk in securities and FX transactions by facilitating the delivery versus payment (DvP) and payment versus payment (PvP) mechanisms. Variants of the basic RTGS systemthe so-called hybrid systems that take into account liquidity-saving features that exist in net settlement systems - are being introduced in some countries.

\section{Status in the Region}

\section{Table 4.3 Main Features of LVPSs in Individual Latin America and the Caribbean Countries}

\begin{tabular}{|c|c|}
\hline Country & Large Value Systems \\
\hline \multirow[t]{4}{*}{ Argentina } & RTGS System \\
\hline & $\begin{array}{l}\text { The RTGS — the Medios Electrónicos de Pago (MEP)—is owned and operated by the BCRA. It was launched } \\
\text { in } 1997 .\end{array}$ \\
\hline & RTGS System Participants \\
\hline & $\begin{array}{l}\text { Banks, electronic clearinghouses, and the BCRA itself are the direct participants of the MEP. Nonbank financial } \\
\text { intermediaries hold limited-purpose accounts at the MEP. }\end{array}$ \\
\hline
\end{tabular}




\section{Table 4.3 Main Features of LVPSs in Individual Latin America and the Caribbean Countries}

\begin{tabular}{l|l} 
Country & Large Value Systems \\
\hline
\end{tabular}

\section{Argentina} (Continued)

\section{RTGS System Operation}

The MEP enables participants to execute real-time gross transfers through the current accounts held with the BCRA over a long operational cycle that extends from 9:00 a.m. to 8:00 p.m.

Cross-border transfers may be executed through the MEP. Clearinghouses also settle their net balances at the MEP at the end of the operational day.

System participants have access to real-time information on funds available on their accounts. They can use their reserve requirement to make payments throughout the operating day. The system does not provide queuing mechanisms or intraday liquidity facilities. Commercial banks have access to BCRA overnight repos and overnight rediscount credit facilities.

\section{Other Systems that Handle Large-Value Interbank Payments}

In Argentina there are two large-value clearinghouses. ${ }^{a}$ Interbanking, owned and operated by a group of private banks, started operations in mid-1998. Provincanje is the other large-value clearinghouse; it serves the provincial banks. Both provide same-day settlement services, are interconnected, and operate in parallel under BCRA coordination.

In practice, Interbanking operates as a complementary service to the MEP: Interbanking holds an account at the MEP and subaccounts for the participants, through which the former offers multilateral netting services. Banks may use this service to net electronic payments ordered through their central bank accounts. It also offers electronic payment services for entities that do not hold an account at the MEP (private sector firms, for example).

Payments made through Interbanking are settled (on a net basis) on day T at the end of the day through funds transfers via the MEP. It has several risk management procedures in place, including bilateral credit limits, a guarantee fund, and a loss-sharing mechanism.

Bahamas, The RTGS System

The Bahamas Interbank Settlement System is an RTGS system owned by the Central Bank of Bahamas (CBOB). It was launched in May 2004.

\section{RTGS System Participants}

Membership is limited to the current seven clearing banks operating in The Bahamas.

\section{RTGS System Operation}

The system handles transactions in both local currency and U.S. dollars. Although it typically handles large-value and time-critical payments, payments of any magnitude-including those of bank customersmay be submitted via the Bahamas Interbank Settlement System.

The Bahamas Interbank Settlement System operates from 8:30 a.m. to 5:00 p.m. Bahamas Interbank Settlement System participants communicate in a closed users' group environment via the SWIFT network, and access the system via a Web browser.

Payment instructions are irrevocable and final when accepted for settlement: Transfers are processed only if the originating account has enough balance or sufficient intraday credit. The reserves requirement currently stands at 5 percent of prescribed liabilities of the clearing banks, and may be used during the day for payment system purposes. The clearing banks also have access to intraday credit from the CBOB. This credit is fully collateralized and must be repaid by the close of the business day.

\section{Other Systems that Handle Large-Value Interbank Payments}

Some large-value cheques (US $\$ 100,000$ and more) are still processed at the daily clearing through a special procedure. Messengers deliver cheques to the $\mathrm{CBOB}$ up to 4:00 p.m. for value the same day. Telephone advices for cheques over US $\$ 100,000$ are accepted by the CBOB as long as the item is presented by 3:30 p.m. A paper order or confirmation must follow the telephone advice in all cases. 
Table 4.3 Main Features of LVPSs in Individual Latin America and the Caribbean Countries (Continued)

\begin{tabular}{|c|c|}
\hline Country & Large Value Systems \\
\hline \multirow[t]{10}{*}{ Bolivia } & RTGS System \\
\hline & $\begin{array}{l}\text { In late 2003, as part of a broad project for large-value payments, the Banco Central de Bolivia (BCB) } \\
\text { launched the electronic transfers system (Sistema de Transferencias Electrónicas, SITE), which enables } \\
\text { banks to settle transactions in domestic currency or U.S. dollars on an RTGS mode. The SITE operates } \\
\text { through electronic messages originated in remote sites, through terminals connected online with the BCB } \\
\text { where payment orders are settled. }\end{array}$ \\
\hline & RTGS System Participants \\
\hline & $\begin{array}{l}\text { At present, only commercial banks that hold an account and the legal reserve requirement at the BCB may } \\
\text { participate in the SITE. }\end{array}$ \\
\hline & RTGS System Operation \\
\hline & $\begin{array}{l}\text { The types of transactions that can be carried out through the Sistema de Pagos de Alto Valor are } \\
\text { classified in two groups, according to the nature and origin of the information. The first group includes } \\
\text { transactions based on information sent by the participant itself that it transfers to direct SITE partici- } \\
\text { pants and transfers to accounts of other entities in the BCB, which are not direct SITE participants. The } \\
\text { second group includes debits and credits for transactions made directly by the BCB for transactions } \\
\text { related to it. }\end{array}$ \\
\hline & $\begin{array}{l}\text { The current reserves requirement stands at } 12 \text { percent of a group of bank liabilities. Banks can mobilize } \\
\text { a } 2 \text { percent trench during the day. Intraday, overnight, and liquidity credits are available in the SITE. } \\
\text { All these facilities must be properly collateralized. The maximum amount of total credit that may be } \\
\text { granted is } 40 \text { percent of the remaining } 10 \text { percent of each participant's reserves requirement. }{ }^{\text {b }}\end{array}$ \\
\hline & Other Systems that Handle Large-Value Interbank Payments \\
\hline & $\begin{array}{l}\text { Manual funds transfer mechanisms such as the paper-based central bank window facility (carta } \\
\text { interbancaria) and BCB cheques are still operational at the central bank for the transfer of interbank } \\
\text { payments. The BCB intends to gradually migrate all payments made through these mechanisms to } \\
\text { the SITE. For example, in the first half of } 2004 \text {, the carta interbancaria mechanism had already reduced } \\
\text { its relevance to only } 900 \text { transactions representing US } \$ 250 \text { million, compared with US\$2.14 billion of } \\
\text { the SITE. }\end{array}$ \\
\hline & $\begin{array}{l}\text { Some large-value interbank payments are still made with cheques: The average value of a cheque exceeds } \\
\text { US } \$ 4,000 \text {. There is no specific session for large-value items. The clearinghouse is explained in detail in the } \\
\text { Retail Settlement Systems section of this chapter. }\end{array}$ \\
\hline \multirow[t]{4}{*}{ Brazil } & RTGS System \\
\hline & 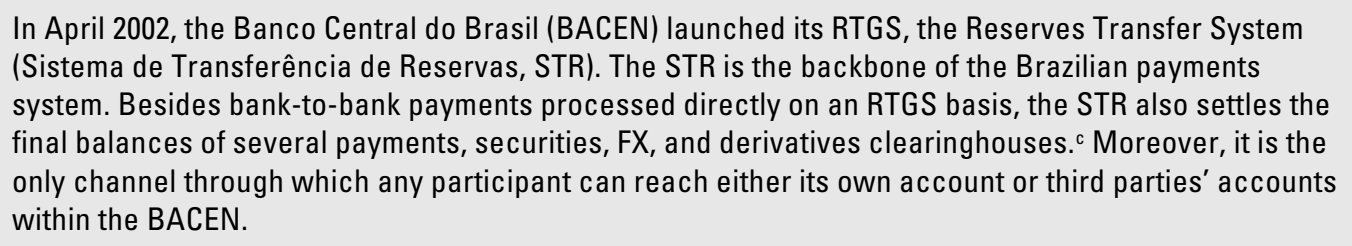 \\
\hline & RTGS System Participants \\
\hline & $\begin{array}{l}\text { In addition to the BACEN and the national treasury (Secretaria do Tesouro Nacional, } 141 \text { deposit-taking } \\
\text { institutions and five private payments clearinghouses (two settlement accounts for the Câmara Interbancária } \\
\text { de Pagamentos [CIP] and three for the Bolsa de Mercadorias e Futuros) are direct participants of the STR. } \\
\text { Deposit-taking institutions are commercial banks, universal banks with commercial banks' capabilities, } \\
\text { and federal savings and loans. They all hold reserve accounts, which are also settlement accounts, within } \\
\text { the BACEN. }^{\text {d }}\end{array}$ \\
\hline
\end{tabular}




\section{Table 4.3 Main Features of LVPSs in Individual Latin America and the Caribbean Countries (Continued)}

Country

Brazil

(Continued)

\section{RTGS System Operation}

The STR's operating hours are from 6:30 a.m. to 6:30 p.m. Nobody but the account owner is allowed to make debits to its settlement account. Making such debits is even forbidden to the BACEN itself. Funds transfers are considered final in the exact moment when the accounts are posted at the BACEN.

Reserves requirements at the BACEN can be freely used during the day. Centralized queuing arrangements are in place in the STR. The main queuing algorithm used is first in, first out (FIFO), allowing for priority, which ranges from $A$ (highest) to $D$ (lowest). An optimization routine is envisaged to prevent gridlock and will be started up at the BCB's discretion.

The BACEN provides the banks with a free, unlimited intraday liquidity facility by means of repo transactions backed with federal government securities. A haircut is applied to the collateral posted. Should an intraday repo not be paid by the end of the day, it will be automatically converted into an overnight repo; a penalty rate applies in this case.

\section{Other Systems that Handle Large-Value Interbank Payments}

In December 2002, the CIP, a Clearing House Interbank Payments System-type system, was launched. At present, the CIP operates two settlement systems - SITRAF and Sistema de Liquidação Diferida de Ordens de Crédito Interbancárias, respectively-for large- and low-value funds transfers.

The SITRAF is a hybrid settlement system. When participants send payment messages, they generate payment obligations that are cleared and settled in a multilateral and deferred manner directly in CIP's settlement account in the STR. However, the CIP also has mechanisms that enable payments to be processed in real time. If sufficient balances are available on the account, the payment can be processed immediately by the clearinghouse. The processed payment immediately affects the accounts within the CIP.

Some large-value cheques are still processed in the Centralizadora da Compensação de Cheques e Outros Papéis (COMPE). The number of large-value cheques has decreased substantially with the introduction of the STR. The decrease is also due to the introduction of a prefunding requirement for cheques with an individual value of reals ( $R$ \$) 5,000 or more. There is no specific session for large-value items. The COMPE system is explained in detail in the Retail Settlement Systems section of this chapter.

\section{Chile}

\section{RTGS System}

Chile launched its RTGS system in 2004. The Sistema de Liquidación Bruta en Tiempo Real (LBTR) is owned and operated by the Banco Central de Chile (BCCH), is fully automated, and handles transactions in local currency only.

\section{RTGS System Participants}

Commercial banks as well as the financial entities licensed by the banking superintendence that hold a current account with the BCCH are RTGS participants. Application for participation must be approved by the $\mathrm{BCCH}$. In addition, all approved participants must sign a contract with the BCCH (the so-called Contrato de Adhesión al Sistema LBTR).

\section{RTGS System Operation}

The LBTR system settles direct funds transfers between system participants and on behalf of their clients, and settles the final positions of the clearinghouses and transactions between the BCCH and system participants. Operating hours are 9:00 a.m. to 6:15 p.m.

Transactions are considered irrevocable and final once accepted for settlement. No current account overdrafts are allowed. All participants have online information on account balances and other relevant statistics.

The system has a queuing and a gridlock resolution mechanism. Payments orders waiting in a queue are processed on the basis of the priority assigned by the participant and, within each priority level, according to the FIFO principle. Payment orders waiting in the queue may be cancelled. The system automatically cancels all payment orders waiting in the queue by the end of the operating day. 


\section{Table 4.3 Main Features of LVPSs in Individual Latin America and the Caribbean Countries (Continued)}

\begin{tabular}{|c|c|}
\hline Country & Large Value Systems \\
\hline \multirow[t]{3}{*}{$\begin{array}{l}\text { Chile } \\
\text { (Continued) }\end{array}$} & $\begin{array}{l}\text { The BCCH offers a credit facility to LBTR participants. This consists of an intraday repo free of charge (Facili- } \\
\text { dad de Liquidez Intradía). In case the participant does not repay by the end of the operating day, the facility is } \\
\text { converted into an overnight repo and a penalty interest rate is applied. Currently, BCCH securities are used } \\
\text { as collateral. }\end{array}$ \\
\hline & Other Systems that Handle Large-Value Interbank Payments \\
\hline & $\begin{array}{l}\text { In addition to the LBTR, the Cámara de Compensación de Pagos de Alto Valor (CCAV) was launched in } \\
\text { December 2005. This system is operated by joint stock company owned by the banks. It is a net system for } \\
\text { large-value payments. The rules of the CCAV approved by the central bank board determine that the CCAV } \\
\text { must establish risk management tools that ensure timely completion of settlement in the event of inability to } \\
\text { settle by the participant with the largest single settlement obligation (i.e., Lamfalussy compliant, Core Princi- } \\
\text { ple V of the CPSS). For this purpose, the CCAV should be able to accommodate several settlement cycles, } \\
\text { require multilateral and bilateral net debit caps, and establish mechanisms to ensure the availability of funds } \\
\text { in case of failure (e.g., multilateral and bilateral limits and loss sharing arrangements). In addition to the } \\
\text { launch of the RTGS and the CCAV systems there is a central bank program for the migration of large-value pay- } \\
\text { ment systems to the new systems that already concluded. Prior to the launch of the RTGS system, payments, } \\
\text { settlement took place through one of the four clearinghouses: interbank operations, cheques and other doc- } \\
\text { uments in domestic currency, ATM, and foreign currency instruments. The migration program targets for the } \\
\text { migration of all large-value payments (over Ch\$50 million) to the new payments system and the use of the clear- } \\
\text { inghouses only for low-value payments. In the medium term, the program targets the closure of the interbank } \\
\text { operations clearinghouse after a period of parallel functioning with the RTGS system; the modification of } \\
\text { operational rules for the cheque to ensure that only low-value payments are settled through this system; and } \\
\text { the gradual elimination of noncollateralized intraday and overnight (one-day) credit. }\end{array}$ \\
\hline
\end{tabular}

\section{Colombia}

\section{RTGS Systems}

In 1998, the Banco de Reserva de Colombia (BR) launched its RTGS system, which operates through the Sistema Electrónico of the BR, the national interbank communications network. Through this RTGS system, called the Sistema Electrónico de Cuentas de Depósito, a variety of operations are settled. These operations include monetary policy operations, treasury payments, interbank money market transactions, the cash leg of securities transactions, and the balances of deferred net payment systems operated by the BR.

\section{RTGS System Participants}

All of financial intermediaries are allowed to hold a current account with the BR and to have direct access to the Sistema Electrónico de Cuentas de Depósito. These financial intermediaries include commercial banks and other deposit-taking institutions, brokers, pension funds administrators, insurance companies, and so on. Payments and securities clearing and settlement service providers are also granted access in order to allow them to settle in central bank money. The government treasury also makes payments in the RTGS through its single account at the BR.

\section{RTGS System Operation}

The system offers all users online information on account balances during the entire operating day (from 8:00 a.m. to 9:00 p.m.). Banks are allowed to mobilize their reserve requirements. All transactions lacking enough funds are put on pending activation (pendiente por activar) status, so that they can be reinserted in the system again as many times as necessary.

The BR provides several liquidity facilities, including intraday and overnight repos. This provision affects the intraday repos, which are charged a 0.1 percent interest rate. The settlement of repo operations with the BR occurs at 2:30 p.m., soon after the funds stemming from cheque clearing are released (approximately 1:00 p.m.) and several hours after knowing the results of the repo auction (approximately 11:30 a.m.). In 2001, the BR authorized the conversion of the intraday repo into an overnight repo, without the seizure of the underlying securities, for the authorized entities. The cost of this conversion is equivalent to the interest rate applied to the Lombard facility of monetary expansion plus 1 percentage point. The requisite for this conversion is that it does not exceed the total limit authorized by the BR for repos for a particular entity. 


\section{Table 4.3 Main Features of LVPSs in Individual Latin America and the Caribbean Countries (Continued)}

\begin{tabular}{l|l}
\hline Country & \multicolumn{1}{c}{ Large Value Systems } \\
$\begin{array}{l}\text { Colombia } \\
\text { (Continued) }\end{array}$ & $\begin{array}{l}\text { Other Systems that Handle Large-Value Interbank Payments } \\
\text { In Colombia, there is no other designated large-value funds transfer system. Some interbank large-value } \\
\text { cheques are still used, although the number has decreased substantially since the introduction of the Sistema } \\
\text { Electrónico de Cuentas de Depósito. There is no specific session for large-value items. The cheque clearing- } \\
\text { house is explained in detail in the Retail Settlement Systems section of this chapter. }\end{array}$
\end{tabular}

\section{Costa Rica}

\section{RTGS System}

Costa Rica's RTGS system, the Transferencias Interbancarias (TI), system was launched in 1999, and is the backbone of the national payments system operated by the Banco Central de Costa Rica (BCCR), the Sistema de Negociación y Pagos Electrónicos. The TI was opened for the settlement of retail payment systems operated by the private sector. Moreover, it has made it possible for the securities and FX markets to settle their transactions safely and efficiently.

\section{RTGS System Participants}

Commercial banks, as well as nonbank financial institutions that hold a current account and reserve requirements with the BCCR, are direct participants of the TI.

\section{RTGS System Operation}

TI operating hours are 8:00 a.m. to 5:00 a.m. Payment orders are settled in real time once they are accepted by the system. In order for this to happen, the beneficiary must indicate to the BCCR that it accepts the credit to its account.

Financial institutions are allowed to use their reserve requirements during the day for payment purposes. Average reserve calculation from second to second during the day has been changed to counting only funds at the end of the day to calculate the two-week (fortnight) average. This has lowered liquidity pressures on banks.

The TI does not have a queuing mechanism. Therefore, a payment order that would lead to an account overdraft is automatically rejected and must be sent in again. The BCCR does not grant intraday loans to banks that have a temporary liquidity shortage. Current account overdrafts are not allowed. Therefore, participants with a temporary liquidity shortage, even though incoming payments later on the day would fully compensate the debit position, are obliged to cover their liquidity needs by means of an overnight repo transaction with the BCCR, or else to cover the debit position in the money market.

\section{Other Systems that Handle Large-Value Interbank Payments}

Some interbank large-value cheques are still used, although the number has decreased substantially since the TI system was introduced. In 2000, its first full year of operation, the TI represented one-third of total settlement throughput. This figure had increased to 70 percent by 2004. Meanwhile, the value of payments settled through cheques has remained stagnant in nominal terms. There is no specific session for large-value items. The cheque clearinghouse is explained in detail in the Retail Settlement Systems section of this chapter.

Dominican Republic

\section{RTGS System}

A RTGS system does not yet exist in the Dominican Republic. The Banco Central de República Dominicana (BCRD) is currently engaged in a project to reform payment systems in the country. The implementation of an RTGS system is included in this project.

\section{Other Systems that Handle Large-Value Interbank Payments}

The LVPS comprises funds transfers among financial intermediaries that hold an account at the BCRD. Such transfers originate mainly from interbank loans made with cheques. These cheques are not processed in the clearinghouse. Multiple banks making a loan draw a cheque that is delivered physically to the BCRD through a messenger. The BCRD executes settlement on a gross basis. Other types of financial institutions also draw cheques that are charged directly to the reserve accounts of multiple banks at the BCRD.

Both retail and large-value payments are processed in the BCRD-operated cheque clearinghouse; these payments include corporate payments, interbank cash withdrawal transactions, funds transfers, and the interbank obligations resulting from other retail payment systems such as credit cards and ATMs. There is no specific session for large-value items. The cheque clearinghouse is explained in detail in the Retail Settlement Systems section of this chapter. 


\section{Table 4.3 Main Features of LVPSs in Individual Latin America and the Caribbean Countries (Continued)}

\begin{tabular}{|c|c|}
\hline Country & Large Value Systems \\
\hline \multirow[t]{8}{*}{ Ecuador } & RTGS System \\
\hline & $\begin{array}{l}\text { The BCE has been working on a payments reform that includes the launch of an RTGS system (Sistema de } \\
\text { Pagos en Línea y Tiempo Real [SPL]). This system was launched in 2005. The BCE does not provide intraday } \\
\text { credit. Banks and other financial institutions with accounts at the BCE are direct participants, in addition to } \\
\text { some public sector entities. }\end{array}$ \\
\hline & Other Systems that Handle Large-Value Interbank Payments \\
\hline & $\begin{array}{l}\text { In addition to the RTGS system, the BCE reform plan includes the following systems: an interbank payments } \\
\text { system (Sistema de Pago Interbancario [SPI]), launched in } 2002 \text { (see the Retail Payments section in this } \\
\text { chapter); a deferred net settlement system (Sistema de Pagos por Valores Netos [SPN]); settlement facilities } \\
\text { for external ACHS (Sistema Nacional de Cámaras de Compensación); a bilateral credit line system (Lineas } \\
\text { Bilaterales de Crédito); and a new custody system for government securities. }\end{array}$ \\
\hline & $\begin{array}{l}\text { Prior to the reform, the Banco Central del Ecuador (BCE) operated three funds transfer mechanisms for large- } \\
\text { value payments (defined as those above US\$500). The first one is the settlement and execution system (Sis- } \\
\text { tema de Liquidación y Ejecución), through which the BCE settled its own transactions with financial } \\
\text { intermediaries. Transactions are irrevocable from the moment they are accepted for settlement by the sys- } \\
\text { tem, which depends solely on the availability of the necessary funds in the Sistema de Liquidación y Ejecu- } \\
\text { ción by the participating banks. }{ }^{f}\end{array}$ \\
\hline & $\begin{array}{l}\text { Financial institutions that participate in the SWIFT closed users' group send credit-type payment messages } \\
\text { to the BCE. Payment instructions are sent online and in real time within the operating hours (9:00 a.m. to } \\
2: 30 \text { p.m.). Although the BCE has developed an interface between this subsystem and its current accounts } \\
\text { system, transactions are not settled in real time but rather at specific cutoff times throughout the day. }\end{array}$ \\
\hline & $\begin{array}{l}\text { The window facility entails the use of paper forms containing standard payment information. Processing is } \\
\text { fully manual and transactions are settled on a gross basis as they arrive at the BCE. Payment instructions are } \\
\text { received from 9:00 a.m. to 3:00 p.m. }\end{array}$ \\
\hline & $\begin{array}{l}\text { The BCE also operates the cheque clearinghouse. Large-value payments and retail payments are channeled } \\
\text { through this system. There is no specific session for large-value items. The cheque clearinghouse is explained } \\
\text { in detail in the Retail Settlement Systems section of this chapter. }\end{array}$ \\
\hline
\end{tabular}

\section{El Salvador} RTGS System

A RTGS system does not yet exist in El Salvador.

\section{Other Systems that Handle Large-Value Interbank Payments}

In El Salvador, there is no other designated large-value funds transfer system. The main means for the exchange of value among banks is the cheque. Commercial banks can also instruct the BCR to debit their reserve accounts during the operating day outside the cheque clearing process, in particular to clear securities transactions.

There is only one formal cheque clearinghouse in the country, located in San Salvador. There is no specific session for large-value items. This system is explained in detail in the Retail Settlement Systems section of this chapter.

Overdrafts of the reserve account are not permitted. As a practical matter, the level of required reserves is high relative to daily clearings, thus, overdrafts are unlikely to occur. The BCR does not provide any form of credit because, due to dollarization, it is constrained by its own law to grant credit to financial institutions, even if collateralized.

Guatemala

\section{RTGS Systems}

In 2004, the Banco Central de Guatemala (BANGUAT) launched the project to implement the RTGS system, which went live in January 2006. The system allows participants to settle in real time large-value and timecritical payments. It also allows participants to settle clearing balances of other payment systems (e.g., the cheque clearinghouse operated by the bankers' association). 


\section{Table 4.3 Main Features of LVPSs in Individual Latin America and the Caribbean Countries (Continued)}

Country

\section{Guatemala}

(Continued)

\section{RTGS System Participants}

All institutions that hold accounts at the BANGUAT (credit institutions and public entities) can participate in the RTGS system. Other institutions can require participation, provided they meet the requirements established by the BANGUAT. System rules explicitly provide for exit and exclusion criteria.

\section{RTGS System Operation}

The RTGS system of the BANGUAT has two main provisions to manage liquidity risk: queuing mechanisms based on optimization techniques, and the provision of intraday credit through collateralized repos. The current reserves requirement stands at 14.6 percent of specified bank liabilities, and banks can mobilize most of it (14.0 percent) during the day. System rules and requirements are included in a document approved by the Monetary Council (Junta Monetaria) on November 30, 2005.

\section{Other Systems that Handle Large-Value Interbank Payments}

Prior to the launch of the RTGS system a funds transfer system between current accounts at the central bank operated through two main mechanisms: (1) the interbank transfers mechanism (mecanismo interbancario de transferencias) in which payment instructions are sent through codified fax; and (2) paper instructions (oficios), a paper-based central bank window facility that is used mainly by the central government. The Sistema de Información Contable y Financiera is the general ledger of BANGUAT. It is fully interconnected with RTGS. The two funds transfer mechanisms mentioned above are not going to be used anymore, as they are being replaced by the RTGS system.

The most relevant system, in addition to the RTGS, is the cheque clearinghouse, which processes both large-value and retail items. There is no specific session for large-value items. Recently, in August 2005, the BANGUAT passed the operation of the system to the bankers association, maintaining a role of oversight and monitoring. The cheque clearinghouse settles its net balances on the RTGS system. BANGUAT is actively involved in reducing the systemic importance of such system by creating price incentives and using moral suasion so as to discourage participants from issuing large-value cheques.

\section{Honduras RTGS System}

An RTGS system does not yet exist in Honduras. The Banco Central de Honduras (BCH) is currently engaged in a project to reform payment systems in the country. The implementation of an RTGS system is included in this project.

\section{Other Systems that Handle Large-Value Interbank Payments}

Although there is no distinction between large- and low-value payments in Honduras, the so-called funds transfer system is used normally only for large-value transactions, whereas the cheque clearinghouse settles both large- and low-value payments.

The funds transfer system is a service offered by the $\mathrm{BCH}$ in association with the current accounts held with it by financial institutions and the government entities with an account at the $\mathrm{BCH}$ include banks, savings and loans, finance companies, FX intermediaries, stock exchanges, and the central government and its agencies and statutory bodies.

The funds transfer system operates through a window at the BCH main office or via SWIFT (only for four banks that are connected to the BCH). Participants can make transactions between 9:00 a.m. and 5:00 p.m., or, in exceptional circumstances, until 7:00 p.m. Funds transfers can be made either in domestic or foreign currency.

Both large- and low-value payments are settled through the cheque clearinghouse. There is no specific session for large-value items. The Centro de Procesamiento Bancario system is explained in detail in the Retail Payment Systems section of this chapter.

The reserve ratio is 12 percent for domestic currency and 50 percent for foreign currency. The domestic currency reserves can be used during the day for payment purposes. In the case of foreign currency reserves, a part must be maintained at the $\mathrm{BCH}$ while another can be in liquid assets with some foreign bank. However, in this case, the part that is maintained with the $\mathrm{BCH}$ cannot be used during the day for payment purposes. 


\section{Table 4.3 Main Features of LVPSs in Individual Latin America and the Caribbean Countries (Continued)}

\begin{tabular}{|c|c|}
\hline Country & Large Value Systems \\
\hline \multirow[t]{7}{*}{ Jamaica } & RTGS System \\
\hline & $\begin{array}{l}\text { An RTGS system does not yet exist in Jamaica. The Bank of Jamaica (BOJ) is currently working on a } \\
\text { project for the modernization of the national payments system, which will include the launching of a } \\
\text { full-fledged RTGS system. The RTGS will replace the current Customer Inquiry and Funds Transfer } \\
\text { System (see below). }\end{array}$ \\
\hline & Other Systems that Handle Large-Value Interbank Payments \\
\hline & $\begin{array}{l}\text { The Customer Inquiry and Funds Transfer System is the communications network and current account } \\
\text { management system operated by the BOJ. This system facilitates the exchange of payment information } \\
\text { among financial institutions, and between them and the BOJ. The system also facilitates movements to } \\
\text { the current accounts financial institutions hold with the BOJ as well as real-time access to account } \\
\text { balances. The main payment instrument that triggers movements in these accounts is the cheque. In } \\
\text { Jamaica, cheques are used for large-value and retail payments, and can be denominated in Jamaican } \\
\text { dollars (J\$) or in some major foreign currencies, of which the U.S. dollars represents more than } 99 \text { percent } \\
\text { of the total. }\end{array}$ \\
\hline & $\begin{array}{l}\text { The clearing and settlement process foresees a special clearing sessions for large-value payments } \\
\text { (J } \$ 500,000 \text { and more) and is held at 3:00 p.m. An additional daily large-value clearing is conducted at } \\
\text { 2:30 p.m. in Montego Bay. Large-value cheques presented at the BOJ during the special clearing have a } \\
T+0 \text { settlement cycle. }\end{array}$ \\
\hline & $\begin{array}{l}\text { In the case of local currency items, at 3:30 p.m. interbank clearing takes place and banks are presented } \\
\text { with their final current account balances which include postings resulting from the clearing of all items } \\
\text { such as cheques. The time window from 3:30 p.m. to 4:20 p.m. is reserved for deposits in order to cover } \\
\text { all outgoing payments and to avoid an account overdraft. }{ }^{9} \text { After 4:20 p.m., settlement of payment instructions } \\
\text { entered into the Customer Inquiry and Funds Transfer System takes place on a net basis. Availability of } \\
\text { funds to Customer Inquiry and Funds Transfer System members occurs normally by the opening of the } \\
\text { next business day. }\end{array}$ \\
\hline & $\begin{array}{l}\text { Settlement of the net balances resulting from the exchange of U.S. dollar-denominated items takes } \\
\text { place directly between two members, according to bilateral agreements. Amounts exchanged exceeding } \\
\text { US } \$ 5,000 \text { must be settled by way of wire transfer into the claiming bank's account in the United States. }\end{array}$ \\
\hline \multirow[t]{8}{*}{ Mexico } & RTGS Systems \\
\hline & $\begin{array}{l}\text { Banco de México owns and operates three systems. The first one is the account holders service system } \\
\text { (Sistema de Atención a Cuentahabientes, SIAC), which handles the current accounts that financial institu- } \\
\text { tions hold at the central bank. Although the majority of large-value transactions are executed through other } \\
\text { systems (see below), the SIAC is particularly important, because all major systems in the country settle their } \\
\text { balances in it. Payment transactions made by third parties or on their behalf may not be processed through } \\
\text { SIAC. }\end{array}$ \\
\hline & $\begin{array}{l}\text { Banco de México also owns and operates the Sistema de Pagos Electrónicos de Uso Ampliado (SPEUA), } \\
\text { which was launched in } 1995 . \text { Only banks have access to the SPEUA, and through it they may execute their } \\
\text { own payments or payments on behalf of customers. At the same time, the processing capacity of the } \\
\text { SPEUA is limited and only transactions of Mex } \$ 50,000 \text { (US } \$ 4,600) \text { or more are accepted for settlement } \\
\text { through it. }\end{array}$ \\
\hline & Finally, the Sistema de Pagos Electrónicos Interbancarios (SPEI) went live on August 2004. \\
\hline & RTGS System Participants \\
\hline & $\begin{array}{l}\text { SIAC: commercial banks, brokerage houses, mutual and pension fund management firms, some insurance } \\
\text { companies, and the national treasury }\end{array}$ \\
\hline & SPEUA: commercial banks \\
\hline & SPEI: commercial banks \\
\hline
\end{tabular}




\section{Table 4.3 Main Features of LVPSs in Individual Latin America and the Caribbean Countries (Continued)}

\begin{tabular}{l|l}
\hline $\begin{array}{l}\text { Country } \\
\text { Mexico } \\
\text { (Continued) }\end{array}$ & RTGS System Operation \\
& SIAC: Orders to transfer funds among institutions holding a current account must be sent through SIAC between \\
8:30 a.m. to 7:30 p.m., and the day of value may be the same day or the following working day. In any given \\
working day (T), the SIAC settles the following: (1) SIAC's own transactions, (2) the balances of the SPEUA \\
(5:45 p.m.), (3) net balances of the retail payments clearinghouse with a T value date (at 8:30 a.m.), and (4) bal- \\
ances of the securities settlement systems, the Sistema Interactivo para el Depósito de Valores, which \\
include transactions made in T - 2, T - 1, and T (at 4:05 p.m.).
\end{tabular}

Only commercial banks may overdraw their accounts at the SIAC. Banco de México sets a limit on overdrafts on the basis of net capital; to use the overdraft facility, banks may post collateral in favor of Banco de México. The SIAC does not settle those payments that would cause the overdraft to exceed this limit or the amount of the collateral posted.

SPEUA: Payment orders are processed and the funds become available to the receiving bank once the system has validated that the issuing bank has enough money or credit available to cover them. The receiving bank must accept these payment orders as long as the beneficiary is the receiving bank itself or one of its account holders, and it must credit the corresponding amount to the respective account within 30 minutes following receipt. The SPEUA operates from 8:30 a.m. to 5:45 p.m. The SPEUA cancels those payment orders that, by closing time, have not passed its controls.

The SPEUA does not operate directly with the banks' current accounts in the SIAC. Rather, it uses a system of virtual cash balances based on bilateral credit lines that are granted among the system's participants. At the end of the day, participants with a debit position, after an end-of-day multilateral netting process, must pay the relevant amount through the SIAC. Final and irrevocable charges are applied in the current accounts of participants with a debit position, and final and irrevocable credits are applied in the accounts of participants with a credit position.

When the multilateral net position of any given bank in the SPEUA exceeds the sum of its current account balance and overdraft limit in SIAC, that bank registers a so-called pending obligation. When this happens, all other banks that granted credit to it face an additional settlement obligation (obligación adicional de liquidación). Banco de México is authorized to charge these latter banks their corresponding obligacións adicionals de liquidación. ${ }^{\text {h }}$

SPEl: The SPEI operates from 8:30 a.m. to 5:00 p.m. The SPEI draws its initial balances from the accounts in the SIAC and settles end-of-day balances in the latter system, as well. The receiving bank must accept payment orders as long as the beneficiary is the receiving bank itself or one of its account holders, and it must credit the corresponding amount to the respective account within 10 minutes following receipt.

There are no overdraft or credit facilities in the SPEI. The SPEI has an advanced queuing system. All payment orders go into the queue and the system continuously executes an algorithm to determine which payments can be settled with the balances that participants have at that particular moment. Payments that cannot be settled immediately remain in the queue and are cancelled by the end of the operating day. Participants can also set priorities and reserve balances to execute priority payments.

The messaging network of the SPEl is based on open protocol, which better allows system participants to automatize their internal processes.

\section{Other Systems that Handle Large-Value Interbank Payments}

Only few large-value cheques, most of them issued by nonfinancial corporations, are processed at the cheque clearinghouse.

The BvdNA operates the Netherlands Antilles Clearing System (NACS), a multicurrency automated network system for the electronic clearing and settlement of large-value interbank payment transactions and small value ACH type payments. The heart of the NACS is the RTGS system, which mainly settles payments denominated in Netherlands Antilles guilders (NA f.) and in U.S. dollars, although settlement in other currencies is also possible. 


\section{Table 4.3 Main Features of LVPSs in Individual Latin America and the Caribbean Countries (Continued)}

\begin{tabular}{|c|c|}
\hline Country & Large Value Systems \\
\hline \multirow{7}{*}{$\begin{array}{l}\text { Netherlands Antilles } \\
\text { (Continued) }\end{array}$} & RTGS System Participants \\
\hline & Only commercial banks can be participants of the RTGS. \\
\hline & RTGS System Operation \\
\hline & $\begin{array}{l}\text { The latter operates with queuing facilities and a V-shape communication structure using the public telephone } \\
\text { infrastructure (dial in) and standard SWIFT messages. According to the rules of the system, all payments } \\
\text { channeled through the RTGS are irrevocable and unconditional. The system uses a strict FIFO settlement } \\
\text { order; it is not possible to change the order of unsettled payment orders. According to the system rulebook, } \\
\text { the participants committed themselves to implement and maintain an adequate cash management and } \\
\text { information program to prevent liquidity, credit, and settlement risks. In practice, however, this is difficult } \\
\text { because the elementary dial-in communication system does not allow the participants to use the information } \\
\text { output of NACS on an online and real-time mode to feed their internal cash management program. If gridlock } \\
\text { occurs in their settlement accounts, banks are obliged to contact the BvdNA. If, at the end of the day, payments } \\
\text { are not settled, the NACS operator is authorized to cancel the entries. }\end{array}$ \\
\hline & $\begin{array}{l}\text { The BvdNA holds current accounts for banks both in local currency (NA f.) and in U.S. dollars. There is a } \\
\text { reserve requirement of } 9 \text { percent for some bank liabilities denominated in NA f., and banks may use their } \\
\text { overnight cash reserves during the day to settle payment obligations in the NACS. The BvdNA also provides } \\
\text { an intraday credit facility. In the case of items denominated in U.S. dollars, because there is no reserve } \\
\text { requirement, settlement can only occur if funds are readily available in the current account or if the BvdNA } \\
\text { grants participants a loan. Normally, all credit must be collateralized in full and is limited to the value of the } \\
\text { pledged securities minus a haircut. The system automatically adds any overdrafts in all the participant's } \\
\text { accounts and compares the total with the available credit before a debit to any of these accounts is executed. }\end{array}$ \\
\hline & Other Systems that Handle Large-Value Interbank Payments \\
\hline & $\begin{array}{l}\text { Cheques are intensively used in the Netherlands Antilles, and large-value cheques are still channeled through } \\
\text { the cheque clearinghouse. Additionally, because only the banks located in Curaçao are connected to the } \\
\text { NACS, bank customers in the other islands of the country have no option other than cheques for interbank } \\
\text { payments. There is no specific session for large-value items. The cheque clearinghouse is explained in detail } \\
\text { in the Retail Payment Systems section of this chapter. }\end{array}$ \\
\hline
\end{tabular}

RTGS System

An RTGS system does not yet exist in Nicaragua.

\section{Other Systems that Handle Large-Value Interbank Payments}

The BCN operates the secure telephone transfer system (Transferencia Telefónica Segura), a credit transfer mechanism for both local currency (córdoba, C\$) and U.S. dollars that settles on a gross basis and that is available for those institutions that hold an account at the BCN, namely banks, nonbank financial institutions (financieras), and the central government's treasury.

The Transferencia Telefónica Segura has become increasingly important: In 2004 it handled nearly 30 percent of total settlement throughput at the BCN. In 2003, the average payment through the Transferencia Telefónica Segura amounted to nearly US\$300,000. The Transferencia Telefónica Segura does not handle payment messages on behalf of third parties and, although there is no designated minimum amount, at present it is used almost exclusively for large-value transactions.

Other large-value payments such as those of commercial and industrial corporations, card schemes, and ATM network-derived interbank obligations are channeled through the cheque clearinghouse, which is also operated by the BCN. This latter system is explained in detail in the Retail Payment Systems section of this chapter.

Banks can mobilize their reserves during the day for payment purposes having only to comply with reserve requirements on a weekly average basis. The $B C N$ provides overnight credit in case a participant is unable to settle its debit position at the cheque clearinghouse. 


\section{Table 4.3 Main Features of LVPSs in Individual Latin America and the Caribbean Countries (Continued)}

\begin{tabular}{|c|c|}
\hline Country & Large Value Systems \\
\hline \multirow[t]{7}{*}{ OECS } & RTGS System \\
\hline & An RTGS system does not yet exist in the OECS. \\
\hline & Other Systems that Handle Large-Value Interbank Payments \\
\hline & $\begin{array}{l}\text { The ECCB operates a gross settlement system for funds transfers between institutions that hold current } \\
\text { accounts with it; this includes commercial banks; governments and statutory agencies; and other nonfinancial } \\
\text { banking institutions including the Eastern Caribbean Central Securities Depository, the Eastern Caribbean } \\
\text { Home Mortgage Bank, and the Eastern Caribbean Institute of Banking. }\end{array}$ \\
\hline & $\begin{array}{l}\text { The technological platform is provided by GLOBUS, which supports ECCB's accounting operations and } \\
\text { processes and records commercial bank transactions in an online, real-time mode. Transactions, when } \\
\text { manually authorized by ECCB staff, are posted directly to the bank's current account. Authorized users, using } \\
\text { dial-up access at their expense, are able to view their balances and recent transactions (for up to two days) } \\
\text { on demand. The GLOBUS system also provides support for the multilateral net settlement of the cheque- } \\
\text { clearing operation that occurs in each of the eight Eastern Caribbean Currency Union countries and for the } \\
\text { securities exchange. There are, on average, a total of } 125 \text { payment transactions per day. }\end{array}$ \\
\hline & $\begin{array}{l}\text { Current accounts at the ECCB are combined with reserve accounts from which banks can temporarily } \\
\text { withdraw funds for the clearance of cheques and the settlement of balances among financial institutions. }\end{array}$ \\
\hline & $\begin{array}{l}\text { At the commercial bank's discretion, large-value transactions, defined normally as cheques with a value } \\
\text { above EC } \$ 50,000 \text { are settled within a special clearings system. In this mechanism, the paying bank, upon } \\
\text { presentation of the cheque, will send a SWIFT message to the ECCB asking to debit its account in favor of } \\
\text { the payee's bank. Bilateral interbank obligations can also be discharged by sending a SWIFT message to the } \\
\text { central bank. All the large-value payments submitted to the ECCB under the current system are settled } \\
\text { promptly on a gross basis during the day of value. }\end{array}$ \\
\hline
\end{tabular}

An RTGS system does not yet exist in Panama.

\section{Other Systems that Handle Large-Value Interbank Payments}

There are two main mechanisms for settling transactions among financial institutions: (1) funds transfers through correspondent banks in the United States, which is the method preferred by financial institutions for interbank payments, and (2) the clearinghouse operated by the BNP.

Concerning the first, the 20 largest banks in the country, at least, use SWIFT, and some of them provide correspondent services to the rest. Interbank transactions are settled on a gross basis through correspondent banks in the United States, either through Fedwire or the Clearing House Interbank Payments System.

All commercial banks operating in Panama are obliged to have a special clearing account with the BNP.j Banks and the ministry of economy and finance can instruct the BNP to debit their accounts during the operating day; this can be done by paper order. This mechanism is seldom used; cheques are the most widely used instrument for domestic interbank transfers.

There are 27 direct and 24 indirect participants in the payments clearinghouse operated by the BNP; all of these participants are commercial banks. Direct participants are fully responsible before the clearinghouse for all operational and financial obligations, both their own and those of the indirect participants they represent. Direct participants settle with indirect participants their mutual obligations on a bilateral basis outside the clearinghouse.

There cannot be overdrafts of the special clearing account, and the BNP does not provide any credit facilities. Banks with debit positions in the clearing process have until 10:00 a.m. to transfer funds to the BNP in case such debit exceeds the balance of the special clearing account. Banks in that position must recur to the interbank market. In case a bank fails to cover a deficit before 10:00 a.m., it is subject to a penalty of US $\$ 20,000$, it will be excluded from the clearing process for one day, and an unwinding process is triggered. 
Table 4.3 Main Features of LVPSs in Individual Latin America and the Caribbean Countries (Continued)

\begin{tabular}{|c|c|}
\hline Country & Large Value Systems \\
\hline \multirow[t]{6}{*}{ Paraguay } & RTGS System \\
\hline & An RTGS system does not yet exist in Paraguay. \\
\hline & Other Systems that Handle Large-Value Interbank Payments \\
\hline & $\begin{array}{l}\text { For interbank payments, banks can affect the accounts they hold at the central bank through the Sistema } \\
\text { Interbancario de Transferencia de Fondos, operated by the BCP. Payments are settled on a gross basis and } \\
\text { are held in queue if the bank does not hold sufficient funds, and are eventually rejected at the end of the day. } \\
\text { Settlement procedures are fully manual in the Sistema Interbancario de Transferencia de Fondos. Payments } \\
\text { orders must be presented physically at the BCP's main office. Payment orders can be of two types: órdenes } \\
\text { for interbank payments and notas for the settlement of transactions related to monetary policy or foreign } \\
\text { currency operations. }\end{array}$ \\
\hline & $\begin{array}{l}\text { The Sistema Interbancario de Transferencia de Fondos does not count on any facilities to manage intraday } \\
\text { liquidity. The current reserve requirement stands at } 15 \text { percent for liabilities denominated in local currency } \\
\text { and } 25 \text { percent for the U.S. dollar-denominated ones. Banks are not allowed at all to mobilize their reserves. } \\
\text { Indeed, these are held in a account separate from the current account banks use for payment purposes. The } \\
\text { interbank money market is rarely used as a means to obtain liquidity. }\end{array}$ \\
\hline & $\begin{array}{l}\text { Despite the existence of the Sistema Interbancario de Transferencia de Fondos, the cheque clearinghouse is } \\
\text { the major funds transfer system and cheques are the main instrument used for the exchange of large-value } \\
\text { interbank payments. Large corporate payments, card schemes, and ATM network-derived obligations are } \\
\text { also settled by cheques. There is no specific session for large-value items. The cheque system is explained } \\
\text { in detail in the Retail Payments System section of this chapter. }\end{array}$ \\
\hline
\end{tabular}

Peru RTGS System

In December 2000, the Banco Central de Reserva del Perú (BCRP) launched the Sistema LBTR, an RTGS for large-value payments. A variety of operations-including monetary policy operations, treasury payments, interbank money market, FX market transactions, and the balances of the Electronic Clearinghouse (ECH)are settled.

\section{RTGS System Participants}

Type I Participants: private commercial banks

Type II: Banco de la Nación (a government-owned commercial bank) and COFIDE (a financial company).

\section{RTGS System Operation}

The system handles transactions in nuevos soles (S/.) and in U.S. dollars. Participants can make transactions on their own behalf or on behalf of their customers. The minimum amount for transfers is $S / .15,000$, or US\$5,000.

The communication structure is Type $\mathrm{V}$, and there is one connection point between each participant and the RTGS. In case of a contingency, the BCRP has terminals available for use by entities experiencing problems; facsimiles will be used only as a last resort.

Operating hours are from 8:00 a.m. to 6:30 p.m. Payment instructions are irrevocable and final when accepted for settlement: Transfers are processed only if the originating account has enough funds or sufficient intraday credit. Banks can mobilize their reserve requirements during the operating day. Before beginning operations, funds to cover debit positions stemming from the ECH are blocked in the accounts of the participants.

The system includes a queuing mechanism that uses a bypass FIFO algorithm, although priority is given to instructions that relate to payments to the BCRP. Payments in the queue may be cancelled by the originating entity. At 5:00 p.m., payments still pending are cancelled automatically. Intraday credit is provided to Type I participants only through intraday repos. If, by the time of closing, participants are not able to cover their debit positions, the collateral they have posted will be executed. Debit positions in U.S. dollars are covered first. 
Table 4.3 Main Features of LVPSs in Individual Latin America and the Caribbean Countries (Continued)

\begin{tabular}{l|l}
$\begin{array}{l}\text { Country } \\
\text { Peru } \\
\text { (Continued) }\end{array}$ & $\begin{array}{l}\text { Other Systems that Handle Large-Value Interbank Payments } \\
\text { With the introduction of the LBTR, the cheque clearinghouse has significantly reduced its systemic importance. } \\
\text { The remaining large-value cheques are generally issued by nonfinancial corporations. There is no specific } \\
\text { session for large-value items. The cheque system is explained in the Retail Payment Systems section of } \\
\text { this chapter. }\end{array}$
\end{tabular}

Trinidad and Tobago

RTGS System

The RTGS system of Trinidad and Tobago called Safe-tt was launched on October 2004. Safe-tt is a system for settling large-value and time-critical payments between the banks. Large-value payments are defined as payments of Trinidad and Tobago dollars (TT\$) 500,000 and more.

\section{RTGS System Participants}

The participants in the Safe-tt are the institutions that hold a current account at the CBTT, namely the commercial banks and the government. As of December 2005, there were a total of 21 participants, of which seven have the status of direct participants.

\section{RTGS System Operation}

As of May 2005, approximately 80 transactions per day were processed in the Safe-tt. The system supports payments made by banks on behalf of third parties. The system is based on SWIFT messaging.

The reserve requirement currently stands at 9 percent of prescribed liabilities of commercial banks. The CBTT provides intraday credit. The system operates from 8:00 a.m. to 2:45 p.m. for all payments, and until 3:15 p.m. for interbank payments only.

A Safe-tt users' group has been formed to address issues related to system improvements.

\section{Other Systems that Handle Large-Value Interbank Payments}

Approximately 200 large-value cheques (TT $\$ 500,000$ or more) are cleared each day through a special clearings procedure. Any commercial bank receiving a large-value cheque drawn by a CBTT account holder seeks clearance by telephone from the CBTT. Once clearance is given, the CBTT credits the commercial bank's reserve account. When the CBTT receives large-value cheques drawn on commercial banks, however, it calls the commercial banks to obtain clearance before affecting the banks' reserve accounts.

The cutoff time for obtaining clearance is 1:30 p.m. on Mondays through Thursdays, and at 12:30 p.m. on Fridays. Each commercial bank involved in the special clearings process of that day will exchange a special clearing facsimile message with each other or with the CBTT within 30 minutes of the deadlines. The physical items are presented and exchanged in the low-value cheque clearinghouse on the following morning.

\section{Uruguay}

\section{RTGS System}

The RTGS system is operated by the BCU. This system operates as a module within the BCU's main operating system, the Sistema Electrónico de Comunicaciones, and is available for some of the institutions holding a current account at the BCU to make funds transfers among them.

\section{RTGS System Participants}

At present, the general policy (not written) is that all participants in the Sistema Electrónico de Comunicaciones must have a current account with the BCU. However, having an account at the BCU does not give automatic access to the Sistema Electrónico de Comunicaciones.

\section{RTGS System Operation}

The RTGS is the major funds transfer system in the country.

Participants have access to real-time information regarding their balances at the BCU, as well as their overall liquidity positions. The funds banks hold at the $\mathrm{BCU}$ as reserves requirements $\mathrm{can}$ be used to make payments during the day. 


\section{Table 4.3 Main Features of LVPSs in Individual Latin America and the Caribbean Countries (Continued)}

\begin{tabular}{|c|c|}
\hline Country & Large Value Systems \\
\hline \multirow[t]{5}{*}{$\begin{array}{l}\text { Uruguay } \\
\text { (Continued) }\end{array}$} & $\begin{array}{l}\text { The system provides settlement on a real-time basis if the participants have sufficient liquidity on their settlement } \\
\text { accounts to cover the payment orders or if they can obtain sufficient credit from the BCU. There is no queuing } \\
\text { system in place. At present, all credit extensions of the BCU are collateralized. There are no particular incentives } \\
\text { (for example, pricing policy) to foster the participants delivering their payments early in the operating day. }\end{array}$ \\
\hline & $\begin{array}{l}\text { The funds transfer system within the Sistema Electrónico de Comunicaciones is migrating to a new } \\
\text { technological platform known as AGATA. }\end{array}$ \\
\hline & Other Systems that Handle Large-Value Interbank Payments \\
\hline & $\begin{array}{l}\text { Cheques are still used as an instrument for the exchange of large-value payments. There is no specific session } \\
\text { for large-value items. The cheque clearinghouse is described in detail in the Retail Payment Systems section } \\
\text { of this chapter. }\end{array}$ \\
\hline & $\begin{array}{l}\text { Manual paper-based interbank transactions via the BCU are still possible, although at present the volume } \\
\text { and value of transactions is small when compared with the RTGS and the cheque clearinghouse. }\end{array}$ \\
\hline \multirow[t]{7}{*}{ Venezuela, R.B. de } & RTGS System \\
\hline & An RTGS system does not yet exist in the República Bolivariana de Venezuela. \\
\hline & Other Systems that Handle Large-Value Interbank Payments \\
\hline & $\begin{array}{l}\text { Approximately } 500 \text { transactions are processed every day in the current account credit transfer facilities that } \\
\text { the BCV provides. Within these facilities, the main system is the so-called SWIFT DC298, a closed users' } \\
\text { group, which represents } 83 \text { percent of total volume and nearly } 80 \text { percent of settlement throughput. } \\
\text { Transactions are settled gross on the same day through an interface between SWIFT DC298 and the BCV's } \\
\text { current account system. }\end{array}$ \\
\hline & $\begin{array}{l}\text { Manual facilities include paper orders (carta orden) and telex transmissions. Processing of these payment } \\
\text { instructions by the central bank is manual, and transactions are settled on a gross basis as they arrive. The } \\
\text { BCV allows approximately } 60 \text { minutes to process telex transmissions. This period is extended to } \\
90 \text { minutes for paper orders, because signature verification is required. }\end{array}$ \\
\hline & $\begin{array}{l}\text { Both large-value and retail payments can be channeled through the cheque-clearing system, which is } \\
\text { operated by the BCV. There is no specific session for large-value items. The cheque clearinghouse is } \\
\text { explained in detail in the Retail Payment Systems section of this chapter. }\end{array}$ \\
\hline & $\begin{array}{l}\text { Participants can use their reserve requirement throughout the day to make payments. The BCV does not } \\
\text { provide credit facilities for payment system purposes. }\end{array}$ \\
\hline
\end{tabular}

Source: Authors' elaboration.

a. The BCRA designates clearinghouses as large value if they settle transactions within 24 hours, regardless of their value.

b. The reserve requirement is invested in securities through a special-purpose fund (Fondo de Reserva de Activos Líquidos).

c. The basic general model for settlement in central bank money is for the clearinghouses to receive funds from participants with net debt position at some time during their operational cycle, and then pay participants with a net credit position. To this end, each clearinghouse was given a settlement window during STR operating hours.

d. Investment banks also have the option to hold a reserve account, provided they meet all technological requirements.

e. In order to process the greatest number of messages possible, processing of queued messages complies with criteria such as selection of processing method (gross, bilateral net, or multilateral net), references chosen by remitting banks and the chronological order of messages' entry. The regulation of the Sistema de Transferência de Fundos (SITRAF) also states that remitting banks should program the sending of payment messages in such a way as to ensure that at least 70 percent of the volume expected for the whole main cycle will effectively be remitted during the first two-thirds of the period.

$f$. The BCE does not provide any form of credit, and does not foresee doing so. The major reason is that Ecuador is a dollarized economy and, thus, the BCE cannot act as lender of last resort.

g. However, all payment instructions entered into the system could be considered final because the BOJ guarantees the settlement of all outgoing funds transfer instructions.

h. Hence, this guarantee would cover the participant's inability to settle with the largest settlement obligation, although it may not be sufficient if two or more big participants are unable to settle.

i. Banks can bring in fresh collateral to enlarge their credit facility at the NACS. However, this procedure cannot be executed on the same day. For this reason, if a gridlock were to occur in the accounts of the sender, the board of the BvdNA, after contacting the participant concerned, can decide to grant it an uncollateralized loan. The latter is usually covered by the next day.

j. Panama is fully dollarized, and there is no central bank in the country. 
Table 4.4 Operational Risk Management in LVPSs in Selected Latin America and the Caribbean Countries*

\begin{tabular}{|c|c|c|}
\hline Country & Backup Facilities & Business Continuity Plans \\
\hline Argentina & $\begin{array}{l}\text { The BCRA has an alternative processing site. This site is } \\
\text { to be used in case of an extended malfunctioning of the } \\
\text { primary site. In other words, the transfer of the processing } \\
\text { from the primary site is not automatic, but occurs only } \\
\text { after the BCRA authorities take this decision. After receiving } \\
\text { an e-mail from the BCRA, the participants must ask their } \\
\text { telecommunications providers to enable the switching } \\
\text { mechanism to start channeling transactions to the } \\
\text { secondary site. }\end{array}$ & $\begin{array}{l}\text { A procedure is in place to enable business continuity } \\
\text { If a malfunctioning of the telecommunications systen } \\
\text { occurs, all payment instructions are to be channeled } \\
\text { through an alternative communications network and } \\
\text { are to be processed in batches every hour. In case } \\
\text { both networks fail, the participants may go to the } \\
\text { BCRA premises and enter transactions through PCs } \\
\text { that will be made available for that purpose. }\end{array}$ \\
\hline
\end{tabular}

\begin{tabular}{l}
\hline Brazil \\
There are two independent and internally redundant \\
(provided by Embratel and AT\&T) using multiprotocol \\
label switching technology and border gateway proto- \\
col routing policies, which provide 99.8 percent uptime \\
guarantee for the whole system, redundant last-mile con- \\
nections for all institutions connected. Additionally, all \\
service providers must have fault and disaster-tolerant \\
sites such as backup sites and data replication.
\end{tabular}

Appropriate backup facilities have been implemented as a result of the payment system reform. A backup site data processing center, which replicates all characteristics of the main center, has been built seven kilometers away from the main processing center. Both sites have independent operational systems.

\begin{tabular}{|c|c|}
\hline \multirow[t]{2}{*}{ Colombia } & $\begin{array}{l}\text { System architecture contains built-in redundancy and } \\
\text { backup capabilities typical of the SUN System architecture. } \\
\text { Data communication networks contain fallback circuits } \\
\text { at the access line level and for accessing the central } \\
\text { primary and backup sites. }\end{array}$ \\
\hline & $\begin{array}{l}\text { Rigorous quality assurance processes and procedures } \\
\text { are in place and are practiced routinely. There is a small } \\
\text { possibility that documentation may not be current, thus } \\
\text { the potential for a problem might exist. However, the } \\
\text { probability of occurrence is low. }\end{array}$ \\
\hline
\end{tabular}

Costa Rica

The BCCR has a contingency site with equipment and technological characteristics identical to those of the main site.

In case a participant faces a situation in which it is not able to transmit its files to the BCCR, the participant has the option to use the alternative operations hall, located inside the BCCR.
The BCB has implemented a formal business continuity plan that consists of two stages. The first stage considers a failure that prevents participants' access to the main computer center of the STR. In this situation, the backup site is immediately started up and the operation resumption is completed in no more than one hour.

The second stage considers the possibility of a complete STR outage. To cover this, the system counts on six monitoring centers, which are distributed among five geographic areas. During that outage event, the monitoring centers are expected to make telephone connection with the participants to ensure business continuity. The contingency plan targets business continuity in a secure way to avoid losses among participants. The contingency plan is to be tested and fully documented at least once a year.

The BR as system operator carries out a formal business continuity planning exercise. Business continuity arrangements are documented and regularly tested. They include procedures for crisis management and information dissemination. The BR routinely undertakes training of participant personnel in addition to the explicit training provided during the certification process.

Business continuity arrangements of the BR normally include diversion of payments to another payment system, a second processing site, or a minimum service level requirement.

Contingency plans have been established for each of the technological elements embodied in the system's processes, such as electric power, telecommunications, hardware, software, and others.

In case of a contingency, the operator informs the rest of the participants of the situation as well as the measures to be adopted to solve it by means of an Extranet bulletin. These measures may include an extension of the closing hour of one phase of the cycle (collection or return), or may include a provision that returned items be transferred to the next cycle for a specific entity.

For the new systems, the BANGUAT is currently working on a contingency plan and backup facilities. In a first phase a duplicate of the databases will be made, and in a second phase an alternative processing site will be built.
An alternative computer hall is currently being developed by the BANGUAT at a secondary site, the Casa de la

Moneda.
New systems being developed under the payments reform take into account operational reliability considerations.

Guatemala 
Table 4.4 Operational Risk Management in LVPSs in Selected Latin America and the Caribbean Countries* (Continued)

\begin{tabular}{|c|c|c|}
\hline Country & Backup Facilities & Business Continuity Plans \\
\hline Jamaica & $\begin{array}{l}\text { System architecture contains redundancy and backup } \\
\text { capabilities. The Customer Inquiry and Funds Transfer } \\
\text { System, which is the data communication network, has } \\
\text { a fallback circuit that is tested every other year. } \\
\text { As part of its reform program, the BOJ is planning a } \\
\text { backup site at an appropriate location on the island. }\end{array}$ & $\begin{array}{l}\text { Emergency procedures have been designed, but no } \\
\text { comprehensive, tested business continuity plan exists. }\end{array}$ \\
\hline Mexico & $\begin{array}{l}\text { Banco de México has an alternative processing site } \\
\text { located outside Mexico City. } \\
\text { To operate in SPEUA, every participant must keep at } \\
\text { least two sets of equipment with the same functions and } \\
\text { capabilities, including security procedures to authenticate } \\
\text { payment orders. }\end{array}$ & $\begin{array}{l}\text { If there are failures in the communications between } \\
\text { Banco de México's equipment and those of one or more } \\
\text { of the participating institutions, if SPEUA is closed } \\
\text { before the established hours, or if any other event has } \\
\text { an extraordinary impact on SPEUA, Banco de México } \\
\text { may take some of the following actions: extend the } \\
\text { operating hours of SPEUA, extend the cutoff time to } \\
\text { determine the pending obligations in SPEUA and the } \\
\text { corresponding additional settlement obligations, } \\
\text { mandate participants to stop sending payment orders } \\
\text { through SPEUA, or order the participants to keep } \\
\text { sending instructions through backup equipment. }\end{array}$ \\
\hline $\begin{array}{l}\text { Netherlands } \\
\text { Antilles }\end{array}$ & $\begin{array}{l}\text { The payments process and the IT system are continuously } \\
\text { monitored. The BvdNA has a backup system available. } \\
\text { Part of the latter system functions in a hot standby mode. } \\
\text { Work is under way to mirror all the functionalities and } \\
\text { activities on the backup system in real time. The backup } \\
\text { facilities and the primary processing site are located in } \\
\text { the premises of the BvdNA. } \\
\text { The BvdNA guarantees the availability of the NACS during } \\
\text { operating hours and working days. Work is on its way to } \\
\text { implement an automated internal and external helpdesk } \\
\text { system to monitor and record all problems and measures } \\
\text { been taken. At the moment, there is no structural monitoring } \\
\text { of problems. }\end{array}$ & $\begin{array}{l}\text { A contingency communication system based on satellite } \\
\text { telephony is available. If participants are not able to } \\
\text { send in their payment orders and payment files elec- } \\
\text { tronically due to a failure of the communication facilities, } \\
\text { they can take their payment files on a diskette together } \\
\text { with a properly authorized hard copy of the entry files } \\
\text { to the BvdNA. } \\
\text { For emergency situations, a redundant power supply } \\
\text { is available that can provide electricity to the central } \\
\text { bank in case of a power failure. }\end{array}$ \\
\hline Nicaragua & $\begin{array}{l}\text { Currently there is no backup system for the computing } \\
\text { center, which is located in the capital city of Managua. }\end{array}$ & $\begin{array}{l}\text { An operational plan for contingency of payment system } \\
\text { applications was prepared in August 1999. This plan } \\
\text { had a particular focus on the Y } 2 \mathrm{~K} \text { issue and does not } \\
\text { take into account modern business continuity planning } \\
\text { for systemically important payment systems. }\end{array}$ \\
\hline OECS & $\begin{array}{l}\text { The major threat to operations is hurricanes, which can } \\
\text { interrupt services for a lengthy period. The current payment } \\
\text { system has redundant processors and power backup equip- } \\
\text { ment that allows the ECCB to maintain operations in case of } \\
\text { temporary disruption of services and short-term (less than } \\
\text { one day) emergencies. In addition, the ECCB has provided } \\
\text { for the off-site storage on a weekly basis of computer tapes } \\
\text { containing databases and accounting information. } \\
\text { ECCB staff is looking at a variety of alternatives should its } \\
\text { headquarters become unavailable for a long time. One } \\
\text { alternative is a separate site on St. Kitts that would be able } \\
\text { to process the workload. Another alternative is expanding } \\
\text { one of the representative offices in another Eastern } \\
\text { Caribbean Currency Union country to function as an } \\
\text { alternative site for processing. }\end{array}$ & $\begin{array}{l}\text { The ECCB established a business continuity committee } \\
\text { headed by the managing director. The objectives of } \\
\text { this committee are to ensure that the ECCB is fully } \\
\text { prepared to cope with disasters; oversee the ECCB's } \\
\text { return to business in the event of a disaster or other } \\
\text { disruption; and develop, review, and continually } \\
\text { update the ECCB's business continuity plan. } \\
\text { Since hurricanes are the major threat, it is doubtful } \\
\text { that the ECCB would be able to relocate people on a } \\
\text { timely basis to ensure continuing operations. The } \\
\text { remote location would need some minimal level of } \\
\text { skills to support hardware as well as normal operating } \\
\text { procedures of the banking and monetary operations } \\
\text { department and other areas. }\end{array}$ \\
\hline
\end{tabular}


Table 4.4 Operational Risk Management in LVPSs in Selected Latin America and the Caribbean Countries* (Continued)

\begin{tabular}{|c|c|c|}
\hline Country & Backup Facilities & Business Continuity Plans \\
\hline Peru & $\begin{array}{l}\text { The BCRP provides, in its headquarters, redundant } \\
\text { equipment readily available for participants that are } \\
\text { experiencing problems with their own equipment. } \\
\text { The BCRP is planning to create a backup site in an } \\
\text { alternative location. }\end{array}$ & $\begin{array}{l}\text { The system counts with contingency procedures for } \\
\text { communications and the BCRP has terminals available } \\
\text { for use by entities experiencing problems in accessing } \\
\text { the system; facsimiles are used as a last resort. } \\
\text { Settlement is done in the time required for the manual } \\
\text { input of operations. }\end{array}$ \\
\hline $\begin{array}{l}\text { Trinidad and } \\
\text { Tobago }\end{array}$ & $\begin{array}{l}\text { The CBTT ensures the availability of the Safe-tt during } \\
\text { operating hours on working days. The main site consists } \\
\text { of two independent servers. } \\
\text { The Safe-tt system resides on Sun Solaris. The two } \\
\text { independent servers use a shared storage device for } \\
\text { data. If one server at the main site should fail, CBTT } \\
\text { incorporates a switchover to the second server that is } \\
\text { transparent to all users. } \\
\text { On a daily basis, the database backs up via the operating } \\
\text { system and database exports, done backend, are per- } \\
\text { formed. The databases for the past month are archived } \\
\text { to tape monthly to be stored onsite and offsite. } \\
\text { Safe-tt is viewed as a critical system, and all such systems } \\
\text { are replicated live to a hotsite at a remote location. If } \\
\text { both servers at the main site should fail CBTT can } \\
\text { switch operations to the hotsite. } \\
\text { There is a helpdesk system to monitor and record all } \\
\text { problems and measures to be taken. }\end{array}$ & $\begin{array}{l}\text { The CBTT started a business continuity plan for } \\
\text { Safe-tt that describes the processes and procedures } \\
\text { to prevent interruption of mission-critical services, } \\
\text { and to reestablish full functioning as swiftly and } \\
\text { smoothly as possible. It addresses technical recovery } \\
\text { issues. It does not attempt to cover business failure, } \\
\text { other than when alternate site recovery may be } \\
\text { involved. Key features of the plan include managing } \\
\text { contingency events, e.g., hurricanes and communi- } \\
\text { cation failure, primary and alternate site facilities, } \\
\text { recovery processes and procedures, and communi- } \\
\text { cation systems. } \\
\text { Currently, the CBTT is working on implementing a } \\
\text { CBTT-wide business continuity plan that would } \\
\text { include plans for the RTGS. }\end{array}$ \\
\hline Uruguay & $\begin{array}{l}\text { At present, the main tools to manage operational risk in } \\
\text { the systems operated by the BCU are backup servers in } \\
\text { hot standby mode and daily information backups. These } \\
\text { servers and the main operating server are all located on } \\
\text { the same premises, the BCU headquarters. The BCU } \\
\text { backs up in tapes the information of the operating day for } \\
\text { all systems it operates, and stores them in a satellite } \\
\text { location. } \\
\text { The operation of the cheque clearinghouse has been del- } \\
\text { egated to a private sector institution. There are no BCU } \\
\text { rules regarding the operational standards or features that } \\
\text { the system should fulfill. }\end{array}$ & $\begin{array}{l}\text { In case participants are not able to connect to the } \\
\text { system due to a malfunctioning of the communications } \\
\text { network, they can still order payment transactions } \\
\text { over the phone. However, there is no manual, structured } \\
\text { emergency procedure, or even written statement on } \\
\text { what to do in case of such a failure. }\end{array}$ \\
\hline $\begin{array}{l}\text { Venezuela, } \\
\text { R.B. de }\end{array}$ & $\begin{array}{l}\text { Currently, there are no backup premises for disasters, } \\
\text { although the BCV is considering starting to develop an } \\
\text { alternative site for transaction processing. }\end{array}$ & $\begin{array}{l}\text { There are several contingency arrangements. In case } \\
\text { of system malfunctioning, orders may keep coming in } \\
\text { to the central bank via SWIFT, telex, or paper means } \\
\text { and the central bank will continue to process these } \\
\text { provisionally in Excel. } \\
\text { External participants experiencing problems with their } \\
\text { terminals may go to the central bank building and con- } \\
\text { tinue entering transactions into the system. Records are } \\
\text { replicated in real time and kept in central bank premises. }\end{array}$ \\
\hline
\end{tabular}

Source: Authors' elaboration.

Note: In Chile, security, contingencies, and business continuity measures are contained in Sections XI and XII, respectively, of the operational regulation of the Sistema LBTR. This information is, however, considered confidential by the BCCH. 
Table 4.5 Pricing Policies in LVPSs in Selected Latin America and the Caribbean Countries

\begin{tabular}{|c|c|}
\hline Country & Pricing Policy \\
\hline Argentina & $\begin{array}{l}\text { The BCRA currently does not apply any charges to commercial banks for the settlement of their transactions } \\
\text { in the MEP. This policy was adopted at the time the system was launched in order to promote its use among } \\
\text { the banking sector. }\end{array}$ \\
\hline \multirow[t]{2}{*}{ Brazil } & $\begin{array}{l}\text { The STR pricing policy aims at full cost recovery: Fees should cover all operating costs, both fixed and variable. } \\
\text { Imputed costs also considered. The STR price schedule is } \mathrm{R} \$ 0.62 \text { (approximately US\$0.28) per each immediate } \\
\text { transfer that is sent and received. Early transfers (before 8:00 a.m.) are charged a lower fee (R\$0.31 for each } \\
\text { transfer sent and received). }\end{array}$ \\
\hline & For the SITRAF, the fees are similar to the fees charged in the STR environment. \\
\hline \multirow[t]{2}{*}{ Chile } & $\begin{array}{l}\text { The pricing policy of the BCCH regarding the RTGS system aims at covering all the costs related to } \\
\text { implementation, daily operation, and maintenance. }\end{array}$ \\
\hline & Each participant is subject to a fixed monthly charge and a fixed amount per transaction settled in the system. \\
\hline Colombia & $\begin{array}{l}\text { The current practices are a fixed amount of Col } \$ 2,000 \text { (approximately US\$0.85) per transaction settled up to } \\
\text { 6:00 p.m. and an ad valorem tariff of Col } \$ 2.5 \text { per million for payment orders after that cutoff time. }\end{array}$ \\
\hline El Salvador & The BCR does not charge any fees for the clearing or settlement services it provides to financial institutions. \\
\hline Mexico & $\begin{array}{l}\text { In the SIAC, each participant pays an annual fee that is intended to cover all costs incurred by the Banco de } \\
\text { México; these covered costs include the telecommunications network, software, and hardware maintenance. } \\
\text { The fee varies according to the number of terminals that each participant has. }\end{array}$ \\
\hline Netherlands Antilles & $\begin{array}{l}\text { The NACS was developed jointly by the BvdNA and commercial banks and the investment costs for the } \\
\text { development and implementation of the NACS were shared between them. Each participant contributes the } \\
\text { same amount and maintenance costs are divided equally among the participants on an annual basis. Personnel } \\
\text { costs to operate the system are at the expense of the BvdNA. Under this arrangement, no fee is charged to } \\
\text { the participants for individual transactions processed through the NACS. }\end{array}$ \\
\hline Nicaragua & $\begin{array}{l}\text { The charges applied by the BCN as part of its pricing policy for the provision of payment services do not cover } \\
\text { operating costs, and are irrespective of considerations such as the volume of operations that participants } \\
\text { insert into the system. }\end{array}$ \\
\hline OECS & $\begin{array}{l}\text { At present, the ECCB does not charge any fees for its clearing or settlement services. However, in } 2003 \text { the } \\
\text { ECCB initiated a study to investigate the feasibility of a pricing scheme; the aim is to reduce the subsidization } \\
\text { of payment services and obtain a level of cost recovery. The objective of full cost recovery will be a longer-term } \\
\text { development; it may be several years before it is fully achieved. }\end{array}$ \\
\hline \multirow[t]{2}{*}{ Peru } & $\begin{array}{l}\text { The pricing scheme created by the BCRP sets a fixed monthly charge and a fixed amount per transaction, which } \\
\text { becomes higher if the operation takes place after 3:00 p.m. Thus, through its pricing policy, the BCRP explicitly } \\
\text { targets the smooth flow of payments. }\end{array}$ \\
\hline & $\begin{array}{l}\text { The prices are adjusted quarterly on the basis of inflation and are applied to transactions denominated in } \\
\text { either local currency or U.S. dollars. }\end{array}$ \\
\hline
\end{tabular}




\section{Table 4.5 Pricing Policies in LVPSs in Selected Latin America and the Caribbean Countries (Continued)}

Country Pricing Policy

Trinidad and Tobago

The CBTT adopted a two-part pricing policy for Safe-tt. An annual membership fee is charged to all participants, which offsets the marginal costs of implementing the system. This fee consists of the total marginal cost of implementing Safe-tt, divided evenly among the six local commercial banks and the CBTT.

The second fee charged is a transaction fee for each transaction processed over Safe-tt. The latter fee assists in offsetting the daily operational cost of the system.

At present, due to the still low volumes on Safe-tt and proportionally higher transaction costs, the CBTT has had to subsidize transaction fees.

Uruguay The BCU currently does not apply any charges to the settlement services it provides. Charges were applied in the past, though, and the BCU intends to reinstate charges once the migration of the RTGS system to the new AGATA platform is concluded.

Venezuela, R.B. de

Large-value payment services offered by the BCV are not priced. Banks pay fees to SWIFT to use the system for the domestic and international traffic

Source: Authors' elaboration.

\section{Observations}

- LVPSs and systemically important payment systems in Latin America and the Caribbean do not fully observe several of the Committee on Payment and Settlement Systems (CPSS) core principles for systemically important payment systems. In many cases, the national central banks, recognizing these weaknesses, initiated reforms in the payments system to improve the safety and efficiency of LVPSs, launch an RTGS system, and reduce the use of cheques for large-value settlements.

- With few exceptions, the high value of cheques settled in cheque clearinghouses throughout the region and the fact that this instrument is still used for interbank payments confirm that cheque systems should still be viewed as a systemically important payment systems in most countries. To strengthen the stability of the payments system, the discharge of obligations among financial intermediaries must be made through an appropriate system, such as an RTGS system. Consequently, central banks should evaluate any measures that help persuade intermediaries to use the RTGS system for interbank transfers and to reduce the use of large-value cheques. It is suggested that pricing policy be used as the main incentive for this transition of the large-value payments from the cheque system to the RTGS system, to reduce, and eventually eliminate, the systemic importance of the cheque clearinghouse.

- Several countries launched an RTGS system several years ago and others are moving in the same direction. In this regard, it has been recommended that all countries in the region count with a designated LVPS that complies with the CPSS core principles for systemically important payment systems. To this end, all aspects of the new systems must be carefully evaluated and discussed with market participants. In particular, central banks should prepare rules and procedures relating to the use of the system covering legal, financial, and operational risks. The design should include elements that could affect efficiency and practicality such as full integration of available systems, convenient operating hours, and reduction and elimination of manual procedures. Some form of cost recovery should be evaluated compared with all other externalities that stem from a robust and efficient payment system (that is, risk reduction).

- An appropriately designed RTGS system has been recommended as a powerful tool to expedite settlement and minimize systemic risk. Countries with smaller or less active financial markets should consider implementing a system of this kind as the markets develop and the number of time-critical interbank payments increases.

- The smooth functioning of the RTGS system requires the availability of appropriate liquidity management tools and an efficient distribution of liquidity among intermediaries during the operational hours of the day. Central banks must remove obstacles that prevent an efficient use of liquidity, including allowing a flexible use of reserves requirements and providing intraday credit by means of properly collateralized intraday loans 
or repos. Intermediaries should also have complete and timely information on incoming and outgoing payments. To this end, central banks should improve the collection of reliable statistical information for analysis purposes. Some central banks have also found it useful to review the time schedule of settlement of payments in the RTGS system during the day and the critical times at which relevant sources of liquidity are injected into the system. In this regard, the proper synchronization of the payments of the national treasury is critical in order to avoid unforeseen injections or withdrawals of reserves, which create volatility in the availability of intraday liquidity and may end up affecting the conduct of the monetary policy. In determining the most appropriate solutions to improve the efficiency of the system, it is important that open discussion takes place among the parties involved in the RTGS system. The introduction of so-called users' groups has been recommended for this purpose.

- Several improvements are also necessary to reduce operational risks and improve the resiliency of LVPSs. To this end, it has been recommended that the following elements be redesigned or added to systems currently in place or included in the design of a new LVPS: (1) implementation of a robust and efficient communication network between the central bank and system participants, which should reduce and eventually eliminate the use of manual- or paper-based procedures; (2) implementation and enforcement of strict security measures both for physical and electronic access to the system; (3) implementation of disaster recovery mechanisms, including the setting-up of a secondary site; and (4) development of comprehensive business continuity plans to be tested on a periodical basis.

- Because LVPSs represent the backbone of the national payments system, reforming the existing RTGS system or implementing one will result in a major improvement to the safety and efficiency for each country's financial infrastructure. From another perspective, completing these processes will not only serve the needs of the individual domestic payment systems, but also create appropriate conditions for an eventual future integration at a subregional level. It is important to stress that any potential integration in this area should be based on the previous harmonization of the systems - that is, the existence of common features in all relevant areas (legal, risk control mechanisms, liquidity provision, access policies, governance, organizational arrangements, operational aspects, reliability and business continuity, and so on).

\section{RETAIL SETTLEMENT SYSTEMS}

This section includes context, status in the region, and observations regarding the retail settlement systems

\section{Context}

A wide range of payment instruments is essential for supporting customers' needs in a market economy. A less-than-optimal supply of payment instruments may ultimately have an impact on economic development and growth. Moreover, the safe and efficient use of money as a medium of exchange in retail transactions is particularly important for the stability of the currency and a foundation of the trust people have in it. As CPSS publications have shown, the use of retail payment instruments differs in industrial countries both within and among the countries considered (CPSS 1999, 2000c). This is due to a variety of factors, including cultural, historical, economic, and legal. However, some common trends may be observed, namely the continued primacy of cash (in volume terms) for face-to-face payments; growth in payment cards use; increased use of direct funds transfers, especially direct debit transfers, for remote payments; and changes in the market arrangements for providing and pricing the retail payment instruments and services delivered to end users. This evolution is likely to continue in the future and is expected to influence traditional (especially paper-based) instruments. As the CPSS reports state, over the long term some of the observed market developments may well alter traditional payment practices and contribute to increased efficiency and convenience in retail payment systems. In an increasing number of countries, more and more attention is devoted by authorities and market participants to the efficiency and efficacy of production and distribution of payment instruments (including cash).

In March 2003, the CPSS published a new report that identifies and explores policy issues for central banks and considers the possible contribution of central banks towards furthering certain policy goals in this area (CPSS 2003a). Central banks are currently involved in retail payments in three main ways: (1) in an operational 
capacity, (2) as payment system overseers, or (3) as catalysts or facilitators of market and regulatory evolution. Even though the involvement of the central bank in retail payments varies from country to country, the report suggests that each central bank should examine developments in its markets periodically in the light of some identified policy issues (see below), in order to form a view on whether such issues arise in practice. Where such issues are judged to arise, relevant public authorities (including central banks) may decide to take action aimed at establishing or reestablishing an acceptable bal- ance of the various aspects of safety and efficiency. The public policy goals, the central bank minimum action and the range of possible additional actions identified in the CPSS report are summarized in box 4.1.

The CPSS report has been prepared in the light of the trends in retail payment markets in the Group of Ten countries and Australia. It is likely that, in developing countries, central banks and other private and public entities need to take a proactive role and explore carefully the possibility of adopting additional measures.

\section{Box 4.1 Public Policy Goals, Central Bank Minimum Actions, and Range of Possible Additional Actions} for Retail Payment Systems

\section{LEGAL AND REGULATORY FRAMEWORK}

Public Policy Goal A: Policies relating to the efficiency and safety of retail payments should be designed, where appropriate, to address legal and regulatory impediments to market development and innovation.

The central bank should, at a minimum:

- Review the legal and regulatory framework to identify any barriers to improvements in efficiency and/or safety;

- Cooperate with relevant public and private entities so that the legal and regulatory framework keeps pace with the changing circumstances and barriers to improvements in efficiency and/or safety are removed, where appropriate.

The range of possible additional actions could include, depending on the individual central bank's responsibilities, powers and priorities:

- Altering regulations that currently present barriers to improving efficiency and safety, where this is within the central bank's remit and where other public interest arguments do not militate against such action;

- Introducing or proposing new regulations, as the central bank's remit allows, where the legal or regulatory framework is insufficient to support increased efficiency and/or safety;

- Offering expert advice to other responsible authorities, for example, in the preparation of relevant legislation.

\section{MARKET STRUCTURE AND PERFORMANCE}

Public Policy Goal B: Policies relating to the efficiency and safety of the retail payments should be designed, where appropriate, to foster market conditions and behaviors.

The central bank should, at a minimum:

- Monitor developments in market conditions and behaviors relating to retail payment instruments and services and assess their significance;

- Cooperate with other public or private entities, as appropriate, to foster competitive market conditions and to address any significant public policy issues arising from market structures and performance.

The range of possible additional actions could include, depending on the individual central bank's responsibilities, powers and priorities:

- Promoting appropriate standards or guidelines for transparency, in cooperation with relevant public and private sector entities;

- Reviewing conditions in the market for cross-border retail payments, with a view to promoting improvements, is such action is warranted;

- Considering and, if appropriate, performing regulatory and/or operational interventions in cases where market forces are judged not to have achieved or not to be likely to achieve an efficient and safe solution.

\section{STANDARDS AND INFRASTRUCTURE}

Public Policy Goal C: Polices relating to the efficiency and safety of retail payments should be designed, where appropriate, to support the development of effective standards and infrastructure arrangements. 


\section{Box 4.1 Public Policy Goals, Central Bank Minimum Actions, and Range of Possible Additional Actions} for Retail Payment Systems (Continued)

The central bank should, at a minimum:

- Monitor developments in security standards, operating standards and infrastructure arrangements for retail payments which the central bank judges to be important for the public interest, and assess their significance;

- Cooperate with relevant public and private entities to encourage market improvements in such standards and infrastructure arrangements, where appropriate.

The range of possible additional actions could include, depending on the individual central bank's responsibilities, powers and priorities:

- Participating actively in reviewing and developing appropriate standards and arrangements, in cooperation with relevant public and private entities, where the central bank judges its more intensive involvement to be necessary to furthering the goal;

- Considering and, if appropriate, performing regulatory and/or operational intervention in cases where market forces are judged not to have achieved or not to be likely to achieve and efficient and safe solution.

\section{CENTRAL BANK SERVICES}

Public Policy Goal D: Policies relating to the efficiency and safety of retail payments should be designed, where appropriate, to provide central bank services in the manner most effective for the particular market.

The central bank should, at a minimum:

- Review and, if appropriate, adapt its provisions of settlement services to contribute to efficient and safe outcomes;

- Be transparent in its provision of services.

The range of possible additional actions could include, depending on the individual central bank's responsibilities, powers and priorities:

- Reviewing the relevant nonsettlement services it provides and considering their adaptation to changing market conditions;

- Reviewing policies on access to central bank services and on pricing.

Note: The text comes directly from the quoted document.

\section{Status in the Region}

\section{Table 4.6 Retail Settlement Systems and Instruments in Individual Latin America and the Caribbean Countries ${ }^{\mathrm{a}}$}

\begin{tabular}{l|ll} 
Country & Retail Settlement Systems and Instruments
\end{tabular}

Argentina

Cheque Clearinghouse and Credit Transfers and Direct Debits

Since 1997, two private clearinghouses have been authorized by the BCRA to electronically process low-value payments: ACH, S.A., and Compensadora Electrónica S.A. mainly serves banks in the Buenos Aires area, whereas ACH serves the provincial banks. All members are direct participants.

The two clearinghouses handle the following payment instruments: cheques, letters of credit, term certificates of deposit, banking payment orders, postal and bank giros and transfers, and sight bills of exchange drawn against quotas of mutual funds.

The two clearinghouses are interconnected to exchange transactions that are presented from the member of one in favor of a member of the other. This procedure applies to all cleared instruments. The structure of the archives and of the messages was developed following NACHA (the electronic payments association) standards.

Settlement is accomplished at the BCRA through the MEP.

\section{Payment Card Systems}

The use of payments cards, especially credit cards, is widespread. There are seven credit card networks active at the national level: Five are owned by banks and operate in an open scheme; the other two are American Express and Diners Club. Debit cards are issued mainly under Visa (Electron) and MasterCard (Maestro). Almost all ATM cards in the country can be used as debit cards for payments. 


\section{Table 4.6 Retail Settlement Systems and Instruments in Individual Latin America and the Caribbean countries ${ }^{\text {a }}$ (Continued)}

\begin{tabular}{|c|c|}
\hline Country & Retail Settlement Systems and Instruments \\
\hline \multirow[t]{3}{*}{$\begin{array}{l}\text { Argentina } \\
\text { (Continued) }\end{array}$} & $\begin{array}{l}\text { The networks are partially interoperable. Payment cards operations for national cards are cleared at the network } \\
\text { level and settled through commercial banks in the accounts held at the BCRA. }\end{array}$ \\
\hline & Other Systems \\
\hline & $\begin{array}{l}\text { The postal administration (Correo, S.A.) manages two types of payment instruments: postal money orders and } \\
\text { recurrent payments operations. The Correo is used extensively for recurrent payments. The network for these } \\
\text { payments, named Sistema Electrónico de Pagos, operates with bar-coded instruments. Payments are received } \\
\text { at the post office in cash and are transferred the following day to Sistema Electrónico de Pagos, which distributes } \\
\text { them to the final beneficiary (utility companies, tax-collecting agencies, and so on). }\end{array}$ \\
\hline
\end{tabular}

\section{Bahamas, The Cheque Clearinghouse}

Cheques are used intensively for all types of payments in The Bahamas. On the one hand, the number of cheques cleared each year in the clearinghouse has remained almost constant in the past few years. On the other hand, the total value of cheques has been rising at an average of 5 percent a year.

The cheque system operates with a clearinghouse managed by the CBOB. The clearing banks have signed an agreement governing the exchange of cheques and their settlement. The exchange of documents continues to be paper based. Although some banks take advantage of the MICR codes in their processing, this technology is not widespread in the banking sector.

Clearing results are presented through each bank's central clearing branch by 9:15 a.m. each day. Following the exchange, net settlement obligations are calculated and vouchers prepared to meet the obligations. These vouchers request that the $\mathrm{CBOB}$ make the necessary debits and credits for the settlement.

\section{Credit Transfers and Direct Debits}

Only recently, some banks have started making available credit transfers and direct debits to their customers. At present, these are available only at an intrabank level.

The $\mathrm{CBOB}$ and the clearing banks association are leading a project for the launching of an $\mathrm{ACH}$ that, among other things, will process credit transfers and direct debits. This is expected to become operational as of year-end 2006.

\section{Payment Card Systems}

Payment cards are used intensively in The Bahamas. Recently, the use of cards as payment instruments (that is, in electronic funds transfer at the point of sale [EFTPOS]) has increased significantly.

Five of the seven clearing banks have their own network of ATMs, and a number of these banks are actively promoting the use of bank cards to replace cheques. There are no shared networks for ATMs in The Bahamas.

\section{Bolivia}

\section{Cheque Clearinghouse}

There is a single national cheque clearinghouse in local currency and in U.S. dollars operated by the Asociación Bancaria, the bankers' association. Cheque standardization, MICR technology, imaging, and other procedures have been implemented recently to increase the degree of automation and to expedite settlement.

There are two daily clearance and settlement sessions for each currency denomination, with parallel processes; and the outgoing balances are settled at the BCB. Funds are normally available on customer accounts by $T$ or $T+1$, depending on the time of presentment and on the clearing bank, because there are no rules stating the time by which funds must be available at customer accounts. The average value of a cheque cleared at the clearinghouse is slightly more than US\$4,000.

The $\mathrm{BCB}$ has already issued a general regulation for payments clearinghouses that mandates the introduction of risk controls and facilitates $B C B$ payment services for the settlement of clearinghouse positions, among other desirable features.

\section{Credit Transfers and Direct Debits}

At present, credit transfers and direct debits are used only at the intrabank level, and the volume is still low. The Asociación Bancaria is planning to launch an ACH that would provide credit transfer and direct debit services. 


\section{Table 4.6 Retail Settlement Systems and Instruments in Individual Latin America and the Caribbean Countries ${ }^{a}$ (Continued)}

\begin{tabular}{l|l}
$\begin{array}{l}\text { Country } \\
\text { Bolivia } \\
\text { (Continued) }\end{array}$ & $\begin{array}{l}\text { Payment Card Systems } \\
\text { There are more than } 500,000,200,000, \text { and } 50,000 \text { debit, credit, and stored-value cards, respectively. Payment } \\
\text { cards, particularly stored-value cards, are becoming increasingly important. }\end{array}$ \\
& $\begin{array}{l}\text { There are two major ATM networks that are interoperable. The combined network comprises almost } 500 \text { machines. } \\
\text { The ATM networks and EFTPOS systems settle interbank balances with cheques or in correspondent bank accounts. }\end{array}$
\end{tabular}

Brazil

\section{Cheque Clearinghouse}

The COMPE provides cheque-clearing services all over the country. Settlement is made against banks' reserve accounts at the BACEN on $T+1$. Banco do Brasil, a government-owned commercial bank, is the operator of the COMPE. The COMPE, however, is regulated by the BACEN.

All commercial banks, multiple banks with commercial operations, and savings banks are participants in the COMPE. Participants' reserve accounts at the BACEN are linked to another account (the linked account) created for the financial settlement of interbank obligations arising from the COMPE. This account receives deposits through funds transfers ordered by the account holders through the STR.

Basic features and processing are standardized across the country. All cheques contain MICR encoding. Cheque truncation has not yet been implemented in Brazil at the system level. The COMPE holds two daily sessions for the exchange and return of documents: The first session includes cheques up to a limit established by the BACEN (currently R $\$ 299.99$ ) that were accepted by the banking network during the previous business day. These cheques are settled by $T+1$ at the level of the participants. The second session covers cheques for individual amounts above the $\mathrm{R} \$ 299.99$ limit and bloquetos de cobrança received in the banking network during the same business day $(\mathrm{T})$.

Because there are no safeguards to guarantee settlement, if a participant does not have sufficient funds for settling its obligations an unwinding of the multilateral positions is made and the relevant institution is excluded from the settlement process.

\section{Credit Transfers and Direct Debits}

Although the infrastructure created with the restructuring of the Brazilian payment system already makes it technologically feasible to develop a wide range of retail payment products, direct debit and credit services are still only available at the intrabank level. Direct debits are used extensively to pay utility bills.

The Sistema de Liquidação Diferida de Ordens de Crédito Interbancárias is a multilateral net settlement system that settles interbank obligations related to interbank credit orders. It is operated by the Câmara Interbancária de Pagamentos and went live in February 2004. All deposit-taking institutions have access to the Sistema de Liquidação Diferida de Ordens de Crédito Interbancárias.

The Sistema de Liquidação Diferida de Ordens de Crédito Interbancárias holds two daily settlement sessions: the interbank credit orders issued in the day before (T - 1) are usually settled in the morning session, through a settlement window that ends at 8:20 a.m., whereas returned items are usually settled in the afternoon session, which ends at 4:10 p.m. The multilateral balances are informed by the Câmara Interbancária de Pagamentos. Funds transfers from participants with a net debit position to Câmara Interbancária de Pagamentos, and funds transfers from Câmara Interbancária de Pagamentos to the participants with net credit positions are made through the STR. Final settlement occurs once the BACEN posts the multilateral balances in the reserve accounts.

Credit transfers through interbank credit orders are limited to $\mathrm{R} \$ 5,000$ per order. An unwinding of the positions would occur if a participant were unable to cover its settlement position.

\section{Payment Card Systems}

The most representative institutions are TecBan, which settles transactions from Banco24Horas, an ATM network with 52 associated financial institutions, and Visanet and Redecard, which settle credit and debit card transactions. 


\title{
Table 4.6 Retail Settlement Systems and Instruments in Individual Latin America and the Caribbean Countries ${ }^{a}$ (Continued)
}

\author{
Country \\ Retail Settlement Systems and Instruments
}

Brazil

(Continued)
Credit cards represent almost 40 percent of the total credit card business in Latin American markets and 2.6 percent of the credit card business in the global market. The number of credit cards issued increased from 23.4 million in December 1999 to 44 million in December 2003. The number of transactions increased from 553.2 million in 1999 to 1.08 billion in 2003. In 2004, the number of credit and debit card transactions per capita exceeded the number of cheques issued for the first time. The main brands are American Express, Diners Club, HiperCard, MasterCard, and Visa. The issuer segment of the industry has increasingly become a bank business. The main players in this area are American Express, Banco do Brasil, Bradesco, CrediCard, and HiperCard.

Since April 2002, the interbank settlement of credit card transactions was removed from the COMPE. For this purpose, RedeCard and VisaNet, the exclusive acquirers for MasterCard and Visa brands in Brazil, turned themselves into clearinghouses to provide settlement services on a bilateral netting basis.

Regarding debit cards, as of year-end 2003, almost 162 million debit cards were in circulation and accepted by more than 1.4 million of affiliated merchants throughout the country. They operated under the same umbrella of major credit card brands. Banco24Horas has its own brands.

ATM networks are not fully interoperable in Brazil. Each of the major private banks in Brazil operates its own ATM network. Smaller banks usually share an ATM network. As of year-end 2003, there were around 137,000 ATMs, connected to 29 ATM proprietary networks.

Only a few banks issue smart cards to their customers. Two systems are currently being adopted: the SIBS and Visa Cash.

\section{Other Systems}

Post offices traditionally have had a limited role in providing payment instruments in Brazil. Two services are available-the vale postal (a payment order) and the collection of bills on behalf of third parties. These are not widely used in Brazil.

Chile Cheque Clearinghouse

Cheques are the main payment instrument in Chile: more than $\mathbf{2 7 0}$ million cheques are processed each year. The Sistema Nacional de Comunicaciones Financieras operates the low-value clearinghouse. There are several clearing sessions to process cheques and vales vista in local currency, cheques in foreign currency, and ATM inter-network balances.

The first clearinghouse session is held at 5:30 p.m. The exchange, clearing, and honoring of cheques and other documents in local currency takes place at this time. Documents pertaining to other banking sites (clearing locations) are processed one day before $(T-1)$ and the results are added to those of the first (local) clearinghouse session held on day T. At 9:30 a.m., a second clearinghouse session is held for errors. A third session is held at 11:30 a.m. for returned items. At 3:00 p.m., a fourth clearinghouse session is held for transactions among financial institutions. ${ }^{\text {b }}$

At the end of day $T+1$, the BCCH debits or credits the participating institutions' current accounts. A central bank liquidity warranty is understood to cover the vale vista under exceptional circumstances (see cheque clearinghouse rules and article 36 of the BCCH legal statute), and the central bank provides automatic credit, if there are overdrafts. Overdrafts are infrequent because a system of severe penalties is in place.

\section{Credit Transfers and Direct Debits}

Direct debits or the automatic payment of bills out of a current account is a commonly used mechanism introduced many years ago. However, it is available only at the intrabank level.

Some years ago, several banks launched the Pago Automático de Cuenta, an interbank direct debit system that enables ad hoc payments, mainly for collections. There are almost 500 organizations participating in this system. 


\section{Table 4.6 Retail Settlement Systems and Instruments in Individual Latin America and the Caribbean Countries ${ }^{a}$ (Continued)}

\begin{tabular}{|c|c|}
\hline Country & Retail Settlement Systems and Instruments \\
\hline \multirow{5}{*}{$\begin{array}{l}\text { Chile } \\
\text { (Continued) }\end{array}$} & Payment Card Systems \\
\hline & $\begin{array}{l}\text { Regarding payment cards, as of year-end } 2005 \text {, there were about } 3.8 \text { million bank-issued credit cards in circulation, } \\
\text { and approximately } 60,000 \text { EFTPOS in the country. There were also approximately } 5.6 \text { million debit cards in use. } \\
\text { This instrument is not used extensively due to disadvantages such as the US } \$ 60 \text { annual administration fee and } \\
\text { a tax levied for each transaction performed. }\end{array}$ \\
\hline & $\begin{array}{l}\text { Transbank, a company that provides support services for the banking business and that is owned by several } \\
\text { banks, provides a national clearing system for credit and debit card transactions. }\end{array}$ \\
\hline & $\begin{array}{l}\text { There are also credit and fidelity cards issued by different businesses. It is estimated that there are } 8 \text { million } \\
\text { cards issued to people who do not have access to bank products. }\end{array}$ \\
\hline & $\begin{array}{l}\text { There are more than } 3,000 \text { ATMs in the country operating through two noninteroperable networks. } \\
\text { Redbanc operates the ATM networks of } 20 \text { banks comprising more than 2,500 ATMs, while Globalnet } \\
\text { operates a network of roughly } 500 \text { ATMs. The results of the Redbanc ATM clearing (from 2:01 p.m. of } \\
T-1 \text { to 2:00 p.m. of day T) are settled at the BCCH. In 2005, the two ATM networks announced they plan to } \\
\text { engage in an interconnection agreement. }\end{array}$ \\
\hline
\end{tabular}

\section{Colombia Cheque Clearinghouse}

Cheques are used not only for low-value payments, but also by the corporate sector and by financial intermediaries for large-value transactions. Recent figures show that the use of cheques has decreased substantially.

Clearing and settlement of cheques at Cámara Electrónica de Compensación occurs in two sessions: The first session, which takes place the same day of the presentation of the cheques, executes a provisional settlement on the participants' accounts at BR. Final settlement is carried out the next day at the second session, in which the balances are calculated, excluding the returned items.

\section{Credit Transfers and Direct Debits}

The implementation of ACH services in Colombia brought with it the opportunity to implement electronic payment operations in both credit and debit form. The volume of transactions in both ACHs is still small.

The first ACH, called Sistema de Compensación Electrónica Nacional Interbancaria, is managed and owned by the $B R$ and is used primarily for public sector retail payments. Settlement occurs three times a day by crediting and debiting the accounts at the BR. The second one, called ACH Colombia, was implemented by the financial intermediaries and is used essentially for recurrent payments of individuals and for corporate payments-mainly payrolls, pensions, and payments to suppliers. ACH Colombia settles its multilateral balances at the BR.

\section{Payment Card Systems}

The main operators in this market are Visa, MasterCard, and Diners Club. Of the 10 million debit cards currently operating in the market, MasterCard has a share of almost 60 percent and Visa the remaining 40 percent.

The number of ATMs is estimated at more than 5,600. The number of transactions a year is close to 400 million. There are six major ATM-EFTPOS networks that are completely interoperable. At the end of the day, each network calculates the net positions of its cardholders and its credit and debit position versus the other networks, and settlement occurs according to an agreed procedure through the Sistema Electrónico de Cuentas de Depósito.

\section{Costa Rica}

\section{Cheque Clearinghouse}

The cheque is the most important retail payment instrument. The cheque-clearing system has well-defined rules and regulations. Standardized procedures and other measures have reduced the processing time from almost two weeks to $T+1$. Rules and regulations prescribe that the receiving bank has to credit the account of the beneficiary for the relevant amount within two hours after the multilateral cheque clearing has taken place in the books of the central bank. At present, the system does not support truncation. 


\section{Table 4.6 Retail Settlement Systems and Instruments in Individual Latin America and the Caribbean Countriesa (Continued)}

\section{Country Retail Settlement Systems and Instruments}

Costa Rica

(Continued)
For the cheque settlement, a guarantee scheme was put in place to ensure timely settlement in case of default by one of the participants. This is also the case for other retail payment systems that clear and settle on a multilateral basis within the Sistema de Negociación y Pagos Electrónicos. These schemes are based on a defaulter's pay principle. Each participant has to pledge to the BCCR an amount of securities issued by the government, or by the BCCR itself. In the case where a participant has no balances or insufficient balances in its account and does not succeed in funding its debit position (banks have one hour to do so), the central bank will automatically conduct a repo based on the available securities and provide the necessary liquidity in order to settle the debit position. This repo has to be reversed within seven days.

\section{Credit Transfers and Direct Debits}

There are credit transfer and debit services as part of the Sistema de Negociación y Pagos Electrónicos. Both operate under straight-through processing (STP): The information required for the clearance and settlement of payment orders is introduced only once into the system.

Both services work with a $T+1$ cycle starting from the moment in which the originating client requests the payment service to its financial entity and the transaction is put into the system. Both services use the same schedule for the electronic transmission of information, returns, and settlement on the reserve accounts at the BCCR. For the direct debit service, however, the current account holder is required to issue a debit order by which it authorizes the relevant company to withdraw funds from its account.

\section{Payment Card Systems}

There are two debit and credit card networks operated by Credomatic and ATH. As to ATMs, five networks are in operation and are not interoperable, in general. Liquidación de Servicios Externos is an application developed recently within the Sistema de Negociación y Pagos Electrónicos to settle services provided by third parties, that is, ATM withdrawals, and debit and credit card payments. The Liquidación de Servicios Externos follows a similar cycle to that of the credit transfers and direct debits service.

\section{Dominican Republic Cheque Clearinghouse}

Cheques are the most relevant payment instrument in the Dominican Republic. Only the multiple banks are direct participants in the cheque clearinghouse operated by the BCRD, which is partially automated.

The processing cycle begins at 9:00 a.m. of $\mathrm{T}+1$. Through the communications network, each bank sends an electronic file to the BCRD with the list of all the interbank cheques that were received for collection. The ECH module of the system automatically calculates the net multilateral positions and makes the corresponding credits and debits to the current accounts. These credits and debits are not final, because banks still have to exchange the physical cheques and produce the returned items.

At 3:00 p.m. of $T+1$, the banks send through the Sistema Bancario en Línea a new electronic file to the BCRD with the returned items. The ECH module processes this file and generates the final credits and debits to the current accounts, which are made at 4:00 p.m. The accounts of the final beneficiaries are generally credited by $T+4$.

\section{Credit Transfers and Direct Debits}

Direct credit and debit services are only available at the intrabank level. In recent years, the use of this alternative to pay utility bills and other similar recurrent payments has been growing at a fast pace.

Recently, ATH Dominicana, the operator of one of the ATM networks in the country, has been working on an ACH project to enable banks and the banks' customers to make credit- and debit-type retail interbank payment transactions.

\section{Payment Card Systems}

In the Dominican Republic, there are two interoperable ATM networks with approximately 1,300 machines. Each network calculates daily the multilateral net balances of its members, as well as the amount to be charged to the other network. The ATH and the BTH networks inform their members of their multilateral net positions and coordinate settlement through a multiple bank designated as settlement agent. For the most part, payments are made through cheques that are cleared at the BCRD clearinghouse. 


\section{Table 4.6 Retail Settlement Systems and Instruments in Individual Latin America and the Caribbean Countries ${ }^{a}$ (Continued)}

\begin{tabular}{l|l} 
Country & \multicolumn{1}{c}{ Retail Settlement Systems and Instruments } \\
$\begin{array}{l}\text { Dominican Republic } \\
\text { (Continued) }\end{array}$ & $\begin{array}{l}\text { In recent years, payments with credit and debit cards have greatly increased their significance as payment } \\
\text { instruments. There are approximately } 3 \text { million cards, of which } 60 \text { percent are credit cards, for a population of } \\
\text { almost } 8 \text { million. In the period from } 1999 \text { to 2003, the total value of card transactions more than doubled. } \\
\text { In early 2003, credit card-issuing firms operated 9,135 EFTPOS terminals. The two major acquirers are VisaNet } \\
\text { and CardNet, which are owned by BTH and ATH, respectively. Their platforms are partially interoperable. Pay- } \\
\text { ments made with all the major card brands can be processed in the CardNet platform, whereas VisaNet only } \\
\text { accepts those made with MasterCard and Visa. The interbank obligations derived from card systems are settled } \\
\text { in a similar way to those of the ATMs system. }\end{array}$
\end{tabular}

\section{Ecuador}

\section{Cheque Clearinghouse}

Cheques are the most relevant payment instrument in Ecuador for large-value and retail transactions. Cheque clearing and the physical exchange of documents are distributed in 17 zones, selected on the basis of geographical distribution of banking infrastructure. Settlement is centralized in the headquarters of the BCE in Quito and its Guayaquil branch. The 17 zones send to one of these offices the result of the clearing session for settlement at the current accounts held in the BCE. Final settlement of the cheque clearinghouse occurs at 1:30 p.m. of $T+1$.

\section{Credit Transfers and Direct Debits}

The Sistema de Pago Interbancario (SPI), launched in August 2002, is an interbank payment system for retail electronic credit transfers. Individual payment transactions for more than US\$10,000 may not be channeled through the SPI. The SPI is accessible through a private communications network using public key infrastructure in an Internet technology framework.

Clearing and settlement processes are similar to those of the cheque clearinghouse, although in the case of the SPI all processes are fully automated. From 8:00 a.m. until noon, the participants send files to each other through the BCE communications network; these files have detailed instructions of the funds to be credited to each institution's customers. Between noon and 1:00 p.m., the SPI makes a cutoff, and automatically calculates the multilateral net positions, and executes a preliminary settlement on the current accounts at the BCE. Participants with a multilateral net debit position have until midnight to fund such positions. Participants receiving payment instructions have until 11:00 a.m. of $T+1$ to reject transactions on the basis of the nonexistence of the beneficiary's account, the account being closed, and so on. Once the returned items session is over, the BCE executes final settlement by making the necessary adjustments to the preliminary multilateral net positions.

\section{Payment Card Systems}

Regarding ATMS and EFTPOS, the major operator in the country is Banred, which processes the transactions made in almost 90 percent of the roughly 1,000 ATMs in the country. At 7:00 p.m., the system makes a cutoff of the daily transactions and calculates the interbank bilateral positions. Banred then produces credit and debit vouchers for all possible bilateral combinations and sends them to the BCE for settlement. These items are processed as part of the returned items session of the cheque clearinghouse. Banred does not have a risk management mechanism in place to deal with potential defaults by any of its member banks.

Unicredit MasterCard processes and clears the transactions made in the Cirrus ATM network. Through Datafast, its subsidiary, Unicredit MasterCard processes payment transactions made with MasterCard credit and debit cards. The system makes a cutoff at 8:00 p.m. and calculates multilateral net positions. Unicredit MasterCard holds a current account at the BCE that serves as a pass-through account for the settlement of these positions. Settlement occurs no later than 11:00 a.m. of $T+1$. However, credit and debit positions are not settled simultaneously, and, due to the lack of risk management tools, Unicredit MasterCard often has to fund net debit positions.

The BCE launched the clearinghouses' system (Sistema de Cámaras de Compensación), which allows payment obligations stemming from private clearinghouse arrangements to be settled in central bank money. 


\title{
Table 4.6 Retail Settlement Systems and Instruments in Individual Latin America and the Caribbean Countries ${ }^{a}$ (Continued)
}

\author{
Country Retail Settlement Systems and Instruments
}

El Salvador Cheque Clearinghouse

The payments system in El Salvador is largely cheque based. Between 180,000 and 220,000 cheques are written in the country every day, with an average value in excess of US $\$ 1,000$.

Following official dollarization, all cheques are written in U.S. dollars. On the one hand, the majority of cheques are "on us" cheques. On the other hand, there is only one formal cheque clearinghouse in the country, located in San Salvador. MICR technology has been recently employed to permit the automated processing of cheques, although full standardization of cheques has not yet been reached. The banks utilize a range of methods for the capture and sorting of cheques, from multipocket proof machines that can encode, capture, and sort cheques in one operation, to single-pocket encoders combined with high-speed-reader sorters, which encode in one operation and capture and sort in a second operation.

Settlement for the clearinghouse takes place on a same-day, multilateral net basis. Almost all cheques are cleared and settled on a next-day basis. Only about 10 -15 percent of the interbank cheques are exchanged outside the San Salvador clearinghouse. The final clearing occurs at 5:00 p.m. for the return of cheques presented in the earlier clearings during the day. The settlement process is manual, and each bank submits its settlement information in paper form showing the volume and value of cheques presented against the other clearinghouse participants. The BCR clearinghouse manager calculates the net position of each bank on a manual basis. These deposit sheets are manually entered into PCs by BCR employees to affect the reserve accounts of banks. On verification of a zero net position and adequate funds in each bank's reserve account, the settlement takes place. Overdrafts of the reserve account are not permitted. The level of required reserves is high relative to daily clearings, so overdrafts are unlikely to occur.

\section{Credit Transers and Direct Debits}

Direct credits and direct debits are used frequently in El Salvador, although only at the intrabank level. Direct deposit has replaced cash as the primary means of paying employees for most businesses of medium and large size. This trend has led to a broader participation in the banking system on the part of the employees of such businesses, because a bank account is required to obtain the direct deposit.

For some time, commercial banks have been trying to implement an $\mathrm{ACH}$ to process interbank electronic credit transfers. The main impediment for this project to materialize is the lack of agreements between banks.

\section{Payment Card Systems}

There are more than 250 ATMs in use in El Salvador. The card used for ATM transactions can also be used as a debit card. It is estimated that about 40 percent of bank retail customers have an ATM-debit card. Many ATMs are deployed off premises, in shopping malls, grocery stores, gas stations, and so on.

There are four networks that are fully interoperable. Two of them are operated by the two largest banks, one by a consortium of smaller banks, and one by a credit card company. The shared networks apply an interchange transaction fee.

There are several networks for the interbank clearing and settlement of card-based transactions, and they are not interoperable. As a result, many merchants that accept debit or credit cards, or both, must have multiple point-of-sale terminals to accommodate the multiple networks.

Guatemala Cheque Clearinghouse

Retail payments are settled mainly by cheque. Cheque standardization, MICR technology, imaging, and other procedures have been implemented recently to increase the degree of automation.

There is a single national cheque clearinghouse in local currency and in U.S. dollars that is operated by a private sector entity, which settles outgoing balances at the BANGUAT. There are 28 participants, mostly banks, but also other nonbank financial institutions. There are two daily clearance and settlement sessions and funds are normally available on customer accounts by $T+2$. 


\title{
Table 4.6 Retail Settlement Systems and Instruments in Individual Latin America and the Caribbean Countries ${ }^{a}$ (Continued)
}

\author{
Country Retail Settlement Systems and Instruments
}

Guatemala

(Continued)

\section{Credit Transfers and Direct Debits}

Direct credits and direct debits are used in Guatemala, although at present almost exclusively at the intrabank level. Bancared, the major ATM and payment card operator, provides credit transfer services for some utilities firms (electricity and telephone) as well as tax collections. Through this service, the clients of any Bancared member bank can use different channels such as Bancared ATMs, phone banking, Internet banking, and banking agencies to make their payments, whereas the payees need to hold only one bank account at a member bank to receive the corresponding credits. Bancared is planning to build a full ACH to process credit transfers and direct debits electronically.

\section{Payment Card Systems}

As of year-end 2003, there were 1.93 million debit cards and 1.65 million credit cards. Payment cards are becoming increasingly important as evidenced by the growth in total settlement throughput from US\$43 million in 1997 to US\$132 million in 2003. There are five major ATM networks that are interoperable; as of year-end 2003, the combined network comprised 774 machines.

Regarding clearance and settlement of the interbank balances generated through ATM transactions, there are multiple arrangements. In general, the outstanding balances among the networks (or among banks that belong to the same network) are settled by cheque or through domestic correspondent bank accounts.

The different card brands cannot be processed at all EFTPOS terminals. The settlement circuits for payment card transactions are also similar to those for ATMs. Furthermore, due to the lack of widely accepted interbank retail electronic payment instruments, card processors pay merchants with cheques, or merchants need to have accounts at various banks to receive credits from every card processor with which they work.

\section{Honduras}

\section{Cheque Clearinghouse}

The cheque is the main payment instrument in Honduras. A new ECH was launched in 2001, and is owned by 20 private banks. The $\mathrm{BCH}$ - a public bank — and a savings and loans association also participate, but are not owners.

Truncation has not been implemented, and physical documents are exchanged in four cities. In any case, the settlement process does not wait for the physical exchange: Participants use the electronic image provided by the system in order to validate the documents and check that enough funds exist in the relevant account.

The clearinghouse operates from 9:00 a.m. to 5:00 p.m. for the first clearing. Participants include in the electronic system the information and images of items to be cleared. Participants know their provisional net debit position as soon as the cheques drawn against them are included in the electronic system. At 5:00 p.m., the BCH debits or credits the accounts of clearinghouse participants according to multilateral net positions. These postings are not final. Between 5:00 p.m. and 7:00 p.m., participants enter information on items rejected. At 7:00 p.m., the BCH executes the final settlement with the adjustments resulting from the rejected items session.

Five banks normally represent about 70 percent of the value settled; 30 percent of all items are entered from 4:00 p.m. to 5:00 p.m.

\section{Credit Transfers and Direct Debits}

Only recently, credit transfers and direct debits have started to become an alternative for making payments in Honduras. They are available only at the intrabank level.

\section{Payment Card Systems}

There is not information of the number of credit cards and debit cards in the system. Nonetheless, payment cards are perceived to become increasingly important. There are five major ATM networks that are interoperable, the combined network comprising 365 machines. 


\section{Table 4.6 Retail Settlement Systems and Instruments in Individual Latin America and the Caribbean Countries ${ }^{a}$ (Continued)}

\begin{tabular}{|c|c|}
\hline Country & Retail Settlement Systems and Instruments \\
\hline \multirow{3}{*}{$\begin{array}{l}\text { Honduras } \\
\text { (Continued) }\end{array}$} & Regarding clearance and settlement of the inter-bank balances generated \\
\hline & $\begin{array}{l}\text { Through ATM transactions, there are multiple arrangements. In general, the outstanding balances among the } \\
\text { networks (or among banks that belong to the same network) are settled by cheque or through domestic corre- } \\
\text { spondent bank accounts. }\end{array}$ \\
\hline & $\begin{array}{l}\text { Settlement circuits for payment card transactions are also similar to those for ATMs. Furthermore, due to the } \\
\text { lack of widely accepted interbank retail electronic payment instruments, card processors pay merchants with } \\
\text { cheques, or merchants need to have accounts at various banks to receive credits from every card processor } \\
\text { with which they work. }\end{array}$ \\
\hline
\end{tabular}

Jamaica Cheque Clearinghouse

The cheque is the most important retail payment instrument in Jamaica. Jamaica's private ACH was established in October 2002, replacing the manual clearing system previously operated by the BOJ. The ACH is governed by the Jamaica Clearing Bankers Association, which comprises all commercial banks and the BOJ.

The cheque-clearing and settlement process foresees two sessions. The first session is held at 7:30 a.m. and is for small-value payments and U.S. dollar-denominated cheques and drafts. At 3:30 p.m., interbank clearing takes place and banks are presented with their current account balances (which include postings resulting from the clearing of all items such as cheques). This information may be accessed online. The time window from 3:30 p.m. to 4:20 p.m. is reserved for deposits in order to cover all outgoing payments, and therefore to avoid an account overdraft. After 4:20 p.m., settlement takes place on a deferred multilateral net basis on accounts held at the BOJ. Availability of funds to system participants occurs normally by the opening of the BOJ on the next business day.

Settlement of the net balances resulting from the exchange of U.S. dollar-denominated items takes place directly between two members according to bilateral agreements.

\section{Credit Transfers and Direct Debits}

Only recently, credit transfers and direct debits have started to become an alternative for making payments in Jamaica. At present, they are available only at an intrabank level, although the Jamaica ACH intends to start processing these payment instruments also at the interbank level in the second stage of the ACH project.

\section{Payment Card Systems}

The Jamaica Electronic Transfers System, a joint venture of several Jamaican financial institutions, is a service platform for electronic retail banking services. It uses a shared network that allows withdrawals at ATMs and card payments at EFTPOS. Interbank obligations arising from these services are settled through Jamaica Electronic Transfers System's own clearinghouse on member banks settlement accounts. Each member is required to secure its net daily settlement obligations by pledging marketable securities to the Jamaica Electronic Transfers System. Settlement takes place on a net basis on the business day following the date the transaction was effected.

\section{Mexico}

\section{Cheque Clearinghouse}

Cheques are still used frequently for retail payments in Mexico, although their importance is decreasing rapidly. The Centro de Compensación Bancaria (CECOBAN) offers countrywide clearance of cheques in Mexican pesos and U.S. dollars, and other retail payment instruments. CECOBAN belongs to the commercial banks.

Cheques and bank accounts are standardized. In the cheque clearinghouse, all institutions have to present to the clearinghouse the documents on the same day they are received from their clients. Circular 2019/95 of Banco de México establishes that banks have to make the corresponding credits or charges to the customer accounts no later than noon of $\mathrm{T}+1$. On September 6, 2002, the banks, together with CECOBAN, began operating a cheque-truncation service. In 2003, the third stage of this process started and all cheques were truncated, and the images exchange clearinghouse (Cámara de Intercambio de Imágenes) became fully operational.

Banco de México's clearinghouse system (Sistema de Cámaras) clears the payments that CECOBAN has processed up to the morning (between 6:30 a.m. and 7:30 a.m.) following the day in which the documents or files are presented for collection. The resulting balances are settled at the SIAC before 9:00 a.m. If a bank is unable to 


\section{Table 4.6 Retail Settlement Systems and Instruments in Individual Latin America and the Caribbean Countries ${ }^{a}$ (Continued)}

\section{Country Retail Settlement Systems and Instruments}

Mexico

(Continued) fulfill its obligations by the time these are due, it is excluded from the process before all other banks credit the payments to the corresponding beneficiaries.

\section{Credit Transfers and Direct Debits}

Regarding retail electronic funds transfers, these have been offered by CECOBAN since 1996. This service was upgraded in 2002, and the former interbank payment system changed its name to Transferencia Electrónica de Fondos. In addition, a direct debit service was implemented. For the clearance and settlement of these electronic instruments, the issuing banks send to CECOBAN the electronic files corresponding to the Transferencia Electrónica de Fondos and direct debit services between 5:30 p.m. and 8:30 p.m. CECOBAN validates the format and dates and informs each participating bank of the outcome. Then electronic files are processed and the corresponding outgoing files generated.

Credit transfer orders executed through the Transferencia Electrónica de Fondos are credited to the beneficiary account in $T+1$ or $T+2$, according to the originator's instructions, and funds are available after 9:00 a.m. The direct debit service operates with a $T+1$ cycle.

\section{Payment Card Systems}

Credit and debit cards are widely used. There are approximately 10 million and 40 million bank-issued credit and debit cards, respectively, outstanding. Major retailers also offer payment cards. Prepaid cards for gas and telephone services are used extensively.

There are three fully interoperable ATM networks with national coverage. Two are the property of the two largest banks of the country, Banamex-Citibank and BBVA Bancomer. The third one, named RED, integrates the networks of all other banks, and is controlled by Promoción y Operación, S.A. de C.V., a company owned by the participating banks.

Interbank settlement of obligations derived from ATM, credit card, and debit card transactions is similar. The three large networks process the operations. Promoción y Operación, S.A. de C.V. then clears the payments and calculates the interbank obligations. These are settled by a commercial bank through electronic funds transfers at the SPEUA.

\section{Other Systems}

Postal money orders purchased through the state-owned Telecom Telégrafos are widely used.

\section{Netherlands Antilles Cheque Clearinghouse}

Cheques are used extensively in the Netherlands Antilles. The clearinghouse is operated by the BvdNA and is partially automated. On day of presentment (T), banks send cheque files from 10:00 a.m. to 1:00 p.m. Paying banks begin to process transactions at 1:30 p.m. and the payer's account is debited on the same day. The accounts of the paying banks are first debited; these banks have two working days to check whether there are any other reasons to reclaim the money. Thus, settlement of cheques in not final and irrevocable on settlement day. Funds are available on the accounts of the beneficiary customers by $T+3$.

The BvdNA initiated a cheque-truncation program by which encoded cheques are transmitted as truncated cheque files with the U.S. National Clearinghouse Association format. Cheques without this feature are transmitted separately and are physically exchanged at the BvdNA's premises. Branches located on islands other than Curaçao settle cheques independently, via facsimile instructions, through a different account at the BvdNA.

\section{Credit Transfers and Direct Debits}

Since October 2001, the NACS has also been used to settle electronic retail payment instruments on a gross basis in batch mode. Credit transfers are processed as ACH-type transactions. If payment instructions comply with all settlement requirements, the batch is settled in real time. The system also has the possibility to handle payment with a future settlement or future value date. The transactions are stored in the so-called future queue and settled on the day indicated in the payment order. 


\section{Table 4.6 Retail Settlement Systems and Instruments in Individual Latin America and the Caribbean Countries ${ }^{a}$ (Continued)}

\begin{tabular}{l|l} 
Country & \multicolumn{1}{c}{ Retail Settlement Systems and Instruments } \\
$\begin{array}{l}\text { Netherlands Antilles } \\
\text { (Continued) }\end{array}$ & $\begin{array}{l}\text { Payment Card Systems } \\
\text { Approximately } 120 \text { ATM machines have been deployed in the country. The three major banks have integrated } \\
\text { their ATMs into a network called Cashnet. The clearing of the Cashnet network is made by a commercial bank } \\
\text { and balances are settled weekly, on a bilateral net basis, at the NACS. ATMs outside the network may interoper- } \\
\text { ate with Cashnet, although transactions have to be processed abroad. }\end{array}$ \\
$\begin{array}{l}\text { The major card brands are Visa and MasterCard, and the major card payment processor is Credomatic. EFTPOS } \\
\text { systems are not completely interoperable locally. All banks act as independent acquirers, and payments with } \\
\text { cards issued by different banks are accepted in terminals other than those of the issuing bank. In some cases, } \\
\text { however, they need to be processed through international circuits. Thus, it is not uncommon for merchants to } \\
\text { have more than one terminal in a single point of sale. }\end{array}$
\end{tabular}

\section{Nicaragua Cheque Clearinghouse}

Cheques are used for both large-value and retail payments. There is one national cheque clearinghouse, which is operated by the BCN. The clearinghouse operates for both local currency and U.S. dollar-denominated cheques. In recent years, cheque standardization and other procedures have been implemented to increase the degree of automation. Recently, the BCN completed the full automation, and fully electronic cheque clearing is now available.

There are two daily clearing and settlement sessions for cheques. Each of the two postings in the current accounts of banks are final, regardless of whether there are sufficient funds in the accounts to which the cheques are related. Funds are normally available on customer accounts by $T+2$ in Managua and from three to five days after presentment for other regions.

\section{Credit Transfers and Direct Debits}

Only recently, credit transfers and direct debits have started to become an alternative for making payments in Honduras. They are available only at an intrabank level.

\section{Payment Card Systems}

Payment cards are only recently starting to become a common payment instrument. Although the card base is low at present with some 250,000 cards (that is, five cards per 100 inhabitants), it has been growing at high double-digit rates for the past two to three years (there has been close to 50 percent increase in the number of credit and charge cards, and 90 percent increase a year in the volume of transactions from 2001 to 2003).

As of year-end 2002, there were 103 ATM machines operating through four noninteroperable networks. EFTPOS terminals are available for both credit- and debit-card payment processing. With few exceptions, the three cardprocessing platforms - Credomatic, Technicap, and Avalcab-are not interoperable.

The ECCB operates a cheque clearinghouse on a deferred net settlement basis. There is an ECCB agency in all territories operating a local clearinghouse under the guidance of the ECCB clearinghouse rules.

Representatives of banks must attend the clearing, which starts at 9:30 a.m. (except in St Vincent and the Grenadines, where it starts at 8:30 a.m.). Instruments are then exchanged and a due-to form is compiled by each bank. The difference between the due-from forms and the due-to forms represents the net balance, which is debited or credited on the accounts held by banks at the ECCB. These accounts should not be overdrawn and should always guarantee the settlement of the clearing balances.

Net positions are settled on the books of the ECCB on $T+1$. Availability of funds to the banks' customers occurs between three days to two weeks, depending on where (intraisland or interisland) the cheque is presented. With respect to extraregional cheques (U.S. dollar-denominated cheques drawn on U.S. banks), availability of funds can take up to six weeks.

A distinction is made between instruments that are returned to a collecting town bank, and instruments returned to a collecting out-of-town bank. In the former case, instruments must be returned by 11:00 a.m. of the working day following presentation at the clearings; in the latter case, instruments must be returned no later than 11:00 a.m. four working days after presentation. 


\section{Table 4.6 Retail Settlement Systems and Instruments in Individual Latin America and the Caribbean Countries ${ }^{a}$ (Continued)}

\begin{tabular}{l|l}
\hline Country & \multicolumn{1}{c}{ Retail Settlement Systems and Instruments } \\
\hline (Continued) & $\begin{array}{l}\text { Credit Transfers and Direct Debits } \\
\text { Direct debits for bill payments, and credit transfers are in the start-up phase and do not represent a significant } \\
\text { share of payment activity. } \\
\text { Payment Card Systems } \\
\text { A credit card company, } 4 \text { Cs, owned by } 13 \text { indigenous banks, is processing credit cards transactions (Visa and } \\
\text { MasterCard) for its members. Approximately } 16,000 \text { cards have been issued for } 10,000 \text { clients. Around } 180,000 \\
\text { cardholders' transactions were processed in } 2003,80 \text { percent of which were foreign transactions. } \\
\text { Around } 43 \text { ATMs and } 850 \text { merchants accept international cards for } 210,000 \text { transactions a year, a large share } \\
\text { of which corresponds to foreign cardholders' transactions. Card transactions in Eastern Caribbean dollars are } \\
\text { based mainly on paper-slip processing, and not on electronic procedures, due to technical specifications and } \\
\text { financial arrangements between 4Cs and the commercial banks. The use of local ATM cards is restricted to the } \\
\text { network of the issuing bank. A scheme for the installation by 4Cs of an interisland common network for debit } \\
\text { cards is envisaged. Some large local banks have projects to launch their own proprietary debit card scheme. }\end{array}$ \\
\hline
\end{tabular}

\section{Panama}

\section{Cheque Clearinghouse}

Cheques are the predominant instrument for retail payments.

Cheques have been standardized as a result of interbank agreements to facilitate the use of MICR technology that permits some automation in cheque processing. Some banks are even able to use imaging, but only for internal purposes, because there are no interbank agreements on electronic cheque presentation or truncation.

Cheques are presented at the clearinghouse operated by the BNP from 3:00 p.m. until 7:00 a.m. of T+1. The clearinghouse operations remain largely manual, because there are no electronic links between the BNP and the commercial banks. Each participating bank submits a sheet showing the volume and value of cheques presented against the other participants. These deposit sheets are manually entered into PCs by BNP employees. Before 7:30 a.m., the BNP provides information to each bank on the results of the session for that day. Simultaneously, the BNP renders an update of the moving average of the net debit positions in the past six months which, according to the regulation, correspond to the required balance in the special clearing account of each direct participant for that day. On verification of balances, the BNP enters the net settlement position of each bank for online posting. The system is not able to provide real-time information on balances or recent transactions.

The clearinghouse requires banks to submit cheques within two days after receiving them, but the common practice is $T+1$. Return items should be informed one day after being received. The common practice is to post the customer account in $T+2$, but there are no official regulations on float.

\section{Credit Transfers and Direct Debits}

ACH services for credit transfers are also offered by Ciasa, a nonfinancial service provider owned by the banks. Transactions are settled through the clearinghouse operated by the BNP. The settlement cycle is similar to that of cheques.

\section{Payment Card Systems}

There are some 300,000 credit cards and 500,000 debit cards issued by commercial banks for a population of 3.1 million. Ciasa is also the clearinghouse for debit and credit cards, and holds accounts for final settlement at BNP. The value of interbank-netted positions at BNP resulting from the clearing process performed by Ciasa on credit and debit cards and ACH operations is about US\$10 million per month.

\section{Cheque Clearinghouse}

The cheque is by far the main payment instrument in Paraguay.

There are three clearinghouses in the country for cheques denominated in local currency. The BCP is a participant, as well as the operator of all three cheque clearinghouses. The clearinghouses located in Ciudad del Este and Encarnación send their multilateral balances to the clearinghouse in the capital city of Asunción, which consolidates its own results with those of the other clearinghouses and settles the outgoing balances at the BCP. 


\title{
Table 4.6 Retail Settlement Systems and Instruments in Individual Latin America and the Caribbean Countries ${ }^{a}$ (Continued)
}

\author{
Country \\ Retail Settlement Systems and Instruments
}

Paraguay

(Continued)
A procedure to achieve some degree of automation was implemented recently, but, in general, the processes remain highly manual. There are two daily clearance and settlement sessions; one in the afternoon of the day of presentment and the second in the morning of the following day for rejected items. Funds are normally available on customer accounts by the end of $T+1$. For cheques denominated in U.S. dollars, which represent 5 percent to 10 percent of the overall volume of cheques and 10 percent to 15 percent of the total value settled, the commercial banks have agreed a settlement procedure because there is no centralized clearinghouse. Balances are settled through foreign correspondents.

The cheque clearinghouse does not have explicit risk management tools.

\section{Credit Transfers and Direct Debits}

Only recently, credit transfers and direct debits have started to become an alternative for making payments in Paraguay. They are available only at an intrabank level.

\section{Payment Card Systems}

As of year-end 2003 , there were almost 250,000 credit cards and 450,000 debit cards. The relative importance of cards as a payment instrument has remained steady over the past few years, although debit cards are expected to increase significantly in the upcoming months as a result of the efforts to increase the use of credit transfers to bank current accounts to pay suppliers and payrolls, which has expanded access to banks.

There are two major ATM networks in the country with very low degree of interoperability; the combined network comprised approximately 220 machines as of year-end 2003. The ATM networks as well as the paymentcard system settle interbank balances with cheques or in correspondent bank accounts (that is accounts local banks hold with other local banks).

Cheque Clearinghouse

Cheques are the most widely used cashless payment instrument. U.S. dollar-denominated cheques account for almost 35 percent of the total value settled. The ECH (Cámara de Compensación Electrónica), launched in 2001, is owned and operated by a private firm.

For each currency, there are two sessions-for presented items and rejected items, respectively. Participants send cheque files from 3:00 p.m. to midnight of day T. Truncation is permitted by the system rules, although it is not yet implemented.

Settlement is made on a multilateral net basis on $T+1$. Before beginning operations in the RTGS system, funds to cover debit positions stemming from the Cámara de Compensación Electrónica are blocked in the accounts of the participants at the BCRP. Funds are credited to participants with a net credit position from 1:15 p.m. to 1:30 p.m.

The rules allow for participants to voluntarily establish bilateral or multilateral credit and debit positions in their operations. However, there are no compulsory bilateral or multilateral limits or other risk management tools. System rules allow for the unwinding of positions in case a participant is unable to settle its position.

\section{Credit Transfers and Direct Debits}

Direct credits and direct debits are used frequently. The Cámara de Compensación Electrónica allows for the clearing and settlement of electronic credit transfers; in the near future, the Cámara de Compensación Electrónica intends to introduce interbank direct debits and bills of exchange, as well.

The clearance and settlement cycle for credit transfers is similar to that of cheques. Net positions are settled through the LBTR system operated by the BCRP.

\section{Payment Card Systems}

The use of payment cards is growing in Peru. For every 1,000 inhabitants, there are approximately 55 credit cards and 175 debit cards. In the past decade, annual growth in both the number of cards issued and payments cleared averaged double-digit figures. 


\title{
Table 4.6 Retail Settlement Systems and Instruments in Individual Latin America and the Caribbean Countries ${ }^{a}$ (Continued)
}

\author{
Country Retail Settlement Systems and Instruments
}

Peru

(Continued)

UNIBANCA is a private entity owned by 14 banks; it operates a network of ATMs and EFTPOS. One memberselected on a rotating basis - is responsible for determining the interbank balances. Settlement is made in central bank money.

A number of other banks have their own networks of ATMs. There is no interoperability across the major networks in Peru.

Visanet is the major processor of credit cards in the country. Most banks undertake all of the administration of their credit cards.

Trinidad and Tobago Cheque Clearinghouse

Cheques are still intensively used for all types of payments in Trinidad and Tobago. The CBTT conducts the low-value cheque clearinghouse using a manual system. Cheques to be presented for collection are physically sent with a listing of the total value to the head offices of the commercial banks between 5:30 p.m. same day and 8:30 a.m. of $T+1$. Banks receive both the physical cheques and a report of the total value. Some banks also exchange diskettes with cheque information for direct upload to their internal systems.

Settlement is based on the values presented with the cheques and is agreed at the clearinghouse, which starts at the CBTT at 9:30 a.m. each business day. The total values confirmed during the clearing process are final and settled. Cheques are validated during the course of the day. There is a time limit of six days, starting from the day of presentment, for the processing of returned and dishonored cheques.

The representatives of all commercial banks and the CBTT meet to review the values of the cheques (in and out), and on completion each bank signs a settlement voucher authorizing the CBTT to credit or debit its reserve account for the net amount of all the cheques between the institutions.

\section{Credit Transfers and Direct Debits}

Only recently, some banks have started to make available credit transfers and direct debits to their customers. At present, these are available only at an intrabank level. However, the CBTT is leading a payment system reform project in which one of the key components is the launching of an $\mathrm{ACH}$ to process credit transfers and direct debits. This is expected to become operational during 2006.

\section{Payment Card Systems}

The volume and value of transactions have almost doubled each year starting from 1997, although in the latest years growth has slowed. Credit and debit cards are mainly issued under the Visa and MasterCard labels.

Infolink Services Limited (ISL) is responsible for the switching and daily settlement of ATM transactions switched between members of the ATM network (four banks). Each bank must provide ISL with settlement vouchers drawn on a designated settlement account, either at the CBTT or elsewhere. For the purposes of settlement, the day ends at 7:00 p.m. The ISL switch hub initiates processing of all transactions at approximately 8:30 a.m. of the following day and prepares a settlement summary report. Each business morning, ISL prepares settlement vouchers based on its settlement report of the previous day. ISL prepares a credit position settlement voucher drawn on its settlement account in favor of the member who is in a credit position in the amount of the net credit. The member deposits the value to its internal settlement account. In the case of debit position settlement vouchers, ISL deposits to its account the values shown on these vouchers.

Most merchants and vendors are equipped to carry out EFTPOS transactions and the use of this facility has increased significantly over the last five years. These transactions are also settled by ISL.

Other Systems

The post office issues money orders, but in general its role in the payment system is limited. 


\section{Table 4.6 Retail Settlement Systems and Instruments in Individual Latin America and the Caribbean Countriesa (Continued)}

\begin{tabular}{l|l} 
Country & Retail Settilement Systems and Instruments \\
Uruguay & Cheque Clearinghouse
\end{tabular}

The main system for retail payments in Uruguay is the national cheque clearinghouse. It is operated by the Bolsa Electrónica de Valores (BEVSA) and regulated by the BCU. Cheques denominated in either local currency or U.S. dollars can be processed at the BEVSA clearinghouse.

Exchange of physical items takes place between 11:00 p.m. and 11:45 p.m. of day T. Cheque information is sent to BEVSA by banks before 12:30 a.m. of T + 1. A first multilateral net settlement balance is calculated at 10:00 a.m. BEVSA executes a process through which the multilateral net debit positions are settled in the accounts at BCU. On $T+1$ between 10:30 a.m. and 11:30 a.m., a rejected items session takes place and new debit positions are settled at BCU accounts.

Cheques can be endorsed several times without any limit. There are no risk management tools. The coverage (settlement guarantee) the BCU provided to the cheque clearinghouse was withdrawn on June 2005. No additional risk management tools are foreseen for the cheque clearinghouse so far.

\section{Credit Transfers and Direct Debits}

Direct credits and direct debits are popular in Uruguay, although for the moment these are offered only at the intrabank level.

BEVSA is working on a project to develop an $\mathrm{ACH}$. The original project aims at making cheque clearing more efficient, although the introduction of new payment instruments such as electronic credit transfers and direct debits is also being considered.

\section{Payment Card Systems}

The use of debit cards and credit cards is still limited. In particular, debit cards are seldom used as payment instruments and are used almost exclusively for cash withdrawals. There are five major credit card issuing companies: OCA, Visa, MasterCard, Diners Club, and American Express. Commercial banks charge relatively high annual fees (US\$30-US\$60) to customers holding debit cards. This is seen as major impediment for debit cards to become widespread payment instrument in the country.

There are three major ATM networks: Banco de la República Oriental del Uruguay (BROU), Redbanc-Bancomat, and Cabal with more than 575 ATMs. For the most part, these networks are interoperable. The interbank obligations stemming from ATM transactions are settled in commercial bank money. In the case of one of the networks, the bilateral balances are settled with cash.

EFTPOS devices are interoperable. Settlement of cards transactions takes place through the local networks in the case of OCA and Visa and regional networks (Argentina) in the case of MasterCard and international networks for the rest. EFTPOS transactions are also settled through commercial banks.

\section{Other Systems}

One peculiarity in Uruguay is the development of nonbank payment networks through which a great variety of payments and collections can be made, mainly with cash. The most relevant are ABITAB and Red de Pagos.

\section{Venezuela, R.B. de Cheque Clearinghouse}

The cheque is by far the main payment instrument in the country.

The cheque clearinghouse underwent a major renovation process and was launched as a fully electronic clearinghouse in 2005. The clearing process is now fully automated. With the information stemming from the $\mathrm{ACH}$, the BCV calculates multilateral net positions, informs the participants from 2:30 p.m. to 3:00 p.m. of T 1 after the returned items session has occurred, and settles net balances on the accounts bank held at the central bank as a result of both sessions.

If an entity has insufficient funds to cover the net debit balance, the BCV separates it from the clearing, unwinds the operations, and calculates new balances. The BCV must inform this situation to the ministry of finance, superintendence of banks, deposit insurance agency, and the national banking board. The BCV does not assume 


\section{Table 4.6 Retail Settlement Systems and Instruments in Individual Latin America and the Caribbean Countries ${ }^{\mathrm{a}}$ (Continued)}

\begin{tabular}{|c|c|}
\hline Country & Retail Settlement Systems and Instruments \\
\hline \multirow[t]{9}{*}{$\begin{array}{l}\text { Venezuela, R.B. de } \\
\text { (Continued) }\end{array}$} & $\begin{array}{l}\text { any responsibility considering the payment of the cheques. The entities will make the claim among themselves } \\
\text { for the reversed cheques. }\end{array}$ \\
\hline & Credit Transfers and Direct Debits \\
\hline & $\begin{array}{l}\text { Banks have incorporated transfer services between accounts within the same bank. Home-banking applications } \\
\text { have been introduced at the intrabank level and are being further developed. }\end{array}$ \\
\hline & $\begin{array}{l}\text { The ACH launched recently by the BCV, the Cámara de Compensación Electrónica de Cheques y otros Medios } \\
\text { de Pago, will also process electronic credit transfers and direct debits in a second phase. }\end{array}$ \\
\hline & Payment Card Systems \\
\hline & $\begin{array}{l}\text { The card base is still low (about } 1 \text { million cardholders and } 2.7 \text { million cards). The main credit cards are Visa and } \\
\text { MasterCard; debit cards are practically nonexistent. }\end{array}$ \\
\hline & $\begin{array}{l}\text { Five independent ATM networks exist in the República Bolivariana de Venezuela; there were 4,500 ATM } \\
\text { machines as of year-end 2004. Two of the networks are administrated by SUICHE 7B and Conexus. These two } \\
\text { networks belong to two private banks groups and are interoperable. The remaining three belong to three } \\
\text { different institutions and operate through Cirrus and Maestro. }\end{array}$ \\
\hline & $\begin{array}{l}\text { Each of the networks clears the operations individually, calculating the net balances for each institution. They } \\
\text { inform those positions that are settled through debits and credits in correspondent accounts, or through } \\
\text { cheques at the BCV. }\end{array}$ \\
\hline & $\begin{array}{l}\text { As for the settlement of transactions made at EFTPOS with credit cards, in May 2002, a group of seven banks } \\
\text { created the interbank payment system (Sistema de Pagos Interbancarios) to automate credit cards payment } \\
\text { instructions to other banks. Final settlement occurs at one of the commercial bank participating in the Sistema } \\
\text { de Pagos Interbancarios. }\end{array}$ \\
\hline
\end{tabular}

Source: Authors' elaboration.

a. Due to the peculiarities of individual Latin America and the Caribbean (LAC) countries, the presentation of information in this table does not strictly follow a standardized model for each country.

b. At which the interbank large-value cheques vales de cámara are exchanged. See BCCH rules in chapter 3.

\section{Observations}

- The region is characterized by a heavy use of cheques, which keeps the retail sector far from being optimal from the point of view of efficiency and risk control. Central banks and all stakeholders in the retail arena must work together in a clear strategy to promote the intensive use of retail electronic payment instruments and reduce the importance of cheques. Customers change their choice of payment service as a response to the price and convenience of the services provided. Thus, to the extent possible central banks might think of using their moral suasion to persuade all participants to price the various payment instruments they offer according to the actual processing cost for each of these, which could mean a relatively higher cost for cheques than that for electronic payment services. It has been noted that in order for such an action to be effective it would have to agreed and applied by all participants (for example, through binding interbank agreements).

- In some countries, ACHs for payment instruments that are fully electronic have been launched or are in the process of being launched. It has been recognized that an automated clearinghouse ( $\mathrm{ACH})$ is a key component that complements the overall efforts to modernize the national payments system. However, in many countries of the region the $\mathrm{ACH}$ project is either too slow to catch up with the needs of customers or too limited in scope. In some cases, the $\mathrm{ACH}$ project aims only at improving the cheque-clearing system. This is not only inadequate, but may even be counterproductive as the investments required for this purpose may crowd out the development of modern payment instruments or give the false impression that cheque processing can be less costly than that of other instruments. 
- It has been strongly recommended that central banks actively support the full deployment of an $\mathrm{ACH}$ that is able to process modern payment instruments such as credit transfers and direct debits. New instruments will directly benefit the urban population or major rural areas, probably, but could also indirectly benefit remote rural areas through the reduction of operational costs in financial institutions. Central banks should take a leadership role to achieve the necessary agreements among banks and other participants so that an $\mathrm{ACH}$ begins operations as soon as possible. Also, central banks should coordinate all efforts under way in order to achieve a single system that encompasses all relevant players and that processes as many services as possible, to avoid duplications and ensure it operates on a full scale. As part of the oversight function, special attention must be given to the governance arrangements of this infrastructure to avoid restrictions to competition and innovation.

- In some countries, payment card circuits are characterized by low or null interoperability resulting in a very inefficient use of the current infrastructure. In contrast, many of the positive effects of a payment cards system for increased efficiency are not being captured due to the lack of electronic payment instruments for retail transactions. Although ATMs are not payment instruments on their own, they are an effective means to reduce the use of "on us" cheques and are a useful infrastructure through which electronic payments and other services can be channeled. ${ }^{4}$ Due to insufficient interoperability of ATMs, among other things the volume of transactions that is needed for a faster amortization of investment costs incurred is not being achieved. In the case of EFTPOS, the lack of interoperability translates in merchants having several terminals (one for each card processor) on their premises, which increases overall costs and favors merchants giving incentives to customers to pay with cash. The lack of retail electronic payment instruments also makes the card system more cumbersome and costly because card processors pay merchants with cheques, or merchants need to have an

\footnotetext{
${ }^{4}$ In this context, "on us" cheques are cheques used by the account holder to cash funds at the teller of his or her bank. In another context, from the bank's perspective, "on us cheques" are cheques in which both the drawer and the drawee are customers of the bank and, therefore, the items do not need to be cleared at the cheque clearinghouse.
}

account at many banks to receive credits from every card processor they work with.

- Central banks and all stakeholders in the retail arena should work together to promote the intensive use of efficient electronic payment instruments in the country, and define a clear strategy and a feasible implementation plan for this purpose. In particular, central banks and payment services providers should engage in major marketing and educational campaigns to raise awareness among consumers of new payment instruments and circuits available, and to provide the necessary information on their features. Similar efforts are also useful when new projects and services (for example, e-government solutions or automation of recurring payments) are launched. Payment services providers can also agree on developing a set of incentives for consumers to begin using these services and testing their benefits. Formal cooperative arrangements, such as a National Payment System Council, should be in place to ensure effective cooperation among stakeholders, between stakeholders and authorities and among authorities (see chapter 6).

- Some banks are starting to offer retail payment instruments and services in multiple countries in the region. These efforts should be monitored by central banks and banking supervisors. While there is no project to develop a common regional or subregional infrastructure in the retail sector, consideration should be given to foster the standardization and harmonization in this area within countries. Eventually, this would facilitate the creation of some form of regional $\mathrm{ACH}$ in case countries believe such an infrastructure would be relevant and viable.

- In sum, central banks and the commercial banks have a role to play to ensure the existing retail circuits support customers' needs, and that such arrangements are safe, convenient, and efficient for the economy as a whole. In particular, the central bank, as the entity leading the efforts to improve the country's financial infrastructure, should promote agreements among banks that would facilitate increased interoperability of the current infrastructure. Following the CPSS retail payments policy report, national central banks should examine developments in the market periodically in the light of public policy goals, and, if issues arise that they judge to be relevant, decide, together with other 
relevant authorities (for example, a consumer protection agency) to take action aimed at establishing or reestablishing an acceptable balance of the various aspects of safety and efficiency. In particular, central banks should (1) review the legal and regulatory framework to identify barriers to improvements in efficiency or safety, and cooperate with relevant public and private entities to ensure that such a framework keeps pace with market developments. Particular issues in this regard would be for the central banks to assess whether the current legal framework effectively supports the use of modern (that is, electronic) payments and related arrangements; (2) monitor whether competitive market conditions and behaviors are in place and take appropriate actions to foster such conditions; and (3) support the development of effective standards and infrastructure arrangements. Once it becomes necessary (for example, when agreements on interoperability are reached or when an $\mathrm{ACH}$ is deployed that would produce interbank obligations that need to be cleared and settled), central banks should adapt their provision of settlement services for systems operated by other entities to contribute to effi- cient and safe outcomes, allowing all such systems to settle in central bank money.

\section{GOVERNIMENT PAYMENTS}

This section includes context, status in the region, and observations regarding government payments.

\section{Context}

In all countries, the public sector is a heavy user of the payments system, and the government receives and remits many payments (for tax collection, salaries, purchase of goods and services, pensions, and so on). In several countries, the public sector has lagged behind the private sector in terms of efficient use of payment instruments and has failed to reach an efficient integration with the banking sector. In recent years, more and more attention has been devoted to this issue and, in some countries, the government has been able to use efficiently the options offered by new technologies ( $\mathrm{ACH}$, smart cards, and so on), significantly reducing its processing costs.

\section{Status in the Region}

\section{Table 4.7 Main Features of Government Payments and Collections in Individual Latin America and the} Caribbean Countries

\begin{tabular}{|c|c|c|c|c|}
\hline Country & $\begin{array}{l}\text { Mechanism to } \\
\text { Process } \\
\text { Government } \\
\text { Payments }\end{array}$ & $\begin{array}{l}\text { Main Payment } \\
\text { Instruments Used } \\
\text { for Payments }\end{array}$ & $\begin{array}{l}\text { Mechanism to } \\
\text { Process } \\
\text { Government } \\
\text { Collections }\end{array}$ & $\begin{array}{l}\text { Main Payment } \\
\text { Instruments Used } \\
\text { for Collections }\end{array}$ \\
\hline Argentina & $\begin{array}{l}\text { The Banco de la Nación, } \\
\text { a government-owned } \\
\text { commercial bank, holds } \\
\text { the single treasury } \\
\text { account. For payments, } \\
\text { the process is central- } \\
\text { ized at Banco de la } \\
\text { Nación. }\end{array}$ & $\begin{array}{l}\text { Direct credits with STP } \\
\text { processed via the ACH. }\end{array}$ & $\begin{array}{l}\text { The Banco de la Nación } \\
\text { also administers collec- } \\
\text { tions. In this case, the } \\
\text { system is fragmented } \\
\text { and is administered from } \\
\text { the Ministry of Finance. }\end{array}$ & $\begin{array}{l}\text { Cash, cheques, and intra- } \\
\text { bank credit transfers are } \\
\text { made through the banking } \\
\text { network, then funds are } \\
\text { transfered via the RTGS } \\
\text { to the single treasury } \\
\text { account. }\end{array}$ \\
\hline Bahamas, The & $\begin{array}{l}\text { The bulk of payments of } \\
\text { the Ministry of Finance } \\
\text { and other public institu- } \\
\text { tions are channeled } \\
\text { through one clearing } \\
\text { bank. }\end{array}$ & $\begin{array}{l}\text { Some of the government's } \\
\text { payments are made with } \\
\text { cheques, but the volume } \\
\text { is decreasing each year. } \\
\text { Some public sector insti- } \\
\text { tutions use direct credits } \\
\text { to bank accounts for pay- } \\
\text { roll. }\end{array}$ & $\begin{array}{l}\text { There is no designated } \\
\text { system to process gov- } \\
\text { ernment collections in a } \\
\text { centralized manner. In } \\
\text { general, collections are } \\
\text { handled through the } \\
\text { banking network. }\end{array}$ & $\begin{array}{l}\text { Generally, cash or } \\
\text { cheques are used at } \\
\text { clearing bank branches. }\end{array}$ \\
\hline
\end{tabular}


Table 4.7 Main Features of Government Payments and Collections in Individual Latin America and the Caribbean Countries (Continued)

\begin{tabular}{|c|c|c|c|c|}
\hline Country & $\begin{array}{l}\text { Mechanism to } \\
\text { Process } \\
\text { Government } \\
\text { Payments }\end{array}$ & $\begin{array}{l}\text { Main Payment } \\
\text { Instruments Used } \\
\text { for Payments }\end{array}$ & $\begin{array}{l}\text { Mechanism to } \\
\text { Process } \\
\text { Government } \\
\text { Collections }\end{array}$ & $\begin{array}{l}\text { Main Payment } \\
\text { Instruments Used } \\
\text { for Collections }\end{array}$ \\
\hline Bolivia & $\begin{array}{l}\text { The BCB holds the single } \\
\text { account of the treasury. } \\
\text { In 2000, it developed the } \\
\text { treasury payments sys- } \\
\text { tem (Sistema de Pagos } \\
\text { del Tesoro). }\end{array}$ & $\begin{array}{l}\text { Direct credits to beneficiary } \\
\text { bank. Manual intervention } \\
\text { for beneficiary account } \\
\text { details. }\end{array}$ & $\begin{array}{l}\text { No designated system. } \\
\text { Payment of taxes and } \\
\text { customs duties are made } \\
\text { mainly at government } \\
\text { offices, and in some } \\
\text { cases are made through } \\
\text { the banking network. }\end{array}$ & $\begin{array}{l}\text { Mainly cash. Cheques } \\
\text { and intrabank credit } \\
\text { transfers are also used } \\
\text { through the banking net- } \\
\text { work; funds are then } \\
\text { transferred via the RTGS } \\
\text { to the single treasury } \\
\text { account. }\end{array}$ \\
\hline Brazil & $\begin{array}{l}\text { The BACEN holds the } \\
\text { single account of the } \\
\text { treasury. The Banco } \\
\text { do Brasil, a govern- } \\
\text { ment-owned commer- } \\
\text { cial bank holds the } \\
\text { accounts of administra- } \\
\text { tive units, which make } \\
\text { the payments to final } \\
\text { beneficiaries. }\end{array}$ & $\begin{array}{l}\text { Direct credits via the RTGS } \\
\text { from single treasury } \\
\text { account to government } \\
\text { administrative units' } \\
\text { accounts at Banco do } \\
\text { Brasil. }\end{array}$ & $\begin{array}{l}\text { No designated system. } \\
\text { Taxpayers may use the } \\
\text { bank of their choice. }\end{array}$ & $\begin{array}{l}\text { Cash, cheques, and intra- } \\
\text { bank credit transfers. } \\
\text { Banks forward the funds } \\
\text { via the RTGS to the } \\
\text { BACEN, and the taxpayer } \\
\text { data to the treasury's data } \\
\text { processing subsidiary, } \\
\text { Soluções para um Brasil } \\
\text { de Todos. }\end{array}$ \\
\hline Chile & $\begin{array}{l}\text { The general treasury } \\
\text { makes its payments } \\
\text { through commercial } \\
\text { banks. }\end{array}$ & $\begin{array}{l}\text { Cheques and intrabank } \\
\text { direct credits. }\end{array}$ & $\begin{array}{l}\text { Most tax collections are } \\
\text { handled through govern- } \\
\text { ment collections offices. } \\
\text { Recently, federal taxes, } \\
\text { and other taxes and sur- } \\
\text { charges can also be } \\
\text { processed via Internet } \\
\text { banking. }\end{array}$ & $\begin{array}{l}\text { Cash and cheques in } \\
\text { treasury collections } \\
\text { branches, and electronic } \\
\text { credit transfers via the } \\
\text { Internet through some } \\
\text { banks. }^{\text {a }}\end{array}$ \\
\hline Colombia & $\begin{array}{l}\text { The BR holds the single } \\
\text { account of the treasury. } \\
\text { Government payments } \\
\text { are channeled via the } \\
\text { ACH of the BR. }\end{array}$ & $\begin{array}{l}\text { In some cases, direct cred- } \\
\text { its with STP processes. In } \\
\text { other cases, transfers to } \\
\text { the final executors of the } \\
\text { national budget, which hold } \\
\text { accounts with banks and } \\
\text { other financial institutions. }\end{array}$ & $\begin{array}{l}\text { No designated system. } \\
\text { Generally, taxpayers use } \\
\text { the banking network as } \\
\text { well as the physical } \\
\text { branches of the tax } \\
\text { agency Direc ción de } \\
\text { Impuestos y Aduanas } \\
\text { Nacionales. That agency } \\
\text { has an electronic pay- } \\
\text { ment system in place for } \\
\text { large taxpayers. }\end{array}$ & $\begin{array}{l}\text { Cash, cheques, and intra- } \\
\text { bank credit transfers are } \\
\text { made through the banking } \\
\text { network; funds are then } \\
\text { transferred to the single } \\
\text { treasury account. }\end{array}$ \\
\hline Costa Rica & $\begin{array}{l}\text { The BCCR holds the } \\
\text { single account of the } \\
\text { treasury. Payments are } \\
\text { channeled exclusively } \\
\text { through the ACH oper- } \\
\text { ated by the BCCR. }\end{array}$ & $\begin{array}{l}\text { Direct credits with STP } \\
\text { processes via the ACH. }\end{array}$ & $\begin{array}{l}\text { Tax collection is done } \\
\text { through the banking } \\
\text { network. There is a } \\
\text { designated system, } \\
\text { the Información y Liq- } \\
\text { uidación de Impuestos, } \\
\text { for banks to transfer } \\
\text { funds and payment } \\
\text { details to the treasury } \\
\text { the day after payments } \\
\text { are made. }\end{array}$ & $\begin{array}{l}\text { Cash, cheques, and intra- } \\
\text { bank credit transfers are } \\
\text { made through the banking } \\
\text { network; funds and pay- } \\
\text { ment details are then } \\
\text { transferred to the ministry } \\
\text { of finance with STP } \\
\text { processes. }\end{array}$ \\
\hline
\end{tabular}




\section{Table 4.7 Main Features of Government Payments and Collections in Individual Latin America and the} Caribbean Countries (Continued)

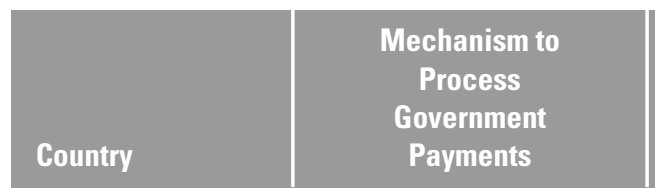

Dominican
Republic

Payments of the Ministry of Finance and other public institutions are channeled through the Banco de Reservas, a stateowned commercial bank. There is no designated system to process these payments centrally.

\begin{tabular}{ll}
\hline Ecuador & The budget execution \\
system (Sistema de \\
Ejecución Presupuestal) \\
is the system for the \\
payments of public sec- \\
tor institutions. Public \\
sector institutions hold \\
an account at the BCE \\
to receive allotments \\
from the national trea- \\
sury, and also hold \\
accounts at commercial \\
banks to pay to the final \\
beneficiaries.
\end{tabular}

\begin{tabular}{ll}
\hline El Salvador & $\begin{array}{l}\text { The BCR serves as the } \\
\text { government bank, issu- } \\
\text { ing payments on behalf } \\
\text { of the government. } \\
\text { There is no designated } \\
\text { system to process these } \\
\text { payments centrally. }\end{array}$ \\
\hline Guatemala & The national treasury \\
holds a single account \\
at the BANGUAT. Until \\
recently, the national \\
treasury was using the \\
ACH-like system offered \\
by Bancared, but it \\
decided to develop an \\
alternative system for \\
cost and efficiency \\
reasons. The final ben- \\
eficiaries are credited \\
on T +3.
\end{tabular}

Main Payment

Instruments Used

for Payments

Payments of the central government are made with cheques. Some public sector institutions are already using direct credits to bank accounts for payroll.

Government agencies first receive the funds from the national treasury at the BCE. From there, the BCE uses direct credits with STP processes via the SPI.

Cheques for payments of the central government. Some public sector institutions use direct credits to bank accounts for payroll.

Same-day credit transfers to beneficiary banks through the Oficios system of the BANGUAT. On T + 1, banks access the Web site of the national treasury to download the payment details. Today, 25 percent of all government payments are still made with cheques.

\section{Mechanism to Process \\ Government Collections}

The customs office, the national treasury, and the internal taxes office are the collection bodies. There is no designated system currently in place to process government collections.

The Sistema de Ejecución Presupuestal is also used as the channel for the collections of public sector institutions. At the end level, the system of government collections is operated by the commercial banks, which collect tax-related payments from taxpayers.

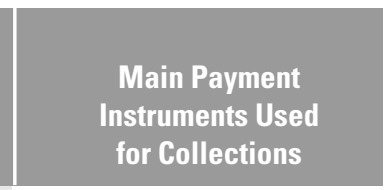

Most taxpayers pay directly with cash or cashiers' cheques at the premises of government collection agencies.
Cash, cheques, and intrabank credit transfers are made through the banking network; funds are then transferred to the account of the relevant public sector agency at the BCE.
The BCR also receives the payments on behalf of the government. There is no designated system to process these collections centrally.

Government collections are managed by the Superintendencia de Administración Tributaria. Taxes and other payments to the government are collected through the commercial banking network.
Mainly cash. Cheques and intrabank credit transfers are also used through the banking network.

Cheques and intrabank credit transfers are made through the banking network. $\ln T+1$, the banks transfer the collected amounts through an official letter (oficio). Finally, banks access the system of the Superintendencia de Administración Tributaria to send the details of payments received. 
Table 4.7 Main Features of Government Payments and Collections in Individual Latin America and the Caribbean Countries (Continued)

\begin{tabular}{|c|c|c|c|c|}
\hline Country & $\begin{array}{l}\text { Mechanism to } \\
\text { Process } \\
\text { Government } \\
\text { Payments }\end{array}$ & $\begin{array}{l}\text { Main Payment } \\
\text { Instruments Used } \\
\text { for Payments }\end{array}$ & $\begin{array}{l}\text { Mechanism to } \\
\text { Process } \\
\text { Government } \\
\text { Collections }\end{array}$ & $\begin{array}{l}\text { Main Payment } \\
\text { Instruments Used } \\
\text { for Collections }\end{array}$ \\
\hline Honduras & $\begin{array}{l}\text { The general treasury } \\
\text { holds its account with } \\
\text { the } \mathrm{BCH} \text {. From there, it } \\
\text { transfers funds to other } \\
\text { government entities. For } \\
\text { final beneficiaries, it } \\
\text { uses cheques drawn } \\
\text { on its } \mathrm{BCH} \text { account. }\end{array}$ & Mainly cheques. & $\begin{array}{l}\text { Collections related } \\
\text { to income taxes and } \\
\text { customs are operated } \\
\text { mainly through the } \\
\text { ministry's own premises. }\end{array}$ & Cash or cheques. \\
\hline Jamaica & $\begin{array}{l}\text { The BOJ serves as the } \\
\text { government bank for } \\
\text { payments. There is no } \\
\text { designated system to } \\
\text { process these payments } \\
\text { centrally. }\end{array}$ & $\begin{array}{l}\text { Cheques are used for the } \\
\text { vast majority of government } \\
\text { payment transactions. }\end{array}$ & $\begin{array}{l}\text { There is no designated } \\
\text { system to process } \\
\text { collections centrally, } \\
\text { although, through its } \\
\text { electronic government } \\
\text { initiatives, the govern- } \\
\text { ment is starting to use } \\
\text { some electronic systems. } \\
\text { The banking network is } \\
\text { generally not used. }\end{array}$ & $\begin{array}{l}\text { Taxpayers pay with cash } \\
\text { or cheque at the locations } \\
\text { of collecting government } \\
\text { agencies. }\end{array}$ \\
\hline Mexico & $\begin{array}{l}\text { The Banco de México } \\
\text { holds the single account } \\
\text { of the federal treasury. } \\
\text { The federal treasury is a } \\
\text { direct participant in the } \\
\text { ACH operated by } \\
\text { CECOBAN. }\end{array}$ & $\begin{array}{l}\text { Direct credits with STP } \\
\text { processes via the ACH } \\
\text { operated by CECOBAN. }\end{array}$ & $\begin{array}{l}\text { Tax collections for the } \\
\text { federal government are } \\
\text { handled through the } \\
\text { banking sector. Starting } \\
\text { in 2003, all federal taxes } \\
\text { must be processed as } \\
\text { Internet transactions. }\end{array}$ & $\begin{array}{l}\text { Electronic credit transfers } \\
\text { via the Internet with STP } \\
\text { processes are made } \\
\text { through the banking } \\
\text { network and the ACH. }\end{array}$ \\
\hline $\begin{array}{l}\text { Netherlands } \\
\text { Antilles }\end{array}$ & $\begin{array}{l}\text { The BvdNA serves as } \\
\text { the government bank } \\
\text { for payments, and has } \\
\text { provided the central } \\
\text { government and island } \\
\text { government of Curaçao } \\
\text { with access to the } \\
\text { NACS. Neither has } \\
\text { made any significant } \\
\text { use of NACS; instead, } \\
\text { each uses the banking } \\
\text { network. }\end{array}$ & $\begin{array}{l}\text { Some payments are made } \\
\text { electronically through the } \\
\mathrm{ACH} \text {, but the vast majority } \\
\text { is still paper based. }\end{array}$ & $\begin{array}{l}\text { There is no designated } \\
\text { system to process these } \\
\text { collections centrally. } \\
\text { The central government } \\
\text { receives collections at } \\
\text { its own premises. The } \\
\text { island government } \\
\text { of Curaçao uses the } \\
\text { banking network. }\end{array}$ & $\begin{array}{l}\text { Cash or cheques are used } \\
\text { for tax payments to the } \\
\text { central government. In } \\
\text { the case of the island } \\
\text { government of Curaçao, } \\
\text { collections are generally } \\
\text { made through intrabank } \\
\text { electronic credit } \\
\text { transfers. }\end{array}$ \\
\hline Nicaragua & $\begin{array}{l}\text { The Ministry of Finance } \\
\text { holds its account with } \\
\text { the BCN. From there, it } \\
\text { transfers funds to other } \\
\text { government entities. For } \\
\text { final beneficiaries, it } \\
\text { uses cheques drawn on } \\
\text { its BCN account. }\end{array}$ & $\begin{array}{l}\text { Mainly cheques. Recently, } \\
\text { the Ministry of Finance has } \\
\text { also been using direct } \\
\text { credits for payroll, but } \\
\text { these represent only } 2 \text { per- } \\
\text { cent of the total volume. }\end{array}$ & $\begin{array}{l}\text { Collections related to } \\
\text { income taxes are oper- } \\
\text { ated mainly through the } \\
\text { ministry's own premises. } \\
\text { Customs taxes and other } \\
\text { collections are operated } \\
\text { through the banking } \\
\text { network. }\end{array}$ & $\begin{array}{l}\text { Cash or cheques. The } \\
\text { Ministry of Finance holds } \\
\text { some } 300 \text { different } \\
\text { current accounts at } \\
\text { commercial banks. }\end{array}$ \\
\hline
\end{tabular}




\section{Table 4.7 Main Features of Government Payments and Collections in Individual Latin America and the} Caribbean Countries (Continued)

\begin{tabular}{|c|c|c|c|c|}
\hline Country & $\begin{array}{l}\text { Mechanism to } \\
\text { Process } \\
\text { Government } \\
\text { Payments }\end{array}$ & $\begin{array}{l}\text { Main Payment } \\
\text { Instruments Used } \\
\text { for Payments }\end{array}$ & $\begin{array}{l}\text { Mechanism to } \\
\text { Process } \\
\text { Government } \\
\text { Collections }\end{array}$ & $\begin{array}{l}\text { Main Payment } \\
\text { Instruments Used } \\
\text { for Collections }\end{array}$ \\
\hline OECS & $\begin{array}{l}\text { There is no designated } \\
\text { system to process the } \\
\text { payments of territorial } \\
\text { governments centrally. } \\
\text { In general, territory gov- } \\
\text { ernments hold accounts } \\
\text { with commercial banks. }\end{array}$ & $\begin{array}{l}\text { Mainly cash or cheques. } \\
\text { Some territorial govern- } \\
\text { ments participate in direct } \\
\text { deposit of payrolls. }\end{array}$ & $\begin{array}{l}\text { There is no designated } \\
\text { system to process col- } \\
\text { lections of territorial } \\
\text { governments centrally. } \\
\text { In general, collections } \\
\text { are managed through } \\
\text { the banking network. }\end{array}$ & $\begin{array}{l}\text { Cash or cheques are used } \\
\text { at banks or at the } \\
\text { premises of tax- and duty- } \\
\text { collecting agencies. }\end{array}$ \\
\hline Panama & $\begin{array}{l}\text { The BNP serves as the } \\
\text { government bank and } \\
\text { acts as its paying agent. } \\
\text { The government has } \\
\text { several accounts, } \\
\text { although it plans to } \\
\text { launch the single trea- } \\
\text { sury account soon. }\end{array}$ & $\begin{array}{l}\text { For payroll, the national } \\
\text { treasury prepares cheques } \\
\text { that are physically handed } \\
\text { to recipients by staff in the } \\
\text { office of the comptroller. } \\
\text { For suppliers, the national } \\
\text { treasury has direct access } \\
\text { to the ACH to make credit } \\
\text { transfers. }\end{array}$ & $\begin{array}{l}\text { The BNP collects govern- } \\
\text { ment revenues through } \\
\text { the banking network. } \\
\text { There is no designated } \\
\text { system to process collec- } \\
\text { tions. The upcoming rev- } \\
\text { enues module of the } \\
\text { single treasury account } \\
\text { will allow the automatic } \\
\text { registry of all revenues. }\end{array}$ & $\begin{array}{l}\text { Cash, cheques, or elec- } \\
\text { tronic credit transfers are } \\
\text { used at banks. }\end{array}$ \\
\hline Paraguay & $\begin{array}{l}\text { The BCP serves as the } \\
\text { government bank, issu- } \\
\text { ing payments on behalf } \\
\text { of the government. } \\
\text { There is no designated } \\
\text { system to process these } \\
\text { payments centrally. }\end{array}$ & Cheques. & $\begin{array}{l}\text { The central government } \\
\text { and other tax and duties } \\
\text { agencies receive collec- } \\
\text { tions at their own } \\
\text { premises. }\end{array}$ & $\begin{array}{l}\text { Mainly cash and } \\
\text { cheques. }\end{array}$ \\
\hline Peru & $\begin{array}{l}\text { The Banco de la Nación, } \\
\text { a government-owned } \\
\text { commercial bank, serves } \\
\text { as the government bank, } \\
\text { issuing payments on } \\
\text { behalf of the govern- } \\
\text { ment. Each public entity } \\
\text { has an account with the } \\
\text { Banco de la Nación; } \\
\text { payments are not } \\
\text { processed through a } \\
\text { central account. }\end{array}$ & $\begin{array}{l}\text { Mainly cheques. Direct } \\
\text { credits through the Cámara } \\
\text { de Compensación Elec- } \\
\text { trónica are becoming } \\
\text { increasingly important for } \\
\text { payments to suppliers. }\end{array}$ & $\begin{array}{l}\text { The Banco de la Nación } \\
\text { is also responsible for } \\
\text { government collections. } \\
\text { Taxpayers may also } \\
\text { make their payments } \\
\text { through other commer- } \\
\text { cial banks. }\end{array}$ & $\begin{array}{l}\text { Mainly cash and cheques } \\
\text { are used at the premises } \\
\text { of Banco de la Nación. }\end{array}$ \\
\hline $\begin{array}{l}\text { Trinidad and } \\
\text { Tobago }\end{array}$ & $\begin{array}{l}\text { The CBTT is banker to } \\
\text { the government and } \\
\text { manages several } \\
\text { accounts on its behalf. } \\
\text { There is no designated } \\
\text { system to process these } \\
\text { payments centrally. }\end{array}$ & $\begin{array}{l}\text { For payroll, each ministry } \\
\text { sends to each bank one } \\
\text { cheque with a list of per- } \\
\text { sons whose accounts are } \\
\text { to be credited. Individual } \\
\text { cheques are used in all } \\
\text { other cases. The govern- } \\
\text { ment is preparing to use } \\
\text { Direct Credits over the } \\
\text { ACH. }\end{array}$ & $\begin{array}{l}\text { A fully manual teller ser- } \\
\text { vice is provided by the } \\
\text { CBTT for the receipt of } \\
\text { deposits (revenues) from } \\
\text { the various ministries } \\
\text { and departments. } \\
\text { Corporation tax can be } \\
\text { collected through one of } \\
\text { the commercial banks. }\end{array}$ & $\begin{array}{l}\text { The government accepts } \\
\text { cash and cheques from } \\
\text { the public for payment of } \\
\text { taxes and services. Some } \\
\text { agencies are equipped } \\
\text { with point-of-sale } \\
\text { machines for collections. }\end{array}$ \\
\hline
\end{tabular}




\section{Table 4.7 Main Features of Government Payments and Collections in Individual Latin America and the Caribbean Countries (Continued)}

\begin{tabular}{|c|c|c|c|c|}
\hline Country & $\begin{array}{l}\text { Mechanism to } \\
\text { Process } \\
\text { Government } \\
\text { Payments }\end{array}$ & $\begin{array}{l}\text { Main Payment } \\
\text { Instruments Used } \\
\text { for Payments }\end{array}$ & $\begin{array}{l}\text { Mechanism to } \\
\text { Process } \\
\text { Government } \\
\text { Collections }\end{array}$ & $\begin{array}{l}\text { Main Payment } \\
\text { Instruments Used } \\
\text { for Collections }\end{array}$ \\
\hline Uruguay & $\begin{array}{l}\text { The financial agent of } \\
\text { the government is the } \\
\text { BROU, a government- } \\
\text { owned commercial } \\
\text { bank. Each government } \\
\text { agency may channel its } \\
\text { payments through the } \\
\text { treasury, or may directly } \\
\text { use its current account } \\
\text { with the BROU. }\end{array}$ & $\begin{array}{l}\text { Cash, cheques, or electronic } \\
\text { transfers when beneficiaries } \\
\text { have accounts with the } \\
\text { BROU. Some entities have } \\
\text { made agreements with other } \\
\text { commercial banks to credit } \\
\text { final beneficiaries. The } \\
\text { banks of final beneficiaries } \\
\text { receive the funds by means } \\
\text { of a large-value cheque } \\
\text { drawn on the BROU. }\end{array}$ & $\begin{array}{l}\text { Government collections } \\
\text { are operated through } \\
\text { the banking network, } \\
\text { and especially through } \\
\text { the nonfinancial net- } \\
\text { works for payments } \\
\text { such as ABITAB. There } \\
\text { is no designated system } \\
\text { to process collections } \\
\text { centrally. }\end{array}$ & $\begin{array}{l}\text { Cash and cheques in the } \\
\text { case of nonfinancial pay- } \\
\text { ment networks. Cash, } \\
\text { cheques, and credit } \\
\text { transfers are used in the } \\
\text { case of the banking } \\
\text { network. }\end{array}$ \\
\hline Venezuela, R.B. de & $\begin{array}{l}\text { The BCV is in charge of } \\
\text { executing the national } \\
\text { budget and holds } \\
\text { accounts for the ministry } \\
\text { of finance and other } \\
\text { public institutions. All } \\
\text { payments are channeled } \\
\text { through a department } \\
\text { (Agencia de Tesorería } \\
\text { Nacional) of the BCV. } \\
\text { The transactional plat- } \\
\text { forms of the BCV and } \\
\text { ministry of finance are } \\
\text { interconnected. }\end{array}$ & $\begin{array}{l}\text { Cheques and direct credits } \\
\text { with some manual interven- } \\
\text { tion. Direct credits with STP } \\
\text { processes will be possible } \\
\text { with the launching of the } \\
\text { ACH. }\end{array}$ & $\begin{array}{l}\text { Government revenues } \\
\text { are collected through } \\
\text { the banking network. } \\
\text { There is no designated } \\
\text { system to process } \\
\text { collections. }\end{array}$ & $\begin{array}{l}\text { Cash, cheques, or elec- } \\
\text { tronic credit transfers are } \\
\text { used at banks. }\end{array}$ \\
\hline
\end{tabular}

Source: Author's elaboration.

Note: CENIT (Sistema de Compensación Electrónica Nacional Interbancaria).

a. Those that have an agreement with the national treasury to process this type of payments.

\section{Observations}

- Many countries throughout the region have implemented or are in the process of implementing projects to integrate the public sector in the national payments system. However, in most cases these are stand-alone projects, and are not fully consistent with a long-term strategic vision of the payments system. Although in some particular cases the integration has been particularly successful, in most other cases the procedures for the payment or collection of government and social security payments are generally not integrated, in the sense that payment details are generally independent from the funds transfer; hence, STP is not achieved.

- In some cases, central banks themselves have engaged in system developments to improve government payments and collections. These initiatives seem to col- lide with those of the private sector to launch an $\mathrm{ACH}$ for direct credits and direct debits; in many countries, the government is the major or one of the major payers or collectors of the national payments system.

- It is recommended that central banks and other relevant government agencies foster coordination and communication to ensure that collection and disbursements of the public sector institutions that are major players in the payments system be processed electronically and in a timely manner through an appropriate system, such as an $\mathrm{ACH}$ for retail electronic payment instruments. It must be noted that, in many cases, the gains in efficiency and cost reductions for government payments have been the main result of the reform effort. Such a strategy can also ensure that the benefits of new payment alternatives be accrued to all segments in the country by, for example, inducing a higher use of bank- 
ing services by the public in general. In contrast, government payments provide a good opportunity to channel a high volume of transactions, thereby making the $\mathrm{ACH}$ project more attractive for potential investors.

- Government payments are also a major source of liquidity for the banking system, and, if coordinated effectively, can facilitate the smooth functioning of the RTGS system being implemented by the region's central banks, thereby increasing its appeal to participants.

\section{FX AND CROSS-BORDER SETTLEMENT MECHANISMS}

This section includes context, status in the region, and observations regarding FX and cross-border settlement mechanisms.

\section{Context}

FX markets present risks that are potentially relevant. The FX settlement risk clearly has a credit risk dimension. If (as it is usually the case under current market practices) a bank cannot make the payment of the currency it sold conditional on its final receipt of the currency it bought, it faces the possibility of losing the full principal value of the transaction. FX settlement risk also has an important liquidity risk dimension. Even temporary delays in settlement can expose a receiving bank to liquidity pressures if unsettled funds are needed to meet obligations to other parties. FX settlement risk has other dimensionsfor example, legal risk. In the case of FX deals, legal risk can be complicated by the fact that settlement normally takes place in more than one jurisdiction. As reported in Settlement Risk in Foreign Exchange Transactions (CPSS 1996a), the Group of Ten central banks agreed on a strategy providing for the following:

- Action by individual banks to control the FX settlement exposures;

- Action by industry groups to provide risk-reducing multicurrency services; and

- Action by central banks to induce rapid private sector progress.

The report (p. 2) also states that, "G-10 [Group of Ten] central banks encourage existing and prospective industry groups to develop and offer services that would contribute to the risk-reducing efforts of individual banks."

\footnotetext{
${ }^{5}$ See also BIS 2000.
}

Also as a result of the recommendations included in the CPSS (1996a) report, the Continuous Linked Settlement Bank International (CLS Bank) started its CLS service in September 2002, settling FX transactions in seven currencies (the Australian dollar, the Canadian dollar, the U.S. dollar, the euro, the Swiss franc, the Japanese yen, and the British pound) on a PvP basis on the books of the seven respective central banks. In 2005, CLS Bank was dealing with a total of 15 currencies (the former plus Danish krone, Norwegian krone, Swedish krona, Hong Kong dollar, Korean won, Singapore dollar, South African rand, and New Zealand dollar), all of which were being settled through CLS Bank. By the end of 2005, CLS Bank had a total of 56 member banks (shareholders, with settlement accounts) and 674 member customers (third parties sponsored by a member bank), and nearly 80 percent of total member volume was being settled through it. The CLS Bank is subject to the cooperative oversight of central banks involved, and is under the direct oversight of the U.S. Federal Reserve.

Retail cross-border payments, notably trade-related payments and personal remittances, are increasingly relevant for economies and their societies as a result of current global realities - particularly a growing economic integration and interdependence among countries at all levels and the increasing flow of immigrants throughout the world. From a policy-making perspective, retail crossborder payments share many of the features of domestic retail payments. Relevant issues to look at include the efficiency of the payment instruments being used, security and other risks, customer protection, costs, diversity of service providers, oversight capabilities of the central bank, and so on. The cross-border dimension brings in some additional issues, including the involvement (in many cases) of a FX transaction and of various national laws, regulations, institutions, and even habits.

Cross-border payment services customers expect to be provided with a set of convenient, cheap, reliable, and predictable instruments to cover their most important payment needs: face-to-face payments, one-off and recurring remote payments, and ATM cash withdrawals. Performance in most of these areas is generally poor as a result of, among others, lack of transparency, the diversity of cross-border payment services (among which several types of nonfinancial institutions that typically remain unregulated as to their provision of payment services), and weak oversight as overseeing the full flow of a 
cross-border transaction would necessarily involve two or more national authorities.

As part of their role as payment system overseers, central banks should strive for the regulatory perspective in crossborder payments to be widened from the traditional areas of balance of payments and money laundering to include payment system issues, in particular issues related to efficiency, transparency, and risks. Furthermore, through enhanced international cooperation, central banks should analyze what the inhibitors and obstacles are for crossborder payments to become as efficient and safe as possible within the general constraints set by national and monetary boundaries.

\section{Box 4.2 The World Bank-CPSS Task Force for General Principles on International Remittance Systems}

An international remittance transfer is a payment from person to person. There is a large body of guidelines and regulations regarding payment systems, and the international standard setter in this field is the Bank for International Settlements' CPSS CPSS reports can be accessed at the Web site www.BIS.org/CPSS/index.htm.

International remittance transfers are cross-border retail payments. These payments are normally of a relatively low value, are largely made by private arrangements between banks or other international payment service providers, and are often not subject to oversight from central banks or other authorities.

International remittance transfers also have special access requirements on both the sending and the receiving sides. On the sending side, remittance senders often do not have full access to the national payments system because they do not have bank accounts, payment cards, or other payment instruments, and they might not be comfortable interacting with banks in their host country. On the receiving side, the national payments system might not be well developed, and recipients might not have access to banks or formal institutions, often simply because there is no such institution where they live. Remittance firms provide a link between the banks that perform the actual cross-border payments and the end users.

The attention of the development community often focuses on these special access requirements-such as financial literacy, poor people's access to financial services, and fair pricing. Payment system overseers are increasingly focusing on the cross-border aspect of remittances and on how to create an internationally coherent framework for regulation and oversight that best allows safe, efficient, and fairly priced remittance services to develop.

In a joint effort between the development community and the international standard setter for payment systems, the World Bank and the CPSS together convened, at the end of 2004, a task force to lay the ground for the international payment system framework for remittances. The members of the task force represent central banks from remittance sending and receiving countries, as well as the multilateral development banks and the International Monetary Fund. This task force issued in March 2006 a consultative report with general principles for the provision of international remittances.

The principles address such issues as the legal basis for remittance systems, competition, fair services, transparency, consumer protection, financial literacy, payment system infrastructure to support the provision of these services, international policy coordination, as well as the role of public authorities and private firms in creating an efficient and safe remittance market.

These principles provide the first internationally recognized payment system framework for remittance transfers, and they are expected to facilitate international policy coordination in the area of remittance transfers.

The general principles presented below are aimed at the public policy objectives of achieving safe and efficient international remittance services. To this end, the markets for the services should be contestable, transparent, accessible and sound.

\section{TRANSPARENCY AND CONSUMER PROTECTION}

General Principle 1. The market for remittance services should be transparent and have adequate consumer protection.

\section{PAYMENT SYSTEM INFRASTRUCTURE}

General Principle 2. Improvements to payment system infrastructure that have the potential to increase the efficiency of remittance services should be encouraged. 


\section{Box 4.2 The World Bank-CPSS Task Force for General Principles on International} Remittance Systems (Continued)

\section{LEGAL AND REGULATORY ENVIRONMENT}

General Principle 3. Remittance services should be supported by a sound, predictable, nondiscriminatory and proportionate legal and regulatory framework in relevant jurisdictions.

\section{MARKET STRUCTURE AND COMPETITION}

General Principle 4. Competitive market conditions, including appropriate access to domestic payments infrastructures, should be fostered in the remittance industry.

\section{GOVERNANCE AND RISK MANAGEMENT}

General Principle 5. Remittance services should be supported by appropriate governance and risk management practices.

\section{ROLES OF REMITTANCE SERVICE PROVIDERS AND PUBLIC AUTHORITIES}

A. The role of remittance service providers. Remittance service providers should participate actively in the implementation of the General Principles.

B. The role of public authorities. Public authorities should evaluate what action to take to achieve the public policy objectives through implementation of the General Principles.

\section{Box 4.3 Cross-Border Payment Arrangements among Central Banks in the Latin America} and Caribbean Region

\section{ASOCIACIÓN LATINOAMERICANA DE INTEGRACIÓN}

In 1965, as part of the agreements within the Asociación Latinoamericana de Integración (ALADI) the central banks of 12 Latin American countries-Argentina, Brazil, Bolivia, Chile, Colombia, the Dominican Republic, Ecuador, Mexico, Paraguay, Peru, Uruguay, and the República Bolivariana de Venezuela-subscribed to the Reciprocal Payments and Credits Agreement (Convenio de Pagos y Créditos Recíprocos) with the objective of reducing the cross-border transfer of foreign currencies among themselves.

Under the ALADI system, the central bank of the country where the export was originated deposits funds, on behalf of the central bank of the importing country, in the commercial bank participating in the foreign trade transaction. Each country's central bank also authorizes its financial institutions to send commercial transactions directly through ALADI as "authorized institutions." These transactions result in net accrued positions in U.S. dollars among central banks. Every four months, the operations center, located in the central bank of Peru, makes a cutoff of multilateral balances among central banks through the automated system supporting the ALADI Reciprocal Payments and Credit Agreement (Sistema Computarizado de Apoyo al Convenio de Pagos y Créditos Recíprocos ALADI). Funds are settled in the Federal Reserve Bank of New York, which is the correspondent bank of all ALADI member central banks.

During the 1970s, nearly three-quarters of all intraregional foreign trade payments were cleared and settled through ALADI. During the 1980s, this figure reached its maximum with approximately 90 percent. However, during the 1990 s, the portion of international foreign trade payments channeled through ALADI decreased significantly, due in part to the availability of new and more convenient financing methods and to the increase in the stock of international reserves in many of the region's central banks.

\section{CARIBBEAN COMMON MARKET}

The central banks in the Caribbean Common Market region have bilateral arrangements to facilitate the settlement of payments between each other. Intraregional payments are made on the basis of instructions received via telex or SWIFT messages, and net settlement takes place on a monthly basis in U.S. dollars. Each net debtor makes payment to the relevant creditor's bank account within two working days after being billed. 
Table 4.8 Main Features of Cross-Border Payments and the Settlement of Domestic FX Transactions in Individual LAC Countries

\begin{tabular}{|c|c|c|c|c|}
\hline \multirow[b]{2}{*}{ Country } & \multicolumn{2}{|c|}{ Settlement of Wholesale FX Transactions } & \multicolumn{2}{|c|}{ Cross-Border Payments } \\
\hline & Organized Market & $\begin{array}{l}\text { Accounts in Foreign } \\
\text { Currency at the } \\
\text { Central Bank }\end{array}$ & SWIFT Use or Others & $\begin{array}{c}\text { Relevance of Workers' } \\
\text { Remittances and } \\
\text { Major Trends }\end{array}$ \\
\hline Argentina & $\begin{array}{l}\text { The FOREX-MAE is an } \\
\text { organized FX market for } \\
\text { banks and other autho- } \\
\text { rized currency dealers. } \\
\text { Transactions are settled } \\
\text { on a multilateral net } \\
\text { basis. ARGENCLEAR, the } \\
\text { settlement agent, steps } \\
\text { in the middle of the set- } \\
\text { tlement of both currency } \\
\text { legs to ensure PvP. }{ }^{\text {a }}\end{array}$ & $\begin{array}{l}\text { Yes. } \\
\text { These accounts are used } \\
\text { for settlement of payment } \\
\text { transactions. }\end{array}$ & $\begin{array}{l}\text { Almost all banks are } \\
\text { connected to SWIFT. }\end{array}$ & Low-Net recipient. \\
\hline Bahamas, The & $\begin{array}{l}\text { There is no organized } \\
\text { market. }\end{array}$ & $\begin{array}{l}\text { Yes. } \\
\text { These accounts are used } \\
\text { for settlement of payment } \\
\text { transactions. }\end{array}$ & $\begin{array}{l}\text { All clearing banks are } \\
\text { connected to SWIFT. }\end{array}$ & Medium-Net recipient. \\
\hline Bolivia & $\begin{array}{l}\text { The bolsín is a mecha- } \\
\text { nism through which } \\
\text { commercial banks regu- } \\
\text { larly purchase a limited } \\
\text { amount of U.S. dollars } \\
\text { from the BCB. At pre- } \\
\text { sent, the bolsín is not } \\
\text { much used. }\end{array}$ & $\begin{array}{l}\text { Yes. } \\
\text { These accounts are used } \\
\text { for settlement of payment } \\
\text { transactions. }\end{array}$ & $\begin{array}{l}\text { Few banks are connected } \\
\text { to SWIFT. } \\
\text { The BCB provides cross- } \\
\text { border payment services } \\
\text { to domestic financial } \\
\text { institutions. }\end{array}$ & High-Net recipient. \\
\hline Brazil & $\begin{array}{l}\text { The Clearing de Cambio, } \\
\text { operated by the Bolsa de } \\
\text { Mercadorias e Futuros } \\
\text { (BM\&F), is a clearing- } \\
\text { house for FX transac- } \\
\text { tions. All deals are } \\
\text { settled on a PvP basis } \\
\text { through correspondent } \\
\text { banks; the clearinghouse } \\
\text { acts as a central coun- } \\
\text { terparty to ensure PvP. } \\
\text { Special attention is given } \\
\text { to correspondent banks' } \\
\text { risk considerations. }\end{array}$ & No. & $\begin{array}{l}\text { Almost all banks are } \\
\text { connected to SWIFT. }\end{array}$ & $\begin{array}{l}\text { Medium-Net recipient. } \\
\text { Some arrangements, } \\
\text { involving mainly federal } \\
\text { government-owned finan- } \\
\text { cial institutions, intend to } \\
\text { facilitate remittances } \\
\text { from Brazilians residing } \\
\text { abroad. }\end{array}$ \\
\hline Chile & $\begin{array}{l}\text { There is an FX clearing- } \\
\text { house. The balances are } \\
\text { settled among banks } \\
\text { with cheques drawn on } \\
\text { banks located in New } \\
\text { York. } \\
\text { No PvP. }\end{array}$ & No. & $\begin{array}{l}\text { All banks are connected } \\
\text { to SWIFT. }\end{array}$ & Low-Net recipient. \\
\hline
\end{tabular}




\section{Table 4.8 Main Features of Cross-Border Payments and the Settlement of Domestic FX Transactions} in Individual LAC Countries (Continued)

\begin{tabular}{|c|c|c|c|c|}
\hline \multirow[b]{2}{*}{ Country } & \multicolumn{2}{|c|}{ Settlement of Wholesale FX Transactions } & \multicolumn{2}{|c|}{ Cross-Border Payments } \\
\hline & Organized Market & $\begin{array}{l}\text { Accounts in Foreign } \\
\text { Currency at the } \\
\text { Central Bank }\end{array}$ & SWIFT Use or Others & $\begin{array}{c}\text { Relevance of Workers' } \\
\text { Remittances and } \\
\text { Major Trends }\end{array}$ \\
\hline Colombia & $\begin{array}{l}\text { Small share of FX trades } \\
\text { is settled through dedi- } \\
\text { cated systems offered by } \\
\text { correspondent banks for } \\
\text { the foreign currency and } \\
\text { the Sistema Electrónico } \\
\text { de Cuentas de Depósito } \\
\text { for the domestic leg. } \\
\text { No PvP. }\end{array}$ & No. & $\begin{array}{l}\text { Almost all banks are } \\
\text { connected to SWIFT. }\end{array}$ & High-Net recipient. \\
\hline Costa Rica & $\begin{array}{l}\text { The MONED, operated } \\
\text { by the local stock } \\
\text { exchange, is a trading } \\
\text { system for domestic FX } \\
\text { transactions. } \\
\text { All operations are set- } \\
\text { tled gross on a real-time } \\
\text { PvP basis. }\end{array}$ & $\begin{array}{l}\text { Yes. } \\
\text { These accounts are used } \\
\text { for settlement of payment } \\
\text { transactions. }\end{array}$ & $\begin{array}{l}\text { Around half of the banks } \\
\text { are connected to SWIFT. } \\
\text { The BCCR provides } \\
\text { cross-border payment } \\
\text { services to domestic } \\
\text { financial institutions. }\end{array}$ & Medium-Net sender. \\
\hline $\begin{array}{l}\text { Dominican } \\
\text { Republic }\end{array}$ & $\begin{array}{l}\text { There is no organized } \\
\text { market. }\end{array}$ & No. & $\begin{array}{l}\text { All banks are connected } \\
\text { to SWIFT. }\end{array}$ & High—Net recipient. \\
\hline Ecuador & $\begin{array}{l}\text { The country is dollar- } \\
\text { ized. Transactions with } \\
\text { other foreign currencies } \\
\text { are negligible. }\end{array}$ & $\begin{array}{l}\text { No. (The U.S. dollar is the } \\
\text { official currency of Ecuador.) }\end{array}$ & $\begin{array}{l}\text { Most banks are con- } \\
\text { nected to SWIFT. }\end{array}$ & High—Net recipient. \\
\hline El Salvador & $\begin{array}{l}\text { The country is dollar- } \\
\text { ized. Transactions with } \\
\text { other foreign currencies } \\
\text { are negligible. }\end{array}$ & $\begin{array}{l}\text { No. (The U.S. dollar is the } \\
\text { official currency of } \\
\text { El Salvador.) }\end{array}$ & $\begin{array}{l}\text { Most banks are con- } \\
\text { nected to SWIFT. } \\
\text { The BCR provides cross- } \\
\text { border payment services } \\
\text { to domestic commercial } \\
\text { banks. } \\
\text { Some banks have devel- } \\
\text { oped their own messag- } \\
\text { ing, clearing, and } \\
\text { settlement systems to } \\
\text { process intraregional } \\
\text { payments. }\end{array}$ & $\begin{array}{l}\text { High-Net recipient. } \\
\text { Some commercial banks } \\
\text { are developing propri- } \\
\text { etary mechanisms to } \\
\text { facilitate the processing } \\
\text { of remittances, mainly } \\
\text { from the United States. }\end{array}$ \\
\hline Guatemala & $\begin{array}{l}\text { There are two formal } \\
\text { trading platforms: the } \\
\text { Sistema de Negociación } \\
\text { de Divisas, managed by } \\
\text { the stock exchange, and } \\
\text { the Sistema de Pagos } \\
\text { Interbancarios para } \\
\text { Divisas. The combined } \\
\text { systems account for less } \\
\text { than } 6 \text { percent of the } \\
\text { total traded value in the } \\
\text { marketplace. } \\
\text { No PvP. }\end{array}$ & $\begin{array}{l}\text { Yes. } \\
\text { These accounts are not } \\
\text { used for settlement of } \\
\text { payment transactions. }\end{array}$ & $\begin{array}{l}\text { About half of the banks } \\
\text { are connected to SWIFT. } \\
\text { Some banks have devel- } \\
\text { oped their own messag- } \\
\text { ing, clearing, and } \\
\text { settlement systems to } \\
\text { process intraregional } \\
\text { payments. }\end{array}$ & $\begin{array}{l}\text { High-Net recipient. } \\
\text { Some commercial banks } \\
\text { are developing propri- } \\
\text { etary mechanisms to } \\
\text { facilitate the processing } \\
\text { of remittances, mainly } \\
\text { from the United States. }\end{array}$ \\
\hline
\end{tabular}




\section{Table 4.8 Main Features of Cross-Border Payments and the Settlement of Domestic FX Transactions} in Individual LAC Countries (Continued)

\begin{tabular}{|c|c|c|c|c|}
\hline \multirow[b]{2}{*}{ Country } & \multicolumn{2}{|c|}{ Settlement of Wholesale FX Transactions } & \multicolumn{2}{|c|}{ Cross-Border Payments } \\
\hline & Organized Market & $\begin{array}{c}\text { Accounts in Foreign } \\
\text { Currency at the } \\
\text { Central Bank }\end{array}$ & SWIFT Use or Others & $\begin{array}{c}\text { Relevance of Workers' } \\
\text { Remittances and } \\
\text { Major Trends }\end{array}$ \\
\hline Honduras & $\begin{array}{l}\text { Banks must convert } \\
\text { foreign currency incom- } \\
\text { ing to the country to } \\
\text { domestic currency with } \\
\text { the BCH. } \\
\text { The purchase of foreign } \\
\text { currency is done through } \\
\text { BCH auctions through the } \\
\text { Sistema Electrónico de } \\
\text { Negociación de Divisas. }\end{array}$ & $\begin{array}{l}\text { Yes. } \\
\text { These accounts are not } \\
\text { used for settlement of } \\
\text { payment transactions. }\end{array}$ & $\begin{array}{l}\text { Few banks are con- } \\
\text { nected to SWIFT. } \\
\text { The BCH provides cross- } \\
\text { border payment services } \\
\text { to commercial banks. }\end{array}$ & $\begin{array}{l}\text { High-Net recipient. } \\
\text { Some commercial banks } \\
\text { are developing propri- } \\
\text { etary mechanisms to } \\
\text { facilitate the processing } \\
\text { of remittances, mainly } \\
\text { from the United States. }\end{array}$ \\
\hline Jamaica & $\begin{array}{l}\text { There is no organized } \\
\text { market. }\end{array}$ & No. & $\begin{array}{l}\text { Most banks are con- } \\
\text { nected to SWIFT. }\end{array}$ & $\begin{array}{l}\text { High-Net recipient. } \\
\text { Legislation to regulate } \\
\text { money transfer and remit- } \\
\text { tance agents has been } \\
\text { passed. License from the } \\
\text { minister of finance and } \\
\text { planning is required. The } \\
\text { BOJ acts as regulator. }\end{array}$ \\
\hline Mexico & $\begin{array}{l}\text { There is no organized } \\
\text { market. }\end{array}$ & No. & $\begin{array}{l}\text { All banks are connected } \\
\text { to SWIFT. }\end{array}$ & $\begin{array}{l}\text { High-Net recipient. } \\
\text { Mexico and the United } \\
\text { States linked their national } \\
\text { payment systems through } \\
\text { the FedACH service. Cur- } \\
\text { rently, only credit trans- } \\
\text { fers from the United States } \\
\text { to Mexico are possible. }\end{array}$ \\
\hline $\begin{array}{l}\text { Netherlands } \\
\text { Antilles }\end{array}$ & $\begin{array}{l}\text { There is no organized } \\
\text { market, although the } \\
\text { majority of FX deals are in } \\
\text { fact channeled through } \\
\text { the BvdNA, in which } \\
\text { case, PvP is achieved. }\end{array}$ & $\begin{array}{l}\text { Yes. } \\
\text { These accounts are used } \\
\text { for settlement of payment } \\
\text { transactions. }\end{array}$ & $\begin{array}{l}\text { All banks are connected } \\
\text { to SWIFT. }\end{array}$ & Medium—Net recipient. \\
\hline Nicaragua & $\begin{array}{l}\text { The BCN operates } \\
\text { the major wholesale } \\
\text { FX market for banks, } \\
\text { financieras, and the gov- } \\
\text { ernment. The BCN is the } \\
\text { seller for every buyer, } \\
\text { and the buyer for every } \\
\text { seller. } \\
\text { PvP is achieved. }\end{array}$ & $\begin{array}{l}\text { Yes. } \\
\text { These accounts are used } \\
\text { for settlement of payment } \\
\text { transactions. }\end{array}$ & $\begin{array}{l}\text { Few banks and the BCN } \\
\text { are connected to SWIFT. } \\
\text { Some banks have devel- } \\
\text { oped their own messag- } \\
\text { ing, clearing, and } \\
\text { settlement systems to } \\
\text { process intraregional } \\
\text { payments. }\end{array}$ & $\begin{array}{l}\text { High-Net recipient. } \\
\text { Some commercial banks } \\
\text { are developing propri- } \\
\text { etary mechanisms to } \\
\text { facilitate the processing } \\
\text { of remittances, mainly } \\
\text { from the United States. }\end{array}$ \\
\hline OECS & $\begin{array}{l}\text { There is no organized } \\
\text { market. }\end{array}$ & $\begin{array}{l}\text { Yes. } \\
\text { These accounts are not } \\
\text { used for settlement of } \\
\text { payment transactions. }\end{array}$ & $\begin{array}{l}\text { Most banks are } \\
\text { connected to SWIFT. } \\
\text { The ECCB provides } \\
\text { cross-border payment } \\
\text { services to domestic } \\
\text { financial institutions. }\end{array}$ & Medium—Net recipient. \\
\hline
\end{tabular}


Table 4.8 Main Features of Cross-Border Payments and the Settlement of Domestic FX Transactions in Individual LAC Countries (Continued)

\begin{tabular}{|c|c|c|c|c|}
\hline \multirow[b]{2}{*}{ Country } & \multicolumn{2}{|c|}{ Settlement of Wholesale FX Transactions } & \multicolumn{2}{|c|}{ Cross-Border Payments } \\
\hline & Organized Market & $\begin{array}{c}\text { Accounts in Foreign } \\
\text { Currency at the } \\
\text { Central Bank }\end{array}$ & SWIFT Use or Others & $\begin{array}{c}\text { Relevance of Workers' } \\
\text { Remittances and } \\
\text { Major Trends }\end{array}$ \\
\hline Panama & $\begin{array}{l}\text { The country is dollar- } \\
\text { ized. Transactions with } \\
\text { other foreign currencies } \\
\text { are negligible. }\end{array}$ & $\begin{array}{l}\text { No. (The U.S. dollar is the } \\
\text { official currency of Panama.) }\end{array}$ & $\begin{array}{l}\text { All banks are connected } \\
\text { to SWIFT. }\end{array}$ & $\begin{array}{l}\text { Medium-Net recipient. } \\
\text { In 2003, the BNP entered } \\
\text { into an agreement with } \\
\text { the U.S. Federal Reserve } \\
\text { to receive ACH-type } \\
\text { direct credits from the } \\
\text { United States. }\end{array}$ \\
\hline Paraguay & $\begin{array}{l}\text { There is no organized } \\
\text { market. }\end{array}$ & $\begin{array}{l}\text { Yes. } \\
\text { These accounts are not } \\
\text { used for settlement of } \\
\text { payment transactions. }\end{array}$ & $\begin{array}{l}\text { Most banks are con- } \\
\text { nected to SWIFT. }\end{array}$ & $\begin{array}{l}\text { Medium-Net recipient. } \\
\text { Some commercial banks } \\
\text { are currently implementing } \\
\text { systems to process remit- } \\
\text { tances at a lower cost. }\end{array}$ \\
\hline Peru & $\begin{array}{l}\text { The Bolsa de Valores de } \\
\text { Lima operates a trading } \\
\text { system for FX operations. } \\
\text { Transactions are settled } \\
\text { PvP on the accounts held } \\
\text { at the BCRP. }\end{array}$ & $\begin{array}{l}\text { Yes. } \\
\text { These accounts are used } \\
\text { for settlement of payment } \\
\text { transactions. }\end{array}$ & $\begin{array}{l}\text { Most banks are con- } \\
\text { nected to SWIFT. } \\
\text { The BCRP is the opera- } \\
\text { tor of the ALADI system. }\end{array}$ & High-Net receiver. \\
\hline $\begin{array}{l}\text { Trinidad and } \\
\text { Tobago }\end{array}$ & $\begin{array}{l}\text { There is no organized } \\
\text { market. }\end{array}$ & No. & $\begin{array}{l}\text { All banks are connected } \\
\text { to SWIFT. }\end{array}$ & Low-Net recipient. \\
\hline Uruguay & $\begin{array}{l}\text { The wholesale FX market } \\
\text { for banks is organized at } \\
\text { a central trading platform } \\
\text { operated by BEVSA. } \\
\text { PvP is not achieved in } \\
\text { the majority of cases. } \\
\text { A relevant portion of the } \\
\text { market (for example, } \\
\text { nonbanks) operates in } \\
\text { the over-the-counter } \\
\text { (OTC) market. }\end{array}$ & $\begin{array}{l}\text { Yes. } \\
\text { These accounts are used } \\
\text { for settlement of payment } \\
\text { transactions. }\end{array}$ & $\begin{array}{l}\text { All banks are connected } \\
\text { to SWIFT. } \\
\text { BEVSA provides cross- } \\
\text { border payment services } \\
\text { to domestic banks and } \\
\text { other financial institu- } \\
\text { tions through its SWIFT } \\
\text { service bureau. }\end{array}$ & Low-Net recipient. \\
\hline $\begin{array}{l}\text { Venezuela, } \\
\text { R.B. de }\end{array}$ & $\begin{array}{l}\text { The BCV is the main } \\
\text { provider of foreign cur- } \\
\text { rency to the market. It } \\
\text { also operates a central- } \\
\text { ized trading mechanism } \\
\text { that is accessible to var- } \\
\text { ious types of financial } \\
\text { entities. } \\
\text { PvP is generally not } \\
\text { achieved for transac- } \\
\text { tions directly between } \\
\text { FX market participants. }\end{array}$ & No. & $\begin{array}{l}\text { Most banks are con- } \\
\text { nected to SWIFT. }\end{array}$ & Low-Net recipient. \\
\hline
\end{tabular}




\section{Observations}

- Throughout the region, FX transactions are not settled on a PvP basis in the majority of cases. In some cases, there is a centralized FX trading platform, but such platforms have no direct links with a settlement infrastructure. Deals and settlement are based purely on mutual trust, although some banks do establish controls with regard to their FX counterparties, and set limits on the amounts that may be traded with such counterparties. In these cases, central banks should investigate the possibility of introducing some measures to mitigate the risks associated to these operations when $\mathrm{PvP}$ is not possible. Central banks might consider evaluating the risks in this market, taking as a reference the reports and questionnaires published by the CPSS of the Bank for International Settlements.

- For domestic FX transactions (that is, those that involve only domestic counterparties), those central banks that allow holding reserve accounts both in local currency and U.S. dollars should ensure that wholesale FX trades are settled on central bank money on a PvP basis.

- Central banks and banking supervisors should be able to use their regulatory and supervisory powers to introduce appropriate measures to mitigate associated risks. Attention should also be given to correspondent arrangements abroad of domestic banks to ensure that risk profiles and operating procedures of correspondents are constantly reviewed and do not generate any relevant risks in the country.

- Proprietary mechanisms of commercial banks for cross-border payments can turn into a less costly and convenient alternative for customers. Another possible benefit is that remittances can now be channeled all the way through banks instead of, typically, through nonregulated specialized companies, apart from the fact that remittances need not be paid in cash. Nevertheless, central banks, in cooperation with banking supervisors, should carefully monitor these mechanisms and other related developments to make sure they do not bring in new or incremental risks for the domestic banks involved.

- A large share of remittances are channeled through nonregulated specialized institutions, which lack minimum acceptable standards in areas such as transparency of fees and other charges or the timing of accreditation of funds to end beneficiaries. In this last regard, the regulatory perspective should be widened from the traditional areas of balance of payments and money laundering to include payment system issues, in particular issues related to efficiency, transparency, and risks. Central banks, in coordination with other authorities, should also decide whether new actions or regulations are necessary to protect customers, and to foster a safe and efficient provision of services in this area. Remittance service providers should be involved in this process along the lines set up by the General Principles for International Remittance Services.

- In sum, it is recommended that the region's central banks carefully monitor trading and settlement platforms and procedures for FX and cross-border transactions to ensure that the principles of safety and efficiency in clearance and settlement activities are applied at all times. In the case of international remittances, a more activist approach is desirable. Eventually, in coordination with other authorities, central banks should also decide whether new regulations are necessary to protect customers, and to foster a safe and efficient provision of remittance services.

\section{INTERBANK MONEY MARKET}

This section includes context, status in the region, and observations regarding the interbank money market.

\section{Context}

The adequate functioning of an interbank money market goes beyond clearance and settlement considerations. An efficient mechanism for trading and settlement of these transactions will allow for the improvement of the liquidity management and, thus, for an increased safety and stability of the financial system. In addition, it will help securities settlement through lower interest rates that will benefit broker-dealers in the credit lines they negotiate with banks. Another important concern for the authorities is the smooth and effective functioning of monetary policy, because the interbank money market is normally the market that central banks use to give a clear signal to banks, a signal that then is extended to the rest of the financial sector. If the operational procedures or the organizational and regulatory arrangements do 
not provide for an efficient system, the central bank can have difficulties in clearly signaling the type of monetary policy it is following.

Two key elements for the development of interbank money markets are (1) a special-purpose system for largevalue payments to provide secure electronic interbank transfers with immediate settlement, interconnected to
(2) an electronic book-entry securities system to register and record changes in ownership of securities. The development of the depository function is an important discussion that a country has to undertake involving responsible authorities and all market participants. An adequate strategy that takes into account the national interest and leaves apart any particular interest should be defined and agreed.

\section{Status in the Region}

\section{Table 4.9 The Interbank Money Market in Selected Latin America and the Caribbean Countries}

\begin{tabular}{l|l} 
Country & \multicolumn{1}{c}{ Interbank Money Market } \\
Argentina & $\begin{array}{l}\text { Interbank money market transactions in Argentina are performed mainly through the Mercado Abierto Electrónico } \\
\text { (MAE). The MAE is an OTC, quote-driven market where trades in government securities and private debt are } \\
\text { executed by telephone and by price spread. Main instruments used are government securities and BCRA notes. } \\
\text { Transactions are instrumented through repos or outright collateralized loans. }\end{array}$ \\
The MAE does not settle or guarantee trades. Instead, Interbanking has partnered with the securities depository, \\
Caja de Valores, and Argenclear (the securities clearinghouse) to facilitate DvP procedures for the MAE. For \\
eligible securities, banks are able to move net securities positions settled at the Caja de Valores against net \\
funds positions settled at MEP through Interbanking.
\end{tabular}

Brazil The interbank money market in Brazil is deep and sophisticated. Securities issued by the federal government are mainly used to back interbank loans, which are handled mainly through repo transactions. The Sistema Especial de Liquidação e de Custódia is the central securities depository and settlement system for the securities issued by the federal government. At the same time, it is used as a source to report on the trading activity of government debt markets and as a tool to conduct monetary policy. The Sistema Especial de Liquidação e de Custódia settles all transactions in real time on a gross basis, and maintains a direct link with the RTGS system, the STR.

Participants may distinguish between repo transactions in which the collateral is prohibited from resale, and those for which the collateral can be resold. Liquidity is hampered by a high degree of fragmentation, that is, a large variety of nonstandardized securities. To optimize the use of securities, some associations of operations are permitted. In these cases, although settlement is processed operation by operation, net balances are considered when checking for availability of securities and funds.

Financial institutions that hold reserve or settlement accounts, or both, at the BACEN participate in the system as liquidating entities (for example, commercial banks and clearinghouses). All other nonsettling institutions are indirect participants (for example, mutual funds, insurance companies, private closed and open pension funds, health insurance management companies, nonfinancial institutions, and so on).

Chile In Chile, the interbank money market is fragmented. The most relevant instruments are the securities issued by the $\mathrm{BCCH}$, as well as some others securities issued by financial sector entities.

Approximately one-third of the transactions with $\mathrm{BCCH}$ securities are carried out through the stock exchanges. Each of the three stock exchanges has a trading system for debt securities. In practice, however, none of these systems is much used.

Repos (pactos) with BCCH securities are the main instrument of the interbank money market, accounting for almost two-thirds of all transactions in the interbank money market. Most repos are traded in the 0TC market; commercial banks are by far the most relevant, if not the only, participants in this market. At the same time, the OTC market can be divided into direct trades among banks and intermediated trades, in which brokers interpose themselves between the seller and the buyer. 


\section{Table 4.9 The Interbank Money Market in Selected Latin America and the Caribbean Countries (Continued)}

\begin{tabular}{l|l} 
Country & \multicolumn{1}{c}{ Interbank Money Market } \\
Colombia & $\begin{array}{l}\text { Although an automated system has been established for the exchange of both collateralized and uncollateralized } \\
\text { funds among banks (the Sistema Electrónico de Negociación), the development of the money market is insufficient } \\
\text { so far. The most important impediments to its development are the constraints over credit lines that banks grant } \\
\text { to each other. The lack of short-term securities and interest rate benchmarks creates disincentives to participation } \\
\text { in the money market. Markets are shallow and fragmented, due to different regulatory treatment, accounting, tax } \\
\text { rules, and market protocols. }\end{array}$
\end{tabular}

Costa Rica For historical reasons, money markets in Costa Rica are peculiar in that broker-dealers are the main players and trading systems are operated by the stock exchange. In fact, trading and settlement systems have been historically designed to provide broker-dealers a means to exchange liquidity in order to operate pseudomutual funds. The current trading and settlement systems, as a result of the measures taken to avoid defaults on the securities leg of a settlement transaction, have introduced fragmentation in the liquidity market due to operational difficulties to arbitrate between different trading systems. This is basically a consequence of the need to block securities before trading to ensure the security delivery in a nonstandardized securities market.

However, as the banking system has evolved and banks have been more active in the money markets, new trading mechanisms have been required to attend to the need for an interbank money market. The Mercado Interbancario system was launched in 1997 by the stock exchange in order to facilitate interbank trading in this market. The Mercado Interbancario system settles transactions under DvP Model 1, and has a real-time link with the Sistema de Negociación y Pagos Electrónicos.

Dominican Republic The interbank money market is not active. There are few interbank loans, ranging from overnight to seven days, in most cases. Funds are generally lent without collateral.

In 2001, the BCRD created a mechanism to intermediate in this market and use banks' surpluses to grant shortterm loans to other banks with temporary liquidity shortages.

Ecuador

The interbank money market is not very active and the liquidity is distributed through a system facilitated by the BCE. Every quarter, the Monetary Board of Ecuador approves the amount of Títulos del Banco Central that can be issued, which is also the amount of credit that the BCE can lend to banks in need of liquidity via open market operations (especially repo with government bond as collateral). Through this means, the BCE redistributes liquidity between banks.

El Salvador The securities market is dominated by repo trading on the stock exchange. It is essentially a money market: The bulk of repo transactions have a maturity of fewer than seven days.

Guatemala

The interbank money market is not very active. Banks exchange liquidity among themselves through the Mecanismo Interbancario de Transferencias and the cheques system, but the central bank does not have the information to differentiate between interbank money market operations and other type of transactions carried out through this system. The interbank money market operations are normally outright loans, because collateralized interbank loans would require the exchange of physical certificates.

The BANGUAT does not have statistics about the market. Interbank money market transactions take place by means of an interbank cheque or a transfer through the funds transfer system, but the central bank does not capture the reason for the operation. This market is mostly uncollateralized, because there is no effective way to collateralize securities and, thus, it would mean the exchange of physical certificates. The other active money market is the repos through the stock exchange, but it is not a banking market but a brokers-dealers market. issued securities and outright loans. There is also a significant overnight repo market. Repo operations with government securities are supported by the physical delivery of the certificates, due to the lack of dematerialization or immobilization of these securities. However, no transfer of ownership takes place in the books of the Ministry of Finance. In effect, there is heavy reliance on counterparty trust. Because of the operational difficulties in transferring ownership, the level of risk inherent in these repo transactions is unacceptable to some market participants, and this limits and concentrates liquidity. 


\section{Table 4.9 The Interbank Money Market in Selected Latin America and the Caribbean Countries (Continued)}

\begin{tabular}{l|l} 
Country & \multicolumn{1}{l}{ Interbank Money Market } \\
Mexico & The interbank money market in Mexico is, for the most part, a bilateral OTC market. Some debt instruments \\
issued by the government, the central bank, and commercial banks are also traded in the stock exchange \\
through a system called SENTRA-Debt. \\
The OTC market can be divided into direct trades among financial intermediaries, and intermediated trades. \\
Intermediated trades comprise three segments: \\
Automated screen trading. Interactive terminals are provided to the participants (banks and brokerage \\
houses), which enter their final bid and ask prices as well as the amounts being offered for outright and \\
repo transactions with government and banking securities. The screens show the best available prices, \\
and participants may match a partial amount of the offer or its total amount. \\
Voice brokerage. In this segment, a group of brokers intermediate outright and repo transactions with \\
government and banking securities by telephone, with some screen support. They provide participants \\
(banks and brokers) with two resources: (1) noninteractive terminals in which the quantities and best bid and \\
ask prices are shown, and (2) a speaker, through which brokers may call the attention of participants to any \\
relevant change on the screens. Participants transmit their final orders by telephone to the brokers, who \\
immediately enter the information on their screens without identifying the participant. Transactions are also \\
closed by telephone, and the result is announced on the screens. Only at this moment do participants know \\
who their counterparty is. \\
Secondary market rounds. In this system, some of the brokers intermediate special auctions of government \\
securities requested by any of the participants. The auction is held in the terminal of the broker.
\end{tabular}

Netherlands Antilles The interbank money market is almost nonexistent. Participants with liquidity shortages may resort to some facilities: (1) They can sell U.S. dollars, (2) activate interbank outright overnight loans, and (3) sell central bank securities to other commercial banks through the BvdNA.

The combination of relatively high reserve requirements ( 9 percent) and the abundance of liquidity under normal circumstances ensure that the system does not experience liquidity shortages as a whole. Nevertheless, the liquidity distribution is unequal.

\section{Nicaragua}

The interbank money market is almost nonexistent. Participants with liquidity shortages may resort to some facilities: (1) They can arrange an uncollateralized loan bilaterally, because there is no effective way to collateralize securities and, thus, it would mean the exchange of physical certificates. (2) They can get liquidity through a repo transaction at the stock exchange. (3) They can obtain liquidity from the BCN.

The market is narrow at present for several reasons. Investors face a lack of investment alternatives, because there are not enough instruments in the market. The public debt market is not yet well organized and the government of Nicaragua does not issue securities on a regular basis. Additionally, banks, nonbank financial institutions, and brokerage houses are not allowed to invest freely in private sector securities, except if the Superintendencia de Bancos y Otras Instituciones Financieras gives them specific authorization, which occurs on a case-by-case basis.

Panama

No public or private sector institution receives and collects systemwide statistics. It is noteworthy that most interbank money market operations in Panama are executed through correspondent banks in the United States (either Fedwire or Clearing House Interbank Payments System), and are noncollateralized. It is not possible to perform same-day domestic operations in BNP funds. When trading securities, banks recur mostly to their own broker-dealers (for tax reasons) and rarely perform OTC transactions.

Peru There is no active debt market in Peru, although some private sector bonds are issued and traded.

The Bolsa de Valores de Lima operates a money market module. Trading is continuous from 9:00 a.m. to 2:00 p.m. Bids are not matched automatically.

There is also an OTC market that is limited in scope.

Trinidad and Tobago The interbank market is the overnight market for funds among commercial banks. Borrowing is usually for the purpose of meeting the reserves requirement. Most of the activity occurs between the banks, with minimal participation from the near-banks, particularly the subsidiaries or affiliated companies of the commercial banks. The market is self-regulated and is monitored by the CBTT for monetary policy purposes as well as for prudential reasons. Each institution has internal exposure limits with regard to counterparties. 


\section{Table 4.9 The Interbank Money Market in Selected Latin America and the Caribbean Countries (Continued)}

Country Interbank Money Market

Trinidad and Tobago (Continued)

If commercial banks do not have adequate funds to settle all their payments on the Safe-tt at the end of a business day, or are short on their reserves held at CBTT, their first option is to borrow on the interbank market. If they are unable to access funding in this market, they can enter into repos with the CBTT to obtain liquidity. Treasury bills and notes are used as collateral for these repos.

Settlement of securities purchases and the registration of ownership are processed in the Government Securities and Settlement system, which has a direct link to Safe-tt for the funds settlement of securities transactions in real time, thereby facilitating delivery versus payment.

Uruguay The value of money market transactions through BEVSA in Uruguay is similar to that of the FX market and the securities market combined.

There is no information about the OTC interbank money market, because the central bank does not collect statistics. This market is mostly uncollateralized even if there is an effective way to collateralize securities.

Venezuela, R.B. de

The BCV has deployed several systems for different types of money market operations. The different interfaces mentioned below above allow for the settlement collateralized interbank money market operations on a DvP basis. These include the following:

- The Sistema Electrónico de Transferencias de Fondos para Préstamos Interbancarios, that allows for an overnight market, either collateralized or not, and counts with an interface with the Sistema Integrado de Garantías y Líneas de Crédito.

- The Sistema de Custodia Electrónica de Títulos, used by the BCV to register ownership transfer of securities issued by the government and the BCV and traded by financial institutions through the BCV. It counts with an interface with the current accounts system for funds settlement.

- The Sistema Integrado de Garantías y Líneas de Crédito for the collateralization of securities and credit lines that the institutions have in their portfolios, in order to guarantee overnight transactions. It has an interface with the Sistema de Custodia Electrónica de Títulos.

- The Sistema Integrado de Mercado Abierto channels primary market operations with CDs issued by the BCV and securities known as Deuda Pública Nacional and treasury bills issued by the government. The system also operates secondary market repos over these securities. Transactions are not executed online, but count with an interface with the current accounts system of the BCV and Sistema de Custodia Electrónica de Títulos that allows for settlement of securities and funds on a DvP basis.

- The Sistema de Tasas Referenciales aims to set a reference interest rate for the market and will have an interface with the Sistema Integrado de Garantías y Líneas de Crédito, the Sistema de Custodia Electrónica de Títulos, and the current accounts system.

Source: Authors' elaboration.

a. Enlaces Prebon, Eurobrokers, Cantor Fitzgerald, and Red Financiera, among others, are special agents whose activities resemble those of brokerage houses. However, they are not considered as such for regulatory purpose.

\section{Observations}

- The adequate functioning of an interbank money market goes beyond clearance and settlement considerations. An efficient mechanism for trading and settling these transactions improves the liquidity management in the system and, thus, may help in achieving lower interest rates. Another important concern for the authorities is the smooth and effective functioning of monetary policy: The interbank money market is normally the market that central banks use to give clear signals to banks that are then extended to the rest of the financial sector. If the operational procedures or the organizational and regulatory arrangements do not provide for an efficient system, the central bank can have difficulties in the implementation of its monetary policy.

- A smooth functioning of the money market is also of key interest for the functioning of LVPS. In particular, the delivery of collateral to the central bank in order to receive intraday or overnight credit is crucial in a dynamic financial market. For this reason, it is important that transactions be settled with intraday finality. The development of this market is crucial in a new environment in which large-value payments are to be settled in a gross system and, thus, liquidity man- 
agement is a crucial issue. Recent reform processes around the region envisage the link of the RTGS system with a central securities depository.

- The future evolution of securities markets is an important discussion to be undertaken jointly by market participants and relevant authorities. An adequate strategy that takes into account the national interest and leaves aside any private interest should be defined and agreed. Once the strategy has been decided, a neutral securities clearance and settlement system can be implemented to allow fair competition in the financial sector. Authorities and market participants should openly discuss what will be the likely future of securities markets and agree on organizational and regulatory arrangements that allow for an adequate development of the interbank money market, on the one hand, and the securities market, on the other. A common strategy is a difficult process because several private interests will be affected, but it is the only solution to develop safe and efficient securities markets that can take a lead in a potential regionalization process.

- In sum, the adequate functioning of an interbank money market is an important element for the smooth function of payments and securities settlement in a country. An efficient mechanism for trading and settling these transactions will allow an improvement in the liquidity management of the system and facilitate the effective functioning of monetary policy. Two key elements for the development of interbank money markets are a special-purpose system for large-value payments to provide secure electronic interbank transfers with immediate settlement interconnected to an electronic book entry securities system to register and record changes in ownership of securities. 



\section{Securities Settlement Systems Assessment Findings in Latin America and the Caribbean}

his chapter covers the main findings of the Western Hemisphere Payments and Securities Clearance and Settlement Initiative assessments in the area of securities settlement systems (SSSs). The countries assessed are Argentina, The Bahamas, Bolivia, Brazil, Chile, Colombia, Costa Rica, Dominican Republic, Ecuador, El Salvador, Guatemala, Honduras, Jamaica, Mexico, Netherlands Antilles, Nicaragua, OECS, Panama, Paraguay, Peru, Trinidad and Tobago, Uruguay, and the República Bolivariana de Venezuela. Table 5.1 indicates the dates of the original assessments. Updates from these assessments have been included in the information presented in this chapter.

The assessments took place following the methodology described in chapter 3. The issues covered are legal basis, clearing and settlement processes, settlement risk, settlement asset, operational issues, custody risk, depositories' organizational arrangements, regulatory and oversight framework, and cross-border settlement.

The rest of the chapter is organized as follows. Section 2 briefly describes securities markets and settlement in Latin America and the Caribbean (LAC). Section 3 deals with issues related to the legal framework. The legal framework for the funds settlement is covered in detail in chapter 4, but some cross-references are included in chapters 4 and 5 because the issues are interrelated. Section 4 includes an analysis of clearing and settlement processes. Section 5 describes settlement risks. Section 6 covers operational issues and section 7 covers custody risk. Section 8 describes the regulatory and oversight issues. Central securities depositories' (CSDs') organizational arrangements are covered in section 9. Finally, section 10 analyzes cross-border settlement.
Table 5.1 Dates of Country Assessments

\begin{tabular}{|c|c|}
\hline Country & Date \\
\hline Argentina & July 1999 \\
\hline Bahamas, The & May 2001 \\
\hline Bolivia & October 2004 \\
\hline Brazil & November 2000 \\
\hline Chile & December 1999 \\
\hline Colombia & February 2001 \\
\hline Costa Rica & June 2001 \\
\hline Dominican Republic & January 2002 \\
\hline Ecuador & August 2002 \\
\hline El Salvador & February 2000 \\
\hline Guatemala & February 2004 \\
\hline Honduras & October 2002 \\
\hline Jamaica & June 2002 \\
\hline Mexico & March 2001 \\
\hline Netherlands Antilles & December 2002 \\
\hline Nicaragua & December 2003 \\
\hline OECS & April 2000 \\
\hline Panama & January 2005 \\
\hline Paraguay & April 2004 \\
\hline Peru & June 1999 \\
\hline Trinidad and Tobago & February 2000 \\
\hline Uruguay & May 2005 \\
\hline Venezuela, R.B. de & November 2002 \\
\hline
\end{tabular}

Source: Authors' elaboration. 
Sections 2 and 3 are descriptive of the situation of the securities markets and settlement procedures for each country. For the rest of the sections, the chapter follows a systematized approach for each issue covered. First, the approach includes a brief context in which the main areas, normally identified through international standards and best practices, are described. Second, a status subsection is included by means of a table describing the facts identified for each of the countries in the specific issue covered. Finally, the observations subsections summarize the findings often encountered in the systems analyzed or that, even if not identified in many systems, are important due to their relevance (for example, issues related to dollarized systems). In any case, it is important to note that the observations made are based on a general situation of the systems assessed in LAC countries, but that in some cases individual systems in different countries have already significantly advanced in the issue indicated, or that the issues are not relevant for them.

\section{SECURITIES MARKETS IN LATIN AMERICA AND THE CARIBBEAN}

Table 5.2 includes a brief description of the securities markets in each of the countries assessed as well as statistics on market capitalization in U.S. dollars, and

Table 5.2 Description of Securities Markets in Latin America and the Caribbean

\begin{tabular}{|c|c|c|c|}
\hline Country & Brief Description of Securities Markets & $\begin{array}{l}\text { Market } \\
\text { Capitalization: } \\
\text { \% Over GDP / } \\
\text { US\$ Billion } \\
\text { (2004) }\end{array}$ & $\begin{array}{l}\text { Central } \\
\text { Government } \\
\text { Debt Over } \\
\text { GDP (2004) }\end{array}$ \\
\hline Argentina & $\begin{array}{l}\text { The Bolsa de Comercio de Buenos Aires was founded in } 1854 \text { as a forum } \\
\text { for business and trading of products, stocks, and bonds. Trades may be } \\
\text { executed either through a screen-based system (Sistema Integrado de } \\
\text { Negociación Asistida por Computador) or the traditional open outcry (floor } \\
\text { trading). Corporate and government bonds are not only traded through } \\
\text { these two systems, but also through the Mercado de Valores de Buenos } \\
\text { Aires S.A.'s (Merval's) continuous trading system. Trading in the over-the- } \\
\text { counter (OTC) market in government securities and corporate bonds takes } \\
\text { place at the Mercado Abierto Electrónico S.A. (MAE). More than } 95 \text { percent } \\
\text { of the stock exchange trading takes place at the Merval. The Merval also } \\
\text { maintains a securities clearing and settlement system. Stock markets in the } \\
\text { provinces (Córdoba, La Plata, Mendoza, Rosario, and Santa Fé) represent } \\
\text { less than } 5 \text { percent. The MAE is an OTC quote-driven market where trades } \\
\text { in government securities and private debt are executed by telephone and } \\
\text { by price spread. The MAE does not settle or guarantee trades. There is } \\
\text { also a futures and option market (Mercado a Término de Buenos Aires) and } \\
\text { a market for foreign exchange (Mercado a Término de Rosario). }\end{array}$ & $27.7 / 42$ & 42.8 \\
\hline Bahamas, The & $\begin{array}{l}\text { Securities markets are still in a start-up phase. Government securities, } \\
\text { which are either in bearer form (treasury bills) or registered (Bahamas } \\
\text { Government Registered Securities), are cleared and settled at the central } \\
\text { bank. A stock exchange, the Bahamas International Stock Exchange, was } \\
\text { launched in May 2000. Currently, there are } 17 \text { domestic public companies } \\
\text { listed on that exchange. In April 2001, the Bahamas International Stock } \\
\text { Exchange launched a mutual fund listing facility. }\end{array}$ & n.a. & n.a. \\
\hline Bolivia & $\begin{array}{l}\text { Securities markets are dominated by debt securities. The government } \\
\text { issues letras del tesoro (maturities from } 90 \text { days to one year) and bonos del } \\
\text { tesoro (maturities of two, four, six, eight, nine, and } 15 \text { years). There is one } \\
\text { stock exchange in the country (Bolsa Boliviana de Valores, BBV). The main } \\
\text { trading systems are the traditional open outcry (floor trading) for equity and } \\
\text { fixed-income securities, and the trading desk (mesa de negociación) for } \\
\text { promissory notes and bills of exchange. The main type of trades undertaken } \\
\text { is the outright sale. }\end{array}$ & 21.6/1.9 & 78.5 \\
\hline
\end{tabular}


Table 5.2 Description of Securities Markets in Latin America and the Caribbean (Continued)

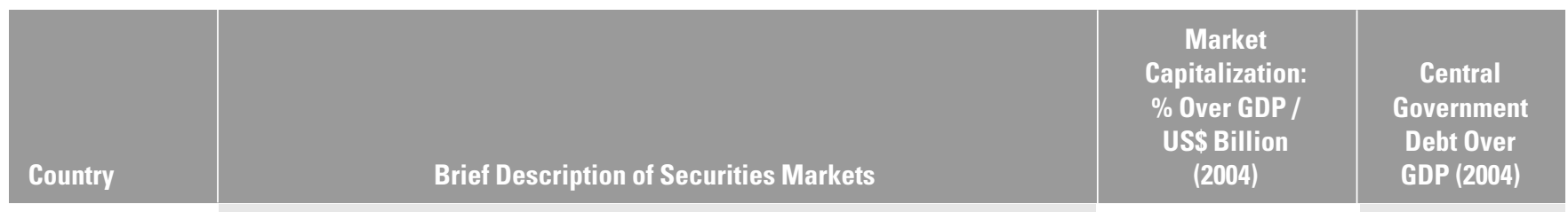

Brazil Securities markets are relatively sophisticated in terms of infrastructure and availability of instruments. However, private corporations do not use capital markets intensively as an alternative financing source. Securities issued by the federal government are the most liquid instruments in the market. These securities include fixed-rate treasury bills, floating rate treasury bills, and treasury bonds. In addition, the federal government issues a number of other types of securities-less liquid-such as public debt certificates, privatization certificates, treasury financial certificates, national treasury certificates, and base-rate-indexed national treasury securities. Stock exchanges in Brazil recently merged operations under the leadership of the São Paulo Stock Exchange (BOVESPA). Under the agreement, the stock exchanges of São Paulo; Rio de Janeiro; Minas-Espírito Santo-Brasília; Extremo Sul; Santos; Bahia-Sergipe-Alagoas; Pernambuco and Paraíba; Paraná; and the Bolsa Regional now comprise a single Brazilian stock market on a nationwide level, with a single trading, custody, and settlement system. The trading of stocks is now carried out from São Paulo, in a totally electronic environment. The other regional exchanges concentrate activities such as market development and providing services to the local markets. The Brazilian Mercantile \& Futures Exchange (BM\&F), also located in São Paulo, is the commodities and derivatives exchange. Also, more recently, the BM\&F expanded its operations into the trading and clearing of foreign exchange and government securities. It constituted, within its organizational structure, three mutually independent clearing systems: the derivatives clearinghouse, the foreign exchange clearinghouse, and the securities clearinghouse. The securities clearinghouse is currently circumscribed to the clearing of government securities, but should expand in the future into the clearing of obligations issued by financial institutions, such as bank certificates of deposit. Foreign exchange and government securities are still traded OTC in parallel with the BM\&F markets.

Chile Three stock exchanges (Bolsa de Comercio de Santiago, Bolsa Electrónica de Chile, and Bolsa de Corredores de Valparaíso) are currently operating in Chile for equity and fixed-income securities transactions. Since the early 1990s, the securities markets have shown a clear tendency to grow-with the exception of the stock market, whose trend has been erratic. The derivatives market is practically nonexistent. There have been few government issues; those few have been targeted toward specific economic policy objectives. The central bank has issued its own instruments in order to conduct monetary policy; in practice, it has become the manager of the domestic public debt, because it issues papers with different maturities. The stock market's liquidity is limited and concentrated in a few stocks. Institutional investors play a fundamental role and account for a high percentage of investments in the securities market. Pension funds are the most important institutional investors and are the most popular vehicle used for domestic savings.

Colombia One stock exchange (Bolsa de Valores de Colombia, BVC), as a result of the merger of the three previous ones (Bolsa de Bogotá, Bolsa de Occidente, and Bolsa de Medellín), is currently operating. The BVC operates an electronic system for fixed-income securities (Mercado Electrónico de Colombia), an electronic system for stocks, and owns a system in which intermediaries register OTC telephone market operations (Sistema de 
Table 5.2 Description of Securities Markets in Latin America and the Caribbean (Continued)

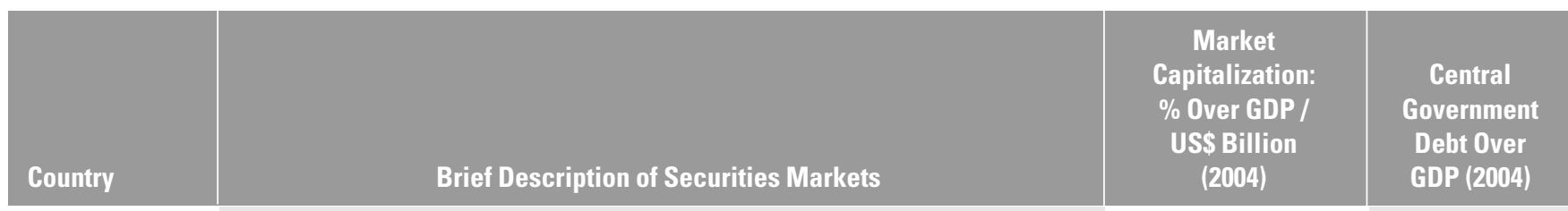

Colombia Registro, Información y Transacciones, INVERLACE). Government securi-

(Continued) ties transactions can take place through the Sistema Electrónico de Negociación (SEN), operated by the Banco de la República (BR), or by one of the trading systems operated or owned by the stock exchange. Transactions in fixed-income securities represent more than 98 percent of the total value for the securities market (mostly government securities). In the OTC market, transactions are carried out through an electronic trading system operated by the Banco de la República, the SEN, or bilaterally between the counterparties recording the transactions through the INVERLACE. In contrast to SEN, INVERLACE is only a recording system. The stock market is very small compared with the fixed-income market, about 1 percent or 2 percent of the total securities market.

Costa Rica One stock exchange (Bolsa Nacional de Valores, BNV) is currently operating for both equity and fixed-income securities transactions. The secondary market activity represents about three-quarters of total market operation. The market is clearly dominated by public securities (mainly treasury and central bank securities). The repo market is very active, with underlying instruments mainly consisting of public securities. An important segment of the stock exchange activity is represented by the market for liquidity, whereas the equity market represents less than 1 percent of total operations. All securities publicly offered must be handled by the respective members of the stock exchange and negotiated in the normal trading mechanisms of the stock exchange (Article 23 of the Securities Market Law, SML). Thus, the OTC market in Costa Rica is minor. Stock exchange transactions are carried out through different trading systems (the online trading system, TEBEL, Mercado de Liquidez, and the Sistema de Transferencias Electrónicas) operated by the BNV in which only broker-dealers can participate. All trades are locked in with automatic clearing and settlement.

\begin{tabular}{ll}
\hline $\begin{array}{l}\text { Dominican } \\
\text { Republic }\end{array}$ & The securities market consists almost entirely of commercial paper issued \\
by major private sector firms. Commercial paper is traded mainly on the \\
primary market. The secondary market is practically nonexistent. Most \\
broker-dealers belong to a banking group; the only stock exchange in the \\
country, the Bolsa de Valores de la República Dominicana, mainly performs \\
a register function of transactions traded in the OTC market, through the \\
Sistema Integrado de Negociaciones Electrónicas. Nearly 75 percent of \\
trades are settled within the same broker-dealer. Government securities \\
have played a minor role so far. Starting in 1999, the government resumed \\
issuing domestic securities for the redemption of public debt accrued since \\
1984. These securities are given directly to final beneficiaries. The central \\
bank also issues short-term securities (certificados) on an as-needed (that \\
is, not continuous) basis to supplement monetary policy operations.
\end{tabular}

Ecuador The securities markets are clearly dominated by government debt. The government of Ecuador issues mainly government bonds (bonos del estado) and treasury bills (certificados del tesoro). In terms of trading, government debt constitutes approximately 85 percent of the market; the rest is distributed among trading in private fixed-income securities (14 percent) and equities trading (1 percent). The central bank also issues short-term securities (títulos del banco central by means of an auction and undertakes repo operations in order to facilitate liquidity distribution in the financial system. The amount of títulos del banco central is determined quarterly by the monetary board of the

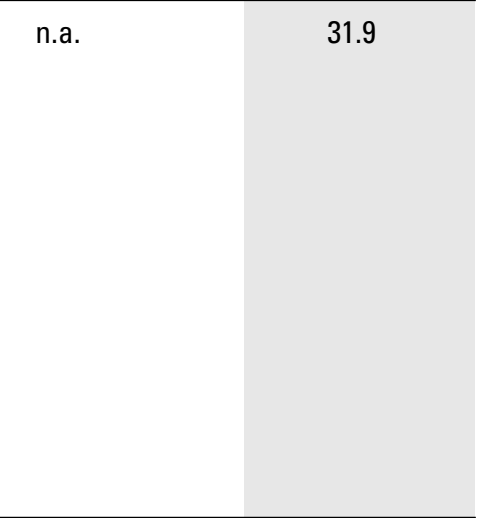


Table 5.2 Description of Securities Markets in Latin America and the Caribbean (Continued)

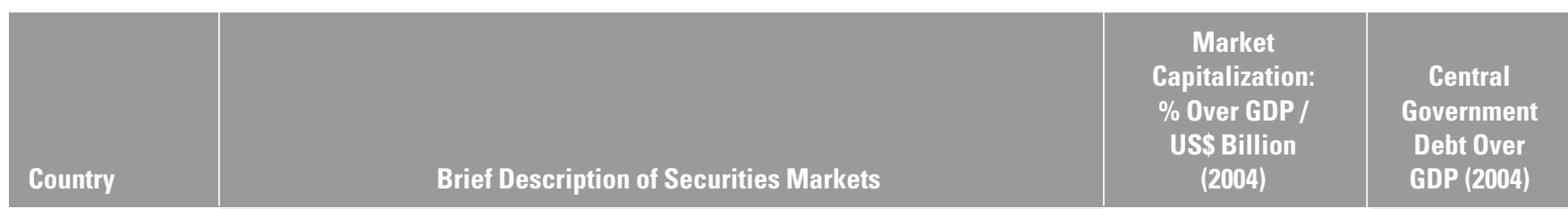

\section{Ecuador (Continued)}

BCE. Trading takes place through the two existing stock exchanges in the country, located in Quito and Guayaquil. The Guayaquil stock exchange operates an electronic trading system (Sistema Electrónico Bursátil). An electronic auction system for public and private securities (Subasta Serializada) in which participants are public entities (Article 37 of the SML) is located in Guayaquil and is interconnected with the Quito stock exchange. The Quito stock exchange operates an electronic system (Sistema de Negociación Electrónica). The bulk of the market is constituted by outright securities sales, although there are also forward and repo operations.

\begin{tabular}{|c|c|}
\hline EI Salvador & $\begin{array}{l}\text { The securities markets are dominated by institutional investors, the } \\
\text { major ones being banks, insurance companies, private pension funds } \\
\text { (Administradoras de Fondos de Pensiones, AFPs), and brokers trading } \\
\text { on their own account. There is almost no retail market, except for a } \\
\text { small number of investors with quasimutual funds that are managed } \\
\text { by brokers. In terms of instruments, the securities market consists } \\
\text { almost entirely of fixed-income securities, with equities forming a } \\
\text { negligible portion. The primary market is dominated by the public sector, } \\
\text { mainly bonds issued by the Banco Central de Reserva (BCR) as part of } \\
\text { its open market operations. The treasury of El Salvador plays a relatively } \\
\text { minor role in securities issues. The secondary market is dominated by } \\
\text { repo trading on the stock exchange (Mercado de Valores del Salvador). } \\
\text { The Mercado de Valores del Salvador started operating in 1992. It is } \\
\text { basically a money market, because the bulk of transactions are repos } \\
\text { with maturity of fewer than seven days. The underlying instruments } \\
\text { for the repos are mostly central bank securities. There is almost no } \\
\text { trading in equities. There is a trend for banks to place their excess } \\
\text { liquidity abroad; their operations in the repo market are becoming } \\
\text { less important. }\end{array}$ \\
\hline
\end{tabular}

Guatemala The securities markets are dominated by central bank and government debt, representing nearly 95 percent of total market activity (primary and secondary market). The central bank issues short-term securities (certificados de depósito a plazo), which at present are used mainly to implement the central bank's monetary policy operations. The government issues mainly government bonds (bonos del tesoro or certibonos) and treasury bills (letras de tesorería). The equity market is almost nonexistent, although some years ago there was a narrow market. Stock exchange transactions are usually made at the Bolsa de Valores Nacional with a minor role of the Bolsa de Valores Global.

Honduras
There are two stock exchanges in Honduras (Bolsa Centroamericana de
almost nonexistent. There is no electronic trading, because it is normally
done through the OTC market over the telephone. Transactions are regis-
tered in the corresponding stock exchange. The stock exchanges are
currently functioning as brokers for the auction of public securities. These
are issued on a dematerialized form and are under the custody of the
Banco Central de Honduras or the stock exchange. In the rare occasion
that those securities are traded in the secondary market, it is done
through the physical exchange of custody certificates or through the
custodian service of the stock exchange.


Table 5.2 Description of Securities Markets in Latin America and the Caribbean (Continued)

\begin{tabular}{|c|c|c|c|}
\hline Country & Brief Description of Securities Markets & $\begin{array}{l}\text { Market } \\
\text { Capitalization: } \\
\% \text { Over GDP / } \\
\text { US\$ Billion } \\
\text { (2004) }\end{array}$ & $\begin{array}{l}\text { Central } \\
\text { Government } \\
\text { Debt Over } \\
\text { GDP (2004) }\end{array}$ \\
\hline Jamaica & $\begin{array}{l}\text { The securities markets are clearly dominated by Jamaica government } \\
\text { debt. The government of Jamaica issues treasury bills, local registered } \\
\text { stock, debentures of the government of Jamaica, U.S. dollar-indexed } \\
\text { bonds, and U.S. dollar bonds. The Bank of Jamaica (BOJ) has estab- } \\
\text { lished an electronic system for the auction of treasury bills in the pri- } \\
\text { mary market. Primary dealers are the participants in the auction market. } \\
\text { The issuance and settlement of all other government securities is split } \\
\text { between the BOJ and the ministry of finance. In addition to the auction, } \\
\text { there is direct placement of government securities. The trading of } \\
\text { government securities takes place OTC. The sale of equity securities is } \\
\text { conducted on the Jamaica Stock Exchange (JSE). The JSE is not } \\
\text { involved in bonds trading. }\end{array}$ & $176.8 / 14.2$ & 140.2 \\
\hline Mexico & $\begin{array}{l}\text { Equities and debt instruments issued by nonbanking private entities are } \\
\text { traded mainly in the stock exchange (Bolsa Mexicana de Valores, BMV), } \\
\text { whereas government and banking instruments are traded mainly in OTCs. } \\
\text { The stock market is small compared with the size of the economy. The } \\
\text { market for corporate debt, as well as the market for debt issued by state- } \\
\text { owned firms and local governments, is also relatively small. Therefore, } \\
\text { the Mexican securities market is concentrated in securities issued by } \\
\text { banks and those issued by the federal government. The BMV is the only } \\
\text { stock exchange in the country. Since 1999, all trades are executed elec- } \\
\text { tronically through the SENTRA-Capitales, SENTRA-Deuda, and REMATE- } \\
\text { Lince systems. The clearance and settlement of operations with } \\
\text { securities traded either at the BMV or in the OTC market is executed } \\
\text { through the central securities depository (Instituto para el Depósito de } \\
\text { Valores; INDEVAL). Since 1998, there has been an organized market for } \\
\text { derivatives, called the Mexican Derivatives Market (Mercado Mexicano } \\
\text { de Derivados, MEXDER). The main instruments traded in this market are } \\
\text { foreign exchange, interest rates, and individual stocks futures. Since it } \\
\text { began operations, the MEXDER has experienced a significant growth in } \\
\text { traded volumes. }\end{array}$ & $25.7 / 174.3$ & 26.1 \\
\hline $\begin{array}{l}\text { Netherlands } \\
\text { Antilles }\end{array}$ & $\begin{array}{l}\text { The securities market consists almost entirely of primary auctions of } \\
\text { government and central bank debt. The government issues mainly long- } \\
\text { term government bonds and short-term treasury bills. The government } \\
\text { issues treasury bills regularly, and bonds irregularly. Bond maturities } \\
\text { vary at every auction. The central bank also issues short-term securities } \\
\text { (certificates of deposit, CDs) every two weeks. There is a very small } \\
\text { (fewer than five transactions a month) secondary market for securities. } \\
\text { In this market, the central bank acts as broker between sellers and buy- } \\
\text { ers and gives indicative prices. The central bank processes transactions } \\
\text { via telephone and facsimile, and then enters securities and cash move- } \\
\text { ments manually. }\end{array}$ & $0 / 0$ & n.a. \\
\hline Nicaragua & $\begin{array}{l}\text { The securities market is heavily dominated by government and central } \\
\text { bank securities, although the private sector is starting to participate, as } \\
\text { well. In recent years, the central government has issued indemnification } \\
\text { bonds (bonos de pago de indemnización). These are long-term (15-year) } \\
\text { bonds that are allotted directly to the beneficiaries, who may sell them to } \\
\text { other parties in a secondary market but who in general hold them until } \\
\text { maturity. The bonos de pago de indemnización are not issued regularly. }\end{array}$ & $0 / 0$ & n.a. \\
\hline
\end{tabular}


Table 5.2 Description of Securities Markets in Latin America and the Caribbean (Continued)

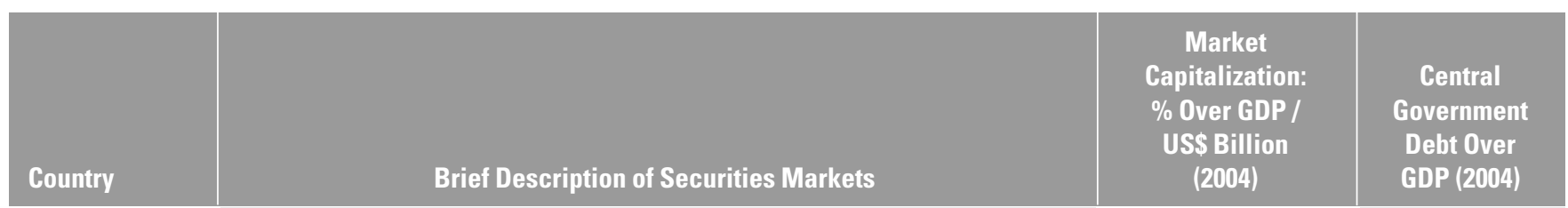

Nicaragua The central bank issues short-term bills (letras) denominated in U.S. dol-

(Continued) lars for monetary policy purposes. These are standardized securities that have been replacing the negotiable investment certificates (certificados negociables de inversión) that were issued until June 2003. Central bank securities are issued every week through the stock exchange and are the most liquid instrument in the market. Certificados negociables de inversión account for approximately 75 percent of total traded volume at the stock exchange. The Bolsa de Valores de Nicaragua (BVDN) is the only stock exchange in the country. The BVDN started operating in 1994; since then, it has experienced significant growth in total traded value. The OTC market is nearly nonexistent, in part because the interbank money market is not very developed.

OECS Despite the existence of a currency union with a common currency and a common central bank (Eastern Caribbean Central Bank, ECCB), the financial system is fragmented, with eight separate securities markets. In this regard, the ECCB has established the goal for the development and integration of these markets into a single financial space within the Eastern Caribbean Currency Union. The ECCB began by launching the creation of markets and institutions to achieve this goal, and identified five institutions to be established at the regional level. These include the Eastern Caribbean Home Mortgage Bank, the Eastern Caribbean Securities Market, the Regional Government Securities Market, the Eastern Caribbean Unit Trust, and the Eastern Caribbean Enterprise Fund. A major component of the ECCB's Money and Capital Market Development initiative started in October 2001, with the launch of the Eastern Caribbean Securities Market. In November 2002, the Regional Government Securities Market was launched, providing primary and secondary market facilities for government securities from the Eastern Caribbean Currency Union member states. The initiative seeks to strengthen the existing primary market for treasury bills and bonds, and to promote the development of a secondary market for these securities. Currently, St. Kitts and Nevis, St. Vincent and the Grenadines, and Grenada have issued securities on the Regional Government Securities Market.

\begin{tabular}{lll}
\hline Panama & Trading takes place on an electronic trading system provided by the & $29.7 / 4.1$ \\
stock exchange (Bolsa de Valores de Panamá, BVP) named the Sistema & \\
de Negociación Autorizado. This is a screen-based electronic system \\
that processes orders from brokers online in real time, and automatically \\
matches the best bids and offers. The volume of transactions is low. All \\
trades must be performed by the broker-dealer members of the stock \\
exchange, who are obliged to actually have the securities in their \\
accounts before trading (no short-selling is allowed). No trades are \\
performed OTC. \\
Securities markets are dominated by central bank and government debt \\
and primary market activity. The central bank issues short-term securi- \\
ties (cartas de compromiso and letras de regulación monetaria), which \\
at present are used mainly to implement the central bank's monetary \\
policy operations. The cartas de compromiso are nonnegotiable short- \\
term securities issued on a registered form and kept under the custody \\
of the Banco Central de Paraguay. The monetary regulation bills (letras
\end{tabular}


Table 5.2 Description of Securities Markets in Latin America and the Caribbean (Continued)

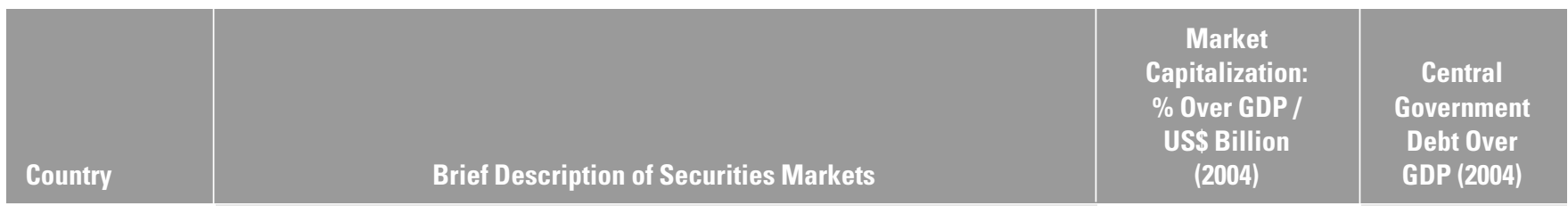

\section{Paraguay} (Continued) de regulación monetaria) are registered short-term securities (up to 365 days of maturity) issued in physical form and transferable by endorsement. The bills can be kept under custody at the Banco Central de Paraguay, with any other custodian, or with the buyer itself. A minor percentage of central bank bills are held under custody at the central bank. The government issues mainly medium- and long-term treasury bonds (bonos del tesoro público) with maturities between one and five years. The primary market represents the bulk of the activity in public sector securities. The stock exchange (Bolsa de Valores y Productos de Asunción) began operations in October 1993. Securities traded at the stock exchange are fixed-income instruments, municipal bonds, private bonds (maturities more than one year), promissory notes (maturities less than one year), and shares. The bulk of the stock exchange activity is constituted by primary market transactions.

\begin{tabular}{|c|c|c|c|}
\hline Peru & $\begin{array}{l}\text { Securities markets in Peru are very narrow and dominated by private } \\
\text { securities, because the government debt market is still incipient. The } \\
\text { Lima Stock Exchange (Bolsa de Valores de Lima, BVL) is the only stock } \\
\text { exchange in Peru. The Caja de Valores de Lima (CAVALI) Institución de } \\
\text { Compensación y Liquidación de Valores is the securities clearing and } \\
\text { settlement institution in Peru. In addition to exchange cleared and trades } \\
\text { settled, there is an OTC market. The bulk of the trading supported by the } \\
\text { BVL historically has been in equities; trading of debt is increasing its sig- } \\
\text { nificance, however, due mainly to public debt (in nuevos soles as well as } \\
\text { in dollars). The BVL trades primarily stocks, bonds, and repos. Trading in } \\
\text { the BVL is executed through an electronic system called ELEX. In the } \\
\text { past four years, Peruvian capital markets have grown significantly. The } \\
\text { government and the central bank worked hard to develop a yield curve } \\
\text { for Peruvian sovereign bonds. This has helped private companies to } \\
\text { issue in domestic currency (nuevos soles). Fixed-income securities are a } \\
\text { larger market than equities in Peru. Most of the fixed-income trading is } \\
\text { done through an OTC market, however. Almost } 100 \text { percent of trading in } \\
\text { equities is done through the BVL. }\end{array}$ & $26.6 / 18.2$ & 43.3 \\
\hline $\begin{array}{l}\text { Trinidad and } \\
\text { Tobago }\end{array}$ & $\begin{array}{l}\text { In Trinidad and Tobago most of the activities associated with securities } \\
\text { business are undertaken by a limited number of financial institutions. } \\
\text { Many of the agencies that provide securities-related services are sub- } \\
\text { sidiaries of the commercial banks. Although there are a few relatively } \\
\text { developed market segments such as treasury bills and bond markets, } \\
\text { the secondary market for corporate securities is still undeveloped. } \\
\text { Treasury bills and notes are sold in the primary market through a com- } \\
\text { petitive bidding process. The central bank has recently implemented } \\
\text { a primary dealer approach for the distribution of treasuries. On the } \\
\text { one hand, introduction of medium-term paper (government notes and } \\
\text { bonds) is a recent event. On the other hand, the government is a signifi- } \\
\text { cant issuer of long-term paper, and most investors hold this paper to } \\
\text { maturity. The Trinidad and Tobago Stock Exchange was established in } \\
\text { 1981. Although the actual volume of OTC trading is not known, it is } \\
\text { believed that this is less than the volume of trades that cross the floor } \\
\text { of the exchange. }\end{array}$ & 103.9/10.6 & 54.5 \\
\hline Uruguay & $\begin{array}{l}\text { Securities markets are dominated by central bank and government secu- } \\
\text { rities. The government issues treasury bills (letras del tesoro), which are }\end{array}$ & $2.3 / 0.3$ & 83.8 \\
\hline
\end{tabular}


Table 5.2 Description of Securities Markets in Latin America and the Caribbean (Continued)

\begin{tabular}{|c|c|c|c|}
\hline Country & Brief Description of Securities Markets & $\begin{array}{l}\text { Market } \\
\text { Capitalization: } \\
\text { \% Over GDP / } \\
\text { US\$ Billion } \\
\text { (2004) }\end{array}$ & $\begin{array}{l}\text { Central } \\
\text { Government } \\
\text { Debt Over } \\
\text { GDP (2004) }\end{array}$ \\
\hline $\begin{array}{l}\text { Uruguay } \\
\text { (Continued) }\end{array}$ & $\begin{array}{l}\text { short-term securities, and treasury bonds (bonos del tesoro), which are } \\
\text { long-term securities. The government also issues securities in foreign } \\
\text { currency and foreign markets, global notes and bonds. The central bank } \\
\text { issues short-term securities for monetary policy purposes (letras de } \\
\text { regulación monetaria). Private sector securities consist of CDs, stocks, } \\
\text { and negotiable bonds. However, operations of private securities are very } \\
\text { limited, with trading in only one stock and five negotiable bonds. The secu- } \\
\text { rities market activities are concentrated in two exchanges-the Bolsa de } \\
\text { Valores de Montevideo (BVM) created in } 1867 \text { and the Bolsa Electrónica de } \\
\text { Valores (BEVSA) created in 1993. Most of the activity is in public securities, } \\
\text { except for the trading in CDs. }\end{array}$ & & \\
\hline $\begin{array}{l}\text { Venezuela, } \\
\text { R.B. de }\end{array}$ & $\begin{array}{l}\text { The securities markets are dominated by government debt, representing } \\
\text { more than } 95 \text { percent of total trading. The government issues mainly gov- } \\
\text { ernment bonds (bonos de la deuda pública nacional) and treasury bills } \\
\text { (letras del tesoro), although recently it has also been issuing securities } \\
\text { directly to particular sectors of the population (a special debt security } \\
\text { known as Vebono). The central bank also issues short-term securities } \\
\text { (CDs), which at present are used mainly to supplement monetary policy } \\
\text { operations due to the lack of sufficient government securities. Primary } \\
\text { placement and secondary trading of government securities, except } \\
\text { Vebonos, take place through the electronic trading systems developed by } \\
\text { the central bank. Primary auctions of government securities are made } \\
\text { through the Sistema Integrado de Mercado Abierto, operated by the cen- } \\
\text { tral bank. Interbank money market transactions, mainly overnight outright } \\
\text { and collateralized loans, are performed mainly through the Sistema Elec- } \\
\text { trónico de Transferencia de Fondos para Préstamos Interbancarios, } \\
\text { although there is also an OTC market for this type of transactions. Stock } \\
\text { exchange transactions are made at the Bolsa de Valores de Caracas } \\
\text { (BVC) established in 1976. The BVC has an electronic trading system, the } \\
\text { Sistema Integrado Bursátil Electrónico (SIBE), for stocks, Vebonos, and } \\
\text { private sector commercial paper issues. Some Venezuelan external debt } \\
\text { issues (that is, Brady Bonds) and mutual fund-like securities trusts } \\
\text { (known as Joyas) are also traded at the stock exchange, although their } \\
\text { share in total trading is minor. }\end{array}$ & 7.3/8 & 39.8 \\
\hline
\end{tabular}

Source: Authors' elaboration and World Bank Development Data Platform.

a. Data corresponds to 2003 .

as a percentage of GDP and central government debt over GDP.

Table 5.3 includes a brief description of the SSSs in each of the countries assessed.

\section{LEGAL ISSUES}

This section includes context, status in the region and observations regarding legal issues.

\section{Context}

The reliable and predictable operation of an SSS depends on (1) the laws, rules, and procedures that support the holding, transfer, pledging, and lending of securities and related payments; and (2) how these laws, rules, and procedures work in practice - that is, whether system operators, participants, and their customers can enforce their rights. If the legal framework is inadequate or its application uncertain, it can give 
Table 5.3 SSSs in Latin America and the Caribbean

\begin{tabular}{|c|c|c|c|}
\hline Country & SSSs & Operator / Owner & General Description \\
\hline \multirow[t]{3}{*}{ Argentina } & $\begin{array}{l}\text { Merval / Caja de } \\
\text { valores }\end{array}$ & Private sector & $\begin{array}{l}\text { SSS for the stock exchange (Merval) transactions. Movement of securi- } \\
\text { ties ownership is through the caja de valores. The caja holds collective } \\
\text { cash deposits in the names of participating financial institutions. Partici- } \\
\text { pants enter into a collective deposit agreement with the caja de valores. } \\
\text { The deposit itself is made in the name of both the participant (for example, } \\
\text { a bank) and its customer (that is, the beneficial owner of the securities). By } \\
\text { the agreement, participants are required to return on request to the benefi- } \\
\text { cial owner an identical amount of securities of the same issuer, class, and } \\
\text { issue entrusted. }\end{array}$ \\
\hline & $\begin{array}{l}\text { Argenclear / Caja } \\
\text { de valores / CRYL }\end{array}$ & Private sector & $\begin{array}{l}\text { SSS for MAE-traded securities. It is operational since September } 2000 \text {. } \\
\text { MAE is an OTC market for government securities and corporate bonds. } \\
\text { Interbanking has partnered with the caja de valores, the securities } \\
\text { custodian for the Argentine market, and a new financial market intermedi- } \\
\text { ary, Argenclear, to facilitate delivery versus payment (DvP) in securities } \\
\text { settlement. For eligible securities, banks are able to move net securities } \\
\text { positions settled at the caja de valores against net funds positions settled } \\
\text { at Interbanking. Argenclear facilitates the movement of a participant's net } \\
\text { securities against their net funds position on confirming that the participant } \\
\text { has sufficient funds for the transaction. Only if the participant has sufficient } \\
\text { funds does Argenclear instruct the caja de valores to transfer the securities } \\
\text { to the account of the buyer at the caja de valores. }\end{array}$ \\
\hline & CRYL & $\begin{array}{l}\text { Central bank } \\
\text { (BCRA) }\end{array}$ & $\begin{array}{l}\text { SSS for treasury bills and medium-term treasury bonds (letes and bontes). } \\
\text { Began operating in 1996. Traders in short- and medium-term government } \\
\text { bills or bonds are not obliged to settle through Central de Registración y } \\
\text { Liquidación de Instrumentos de Endeudamiento Público (CRYL). Those that } \\
\text { do not settle in CRYL have their securities accounts in the caja de valores, } \\
\text { the depository. To facilitate this process, the caja de valores (and Merval) } \\
\text { have accounts in CRYL. }\end{array}$ \\
\hline Bahamas, The & Securities firms & Private sector & $\begin{array}{l}\text { Two securities firms provide registry, transfer, clearing, and settlement } \\
\text { services for the publicly traded companies. The clearing and settlement } \\
\text { is done on a trade-by-trade basis, using cheques for the payments. Some } \\
\text { securities are in book-entry form, through the services of one of the } \\
\text { securities firms. Settlement is not done on a DvP basis, and the risk } \\
\text { management is left up to each firm and to its customers. A CSD has not } \\
\text { yet been established. }\end{array}$ \\
\hline Bolivia & $\begin{array}{l}\text { Stock exchange / } \\
\text { EDV }\end{array}$ & Private sector & $\begin{array}{l}\text { Although by } 2004 \text { the dematerialization process began at the Entidad de } \\
\text { Depósito de Valores (EDV), until the first half of } 2005 \text { most securities were } \\
\text { still issued in physical form. By now, most private and public securities } \\
\text { have been dematerialized by the EDV or are issued in a dematerialized } \\
\text { form, or both. It is estimated that by the end of the second quarter of } 2006 \\
\text { all securities will be completely dematerialized. Until then, all trans- } \\
\text { actions with physical certificates will be settled in the traditional form } \\
\text { (physical certificates on receipt of cheques) in the offices of the Bolsa } \\
\text { Boliviana de Valores. Stock exchange activity is undertaken on the floor } \\
\text { of the exchange for fixed-income securities and for stocks. No electronic } \\
\text { trading system operates at the moment. Settlement takes place on T at } \\
4: 00 \text { p.m. on a gross basis by means of exchange of physical securities } \\
\text { and cheques. Securities still held in physical form must be previously } \\
\text { registered in the stock exchange in order to be traded, although the } \\
\text { Bolsa Boliviana de Valores does not keep record of ownership transfer. } \\
\text { However, all transactions with dematerialized securities will settle } \\
\text { through the EDV (Model 2) on T. Funds will go through the Banco Central } \\
\text { de Bolivia (BCB) using a centralized account handled by the EDV. All }\end{array}$ \\
\hline
\end{tabular}


Table 5.3 SSSs in Latin America and the Caribbean (Continued)

\begin{tabular}{|c|c|c|c|}
\hline Country & SSSs & Operator / Owner & General Description \\
\hline $\begin{array}{l}\text { Bolivia } \\
\text { (Continued) }\end{array}$ & & & $\begin{array}{l}\text { information regarding transactions settled through the EDV is transferred } \\
\text { electronically by the Bolsa Boliviana de Valores. Finally, the Bolsa Boliviana } \\
\text { de Valores is planning on implementing an electronic trading system by } \\
\text { the end of } 2006 \text {. }\end{array}$ \\
\hline \multirow[t]{4}{*}{ Brazil } & CBLC & Private sector & $\begin{array}{l}\text { The Companhia Brasileira de Liquidacao e Custodia (CBLC) is the custody } \\
\text { and settlement system for equities. It settles equity securities transactions } \\
\text { in Brazil. Following an agreement among Brazilian stock exchanges at the } \\
\text { beginning of 2000, BOVESPA became the only active stock exchange in } \\
\text { the country. The erstwhile Rio stock exchange (Bolsa de Valores do Rio de } \\
\text { Janeiro, BVRJ), assumed the specialized responsibility for designing and } \\
\text { operating a system for the automated trading of public securities (SISBEX) } \\
\text { and foreign exchange, which was afterwards transferred to the BM\&F } \\
\text { upon its acquisition of BVRJ. The CBLC, which was the clearinghouse of } \\
\text { the São Paulo Stock Exchange, incorporated the former clearinghouse of } \\
\text { the Rio exchange (Camara de Liquidaçao e Custodia, CLC). }\end{array}$ \\
\hline & SELIC & Central bank & $\begin{array}{l}\text { The Sistema Especial de Liquidacao e Custodia (SELIC) is the central } \\
\text { depository for the most negotiated federal public securities. The SELIC } \\
\text { system, used for clearance and settlement of government securities eligible } \\
\text { for discount at the central bank discount window, is fully integrated with } \\
\text { the central bank's owned and operated real-time gross settlement system. } \\
\text { Government securities trading occurs OTC or in electronic markets and } \\
\text { exchanges, or both. }\end{array}$ \\
\hline & BM\&F & Private sector & $\begin{array}{l}\text { The Brazilian Mercantile \& Futures Exchange (BM\&F) carries the vast } \\
\text { majority of transactions with derivatives. Brazil has a relatively large and } \\
\text { diverse financial derivatives market. Most of Brazil's financial derivatives } \\
\text { are futures. Options based on individual corporate securities are traded } \\
\text { on the São Paulo Stock Exchange. Derivative contracts are cleared } \\
\text { within the BM\&F by an in-house department (Derivatives Clearinghouse). } \\
\text { The BM\&F has also launched a clearinghouse (Securities Clearinghouse } \\
\text { or Clearing de Ativos) for the clearing and settlement of public securities } \\
\text { trading through the Sisbex-Negociação and Sisbex-Registro electronic } \\
\text { trading systems. }\end{array}$ \\
\hline & CETIP & Central bank & $\begin{array}{l}\text { The Central de Custódia e de Liquidação Financeira de Títulos (CETIP), } \\
\text { created in 1986, handles mainly the primary market for corporate bonds } \\
\text { and other securities (including government and state securities). It is the } \\
\text { central custodial and settlement system for some private securities, } \\
\text { special purpose public securities, and swaps. The system also registers } \\
\text { borrowing and lending of reserves between financial institutions through } \\
\text { repurchase agreements with the borrower issuing CDs, as well as for } \\
\text { state and municipal bonds. It constituted and sold to the banks a new } \\
\text { clearinghouse, Centralclearing de Compensacao e Liquidacao S.A., which } \\
\text { was intended to start operating as a central counterparty (CCP) a few } \\
\text { months after the launch of the Sistema de Transferencia de Reservas } \\
\text { (STR), and to settle transactions on a DvP basis in the STR system (on } \\
\text { August 16, 2002). Instead, it ceased operating in February 2003, and was } \\
\text { later shut down. In the new environment, corporate bond operations are } \\
\text { settled mainly through CETIP, whether they are primary or secondary market } \\
\text { operations. }\end{array}$ \\
\hline Chile & $\begin{array}{l}\text { Stock } \\
\text { exchanges / } \\
\text { OTC / DCV }\end{array}$ & Private sector & $\begin{array}{l}\text { Securities can be traded in any of the exchanges in which they are regis- } \\
\text { tered, and in the OTC market. The exception is shares, which may only be } \\
\text { traded in the exchanges. Buy or sell orders must be channelled through a } \\
\text { broker-dealer. Dematerialization-immobilization is applied. Shares can be }\end{array}$ \\
\hline
\end{tabular}


Table 5.3 SSSs in Latin America and the Caribbean (Continued)

\begin{tabular}{|c|c|c|c|}
\hline Country & SSSs & Operator / Owner & General Description \\
\hline \multirow[t]{2}{*}{$\begin{array}{l}\text { Chile } \\
\text { (Continued) }\end{array}$} & & & $\begin{array}{l}\text { represented by physical certificates or remain in the issuer's register until a } \\
\text { request for the certificate is made by the shareholders. A large portion of } \\
\text { fixed-income securities and financial intermediation instruments and, to a } \\
\text { lesser extent, shares and investment fund quotas, are immobilized in the } \\
\text { accounts at the securities depository (Depósito Central de Valores, DCV). } \\
\text { Settlement of stock exchange transactions can be made either bilaterally, } \\
\text { that is directly between the parties, or in a centralized way, through the DCV } \\
\text { or the clearing system of the corresponding stock exchange. Centralized } \\
\text { settlement is only valid for transactions settled on T }+2 \text { (contado normal). } \\
\text { There is a clearinghouse operated by the bolsa de comercio that settles } \\
\text { fixed-income instruments on } T+1 \text {. }\end{array}$ \\
\hline & & & $\begin{array}{l}\text { In centralized settlement, the securities are delivered, separately, by means } \\
\text { of bilateral netting between the parties. The settlement can be made by } \\
\text { physical transfer (in an exchange) or electronic transfer (in accounts held } \\
\text { at the DCV). Payments (cash settlement) are always made in the clearing } \\
\text { system of the respective exchange by means of multilateral netting. How- } \\
\text { ever, final settlement occurs through the interbank payment system. Cen- } \\
\text { tralized settlement is the usual practice for shares and investment fund } \\
\text { quotas traded in exchanges. Most are settled electronically in the DCV, and } \\
\text { the rest are settled by physical transfers in the clearing systems of the } \\
\text { exchanges. Bilateral settlement is compulsory for transactions with fixed- } \\
\text { income securities traded in the OTC, regardless of the settlement condition } \\
\text { (T, T + } 1 \text { or T + 2). For OTC transactions, settlement on T is the usual cycle. The } \\
\text { bilateral settlement may be physical (in the clearing system of an exchange or } \\
\text { at the buying broker's office), or electronic, through the accounts held at the } \\
\text { DCV. Cash settlement takes place directly between the parties. }\end{array}$ \\
\hline \multirow[t]{2}{*}{ Colombia } & $\begin{array}{l}\text { Stock exchange } \\
\text { clearinghouse / } \\
\text { DECEVAL / DCV }\end{array}$ & $\begin{array}{l}\text { Private sector } \\
\text { except DCV } \\
\text { settlement } \\
\text { (central bank) }\end{array}$ & $\begin{array}{l}\text { Securities are immobilized or dematerialized in the two existing deposito- } \\
\text { ries: Depósito Centralizado de Valores de Colombia, S.A. (DECEVAL) and } \\
\text { DCV. DCV is a depository operated by the BR for public securities. All } \\
\text { securities in DCV are dematerialized. DECEVAL is a private company } \\
\text { owned by the banks, stock exchange, fiduciary societies, financial corpo- } \\
\text { rations, mortgage corporations, the banking association, and broker- } \\
\text { dealers. Any security registered in the issuers and securities national } \\
\text { register (Registro Nacional de Valores y Emisores) could be deposited for } \\
\text { custody in DECEVAL, where securities are immobilized (global notes or } \\
\text { individual securities). DECEVAL basically immobilizes private securities, } \\
\text { although it also has in deposit some public securities (for example, bonos } \\
\text { pensionales). In addition, DECEVAL has an omnibus account in DCV for } \\
\text { securities registered in DCV. Thus, depositors of DECEVAL can maintain } \\
\text { public securities at DECEVAL. For securities traded through the stock } \\
\text { exchange systems, the stock exchange is responsible for the clearance } \\
\text { and settlement process. Mercado Electrónico de Colombia transactions } \\
\text { can be settled on DvP basis Model } 1 \text { through an interface to the DCV- } \\
\text { Sistema Electrónico de Cuentas de Depósito (CUD) system, "free of pay- } \\
\text { ment" or "free of payment and securities delivery." Securities settlement } \\
\text { is done through a book-entry movement in DECEVAL or in DCV, depending on } \\
\text { where the respective securities are deposited in custody. For spot equity } \\
\text { transactions, the standard settlement cycle is T + 3. Funds settlement is done } \\
\text { on the day of settlement on a multilateral net basis by electronic transfer. }\end{array}$ \\
\hline & SEN / DCV & Central bank & $\begin{array}{l}\text { In the OTC market, fixed-income securities (mainly public securities) are } \\
\text { traded. If securities are traded through SEN, the clearance and settlement } \\
\text { process is carried out through DCV on a Model } 1 \text { DvP basis. Otherwise, OTC } \\
\text { market transactions are settled bilaterally by the counterparties and regis- } \\
\text { tered in the INVERLACE system. }\end{array}$ \\
\hline
\end{tabular}


Table 5.3 SSSs in Latin America and the Caribbean (Continued)

\begin{tabular}{|c|c|c|c|}
\hline Country & SSSs & Operator / Owner & General Description \\
\hline Costa Rica & $\begin{array}{l}\text { Stock exchange / } \\
\text { CEVAL }\end{array}$ & Private sector & $\begin{array}{l}\text { Stock exchange transactions are carried out through different trading sys- } \\
\text { tems (TEBEL, Mercado de Liquidez, Sistema de Transferencias Electrónicas, } \\
\text { primary market auctions) operated by the Bolsa Nacional de Valores in } \\
\text { which only brokerage houses can participate by conducting trades for their } \\
\text { own account and for their clients. For all four systems previously mentioned, } \\
\text { only one multilateral net debit position is calculated every day for the cash } \\
\text { settlement that takes place by means of bank transfers in the bank's reserve } \\
\text { accounts in the central bank. The securities leg is settled, on a gross basis } \\
\text { in the accounts of brokerage houses in the securities depository (CEVAL). } \\
\text { Securities are blocked prior to be available for trading. The Costa Rican } \\
\text { authorities have been working on a project to upgrade the SSS, named } \\
\text { Sistema de Anotaciones en Cuenta. }\end{array}$ \\
\hline $\begin{array}{l}\text { Dominican } \\
\text { Republic }\end{array}$ & $\begin{array}{l}\text { Stock exchange / } \\
\text { CEVALDOM }\end{array}$ & Private sector & $\begin{array}{l}\text { Most broker-dealers belong to a banking group and the only stock exchange } \\
\text { in the country, the Bolsa de Valores de la República Dominicana, mainly } \\
\text { performs a register function of transactions traded in the OTC market, } \\
\text { through the Sistema Integrado de Negociaciones Electrónicas system. } \\
\text { Nearly } 75 \text { percent of trades are settled within the same broker-dealers } \\
\text { (operaciones cruzadas). The securities depository (Central de Valores } \\
\text { Dominicana, CEVALDOM) authorization was granted by the securities com- } \\
\text { mission in January 2005. Securities are not dematerialized yet, but the legal } \\
\text { basis has been set with the new law for electronic trade (Ley de Comercio } \\
\text { Electrónico No. 126-02). Investors pay by cash or cheques for their transac- } \\
\text { tions, and usually withdraw the physical security from broker-dealers. }\end{array}$ \\
\hline Ecuador & $\begin{array}{l}\text { Stock } \\
\text { exchanges / } \\
\text { DECEVALE }\end{array}$ & Private sector & $\begin{array}{l}\text { Securities settlement takes place by means of the delivery of physical cer- } \\
\text { tificates to the stock exchanges, on the securities side, and transfers on the } \\
\text { current accounts of the stock exchanges at the central bank, on the pay- } \\
\text { ments side. The current depository, Depósito Centralizado de Valores de } \\
\text { Ecuador (DECEVALE) S.A., was established in } 1994 \text { mainly by the two stock } \\
\text { exchanges, but since then has only performed the custody of dematerialized } \\
\text { securities issued by the Corporación Financiera Nacional (that represent a } \\
\text { very small share of the market, less than } 1 \text { percent) and never developed } \\
\text { into a full-fledged depository. Thus, the central bank has become the major } \\
\text { provider of central custodian services for public and private securities. }\end{array}$ \\
\hline El Salvador & $\begin{array}{l}\text { Stock exchange / } \\
\text { CEDEVAL }\end{array}$ & Private sector & $\begin{array}{l}\text { Settlement for trades takes place on a same-day }(T+0) \text { basis. Whereas } \\
\text { the securities are also transferred on a same-day basis, securities and } \\
\text { payment settlements are not linked. The payment settlement is coordinated } \\
\text { by the stock exchange on a multilateral net basis. The stock exchange main- } \\
\text { tains an account with the BCR and each commercial bank to facilitate the } \\
\text { settlement. Securities settlement occurs through Central de Depósito de } \\
\text { Valores (CEDEVAL), which is the nation's security depository. Securities } \\
\text { settlement occurs by transferring the ownership records at CEDEVAL. } \\
\text { Because not all securities are immobilized, sellers must deliver physical } \\
\text { securities to CEDEVAL } 24 \text { hours before the sale is made. }\end{array}$ \\
\hline Guatemala & $\begin{array}{l}\text { Stock exchange / } \\
\text { Central bank }\end{array}$ & $\begin{array}{l}\text { Private sector / } \\
\text { Central bank }\end{array}$ & $\begin{array}{l}\text { The primary market of central bank and government securities is done } \\
\text { through direct placement (window), auction (licitación), electronic floor } \\
\text { (correo electrónico), and the electronic interbank money desk (mesa elec- } \\
\text { trónica bancaria de dinero). The window is managed by the central bank } \\
\text { to deal with the demand of securities from individuals and public sector } \\
\text { entities. Securities are issued in physical form or simply registered at the } \\
\text { central bank if the investor decides to leave the securities under central } \\
\text { bank custody. Funds settlement is normally done through cheque for indi- } \\
\text { viduals and through deposit accounts at the central bank (cuentas de }\end{array}$ \\
\hline
\end{tabular}


Table 5.3 SSSs in Latin America and the Caribbean (Continued)

\begin{tabular}{|c|c|c|c|}
\hline Country & SSSs & Operator / Owner & General Description \\
\hline $\begin{array}{l}\text { Guatemala } \\
\text { (Continued) }\end{array}$ & & & $\begin{array}{l}\text { depósito) by public sector entities. In the case of cheque settlement, } \\
\text { securities are not delivered until the cheque has been settled. The auction } \\
\text { and the electronic floor systems are managed by the stock exchange, and } \\
\text { funds settlement is done through a cheque delivered by the stock exchange } \\
\text { on behalf of their members. Delivery of securities only takes place after } \\
\text { 12:30 p.m. on T + } 1 \text { once the cheques have been settled. The electronic } \\
\text { interbank money desk is managed by the banks through the Bancared } \\
\text { network. Funds settlement is done through the bank's reserve accounts at } \\
\text { the central bank, and the securities are delivered on T. The central bank } \\
\text { only performs the custody function and not the ownership transfer, that is, } \\
\text { the central bank only registers the ownership of the investor in the primary } \\
\text { market. Subsequent ownership transfers are done by means of delivery } \\
\text { (if bearer securities), or endorsement (if order securities), or book-entry } \\
\text { note in the stock exchanges' securities depository, once previously deposited. } \\
\text { Stock exchange trading may be settled in or outside the stock exchange. } \\
\text { Approximately } 50 \text { percent of transactions are settled through the exchange. } \\
\text { For stock exchange settlement, it is mandatory to have previously deposited } \\
\text { the securities at the securities depository of either stock exchange. Settle- } \\
\text { ment of secondary market operations (outright transactions and repos) } \\
\text { takes place on T. Brokers deliver funds by means of cheque, and the stock } \\
\text { exchange delivers securities on T once the cheque has been received by } \\
\text { means of a book-entry note in the securities depository. }\end{array}$ \\
\hline Honduras & Stock exchanges & Private sector & $\begin{array}{l}\text { The secondary market is almost nonexistent, and current settlement } \\
\text { arrangements consist basically of custody arrangements. For the rare } \\
\text { secondary market operations, trading takes place OTC and then it is } \\
\text { informed to the corresponding stock exchange, and settlement is done } \\
\text { through the custody function of the stock exchanges. Stock exchanges } \\
\text { currently perform the functions of brokers for the primary market, informa- } \\
\text { tion registration of the rare OTC secondary market operations, and custody } \\
\text { services; they do not perform the function of trading, however. The bulk of } \\
\text { the market is the auction of public securities. }\end{array}$ \\
\hline Jamaica & JCSD & Private sector & $\begin{array}{l}\text { The sale of equity securities is conducted on the Jamaican Stock Exchange } \\
\text { (JSE) and settled through the Jamaica Central Securities Depository (JCSD). } \\
\text { The JCSD as well as broker-dealers have accounts at the BOJ and can } \\
\text { transfer funds through the Customer Information Funds Transfer System, a } \\
\text { funds settlement system operated by the BOJ. This allows for timely funds } \\
\text { settlement on central bank assets. The JCSD, a wholly owned subsidiary } \\
\text { of the JSE, was established in January 1999. The JSE has implemented an } \\
\text { electronic trading system called SUNRISE. Because the trading system is } \\
\text { linked to or coupled with the JCSD, trades effect book-entry movements } \\
\text { or changes ownership of securities. Both brokers and customers have } \\
\text { accounts at the JCSD. Securities are blocked in the account of the seller } \\
\text { before they are traded. }\end{array}$ \\
\hline Mexico & INDEVAL & Private sector & $\begin{array}{l}\text { All securities in the Registro Nacional de Valores are represented physi- } \\
\text { cally, generally by global notes, and are immobilized in INDEVAL, the CSD. } \\
\text { INDEVAL is the only entity authorized to operate as a CSD. Among other } \\
\text { services, it is the custodian and administrator of all the securities regis- } \\
\text { tered in the Registro Nacional de Valores, and it clears and settles all } \\
\text { transactions made with such securities. Until 1994, INDEVAL was respon- } \\
\text { sible only for the transfer of securities, whereas payments were arranged } \\
\text { bilaterally among counterparties. At the end of 1995, together with the } \\
\text { Banco de México, INDEVAL implemented Sistema Interactivo para el } \\
\text { Depósito de Valores (SIDV), which allows the settlement of all operations } \\
\text { under a DvP framework. For settlement of the cash leg, SIDV has a real-time }\end{array}$ \\
\hline
\end{tabular}


Table 5.3 SSSs in Latin America and the Caribbean (Continued)

\begin{tabular}{|c|c|c|c|}
\hline Country & SSSs & Operator / Owner & General Description \\
\hline $\begin{array}{l}\text { Mexico } \\
\text { (Continued) }\end{array}$ & & & $\begin{array}{l}\text { link with the payment systems of Banco de México, Sistema de Atención a } \\
\text { Cuentahabientes, and Sistema de Pagos Electrónicos de Uso Ampliado. } \\
\text { Stock exchange trades, mainly equities and debt securities issued by pri- } \\
\text { vate sector entities, are settled in T }+2 \text { under a multilateral netting scheme } \\
\text { for the cash leg and securities (DvP Model } 3 \text { of the BIS). Securities traded in } \\
\text { the OTC market are settled according to conditions established by the par- } \\
\text { ties, generally in T or T+1, on a gross basis for both the securities leg and } \\
\text { the cash leg (DvP Model } 1 \text { of the BIS). INDEVAL does not act as CCP. The } \\
\text { settlement of all transactions executed through BMV is covered by means } \\
\text { of a settlement fund. To qualify for this guarantee, operations need to be } \\
\text { declared unfulfilled because of the lack of either securities or cash, which } \\
\text { would happen at the closing of T + 5. Prior to this day, if the operations are } \\
\text { not settled normally by T + 2, they are declared in arrears, and the partici- } \\
\text { pants may access the securities-lending facility created by INDEVAL in } \\
\text { order to accomplish settlement. Regarding the derivatives market, a clearing } \\
\text { house (Asigna Compensación y Liquidación, ASIGNA) operates as a CCP for } \\
\text { all derivative contracts traded in MEXDER. ASIGNA shares the credit risks } \\
\text { with four trusts, each of which was established by a commercial bank. }\end{array}$ \\
\hline $\begin{array}{l}\text { Netherlands } \\
\text { Antilles }\end{array}$ & BvdNA & Central bank & $\begin{array}{l}\text { The Bank van de Nederlandse Antillen (BvdNA) is the custodian and CSD of } \\
\text { government securities. Most government securities are dematerialized. The } \\
\text { secondary market is not very active, but is increasing in size. Investors in } \\
\text { securities usually hold their positions until maturity, and there is no stock } \\
\text { exchange. For the few secondary market transactions, the BvdNA processes } \\
\text { transactions via telephone and facsimile, and then enters securities and } \\
\text { cash movements manually. The CSD of the BvdNA operates with segrega- } \\
\text { tion of accounts at the participant level. Banks are obliged by the BvdNA to } \\
\text { segregate their own assets from the securities owned by their clients. No } \\
\text { securities depository exists for private bonds or equities. Transactions in the } \\
\text { book-entry system of the BvdNA are matched and settled on T + } 1 \text { on a } \\
\text { gross basis and processed manually. Once the transactions are matched } \\
\text { and once the availability of the securities has been checked, the securities } \\
\text { are transferred to the account of the seller and the BvdNA inputs a direct } \\
\text { debit order (MT 202) in the Netherlands Antilles Clearing System to transfer } \\
\text { the money from the account of the buyer to the account of the seller. Banks } \\
\text { can pledge their government securities to the central bank in order to obtain } \\
\text { intraday credit facilities. Pledging takes place by blocking the securities in } \\
\text { the account of the pledger. }\end{array}$ \\
\hline Nicaragua & $\begin{array}{l}\text { Stock exchange / } \\
\text { CENIVAL }\end{array}$ & Private sector & $\begin{array}{l}\text { The stock exchange has an electronic trading system connected to that of the } \\
\text { CSD, the Central Nicaragüense de Valores (CENIVAL). For the most part, the } \\
\text { CENIVAL settles securities trades on T, although this is a market practice and } \\
\text { not an official rolling settlement cycle. The securities leg is settled through } \\
\text { book entry, and the cash leg is settled independently outside the system. The } \\
\text { BVDN has an electronic trading system, the Sistema de Negociación de la } \\
\text { BVDN (SN-BVDN), to which the broker-dealers submit their orders that are } \\
\text { traded, matched, and confirmed automatically. Broker-dealers may withdraw } \\
\text { their bids as long as there has been no match. The SN-BVDN is used for } \\
\text { both primary market and secondary market of private and public securities. } \\
\text { Outcry floor transactions would only be available in case of malfunctioning } \\
\text { of the SN-BVDN. The CENIVAL's system has a connection with the trading } \\
\text { system of the stock exchange, but securities transfer instructions from the } \\
\text { latter cannot be processed automatically. Instead, CENIVAL must receive a } \\
\text { transfer order from the selling participants for the securities to be transferred } \\
\text { to the buyer's account, which happens once the seller acknowledges the } \\
\text { receipt of the payment. Securities are not delivered otherwise. }\end{array}$ \\
\hline
\end{tabular}


Table 5.3 SSSs in Latin America and the Caribbean (Continued)

\begin{tabular}{|c|c|c|c|}
\hline Country & SSSs & Operator / Owner & General Description \\
\hline OECS & ECCSD & Private sector & $\begin{array}{l}\text { The Eastern Caribbean Securities Exchange (ECSE) trading system allows } \\
\text { for automated processing of buy and sell orders from brokers that are } \\
\text { located remotely in any of the eight countries that form part of the market. } \\
\text { A daily call auction process has been set up that matches all submitted } \\
\text { bids and offers. With increase in market activity and liquidity, the ECSE } \\
\text { intends to migrate to a continuous order-driven system. The ECSE offers } \\
\text { both primary and secondary trading platforms, creating a single focal point } \\
\text { for all securities activities. The Eastern Caribbean Central Securities } \\
\text { Depository (ECCSD) is owned by the ECSE. Its major function is to provide } \\
\text { clearance and settlement of trades transacted on the ECSE. The main } \\
\text { participants on the ECCSD are broker-dealers, limited service brokers, and } \\
\text { custodians. The ECCSD provides services to participant intermediaries and } \\
\text { processes transactions for trades reported by the exchange or other } \\
\text { markets. Custody services are also being provided to those entities that } \\
\text { wish to hold securities at the ECCSD on behalf of their customers-for } \\
\text { example, custodian banks for foreign investors. }\end{array}$ \\
\hline Panama & LATINCLEAR & Private sector & $\begin{array}{l}\text { The CSD in Panama, Central Latinoamericana de Valores S.A. (LATINCLEAR), } \\
\text { was created in 1997. All trades must be performed by the broker-dealers } \\
\text { members of the stock exchange, who are obliged to have the securities in } \\
\text { their accounts before trading (no short-selling is allowed); the securities } \\
\text { are not blocked until T }+2 \text { for final settlement. At the end of the day, the } \\
\text { stock exchange confirms trades to participants. Affirmation with final } \\
\text { customers takes place on T }+1 \text {. The final settlement is at T }+3 \text { early in the } \\
\text { morning at BNP, but for this purpose LATINCLEAR has actually to process } \\
\text { operations and estimate multilateral clearing in T }+2 \text { (at present, it has no } \\
\text { account at BNP, so it has to settle through CIASA-Telered [see chapter 4]). } \\
\text { The final settlement of the cash leg of the transactions takes place on } \\
\text { BNP books based on the files submitted by CIASA against the accounts of } \\
\text { the banks of the corresponding financial group, because broker-dealers } \\
\text { do not hold accounts at BNP. LATINCLEAR settles the securities leg under } \\
\text { a Model } 2 \text { DvP basis. }\end{array}$ \\
\hline Paraguay & $\begin{array}{l}\text { Central bank / } \\
\text { government / } \\
\text { broker-dealers }\end{array}$ & $\begin{array}{l}\text { Central bank / } \\
\text { Private sector }\end{array}$ & $\begin{array}{l}\text { The central bank and the government maintain a registry for the primary } \\
\text { market of their own securities. Subsequent ownership transfers are } \\
\text { executed by means of physical delivery and endorsement (if registered } \\
\text { securities). Changes in ownership are then communicated to the respec- } \\
\text { tive registry in order to register the new owner. The process for owner- } \\
\text { ship transfer is slow and cumbersome, especially in the treasury. The } \\
\text { rare secondary market transactions of public securities are settled bilat- } \\
\text { erally by the parties with the delivery of physical certificates and funds, } \\
\text { normally through cheques. The bulk of stock exchange transactions are } \\
\text { settled in-house at the broker-dealer books. Stock exchange activity } \\
\text { takes place on the floor of the exchange, although actual trading does } \\
\text { not take place every day. No electronic trading system operates at the } \\
\text { moment. Ninety-nine percent of the transactions are settled in-house, } \\
\text { because the buyer and seller are clients of the same broker-dealer. The } \\
\text { stock exchange reviews the broker-dealer processes to ensure that } \\
\text { funds and securities have been delivered to the clients before T + } 2 \text {. } \\
\text { Thus, the stock exchange does not participate in the clearance and } \\
\text { settlement process directly and only reviews it ex post. Securities are } \\
\text { normally kept at the brokers-dealers that act as custodians (this is } \\
\text { allowed by the SML, Article 105f). A private settlement bank is used for } \\
\text { funds settlement (the contract is renewed yearly). }\end{array}$ \\
\hline
\end{tabular}


Table 5.3 SSSs in Latin America and the Caribbean (Continued)

\begin{tabular}{|c|c|c|c|}
\hline Country & SSSs & Operator / Owner & General Description \\
\hline Peru & $\begin{array}{l}\text { Stock exchange / } \\
\text { CAVALI / Central } \\
\text { bank }\end{array}$ & $\begin{array}{l}\text { Private sector / } \\
\text { Central bank }\end{array}$ & 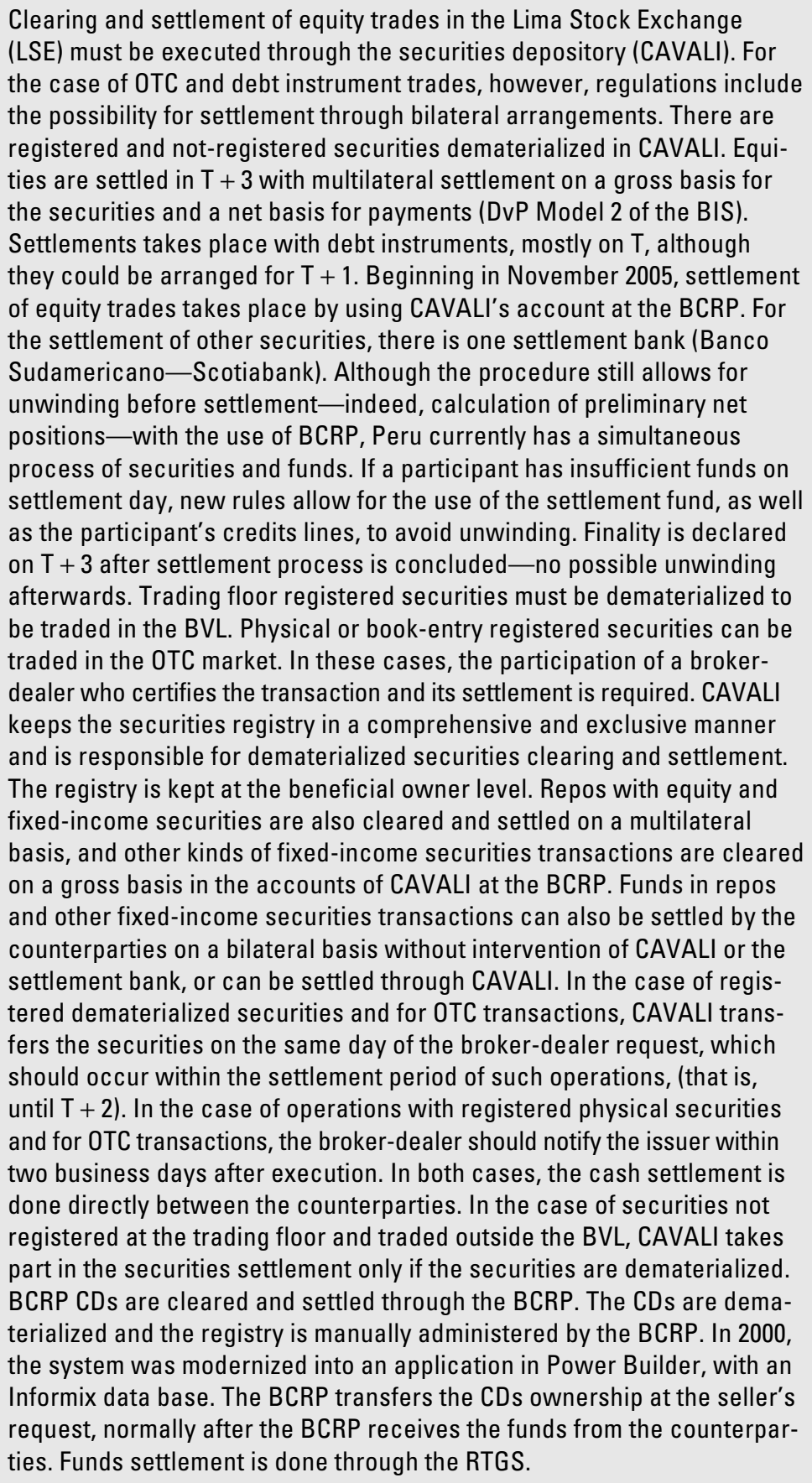 \\
\hline $\begin{array}{l}\text { Trinidad and } \\
\text { Tobago }\end{array}$ & $\begin{array}{l}\text { Central Bank of } \\
\text { Trinidad and } \\
\text { Tobago } \\
\text { depository }\end{array}$ & Central bank & $\begin{array}{l}\text { Under the Treasury Bills Act and the Treasury Note Act of 1995, the cen- } \\
\text { tral bank of Trinidad and Tobago is authorized to issue short-term trea- } \\
\text { sury securities on behalf of the government for the conduct of open } \\
\text { market and debt management operations. The acts provide for the } \\
\text { issuance of treasury bills with a maturity of up to one year, and for trea- } \\
\text { sury notes with maturities of up to five years. The central bank provides } \\
\text { clearance and settlement for treasury bills and notes. The central bank is }\end{array}$ \\
\hline
\end{tabular}


Table 5.3 SSSs in Latin America and the Caribbean (Continued)

\begin{tabular}{|c|c|c|c|}
\hline Country & SSSs & Operator / Owner & General Description \\
\hline \multirow[t]{2}{*}{$\begin{array}{l}\text { Trinidad and } \\
\text { Tobago } \\
\text { (Continued) }\end{array}$} & & & $\begin{array}{l}\text { the fiscal and paying agent for treasury bills and notes. The central bank } \\
\text { also provides depository services for government and other selected } \\
\text { entities. Each bank has a securities account at the central bank to con- } \\
\text { duct treasury bill activity. The government securities depository is linked } \\
\text { to the RTGS system. }\end{array}$ \\
\hline & $\begin{array}{l}\text { Stock exchange / } \\
\text { TTCD }\end{array}$ & Private sector & $\begin{array}{l}\text { The Trinidad and Tobago Stock Exchange, mutual fund companies, and } \\
\text { other financial institutions provide clearance and settlement functions in } \\
\text { their respective market segments. Mutual funds companies, which are } \\
\text { mainly subsidiaries of commercial banks, handle the clearance and set- } \\
\text { tlement for mutual fund transactions. The stock exchange performs } \\
\text { clearance and settlement functions for trades undertaken on the floor } \\
\text { of the exchange. However, these functions are to be transferred to the } \\
\text { Trinidad and Tobago Central Depository (TTCD). Some of the clearance } \\
\text { and settlement systems are manually operated, and other systems are } \\
\text { computerized. In January 2003, the Trinidad and Tobago Stock Exchange } \\
\text { launched the TTCD. Only stocks are currently being received on deposit } \\
\text { by the TTCD. Since TTCD stated operating, the on-floor trading of the } \\
\text { stock exchange can only be done with securities previously immobilized. } \\
\text { Listed companies have to accept the immobilization of their shares } \\
\text { through the signing of an agreement with the TTCD. The TTCD receives } \\
\text { the stocks in deposit, and at the end of the month, the register (that is } \\
\text { maintained and managed by the issuer) issues a global certificate for the } \\
\text { total value received in deposit during the corresponding month. The TTCD } \\
\text { is linked to the RTGS system for funds settlement }\end{array}$ \\
\hline Uruguay & $\begin{array}{l}\text { Stock } \\
\text { exchanges / } \\
\text { AGATA }\end{array}$ & $\begin{array}{l}\text { Central bank and } \\
\text { private sector }\end{array}$ & $\begin{array}{l}\text { Securities are issued in dematerialized (escriturales) or physical form. } \\
\text { BVM activity is undertaken on the floor of the exchange from 2:00 p.m. to } \\
2: 30 \text { p.m., and from 4:15 p.m. to 5:00 p.m. No electronic trading system } \\
\text { currently operates. Confirmation process takes place in the } 30 \text { minutes } \\
\text { following closing of the trading. Settlement takes place on T + } 1 \text { for } \\
\text { domestic securities and T + } 3 \text { for securities issued in foreign markets at } \\
5: 00 \text { p.m. (the time at which bank offices close) on a gross basis for secu- } \\
\text { rities and multilateral net basis for funds. Physical securities and global } \\
\text { securities are under custody in one private bank, and government and } \\
\text { central bank dematerialized securities in the Banco Central del Uruguay } \\
\text { (BCU) under the name of the BVM identifying the broker-dealer. Once the } \\
\text { BVM receives the funds through ABN Amro, funds settlement account, or } \\
\text { in its account at the central bank via the Sistema Electrónico de Comuni- } \\
\text { caciones, the BVM transfers the ownership (delivers, if physical) the } \\
\text { securities. If securities or funds are not delivered at settlement, the BVM } \\
\text { rules include buy-in and sell-out procedures at the cost of the failing } \\
\text { party through its generic stock exchange guarantee. The Bolsa Elec- } \\
\text { trónica de Valores (BEVSA) operates an electronic trading system } \\
\text { opened from 10:00 a.m. to 5:00 p.m. The BEVSA trading system is con- } \\
\text { nected online with the BCU securities custody system (AGATA). For secu- } \\
\text { rities under BCU custody, settlement takes place on a gross basis in real } \\
\text { time for both securities and funds. Trading in other securities is settled } \\
\text { bilaterally. Global securities settlement takes place bilaterally through } \\
\text { international custodians on T + 3. }\end{array}$ \\
\hline $\begin{array}{l}\text { Venezuela, } \\
\text { R.B. de }\end{array}$ & SICET & Central bank & $\begin{array}{l}\text { Except for Vebonos, the central bank is the central depository for govern- } \\
\text { ment securities. Accordingly the central bank, through its Sistema de } \\
\text { Custodia Electrónica de Títulos (SICET), provides all custody and central } \\
\text { depository functions for government securities, including ownership transfers } \\
\text { and collecting associated rights. Central bank trading and depository systems } \\
\text { are linked to its current accounts system. Transactions and collateralized }\end{array}$ \\
\hline
\end{tabular}


Table 5.3 SSSs in Latin America and the Caribbean (Continued)

\begin{tabular}{|c|c|c|c|}
\hline Country & SSSs & Operator / Owner & General Description \\
\hline \multirow[t]{2}{*}{$\begin{array}{l}\text { Venezuela, } \\
\text { R.B. de } \\
\text { (Continued) }\end{array}$} & & & $\begin{array}{l}\text { operations with government securities executed through the Sistema Elec- } \\
\text { trónico de Transferencia de Fondos para Préstamos Interbancarios, Sis- } \\
\text { tema Integrado de Mercado Abierto, and SICET systems of the central bank } \\
\text { have different settlement cycles. For primary auctions, even for the same } \\
\text { type of securities, there are different settlement cycles (that is, T+0 or T+1) } \\
\text { depending on the day of the week in which such securities are auctioned. } \\
\text { For secondary market transactions, the central bank uses a rolling settle- } \\
\text { ment cycle of T + 0. In the case of the interbank money market (that is, the } \\
\text { Sistema Electrónico de Transferencia de Fondos para Préstamos Interban- } \\
\text { carios), once transactions are matched the system settles them immedi- } \\
\text { ately. This is also the case for interbank OTC transactions that use the SICET } \\
\text { system for settlement. Thus, once participants input the operation into the } \\
\text { SICET system, transactions are settled. }\end{array}$ \\
\hline & $\begin{array}{l}\text { Stock exchange / } \\
\text { CVV }\end{array}$ & Private sector & $\begin{array}{l}\text { The current private sector depository, Caja Venezolana de Valores S.A. } \\
\text { (CVV), was established in } 1992 \text { under the initiative of the BVC and started } \\
\text { operating in 1996. The CVV holds stock issues and Vebonos in a system of } \\
\text { direct depositors and client subaccounts. At the stock exchange, clearance } \\
\text { and settlement takes place by means of book entries at the CVV on the } \\
\text { securities leg and through a commercial bank for the cash leg. The BVC } \\
\text { uses a rolling settlement cycle of T }+3 \text {. Settlement of securities and funds } \\
\text { occurs independently, the first done on a gross basis by the CVV, and the } \\
\text { second done on a multilateral net basis by the stock exchange. The CVV set- } \\
\text { tles the securities on T }+3 \text { and informs the stock exchange of the securities } \\
\text { transfers it already made. }\end{array}$ \\
\hline
\end{tabular}

Source: Authors' elaboration.

rise to credit or liquidity risks for system participants and their customers, or to systemic risks for financial markets as a whole.

A variety of laws and legal concepts can affect the performance of clearing and settlement systems. Contract laws, company laws, bankruptcy and insolvency laws, custody laws, property laws, and tax laws may impede a better performance of clearing systems. The general need is to have an adequate legal basis that is able to accommodate technological advances and that, thus, does not constitute a constraint for the operation or future development of the system. Key aspects of the settlement process that the legal framework should support include enforceability of transactions, protection of customer assets (particularly against insolvency of custodians), immobilization or dematerialization of securities, netting arrangements, securities lending (including repurchase agreements and other economically equivalent transactions), finality of settlement, arrangements for achieving DvP, default rules, liquidation of assets pledged or transferred as collateral, and protection of the interests of beneficial owners. The rules and contracts related to the operation of the SSS should be enforceable in the event of the insolvency of a system participant, whether the participant is located in the jurisdiction whose laws govern the SSS, or is located in another jurisdiction.

Another important emerging issue is the legal status of digital signatures. If digital signatures are to substitute for handwritten signatures, they must have the same legal status as handwritten signatures - that is, they must be legally binding. A critical need is to ensure that laws are enforced and enforceable in all relevant jurisdictions. In addition, disputes should become the subject of court proceedings only as a last resort. This can be achieved through the specification and acceptance of comprehensive and fair arbitration processes that are clear and nonambiguous.

\section{Status in the Region}

Table 5.4 includes a brief description of the legal framework for SSSs in each of the countries assessed. 


\section{Table 5.4 Legal Issues in SSSs}

\begin{tabular}{|c|c|}
\hline Country & Legal Issues \\
\hline Argentina & $\begin{array}{l}\text { The Public Offering of Securities Act (Law 17.811) of } 1968 \text { is the comprehensive body of law for securities market } \\
\text { activities, the public offering of securities, the organization and operation of stock market institutions, and } \\
\text { the acts of brokers and others engaged in securities trading. Other important laws are Law } 19.550 \text { (Business } \\
\text { Companies Act), Law } 20.643 \text { (Registered Nature and Rules of the Caja de Valores), Law } 21.382 \text { (Foreign } \\
\text { Investment), Law } 24.083 \text { (Mutual Funds), and Law } 24.441 \text { (Financial Trust). The securities regulator (Comisión } \\
\text { Nacional de Valores, CNV) approved General Resolution (RG) 337/99 in 1999, modifying RGs 194/92 and 294/97 } \\
\text { regarding futures and options. The Communication "A" } 2426 \text { of the central bank regulates the CRYL system. } \\
\text { On July 15, 1999, the CNV approved RG 337/99 (Futures and Options), thereby repealing CNV RGs 194/92 and } \\
\text { 294/97. RG 337/99 also reflects the principal issues included in the Futures Industry Association task force } \\
\text { recommendations on financial integrity for futures and options for exchanges, clearinghouses, regulators, } \\
\text { intermediaries, and customers, dated June 1995. Other relevant laws are Law 17.811 (Public Offering of } \\
\text { Securities), Law } 19.550 \text { (Business Companies Act), Law } 20.643 \text { (Registered Nature and Rules of the Caja de } \\
\text { Valores), Law } 21.382 \text { (Foreign Investment), Law 24.083 (Mutual Funds), and Law } 24.441 \text { (Financial Trust). }\end{array}$ \\
\hline
\end{tabular}

Bahamas, The

The Securities Act (as amended in 1999) regulates the securities commission, the securities exchanges and market participants, the authority of the securities commission, financial requirements of broker-dealers, the issue of securities to the public, reporting requirements, conduct of security business, and interest in securities of public and listed companies. Other relevant legislation for the securities industry includes the Investment Funds Act of 2003.

\section{Bolivia}

Regarding securities settlement, the SML (Ley 1834 del Mercado de Valores) was approved on March 31, 1998. This law includes the legal basis for the immobilization and dematerialization of securities in depositories (title 5, chapters 1 and 2). It is applicable to both private and public securities (see Article 2), although the $\mathrm{BCB}$ and treasury issues are excluded from the public offer requisite. This law regulates the functions and responsibilities of the securities superintendency (Articles 2, 15, and 16). The securities regulation and supervision is currently under the securities department (Intendencia de Valores) of the Insurance, Pensions, and Securities Superintendency (Superintendencia de Pensiones, Valores y Seguros). Article 15.4 of the SML empowers the Superintendencia de Pensiones, Valores y Seguros to supervise of the entities under its jurisdiction, including the depositories, stock exchanges, and market participants. However, the oversight function over securities clearance and settlement is not included in the law. The stock exchanges are considered as self-regulatory organizations (SROs) in all aspects of their activity (see Articles 31 and 33). Other relevant laws are the Pensions Law of November 29, 1996 (Ley 1732), and the Insurance Law of June 25, 1998 (Ley 1883).

Relevant regulation for securities settlement includes

- the Depositories and Securities Clearance and Settlement Regulation approved by the Superintendencia de Pensiones, Valores y Seguros Administrative Resolution 530, December 13, 2002;

- the internal rules of the stock exchange; and

- the internal rules of the depository, draft to be approved by the Superintendencia de Pensiones, Valores y Seguros.

Article 3 of Law 2297 provides the legal basis for the use of electronic documents and signatures. The BCB has issued regulation $086 / 2004$ in order to apply this legal basis to payments system operations. In the absence of a general legal framework for the certification process, the BCB allows for the use private keys certified through a notarized process (certificado digital autofirmado) or public keys certified by a certification entity (certificado digita). Currently, the BCB is using the certificado digital autofirmado, and ASOBAN is using a foreign certification entity for the systems they respectively operate.

A new legal framework was first established by Provisional Law 2008 in December 1999, which granted private clearinghouses certain legal rights and protections - for example, in terms of the use of collateral and recognition of multilateral netting. Specifically, it granted legal rights to seize the collateral of bankrupt participants held to secure financial transactions, protected settlement systems against the implications of a zero-hour rule, and gave legal recognition to multilateral netting schemes. The new legal framework also clarifies specific responsibilities for clearinghouses. According to the new law, clearinghouses must assume in total the counterparty risk with regard to their participants and the central bank. The provisional measure was revised (2115-14) in December 2000 in order to incorporate some additional safeguards, including the legal separation of the net assets of each discrete clearing and settlement environment, thus ensuring that any collateral posted in a specific environment will be solely used for settlement in that specific environment. In addition, clearinghouses are now subject to sanctions similar to those that apply to financial institutions. A specific restriction 
Table 5.4 Legal Issues in SSSs (Continued)

\begin{tabular}{|c|c|}
\hline Country & Legal Issues \\
\hline $\begin{array}{l}\text { Brazil } \\
\text { (Continued) }\end{array}$ & $\begin{array}{l}\text { is that the net assets of a clearinghouse cannot be used as pledged collateral for any loans sought by the } \\
\text { clearinghouse. On March 27, 2001, the Brazilian congress approved and converted the Medida Provisoria } 2115 \\
\text { into Law 10214. New bylaws for clearinghouses have been issued by the central bank. In particular, Conselho } \\
\text { Monetário Nacional's (CMN's) Resolution } 2882 \text { of August 30, 2001, sets up the payments system objectives of } \\
\text { the Banco Central do Brasil (Article 1). The resolution also specifies that specific provisions can be applied } \\
\text { by the central bank to those systems that are considered systemically important, and clarifies the role of the } \\
\text { securities regulator (Comissão de Valores Mobiliários, CVM) and its cooperation framework with BACEN. }\end{array}$ \\
\hline
\end{tabular}

Financial institutions are regulated by the Banking Act of December 1964 (Law 4595/64) and by the Capital Market Act of July 1965 (Law 4728/65). Law 6385 establishes the authority of CVM to regulate and supervise the clearance and settlement process of securities in general, excepting government-issued securities, which continue to be regulated and supervised solely by the central bank. The legal framework of the clearance and settlement system is contained in the bylaws and operational regulations of the clearing agencies. CVM Rule no. 89/88 states that companies that provide services related to register of companies, custodians, and stock certificates issuers must be accredited by the CVM. Such services must be performed by financial institutions and stock exchanges that have proper and operational financial conditions. BACEN and the CVM provide legal basis for the rules applicable to (1) the CBLC depository service (for example, dematerialization and protection of investors assets against insolvency of custodians through a beneficial owner account structure); (2) CBLC and BM\&F securities lending service; (3) CBLC and BM\&F Securities Clearinghouse CCP and settlement services (for example, mandatory CCP for systemically important settlement systems, multilateral netting, DvP arrangements between a clearinghouse and its participants, consequences of a participant's default and priority over the execution of assets pledged as collateral to support participants obligations). Brazilian Law 10.214 sets a legal basis for execution of assets pledged as collateral by clearing and settlement systems.

Chile

The basic principles for the operation of the stock market in Chile are collected under the SML. In addition, the Organic Law of the Superintendencia de Valores y Seguros (SVS) - the laws which cover stock corporations, third-party fund management (investment funds, mutual funds, pension funds, housing funds, and the like), bank and financial institutions, insurance and reinsurance companies, and the depository and custody of securities-completes the basic regulatory framework related to the securities market. The SML establishes that the institution responsible for supervising and controlling compliance with the rules established in it is the SVS, in accordance with the duties conferred on it by its Organic Law and the SML itself. In view of its regulatory powers, the SVS issues a set of regulations to complement this legal framework. These comprise general rules in terms of authority determined by the law, circular letters that contain practical applications in the different areas, and official circular letters containing precise instructions issued to the supervised institutions. The SVS also has powers of approval (for example, of special companies) and of application of sanctions. The relationship between the SVS and the supervised entities, in answer to consultations and remarks, takes place by means of numbered, dated, and filed official letters. Finally, this legal framework is completed with the internal regulations issued by the entities under the supervision of the SVS, as the supervised institutions have the authority and the obligation to so issue and enforce their internal regulations. The SVS approves these internal regulations.

Colombia

Law 964 of 2005 assigns regulatory powers to the national government in relation to securities markets and eliminates the general responsibility of the Superintendencia de Valores (SV). The SV has been merged with the banking superintendency to create the Superintendencia Financiera de Colombia (SFC) by Decree 4327 of November 2005. Resolution 400 of 1995 determines that the clearing of stock exchange operations must be done on a daily basis on settlement day. In this sense, stock exchange regulations must indicate the mechanisms and procedures through which operations are to be settled, and the measures to be adopted in cases of participant failure. To this end, the securities traded must be put at the disposition of the stock exchanges by the broker-dealers. Thus, broker-dealers can proceed to carry out the necessary procedures to transfer ownership. Resolution 1200 of 1995 establishes the definition of certificate and its proof, the type of information it must include, its uses, its mandatory expedition, and the obligation of information of the issuer toward the CSD. Circular 13 of 1994 of the SV states that the issuers must record registered securities in the register book on the same day that they receive the information from the stock exchanges or the CSDs. The following regulations are applicable to CSDs: Law 964 of 2005, Articles 9 to 14; Law 27 of 1990, Articles 13 to 29 (Items 1 and 2 of Article 26 have been derogated by Law 964); Decree 437 of 1992; Decree 1936 of 1995; and Resolution 1200 of 1995 approved by the superintendent of securities, Articles 3.9.1.1. to 3.9.2.9. Regulations applicable to stock 


\section{Table 5.4 Legal Issues in SSSs (Continued)}

\begin{tabular}{|c|c|}
\hline Country & Legal Issues \\
\hline $\begin{array}{l}\text { Colombia } \\
\text { (Continued) }\end{array}$ & $\begin{array}{l}\text { exchanges and brokers are Law } 45 \text { of 1990, Law } 27 \text { of 1990, Law } 35 \text { of 1993, and Law } 510 \text { of 1999; Decree } 2969 \\
\text { of 1960, Decree } 1172 \text { of 1980, Decree } 2739 \text { of 1991, Decree } 2016 \text { of } 1992 \text { (mainly); and part of Resolutions } 400 \\
\text { and } 1200 \text { of 1995. In November 1992, the Sociedad Administradora del DECEVAL was established, and its } \\
\text { operation approved by Resolution } 702 \text { of } 1993 \text { of the SV. Based on Decree } 436 \text { of 1990, Law } 27 \text { of 1990, } \\
\text { Articles } 13 \text { to 29; Law } 31 \text { of 1992, Article 21; Decree } 437 \text { of 1992; and Decree } 2520 \text { of 1991, Article 22, the BR } \\
\text { established, in June 1992, an automated system named DCV, to provide custody services to the financial } \\
\text { system and its intermediaries, and facilitate the ownership transfer of dematerialized public securities. The } \\
\text { SV approved DCV rules by means of Resolution } 235 \text { of April 23, 1992. There is no specific legal framework for }\end{array}$ \\
\hline
\end{tabular}
clearance and settlement of derivatives.

The Colombian Civil Code, from Articles 1687 to 1710 , rules the legal figure of novation; it is defined as the substitution of an old obligation by a new one, thus extinguishing the old one.

Costa Rica

The SML, Law 7732 of 1998, is the framework rule in force for the securities market. It regulates the persons or firms that participate either directly or indirectly in the securities markets; the actions, contracts, and securities related to these markets; and the securities regulator (Superintendencia General de Valores, SUGEVAL). Article 4 the SML establishes that the central government, and all other public sector institutions, will have to consult SUGEVAL before issuing any act of general application related to the securities market. Regarding the secondary markets, the law establishes that these will be organized by the stock exchanges, which must be authorized by SUGEVAL, and that only the securities issuances registered in the securities and intermediaries national registry may be traded or publicly offered in these markets. The buying, selling, and repos of publicly offered securities must be executed through the members of the stock exchanges, which must be the property of the brokers-dealers participating in them. Title VII deals with the clearance, settlement, and custody of the securities. Article 115 states that the securities issuances registered in the securities and intermediaries national registry may be represented by means of electronic book entries or with paper certificates, the first of which is irreversible. Chapter 1 of the same title establishes a special regime for the dematerialized issues, regulating aspects such as the entities that may perform the functions of a CSD, investors' rights, securities transfers, and the creation of liens on this kind of securities. The legal background of the securities clearance and settlement system is found in Articles 126-133 of the SML. The system will be integrated by the stock exchanges and by clearance and settlement firms. All transactions executed in the organized markets must be settled through this system. The system will provide for the generalization of the electronic book-entry system, following the principles of universality, DvP, guarantee of delivery, and financial neutrality. The system will also have to establish mechanisms to ensure that payment will be made in those cases in which participants lack the necessary funds, through the use of the collateral systems to be established by SUGEVAL.

The law explicitly supports immobilization and dematerialization. For securities in dematerialized form, a special regime is in force (Articles 115-125 of the SML) that regulates the issuing of these securities, the entities that are allowed to act as central depository, the responsibilities of the members or associates in the central depository, the right of the investors, the transfer of security and finality thereof, and the constitution of any kind of lien on this kind of securities. For dematerialized securities, a pledge is realized by registration in the corresponding account; the registry of property pledge on the corresponding account is equivalent to the transference of possession of the title (Article 123) and therefore can be executed in a bankruptcy case without the need of a court order.

Dominican Republic

The SML (Ley del Mercado de Valores, No. 19-2000) is the legal framework in force for the securities market. This law regulates the public offering of securities either in domestic or foreign currency; issuers; stocks and commodities exchanges; participating financial institutions; and any other individuals or firms, national or foreign, that are participating in the market. The regulation implementing the SML was approved through an executive power decree in March 2002. It regulates the basic aspects involved in the development of securities markets activities. Novation is regulated by Article 1271 of the civil code. In August 2002, a law on electronic trade, documents, and digital signatures was approved.

The SML was approved in 1998. According to the SML, the Securities National Council (Consejo Nacional de Valores, CNV) establishes the general policy of the securities market and approves its regulation. The executor of this general policy is the superintendency of companies (superintendencia de compañías). Stock exchanges are defined as not-for-profit organizations (corporaciones civiles) and are SROs whose regulations must be approved by the superintendency of companies. Securities depository regulation has been issued by the CNV, as the depositories are not considered SROs. Their operating rules have to be approved by the superintendency of companies. 
Table 5.4 Legal Issues in SSSs (Continued)

\begin{tabular}{l|l} 
Country & \multicolumn{1}{c}{ Legal Issues } \\
$\begin{array}{l}\text { Ecuador } \\
\text { (Continued) }\end{array}$ & $\begin{array}{l}\text { Recently, a law on electronic transfers and electronic signatures was approved by the parliament (Law no. 67, } \\
\text { Ley de Comercio Electronico, Firmas y Mensajes de Datos, April 2002). It rules the data messages, electronic } \\
\text { signatures, and certification services, among other issues. Under this law, data messages have the same } \\
\text { validity as paper documents, and electronic signatures the same validity as written ones. Annexed messages } \\
\text { through a direct electronic link also have legal validity. }\end{array}$
\end{tabular}

El Salvador

The legal and regulatory framework that governs the nation's payment system is provided, in a limited way, through the Banking Law, the commercial code, and BCR regulations. The BCR has responsibility for maintaining the legal reserve requirements established by its board of directors on the daily balances of deposits of commercial banks. The BCR also has the authority to regulate the payment system and provide clearing and settlement services for payment transactions, with settlement taking place through the commercial banks' dedicated reserve accounts. The superintendent of the financial sector (superintendencia del sistema financiero) supervises banks and other financial institutions. Finally, the BCR is authorized to issue regulations regarding the payment system. In general, it would appear that the BCR leaves the proposal of new regulations largely to the commercial banks.

Guatemala

The SML (Ley del Mercado de Valores y Mercancías), was approved in June 1996. This law includes the legal basis for the immobilization and dematerialization of private securities. It also refers to public securities (see Article 52) but the commercial law indicates that these securities are ruled by their specific laws. Article 79 regulates the securities depositories. This law regulates a registry (Article 8 to 17) under the ministry of economy, but does not refer to a securities regulator. On the contrary, the stock exchanges are considered as SROs in all aspects of their activity (see Articles 18 and 24), including securities settlement. The stock exchanges are approved by the registry (see Article 23 of the SML). The regulations of the registry were approved in July 1997 by the government.

The relevant regulation for securities settlement developed by the stock exchange includes

- internal rules of the stock exchange, 2003;

- operations manual of the floor, 2001;

- operations manual of the securities depository, 2001; and

- broker-dealer rules, 2002.

The operations manual of the floor includes the details of securities clearance and settlement procedures (see Articles 47 to 63). The operations manual of the securities depository indicates that the caja de valores (securities depository) is created as a department of the stock exchange (see Article II.1). It obliges the broker-dealer to elaborate a trust contract (contrato de comisión) for custody services; the securities depository has to maintain the registry of the beneficial owner separate form the account of the broker-dealer (see Article V.2). Settlement of funds has to take place by means of cheques issued in the name of the stock exchange (see Article 1.2.2). Representation in book-entry notes is reversible, both in the custody system of the central bank and in the securities depository (see Article V.3.3 of the operational manual of the securities depository). The Brokers-Dealers Regulation includes the protection of custodian arrangements (see Articles 16 to 20) at the subcustodian level. The Civil Law (see Article 744) and the operations manual of the floor (see Article 20) include the definition of repo transactions. In both, a repo transaction is defined as the ownership transfer of securities by an agreed-on price with the commitment, after an agreed period, to transfer back the ownership of fungible securities. The repurchase operation takes place under a contractual arrangement between the counterparties.

Honduras

Regarding securities, an SML was approved in 2001 and its associated regulation is still under development. The SML (Title IV) regulates the establishment of a securities depository as a joint stock company, and provides legal support for a book-entry note system of securities ownership transfer. However, currently there is no securities depository operating in Honduras. In fact, custody services are provided primarily by the central bank and the stock exchanges. However, there could be a legal uncertainty because the Commercial Law (Title I, Articles 449 to 643) deals with securities issues, referring to them always as represented in physical form. The decrees approved for the issue of public securities include the basis for dematerialization; these decrees are hierarchically inferior to the Commercial Law. In any case, a depository function has not been developed. However, all public securities (Banco Central de Honduras certificates, certificados de absorción, treasury securities, and bonos del estado), which constitute the bulk of the market, are issued in dematerialized form. The regulations for the trading of government securities (Reglamento de Negociación de Valores Gubernamentales, 1997) establish the conditions for the auction of government securities in the primary market. 


\section{Table 5.4 Legal Issues in SSSs (Continued)}

\begin{tabular}{|c|c|}
\hline Country & Legal Issues \\
\hline Jamaica & $\begin{array}{l}\text { The Securities Act of } 1993 \text { (Amended in 2001) regulates the securities business, mutual funds, stock exchanges, } \\
\text { the compensation fund, the conduct of securities business, dealers accounts, and audits and CSDs. Under the } \\
\text { Securities Act and Unit Trust Act, the Financial Services Commission (FSC) is responsible for the supervision } \\
\text { of all brokers, securities companies, and their representatives. This supervision is directed from the securities } \\
\text { division of the commission. The FSC Act of } 2001 \text { regulates the constitution and functions of the FSC. Other } \\
\text { relevant legislation for the securities industry includes }\end{array}$ \\
\hline & $\begin{array}{l}\text { - the Companies Act of 2004; } \\
\text { - the Financial Institutions Act of } 1992 \text { (amended in } 1997 \text { and 2002); } \\
\text { - the Banking Act of } 1992 \text { (amended in } 1997 \text { and 2002); } \\
\text { " the Unit Trust Act of } 1970 \text { (amended in 2001); } \\
\text { - the Industrial and Provident Societies Act of } 1975 \text { (amended in 1997); and } \\
\text { - the Insurance Act of } 2001 .\end{array}$ \\
\hline
\end{tabular}

\section{Mexico}

The SML of 1975 (amended in 2001) regulates securities dealers, securities market intermediaries, stock exchanges, and CSDs. It also regulates public offerings of securities, the intermediation of these securities, the national securities registry, and the authorities and services related to this market. Intermediation in the securities market may be executed by brokerage houses, stock exchange specialists, other financial entities, and individuals. The ministry of finance and public credit (secretaría de hacienda y crédito público, SHCP) is empowered to interpret, for administrative purposes, the precepts of this law, and to provide through general rules everything necessary to apply it. The Comisión Nacional Bancaria y de Valores (CNBV) is empowered to supervise the securities market.

Banco de México Circular 2019/95 is the reference to formal regulations for the trading of financial operations known as derivatives. This circular regulates the operations of credit institutions. As a result of the June 2001 reform of the SML, brokerage houses and stock exchange specialists also can trade derivatives, subject to regulations issued jointly by the Banco de México and CNBV. This circular contains rules regarding the authorization requirements for derivatives trading. The rules establish that authorized credit institutions may trade derivatives with any counterparty, subject to the existence of a written contract, as long as they inform Banco de México about the transaction. Trades may be executed either in OTC markets or on recognized exchanges. MEXDER, established in 1998, is one of the recognized markets for derivatives.

The federal civil code contains the legal underpinning for netting arrangements. In order for netting to take place, debts must be equal in both liquidity and maturity. Operations different from these may be netted only if the parties explicitly agree. Netting, once legally executed, produces its full effects and extinguishes all related obligations. The legal dispositions regarding novation are also contained in the federal civil code. A contract is novated when the interested parties significantly modify it by substituting a new obligation for an old one.

The commercial code contains a section on electronic commerce. Article 89 establishes that, for the purposes of the code, electronic and optic media and any other technology may be used in commercial activities. Also, Article 1298-A establishes that data messages are accepted as proof in a court of law. On July 5 , 2002, the Banco de México issued Circular 19/2002, known as the circular on extended infrastructure (infraestructura extendida). This circular allows the Banco de México to authorize commercial banks to issue digital certificates to their clients for operational purposes, and to register and process such certificates through the extended infrastructure. Starting on September 9, 2002, the Banco de México, as the infraestructura extendida Central Registration Agency (Agencia Registradora Central), may issue digital certificates to commercial banks, which allow them to act as registration or certification agencies of infraestructura extendida.

Netherlands Antilles
There is no designated legal framework for the securities market or for the settlement of securities transactions. Supervision on investment institutions was recently introduced when the national ordinance on the supervision of investment institutions and administrators became operational in January 2003. Some of the main elements on supervision of investment firms are that it focuses on conduct of business rules rather than on prudential concerns; the separation between the manager of an investment institution and the custodian; a license or dispensation is required to operate an investment institution; the manager and the custodian must meet fit and proper criteria; the custodian must be organized as a legal entity with own funds separated from the assets of the investment institution; and investment institutions shall meet the requirements of BvdNA with regard to integrity, financial safeguards, conduct of business, and disclosure. 
Table 5.4 Legal Issues in SSSs (Continued)

\begin{tabular}{|c|c|}
\hline Country & Legal Issues \\
\hline $\begin{array}{l}\text { Netherlands Antilles } \\
\text { (Continued) }\end{array}$ & $\begin{array}{l}\text { Regarding electronic means of payment, in September } 2000 \text {, the parliament enacted a law } \\
\text { conduct of contracts via electronic channels and the electronic signature. An electronic s } \\
\text { the same legal force as a written one, and there are no judicial hindrances to citing electro } \\
\text { or data in a court of law. }\end{array}$ \\
\hline \multirow[t]{3}{*}{ Nicaragua } & $\begin{array}{l}\text { There is no designated legal framework for the securities market or for the settlement of secu } \\
\text { The securities market has been working so far on the basis of the internal regulations of the B } \\
\text { and on contract law. }\end{array}$ \\
\hline & $\begin{array}{l}\text { A project for an SML is currently being discussed in congress. The draft contains many } \\
\text { elements for securities transactions to be cleared and settled on a safe and efficient fashi } \\
\text { recognition or definition of the following: }\end{array}$ \\
\hline & $\begin{array}{l}\text { - } \text { the standardization and fungibility of securities (Article 11); } \\
\text { - } \text { the definition of repurchase (repo) transactions (Article 58); } \\
\text { - } \text { the dematerialization of securities (Article 137); } \\
\text { - CSDs (Article 139); } \\
\text { - } \text { the segregation of accounts (Article 146); } \\
\text { " the beneficial ownership being transferred through book entries (Article 150,151); and } \\
\text { - } \text { the protection of investors in case of bankruptcy of the custodian (Article 168). }\end{array}$ \\
\hline
\end{tabular}

OECS

A regulatory framework for the trade and settlement of securities was implemented in 2001. This new law provides for the establishment of a securities commission, as the supervisor of activities of securities markets, and of the providers of services for the clearing and settlement of securities transactions. The Securities Act provides for the protection of investors by regulating the securities market, exchanges, and persons engaged in securities business, and by regulating the public issue of securities and to provide for related matters. Part III (Sections 22-45) deals with clearing agencies, that is companies whose business is the provision of services or the clearing and settlement of transactions in securities.

To carry out securities business, a license delivered by the securities commission is needed; capital adequacy is evaluated before a license is given. The securities commission can also suspend or revoke licenses, but this would not affect any agreement, transaction, or arrangement related to dealing in securities, nor any right, obligation, or liability stemming from such agreements, transactions, and arrangements. Licensees shall comply with the rules of conduct listed in the act and with those contained in the regulations issued for this purpose by the minister of finance. Moreover, the Securities Act regulates the establishment and management of securities markets. Members of securities markets are subject to the disciplinary powers of both the ECSE and the commission. There is no specific legal framework regarding the acceptability of electronic signatures for transfer instructions from banks and other account holders.

The SML, Decree-Law 1, 1999, provides the framework for securities market regulation, including oversight of the agents who participate in the market and their activities. Under the SML, the securities regulator is the CNV de Panama. The main agents are the broker-dealers, investment societies, and SROs (BVP, the CSD, and LATINCLEAR).

Article 82 of the Decree Law 1, 1999 (SML) establishes that only securities issuances registered at the CNV can be traded, except the case of public securities, which are exempt from the register requirement. Title IV of SML deals with SROs, which are the stock exchange (BVP) and the securities depository (LATINCLEAR). A more detailed regulation on this subject is developed in Acuerdo 7, 2003, of the CNV. SROs are authorized to issue internal regulations following the principles stated in Title IV of the SML and in Acuerdo 7, including: ensuring fair and open access, promoting cooperation among participants, exercising surveillance on participant behavior, reprimanding and imposing fines on participants, and even excluding them from the organization.

Concerning securities custody, clearing, and settlement, the basic principles of regulation are contained in Title XI of the SML, which are developed in more detailed in Acuerdo 9, 2003, of the CNV. The main principles are: the internal regulations of SROs providing for certainty and finality of transactions; segregation of customers' securities; settlement on a DvP basis; securities lending; guarantee mechanisms; timely confirmation and settlement of transactions; dematerialization and fungibility of securities; and book-entry transfer of ownership and pledging. The law is clear in protecting securities pledged against any third-party claim, even in case of insolvency, and therefore can be executed in a bankruptcy case without the need of a court order. The law also states that assets under custody of broker-dealers and investment societies are not part of the insolvency procedures (no-masa). Multilateral netting is authorized for transactions executed through the stock exchange. 


\section{Table 5.4 Legal Issues in SSSs (Continued)}

Country Legal Issues

\section{Paraguay}

The SML (Ley 1284/98 de Mercado de Valores) as well as the laws authorizing government securities issuances allow for the dematerialization of securities, but do not provide the legal basis for the ownership transfer. Thus, the ownership transfer is still based on the civil code articles. Article 1517 indicates that the ownership transfer of bearer securities is executed by means of the certificate delivery. The ownership transfer of order securities is executed by means of endorsement written in the certificate (see Article 1522), and registered securities ownership transfer is executed by means of endorsement written in the certificate and in the issuers' registry when it exists (see Article 1540). Article 8 of the SML allows for the issuance of securities in dematerialized form. The regulation of the SML was only approved in March 2004. A draft of a securities depository law was produced soon after the SML was approved, but has not been passed by congress. The SML is applicable to public securities, but is conditioned on the government bonds issue laws.

Peru The Securities Law ruled by Act 16587 (Ley de Títulos-Valores, October 2000) empowers the BCRP to issue regulations regarding electronic clearing and settlement of cheques and securities. In June and July 2000, regulations for the legal recognition of electronic signatures and documents were issued. Law 27291 modifies the civil code to adapt its provisions to the use of electronic documents. Law 27269 regulates electronic signatures. In addition, Law 27309 incorporates information technology offenses in the criminal code (código pena).

The SML approved by Legislative Decree 861 in 1996 allows for the dematerialization of securities and provides the legal basis for the ownership transfer (see Title VIII). The Comisión Nacional Supervisora de Empresas y Valores (CONASEV) grants authorization to operate clearing and settlement institutions for the capital markets, and is responsible for their supervision. Novation is recognized by the civil code, Article 1277-1288, although it is only effective when the parts explicitly state their intention to novate. The SML establishes the regulatory framework for the securities market and addresses issues such as market transparency; primary and secondary markets; stock exchange functions and features; brokers; clearance and settlement; mutual fund managers; credit risk-rating agencies; asset securitization; protection of investors' assets; conflict resolution; and disciplinary actions. The SML also specifies that the institution in charge of supervising and controlling the fulfilment of its regulations be the CONASEV. Pursuant to the Organic Law of the National Commission for Companies and Securities Supervision, Decree Law 26126 (effective December 30, 1992), CONASEV is responsible for supervising the public unregistered securities operations, as well as all securities market participants. By virtue of its regulatory power, CONASEV established a number of regulations to complement the SML. Among the principal regulations are the following:

- regulation of stockbrokers;

- regulation of securities mutual funds and their managing firms;

- regulation of the public registrar of securities;

- regulation of mutual funds and of their administrators;

- regulation of primary public offering and sale of unregistered securities;

- regulation of important facts and confidential information to which securities issuers are subject;

- regulations on the asset securitization process;

- regulations on credit risk rating agencies;

- regulations on securities clearing and settlement institutions;

- internal regulation of the BVL; and

- regulation of the trading-floor of the BVL.

The national legal system includes a number of other acts that affect the securities market. The Business Company Act 26887, for example, governs the procedures that can be adopted by firms, including joint stock, which also require the authorization of CONASEV to operate, as in the case of securities depositories.

\section{Trinidad and Tobago}

In Trinidad and Tobago, the legal framework for the securities market is based on the following key pieces of legislation:

- the Central Bank Act, Chapter 79:02;

- the Treasury Bills Act, Chapter 71:40;

- the Unit Trust Corporation of Trinidad and Tobago Act, 1981, Chapter 83:03;

- the Financial Institutions Act, 1993;

- the Companies Act, 1995;

- the Securities Industry Act, 1995;

- the Securities Industry Bylaws, 1997; and

- the Companies Regulations, 1997. 
Table 5.4 Legal Issues in SSSs (Continued)

\section{Country \\ Trinidad and Tobago (Continued)}

Legal lssues

The Securities and Exchange Commission (SEC) also issues policy guidelines that set forth the basic policies of the SEC relating to securities regulation in Trinidad and Tobago, and the role of the SEC with respect thereto. Although the policy guidelines do not have the force of law and are not intended to have such effect, the SEC expects compliance with the guidelines unless compliance is waived.

The Trinidad and Tobago securities legislation is based on the Canadian securities legislation. The Securities Industry Act, 1995, and the accompanying regulations, the Securities Industry Bylaws of 1997, are the pieces of legislation governing the securities market. The Securities Industry Act, Section 6, vests the SEC with wideranging powers. The act requires all persons or corporations that issue securities to the public to be registered with the SEC as reporting issuers. Thus, all market actors (including brokers, traders, dealers, securities companies, and investment advisers), SROs, and reporting issuers must be registered with the SEC. The act also requires the registration of all securities distributed to the public. Under the provisions of the Securities Industry Act, 1995, the Trinidad and Tobago Stock Exchange is registered with the SEC as an SRO. The Securities Industry Act also provides for regulations to be issued by the minister of finance on the recommendations of the commission. Section 131 of the Securities Industry Act, 1995, empowers the minister of finance with the advice of the commission to make bylaws on several matters.

The Companies Act of 1995 contains provisions that regulate some aspects of securities business. The act addresses, among other things, shareholders' rights, the responsibilities of the registrar, the procedures for the corporate restructuring of public companies, and the disclosure obligations of public companies. The Treasury Bills Act empowers the minister of finance to borrow money by the issuance of treasury bills and to declare the conditions applicable to such borrowings. The act does not specifically mention clearance and settlement. The Treasury Notes Act authorized the minister of finance to borrow by the issuance of treasury notes, and made specific amendments to the Treasury Bills Act, notably to increase the ceiling for borrowing. The Unit Trust Corporation of Trinidad and Tobago Act regulates the activities of the Trinidad and Tobago Unit Trust Corporation, which was established by statute in 1981 although launched in November 1982. Apart from the mutual fund legislation, which governs the activities of the unit trust corporation, there is no legislation that specifically regulates collective investment schemes. The Financial Institutions Act regulates banks and nonbank financial institutions licensed under the Central Bank Act. However, the act does not contain special clauses that address the specific concerns of the collective investments industry. Futures and options are regulated under the Securities Industry Act, 1995.

\section{Uruguay}

The SML was approved on May 2, 1996. This law includes the legal basis for the immobilization and dematerialization of private securities (Articles 7-12). Article 45 regulates the approval by the BCU of the securities depositories. The stock exchanges are considered as SROs in all aspects of their activity (see Article 15), including securities settlement. The BCU is the entity in charge of securities market regulation and supervision (Article 20).

Other laws and regulation relevant for securities settlement developed include the following:

- Mutual Funds and Securitization Law No. 16.774 and No 17.202, 1996 and 1999;

- Trust Fund (Fideicomiso) Law No 17.703 and its Regulatory Decree No. 516/003, 2003; and

- SML Regulatory Decree No. 344/96 and 261/96, 1996.

Venezuela, R.B. de funds and securities of the government. The treasury can delegate this function to the central bank (Banco Central de Venezuela, BCV). Indeed, Article 48 of the BCV Law includes as a BCV function the custody of physical or dematerialized securities of any kind.

The SML (Ley del Mercado de Capitales, Official Gazette No. 36565), was approved on October 22, 1998. Article 1 of the SML excludes public debt securities from its application. This law includes the legal basis for the immobilization and dematerialization of private securities, which can be issued in physical or dematerialized form. Representation in book-entry notes is irreversible, whereas securities issued in physical form can be reversed by their owners' acceptance. The CNV is empowered to require that securities be represented in book-entry form in order to be accepted for trading; this is the case for securities traded in the stock exchange. A CSD Law (Ley de la Caja de Valores, CVV), approved in August 1996, includes the legal basis for custodian arrangements when the securities are deposited in the CVV. Protection for custodian arrangements in respect to broker-dealers is included in the SML (Article 80). According to Article 21 of the CSD Law, in this system a depositor must open an account for its own holdings and a subaccount on behalf of each of its 


\section{Table 5.4 Legal Issues in SSSs (Continued)}

\begin{tabular}{l|l} 
Country & \multicolumn{1}{c}{ Legal Issues } \\
$\begin{array}{l}\text { Venezuela, R.B. de } \\
\text { (Continued) }\end{array}$ & $\begin{array}{l}\text { clients, directly in the CVV. The CVV Law (Article 22) states that the ownership transfer takes place by means } \\
\text { of the registry of securities in the name of the depositor or the beneficial owner in its account or subaccount } \\
\text { respectively. The CVV rules (Normas Relativas a la Organización y Funcionamiento de las Cajas de Valores) } \\
\text { were approved by the CNV in October 1996. } \\
\text { As mentioned before, Article } 24 \text { of the SML provides the legal basis for representation of securities in book- } \\
\text { entry form, but the article does not apply to public debt securities. For securities issued by the BCV, Article } 57 \\
\text { of the BCV establishes that the central bank can issue and trade securities according to the regulation } \\
\text { approved for each issuance. For public debt securities, specific regulations for each issuance include the } \\
\text { dematerialization as a characteristic but a specific legal definition of immobilization and dematerialization } \\
\text { does not exist. } \\
\text { The Banking Law (Article 46) and the SML (Article 79) include the definition of repo transactions. In both, a repo } \\
\text { transaction is defined as the ownership transfer of securities by an agreed-on price with the commitment, after } \\
\text { an agreed-on period, to transfer back the ownership of fungible securities. The repurchase operation takes } \\
\text { place under a contractual arrangement between the counterparties. In case the underlying securities of repo } \\
\text { transactions are constituted by shares, the ownership transfer must occur at the issuer's registry. }\end{array}$ \\
\hline
\end{tabular}

Source: Authors' elaboration.

\section{Observations}

Some of the specific problems identified in the legal and regulatory framework follow:

- Although Securities Markets Laws (SMLs) normally include the legal basis for immobilization and dematerialization, in a few cases SMLs only apply to private securities. In addition, the legal framework for public debt securities has not evolved in a similar way, and the legal definition for dematerialization and immobilization for these types of securities is not included in the legal framework.

- A sound legal basis requires the legal definition of the depository function (and not only the custody function) that the central bank is undertaking for public debt securities in many cases. However, the depository function is normally defined in the SMLs for joint stock companies, whereas the central bank legal basis only covers the custody function. That is, central banks maintain the registry of the primary market, but have not developed the ownership transfer functionality for the secondary market, even when another depository does not exist. This is a clear impediment for the development of the secondary market, because settlement rests on the exchange of physical certificates, or on very insecure practices in the case of a dematerialized registry.

- There is a lack of laws that support finality of transactions linked to SSSs. Thus, there is a potential for counterparty risk in securities markets operations.
Finality must be integrated in the legal framework. This is an important issue in all existing net settlement systems, especially for systems that have longer settlement cycles. Without this legal basis, it is uncertain whether in case of a bankruptcy the transfer of securities to the counterparty or his custodian could take place, even if the counterparty has already paid for the securities. (In some systems there is a time lag between the settlement of the cash leg and the settlement of the securities leg.) Due to this uncertainty, an unwinding of the net settlement might be the only solution if the cash settlement process does not take place. If the cash settlement already took place, it might bring forward principal risk if the court did not grant the request to transfer the securities.

- Systems with more advanced legal frameworks still present a potential impact on settlement finality because of bankruptcy proceedings that may reverse fraudulent transactions up to certain days before the participant is declared failed. However, the impact in case of RTGS systems is likely to be negligible due to the gross nature of the system. Also, some problems of interpretation might arise because settlement finality is regulated in detail by regulations, which have a lower hierarchy than the bankruptcy law. Initiatives to engage the judicial system in this debate is worth pursuing to clarify the issue.

- Multilateral netting is not often recognized in the current legislations. Multilateral netting schemes are 
very common in securities settlement. It is important to protect netting schemes from potentially disruptive insolvency laws so that, even if a system participant fails during the day, a liquidator cannot unwind settlement occurring on a net basis later in the day (see, for instance, the "Finality Directive of the European Commission").

- In general, protection of customer's assets under custodian arrangements is not clearly established. Therefore, assets pledged as collateral by clearing members are not covered adequately by the laws, thus compromising the capacity to execute collateral posted by the members' customers. Sometimes the protection of custody arrangements is only included for the depository and broker-dealers but not for other custodians, or vice versa. In addition, this legal limitation could bar potential settlement arrangements. ${ }^{1}$ In the case of government securities, it could constitute a factor limiting the development of the retail market, because beneficial owners are normally not identified in the accounts of the depository.

- Custodian arrangements for government securities (that in many cases are issued in physical form) do not have a secure legal support, because primary dealers keep the ownership in the registry of the ministry of finance or central bank. Thus, it is uncertain whether the certificate endorsements in subsequent repo operations can be considered as a proof of ownership in a court of law. In some cases, participants agree that the transferred certificate will be kept but not used to transfer ownership in the ministry of finance or central bank registry.

- Definitions of repo normally only cover a sell-andbuy-back transaction. However, the scope of a repo is much wider, internationally. Repos are especially used to collateralize cash or securities loans. If during the collateralization period, due to market developments, the collateral offered does not fully cover the obligation to pay back the loan or no longer covers the full value of the securities borrowed, additional collateral can normally be requested by means of a

${ }^{1}$ For example, markets with a high volume of transactions sometimes do not maintain subaccounts with the beneficial owner information, but only with accounts at the participant level with the aim of simplifying the operation of the settlement system. Of course, such settlement systems should be accompanied by strong legal protection of custody arrangements and by a supervisory framework. margin call. The present definition seems to leave no room for this market practice, and makes it difficult to use international standard contracts. Margin calls during the contract period might also give rise to legal risk if the court recharacterizes a repo agreement with interim margin calls as an improper pledge. It might be worth studying if there should be an explicit distinction between a repo in the form of a collateralized cash or securities loan, and an explicit sell-and-buyback transaction.

- Laws are clear in terms of the segregation of accounts regarding the securities depository, but this is not the case in terms of the custody of securities or funds by the custodians (for example, banks and brokerdealers), although normally segregation is done in practice. In custodian arrangements are not adequately covered in the legal framework, it is unclear whether the customer assets will be protected against the insolvency of custodians. This issue is relevant in circumstances when the bulk of the market is represented by government securities (a common situation in LAC countries) that are issued in physical form and held by custodians.

- Legal basis for securities lending does not exist in many cases, nor have detailed regulations been developed. In any case, for many markets, the low volume of market trading makes it difficult to develop that legal basis in any kind of practical way. However, the current situation could constitute a good opportunity to consider the development of the legal and regulatory framework to be prepared for an eventual recovery of market volumes.

- The fragmentation of regulations of wide legal rank and hierarchy relating to securities and capital markets is common in the region. The current situation implies an uncertain and confused legal framework that could increase the legal risk of the securities transactions, and that, at the end, could influence both the functioning of the markets and the activities of the markets' participants. A unified payments system law that systematizes all existing provisions in the field might help to resolve the any conflicts of interpretation on issues such as finality and oversight.

- Legal frameworks in many countries do not contain explicit conflicts of law rules. This could hamper the development of interregional financial markets and international cooperation in the areas of trading, custody, and clearing and settlement. 
- Lack of the legal framework enforceability hampers the development of the SSS. Many countries have introduced an adequate legal and regulatory framework for the processing of electronic operations, but the poor enforcement of legal and regulatory framework prevents further development of financial markets.

- In sum, updated laws and regulations on SSSs are necessary to focus on the development and improvement of specific aspects, such as the irrevocability of final settlement, adequate protection of the systems against the effects of bankruptcy proceedings, the improvement of the legal basis for custody arrangements, the legal definition of a repo operation, the legal recognition of multilateral netting arrangements, the legal definition of immobilization and dematerialization of securities, especially for public securities. Other legal issues could be considered from a developmental point of view, and imply a lower degree of urgency, although they can become increasingly important with the development of the securities markets in the region. They include the legal basis for the collateral pledge and securities lending. Due to the variety and extreme importance of these legal aspects, the great benefits of a unified payments and securities settlement law should be carefully assessed.

\section{CLEARING AND SETTLEMENT PROCESSES}

This section includes context, status in the region, and observations regarding clearing and settlement processes.

\section{Context}

The clearance and settlement process includes capturing trade information, trade matching, confirming and affirming institutional investor's trades, clearing, and settlement. Various international organizations have attempted to set standards for the prompt, efficient, and effective trade processing, including its cost effectiveness (in terms of system operation and fees paid by participants) and ease and convenience of use. One of the most widely recognized concepts is that the longer it takes to settle a securities trade, the greater is the risk that settlement will not take place. In this regard, the Committee on Payment and Settlement Systems (CPSS)International Organization of Securities Commissions (IOSCO) "Recommendations for Securities Settlement" recommends that trade settlement should occur by $\mathrm{T}+3$ or less. However, $\mathrm{T}+3$ often is no longer regarded as best practice. Clearly, the shortest possible elapsed time between trade date and settlement date is a desirable goal in system design. Nevertheless, the practical impact of shortening this time must be assessed, especially if it has an impact on the number of trades that fail to settle. ${ }^{2}$ Same-day settlement could be considered as the final goal, although it is generally recognized that this may not be achievable in the short or medium term, particularly for cross-border transactions. The magnitude of the changes required to achieve a particular standard must also be carefully considered. For example, whereas it might be relatively easy to move from $\mathrm{T}+5$ to $\mathrm{T}+3$ by simply imposing more discipline on all system participants, more fundamental changes (process reengineering) in all aspects of the system are likely to be necessary to move to $\mathrm{T}+2$ or $\mathrm{T}+1$. Regardless of the settlement cycle, the frequency and duration of settlement failures should be monitored closely.

The profile of market investors (retail compared to wholesale, and the amount of foreign investment) as well as the profiles of their intermediaries should be taken into account, because this can influence the practicality of the targeted clearing and settlement cycle. Appropriate trade-off between risk, cost, and convenience must be made, or else the system will not satisfy user requirements at an affordable and acceptable cost, and thus might constrain market development.

Another widely recognized concept is that trade matching should occur as soon after the trade as possible, so those errors and discrepancies can be discovered early in the settlement process. The CPSS-IOSCO recommended that trade comparison should be accomplished by $\mathrm{T}+0$, and in any case no later than $\mathrm{T}+1$. In addition, indirect market participants - institutional investors and custodians - should be members of a trade comparison system that achieves positive affirmation of trade details. Moreover, there should also be an integration system for trade matching, comparison, and book-entry settlement

\footnotetext{
${ }^{2}$ Currently, there is a debate about the adequacy of moving the settlement cycle to $T+2$. However, given the globalization process in financial markets, there is an increasing necessity to standardize this process at an international level, even if this would imply that some countries should increase their settlement cycle.
} 
of securities and funds. An automated link between the exchange (OTC) and the CSD is generally considered to be desirable, and is a prerequisite for broker-dealer STP from execution to settlement. Likewise, when clearing and depository services are provided by different entities, it is recommended that these two functions are closely tied; otherwise, finality of settlement is difficult to achieve. Fortunately, the cost of implementing automated systems is decreasing; care should be taken, however, to ensure that sufficient transaction volume exists, and that users are willing to pay for the automated services based on tangible benefits in terms of efficiency or risk reduction.

Mature and liquid securities lending markets (including markets for repurchase agreements and other economically equivalent transactions) generally improve the functioning of securities markets by allowing sellers ready access to securities needed to settle transactions where those securities are not held in inventory, by offering an efficient means of financing securities portfolios, and by supporting participants' trading strategies. The existence of liquid markets for securities lending reduces the risks of failed settlements because market participants (with an obligation to deliver securities that they have failed to receive and do not hold in inventory) can borrow these securities and complete delivery. Securities lending markets also enable market participants to cover transactions that have already failed, thereby curing the failure sooner. Intraday finality is crucial for these operations. In cross-border transactions, particularly back-to-back transactions, it is often more efficient and cost effective for a market participant to borrow a security for the delivery rather than to deal with the risk and costs associated with a settlement failure.

Because of increased automation and globalization of securities markets, it is beneficial from an interconnectivity perspective for domestic systems to use internationally recognized securities identification numbering standards. With this in mind, the Group of Thirty recommended that all markets should adopt a numbering system that meets the ISIN standards. The CPSS-IOSCO document insisted again on this point through its Recommendation 16.

\section{Status in the Region}

Table 5.5 includes a brief description of the securities settlement processes in each of the countries assessed.

\section{Observations}

Some of the specific problems identified in the clearing and settlement processes follow:

- In some cases, confirmation of trades between securities markets and SSSs or securities depositories takes place later than $\mathrm{T}+0$. There is also an important degree of manual handling in the confirmation process.

- Some systems have close links between trading and settlement, such as blocking of transactions before they are matched. Although this procedure ensures the availability of securities, it also influences the possibilities to do back-to-back transactions and forms a barrier for effective arbitrage between different trading and settlement platforms. To be able to arbitrate, an investor might be willing to sell securities in one system that were bought in another system during the same day. However, the investor cannot do that, because securities have to be blocked in advance. This blockage also makes the rollover of repos very difficult. Risk management tools that are more orthodox should be used to avoid the rigidity introduced by this mechanism.

- In addition, as long as there are no robust risk management procedures implemented, cash settlement on a multilateral net basis should be done separately for each trading system, to minimize systemic risk even if it implies higher costs because of higher liquidity needs of broker-dealers.

- A standardized settlement cycle must be clearly fixed and identified for all the trades executed in the securities markets. This is particularly relevant in the stock exchanges, where a $\mathrm{T}+3$ settlement cycle could be implemented. Shorter settlement cycles for securities traded in the stock exchanges should be taken into consideration, especially those related to bilateral trades between market participants.

- Some stock exchanges play a crucial role in money markets and have difficulties to accommodate different settlement needs. Should these stock exchanges evolve in the future to a more traditional role of secondary market transactions, the introduction of standardized settlement cycles would be needed. This is required because the settlement cycles needed for money markets are much shorter than the settlement cycles required for regular securities trading. If no changes are included, it would be difficult for these stock exchanges to play a role beyond money markets. 
Table 5.5 Clearance and Settlement Processes

\begin{tabular}{|c|c|c|c|c|c|}
\hline Country & SSS & $\begin{array}{c}\text { Trade } \\
\text { Confirmation }\end{array}$ & $\begin{array}{l}\text { Settlement } \\
\text { Cycles }\end{array}$ & $\begin{array}{l}\text { Securities } \\
\text { Lending }\end{array}$ & $\begin{array}{l}\text { International } \\
\text { Numbering }\end{array}$ \\
\hline \multirow[t]{3}{*}{ Argentina } & Merval & $\mathrm{T}+1$ & $\begin{array}{l}T+3 \text { (extension to } \\
T+4)\end{array}$ & Yes & No \\
\hline & Argenclear & $T+1$ & $T+3$ & No & No \\
\hline & CRYL & $\mathrm{T}+1$ & $\begin{array}{l}T+3 \text { (extension to } \\
T+4 \text { ) }\end{array}$ & No & No \\
\hline Bahamas, The & Securities firms & $\begin{array}{l}\text { No standardized } \\
\text { settlement cycle }\end{array}$ & $\begin{array}{l}\text { No standardized } \\
\text { settlement cycle }\end{array}$ & No & No \\
\hline Bolivia & $\begin{array}{l}\text { Stock exchange / } \\
\text { EDV }\end{array}$ & $\mathrm{T}$ & $\mathrm{T}$ & No & No \\
\hline \multirow[t]{4}{*}{ Brazil } & CBLC & Lock in & $\begin{array}{l}T+3 \\
T+0 \text { (fixed-income } \\
\text { securities) } \\
T+1 \text { (fixed-income } \\
\text { securities) }\end{array}$ & $\begin{array}{l}\text { Yes (since } 1997 \text { for } \\
\text { equities) }\end{array}$ & Yes \\
\hline & SELIC & Lock in & $\begin{array}{l}T+0 \\
T+1\end{array}$ & No & Yes \\
\hline & $\mathrm{BM} \& \mathrm{~F}$ & Lock in & $\begin{array}{l}T+1 \text { (derivatives) } \\
T+1 \text { (government } \\
\text { securities). It can also } \\
\text { be } T+n, n \text { varying } \\
\text { from } 0 \text { to } 23\end{array}$ & - & Yes \\
\hline & CETIP & Lock in & $\mathrm{T}+1$ & No & Yes \\
\hline Chile & $\begin{array}{l}\text { Stock exchanges / } \\
\text { OTC / DCV }\end{array}$ & $\mathrm{T}$ & $\begin{array}{l}\mathrm{T} \text { (money markets) } \\
\mathrm{T}+1 \text { (fixed income) } \\
\mathrm{T}+2 \text { (equities) }\end{array}$ & No & No \\
\hline \multirow[t]{2}{*}{ Colombia } & $\begin{array}{l}\text { Stock exchange / } \\
\text { Clearinghouse / } \\
\text { DECEVAL / DCV }\end{array}$ & $\mathrm{T}$ & $\begin{array}{l}T+3 \text { (extension to } \\
T+6)\end{array}$ & No & $\begin{array}{l}\text { No (only issues } \\
\text { allocated in } \\
\text { foreign markets) }\end{array}$ \\
\hline & SEN / DCV & Real time & Real time & $\begin{array}{l}\text { No (in } \\
\text { implementation) }\end{array}$ & No \\
\hline Costa Rica & $\begin{array}{l}\text { Stock exchange / } \\
\text { CEVAL }\end{array}$ & $\begin{array}{l}\text { Lock in (securities } \\
\text { blocked before } \\
\text { matching) }\end{array}$ & $\begin{array}{l}T \text { (Mercado de } \\
\text { Liquidez) } \\
T+1 \text { (TEBEL) } \\
T+1 \text { (SITE } \\
\text { international } \\
\text { securities) } \\
T+2 \text { (primary } \\
\text { auction) } \\
T+3 \text { (SITE equities) } \\
\text { For all the systems, } \\
\text { only one multilateral } \\
\text { net debit position is } \\
\text { calculated every } \\
\text { day for the cash } \\
\text { settlement. }\end{array}$ & No & $\begin{array}{l}\text { A standardiza- } \\
\text { tion process is } \\
\text { under way for } \\
\text { both private and } \\
\text { public securities } \\
\text { and all issues in } \\
\text { CEVAL have } \\
\text { been assigned } \\
\text { the ISIN. }\end{array}$ \\
\hline
\end{tabular}


Table 5.5 Clearance and Settlement Processes (Continued)

\begin{tabular}{|c|c|c|c|c|c|}
\hline Country & SSS & $\begin{array}{c}\text { Trade } \\
\text { Confirmation }\end{array}$ & $\begin{array}{l}\text { Settlement } \\
\text { Cycles }\end{array}$ & $\begin{array}{l}\text { Securities } \\
\text { Lending }\end{array}$ & $\begin{array}{l}\text { International } \\
\text { Numbering }\end{array}$ \\
\hline $\begin{array}{l}\text { Dominican } \\
\text { Republic }\end{array}$ & CEVALDOM & Not yet operational & Not yet operational & Not yet operational & $\begin{array}{l}\text { Not yet } \\
\text { operational }\end{array}$ \\
\hline Ecuador & $\begin{array}{l}\text { Stock exchanges / } \\
\text { DECEVALE }\end{array}$ & Lock in & $\begin{array}{l}\mathrm{T}+3 \text { (both Quito and } \\
\text { Guayaquil) }\end{array}$ & No & Yes \\
\hline El Salvador & $\begin{array}{l}\text { Stock exchange / } \\
\text { CEDEVAL }\end{array}$ & $\mathrm{T}$ & $\mathrm{T}$ & No & $\begin{array}{l}\text { No (CEDEVAL is } \\
\text { in the process of } \\
\text { becoming an ISIN } \\
\text { encoder.) }\end{array}$ \\
\hline Guatemala & Stock exchange & $\mathrm{T}$ & $\mathrm{T}$ & No & No \\
\hline Honduras & Stock exchanges & No confirmation & $\begin{array}{l}\text { No standardized } \\
\text { settlement cycle }\end{array}$ & No & No \\
\hline \multirow[t]{2}{*}{ Jamaica } & $\begin{array}{l}\text { Stock exchange } \\
\text { JSE / JCSD }\end{array}$ & $\mathrm{T}$ & $\begin{array}{l}T+5 \text { (although JSE } \\
\text { rules will allow for } \\
T+14 \text { ) }\end{array}$ & No & Yes \\
\hline & $\begin{array}{l}\text { OTC (government } \\
\text { securities) }\end{array}$ & $\mathrm{T}$ & $\mathrm{T}$ & No & No \\
\hline \multirow[t]{2}{*}{ Mexico } & $\begin{array}{l}\text { Stock exchange / } \\
\text { INDEVAL }\end{array}$ & Lock in & $\mathrm{T}+2$ & Yes (VALPRE) & Yes \\
\hline & OTC / INDEVAL & $\mathrm{T}$ & $\mathrm{T}, \mathrm{T}+1$ & Yes (VALPRE) & Yes \\
\hline $\begin{array}{l}\text { Netherland } \\
\text { Antilles }\end{array}$ & BvdNA & $\mathrm{T}+1$ & $\mathrm{~T}+1$ & No & No \\
\hline Nicaragua & $\begin{array}{l}\text { Stock exchange / } \\
\text { CENIVAL }\end{array}$ & $\mathrm{T}$ & $\begin{array}{l}\mathrm{T} \text { (market practice, } \\
\text { no official settlement } \\
\text { cycle) }\end{array}$ & No & No \\
\hline OECS & ECCSD & $\mathrm{T}$ & $\mathrm{T}+2$ & No & Yes \\
\hline Panama & $\begin{array}{l}\text { Stock exchange / } \\
\text { LATINCLEAR }\end{array}$ & $\mathrm{T}$ & $\mathrm{T}+3$ & No & No \\
\hline Paraguay & Broker-dealers & $\begin{array}{l}\text { No standardized } \\
\text { settlement cycle }\end{array}$ & $\begin{array}{l}\text { No standardized } \\
\text { settlement cycle }\end{array}$ & No & No \\
\hline \multirow[t]{3}{*}{ Peru } & $\begin{array}{l}\text { Stock exchange / } \\
\text { CAVALI }\end{array}$ & $\mathrm{T}$ & $\begin{array}{l}\mathrm{T} \text { (fixed income with } \\
\text { extension to } T+1 \text { ) }\end{array}$ & Yes & Yes \\
\hline & & & $\mathrm{T}+3$ (equities) & & \\
\hline & OTC / CAVALI & $\mathrm{T}$ & $\mathrm{T}+2$ & No & Yes (if registered) \\
\hline \multirow{3}{*}{$\begin{array}{l}\text { Trinidad and } \\
\text { Tobago }\end{array}$} & Stock exchange / & $\mathrm{T}$ & $\mathrm{T}+5$ & No & Yes \\
\hline & IILD & & $\begin{array}{l}T+1 \text { (for mutual } \\
\text { funds, though it can } \\
\text { be up to } T+10 \text { for } \\
\text { large amounts) }\end{array}$ & & \\
\hline & СВTT depository & Real time & Real time & No & No \\
\hline
\end{tabular}


Table 5.5 Clearance and Settlement Processes (Continued)

\begin{tabular}{|c|c|c|c|c|c|}
\hline Country & sSs & $\begin{array}{c}\text { Trade } \\
\text { Confirmation }\end{array}$ & $\begin{array}{l}\text { Settlement } \\
\text { Cycles }\end{array}$ & $\begin{array}{l}\text { Securities } \\
\text { Lending }\end{array}$ & $\begin{array}{l}\text { International } \\
\text { Numbering }\end{array}$ \\
\hline \multirow[t]{2}{*}{ Uruguay } & \multirow[t]{2}{*}{$\begin{array}{l}\text { Stock exchanges / } \\
\text { AGATA }\end{array}$} & $\begin{array}{l}\mathrm{T} \text { ( } 30 \text { minutes after } \\
\text { trading for BVM) }\end{array}$ & $\begin{array}{l}T+1 \text { (domestic } \\
\text { securities) }\end{array}$ & \multirow[t]{2}{*}{ No } & \multirow[t]{2}{*}{ No } \\
\hline & & Lock in (BEVSA) & $\begin{array}{l}\mathrm{T}+3 \text { (global notes } \\
\text { and bonds) }\end{array}$ & & \\
\hline \multirow[t]{2}{*}{$\begin{array}{l}\text { Venezuela, } \\
\text { R.B. de }\end{array}$} & $\begin{array}{l}\text { Stock exchange / } \\
\text { CVV }\end{array}$ & Lock in & $\begin{array}{l}T+3 \text { (extended to } \\
T+5)\end{array}$ & No & Yes \\
\hline & $\begin{array}{l}\text { SET / SIMA / } \\
\text { SICET / current } \\
\text { accounts at BCV }\end{array}$ & $T$ & $\begin{array}{l}T \text { (primary and sec- } \\
\text { ondary market) } \\
T+1 \text { (primary market) }\end{array}$ & No & No \\
\hline
\end{tabular}

Source: Authors' elaboration.

Note: CBTT (Central Bank of Trinidad and Tobago); CENIVAL (Central Nicaragüense de Valores); SELIC (Servico Especial de Liquidacao e Custodia); SET (Sistema Electrónico de Transferencia de Fondos para Préstamos Interbancarios); SIMA (Sistema Integrado de Mercado Abierto); SITE (Sistema de Transferencias Electrónicas); TEBEL (online trading system); VALPRE (Préstamo de Valores).

- Some SSSs allow for extensions of the standardized settlement cycle should a failure occur in the settlement process. It is essential to count on appropriate risk management tools to guarantee settlement in the case of failure on settlement date. Settlement procedures on a DvP basis would be highly contributive to avoid settlement extensions. Given a failure in the delivery of securities on settlement date (and counting on a guarantee regime and a settlement system on a DvP basis), SSSs could execute buy-in procedures in the securities markets to reduce the risk in the system. That is, in case of a settlement failure, allow the purchase of securities in the market at the seller's (who failed) cost.

- Sometimes the shortening of settlement cycles is not possible, due to the participation of foreign investors in the local markets and the need to provide instructions to custodians regarding the release of securities. The introduction of STP mechanisms could help to avoid longer settlement cycles in these cases. However, another factor is the lack of facilities to move the monies on $\mathrm{T}$, even locally, if there is no direct access to central bank settlement.

- As a result of complex procedures in some cases, settlement participants engage themselves in the manual handling of securities, incurring inefficiencies and risks that limit the development of the securities markets. Indeed, the bulk of the market is sometimes settled in-house to minimize risks.
- In the case of OTC transactions, it is difficult to know if transactions are confirmed on $\mathrm{T}+0$, and $\mathrm{T}+1$ for indirect participants. In most cases, these transactions are settled-bilaterally between the parties. When centralized settlement takes place, transactions are normally registered in the system as locked in, but there is no possibility to make sure that those transactions were confirmed in a specified period.

- Automatic securities lending and borrowing facilities are not the rule in markets throughout the region, mainly due to the low level of activity. Such mechanisms can provide the SSS with an effective risk management tool for the securities leg of market transactions. Prior to its establishment, securities lending must be recognized and encouraged by law. The finalization of the standardization process is essential for this mechanism to be effective. Barriers of any kind (for example, lack of standardization, legal barriers, tax barriers) should be removed. Securities lending could be implemented in one of two different ways:

- In a bilateral way between market participants. In this case, the CSD will act as a register of the stocks loans.

- In a multilateral or centralized way. This implies the creation of a pool of entities (mostly banking and financial institutions) capable of lending securities from their portfolios (either their own or clients' accounts) against an interest rate. The 
administration of the pool of potential available securities for lending operations and the allocation process normally has been delegated to the securities depository or to another entity that is suitable, acting on a policy of not taking risk. The efficiency of the several current ways to cope with securities shortages should be evaluated with regard to standardized forms of securities lending.

In addition,

- All securities lending operations must be collateralized and backed by private contracts, subject to international standards.

- Fiscal treatment of securities-lending contracts must be neutral and objective.

- If short-selling is permitted-for example, as a way to increase the liquidity of the markets - it should be linked to securities lending operations to cover the oversold positions. In any case, securities regulators must be alert against unhealthy market practices relating to short-selling that could lead to market manipulation.

- Some communication networks do not follow international standards. Although many local communication networks work correctly, in case of increasing volume of cross-border transactions the progressive implementation of international communication procedures should be taken into account. Securities depositories and investment firms with a relevant foreign business share should adopt, in the short term, international standardized communications procedures (that is, SWIFT or similar) to facilitate cross-border transactions both free or against payment. Local firms should adapt their communication procedures to the international communications networks using the same standards.

In sum, improved clearing and settlement processes in SSS are necessary to allow for confirmation of trades on the trade date, reduce market fragmentation, increase standardization of settlement cycles, accommodate different settlement needs, operate with shorter settlement cycles, avoid extension of settlement cycles due to inadequate risk management tools, improve markets' liquidity through automatic securities lending, and introduce international communication standards.

\section{SETTLEMENT RISKS}

This section includes context, status in the region and observations regarding settlement risks.

\section{Context}

The important issues of efficiency and flexibility have been touched on previously. The safety of the system is paramount from a participant and a regulatory perspective, and should be given specific attention. The settlement process exposes market participants and clearance and settlement systems to different risks. The system should be designed to minimize these risks. The immobilization or dematerialization of securities reduces or eliminates certain risks - for example, destruction or theft of certificates. The transfer of securities by book entry is a precondition for the shortening of the settlement cycle for securities trades reducing replacement cost risks.

The major settlement risk is counterparty risk (credit and principal risk). DvP is one of the primary means by which a market can reduce the risk inherent in securities transactions. The DvP concept seeks to eliminate principal risk from securities transactions by ensuring that sellers give up their securities if, and only if, they receive full payment, and vice versa. There are three essential elements in a DvP transaction: (1) good and irrevocable delivery of securities, (2) final and irrevocable funds, and (3) simultaneous exchange. The CPSS of the BIS has identified three different models of DvP (CPSS 1992). Although these models vary in their approach to achieving DvP, all three models meet the concept of real DvP.

The use of a CCP trades is becoming more and more a common practice. A CCP interposes itself between the counterparties to securities trading. A CCP is an especially effective tool for reducing risks with regard to active market participants, but use of a CCP concentrates risk, and reallocates risk among its participants through its policies and risk management procedures. The ability of the system as a whole to withstand the default of individual participants depends on the risk management procedures of the $\mathrm{CCP}$ and its access to resources to absorb financial losses.

There is a variety of risk management procedures to reduce market risk and strengthen a DvP mechanism. Those procedures include admission standards, members' creditworthiness monitoring, novation, participation funds, collateral, margins, buy-ins and sell-outs, net debit caps, bilateral credit limits, and loss-sharing arrangements. Most settlement systems use more than one procedure to minimize market risk. In addition, there are a 
number of mechanisms designed to improve the settlement process. Among them are central lending facilities, pledge recording facilities, and prompt reregistration procedures. Properly regulated securities lending and borrowing can bring significant benefits to a market and its users, leading to more liquid markets. Short-selling could be a useful mechanism to add liquidity. However, when short-selling is permitted, regulation must guard against manipulative practices, including those associated with a significant short position.

Systems that are considering whether to implement an RTGS or a netting scheme should carefully study market volume and participation to determine if these mechanisms are appropriate. Netting was introduced originally as an efficient measure to reduce the number of physical documents passing between market members. Later, with the introduction of early computer systems, it was used to reduce the number of electronic settlements. Today, with powerful high-speed computers and the introduction of RTGS systems, the efficiency advantages are less important. Thus, the debate is focused on the trade-off between liquidity requirements and risk mitigation, as discussed previously in this paper.

Settling in same-day funds is essential when operating in an RTGS environment and is useful in achieving real intraday DvP. ${ }^{3}$ To achieve timely and risk-free settlement in same-day funds, efficient banking arrangements will need to be developed that enable funds to be moved quickly and relatively inexpensively.

The finality of payments and securities' ownership transfer is a crucial factor in the development of a securities market. Otherwise, only local investors will operate in the market; their operation will be based on well-established client relationships and the confidence that this provides. In emerging markets, this factor is of critical importance if there is a desire to attract foreign investment. Foreign investors will be reluctant to participate in a market that they do not consider safe. Payments finality is equally important.

The failure of any bank that provides cash accounts to settle payment obligations for CSD members could disrupt settlement and result in significant losses and liquidity

${ }^{3}$ Payment is made in same-day funds when payment of such funds is made on an irrevocable basis to the counterparty on the day of settlement such that the funds are available for use on the day of settlement. pressures. Use of the central bank of issue as the single settlement bank may not, however, always be practicable. In such cases, a private bank sometimes is used as the single settlement bank, and steps must be taken to protect CSD members from potential losses and liquidity pressures that would arise from settlement banks failure.

\section{Status in the Region}

Table 5.6 includes a brief description of the status of immobilization and dematerialization of settlement systems in each of the countries assessed.

Table 5.7 includes a brief description of risk management mechanisms for settlement systems in each of the countries assessed.

\section{Observations}

Some of the specific problems regarding settlement risks follow:

- Additional efforts are necessary to achieve full dematerialization and immobilization of securities, as well as to achieve greater standardization. Central banks and the ministries of finance have made great efforts in the past years to achieve the complete dematerialization of government securities. Similar efforts have been undertaken by the private sector. Lack of securities standardization is an important obstacle, mainly in the case of public securities. In some markets the bulk of securities have been issued without ISIN numbering and in relative small amounts. Neither the redemption date nor the nominal value were standardized and they have a large variety of interest rate schemes, and so on. A large amount of these securities are not in the vaults of the brokers or the depository but are still in circulation. Trading and clearing and settlement of this kind of securities is extremely difficult, cumbersome, and costly. At the moment, there are attempts to standardize and immobilize the outstanding securities but this is a time-consuming task. After standardization this kind of securities will be also fungible and easier to register and to keep in a central depository. A modern securities market needs to have a securities depository and fungible securities. Therefore two actions are needed: (1) the amount of outstanding government debt in the form of nonstandardized and nonfungible securities should be 
Table 5.6 Immobilization and Dematerialization of Securities and Settlement Type

\begin{tabular}{|c|c|c|c|}
\hline Country & SSS & Immobilization and Dematerialization & DvP modela \\
\hline Argentina & $\begin{array}{l}\text { Merval } \\
\text { Argenclear } \\
\text { CRYL }\end{array}$ & $\begin{array}{l}\text { The vast majority of securities issued in Argentina are held } \\
\text { (immobilized or dematerialized) in the caja de valores or in } \\
\text { CRYL. The caja de valores was founded in } 1974 \text {. }\end{array}$ & $\begin{array}{l}\text { Model } 3 \\
\text { Model } 3 \\
\text { Model } 3\end{array}$ \\
\hline Bahamas, The & & $\begin{array}{l}\text { No depository exists, and securities are normally issued in } \\
\text { physical form. Some securities are issued in book-entry form } \\
\text { through the securities firms. }\end{array}$ & No DvP \\
\hline Bolivia & EDV & $\begin{array}{l}\text { All securities are issued in physical form. A dematerialization } \\
\text { and immobilization process started with the launch of the EDV. } \\
\text { Dematerialization of outstanding securities began in } 2004 \text {, but } \\
\text { they were still issued in both forms. Starting in the fourth } \\
\text { quarter of 2005, most securities have been issued in a } \\
\text { dematerialized form. It is expected that all securities will be } \\
\text { dematerialized by the second quarter of } 2006 \text {. }\end{array}$ & Model 2 \\
\hline \multirow[t]{4}{*}{ Brazil } & CBLC & $\begin{array}{l}\text { All securities in CBLC depository services are dematerialized } \\
\text { and registered, in book-entry form, in the name of beneficial } \\
\text { owners. More than } 50 \text { percent of equity securities are held in } \\
\text { custody by the CBLC. }\end{array}$ & Model 3 \\
\hline & SELIC & Government securities are immobilized and dematerialized. & Model 1 \\
\hline & $\mathrm{BM} \& \mathrm{~F}$ & All futures contracts are dematerialized. & - \\
\hline & CETIP & Some state-owned companies still issue certificated securities. & $\begin{array}{l}\text { Model } 1 \text { (the majority of } \\
\text { transactions) }\end{array}$ \\
\hline Chile & DCV & $\begin{array}{l}\text { All types of securities are currently issued in dematerialized } \\
\text { form. Some securities are represented by means of physical } \\
\text { certificates that can be immobilized at DCV. Immobilization is } \\
\text { not a necessary condition for trading securities, but in the case } \\
\text { of shares and in order to participate in the centralized settle- } \\
\text { ment, securities must be deposited in the DCV by } 6: 00 \text { p.m. of } \\
\text { the trading date. }\end{array}$ & $\begin{array}{l}\text { Model } 3 \text { (centralized } \\
\text { settlement) } \\
\text { Model } 2 \text { (bilateral settle- } \\
\text { ment through the stock } \\
\text { exchange) }\end{array}$ \\
\hline Colombia & $\begin{array}{l}\text { Stock exchange } \\
\text { clearinghouse / } \\
\text { DECEVAL / DCV }\end{array}$ & $\begin{array}{l}\text { Securities are represented in physical form, immobilized, or } \\
\text { dematerialized in the two existing depositories: DECEVAL and } \\
\text { DCV. Any security registered in the intermediaries and securities } \\
\text { national registry could be deposited for custody in DECEVAL. In } \\
\text { DECEVAL, physical securities are immobilized in a safety cave } \\
\text { and entire issues are backed by a physical macrocertificate. } \\
\text { DECEVAL basically immobilizes private securities, although it } \\
\text { also has in deposit some public securities (for example, bonos } \\
\text { provisionales). In addition, DECEVAL has an omnibus account in } \\
\text { DCV for securities registered in DCV. Thus, depositors of DECE- } \\
\text { VAL can maintain public securities at DECEVAL. Immobilization, } \\
\text { dematerialization, and transfers of securities in book-entry form } \\
\text { are not mandatory. More than } 99 \text { percent of public debt securi- } \\
\text { ties are dematerialized and all the secondary market transac- } \\
\text { tions take place in book-entry form either in DCV or DECEVAL. }\end{array}$ & $\begin{array}{l}\text { Mercado Electrónico de } \\
\text { Colombia transactions } \\
\text { can be settled on DvP } \\
\text { basis Model } 1 \text { through an } \\
\text { interface to the DCV- } \\
\text { Sistema Electrónico de } \\
\text { Cuentas de Depósito } \\
\text { (CUD) system, "free of } \\
\text { payment" or "free of } \\
\text { payment and securities } \\
\text { delivery." }\end{array}$ \\
\hline Costa Rica & $\begin{array}{l}\text { Stock exchange / } \\
\text { CEVAL }\end{array}$ & $\begin{array}{l}\text { At the moment, securities are represented by means of title (that } \\
\text { is, physical securities) or a global note that represent the whole } \\
\text { issue. All issues represented by means of a global note and part } \\
\text { of the existing physical securities are immobilized in the existing } \\
\text { depository, CEVAL. The government still issues debt in physical } \\
\text { form. Dematerialization and immobilization are irrevocable. }\end{array}$ & $\begin{array}{l}\text { Model } 2 \text { (although there } \\
\text { are one and one-half } \\
\text { hours difference between } \\
\text { the settlement of the cash } \\
\text { and securities leg) }\end{array}$ \\
\hline
\end{tabular}


Table 5.6 Immobilization and Dematerialization of Securities and Settlement Type (Continued)

\begin{tabular}{|c|c|c|c|}
\hline Country & SSS & Immobilization and Dematerialization & DvP modela \\
\hline $\begin{array}{l}\text { Dominican } \\
\text { Republic }\end{array}$ & Stock exchange & $\begin{array}{l}\text { Transactions traded in the OTC are registered through the } \\
\text { Sistema Integrado de Negociaciones Electrónicas (SINE) } \\
\text { by the only stock exchange in the country, the Bolsa de } \\
\text { Valores de la Republica Dominicana. The SINE could also } \\
\text { be used for electronic trading, but, because trade is still } \\
\text { very limited, it is still done over the telephone. Nearly } 75 \\
\text { percent of trades are transactions within the same broker- } \\
\text { dealers (operaciones cruzadas). A CSD has been recently } \\
\text { established, the CEVALDOM. }\end{array}$ & No DvP \\
\hline Ecuador & $\begin{array}{l}\text { Stock exchanges / } \\
\text { DECEVALE }\end{array}$ & $\begin{array}{l}\text { Although government securities are issued in an immobi- } \\
\text { lized form by means of a global note, once the primary } \\
\text { auction has been placed, individual physical certificates } \\
\text { are produced and delivered, if required by the investor. } \\
\text { The physical certificates can be kept in custody at the } \\
\text { central bank or withdrawn for trading, or maintained with } \\
\text { another custodian. Although the depository DECEVALE was } \\
\text { created in } 1994 \text { under the SML, it has only performed the } \\
\text { custody function of dematerialized securities issued } \\
\text { by the Corporación Financiera Nacional (less than } 1 \text { percent } \\
\text { of the securities market). In addition, private securities } \\
\text { are issued in physical form due to the lack of depository } \\
\text { function. Furthermore, they cannot even be kept immobi- } \\
\text { lized in DECEVALE, because it has not developed the immo- } \\
\text { bilization business and does not use vaults to provide } \\
\text { physical custody. }\end{array}$ & No DvP \\
\hline El Salvador & $\begin{array}{l}\text { Stock exchange / } \\
\text { CEDEVAL }\end{array}$ & $\begin{array}{l}\text { Currently, the BCR has physical custody of public securities } \\
\text { while they are immobilized in CEDEVAL. Because not all } \\
\text { securities are immobilized, sellers must deliver physical } \\
\text { securities to CEDEVAL } 24 \text { hours before the sale is made. }\end{array}$ & No DvP \\
\hline Guatemala & Stock Exchange & $\begin{array}{l}\text { In principle, all public securities are issued in physical } \\
\text { form, although if the investor decides to keep them under } \\
\text { the custody of the central bank, they are not issued in phys- } \\
\text { ical form but as book-entry notes at the central bank reg- } \\
\text { istry. Subsequent ownership transfers are done by means } \\
\text { of delivery (if bearer securities) or endorsement (if order } \\
\text { securities) or book-entry notes in the stock exchange's } \\
\text { securities depository, once previously deposited. For stock } \\
\text { exchange settlement, it is mandatory to have previously } \\
\text { deposited the securities at the securities depository of } \\
\text { either stock exchange. }\end{array}$ & No DvP \\
\hline Honduras & Stock exchanges & $\begin{array}{l}\text { Public securities are issued on a dematerialized form and can } \\
\text { be under the custody of the Banco Central de Honduras or the } \\
\text { stock exchange. }\end{array}$ & No DvP \\
\hline \multirow[t]{2}{*}{ Jamaica } & $\begin{array}{l}\text { Government } \\
\text { securities }\end{array}$ & All government securities are represented in physical form. & Model 2 \\
\hline & $\begin{array}{l}\text { Stock exchange / } \\
\text { JCSD }\end{array}$ & Equities are immobilized or dematerialized in the JCSD. & No DvP \\
\hline Mexico & INDEVAL & $\begin{array}{l}\text { All securities in the national securities registry (Registro } \\
\text { Nacional de Valores) are physically represented, generally by } \\
\text { global notes, and are immobilized in INDEVAL. }\end{array}$ & $\begin{array}{l}\text { Model } 3 \text { (stock exchange) } \\
\text { Model } 1 \text { (OTC) }\end{array}$ \\
\hline
\end{tabular}


Table 5.6 Immobilization and Dematerialization of Securities and Settlement Type (Continued)

\begin{tabular}{|c|c|c|c|}
\hline Country & SSS & Immobilization and Dematerialization & DvP model ${ }^{\mathrm{a}}$ \\
\hline $\begin{array}{l}\text { Netherlands } \\
\text { Antilles }\end{array}$ & BvdNA & $\begin{array}{l}\text { Almost all securities issued by the central and local government } \\
\text { (except one issue) and all of the CDs issued by the central } \\
\text { bank are dematerialized, and the ownership and other rights } \\
\text { are registered in the book-entry system of the BvdNA. }\end{array}$ & No DvP \\
\hline Nicaragua & $\begin{array}{l}\text { Stock exchange / } \\
\text { CENIVAL }\end{array}$ & $\begin{array}{l}\text { CENIVAL receives in deposit mainly government securities } \\
\text { (bonos de pago de indemnización) and bonds issued by the } \\
\text { Banco Central de Nicaragua. It also receives in deposit } \\
\text { securities issued by the private sector, but these are securities } \\
\text { with a much lower quantitative importance. }\end{array}$ & No DvP \\
\hline OECS & ECCSD & $\begin{array}{l}\text { All securities are dematerialized. Therefore, transfer of } \\
\text { ownership is done via book entry at the ECCSD. }\end{array}$ & Model 2 \\
\hline Panama & $\begin{array}{l}\text { Stock exchange / } \\
\text { LATINCLEAR }\end{array}$ & $\begin{array}{l}\text { Assets deposited in LATINCLEAR include treasury bonds, } \\
\text { treasury notes and bills, corporate stocks, preferred stocks, } \\
\text { and corporate bonds. All trades must be performed by the } \\
\text { broker-dealers members of the stock exchange, who are } \\
\text { obliged to actually have the securities in their accounts } \\
\text { before trading (no short-selling is allowed). }\end{array}$ & Model 2 \\
\hline Paraguay & Broker-dealers & $\begin{array}{l}\text { No depository exists; securities are issued in physical form. } \\
\text { Most trades are settled in-house with broker-dealers. }\end{array}$ & No DvP \\
\hline Peru & $\begin{array}{l}\text { Stock exchange / } \\
\text { CAVALI }\end{array}$ & $\begin{array}{l}\text { Almost all-97 percent-of debt instruments (corporate debt; } \\
\text { treasury bonds, bills, and notes) and } 47 \text { percent of all equities } \\
\text { (remaining portion on equities belongs mainly to controlling } \\
\text { interests of companies) are registered in a dematerialized } \\
\text { form at CAVALI. }\end{array}$ & Model 2 \\
\hline \multirow[t]{2}{*}{$\begin{array}{l}\text { Trinidad and } \\
\text { Tobago }\end{array}$} & TTCD & $\begin{array}{l}\text { Since TTCD started operating, the on-floor trading of the stock } \\
\text { exchange can only be done with securities previously immobi- } \\
\text { lized. Listed companies have to accept the immobilization of } \\
\text { their shares through the signing of an agreement form with the } \\
\text { TTCD. On signing the contract, securities are assigned an ISIN. }\end{array}$ & Model 3 (Stock Exchange) \\
\hline & TTCB depository & $\begin{array}{l}\text { Government securities, bills, and notes are issued in a } \\
\text { dematerialized form. }\end{array}$ & Model 1 \\
\hline Uruguay & $\begin{array}{l}\text { Stock exchanges / } \\
\text { AGATA }\end{array}$ & $\begin{array}{l}\text { Securities are issued in dematerialized (escriturales) or } \\
\text { physical form. }\end{array}$ & $\begin{array}{l}\text { Model } 3 \text { (BVM) } \\
\text { Model } 1 \text { (BEVSA) }\end{array}$ \\
\hline \multirow[t]{2}{*}{$\begin{array}{l}\text { Venezuela, } \\
\text { R.B. de }\end{array}$} & Central bank (SICET) & $\begin{array}{l}\text { Most government securities are dematerialized or immobi- } \\
\text { lized in the central bank. The custody and depository function } \\
\text { of public securities, except for Vebonos and export bonds, is } \\
\text { undertaken by SICET, a system developed and operated by } \\
\text { the BCV. }\end{array}$ & Model 1 \\
\hline & CVV & Shares and Vebonos are immobilized in the CVV. & No DvP \\
\hline
\end{tabular}

Source: Authors' elaboration.

a. This is not an attempt to determine if true DvP is achieved in the SSSs described, but rather a detail on how settlement takes place (gross-gross, gross-net, or net-net). 
Table 5.7 Risk Management Tools and Settlement Asset

\begin{tabular}{|c|c|c|c|c|}
\hline Country & SSS & Risk Management Tools & CCPs & $\begin{array}{l}\text { Cash Settlement } \\
\text { Asset }\end{array}$ \\
\hline \multirow[t]{3}{*}{ Argentina } & Merval & $\begin{array}{l}\text { Guarantee fund } \\
\text { Special guarantee fund } \\
\text { Buy-ins }\end{array}$ & $\begin{array}{l}\text { The Merval guarantees trades } \\
\text { settlement that take place in the } \\
\text { outcry system (floor) or in the } \\
\text { automatic trading system (Sis- } \\
\text { tema Integrado de Negociación } \\
\text { Asistida por Computador), but } \\
\text { only for those specifically des- } \\
\text { ignated within the continuous } \\
\text { session. }\end{array}$ & $\begin{array}{l}\text { Private settlement } \\
\text { bank }\end{array}$ \\
\hline & Argenclear & None (unwinding) & No & $\begin{array}{l}\text { Medio Electrónico } \\
\text { de Pagos (central } \\
\text { bank RTGS system) } \\
\text { or through } \\
\text { Argenclear's U.S. } \\
\text { dollar account at } \\
\text { Deutsche Bank, } \\
\text { New York }\end{array}$ \\
\hline & CRYL & None (unwinding) & No & $\begin{array}{l}\text { Medio Electrónico } \\
\text { de Pagos }\end{array}$ \\
\hline Bahamas, The & - & No & No & Cheques \\
\hline Bolivia & EDV & Settlement fund and guarantee fund & No & $\begin{array}{l}\text { Cheques for trans- } \\
\text { actions with physi- } \\
\text { cal certificates } \\
\text { Centralized account } \\
\text { at the central bank } \\
\text { for all dematerialized } \\
\text { securities }\end{array}$ \\
\hline \multirow[t]{5}{*}{ Brazil } & CBLC & $\begin{array}{l}\text { Settlement fund (defaulters pay or } \\
\text { survivors pay) } \\
\text { Margins (for collateralization of } \\
\text { derivatives market and securities } \\
\text { lending program) } \\
\text { Buy-ins }\end{array}$ & $\begin{array}{l}\text { CBLC acts as a CCP to its clear- } \\
\text { ing members for all securities } \\
\text { settled through its systems at } \\
\text { the time of execution. Trades } \\
\text { are channeled into the settle- } \\
\text { ment systems in real time; once } \\
\text { they have been tested against } \\
\text { acceptance parameters, they } \\
\text { are automatically reported to } \\
\text { clearing members. }\end{array}$ & $\begin{array}{l}\text { STR (central bank } \\
\text { RTGS system) }\end{array}$ \\
\hline & SELIC & $\begin{array}{l}\text { Bilateral debit caps (for indirect } \\
\text { participants) }\end{array}$ & No & STR \\
\hline & & $\begin{array}{l}\text { Queuing } 30 \text { minutes (until } \\
\text { 12:30 p.m.) }\end{array}$ & & \\
\hline & & $\begin{array}{l}\text { Queuing until 6:00 p.m. (only in the } \\
\text { case of insufficiency of the nego- } \\
\text { tiated securities) }\end{array}$ & & \\
\hline & & Optimization algorithms & & \\
\hline
\end{tabular}


Table 5.7 Risk Management Tools and Settlement Asset (Continued)

\begin{tabular}{|c|c|c|c|c|}
\hline Country & SSS & Risk Management Tools & CCPs & $\begin{array}{c}\text { Cash Settlement } \\
\text { Asset }\end{array}$ \\
\hline \multirow[t]{2}{*}{$\begin{array}{l}\text { Brazil } \\
\text { (Continued) }\end{array}$} & BM\&F & $\begin{array}{l}\text { Pledge (associated with their } \\
\text { membership of BM\&F) } \\
\text { Risk limits } \\
\text { Guarantee margins } \\
\text { Limits on concentration of } \\
\text { positions and price fluctuations } \\
\text { Calls for additional guarantee } \\
\text { margins } \\
\text { System of valuing and monitoring } \\
\text { risk guarantees } \\
\text { Value at risk system } \\
\text { System of additional safeguards } \\
\text { Clearing fund (minimum net work- } \\
\text { ing capital) }\end{array}$ & $\begin{array}{l}\text { The BM\&F clearinghouses for } \\
\text { derivatives transactions, for- } \\
\text { eign exchange, and govern- } \\
\text { ment securities are CCPs, and } \\
\text { become liable for the defaulter's } \\
\text { positions to the clearing mem- } \\
\text { bers that have honored their } \\
\text { commitments. } \\
\text { The securities clearinghouse } \\
\text { performs risk analysis in real } \\
\text { time, that is, trades submitted } \\
\text { to acceptance by the clearing- } \\
\text { house are instantaneously } \\
\text { checked with regard to the avail- } \\
\text { ability of collaterals to cover the } \\
\text { additional overall portfolio risk } \\
\text { brought on by the trade. }\end{array}$ & STR \\
\hline & CETIP & $\begin{array}{l}\text { Predeposit of securities } \\
\text { Funds fail (unwinding) }\end{array}$ & No & STR \\
\hline Chile & $\begin{array}{l}\text { Stock exchanges / } \\
\text { DCV }\end{array}$ & Guarantee fund & No & $\begin{array}{l}\text { Private banks' } \\
\text { clearinghouse that } \\
\text { settles balances in } \\
\text { the RTGS (LBTR) } \\
\text { system of the } \\
\text { central bank }\end{array}$ \\
\hline \multirow[t]{2}{*}{ Colombia } & $\begin{array}{l}\text { Stock exchange } \\
\text { clearinghouse / } \\
\text { DECEVAL / DCV }\end{array}$ & Guarantee fund & $\begin{array}{l}\text { The stock exchanges' clearing- } \\
\text { houses do not assume counter- } \\
\text { party risk. }\end{array}$ & $\begin{array}{l}\text { Funds are settled } \\
\text { separately from } \\
\text { securities (except } \\
\text { DCV settlement; } \\
\text { see below) on a net } \\
\text { basis, by cheque or } \\
\text { electronic transfer }\end{array}$ \\
\hline & SEN / DCV & Queuing (repique) & No & $\begin{array}{l}\text { RTGS system of the } \\
\text { central bank (CUD / } \\
\text { SEBRA) }\end{array}$ \\
\hline Costa Rica & $\begin{array}{l}\text { Stock exchange / } \\
\text { CEVAL }\end{array}$ & $\begin{array}{l}\text { Block of securities prior to } \\
\text { trading } \\
\text { Credit line } \\
\text { Guarantee fund (defaulters pay) }\end{array}$ & No & Central bank \\
\hline $\begin{array}{l}\text { Dominican } \\
\text { Republic }\end{array}$ & Stock exchange & None & No & Cash or cheques \\
\hline Ecuador & $\begin{array}{l}\text { Stock exchanges / } \\
\text { DECEVALE }\end{array}$ & $\begin{array}{l}\text { Guayaquil Stock Exchange } \\
\text { Deferred bilateral settlement } \\
\text { Guarantee fund } \\
\text { In case of a securities failure a } \\
\text { buy-in mechanism exists; the } \\
\text { guarantee fund covers the poten- } \\
\text { tial market risk }\end{array}$ & No & $\begin{array}{l}\text { Current accounts } \\
\text { of the exchanges } \\
\text { at the central } \\
\text { bank }\end{array}$ \\
\hline
\end{tabular}


Table 5.7 Risk Management Tools and Settlement Asset (Continued)

\begin{tabular}{|c|c|c|c|c|}
\hline Country & sSS & Risk Management Tools & CCPs & $\begin{array}{l}\text { Cash Settlement } \\
\text { Asset }\end{array}$ \\
\hline $\begin{array}{l}\text { Ecuador } \\
\text { (Continued) }\end{array}$ & & $\begin{array}{l}\text { Quito Stock Exchange } \\
\text { Guarantee fund } \\
\text { Unwinding (for securities failure) }\end{array}$ & & \\
\hline El Salvador & $\begin{array}{l}\text { Stock exchange / } \\
\text { CEDEVAL }\end{array}$ & Credit lines of the stock exchange & No & Central bank \\
\hline Guatemala & Stock exchange & None & No & $\begin{array}{l}\text { Central bank or } \\
\text { cheques }\end{array}$ \\
\hline Honduras & Stock exchanges & None & No & Cash or cheques \\
\hline Jamaica & $\begin{array}{l}\text { Stock exchange } \\
\text { (JSE) / JCSD }\end{array}$ & $\begin{array}{l}\text { Securities blocked prior to } \\
\text { trading } \\
\text { Credit lines of brokers with } \\
\text { banks }\end{array}$ & No & Central bank \\
\hline Mexico & INDEVAL & $\begin{array}{l}\text { Irrevocable guarantee trust for } \\
\text { defaulted transactions (contribu- } \\
\text { tions calculated through value at } \\
\text { risk methodology) } \\
\text { Buy-in and sell-out procedures }\end{array}$ & $\begin{array}{l}\text { INDEVAL plans to create a CCP } \\
\text { For derivatives, ASIGNA is a } \\
\text { CCP }\end{array}$ & $\begin{array}{l}\text { Central bank through } \\
\text { SIDV and SPEUA }\end{array}$ \\
\hline $\begin{array}{l}\text { Netherlands } \\
\text { Antilles }\end{array}$ & BvdNA & None & No & $\begin{array}{l}\text { Central bank through } \\
\text { the Netherlands } \\
\text { Antilles Clearing } \\
\text { System }\end{array}$ \\
\hline Nicaragua & $\begin{array}{l}\text { Stock exchange / } \\
\text { CENIVAL }\end{array}$ & None & No & Cheques \\
\hline OECS & ECCSD & No & No & $\begin{array}{l}\text { Private settlement } \\
\text { bank }\end{array}$ \\
\hline Panama & $\begin{array}{l}\text { Stock exchange / } \\
\text { LATINCLEAR }\end{array}$ & $\begin{array}{l}\text { Securities blocking prior to } \\
\text { selling } \\
\text { Guarantee scheme on a defaulters } \\
\text { pay basis }\end{array}$ & No & $\begin{array}{l}\text { Private settlement } \\
\text { agent (CIASA) }\end{array}$ \\
\hline Paraguay & Broker-dealers & No & No & $\begin{array}{l}\text { Private settlement } \\
\text { bank }\end{array}$ \\
\hline Peru & $\begin{array}{l}\text { Stock exchange / } \\
\text { CAVALI }\end{array}$ & $\begin{array}{l}\text { Settlement fund handled by } \\
\text { CAVALI } \\
\text { Guarantee fund handled by the } \\
\text { stock exchange. } \\
\text { Brokers' credit lines }\end{array}$ & No & $\begin{array}{l}\text { LBTR (CAVALI } \\
\text { currently holds } \\
\text { an account at the } \\
\text { central bank) }\end{array}$ \\
\hline \multirow[t]{2}{*}{$\begin{array}{l}\text { Trinidad and } \\
\text { Tobago }\end{array}$} & $\begin{array}{l}\text { Stock exchange / } \\
\text { TTCD }\end{array}$ & $\begin{array}{l}\text { Irrevocable standby letters of } \\
\text { credit } \\
\text { Buy-in and sell-out procedures }\end{array}$ & No & $\begin{array}{l}\text { Private settlement } \\
\text { agents (banks) }\end{array}$ \\
\hline & TTCB depository & $\begin{array}{l}\text { Real-time settlement } \\
\text { Buy-in and sell-out procedures }\end{array}$ & No & $\begin{array}{l}\text { Central bank RTGS } \\
\text { system }\end{array}$ \\
\hline
\end{tabular}


Table 5.7 Risk Management Tools and Settlement Asset 1 (Continued)

\begin{tabular}{|c|c|c|c|c|}
\hline Country & SSS & Risk Management Tools & CCPs & $\begin{array}{l}\text { Cash Settlement } \\
\text { Asset }\end{array}$ \\
\hline \multirow[t]{2}{*}{ Uruguay } & \multirow[t]{2}{*}{ AGATA } & (BVM) & \multirow[t]{2}{*}{ No } & \multirow[t]{2}{*}{ Central bank } \\
\hline & & Real-time settlement (BEVSA) & & \\
\hline \multirow[t]{5}{*}{$\begin{array}{l}\text { Venezuela, } \\
\text { R.B. de }\end{array}$} & $\begin{array}{l}\text { Central bank } \\
\text { (SICET) }\end{array}$ & Real-time settlement & No & Central bank \\
\hline & \multirow[t]{4}{*}{ CVV } & $\begin{array}{l}\text { Guarantee fund (general } \\
\text { purpose) }\end{array}$ & \multirow{4}{*}{$\begin{array}{l}\text { Although not defined as a } \\
C C P \text {, the stock exchange rules } \\
\text { state that the BVC guarantees } \\
\text { settlement. }\end{array}$} & \multirow[t]{4}{*}{ Settlement bank } \\
\hline & & Margins & & \\
\hline & & Credit line with settlement bank & & \\
\hline & & $\begin{array}{l}\text { Buy-in (two days after } \\
\text { settlement) }\end{array}$ & & \\
\hline
\end{tabular}

Source: Authors' elaboration.

Note: CENIVAL (Central Nicaragüense de Valores); LBTR (Sistema de Liquidación Bruta en Tiempo Real); SEBRA (Sistema Electrónico del Banco de la República); TTBC (Trinidad and Tobago Central Bank).

drastically reduced or totally exchanged into fungible ones within a specific time span; (2) all the physical securities kept in custody by participants of the securities depositories should be immobilized in the securities depository. Regular meetings with issuers and institutional and noninstitutional investors are practical measures to promote dematerialization and immobilization, and the massive movement of securities on a book-entry basis.

- Some systems do not yet settle on a DvP basis, i.e., payments are not necessarily linked to securities transfers, and vice versa. Therefore, principal risk exists and no measures have been taken to eliminate principal risk and to reduce and mitigate replacement risk (that is, a guarantee regime). Coordination and links between securities and monetary flow transfers on a DvP basis model are essential. Replacement risk must be reduced or mitigated with the implementation of a strict guarantee regime.

- Many systems have imperfect DvP procedures. Due to the time differences between the clearing of the cash leg and the clearing of the securities leg, principal risk could occur if a broker goes bankrupt in the meantime. In that case, it might be difficult to transfer the securities from the special pledge account of the depository in which they are blocked at the beginning of the trade day to the defaulter's counterparty, even if the counterparty has already paid for these securities.
- There is room for improvement in the current risk management tools used to cover settlement failures. Some systems do not count with any risk management tools, and others count with tools that are clearly insufficient. The authorities should determine if current risk management tools are enough to cover potential failures, especially taking into account the fact that existing guarantee funds can be used for failures other than those associated with settlement. A specific guarantee fund exclusively for settlement failures could be separated from a more general guarantee fund. In some cases, operations are unwound previous to the use of the guarantee funds, and no risk management tool is established for failures on the settlement side, except to compensate the broker-dealer for the fee. In order to avoid potential systemic risk, the guarantee funds should be used previous to the unwinding and a buyin or similar mechanism should be established to cover securities failures. In some cases, the total value of the guarantees seems enough to cover failures for both - securities and funds - at the current levels of market volume and value. The introduction of systems of dynamic guarantees should be explored.

- Related to the funds side, the use of cheques in the settlement process implies important settlement risks. Central bank money is used in transactions, on many occasions. However, settlement in the central bank's money is not normally mandatory and payments by cheque are sometimes used. The use of central bank 
money to settle transactions relating to securities markets should be encouraged (this is especially important for developing markets, although not required by the international standards). Existing funds settlement systems in some countries throughout the region already allow for the use of other type of funds transfer systems (for example, RTGS) that would eliminate this risk. Due to the nature of securities transactions, funds settlement should take place by an instrument that allows for finality at the end of settlement day.

- In the case where settlement of funds is made at the accounts of a private settlement bank (this is an existing, although not common, situation in some SSSs in LAC) assets used to settle the cash leg of securities transactions between SSS members should carry little or no credit or liquidity risk. If central bank money is not used, steps must be taken to protect participants from potential losses and liquidity pressures arising from the failure of a settlement bank. However, in most cases when a private settlement bank is used, the lack of specific supervision of the settlement bank regarding its settlement function does not allow for a clear understanding of the risks involved. In addition, the lack of coordination between regulators of this aspect increases the concern. The authorities should explore alternatives in terms of the assets used to settle the cash leg of securities transactions; if the use of a private settlement bank is used, adequate regulatory and supervisory mechanisms should be in place.

- Normally, nonbank clearing members and brokerdealers do not have access to central bank money; this imposes a liquidity constraint for their operations. If there is a lack of liquidity in the financial system or an inefficient management of liquidity and market practices of the broker-dealers and their clients, the shortage of liquidity could be exacerbated; if combined with the problem of settlement without DvP, this increases the liquidity problem. In some cases, broker-dealers have difficulties accessing intraday liquidity facilities from commercial banks. Banking innovation in payments mechanisms might bring some reduction of liquidity pressures at the broker and customers level. Also, provision of funds from the final investor to the broker-dealer to execute the transactions would ease the liquidity problem. The reliability of the system as a whole, and clearing and settlement procedures on a DvP basis, are essential to give confidence to the system and, thus, to create the conditions that will allow the final investors to be the providers of liquidity to broker-dealers for operations carried out on behalf of final investors.

- Most of the securities markets in the region do not have a turnover high enough to justify a CCP. For the biggest markets in the region, following an integration process of SSSs, some settlement systems for government securities might become a CCP; the benefits and costs of the change would need to be carefully evaluated. On some occasions, arrangements of the CCP type are present, because participants' failures are covered by credit lines granted by settlement banks or stock exchanges. However, this is normally done on a voluntary basis without any legal or regulatory support. In those cases, the rules are not specific about where the final risk stands once the guarantee systems have been used, and the systems are unable to cover the loss of a failure.

- Sometimes, plans for the development of new securities depositories in the region are not realistic in terms of timing, and are driven by a specific technological solution and not by a strategy agreed upon by all stakeholders. Some stock exchanges are developing technological solutions based on the experience of other countries in the region. The launch of a securities depository is a desirable and necessary element, but it implies much more than the establishment of an operational system. The launch of a securities depository should be considered in the context of a comprehensive reform of the payments and SSSs. Some crucial elements should be agreed on by regulators and other stakeholders before any implementation takes place. These elements include the role of the central bank; what kind of securities the securities depository will immobilize or dematerialize; who the settlement bank will be, and especially what implications the legal framework has in this regard; what the most appropriate settlement cycles would be; whether the depository should identify the beneficial owner, or whether this should only be done at the custodian level (this decision highly depends on the strength of the supervisory function); what model of DvP will be implemented; what risk management tools will be in place to mitigate settlement risks in case of a multilateral net system; operational security requirements and its supervision; the ownership structure that the depository should have; what the system will allow 
for fair and open access to all participants; what the governance arrangements will be; and so on. It is important that the reform focus on all elements of SSSs, and not only on the operational system for a securities depository. It is also important that the new SSS implemented observe the "Recommendations for Securities Settlement Systems" issued by CPSSIOSCO in November 2001, which include aspects such as legal and custody issues, clearance and settlement procedures, settlement risk, cash settlement asset, operational risk, regulation and oversight, transparency, efficiency, access, and governance. Finally, formal coordination among regulators (led by the central bank) and cooperation with the private sector are crucial in developing this piece of financial infrastructure. Commitment from the private sector should not only be from brokers, but also from issuers, banks, custodians, and even investors (mainly institutional).

- Sometimes public authorities are not taking a leadership role in the development of settlement arrangements for the securities markets, so private institutions are advancing through particular solutions that are not integrated in a comprehensive payments and securities settlement reform. Due to the public interest on the development of an SSS infrastructure (implications to fiscal and monetary policy, liquidity management, and development of the capital markets), public authorities (the central bank, securities regulator, pension funds regulator, and ministry of finance) should lead the way in defining how to develop such a system and how to cooperate with the private sector to design and implement the system. Several issues mentioned in the paragraph above need to be agreed on by stakeholders. Experiences in other countries show that if those issues are not appropriately debated and agreed on, a bottleneck situation could be created, delaying the establishment of the depository function for a long time. The public nature and neutral position of regulators can help to overcome the logical problems of conflict of private interests.

- Some markets are exposed to concentration risk in settlement activity. Broker-dealers have a central function in some trading and SSSs. In some cases, they have the monopoly on trading in the stock exchange. They are also the only participants in the depository with operational rights (pension funds and banks have nonoperational custody accounts), and for that reason have a monopoly on custody services for immobilized securities. In some cases, all money market transactions have to be done via broker-dealers. Broker-dealers also provide services to the public by attracting deposits, and by investing the relevant amount in capital or money market instruments. This full range of services includes many liabilities of the broker-dealers to the banks, other financial institutions, and the public. However, the capital requirements for broker-dealers' houses are relatively low.

- Short-selling is allowed in some cases, although it is not common. However, in cases of weak settlement arrangements and an inadequate legal, regulatory, and supervisory environment, this practice could be risky. The authorities should determine if appropriate mechanisms are in place to allow for short-selling, and should regulate accordingly. Alternatively, as a developmental issue the authorities should explore the implementation of securities lending as another mechanism to provide liquidity to the market. As indicated in the clearing and settlement processes section, it is difficult to develop securities lending in a context of low market liquidity. In the future, the market could be more active and these developments could take time to be implemented.

- In summary, the main aspects to be improved are the achievement of full dematerialization and immobilization of securities, establishment and completion of DvP procedures, upgrade of current risk management tools, mitigation of credit and liquidity risk in the cash leg settlement (including elimination of the use of cheques as a cash asset), better access to liquidity for SSSs participants, careful follow-up of shortselling when used, and a comprehensive approach for the reform of SSSs versus technology-driven and exclusively operational reform projects.

\section{OPERATIONAL ISSUES}

This section includes context, status in the region and observations regarding operational issues.

\section{Context}

Operational risk is the risk that deficiencies in information systems or internal controls, human errors, or management failures result in unexpected losses. As clearing and settlement systems become increasingly dependent on IT systems, their reliability is a key element in 
operational risk. Operational risk can arise from inadequate control of systems and processes; from inadequate management more generally (lack of expertise, poor supervision or training, inadequate resources); from inadequate identification or understanding of risks and the controls and procedures needed to limit them; and from inadequate attention being paid to ensure that procedures are understood and complied with.

To minimize operational risk, system operators should identify sources of operational risk. All key systems should be secure (that is, have access controls, adequate safeguards to prevent external intrusions, and provide audit trails), reliable, scaleable, able to handle stress volume, and have appropriate contingency plans to account for system interruption. The system should maintain an adequate capacity to process current and anticipated future transaction volume, including projected peak-day and peak-hour volume demands. To achieve this, the operator must (1) establish formal current and future capacity estimates for their automated trade comparison systems; (2) conduct periodic capacity stress tests to determine the behavior of systems under a variety of simulated conditions; and (3) conduct independent annual reviews to assess whether these systems can perform adequately at their current and estimated future capacity levels.

Operational capacity must also be demonstrated to exist at the mandatory disaster-recovery site. Operators must have in place a well-designed and adequately tested mechanism for transferring system control to the backup site in an acceptable time frame without loss of data or unacceptable reduction in service levels.

In assessing the efficiency of settlement systems, the needs of users and the costs imposed on them must be carefully balanced with the requirement that the system meet appropriate standards of safety and security.

\section{Status in the Region}

Table 5.8 includes a brief description of operational features for settlement systems in each of the countries assessed.

\section{Observations}

Some of the specific problems regarding operational issues follow:
- The physical handling of securities is still common in many SSSs. The clearing and settlement of securities transactions with physical certificates is not only risky, but also cumbersome and costly, and it hampers the development of capital markets. It is absolutely not in line with international code and standards. Thus, an important target should be to eliminate the physical handling of securities. General laws on securities or capital markets must recognize the immobilization, dematerialization, and transfer of securities on a bookentry basis. Depositories should encourage the dematerialization and immobilization of all securities as a matter of urgency. Regular meetings must be held by depositories with issuers and institutional and noninstitutional investors to promote immobilization and the massive movement of securities on a book-entry basis. Securities regulators should promote this process.

- STP is not the rule in SSSs in the LAC region. Many procedures imply physical handling of the securities. This makes some clearance and settlement procedures cumbersome - for example, dividends payments and corporate actions in general require a substantial amount of manual intervention. A gradual implementation of STP procedures would be desirable for all kind of securities to reduce operational risk. STP for securities transactions will mean a fully automated transactional link for trade matching, comparison, and book-entry settlement of securities and funds. Such an integrated system would not only reduce the possibility of errors, but also make the clearing and settlement process more efficient by-for example, eliminating duplicate processes and giving the participants immediate information to enable them to manage their liquidity effectively.

- In many cases, backup facilities are not available, are missing, or are in the process of being implemented. They should be in place at the earliest possible time to cover any contingency in the system. Alternative sites and disaster-recovery facilities must enable operations to be recovered in a manner that does not disrupt settlement.

- External auditing of the operational systems should be considered in order to assess the security and cost efficiency of all of the systems. The authorities and the private sector have made important efforts in the development of the technological platforms for the operation of the SSSs. In some cases, an "in-house" solution has been developed, in other cases, standard 


\section{Table 5.8 Operational Reliability in SSSs}

\begin{tabular}{|c|c|c|}
\hline Country & SSS & Operational Reliability \\
\hline Argentina & Caja de valores & $\begin{array}{l}\text { Major participants are linked electronically through a safe communications } \\
\text { system that the caja de valores has put in place. Without any prejudice to the } \\
\text { foregoing, securities markets have proprietary electronic securities trading } \\
\text { systems, namely Mercado de Valores S.A. and Mercado Abierto Electrónico. } \\
\text { At its electronic data processing center, the caja de valores runs every program } \\
\text { connected with securities trading, dissemination, settlement, and custody. These } \\
\text { systems are interconnected, and all participants have access thereto. Furthermore, } \\
\text { the caja de valores maintains its proprietary securities custody system in a } \\
\text { stand-alone environment. }\end{array}$ \\
\hline Bahamas, The & Securities firms & Mainly manual procedures, low level of automation. \\
\hline Bolivia & EDV & $\begin{array}{l}\text { The EDV has an electronic linkage and handles online information with all its } \\
\text { participants. }\end{array}$ \\
\hline Brazil & CBLC & 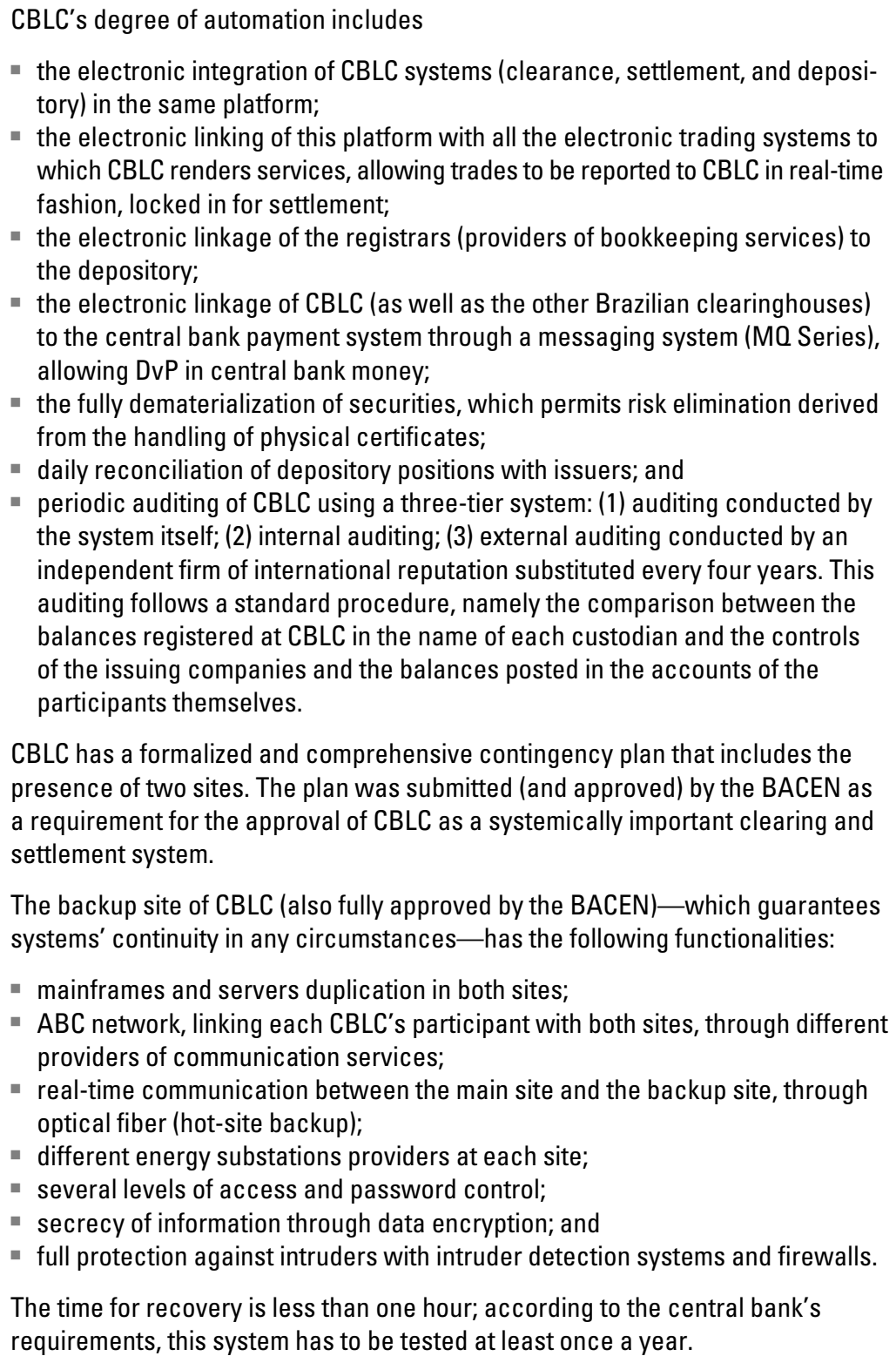 \\
\hline
\end{tabular}


Table 5.8 Operational Reliability in SSSs (Continued)

\begin{tabular}{|c|c|c|}
\hline Country & SSS & Operational Reliability \\
\hline \multirow{2}{*}{$\begin{array}{l}\text { Brazil } \\
\text { (Continued) }\end{array}$} & SELIC & SELIC shares several operational features with the STR (see chapter 4). \\
\hline & BM\&F & $\begin{array}{l}\text { BM\&F operations (including clearing operations) include operational reliability } \\
\text { and contingency arrangements to guarantee business continuity (fully approved } \\
\text { by BACEN): (1) Business application and data are protected against external } \\
\text { or internal threats by two layers of firewalls. (2) Data are stored in an external } \\
\text { enterprise storage. All the data are mirrored and backed up periodically by a } \\
\text { corporate backup system. (3) All the data written to the enterprise storage are } \\
\text { replicated (real time) to the contingency site. (4) BM\&F works with an archi- } \\
\text { tectural design that allows scale-up (CPU and memory scalability) and scale- } \\
\text { out (multiple servers processing the same application). (5) System resources } \\
\text { uses are monitored by a centralized management system. Stress tests are } \\
\text { conducted regularly. (6) Clustering technology with automatic takeover is used } \\
\text { to minimize downtime in case of computer failure. In case of site disaster, all } \\
\text { the data will be available in the contingency site to restart the business. (7) For } \\
\text { the services that run only in the main site, the servers in the contingency site } \\
\text { will be periodically activated. (8) The contingency plan document describes all } \\
\text { the procedures required to restart all the processes. (9) The contingency site } \\
\text { is operationally active. }\end{array}$ \\
\hline \multirow[t]{2}{*}{ Chile } & \multirow[t]{2}{*}{ DCV } & $\begin{array}{l}\text { DCV is linked to trading and matching platforms (exchanges), from which it } \\
\text { receives the information regarding trades executed in that market. It is also linked } \\
\text { to recurrent issuers (banks and the central bank), from which DCV receives the } \\
\text { detail of the securities issued dematerialized and to which DCV sends the informa- } \\
\text { tion regarding securities' maturities and the respective beneficiaries. Opera- } \\
\text { tional features of the DCV system are described in chapters } 10 \text { and } 11 \text { of their } \\
\text { internal rules (reglamento interno). }\end{array}$ \\
\hline & & $\begin{array}{l}\text { The DCV has a business continuity plan with two mirror sites online. The DCV is } \\
\text { audited, among others, by external auditors hired by the Comité de Vigilancia, } \\
\text { comprised of DCV clients. From December 2005, the DCV has a Comite de Directores } \\
\text { that analyzes issues related to operational risk and its audit. }\end{array}$ \\
\hline \multirow[t]{2}{*}{ Colombia } & \multirow[t]{2}{*}{ DECEVAL } & Below are operational features of DECEVAL: \\
\hline & & 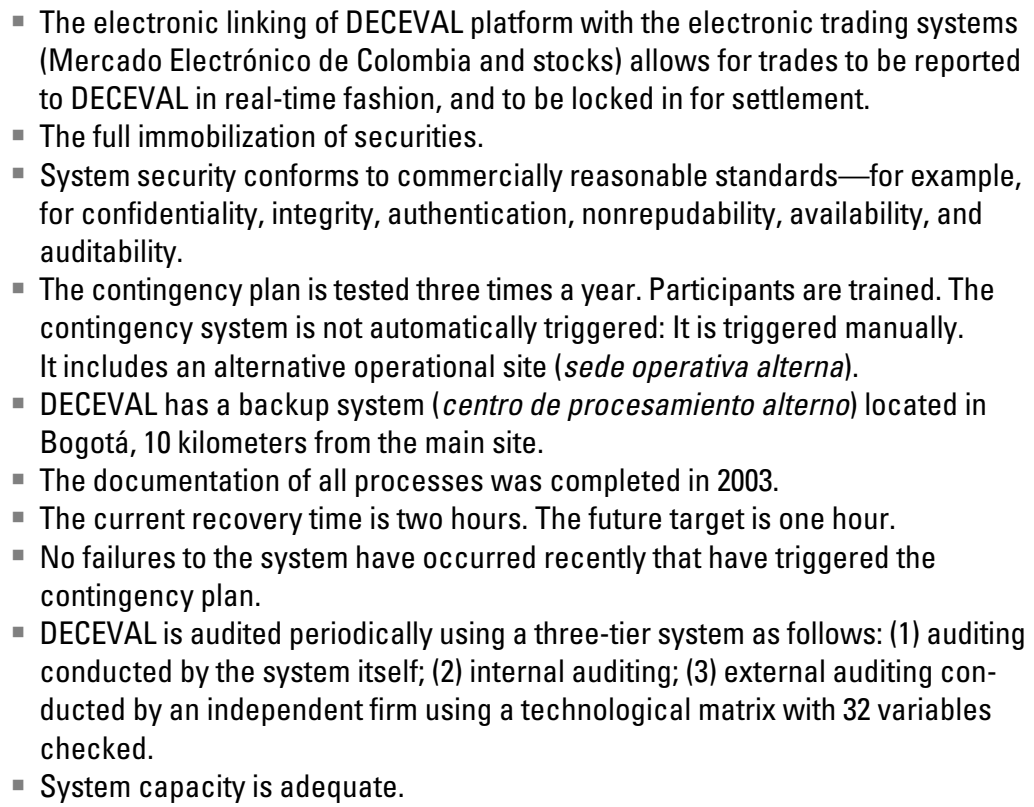 \\
\hline
\end{tabular}


Table 5.8 Operational Reliability in SSSs (Continued)

\begin{tabular}{|c|c|c|}
\hline Country & SSS & Operational Reliability \\
\hline \multirow[t]{3}{*}{$\begin{array}{l}\text { Colombia } \\
\text { (Continued) }\end{array}$} & \multirow{3}{*}{ DCV } & $\begin{array}{l}\text { DECEVAL and the stock exchange are working toward the electronic integration } \\
\text { of both systems (trading, settlement, and depository) in order to allow for full } \\
\text { straight-through processing (STP). } \\
\text { - DECEVAL has completed a process of technological upgrade: The hardware } \\
\text { platform SunMicrosystems substituted the Hewlett Packard platform in } \\
\text { October } 2003 \text {. } \\
\text { - Regarcling IT security, the Virtual Private Network (VPN) platform used will be } \\
\text { substituted by the Checkpoint platform in } 2004 \text {. } \\
\text { - Existing communications used will be upgraded in } 2005 \text {. }\end{array}$ \\
\hline & & Below are operational features of DCV: \\
\hline & & $\begin{array}{l}\text { The connection to DCV by direct depositors is made through the Sistema } \\
\text { Electrónico del Banco de la República system of the central bank. The techno- } \\
\text { logic platform for the central bank systems (CUD, SEN, and DCV) is installed in } \\
\text { SUN servers with a Solaris } 8 \text { operational system, Oracle databases, and Web } \\
\text { Tomcat databases. The Internet application is Oracle IAS. } \\
\text { - The system ensures the main principles of security such as integrity, confiden- } \\
\text { tiality, and access controls. Through a unique entrance point, the system allows } \\
\text { access only to authorized users. The DCV software ensures that whoever } \\
\text { accesses the information can register operations only in the amounts previously } \\
\text { defined by the direct depositor. In addition, the system allows for the segregation } \\
\text { of the inclusion, review, and transfer activation functions. } \\
\text { - The communication among direct depositors and the DCV is protected by } \\
\text { encryption and control figures that ensure data integrity. } \\
\text { - SEN and DCV have appropriate identification of the operational risks arising in } \\
\text { the securities settlement process. There are clear policies and procedures to } \\
\text { address the risks } \\
\text { - Backup facilities (centro de cómputo alterno) and contingency plans are available } \\
\text { and tested regularly. They guarantee a } 99 \text { percent of availability. Contingency } \\
\text { plans are tested four times a year. The contingency plans follow the Disaster } \\
\text { Recovery Institute methodology, and allows for a } 10 \text { to } 20 \text { minutes recovery, } \\
\text { depending on the specific incident. } \\
\text { - The capacity is assessed every year, and estimates of processing growth are } \\
\text { calculated. } \\
\text { - The BR has policies and methodologies to manage business and } \\
\text { operational risks. The operational model follows the Australian methodology } \\
\text { AS/NZS: } 4360 \text { of 1999. All processes are documented. } \\
\text { Management controls are adequate, and there is enough staff to ensure that } \\
\text { procedures are correctly implemented. The central bank has established a } \\
\text { committee (Comité de Coordinación del Sistema de Control Interno) to assess } \\
\text { payments systems operated by the central bank: DCV, Sistema de Compen- } \\
\text { sación Electrónica de Cheques (CEDEC), Sistema de Compensación Elec- } \\
\text { trónica Nacional Interbancaria (CENIT), CUD, and SEN. }\end{array}$ \\
\hline
\end{tabular}

Costa Rica CEVAL

Attention is paid to operational reliability for clearing and settlement and for central custody services. Every year, an analysis of potential threats is made and the existing emergency plan is adapted accordingly. A contingency committee is in place. Protection measures against unauthorized access are tested periodically by an external expert. There is an own-power supply. Communication with the brokers is based on a client-server infrastructure. Every participant is connected with the server via two dedicated optical fiber lines. Capacity of the systems can handle two times the demand during peak hours. Procedures are in place concerning procurement, development, and modification of the systems; modifications are adequately tested before becoming operational. The systems have 
Table 5.8 Operational Reliability in SSSs (Continued)

\begin{tabular}{|c|c|c|}
\hline Country & SSS & Operational Reliability \\
\hline $\begin{array}{l}\text { Costa Rica } \\
\text { (Continued) }\end{array}$ & & $\begin{array}{l}\text { separate environments for production, developing, and testing. A changeover } \\
\text { committee is installed with participants of the IT department who designed and } \\
\text { implemented the modification, the internal audit department, and the person } \\
\text { responsible for testing. The committee is chaired by the CEO. Disaster recovery } \\
\text { facilities are not up to standard, however. There is no backup server in hot } \\
\text { standby mode, and there is no second contingency site. }\end{array}$ \\
\hline Dominican Republic & Stock exchanges & Mainly manual procedures \\
\hline Ecuador & $\begin{array}{l}\text { Stock exchanges / } \\
\text { DECEVALE }\end{array}$ & $\begin{array}{l}\text { Both stock exchanges use the data provided by their trading systems on securities } \\
\text { to be delivered, and the calculation of net positions on the money side. These } \\
\text { systems have the usual backup procedures. However the real operational risk is } \\
\text { in the handling of physical securities and the cumbersome procedures involved } \\
\text { in splitting the securities traded in the right denominations to be delivered to the } \\
\text { different parties. }\end{array}$ \\
\hline El Salvador & $\begin{array}{l}\text { Stock exchange- } \\
\text { CEDEVAL }\end{array}$ & Contingency plans are based on manual procedures. \\
\hline Guatemala & Stock exchange & $\begin{array}{l}\text { The Bolsa de Valores Nacional reports that all their systems, including the CSD, } \\
\text { have safe operational features, backup sites, and contingency plans. However, } \\
\text { there is no regulation or supervision of these issues by any regulatory authority, } \\
\text { because the stock exchange operates as a full SRO. }\end{array}$ \\
\hline Honduras & Stock exchanges & Mainly manual procedures. \\
\hline Jamaica & $\begin{array}{l}\text { Stock exchange (JSE)- } \\
\text { JCSD }\end{array}$ & $\begin{array}{l}\text { The JSE and the JCSD have established coordinated security measures, contin- } \\
\text { gency planning procedures, and internal controls designed to limit operational } \\
\text { risk. Nevertheless, the organizations separate functions where appropriate. For } \\
\text { example, the JCSD's audit procedures are independent from the JSE's. Also, the } \\
\text { JSE relies on a vendor to develop its core applications; however, testing, imple- } \\
\text { mentation, and other applications are done by JSE staff to ensure integrity. } \\
\text { The JSE and the JCSD can trace transactions from execution through settlement. } \\
\text { The organizations maintain procedures to identify and resolve discrepancies. Their } \\
\text { records are backed up nightly, and the JCSD performs a daily audit of critical } \\
\text { activities-settlement, deposit approval, inter- and intramember movement, and } \\
\text { trade data. The records are stored in a location that is separate from their pri- } \\
\text { mary facilities. There is a disaster recovery plan, and the organizations plan to } \\
\text { implement a hot backup site. The JCSD also conducts regular meetings with its } \\
\text { participants to ensure smooth daily processing. }\end{array}$ \\
\hline Mexico & INDEVAL & $\begin{array}{l}\text { Regarding communication systems, INDEVAL has routers, hubs, and network } \\
\text { concentrating equipment for the internal links and all the necessary hardware to } \\
\text { create remote links using a high-speed private telephone network. The chapter } \\
\text { "Communications Infrastructure" in INDEVAL's operations manual describes the } \\
\text { technical and safety requirements for connecting to INDEVAL's systems through } \\
\text { a terminal and through the depositor's electronic, computer, or other telecommu- } \\
\text { nication network. It also provides information about the reciprocal and identification } \\
\text { access keys, and about verification of the elements and goods related to main- } \\
\text { taining and operating the systems. Bursatec-a firm owned by BMV, INDEVAL, } \\
\text { MEXDER, and ASIGNA-provides a contingency network, backup equipment, } \\
\text { and a backup alternative site that ensure continuous processing and communica- } \\
\text { tion during unanticipated contingencies. A fiber-optic network is used on a regu- } \\
\text { lar basis, and contingency is guaranteed through KBTel microwaves. The } \\
\text { alternative site is located in the city of Pachuca, in Hidalgo State. This site has } \\
\text { alternative links for participants; it replicates the database every half hour, and is } \\
\text { capable of substituting for the main processing site within an hour of failure. }\end{array}$ \\
\hline
\end{tabular}


Table 5.8 Operational Reliability in SSSs (Continued)

\begin{tabular}{|c|c|c|}
\hline Country & SSS & Operational Reliability \\
\hline Netherlands Antilles & BvdNa & Mainly manual procedures. \\
\hline Nicaragua & CENIVAL & $\begin{array}{l}\text { Neither the BVDN nor the CENIVAL has contingency facilities or backup sites. } \\
\text { The only contingency plan at present is the possibility to hold outcry floor ses- } \\
\text { sions for trading purposes in case of malfunctioning of the electronic trading } \\
\text { system. }\end{array}$ \\
\hline OECS & ECCSD & $\begin{array}{l}\text { The ECCSD includes the operational procedures. The operational requirements } \\
\text { to become a participant in the ECCSD are included in the documents "ECCSD } \\
\text { Requirements and Application Instructions" and "Participant Operational } \\
\text { Procedures Manual" that contain requirements regarding the adequate physical } \\
\text { facilities, books, records, and procedures. }\end{array}$ \\
\hline Panama & LATINCLEAR & $\begin{array}{l}\text { Periodic analyses of potential threats are made. Communications with the bro- } \\
\text { kers are made through dedicated lines. There is no backup server in hot standby } \\
\text { mode, but there is an alternative contingency site located in Panama City, about } \\
6 \text { kilometers from the primary site. A tape containing a backup copy of operations } \\
\text { is sent daily to the backup site. }\end{array}$ \\
\hline Paraguay & - & No centralized settlement system is in place. \\
\hline Peru & CAVALI & $\begin{array}{l}\text { According to the depositories' (Instituciones de Compensación y Liquidación } \\
\text { de Valores) regulations, the depositories must have safe premises, capable of } \\
\text { adequately preserving the information, avoiding any loss or alteration thereof, } \\
\text { and granting it confidentiality. Safeguard systems must include access con- } \\
\text { trols to the information contained in the accounting record and to any other } \\
\text { information of a nonpublic nature, to avoid third-parties' access therein. } \\
\text { They must have backup copies kept in places that are separate from the } \\
\text { respective depositories; controls to avoid removal, loss, or modification of the } \\
\text { information; and restricted access to users. The depositories' regulations } \\
\text { require the depositories to provide measures to specifically cover system } \\
\text { operational risks. These include alteration or destruction of records, commu- } \\
\text { nications disruption, availability of securities or funds by nonauthorized peo- } \\
\text { ple, and data manipulation. The depositories' regulations require that the } \\
\text { depositories have contingency plans for the recovery of the depository's oper- } \\
\text { ating capacity as soon as possible, to ensure that the normal development of } \\
\text { the market is not affected. Contingency plans must include alternative power } \\
\text { supplies; and auxiliary equipment for data processing and communication, } \\
\text { among other plans. These plans must be reviewed, updated, and tested at } \\
\text { least once a year, and any substantial modification thereto must be duly } \\
\text { reported to CONASEV. }\end{array}$ \\
\hline
\end{tabular}

CAVALI has advanced significantly in terms of operational reliability, safeguards, and contingency plans.

- All participants are linked electronically through a safe communications system (by using an enclosed private network) to CAVALI. Contingency communication systems through different providers of communication services are also in place. CAVALI is also linked electronically with the stock exchange for transfer of information online. Most processes at CAV$A L I$ have been automated, and currently most requests and transfers of information are processed through the system by participants and issuers. Over the past years, CAVALI has been actively pursuing the elimination of all paperwork and the use of magnetic systems (such as diskettes) for handling information.

- An alternative computer site is in place (duplication of mainframes), with real-time communication between the main site and the backup site. Physical backups are also kept on two other sites. 
Table 5.8 Operational Reliability in SSSs (Continued)

\begin{tabular}{|c|c|c|}
\hline Country & SSS & Operational Reliability \\
\hline $\begin{array}{l}\text { Peru } \\
\text { (Continued) }\end{array}$ & & $\begin{array}{l}\text { Periodic risk assessments take place at CAVALI. At least once a year, all con- } \\
\text { tingency plans (including different scenarios, in order to ensure continuity } \\
\text { under different circumstances) are tested, including a complete disaster scenario } \\
\text { with the participation of all brokers, custodians, and major issuers. Regulators, } \\
\text { as well as external auditors oversee the exercise. } \\
\text { - Full attention is given to information security (internal full-time dedicated officer) } \\
\text { for protection against intruders, and to permanently analyze the safeguard of } \\
\text { information. }\end{array}$ \\
\hline
\end{tabular}

\section{Trinidad and Tobago TTCD}

TTCB depository

\begin{tabular}{ll}
\hline Uruguay & Stock exchanges- \\
AGATA
\end{tabular}

All agencies engaged in the securities are subjected to internal and external audits. In addition, these agencies are supervised either by the central bank or the SEC. The Securities Industry Act, Section 39 (3), requires that the rules of these agencies contain provisions designed to develop and operate a prompt and accurate clearance and settlement systems, and to safeguard money and securities in custody, under their control, or for which they are responsible. All agencies providing facilities for clearance and settlement of securities have adopted measures to protect and safeguard their systems. These include routine daily backups of their transactions, offsite storage, and appropriate security access levels. In addition, many agencies have developed disaster recovery programs. Brokers' connections with TTCD are available online. Backup contingency plans are currently manual. Plans to establish a disaster recovery system are not yet complete; alternatives are to establish it outside the country (in Jamaica or Barbados) or use the unit trust corporation facilities.

See operational features of RTGS in chapter 4.

The BCU has been undertaking important efforts to improve the operational efficiency and safety of the system it operates, AGATA. The BVM has a backup system in a different location in Montevideo. An online contingency system and a contingency plan are currently being developed. BEVSA has indicated that for all their systems, they count with safe operational features, backup sites, and contingency plans.

Venezuela, R.B. de Central bank (SICET)

As for central bank systems for securities clearance and settlement, all applications have been developed in-house. Manuals are developed by the central bank; in order for participants to be able to trade in these systems, they must sign a letter stating that they have full knowledge of how the systems work and that they accept all conditions stated thereof. Modifications are developed by the central bank in coordination with market participants. The IT department of the central bank has a service unit to deal with system malfunctions reported by participants.

Central bank systems run on an IBM 0S/390 mainframe. The central bank has developed various access controls, including providing passwords to authorized users; those users may change the passwords at any time. The network has two firewalls, one for internal users, and the other for external users. All central bank personnel may access the systems for which they have authorization from any terminal inside the institution. External participants experiencing problems with their terminals may go to the central bank building and continue entering transactions into the system. Records are replicated in real time, and kept in central bank premises.

There are several other contingency arrangements. In case of system malfunction orders may keep coming in to the central bank via SWIFT, telex, or paper means, and the central bank will continue to process these provisionally in Excel. The central bank makes cutoffs of account holdings daily. Currently, there are no backup premises for disasters.

The current capacity of the systems can handle the current demand during peak hours. Moreover, gains in systems efficiency have been achieved by several developments, such as securities standardization. 
Table 5.8 Operational Reliability in SSSs (Continued)

\begin{tabular}{l|c|}
\hline Country & \multicolumn{1}{c}{ SSS } \\
\hline $\begin{array}{l}\text { Venezuela, R.B. de } \\
\text { (Continued) }\end{array}$ & Stock exchange / CVV \\
\hline
\end{tabular}

Operational Reliability

The stock exchange (BVC) uses an electronic trading system originally developed in Spain, the SIBE. All system modifications are developed in Spain with usual quality control procedures, including appropriate testing. The BVC informs on changes to brokers dealers via e-mail, facsimile, and letters. However, there is no centralized functionality through which brokerage houses may track such changes. The SIBE runs on two mirror mainframes that are rotated every day. Records are backed up every night, and the BVC has a facility that enables the SIBE to continue running for one hour in case of a general electricity cutoff. However, apart from the latter, there are no other backup facilities such as an alternative site away from the primary facilities. Backed-up information is also kept at the primary site. Through the SIBE, the BVC defines two types of authorized users: transactional, and consultation only. Brokerage houses select the person(s) authorized for each type of operation and the BVC provides passwords to authorized users. Brokers may access the SIBE through the terminals inside the BVC, but mainly do so through remote-frame relay connections. The capacity of the system can easily handle the current demand during peak hours, because it was developed at a time when trading was much more active.

Communications between the BVC and brokers are made via e-mail and diskette. Information between the BVC and CVV systems is not exchanged online, but rather via modem. The information is transmitted with the use of encryption techniques and general characteristics (for example, the size of the message, and so on) are confirmed via facsimile.

Notwithstanding the fact that communications between BVC and brokers, and between the BVC and the CVV, allow for file transfers into their respective systems, thereby reducing the possibility of mistakes because of reentering the information, it seems that there is space for improvements, both in terms of risk and cost efficiency.

The CVV backs up its information every night, generating three tapes, two of which are kept outside the CVV's facilities. The overall system has a backup site in hot standby mode.

Source: Authors' elaboration.

systems have been acquired from vendors. In cases when the system has been developed in-house, it is important to consider an external audit of the systems developed to make sure that all the required features (that is, security, contingency, backups, capacity, and so on) are in place for safe and efficient operation of the new systems. This is even more important when the supervisory framework of the operational issues is not well developed in the country.

- In summary, there is room for important efficiency gains of the securities settlement infrastructure. In particular, physical handling of securities should be eliminated to increase the safety and efficiency of SSSs. In addition, there is room for improvement in the clearing and settlement process, because STP is not the common rule. The various plans for backup sites and disaster recovery facilities should be accel- erated or established when nonexistent. Finally, external audit of the systems should be undertaken, especially when the systems have been developed in-house. The latter is especially important when the supervisory framework for operational issues is weak.

\section{CUSTODY RISK}

This section includes context, status in the region and observations regarding custody risk.

\section{Context}

Custody risk is the risk of a loss of securities held in custody; the loss is occasioned by the custodian's (or subcustodian's) insolvency, negligence, misuse of assets, fraud, poor administration, or inadequate record keeping. A custodian should employ procedures ensuring 
that all customer assets are appropriately accounted for and kept safe. Customer securities also must be protected against the claims of the custodian's creditors; typically, client assets are given preferential treatment under insolvency law.

Custodians must have a demonstrable capability to safeguard securities and funds in their custody or control or for which they are responsible, and for protecting against reasonably anticipated internal or external threats to the integrity of their operations. In many markets, settlement is carried out and controlled through automatic data processing systems. In these cases, the system should have appropriate procedures to back up data, and a contingency plan to minimize disruptions.

Electronic technologies now in place or under development, such as the use of the Internet for initiating financial transactions, increase consumer choice, but also provide additional means for abuse and illegal activity. Safeguards should anticipate, and be designed to provide protection against, the possibility of theft; accidental or malicious destruction or loss of securities or funds; and the possibility of accidental or intentional, but unauthorized, modification, disclosure, or destruction of data.

In connection with these objectives, the organization should have an adequately staffed internal audit department that has the authority to review, monitor, and evaluate the organization's system of internal controls and the integrity of the operational procedures.

In summary, particular attention is required to reduce fraud. Some of the issues to be addressed are (1) the operational security of systems including identification systems, message authentication, and protection measures in safeguarding access to the system; (2) protection against insider fraud; (3) a regular independent audit of the systems to ensure continued system integrity; and (4) the determination of liability for loss or technical failure.

\section{Status in the Region}

Table 5.9 includes a brief description of custody arrangements for settlement systems in each of the countries assessed.

\section{Observations}

Some of the specific problems regarding custody risk follow:
- Additional legal developments are still needed to guarantee the protection of a customer's assets in the event of bankruptcy of the depositary holding its titles, or insolvency of the custodian. The country authorities should ensure that the segregation of accounts for securities and funds under custody has a clear legal basis under all circumstances. They must also ensure that all customer assets are appropriately accounted for as beneficial owners in the depository or in the custodian's omnibus accounts. Specifically, they must ensure that customer assets are protected against the insolvency of custodians, whatever the nature of the custodian. This issue should be explored under the consideration of the overall legal framework for payments and SSSs.

- The immobilization or dematerialization of securities will eliminate the custody risk associated with dealing with physical certificates, but it also requires an appropriate legal framework for electronic documents and signatures. In LAC, there are important advances in this direction (many laws have been recently approved). The authorities should make sure that the corresponding regulations are approved to make it applicable for settlement purposes.

- In general, there is no specific legal and regulatory framework for the pledge in the context of financial transactions. The consequence of this is that, in case of a bankruptcy, realization of the pledged securities could not take place without a court order.

\section{REGULATORY AND OVERSIGHT ISSUES}

This section includes context, status in the region and observations regarding regulatory and oversight issues.

\section{Context}

Regarding regulation and oversight by the authorities, a specific allocation of responsibilities for securities clearance and settlement supervision is important. However, in most cases, this function is performed together with the general supervision function of the participant entities without any special attention being given to clearance and settlement issues. There is a trend toward regulatory oversight policy being implemented at two levels; this trend is substituting for traditional direct supervisory activity. The regulator conducts the oversight of the SROs' activities (CSDs, exchanges), whereas these 


\section{Table 5.9 Custody Arrangements}

\begin{tabular}{|c|c|c|}
\hline Country & Depository & Custody Arrangements \\
\hline Argentina & Caja de valores & $\begin{array}{l}\text { The caja de valores adopts a tiered account structure, with the account in the } \\
\text { name of the depositor or direct participant, who then provides subaccounts for } \\
\text { identifying the securities holdings of the ultimate beneficiaries. In the event of } \\
\text { bankruptcy of the primary account holder or depositor, the assets in the sub- } \\
\text { accounts are automatically excluded from the bankruptcy estate, and the ultimate } \\
\text { beneficiaries' assets are protected. The caja de valores acts as a registrar in } \\
\text { case of issuers' demand (most of the cases) and as a payment agent for dividends, } \\
\text { interests, and redemptions. }\end{array}$ \\
\hline Bahamas, The & - & - \\
\hline Bolivia & EDV & $\begin{array}{l}\text { The protection of custody arrangements is only included for the securities } \\
\text { depository, but not for other custodians. It is included in Article } 49 \text { b of the SML } \\
\text { and Article 59a (being Article 59a in line with Article } 39 \text { of the depository regulation) } \\
\text { regarding the final ownership of the securities, the custodian, or the depository, } \\
\text { respectively. }\end{array}$ \\
\hline \multirow[t]{2}{*}{ Brazil } & CBLC & $\begin{array}{l}\text { Although the CBLC depository service is a typical indirect holding system, it } \\
\text { has a two-tiered account level structure, thus enabling the maintenance of sub- } \\
\text { accounts in the name of the beneficial owners. This is a mandatory rule of the } \\
\text { CVM, in order to permit the tracking of ownership in the case of any custodian's } \\
\text { bankruptcy or fraud, thus providing security for the investors. CBLC provides dif- } \\
\text { ferent mechanisms through which final investors can access information on their } \\
\text { holdings. In addition, the investors can check their daily positions directly by } \\
\text { Internet, provided they have the necessary password, which CBLC sends to the } \\
\text { investor's address. }\end{array}$ \\
\hline & SELIC & $\begin{array}{l}\text { Accounts are segregated within the SELIC system. It is worth noting that secu- } \\
\text { rities clearinghouses (for example, BM\&F Securities Clearinghouse) may use } \\
\text { SELIC custody to which will be transferred securities available for trading in } \\
\text { their environments without financial movement. Securities clearinghouses may } \\
\text { also use a specific account for the safeguard of securities that have been regis- } \\
\text { tered in SELIC and delivered as guarantee for transactions handled in its deferred } \\
\text { net settlement systems. Securities registered in the custody accounts of clear- } \\
\text { inghouses for this purpose may only be transferred by the clearinghouse to } \\
\text { third parties' custody accounts in specific situations, which are clearly laid } \\
\text { down in the clearinghouse regulations. Securities eventually registered in SELIC } \\
\text { that belong to the clearinghouses will be registered in the clearinghouses' } \\
\text { individual accounts. }\end{array}$ \\
\hline \multirow[t]{2}{*}{ Chile } & DCV & $\begin{array}{l}\text { Code of Commerce, Article 192, includes protection of investors' or clients' assets } \\
\text { against insolvency or bankruptcy procedures of custodians. Ownership transfer } \\
\text { of registered securities is not completed until the securities are registered in the } \\
\text { issuer's registry. Securities issued in order form are transferred by endorsement; } \\
\text { in order to register them with a custodian, they must be endorsed in favor of such } \\
\text { custodian. For securities deposited in the DCV, the DCV is responsible for the } \\
\text { authenticity of the securities. In order to be depositors in the DCV, participants } \\
\text { must sign a depositor contract. Participants must have their own securities in an } \\
\text { account that is separate from those of their clients. Clients' securities records are } \\
\text { kept in an aggregate way in the accounts. Depositors may also request the open- } \\
\text { ing of special accounts, known as mandante accounts, to register clients' securi- } \\
\text { ties in a segregated way. }\end{array}$ \\
\hline & & $\begin{array}{l}\text { Other than keeping the securities at the DCV, investors may choose among } \\
\text { keeping the certificates directly with them (which is common in the case of } \\
\text { individuals), keeping them in custody with the issuing company (which is } \\
\text { frequent in the case of institutions that own control share portfolios of the }\end{array}$ \\
\hline
\end{tabular}


Table 5.9 Custody Arrangements (Continued)

\begin{tabular}{|c|c|c|}
\hline Country & Depository & Custody Arrangements \\
\hline $\begin{array}{l}\text { Chile } \\
\text { (Continued) }\end{array}$ & & $\begin{array}{l}\text { companies and also for individuals), or keeping them in the custody of broker- } \\
\text { dealers and securities agents (which is the case of clients with frequent } \\
\text { transaction activity in exchanges). It is also possible to keep an investor's } \\
\text { securities in custody with a bank or a financial institution authorized to do } \\
\text { so. The options are available to keep the securities in the name of the } \\
\text { investor (by renting a vault or safe deposit box); or to make a transfer to } \\
\text { the name of the custodian agency and register it with the issuing company, } \\
\text { in the case of shares, or through endorsement, in the case of order } \\
\text { securities. }\end{array}$ \\
\hline \multirow[t]{2}{*}{ Colombia } & DCV & $\begin{array}{l}\text { DCV's depository accounts are segregated at the level of the beneficial owner, } \\
\text { thus ensuring the full protection of customers against the claims of any custodian's } \\
\text { (DCV's direct participant) creditors. The protection of customer assets, partic- } \\
\text { ularly against insolvency of custodians, is included in the Code of Commerce } \\
\text { (Article 192). DCV provides to the final investors access information on their hold- } \\
\text { ings via Internet. The most updated information available at any moment is the } \\
\text { situation two days before. Movements of up to two months can be obtained } \\
\text { through Internet. }\end{array}$ \\
\hline & DECEVAL & $\begin{array}{l}\text { DECEVAL's depository accounts are segregated at the level of the beneficial } \\
\text { owner, thus ensuring the full protection of customers against the claims of any } \\
\text { custodian's (DECEVAL's direct participant) creditors. The protection of customer } \\
\text { assets, particularly against insolvency of custodians, is included in the Code of } \\
\text { Commerce (Article 192). DECEVAL provides to the final investors access to infor- } \\
\text { mation on their holdings. }\end{array}$ \\
\hline Costa Rica & CEVAL & $\begin{array}{l}\text { Segregation of accounts in CEVAL exists at the level of the client. Ownership } \\
\text { rights of an investor are clearly defined. An investor who has given his } \\
\text { or her securities in custody is protected by law against the claims of the } \\
\text { creditor of his or her custodians (Article 142). Independent of the form and } \\
\text { the location, securities of clients form no part of custodian assets, stay } \\
\text { outside the available assets after bankruptcy, and cannot be claimed by the } \\
\text { custodian creditors. This is also the case if securities had been deposited for } \\
\text { third parties. This article not only protects securities issued in Costa Rica that } \\
\text { are owned by the investor, but also foreign securities that are kept in custody } \\
\text { by a local custodian. The law not only protects inhabitants of Costa Rica, } \\
\text { but also foreign investors and foreign custodians that use a Costa Rican } \\
\text { local agent. }\end{array}$ \\
\hline Dominican Republic & CEVALDOM & $\begin{array}{l}\text { The legal basis for custody arrangements is included for the CSD but not for other } \\
\text { financial institutions. The social security law obliges the BCRD to have custody of } \\
\text { the securities administered by pension funds. }\end{array}$ \\
\hline Ecuador & $\begin{array}{l}\text { SCT at the } \\
\text { central bank }\end{array}$ & $\begin{array}{l}\text { Most of the securities (around } 75 \text { percent) are deposited in Sistema de Custodia } \\
\text { de Títulos (SCT) operated by the Banco Central del Ecuador. In this system, banks } \\
\text { have opened omnibus accounts. Banks are not obliged in SCT to segregate their } \\
\text { own securities from their client securities. Most of the regulations on depository } \\
\text { and custody refer to DECEVALE and the custodial services of banks and brokers } \\
\text { for their clients. The law does also not explicitly protect the clients of a custodian } \\
\text { who held the securities of this client in SCT, or in a foreign CSD, or by means of a } \\
\text { local agent abroad, against the bankruptcy of the custodian. Whereas the trading } \\
\text { of the securities on the stock exchanges demands the handing over of physical } \\
\text { securities, most of the custody risk in Ecuador stems from the use of physical } \\
\text { securities. }\end{array}$ \\
\hline
\end{tabular}


Table 5.9 Custody Arrangements (Continued)

\begin{tabular}{|c|c|c|}
\hline Country & Depository & Custody Arrangements \\
\hline El Salvador & CEDEVAL & $\begin{array}{l}\text { Securities settlement occurs through CEDEVAL. Securities settlement occurs by } \\
\text { transferring the ownership records at CEDEVAL. Because not all securities are } \\
\text { immobilized, sellers must deliver physical securities to CEDEVAL } 24 \text { hours before } \\
\text { the sale is made. A law for dematerialization of securities was approved in } 2002 \text {. } \\
\text { The law makes it possible for the BCR to be the depository and to maintain the } \\
\text { registry for public securities. Considering that } 80 \text { percent of all transactions in the } \\
\text { securities market are of official securities (treasury and BCR paper), mainly in the } \\
\text { form of short-term repos, the ongoing dematerialization is having an important } \\
\text { impact in the securities settlement. }\end{array}$ \\
\hline Guatemala & Stock exchange & $\begin{array}{l}\text { The securities depository of the Bolsa de Valores Nacional started operating in } \\
\text { 1994. Physical custody of securities deposited in the caja de valores has been } \\
\text { outsourced to a private bank. Custody of securities is formalized by means of } \\
\text { a deposit contract, regulated in the SML (Article 79). Each participant in the deposi- } \\
\text { tory must open his or her own account and an account on behalf of final beneficia- } \\
\text { ries, of which the depository keeps a record. Broker-dealers must send periodic } \\
\text { information to their customers about their accounts statements. The depository } \\
\text { also offers the services of administering economic rights associated to the secu- } \\
\text { rities deposited. }\end{array}$ \\
\hline Honduras & Stock exchanges & $\begin{array}{l}\text { Public securities are issued on a dematerialized form and can be under the } \\
\text { custody of the Banco Central de Honduras or the stock exchange. In the rare } \\
\text { occasion that those securities are traded in the secondary market, it is done } \\
\text { through the physical exchange of custody certificates or at the custodian ser- } \\
\text { vice of the stock exchange. In any case, there is no legal basis for this custody } \\
\text { arrangement, because the commercial law only recognizes securities issued in } \\
\text { physical form. The SML provides the legal support for a CSD and ownership } \\
\text { transfer of securities by book-entry notes through it, but the CSD has not yet } \\
\text { been established. }\end{array}$ \\
\hline Jamaica & $\begin{array}{l}\text { Government } \\
\text { securities / JCSD }\end{array}$ & $\begin{array}{l}\text { Government securities settlement occurs through the physical delivery of the } \\
\text { certificate, with cash settlement occurring either by cheque or by a funds } \\
\text { transfer over the BOJ's customer information funds transfer system. When } \\
\text { government securities are sold, they are delivered with a transfer form so that } \\
\text { they can be reregistered with the ministry of finance. Registration at the min- } \\
\text { istry of finance may take up to two weeks. Jamaican securities markets face } \\
\text { the typical custody risks associated with physical certificates: lost, stolen, and } \\
\text { destroyed securities and the potential fraud associated with those certificates. } \\
\text { In addition, although the law is clear in terms of the segregation of accounts } \\
\text { regarding the JCSD, it is not clear in terms of the custody of securities or funds } \\
\text { by the brokers, although segregation occurs in practice. Repo operations with } \\
\text { government securities (that are all physical, bearer, or registered) do not have } \\
\text { secure legal support, because the primary dealer always keeps the ownership } \\
\text { in the registry of the ministry of finance, and it is uncertain whether the certifi- } \\
\text { cate endorsements in subsequent repo operations can be considered as a } \\
\text { proof of ownership in a court of law. Indeed, there is an agreement between } \\
\text { participants (the Inter-Dealer Master Repurchase Agreement) that the transfer } \\
\text { certificate will be kept, but not used to transfer ownership, in the ministry of } \\
\text { finance registry. }\end{array}$ \\
\hline Mexico & INDEVAL & $\begin{array}{l}\text { Article } 18 \text { of the Ley General de Títulos y Operaciones de Crédito establishes that the } \\
\text { ownership of securities is transferred by transmitting the credit certificate through } \\
\text { which ownership was originally established. However, all securities traded on the } \\
\text { Mexican securities market are deposited and immobilized in INDEVAL. Hence, once } \\
\text { the securities have been deposited, the transfer of ownership legally occurs by }\end{array}$ \\
\hline
\end{tabular}


Table 5.9 Custody Arrangements (Continued)

\begin{tabular}{|c|c|c|}
\hline Country & Depository & Custody Arrangements \\
\hline $\begin{array}{l}\text { Mexico } \\
\text { (Continued) }\end{array}$ & & $\begin{array}{l}\text { transferring ownership from one account to another at the CSD; this does not involve } \\
\text { either physically delivering the asset, or writing a legend on the securities them- } \\
\text { selves, or, when applicable, on the issuer's registry. The certificates representing } \\
\text { nominative shares must be endorsed to INDEVAL for administration. The endorse- } \\
\text { ment enables INDEVAL to justify its securities holdings and to execute the functions } \\
\text { granted by law to CSDs. When the securities are no longer deposited at INDEVAL, } \\
\text { the endorsement no longer affects administration, and these securities become sub- } \\
\text { ject to the regime established in the general commercial law and other applicable } \\
\text { laws. INDEVAL must issue to depositors nonnegotiable letters of proof of ownership } \\
\text { of the deposited securities. These letters are sufficient to demonstrate ownership of } \\
\text { the related securities, to exercise them to attend shareholder meetings, and, in the } \\
\text { case of equities, to permit the issuing company to be included in the registry of } \\
\text { shareholders. These documents also serve to legitimate the execution of those } \\
\text { actions mentioned in Articles } 185 \text { and } 201 \text { of the Commercial Enterprises General } \\
\text { Law, as well as any other action in which it might be necessary to exhibit the securi- } \\
\text { ties held in custody by INDEVAL. }\end{array}$ \\
\hline
\end{tabular}

There are two basic legal frameworks for collateralization: the pledge and securities safekeeping (caución bursátil). In the Ley General de Títulos y Operaciones de Crédito, the pledge refers to credit transactions. When fungible goods or securities are pledged, the pledge prevails if the securities or goods are substituted with others of the same kind. The Ley General de Títulos y Operaciones de Crédito also contains a concept called pledge without ownership transfer. This constitutes a real right over goods; its purpose is to guarantee the fulfilment of an obligation and its seniority for payment, while the debtor retains ownership. This type of pledge can guarantee any obligation. In case of bankruptcy of the debtor, the secured creditor may execute through judicial proceedings the goods with this kind of pledge. Securities safekeeping is described in Article 99 of the SML.

The securities custody service is considered to be of public interest and can be provided by private sector firms only by concession of the federal government. Banco de México, brokerage houses, stock exchange specialists, stock exchanges, banks, and insurance companies can be the sole providers of this service. At the same time, these companies can provide custody services to brokerage houses, stock exchange specialists, stock exchanges, CCPs, banks, insurance firms, mutual funds and their management firms, and foreign financial entities, as well as to other CSDs whose nationality is Mexican or foreign. Central depositories are subject to the inspection and control of CNBV. The SML does not mention explicitly the protection of securities held in custody in case of bankruptcy or insolvency of the custodian. In case of dissolution and liquidation of a CSD, the SML states that the occurrence will be handled according to rules established in the Commercial Firms General Law or, if applicable, to rules established in the Bankruptcy Law. Article 70 of the Bankruptcy Law states that the goods that can be identified as in possession of a firm but whose ownership has not been transferred to it in a legally final and irrevocable way may be separated from the bankruptcy process by the legal owners. Article 71 states that it is possible to separate from the total those goods that, among other circumstances, are in possession of a firm as a deposit or a trust or that were received in administration or consignation. The Bankruptcy Law contains a paragraph dealing with entities providing public goods under concession, as is the case for INDEVAL. The article states that bankruptcy procedures for these kinds of entities are subject to the laws, regulations, concession titles, and other dispositions regulating that specific concession and public service. 
Table 5.9 Custody Arrangements (Continued)

\begin{tabular}{|c|c|c|}
\hline Country & Depository & Custody Arrangements \\
\hline Netherlands Antilles & BvdNa & $\begin{array}{l}\text { The National Ordinance on the Supervision of Investment Institutions and Admin- } \\
\text { istrators became operational in January } 2003 \text {. Some of the main elements on } \\
\text { supervision of investment firms focus on custody arrangements: there must be } \\
\text { separation between the manager of an investment institution and the custodian; } \\
\text { the manager and the custodian must meet fit and proper criteria; and the custodian } \\
\text { must be organized as a legal entity with funds separated from the assets of the } \\
\text { investment institution. }\end{array}$ \\
\hline Nicaragua & CENIVAL & $\begin{array}{l}\text { All public securities are issued in physical form. Subsequent ownership transfers are } \\
\text { done by means of delivery (if bearer securities) or endorsement (if order securities) } \\
\text { or book-entry note in the CENIVAL. In order to be traded at the stock exchange in a } \\
\text { secondary market, securities must be deposited in the CENIVAL. Physical custody of } \\
\text { securities is formalized by means of a deposit contract. Participants endorse their } \\
\text { securities to CENIVAL in order for CENIVAL to make the necessary securities trans- } \\
\text { fers through book entries. The depository also offers the services of administering } \\
\text { economic rights associated to the securities deposited. Regarding the protection of } \\
\text { customer assets in the event of bankruptcy or insolvency of the custodian, each par- } \\
\text { ticipant in the depository must open an own account and an account on behalf of } \\
\text { final beneficiaries, of which the depository keeps a record. In turn, the CENIVAL } \\
\text { keeps the deposited securities in so-called memorandum accounts. However, there } \\
\text { is no specific legal protection for assets under custody for the securities market. }\end{array}$ \\
\hline OECS & ECCSD & $\begin{array}{l}\text { There is uncertainty about the enforceability of security interests provided under col- } \\
\text { lateral arrangements and of any repurchase agreements. The validity of an interest } \\
\text { held by a creditor (including a creditor that is not a regulated financial institution) in } \\
\text { securities pledged or charged as collateral (including securities held in the ECCSD, } \\
\text { and any other collateral pledged across national boundaries), is disputable under the } \\
\text { current laws. So, too, are the rights and the ability of the creditor to quickly realize } \\
\text { that collateral in the event of a default by the debtor. Pledging of securities as collat- } \\
\text { eral is presently being looked at as part of the payment system improvement project. }\end{array}$ \\
\hline Panama & LATINCLEAR & $\begin{array}{l}\text { The SML mandates segregation of accounts of clients. The ownership rights of } \\
\text { an investor are clearly defined. An investor who has given his or her securities in } \\
\text { custody is protected by law against the claims of creditors. Independent of the } \\
\text { form and location, the securities of the clients are not part of the assets of the } \\
\text { custodian, stay outside the available assets after bankruptcy, and cannot be } \\
\text { claimed by the custodian creditors (SML, Articles } 27,37,122,177 \text {, and 179). About } \\
99 \text { percent of securities are dematerialized or immobilized. }\end{array}$ \\
\hline Paraguay & Broker-dealers & $\begin{array}{l}\text { No legal basis for custody arrangements exists. A draft of a securities depository } \\
\text { law was produced soon after the SML was approved, but it has not passed congress. }\end{array}$ \\
\hline Peru & CAVALI & $\begin{array}{l}\text { In terms of clear definition of property rights, Article } 237 \text { of the SML states that, in } \\
\text { case of dissolution or liquidation of the depositories, securities will not be included } \\
\text { in the liquidation process. Changes to the law, approved in 2002, also include full } \\
\text { protection for investors funds held by CAVALI or intermediaries. Securities are } \\
\text { held at the beneficial owner level. The DvP process ensures immediate owner- } \\
\text { ship to buyers after settlement process. By law, CAVALI's registry prevails as } \\
\text { evidence of property. CAVALI provides different mechanisms through which par- } \\
\text { ticipants or investors, or both, can access information about their holdings online. } \\
\text { In addition, investors can check their positions directly via the Internet, provided } \\
\text { they have a signed agreement with CAVALI and the necessary password. }\end{array}$ \\
\hline Trinidad and Tobago & TTCD & $\begin{array}{l}\text { The Companies Act Section 195(1) states that the shares or debentures of a com- } \\
\text { pany may be transferred by a written instrument of transfer signed by the transferor } \\
\text { and by naming the transferee. The transfer of legal ownership of a security, how- } \\
\text { ever, is not effected until the transferee's name is registered in the shareholder's } \\
\text { registry by the issuer. Until the transferee is entered in the shareholder registry, } \\
\text { the transferor is regarded as the legal owner of the security, although the buyer } \\
\text { becomes the beneficial owner at the time a trade is executed. }\end{array}$ \\
\hline
\end{tabular}


Table 5.9 Custody Arrangements (Continued)

\begin{tabular}{|l|l|l}
\hline Country & \multicolumn{1}{|c}{ Depository } & \multicolumn{1}{c}{ Custody Arrangements } \\
\hline Trinidad and Tobago & $\begin{array}{l}\text { The Securities Industry Act of } 1995 \text { contains provision for the transfer of securi- } \\
\text { ties through a clearing facility. Section } 105 \text { of the act states that "the clearing } \\
\text { agency, upon receipt of written instruction and a security certificate from a } \\
\text { participant, is required to deliver the certificate to the issuer and request the } \\
\text { transfer of the securities evidenced by the certificate to the clearing agency. }\end{array}$ \\
$\begin{array}{l}\text { The issuer on receiving notification from the clearing agency has a duty to reg- } \\
\text { ister the transfer, immediately enter the transfer in its securities register, and } \\
\text { deliver to the clearing agency a security certificate representing the securities } \\
\text { and showing the clearing agency as registered owner." The Securities Industry } \\
\text { Act of 1995, Section 108, determines that on receipt of written instructions from } \\
\text { a participant, a clearing agency shall, in accordance with the instructions, } \\
\text { effect a transfer by way of pledge of a security from the participant to the } \\
\text { pledgee. The pledge shall be done by making an entry in the records to block } \\
\text { the account in favor of the pledgee for the amount of the debt, other obligation, } \\
\text { or the number of securities pledged. The clearing agency is not liable for any } \\
\text { loss resulting from compliance with the instructions of a pledgee unless it } \\
\text { knows before the transfer that the pledgee is not entitled to the securities. A } \\
\text { participant has no right to pledge a security held for him by a clearing agency } \\
\text { except through the facilities of the clearing agency. The rules of the proposed } \\
\text { TTCD outline procedures for the pledging of securities. }\end{array}$
\end{tabular}

The Securities Industry Act of 1995 recognizes the right of a person or legal entity to hold property for another in custody or trust relationship. The law also recognizes the fungibility of securities. Apart from the clearing agency, no other entity or person has the right to hold securities for another in custody or trust relationship. Additionally, the Companies Act of 1995 recognizes that a trustee relationship can exist (see Section 148). However, Section 186(1) states that notice of a trust, whether expressed, implied, or constructive, shall not be entered in any register maintained by the company.

\begin{tabular}{|c|c|c|}
\hline \multirow[t]{3}{*}{ Uruguay } & $\begin{array}{l}\text { Stock exchanges- } \\
\text { AGATA }\end{array}$ & $\begin{array}{l}\text { In principle, most public securities are issued in book-entry form. There is a legal } \\
\text { basis for ownership transfer of book-entry (escriturales) for private securities, but } \\
\text { it is uncertain if the SML is applicable to public securities, because Article } 1 \text { seems } \\
\text { to exclude them from the application of the law. }\end{array}$ \\
\hline & & $\begin{array}{l}\text { The protection of custody arrangements is included through the depository contract } \\
\text { regulated by the commercial code. However, protection of custody arrangements } \\
\text { is not included directly in any law or regulation. }\end{array}$ \\
\hline & & $\begin{array}{l}\text { There is currently no supervision of custody arrangements by the BCU or stock } \\
\text { exchanges. }\end{array}$ \\
\hline Venezuela, R.B. de & Central bank CVV & $\begin{array}{l}\text { Regarding public debt, the BCV and the ministry of finance have made great } \\
\text { efforts in the past three years to achieve the complete dematerialization of } \\
\text { government securities. These are registered in book-entry form in the SICET, the } \\
\text { central bank electronic custody system for government securities, and central } \\
\text { bank issues. Banks (universal, commercial, mortgage, and investment), savings } \\
\text { and loans institutions, broker-dealers, and other institutions allowed by the BCV } \\
\text { can be participants (depositors) in this system. There is segregation between the } \\
\text { depositor's own securities and its clients' assets. For fiscal reasons, each deposi- } \\
\text { tor must hold six different omnibus client accounts according to the type of client, } \\
\text { which gives extra statistical information to the system. Therefore, each depositor } \\
\text { registers the beneficial owner; such owners are not known by the system. } \\
\text { Although on an operational basis segregation is used, the customer's assets } \\
\text { might not be clearly protected from a legal point of view against the claims of } \\
\text { depositor's creditors. }\end{array}$ \\
\hline
\end{tabular}


Table 5.9 Custody Arrangements (Continued)

\begin{tabular}{|c|c|c|}
\hline Country & Depository & Custody Arrangements \\
\hline $\begin{array}{l}\text { Venezuela, R.B. de } \\
\text { (Continued) }\end{array}$ & & $\begin{array}{l}\text { Concerning shares and commercial paper traded in the BVC, the physical security } \\
\text { must be deposited and immobilized in the CVV, which may outsource the physical } \\
\text { custody of the securities to an authorized custodian. In this system, a depositor } \\
\text { (depositante) must open an account for its own holdings and a subaccount on } \\
\text { behalf of each of its clients (subcuentista), directly in the CVV, in order to ensure } \\
\text { that securities are registered in the account of the beneficial owner. Segregation } \\
\text { of accounts is therefore implemented, and protection of the customer's assets in } \\
\text { case of bankruptcy of the depositor is legally stated in Article } 17 \text { of the Ley de } \\
\text { Caja de Valores, which states that the owner of the securities deposited in the CVV } \\
\text { will always be the holder of the accounts and subaccounts. Once the securities } \\
\text { are immobilized and registered in the account or subaccount of the beneficial } \\
\text { owner, transmission of ownership is done by means of an electronic transfer } \\
\text { between the accounts or subaccounts opened in the CVV. }\end{array}$ \\
\hline
\end{tabular}

Source: Authors' elaboration.

Note: CEVALDOM (Central de Valores Dominicana).

institutions perform the same function with regard to its participants.

A securities regulator should have the authority to license central clearinghouses and CSDs (system operators) as SROs, and to review and approve their rules. As an SRO, a system operator should have the authority to make and enforce rules on its participants. The securities regulator should have the power to issue the guidelines that system operators should follow. In addition, the securities regulator should ensure that the rules and procedures issued by SROs permit a sound and effective operation of the system, and provide fair access to all market participants. The securities regulator should also have the authority to conduct periodic inspections, require the production of periodic reports, and enforce the securities laws and regulations.

Cooperation between the securities regulator and the central bank, as well as their cooperation with other relevant authorities, is important in achieving the securities regulator and central bank respective policy goals.

\section{Status in the Region}

Table 5.10 includes a brief description of regulatory and oversight issues for each of the countries assessed.

\section{Observations}

Some of the specific problems regarding regulatory and oversight issues follow:
- Some countries do not have any regulatory agency or function over securities settlement other than the SRO role of the stock exchange. This undermines the trust in the system, especially from a foreign investor perspective, and it constitutes an important obstacle for further development of the securities market. This becomes more crucial in some envisaged reforms for the payments system, because liquidity management will become a crucial issue and an important element through the collateralized money market.

- In general, the capacity of the securities regulators regarding securities settlement should be strengthened. Some securities regulators are recently-created institutions whose regulatory capacity for securities settlement should be strengthened. The securities regulator must have the appropriate human and material resources to discharge its functions of supervision of the institutions and the oversight of the SSSs as a whole. If the skills are not in-house, external assistance should be obtained.

- The oversight empowerment for SSSs is missing in some cases. The securities supervisor oversight responsibilities on the SSSs must be strengthened by law. This law must regulate the powers of the securities regulator and authorize it to cooperate with the central bank to issue regulations relating to securities clearing and settlement activities.

- The oversight of a SSS and its participants is normally divided between several regulators (central bank, securities regulator, pension funds regulator, 


\section{Table 5.10 Regulatory and Oversight Issues in SSSs}

Country Regulatory and Oversight lssues

Argentina

The CNV, the national securities supervisor in Argentina, was created by the Public Offering of Securities Act in 1968. It is given broad supervisory authority over securities market activities, including supervising securities market institutions, regulating public offerings of securities, and regulating trading securities issued by private and partially government-owned companies. The CNV also has supervisory authority over SROs, including stock exchanges, stock markets, and CSDs. A secretariat of the ministry of economy is responsible for overseeing the clearing and settlement of primary market transactions that take place on the CRYL system.

Bahamas, The The Securities Act (as amended in 1999) regulates the securities commission and its authority.

Bolivia $\quad$ The SV is the institution in charge of securities markets regulation and supervision (Article 15 of the SML). The securities depositories must be constituted as joint stock companies and their only activity must be the depository function. The SV authorizes the establishment and the legal statutes of the company as established by the SML. The depositories as SROs must develop operational rules that their participants should follow. The stock exchanges are also defined as SROs by the SML, and they develop their internal regulations.

Brazil

The BACEN is responsible for the supervision of financial institutions, oversight of payments and SSSs, and surveillance of some financial markets. Also, the BACEN acts as fiscal agent for the Brazilian government because the national treasury holds an account at the central bank. This account is used to transfer reserves related to treasury transactions. Surveillance of financial markets is also exercised by the CVM, which causes some overlapping with the BACEN oversight functions, especially in the area of securities settlement. Forms of cooperation and information exchange and cooperation exist between payment system overseers.

CBLC is subject to the central bank and the securities commission regulations. SELIC is regulated and overseen by the central bank. BM\&F is currently submitted to central bank and securities commission regulations. Cooperation between the BACEN and the CVM was recently formalized in the area of SSSs.

\section{Chile}

The bodies that regulate the Chilean financial system are the central bank of Chile, the Superintendencia de Valores y Seguros (SVS), the Superintendencia de Administradores de Fondos de Pensiones (SAFP), and the Superintendencia de Bancos e Instituciones Financieras (SBIF), as described below:

- The Central Bank of Chile: This is the institution responsible for issuing rules on the monetary, credit, financial, and international exchange fields; it is also responsible for their monitoring.

- The SVS is the entity charged with regulating and supervising the securities and insurance markets.

- The SAFP is the entity in charge of regulating and supervising the pension fund market and the fund's management companies.

- The SBFI is the organization charged with regulating and supervising the banking system.

The SVS is an autonomous institution, with legal capacity and its own capital, which is related to the government through the ministry of finance. Its duties are the following:

- supervising the issuers and intermediaries of publicly offered securities, the exchanges and their transactions, third-party funds and their managing companies (other than those entrusted by law to other supervisory agencies), insurance and reinsurance companies, open stock corporations, and any other entity or legal person entrusted to the SVS by the laws;

- ensuring that the individuals or institutions being supervised comply with the laws, regulations, bylaws, and other provisions that govern them;

- sanctioning of individuals or entities subject to monitoring by the SVS that infringe the laws, regulations, bylaws, and other rules that govern them, including censure, revenue penalty, cancellation of the registration, or revocation of the authorization for the company to exist; and

- finally, the SVS is the body responsible for requiring that the parties it supervises provide true, full, and timely information about their transactions. with the SV. The SFC supervision and monitoring function in relation to securities markets is to ensure that market agents' operations comply with the regulations and with market fair play. Before initiating operations, the stock exchanges and CSDs must have the authorization of the SFC that includes the approval of the general rules, operating rules, and trading systems. In the case of broker-dealers, the SFC must inspect and supervise them, and must ensure that they are complying with all applicable rules. Among those rules are equity requirements, financial statements disclosure, conflict of interest management, obligation to advise clients, 


\section{Table 5.10 Regulatory and Oversight Issues in SSSs (Continued)}

\begin{tabular}{|c|c|}
\hline Country & Regulatory and Oversight Issues \\
\hline $\begin{array}{l}\text { Colombia } \\
\text { (Continued) }\end{array}$ & $\begin{array}{l}\text { and development of their activities. The stock exchanges are empowered to issue operating and disciplinary } \\
\text { regulations and to establish the requirements to become a member of the exchange. The CSDs must oversee } \\
\text { their depositories' compliance with the depositories' operating rules and the securities market regulation. } \\
\text { The CSDs-DECEVAL and DCV-and the stock exchanges clearinghouses are subject to regulation and } \\
\text { oversight by the SV that, under governmental delegation, is the body responsible for oversight. Oversight is } \\
\text { extended to all market participants. The SFC also regulates subjects defined by law, and promotes and imposes } \\
\text { fines to market participants. The clearing and settlement activities developed by the stock exchanges are } \\
\text { also subject to the supervision and oversight of the SFC. The SFC is empowered to require information from } \\
\text { the issuers and market participants, and to conduct on-site inspections. }\end{array}$ \\
\hline
\end{tabular}

Costa Rica

The Consejo Nacional de Supervisión del Sistema Financiero (CONASSIF) is responsible for issuing all regulations for the financial system, as well as for the overall policies that govern the three supervisory agencies of the financial system. In this regard, Article 169 of the SML states that the Superintendenci General de Entidades Financieras (SUGEF), the Superintendencia General de Valores (SUGEVAL), and the Superintendencia de Pensiones (SUPEN) will all function under the direction of the CONASSIF. The members of CONASSIF are the minister of finance, the president or the general manager of the Banco Central de Costa Rica, and five representatives not holding public sector positions. The SUGEVAL was created by Law 7732 of 1998, the SML; it replaced the former National Securities Commission, which in turn had been created by the previous SML, Law 7201 of 1990. Before the CNV, only the BNV exercised some sort of supervision, although with a selfregulatory character. The SUGEVAL is responsible for supervising broker-dealers, investment funds managing companies, financial groups, and financial and nonfinancial securities issuers. The SUGEVAL is an autonomous entity functioning under the umbrella of the Banco Central de Costa Rica. SUGEVAL is charged with the regulation, supervision, and control of the securities markets. However, its powers are limited by the SML, which confers to the CONASSIF the powers to dictate the rules for authorization, regulation, supervision, control, and surveillance that SUGEVAL and the other supervisory agencies must execute. In this regard, SUGEVAL may propose new regulations to the CONASSIF. The functions of the SUGEVAL are established in Article 3 of the SML. SUGEVAL must watch over the securities markets for transparency, adequate price formation, investor protection, and the necessary disclosure of information. SUGEVAL regulates, supervises, and controls the securities market, the activities of the individuals or firms participating either directly or indirectly in it, and the related actions and contracts determined by law. Regarding securities clearance and settlement, the SUGEVAL sets and supervises the rules regarding the functioning of CSDs, clearance systems, centralized transaction, and information systems for securities transactions. Article 6 of the SML specifically entitles SUGEVAL to regulate the organization and functioning of the Securities and Intermediaries National Registry, including the necessary information and updates, to which all individuals and firms participating either directly or indirectly in the securities market (except for investors) must subscribe. All actions and contracts associated with this market, as well as all public offerings of securities, must be registered in the Securities and Intermediaries National Registry.

Depositories must be authorized by SUGEVAL. Article 134 of the SML gives them also the possibility, together with broker-dealers and entities subject to SUGEF control, to offer custody services, including the administration of economic rights associated with the securities under custody. Articles 119 and 134-143 regulate different aspects of the central depository and custody functions, such as the constitution of a deposit; proof issuance; restitution of securities, bonds, or documents; and depositor protection in case of bankruptcy or insolvency of a custodian. In August 1994, the only CSD in Costa Rica, the CEVAL, was created. Its equity is totally owned by the BNV. Currently, CEVAL administers and performs the clearance and settlement of the securities deposited in it. The regulations of the BNV establish the main characteristics of the CEVAL. Meanwhile, CEVAL's own regulations specify the features of the registry system.

Oversight on SSSs and on the CSD is still to be developed and implemented.

Dominican Republic The superintendency of securities was only established in 2002. Its regulatory and oversight capacity for securities settlement is in the process of being strengthened.

Ecuador

There is an unclear situation in Ecuador with respect to the oversight of SSSs. The securities regulator oversees the DECEVALE, but not the SCT. On the other side, the Banco Central del Ecuador has no clear authority for the oversight of payments and SSSs. 


\section{Table 5.10 Regulatory and Oversight Issues in SSSs (Continued)}

Country Regulatory and Oversight Issues

El Salvador

The SV is the entity in charge of supervising and overseeing the stock market and its participants. This institution began its operations on January 1, 1997, with the stock exchange, brokerage firms, deposit and securities custody firms, and risk-rating firms falling within its limits of supervision. The securities depositories must be approved by the SV; apart from this, however, there is no specific oversight function over securities settlement.

Guatemala

According to the SML, the stock exchanges are SROs with regulatory and supervisory power over their members. There is neither a securities regulator nor any other public agency that performs this role. This function is completely assumed by the stock exchanges in their SRO capacity. Article $18 \mathrm{e}$ of the SML indicates that it is a function of the stock exchange to oversee and ensure that the activity of the broker-dealers and issuers comply with the regulation. Title $\mathrm{V}$ of the internal rules of the stock exchange develops the supervisory role of the stock exchange over the registered entities and broker-dealers. Penalties are included in chapter 3 of title 2.

Honduras

The Comisión Nacional de Bancos y Seguros Law (Ley de la Comisión Nacional de Bancos y Seguros, 1995) defines the institutions under the supervision of the Comisión Nacional de Bancos y Seguros (see Article 6), including entities involved in securities markets. There is no formal oversight over the securities settlement.

Jamaica

The BOJ and the FSC share authority for the regulation and oversight of the securities market and settlement system in Jamaica. Both agencies were created by statute, and report to the ministry of finance and planning. The BOJ derives its authority from the BOJ Act, the Banking Act, and the Financial Institutions Act. It licenses and regulates the activities of commercial banks and merchant banks. The FSC was established by the FSC Act of 2001. Under the FSC Act, the FSC assumed the responsibilities of the previous office of the superintendent of insurance, the securities commission, and the pension fund regulator. Accordingly, the supervision of nonbanking and non-deposit-taking institutions (insurance companies; pension funds; and securities and collective investment funds) are the responsibility of one entity. In order to supervise each industry, the FSC administers the Securities Act, Insurance Act, and the Unit Trust Act.

With regard to the Jamaican SSS, the Securities Act authorizes the FSC to license the JCSD and approve the rule changed by the JSE and JCSD. In addition, under the Securities (Conduct of Business) Regulations, 1999, broker-dealers are required to comply with standards for internal organization and operational conduct designed to protect the interests of clients, and to ensure the proper management of risk. These requirements include

- determining the credit worthiness of the client;

- ensuring that the client completes a request for proposal;

- ensuring that the request clearly states the level of authority being given to the portfolio manager by the client; and

- ensuring that the request clearly sets out the risk tolerances of the client.

Through a memorandum of understanding, a forum has been established for the FSC, the BOJ, and other Jamaican financial services regulators to meet and share information. However, Sections 15 and 16 of the FSC Act, 2001, limit disclosures to foreign regulators.

\section{Mexico} According to Article 8 of the SML, SHCP is responsible for the interpretation, in administrative terms, of the SML. SHCP must provide, through general dispositions, everything that is needed for the law's full application. SHCP executes its functions in this area once it hears CNBV's opinion. CNBV issues the prudential regulations and general dispositions that entities have to follow, and is in charge of their supervision. More specifically, CNBV supervises and regulates financial entities to ensure their overall stability and proper functioning as well as to maintain and foster a healthy and balanced development of the financial system as a whole, protecting the public interests. Financial group holding companies, banks, brokerage houses, market specialists, stock exchanges, CSDs, and risk-rating firms, among others, are all considered financial entities for these purposes.

A concession is required to create an exchange. The concession is granted discretionally by SHCP once it hears the opinions of Banco de México and CNBV. The Incorporation Act and stock exchange bylaws and their modifications need to be approved by SHCP. Once this approval has been obtained, the stock exchange can be registered in the Public Registry of Trade. Article 37 of the SML states that stock exchanges must elaborate a set of internal regulations that include the self-regulatory rules applicable to the stock exchange itself, brokerage houses, and stock market specialists; the process for their adoption and supervision; the disciplinary and corrective measures that will be applied in case of failure to comply; and the procedures to apply these measures. These regulations and any modifications must be authorized by CNBV.

In more general terms, CNBV is responsible for verifying compliance with the rules regulating stock exchange activity, and with self-regulatory rules, financial statements, assessment of trading system management, and confirmation of the dissemination of information to the market. 


\section{Table 5.10 Regulatory and Oversight Issues in SSSs (Continued)}

Country Regulatory and Oversight Issues

Mexico

(Continued)
The SML states that the services of custody, administration, clearance, settlement, and transfer of securities are of public interest. These services can only be provided by entities obtaining a concession from SHCP, once it hears the opinion of CNBV. Among other functions, CSDs are empowered to carry out depository functions; administer the deposited securities; and transfer, clear, and settle transactions made with the deposited securities. Article 58 of the SML states that CSDs are subject to inspection and surveillance by CNBV, to which they must provide all the necessary information and documents. More specifically, CNBV has powers regarding CSDs;

- to authorize the accounting records and issue the rules for grouping accounts and for registering operations:

- to issue general rules to which CSDs are subject according to the application of their equity; and

- to order inspection visits to CSDs. If applicable, CNBV is empowered to intervene in these institutions for the purpose of suspending, normalizing, or settling those operations that may endanger their solvency, stability, or liquidity, or those that violate the law or the general rules deriving from it.

Article 60 of the SML states that CSDs must elaborate a set of internal regulations that include, among others, rules applicable to the delivery and withdrawal of deposited securities, physical custody and administration of deposited securities; procedures for the transfer, clearance, and settlement of deposited securities; procedures for the execution of ownership rights; and procedures for the handling of settlement defaults and sanctions. The internal regulations and subsequent modifications must be approved jointly by CNBV and Banco de México.

The provision of CCPs is of public interest and can only be performed by companies that obtain a concession from SHCP, once it hears the opinions of Banco de México and CNBV. CCPs are subject to the inspection and surveillance of CNBV. The powers of CNBV over CCPs are the same ones detailed in Article 58 of the SML (that is, those applicable to CSDs).

Article 89 Bis 7 of the SML establishes the minimum requirements for the internal regulations that CCPs must elaborate. These minimum requirements include the requirements that the intermediaries must meet at all times so that the CCPs may act as reciprocal debtor and creditor; the procedures and systems through which the operations will be cleared and settled; and the systems of financial safeguards and operational, prudential, and self-regulatory rules applicable to the CCP and its reciprocal debtors and creditors. The internal regulations and any modifications to them are subject to authorization of Banco de México and CNBV, except for self-regulatory rules, over which these authorities may exercise veto power.

Article 125 of the SML considers as SROs stock exchanges, CCPs, associations of securities market intermediaries, and associations of providers of services linked to the securities market. Article 126 establishes that SROs are subject to the supervision and surveillance of CNBV for concerns with compliance with the selfregulatory rules they have issued.

The functions of stock exchanges include establishing the necessary measures so that the transactions that brokerage houses or stock market specialists execute on their premises conform with the applicable rules. As mentioned, Article 37 of the SML states that stock exchanges must include in their internal regulations the self-regulatory rules applicable to the stock exchange itself, brokerage houses, and stock market specialists; the process for their adoption and supervision; the disciplinary and corrective measurements that will be applied in case of failure to comply; and the procedure for applying these measures effectively. The self-regulatory rules do not require the previous authorization of CNBV. Nevertheless, CNBV has veto power over them.

The current internal regulations of BMV were authorized by CNBV on September 27, 1999, and became effective on October 25, 1999. Regarding supervision of its internal activities, the regulation includes detailed rules on aspects such as admission criteria; obligations of members, operators, and issuers; transaction fulfilment; surveillance; preventive measures; and sanctions.

The INDEVAL regulation was authorized by CNBV on December 22, 1995, and since then it has changed. Moreover, INDEVAL has developed an operations manual for the services it offers, which details the requirements to participate and execute operations in its system. Failure to comply with the dispositions in the operations manual is considered a violation of the regulation; offenders are subject to the penalties described in the regulation. 


\section{Table 5.10 Regulatory and Oversight Issues in SSSs (Continued)}

\begin{tabular}{l|l} 
Country & \multicolumn{1}{c}{ Regulatory and Oversight lssues } \\
\hline Netherlands Antilles & $\begin{array}{l}\text { There is no designated legal framework for the securities market or for the settlement of securities transac- } \\
\text { tions. Supervision of investment institutions was recently introduced when the National Ordinance on the } \\
\text { Supervision of Investment Institutions and Administrators became operational in January } 2003 .\end{array}$
\end{tabular}

Nicaragua $\quad$ The stock exchange, the depository (or depositories), and broker-dealers are all regulated by the Superintendencia de Bancos y Otras Instituciones Financieras (SBOIF), but only on the basis of the banking law.

The SML draft gives self-regulatory powers to the stock exchange (Articles 39 and 123). In this draft, depositories are to be authorized by the SBOIF according to some of the requirements set forth in the banking law. Depositories are not considered SROs in the SML draft.

The Eastern Caribbean Securities Regulatory Commission (ECSRC) is the regulatory authority, charged under the Securities Act, with full and ultimate responsibility for the safe and sound operation of the market and for investor protection. It has the objectives

- to license persons engaged in securities business and to monitor and supervise the conduct of such business by a licensee;

- to ensure investor protection through promotion of the highest standards of professional and other activities within the securities market;

- to maintain effective compliance and enforcement programs supported by adequate statutory powers; and

- to promote the growth and development of the capital market.

All public companies within the region have to reregister with the ECSRC. Similarly, all new companies wishing to raise capital through a public offering will also need to register with the ECSRC. The corporate securities market is regulated by the ECSRC. The Regional Debt Coordinating Committee (RDCC) regulates the Regional Government Securities Market with support from the ECSRC. The ECCB provides technical and administrative support to the commission, which has been formalized under the terms of a memorandum of understanding. Under this arrangement, the ECCB provides a technical secretariat within its bank supervision department to handle the day-to-day operations of the ECSRC and to assist the commissioners in carrying out their mandate.

The powers and responsibilities of the securities commission are stated in Articles 4 through 6 of the agreement, and are enumerated in detail in the Securities Act with regard to licensing; approval of rules; suspension and revocation; the ability to issue directions; the ability to call for information, inspection, and investigation; and dispute settlement. The commission is accountable to the monetary council of the ECCB under Articles 12 and 16 of the agreement. These articles set out the procedures for appointment, remuneration, and removal. Publication of appointment is to be carried out by publication in the gazette, and notice of removal is given to the participating government or public body that nominated the commissioner. By virtue of the common law system, judicial review of the decisions of bodies such as the commission exists. Amendments have been drafted to allow for appeal of commission decisions to a disciplinary committee; those amendments explicitly provide for judicial review of that tribunal. These amendments have already been enacted in St Kitts and Nevis and in Grenada.

Regulators should:

- conduct direct supervision of clearing and settlement systems and their operators; and

- require a framework that permits them to ensure the accountability of such systems, to monitor and, if possible, predict and prevent problems associated with clearing and settlement through (1) review of system mechanisms and establishment of operating standards; (2) the power to issue mandatory directions; and (3) inspection and periodic review.

Also, the clearing agency has a duty to assist the commission. There is an element of periodic review under Sections 27-29 of the Securities Act, which provide for mandatory review of proposed amendments to rules by the commission; mandatory reporting of proposed alteration to or the occurrence of any event that affects or may affect in a material respect information supplied to the commission, or any matter in respect of which the clearing agency was required to supply information to the commission. Clearing and settlement organizations should be required to make reports to the regulator, and may be required to submit to periodic and, if necessary, special audits and examinations. Securities Act Section 150 can be used for commissioning special audits or examinations. 


\section{Table 5.10 Regulatory and Oversight Issues in SSSs (Continued)}

\begin{tabular}{l|l} 
Country & \multicolumn{1}{c}{ Regulatory and Oversight Issues } \\
(Continued) & The ECSE is the sole SRO in the Eastern Caribbean Currency Union securities market. Membership criteria is \\
established and assessed by the ECSE, which also defines rules of conduct with which its members shall \\
comply in the relationships with their customers, to ensure transparency and fairness in the performance of \\
their activity. To this end, communication of securities exchange members with the public is based on the \\
principles of fairness and good faith.
\end{tabular}

Panama

CNV is an autonomous entity, responsible for issuing all regulations for the securities market based on the principles of the Decree-Law 1, 1999. BVP and LATINCLEAR are SROs who have the capacity to issue and enforce regulations. CNV is responsible for supervising market participants (broker-dealers, investment societies, securities issuers, and SROs). Broker-dealers, investment societies, and SROs must be authorized by SUGEVAL. Articles 27, 56, and 122 of the SML regulate the conditions for the provision of custody services, including the administration of economic rights associated with the securities under custody. Title 11, chapters 1,2, and 3, regulate different aspects of the central depository and custody functions, such as the constitution of a deposit; proof issuance; restitution of securities, bonds, or documents; and depositor protection in case of bankruptcy or insolvency of a custodian.

Paraguay

The CNV is the regulatory body for securities in the country. The CNV has broad empowerment over securities markets, including monitoring of public offers and trading of public and private securities. The CNV also is empowered to supervise the SROs (the stock exchanges and depositories).

Peru

The CONASEV has supervisory responsibility over stock exchanges (BVL), the depository (CAVALI), the broker-dealers, the issuers, and other institutions participating in the clearing and settlement process. Although the main supervisory responsibility for banks and insurance companies falls on the Superintendencia de Banca y Seguros (SBS), CONASEV is also responsible for supervising these institutions in those activities related to securities clearing and settlement. For this reason, CONASEV also supervises the custodians and settlement banks. The general supervisory powers granted by law to CONASEV must be understood in the context of a self-regulating concept of securities market supervision. The BVL bylaws, its internal regulations, and its modifications require CONASEV's prior approval. In this sense, without excluding CONASEV from having its own supervision systems for the BVL supervision, the SML grants the BVL self-regulating powers with regard to its members. The authorization for the depositories' operation, and therefore for CAVALI's operation, must be granted by CONASEV, according to provisions of the SML and depositories' regulations. The depositories' regulations empower CAVALI to develop its own internal regulations and related rules. Furthermore, it grants the institution in charge of the clearing and settlement the supervision of its participants and the power to sanction them if they do not observe the appropriate rules. CAVALI internal rules, which consist of 13 chapters, were first approved in 2003. Any changes to CAVALI's rules must be approved by CONASEV; any changes must be exposed to the market for at least 10 working days to receive opinions from interested parties.

Since its recent access to an account at the central bank, CAVALI is also subject to a central bank disposition on all issues related to the settlement processes that use the RTGS system.

Trinidad and Tobago

The SEC is established by the government but operates independently. The Securities Industry Act of 1995 provides for the appointment of no fewer than three and no more than five commissioners to the board of the SEC. The Securities Industry Act, 1995, Section 9(2), states that the commissioners are to be selected from among persons with "wide experience and ability in legal, financial, business or administrative matters, one of whom shall be an attorney-at-law of at least 10 years' standing." The present board consists of five commissioners.

In general, the SEC is charged with the responsibility of ensuring that market actors comply with the provisions of the Securities Industry Act, 1995, and the accompanying regulations, the Securities Industry Bylaws, 1997. In particular, Section 6 of the act vests the SEC with wide-ranging powers.

Furthermore, all securities clearing agencies are required to register with the SEC. The SEC is responsible for determining the broad framework under which the clearing agency will operate. In addition, the SEC:

- reviews the rules of a clearing agency prior to granting approval for registration;

- may make an order requiring a change in the rules of the clearing agency;

- oversees and regulates the activities of the clearing agency; and

- has rule-making powers and can prescribe bylaws to effect the operations of the clearing agency. 


\section{Table 5.10 Regulatory and Oversight Issues in SSSs (Continued)}

\section{Country}

Trinidad and Tobago (Continued)
Regulatory and Oversight Issues
The SEC has the responsibility of maintaining surveillance over the securities market and ensures orderly, fair, and equitable dealings in securities. In particular, the SEC has the authority to review and approve rules of clearance and settlement facilities. The clearing agency is also required to submit all proposed amendments to the SEC for approval. The SEC has the power to require changes in the rules of any SRO that are necessary to bring the rules into conformity with the requirements of the Securities Industry Act. The central bank is not required to register with the SEC. Its activities are governed by the provisions of the Central Bank Act Chapter 79:02 and its amendments.

According to the Securities Industry Act, Section 36 , no person shall carry on business as a securities exchange or clearing agency or carry on activities as an association of securities companies unless registered as an SRO under the law. All SROs must register with the SEC before starting their activities.

In the case of an applicant for registration as a clearing agency, the rules to be submitted for the SEC's consideration must contain provisions designed to develop and operate a prompt and accurate clearance and settlement system; to safeguard money and securities in its custody or under its control or for which it is responsible; and to provide that a securities company, a financial institution, another clearing agency, or a person or class of persons designated by the SEC may become a participant in the clearing agency.

Amendments of SROs' rules must also be submitted for the SEC's consideration and approval. The SEC can make an order requiring changes in the rules of the SROs to ensure fair administration, or to make the rules conform to the requirements of the Securities Industry Act.

SROs have supervisory and statutory responsibilities over their members and participants. In particular, an SRO may refuse membership or impose conditions on membership or prohibit or limit access to services furnished by it or its members in the specific cases established in Section 43 of the Securities Industry Act (lack of financial responsibility, not meeting the criteria required, not carrying the type of business specified, lack of training, or contravention of the law).

Uruguay

The BCU (Gerencia de Valores) supervises securities institutions under its jurisdiction, but has not developed a securities settlement oversight function, for which it lacks adequate resources. This activity is in part undertaken in a limited way through the stock exchange in its SRO capacity.

Venezuela, R.B. de
The securities regulator in the República Bolivariana de Venezuela, CNV, is charged in the Capital Market Law with the authority to oversee stock exchanges and CSDs outside the central bank. As stated by the CSD Law, Article 2, the CNV must authorize the creation, functioning, and control of CSDs, and must oversee its activities. The CNV is also the competent authority to carry out the supervision of the activities of brokerdealers, their accounts, and those broker-dealers maintain on behalf of their clients in the CVV, the SICET, and in any other national or foreign custody system in which the broker-dealer might hold an account.

The CNV, as the securities markets regulator and according to its functions stated in Article 9 of the Ley del Mercado de Capitales, has to authorize the internal rules and regulations of stocks exchanges, as well as their modifications. The CNV has the same functions over CSDs' regulations (Article 16 of Normas relativas a la Organización y Funcionamiento de las Cajas de Valores). As a result, the CNV must certify that the internal regulations of the BCV and the CVV are updated.

The Central Bank of the República Bolivariana de Venezuela is the owner of SICET (the electronic custody system for government securities). It is in charge of its smooth functioning and must monitor its performance.

The Superintendencia de Bancos y Otras Instituciones Financieras (SUDEBAN), as the authority responsible for the supervision of banks and other financial institutions, supervises the banks that are involved in the SSS, either as participants in the CVV and SICET, as custodians, or as settlement banks. Most of the holdings of public debt are registered in the accounts that banks and other financial institutions have in SICET, which means that the verification of customers' holdings of public debt is mainly in the hands of SUDEBAN. As regards banks that participate in the CVV, SUDEBAN is the competent authority to guarantee that the client's holdings are properly accounted for. All the payments associated with transactions of shares and Vebonos, which take place in BCV, are settled in a private bank, Banco Provincial. The supervisor must take this fact into account in its task of oversight. 
and so on) that should cooperate in the oversight of the SSSs. Potential conflicts between the roles of the central banks as operator and overseer of SSSs should be addressed by appropriate internal organizational arrangements. Cooperation could be through a framework (for example, a memorandum of understanding) or other formal agreement between the parties.

- In sum, securities settlement oversight should be institutionally strengthened by devoting adequate resources and establishing an effective cooperative framework with other regulators, SROs, and the private sector.

\section{CSDS' ORGANIZATIONAL ARRANGEMENTS}

This section includes context, status in the region, and observations regarding CSD's organizational arrangements.

\section{Context}

It is widely accepted that a securities market should be supported by the CSD with the broadest possible industry participation. Admission should be open to all qualified market participants needing access to the CSD. ${ }^{4}$

Membership standards for system operators should be established to minimize risk. Certain minimum standards of financial responsibility, operational capacity (including system security and integrity), experience, and competence should be prescribed for participation in the systems. Mandatory capital requirements for participants are the first safety net to mitigate against a participant failure and, thus, an important risk management tool. However, these requirements are frequently established for reasons other than clearance and settlement and a system operator should have the authority to impose higher financial standards on its members or participants if the general requirements do not adequately cover the perceived risks.

The rules for clearing and depository organizations should avoid unfair discrimination with regard to the admission of participants or among participants in the use of the system. The rules should provide fair procedures for review of decisions concerning denials of access. In addition, the system should provide participants with a meaningful opportunity to participate in the administration of the organization's affairs.

\footnotetext{
${ }^{4}$ The cost is an important element to consider in order to avoid an unfair situation for the minority investor. In any case, transactions cost per unit should be clearly identified.
}

CSDs and CCPs sit at the heart of the settlement process as in many cases they are the sole providers of services to the markets they serve. Thus, their performance is a critical determinant of the safety and efficiency of those markets. Therefore, their performance is a matter of public as well as private interest. In addition, there may be other providers of services (for example, trade comparison, or messaging services) whose performance is also critical to the functioning of some markets. The governance arrangements of any critical service providers should also be consistent with this recommendation.

No single set of governance arrangements is appropriate for all institutions within the various securities markets and regulatory schemes. However, an effectively governed institution should meet certain basic requirements. Governance arrangements should be clearly articulated, coherent, comprehensible, and fully transparent. Governance arrangements should therefore seek to minimize the conflicts between the objectives of owners, users, and other interested parties, and as far as possible should seek to resolve remaining conflicts.

Financial markets operate most efficiently when participants have access to relevant information concerning the risks to which they are exposed; therefore, financial markets participants can take actions to manage those risks. The need for transparency applies to the entities that form the clearing, settlement, and custodial infrastructure of the securities markets. Informed market participants are better able to evaluate the costs and risks to which they are exposed because of participation in the system. Relevant information should be accessible to market participants. Information should be current and available in formats that meet the needs of users.

\section{Status in the Region}

Table 5.11 includes a brief description of CSDs' organizational arrangements for settlement systems in each of the countries assessed.

\section{Observations}

Some of the specific problems regarding CSDs organizational arrangements follow:

- In general, governance arrangements are adequate, but in some cases it is not clear whether they prevent potential conflict of interests. These aspects should be 
Table 5.11 CSDs' Organizational Arrangements

\begin{tabular}{|c|c|c|}
\hline Country & Depository & CSD's Organizational Arrangements \\
\hline Argentina & Caja de valores & $\begin{array}{l}\text { Securities market SROs, such as Merval, MAE, and the caja de valores, have as } \\
\text { part of their statutory supervisory responsibilities over their members the right to } \\
\text { refuse or impose conditions on membership, and to prohibit or limit access to ser- } \\
\text { vices provided. Members of the caja de valores' board of directors are elected by } \\
\text { stock exchanges and securities markets, which are the caja de valores' share- } \\
\text { holders. Securities markets represent brokers nationwide. Stock exchanges, } \\
\text { through their respective boards of governors, represent every section of the } \\
\text { country's financial, industrial, and commercial activity. The voting position at the } \\
\text { board is split between stock exchanges and securities markets, } 50 \text { percent each. } \\
\text { Caja de valores issues circulars and newsletters reporting the rules that regulate } \\
\text { the activity of participants, as well as the various corporate events that are con- } \\
\text { ducted by issuers. Caja de valores has an up-to-date, comprehensive Web site, } \\
\text { containing all its circulars and newsletters, as well as its financial statements. } \\
\text { The depository publishes an annual report detailing its actions and plans, as well } \\
\text { as its financial statements. }\end{array}$ \\
\hline Bahamas, The & - & There is no securities depository. \\
\hline Bolivia & EDV & $\begin{array}{l}\text { The EDV was established in } 2002 \text { and began the dematerialization process } \\
\text { of all outstanding securities in } 2004 \text {. The EDV fully initiated operations } \\
\text { (including the clearing and settlement of transactions with dematerialized } \\
\text { securities) in } 2005 \text {. }\end{array}$ \\
\hline Brazil & CBLC & $\begin{array}{l}\text { CBLC is a for-profit company, organized as a corporation, owned by } 86 \text { share- } \\
\text { holders, most of which are banks and brokerage firms. CBLC's board of direc- } \\
\text { tors comprises seven permanent representatives of its shareholders: two } \\
\text { representatives from the full clearing agents category, two representatives } \\
\text { from the self-clearing agents category, two representatives from BOVESPA, } \\
\text { and the CEO. The executive responsibilities are divided into three areas: } \\
\text { operations, risk management, and products and services. Clearing member- } \\
\text { ship criteria are well and clearly established in CBLC's rules and procedures } \\
\text { (available on CBLC's Web site at www.cblc.com.br). Specific capital require- } \\
\text { ments apply, depending on the comprehensiveness of participants' activities- } \\
\text { for instance, if they are rendering services for their own customers or to other } \\
\text { financial institutions. } \\
\text { CBLC provides the market with information through different means: } \\
\text { - As a corporation, CBLC is obliged by law to publish its financial balances } \\
\text { periodically. } \\
\text { - CBLC is audited both by market authorities and by independent auditors at least } \\
\text { twice a year. } \\
\text { " CBLC bylaws as well as its rules and operational procedures are available on } \\
\text { its Web site. } \\
\text { - CBLC has authorized the publication of its answers to international question- } \\
\text { naires, such as the International Services Securities Association, the Associa- } \\
\text { tion of Global Custodians (AGC), and the International Federation of Stock } \\
\text { Exchanges. } \\
\text { - Through the RiskWatch system, clearing agents have access to all information } \\
\text { related to their risk and their customers' risk. Through a special tool of RiskWatch, } \\
\text { they can make simulations to assess the impact of a specific operation on their } \\
\text { risk exposure. For the Theoretical Intermarket Margin System (TIMS)-the } \\
\text { margin system for derivatives and securities lending contracts-the same is } \\
\text { applicable. } \\
\text { begarding its clearing services, CBLC issues reports on clearing members and } \\
\text { brokers' positions since trade execution. }\end{array}$ \\
\hline
\end{tabular}


Table 5.11 CSDs' Organizational Arrangements (Continued)

\begin{tabular}{|l|l}
\hline Country & \multicolumn{1}{c}{ CSD's Organizational Arrangements } \\
\hline $\begin{array}{l}\text { Brazil } \\
\text { (Continued) }\end{array}$ & Bepository \\
& limits in real time. \\
& Regarding its depository service, CBLC issues monthly statements directly to \\
& investors at their home addresses. Investors can also check on their holdings \\
& through the Internet, provided they have the password that CBLC assigns and \\
& mails directly to them; they can also check by facsimile.
\end{tabular}

SELIC

SELIC is managed by the central bank's open market operations department. SELIC access and exclusion criteria are publicly disclosed. SELIC participants include the BACEN itself, the national treasury (through the BACEN), and financial and other institutions authorized to operate by the central bank. A distinction is made between settling participants and nonsettling participants, depending on whether or not they hold bank reserves accounts. Institutions holding bank reserves accounts may take part in SELIC and are responsible for making their own financial settlement to third parties and institutions that do not hold such an account. The latter may only operate on SELIC by obtaining a credit limit from a settling participant or through the brokerage account, acting as intermediaries. There is a credit limit up to which a participant accepts responsibility for entries made in its bank reserves account by a nonsettling participant.

The BM\&F clearinghouses integrate into BM\&F's administrative structure. The exchange's most authoritative body is its general meeting; it is managed by an administrative council (Board of Governors) — through a general director-comprising 17 council members and four substitutes. These are elected by the annual general meeting, except for the general director who is an ex officio member, and representatives of the honorary member indicated by it. Council members who have been elected or nominated have a term of office of three years, and substitutes have a term of office of one year; both are eligible for reelection or renomination. The council will designate from among its members those who will hold the positions of president and vice president, with a term of office of one year, with reelection permitted. Ordinary meetings will take place at least once a month, and extraordinary meetings will be held whenever called by the president or seven council members. Among its other attributions, the administrative council will establish the BM\&F's general policy and ensure its execution, being also responsible for nominating the director general and supervising his or her management. The latter's role is to execute the council's policy and decisions with the exchange's executive body under his or her direction; the executive body is made up of 14 directors. The main decisions relating to risk management are taken by the BM\&F's administrative council, the director general, and the risk committee.

Derivatives and securities clearing participants fall into two categories: (1) direct, when they take part in the chain of liabilities in the settlement of transactions processed in the clearing; and (2) indirect-that is, other entities or institutions that provide services that are instrumental for the activities carried out by the clearing.

The main features of the direct and constituent participants are as follows:

- Clearing members (CMs): Exclusive participants that access the clearinghouses' services of clearing, settlement, and provision of guarantees. They settle transactions for their own account and the accounts of their clients (commodity brokers, special operators and securities trading participants), and are responsible for them to the clearing, which in its turn acts as guarantor of the net multilateral settlement made between its CMs.

- Commodity brokers: Participants with direct access to the BM\&F's trading systems. They work for their own account or that of their clients, using the services of the clearing, with $\mathrm{CM}$ acting as intermediaries. 
Table 5.11 CSDs' Organizational Arrangements (Continued)

\begin{tabular}{|c|c|c|}
\hline Country & Depository & CSD's Organizational Arrangements \\
\hline \multirow[t]{3}{*}{$\begin{array}{l}\text { Brazil } \\
\text { (Continued) }\end{array}$} & & $\begin{array}{l}\text { - Participants with direct settlement: Clearing members with the right to direct } \\
\text { access to the trading session viva voce, through the commodities brokering desk. } \\
\text { Special operators: Participants with direct access to the BM\&F's trading systems. } \\
\text { They operate only for their own account, using the services of the clearing with } \\
\text { CMs acting as intermediaries. } \\
\text { - Constituents: Final clients that access the BM\&F's markets through the com- } \\
\text { modity broker, acting as intermediaries, and are responsible to the CM for all } \\
\text { their clients' transactions. } \\
\text { - Securities trading participants: Financial institutions authorized by the central } \\
\text { bank to conduct transactions and intermediation in the government securities } \\
\text { market. } \\
\text { - Centralized settlement participants: Participants that trade through a securities } \\
\text { trading participant but are allowed to settle directly with the Securities Clear- } \\
\text { inghouse. This kind of participant was specifically designed to cater for domes- } \\
\text { tic investment and pension funds. } \\
\text { - Settling banks: Banks holding bank reserves accounts with the central bank. } \\
\text { They provide the financial settlement service for the CMs. }\end{array}$ \\
\hline & & $\begin{array}{l}\text { BM\&F provides accurate information on risks and costs associated with its use } \\
\text { to market participants in several forms, including the publicly available Web site. }\end{array}$ \\
\hline & CETIP & $\begin{array}{l}\text { CETIP is a nonprofit organization providing a public service to the financial com- } \\
\text { munity. Eligibility for membership is regulated by the central bank's regulation } \\
\text { manual. }\end{array}$ \\
\hline Chile & DCV & $\begin{array}{l}\text { Law 18,876 (Securities Depository and Custody) governs the constitution of pri- } \\
\text { vate organizations for securities deposits and custody. It establishes that these } \\
\text { entities must have as their exclusive corporate purpose to receive in deposit } \\
\text { publicly offered securities and to facilitate their transfer operations. The SVS } \\
\text { authorized the creation of the DCV and approved its statutes, internal regula- } \\
\text { tions, and the deposit contract to be used. At the DCV, accounts may be opened } \\
\text { by securities intermediaries (broker-dealers and securities agents), by other } \\
\text { institutions participating in the financial system (banks; AFPs; Administradoras } \\
\text { de Fondods de Valores, AFV; Administradoras de Fondos Mutuos, AFM; } \\
\text { exchanges; insurance companies; general insurance companies; reinsurance } \\
\text { companies; investment funds; and foreign capital investment funds), nonfinan- } \\
\text { cial companies, and all others authorized by the DCV. Ownership of the DCV is } \\
\text { shared among the Sociedad Interbancaria de Depósito de Valores, owned by } \\
\text { banks and financial societies ( } 30 \text { percent); Inversiones DCV S.A., owned by AFPs } \\
\text { (30 percent); the Bolsa de Comercio de Santiago, DCV Vida S.A., owned by Life } \\
\text { Insurance Companies (10 percent); Inversiones Bursátiles S.A., owned by Bolsa } \\
\text { Electrónica de Chile (6 percent); and the Bolsa de Corredores de Valparaíso and } \\
\text { other minority shareholders (1 percent). }\end{array}$ \\
\hline \multirow[t]{2}{*}{ Colombia } & DCV & $\begin{array}{l}\text { DCV direct participants are banks, financial corporations, fiduciary societies, } \\
\text { stock exchanges, broker-dealers, pension funds, public entities, and CSDs. Indi- } \\
\text { rect participants are direct investors. The board of governors of the BR, that rules } \\
\text { DCV, has disclosed criteria that allow fair and open access to their systems. } \\
\text { There is no daily operative limit for transactions carried out by broker-dealers in } \\
\text { relation to their capital. DCV is not a private society, but a service provided by the } \\
\text { BR. DCV provides adequate information to its participants. }\end{array}$ \\
\hline & DECEVAL & $\begin{array}{l}\text { DECEVAL is a private company owned by the banks, stock exchanges, fiduciary } \\
\text { societies, financial corporations, saving and housing corporations, the banking } \\
\text { association, and broker-dealers. DECEVAL participation is open to a wide range of } \\
\text { entities: credit entities, stock exchanges, brokers, financial services companies, } \\
\text { capitalization companies, insurance companies, pension fund companies, and some }\end{array}$ \\
\hline
\end{tabular}


Table 5.11 CSDs' Organizational Arrangements (Continued)

\begin{tabular}{|c|c|c|}
\hline Country & Depository & CSD's Organizational Arrangements \\
\hline $\begin{array}{l}\text { Colombia } \\
\text { (Continued) }\end{array}$ & & $\begin{array}{l}\text { public companies. Participants pay a predetermined fee for its services. The board } \\
\text { of directors of DECEVAL has disclosed criteria that allow fair and open access to } \\
\text { their systems. There is no daily operative limit for transactions carried out by broker- } \\
\text { dealers in relation to their capital. DECEVAL provides adequate information to its } \\
\text { shareholders. }\end{array}$ \\
\hline \multirow[t]{3}{*}{ Costa Rica } & \multirow[t]{3}{*}{ CEVAL } & $\begin{array}{l}\text { Currently, only brokerage houses, with the exception indicated below, can open } \\
\text { an account in CEVAL; for this reason, they have a monopoly on custodial ser- } \\
\text { vices. Brokerage house accounts are segregated in own accounts and clients' } \\
\text { accounts. Also, banks and pension funds have their own accounts at CEVAL; } \\
\text { securities in these accounts, however, can only be traded if they are transferred } \\
\text { to a broker's account or to the Mercado Interbancario de Dinero (MIB) account } \\
\text { in the case of the interbank market. In the present governance structure, brokers, } \\
\text { as owners of the stock exchange, dominate the policy with respect to trading, } \\
\text { custody, clearing, and settlement. It is sometimes difficult to change the situation } \\
\text { separating money markets and capital markets. }\end{array}$ \\
\hline & & $\begin{array}{l}\text { All brokerage houses that fulfill the legal capital requirements of } 50 \text { million Costa } \\
\text { Rican colones (Article } 54 \text { of the SML) have access to the settlement systems. This } \\
\text { capital requirement allows for fair and open access to the settlement systems. In } \\
\text { contrast, an issue of concern could be that, because brokers are involved in a } \\
\text { wide range of financial services and transactions, this capital requirement might } \\
\text { not be sufficient in the current situation. Indeed, brokerage houses maintain capi- } \\
\text { tal well above the minimum requirement. There is no daily limit for transactions } \\
\text { carried out by broker-dealers in relation to their capital. }\end{array}$ \\
\hline & & $\begin{array}{l}\text { The CEVAL is a private institution fully owned by the exchange and governed by } \\
\text { the members of the exchange board of directors (brokerage houses and the stock } \\
\text { exchange). The CEVAL provides information to its shareholders. Online connec- } \\
\text { tion exists among the CEVAL, the stock exchange, and its participants. The new } \\
\text { private entity that will operate the Sistema de Anotaciones en Cuenta could have } \\
\text { the following ownership structure: a maximum of } 40 \text { percent owned by the stock } \\
\text { exchange, and the remaining } 60 \text { percent owned in equal parts among the rest of } \\
\text { participants. Two Banco Central de Costa Rica representatives will sit on the } \\
\text { board of the new entity. }\end{array}$ \\
\hline Dominican Republic & CEVALDOM & Not yet operational. \\
\hline Ecuador & DECEVALE & $\begin{array}{l}\text { The CSD (DECEVALE) was constituted in } 1994 \text { under the regulation of the SML. } \\
\text { Article } 60 \text { of the SML (also Article } 3 \text { of the depository general rules) allows for a } \\
\text { broad participation in the depositary by institutions in the financial sector, and } \\
\text { requires a minimum initial capital of } 100,000 \text { Unidades de Valor Constante (UVC) } \\
\text { (indexed units) - that is, approximately US } \$ 260,000 \text {. Governance arrangements } \\
\text { must be included in the internal rules that have to be approved by the securities } \\
\text { regulator. However, due to financial problems, the depository has only worked as } \\
\text { a custodian for dematerialized securities issued by the Corporación Financiera } \\
\text { Nacional (which is a very small portion of the market, less than } 1 \text { percent of out- } \\
\text { standing securities); the ownership transfer book-entry function has never been } \\
\text { established. In this situation, the Banco Central del Ecuador has become the } \\
\text { major custodian for public securities, although it is also custodian for private } \\
\text { securities; it has not developed the depository function. }\end{array}$ \\
\hline El Salvador & CEDEVAL & $\begin{array}{l}\text { Title } V \text { of the SML develops the theme of companies specializing in the deposit } \\
\text { and custody of securities. These companies are constituted as corporations and } \\
\text { offer services including transfers, clearance, and settlement of operations that } \\
\text { are carried out in respect to the securities under supervision. Presently, there is } \\
\text { an association specializing in the deposit and custody of securities under the } \\
\text { name CEDEVAL-CSD-which began operations in } 1998 \text {. }\end{array}$ \\
\hline
\end{tabular}


Table 5.11 CSDs' Organizational Arrangements (Continued)

\begin{tabular}{|c|c|c|}
\hline Country & Depository & CSD's Organizational Arrangements \\
\hline \multirow[t]{3}{*}{$\begin{array}{l}\text { El Salvador } \\
\text { (Continued) }\end{array}$} & & $\begin{array}{l}\text { Companies specialized in the deposit and custody of securities are constituted as } \\
\text { corporations and are subject to the commercial laws. The deposit and custody } \\
\text { services can only be offered through stock exchanges, banks, financial institu- } \\
\text { tions, or specialized institutions. }\end{array}$ \\
\hline & & $\begin{array}{l}\text { Since January } 11,1994, \text { CEDEVAL, a company constituted as a specialized com- } \\
\text { pany in the deposit and custody of securities, whose operations began on } \\
\text { November } 18,1998 \text {, has been of variable capital, having the stock exchange } \\
\text { and brokerage firms as its principal shareholders. }\end{array}$ \\
\hline & & $\begin{array}{l}\text { The institutions that have an account at CEDEVAL are the Administradoras de } \\
\text { Fondos de Pensiones (AFPs), the stock exchange, and other foreign trustees. } \\
\text { Presently, brokerage firms are not connected online with CEDEVAL. Neverthe- } \\
\text { less, this institution works so that the AFPs and the brokerage firms can directly } \\
\text { access the trustees' information from their terminals. }\end{array}$ \\
\hline Guatemala & Stock exchange & $\begin{array}{l}\text { The creation of the cajas valores is regulated in the SML (Article 79). They have } \\
\text { been created as a department of the respective stock exchanges. Thus, the gov- } \\
\text { ernance arrangements of the securities depositories in Guatemala are the same } \\
\text { as the stock exchanges. The stock exchanges are equally owned by each mem- } \\
\text { ber, with each of them owning a share. As of December 2003, there were } 33 \text { reg- } \\
\text { istered broker-dealers, of which } 20 \text { remain active, with } 14 \text { of those linked to a } \\
\text { banking group. Some banking groups own more than one broker-dealer. In order } \\
\text { to use the services of the cajas de valores, an entity must be an agent or broker- } \\
\text { dealer of the respective stock exchange. The cajas de valores also allow for insti- } \\
\text { tutional participants' own operations to use the services of the depository, but not } \\
\text { for the operations of others. }\end{array}$ \\
\hline Honduras & - & There is no securities depository. \\
\hline Jamaica & JCSD & $\begin{array}{l}\text { The JCSD has a six-member board of directors with a representative from } \\
\text { the JSE, the BOJ, and the ministry of finance. All of the brokers that are mem- } \\
\text { bers of the JSE are members of the JCSD. The JCSD publishes an annual } \\
\text { report and an informational brochure for market participants and the investing } \\
\text { public. The operating rules and procedures of the JCSD are pending approval } \\
\text { by the FSC. }\end{array}$ \\
\hline \multirow[t]{3}{*}{ Mexico } & INDEVAL & $\begin{array}{l}\text { The first CSD in Mexico was created on April } 28,1978 \text {, under the name of INDE- } \\
\text { VAL. This public sector entity was created to offer custody services, administra- } \\
\text { tion, clearance, settlement, and transfer of securities through book entries. In } \\
\text { 1987, this organization went private, and was legally constituted under the name } \\
\text { of S.D. INDEVAL, starting operations on October } 1 \text { of the same year. INDEVAL is } \\
\text { the only company in Mexico authorized to operate as a CSD according to the } \\
\text { terms established in the Securities Market Law. INDEVAL is a private sector firm } \\
\text { whose shareholders include } 29 \text { brokerage houses, } 13 \text { commercial banks, six } \\
\text { insurance and guarantee firms, as well as the Banco de México, BMV, and } \\
\text { Nacional Financiera, a state-owned development bank. }\end{array}$ \\
\hline & & $\begin{array}{l}\text { Besides the services of deposit, custody, administration, clearance, settlement, } \\
\text { and transfer of securities, INDEVAL provides the following services: }\end{array}$ \\
\hline & & $\begin{array}{l}\text { Securities lending: In January 1997, INDEVAL created a securities lending pro- } \\
\text { gram, Préstamo de Valores (VALPRE), making available to market participants } \\
\text { an electronic system for securities lending. } \\
\text { - ISIN codes: BMV designated INDEVAL as the national numbering agency for } \\
\text { ISIN codes. } \\
\text { - Specialized services: INDEVAL offers the following services directly to issuing } \\
\text { companies: (1) registration of shareholders who are entitled to the rights of }\end{array}$ \\
\hline
\end{tabular}


Table 5.11 CSDs' Organizational Arrangements (Continued)

\begin{tabular}{|c|c|c|}
\hline Country & Depository & CSD's Organizational Arrangements \\
\hline $\begin{array}{l}\text { Mexico } \\
\text { (Continued) }\end{array}$ & & $\begin{array}{l}\text { ownership but who have not registered their shares in a brokerage house, and } \\
\text { thus have not deposited them with INDEVAL; }(2) \text { the exercise of ownership } \\
\text { rights, such as dividend payments, capitalizations, subscriptions, exchanges, } \\
\text { and splits; and (3) rights updates. }\end{array}$ \\
\hline Netherlands Antilles & - & There is no securities depository. \\
\hline \multirow[t]{3}{*}{ Nicaragua } & \multirow[t]{3}{*}{ CENIVAL } & $\begin{array}{l}\text { The CENIVAL is a subsidiary of the stock exchange, which owns } 90 \text { percent of the } \\
\text { equity of the former. The CENIVAL started operating in December of 1997; current } \\
\text { arrangements and practices are based on bilateral agreements and contract law, } \\
\text { because in Nicaragua there is no legal basis for the operation of a CSD. }\end{array}$ \\
\hline & & $\begin{array}{l}\text { The governance arrangements of the securities depository are, in general, the } \\
\text { same as those of the stock exchange. They even share the same board of direc- } \\
\text { tors and some managing directors. }\end{array}$ \\
\hline & & $\begin{array}{l}\text { Access to the CENIVAL is broad, because, according to Article } 8 \text { of its internal } \\
\text { regulation, all types of financial institutions that are duly authorized by the Super- } \\
\text { intendencia de Bancos y Otras Instituciones Financieras (SBOIF), foreign banks, } \\
\text { and other nonfinancial institutional investors, may open a deposit account. }\end{array}$ \\
\hline \multirow[t]{4}{*}{ OECS } & \multirow[t]{4}{*}{ ECCSD } & $\begin{array}{l}\text { The ECCSD is owned by the Eastern Caribbean Stock Exchange (ECSE). Its major } \\
\text { function is to provide clearance and settlement of trades transacted on the ECSE. } \\
\text { The main participants on the ECCSD are broker-dealers, limited service brokers, } \\
\text { and custodians. The ECCSD provides services to participant intermediaries and } \\
\text { processes transactions for trades reported by the exchange or other markets. } \\
\text { Custody services are also provided to those entities that wish to hold securities } \\
\text { at the ECCSD on behalf of their customers-for example, custodian banks for } \\
\text { foreign investors. }\end{array}$ \\
\hline & & $\begin{array}{l}\text { Established on October } 19,2001 \text {, the ECSE is a regional electronic securities } \\
\text { exchange designed to facilitate the buying and selling of financial products. The } \\
\text { ECSE is an SRO, and has developed a set of bylaws that, together with its opera- } \\
\text { tional rules, govern and monitor exchange-related activities. The majority of its } \\
\text { shares will always be owned by the private sector. }\end{array}$ \\
\hline & & $\begin{array}{l}\text { The ECSE plays an important role in promoting investment banking capability } \\
\text { within its member firms. It positioned its intermediaries to take on the role of } \\
\text { underwriters for governments and corporate issuers. Working under the aus- } \\
\text { pices of a syndicate relationship championed by the ECSE, the intermediaries } \\
\text { collectively began offering a full array of services leading up to the successful } \\
\text { placement of debt and equity offerings for issuers. The ECSE also began assisting } \\
\text { its intermediaries to develop the capability to put together effective packages and } \\
\text { investment or research reports for governments and corporate issuers. }\end{array}$ \\
\hline & & $\begin{array}{l}\text { The ECSE is presently engaged with three additional institutions in Anguilla, } \\
\text { St. Lucia, and St. Kitts and Nevis to facilitate their inclusion as intermediaries. }\end{array}$ \\
\hline Panama & LATINCLEAR & $\begin{array}{l}\text { Broker-dealers accounts are segregated in own accounts and clients' accounts. } \\
\text { In addition, banks and corporations have their own accounts at BVP, but securi- } \\
\text { ties can only be traded if they are transferred to a broker's account. Acuerdo 7, } \\
2003 \text {, of CNV explicitly encourages SROs' internal regulation to create conditions } \\
\text { for fair and open access and to prevent any discriminatory practice. }\end{array}$ \\
\hline Paraguay & - & There is no securities depository. \\
\hline Peru & CAVALI & $\begin{array}{l}\text { Securities depositories, in their capacity as book-entry service providers, } \\
\text { have been recognized in the SML of 1991, approved by Decree-Law 755, as } \\
\text { well as in the current SML. As of May 1997, a single-entity CAVALI was formed } \\
\text { to provide centralized clearing and settlement for the exchange. The SML }\end{array}$ \\
\hline
\end{tabular}


Table 5.11 CSDs' Organizational Arrangements (Continued)

\begin{tabular}{|c|c|c|}
\hline Country & Depository & CSD's Organizational Arrangements \\
\hline $\begin{array}{l}\text { Peru } \\
\text { (Continued) }\end{array}$ & & $\begin{array}{l}\text { states that depositories are companies whose exclusive objective is the } \\
\text { recording, custody, clearing, settlement, and transfer of securities. CAVALI is } \\
\text { a for-profit company, organized as a corporation, owned by } 25 \text { shareholders, } \\
\text { most of which are banks and brokerage firms. The SML allows for any individ- } \\
\text { ual or entity to participate in the depository; no one, however, can directly or } \\
\text { indirectly own more than } 5 \text { percent of the outstanding stock, except for the } \\
\text { exchanges, which may have up to } 40 \text { percent control ownership. (Currently, } \\
\text { the BVL holds about } 29 \text { percent ownership of CAVALI.) CAVALI's board of } \\
\text { directors comprises seven permanent representatives of its shareholders. The } \\
\text { depositories establish the requirements to become a participant that include } \\
\text { the following: financial and economic capacity; operational capacity and infra- } \\
\text { structure; moral suitability of their directors and managers; and existence of a } \\
\text { supervisory body over the entity. Depositories are charged with the responsi- } \\
\text { bility of admitting participants and evaluating on an ongoing basis that they } \\
\text { comply with the requirements prescribed. They are also responsible for the } \\
\text { suspension of participant status. }\end{array}$ \\
\hline Trinidad and Tobago & TTCD & $\begin{array}{l}\text { TTCD is owned by the Trinidad and Tobago Stock exchange. The participants in } \\
\text { the TTCD will be as follows: } \\
\text { - The clients and brokers. The clients will deposit their share certificates with } \\
\text { their brokers, who will register the shareholdings with the TTCD. The share cer- } \\
\text { tificates will be submitted to the registrars for cancellation. Brokers will have } \\
\text { online connection to the system through dial-up lines; they will also have pass- } \\
\text { word protection to enter their trades. Only brokers will be allowed to enter data } \\
\text { into the CSD software. } \\
\text { - The registrars and the stock exchange. The brokers will send the securities to the } \\
\text { registrars for verification and cancellation. The stock exchange will provide the } \\
\text { TTCD with the details of the securities traded. The TTCD will verify and keep } \\
\text { records of all transactions entered by the brokers. }\end{array}$ \\
\hline Uruguay & $\begin{array}{l}\text { Stock Exchanges- } \\
\text { AGATA }\end{array}$ & $\begin{array}{l}\text { There is no single depository institution, but a multiplicity of custody or depository } \\
\text { institutions. A private bank undertakes the depository function for physical and } \\
\text { dematerialized securities traded on the BVM through the private bank omnibus } \\
\text { account in the BCU. The private bank also performs the securities physical cus- } \\
\text { tody function (also for global securities under its custody). The BVM performs the } \\
\text { depository function through its omnibus account at the BCU. Other custodians } \\
\text { undertake the custody or depository function for securities traded through } \\
\text { BEVSA or OTC. }\end{array}$ \\
\hline Venezuela, R.B. de & CVV & $\begin{array}{l}\text { The creation of the CVV was authorized by the CNV in November 1996, under the } \\
\text { regulation of the Ley de Caja de Valores (CSD Law). According to this law, broker- } \\
\text { dealers, banks, insurance companies, issuers, and other persons could be share- } \\
\text { holders. The CVV was designed as a for-profit entity. It does not have a mutual } \\
\text { structure, which means that not all the stakeholders of the CVV must be partici- } \\
\text { pants, and not all participants in the system must be stakeholders. Currently, a } \\
\text { high percentage of its capital is concentrated in the hands of six major share- } \\
\text { holders. Article } 5 \text { of the CVV regulations states the steps that must be followed by } \\
\text { an applicant who wishes to be a participant of the system. Nevertheless, there } \\
\text { is no public disclosure of the specific criteria for the participation in the CVV, to } \\
\text { permit fair and open access. }\end{array}$ \\
\hline
\end{tabular}

Source: Authors' elaboration. 
carefully evaluated by the overseers, especially in light of possible expansion of the stock exchanges in the clearing and settlement industry. Also, the stock exchanges might want to form a users' group to ensure that the needs of all participants are represented, and that all parties have the opportunity to participate in the decision-making process.

- Some legal and governance arrangements introduce monopolistic situations that impede the adequate development of some markets (for example, money markets). This could lead to the development of settlement infrastructures that are not adequate for market needs (this is not only the case with SSSs, but also with payments systems). Some of problems are high entrance fees, existence of inadequate facilities, lack of facilities to process intraday repos used by the central bank to provide intraday liquidity, and so on.

- Unresolved conflicts of interest are the main reason for the underdevelopment of basic SSS infrastructures, such as depositories. In these cases, under the leadership of the securities regulator and the central bank in coordination with the ministry of finance, a legally sound solution should be agreed on with stakeholders to establish the depository function as soon as possible. Depending on the solution adopted for the immobilization or dematerialization of securities and establishment of the depository function, careful attention should be given to the ownership structure of the depository to make sure that the system is efficient, fair in terms of access, and has appropriate governance arrangements. The depository should provide participants with a meaningful opportunity to participate in the organization's decision-making process for system design and settlement procedures.

- A strong, capitalized, autonomous, and independent securities depository, with reliable and flexible systems to expedite settlement of transactions and accessory rights is crucial for the development of the securities markets. When important conflicts of interest emerge, the authorities should take the lead in their resolution, avoiding any standstill situation that could prevent the development of basic pieces of SSS infrastructure.

\section{CROSS-BORDER SETTLEMENT}

This section includes context, status in the region and observations regarding cross-border settlement.

\section{Context}

Settlement of cross-border securities transactions is typically more complicated and potentially involves more risk than domestic transactions. Links between CSDs permit participants in either CSD to settle trades in securities from multiple jurisdictions through a simple gateway operated by the domestic CSD or by an international CSD. However, CSDs need to design links carefully to ensure that risks are reduced. They must address legal and operational complexities. If links are not properly designed, risks can be exacerbated. Inefficiencies may arise because of variations in the operating hours. Links may create significant credit and liquidity interdependencies between systems. A CSD should evaluate the financial integrity and operational reliability of any CSD with which it intends to establish a link. Any credit extensions between CSDs should be fully secured by securities, letters of credit, or other highquality collateral, and should be subject to limits.

\section{Status in the Region}

Table 5.12 includes a brief description of CSDs' links for settlement systems in each of the countries assessed.

\section{Observations}

Some of the specific problems regarding cross-border links follow:

- Most securities depositories in the region do not have cross-border links. The authorities should analyze the risks associated with these links, because settlement of cross-border transactions typically involves more risk than settlement of domestic transactions. Particular attention should be devoted to the multiple jurisdiction profile of these transactions, especially from the legal and operational perspective. At the international level, the main improvement in this area is related to the international law governing the cross-border pledge of securities as collateral. Some depositories have participated in the Hague Convention's efforts to build a consensual internationally accepted principle on this issue. Some securities regulators are already involved in this discussion. There is a clear tendency to continue these efforts, and a proposal by the Federación Iberoamerivcana de Bolsas de Valores to facilitate and increase intraregional trading, which is based on and is dependent on linkages among depositories. 
Table 5.12 Links between Securities Depositories

\begin{tabular}{|c|c|c|}
\hline Country & Depository & CSDs Links \\
\hline Argentina & Caja de valores & $\begin{array}{l}\text { The depository (caja de valores) has a global account in his name at Cedel Inter- } \\
\text { national SA (CEDEL, Luxembourg), Euroclear (Belgium), Depository Trust Company } \\
\text { (DTC, United States), and Servicio de Compensación y Liaquidación de Valores } \\
\text { (SCLV, Spain) allowing securities listed in Argentina but registered in these } \\
\text { centers to be traded at the Buenos Aires Stock Exchange. }\end{array}$ \\
\hline Bahamas, The & - & No cross-border links. \\
\hline Bolivia & EDV & No cross-border links. \\
\hline \multirow[t]{3}{*}{ Brazil } & CBLC & $\begin{array}{l}\text { CBLC has a pledge account at the Depository Trust and Clearing Corporation (DTCC) } \\
\text { and accounts in Clearstream and Euroclear that are used mainly by foreign } \\
\text { investors that can choose this alternative to collateralize their positions in the } \\
\text { derivatives market and in the securities lending program. CBLC is conservative in } \\
\text { accepting foreign securities as collateral, and eligible securities are basically } \\
\text { U.S. government bonds and bills. The linkage between CBLC and the Spanish } \\
\text { SCLV is related to custody infrastructure to support the Mercado de Valores Latino } \\
\text { Americano, which trades Brazilian equities in Spain. Foreign institutions are per- } \\
\text { mitted to keep their securities at the CBLC through local custodians acting as par- } \\
\text { ticipants. Local custodians, as direct participants of CBLC depository service, are } \\
\text { fully responsible for all movements instructed in the custody. }\end{array}$ \\
\hline & SELIC & No cross-border links. \\
\hline & BM\&F & $\begin{array}{l}\text { The BM\&F derivatives clearinghouse has custodial arrangements with interna- } \\
\text { tional banks for the receipt of collaterals pledged abroad only for agricultural } \\
\text { commodities derivatives, according to CMN Resolution } 2687 \text {. }\end{array}$ \\
\hline Chile & DCV & No cross-border links. \\
\hline \multirow[t]{2}{*}{ Colombia } & DCV & No cross-border links. \\
\hline & DECEVAL & No cross-border links. \\
\hline Costa Rica & CEVAL & Regional links (see information for Guatemala and Nicaragua). \\
\hline Dominican Republic & CEVALDOM & No cross-border links. \\
\hline Ecuador & DECEVALE & No cross-border links. \\
\hline El Salvador & CEDEVAL & Regional links (see information for Guatemala and Nicaragua). \\
\hline Guatemala & Stock exchange & $\begin{array}{l}\text { The securities depository (caja de valores) also offers the custody of securities, } \\
\text { in physical or book-entry form, for securities issued outside Guatemala. To this } \\
\text { purpose, the depository has links with Clearstream Banking, CEDEVAL, S.A. } \\
\text { (El Salvador); Bolsa Hondureña de Valores, S.A., CENEVAL, Central para el Depósito } \\
\text { de Valores en la Bolsa Nacional de Valores, S.A. (Costa Rica); and Central Latino- } \\
\text { americana de Valores, S.A. (Panama). These operations are settled through an } \\
\text { omnibus account open in the name of Bolsa de Valores Nacional, S.A. at each of } \\
\text { these entities. The Bolsa de Valores Nacional keeps a detailed registry of the } \\
\text { securities deposited in each of the omnibus accounts. }\end{array}$ \\
\hline Honduras & - & No cross-border links. \\
\hline Jamaica & JCSD & No cross-border links. \\
\hline Mexico & INDEVAL & $\begin{array}{l}\text { INDEVAL, through SIDV's international division, provides direct accounts to foreign } \\
\text { entities holding securities issued in Mexico-for example, the American depository } \\
\text { receipts of Mexican firms that are traded in New York. These are free-of-payment } \\
\text { custody accounts, because payment occurs outside SIDV. SIDV international } \\
\text { receives free-of-payment transfer instructions and sends them to its foreign } \\
\text { depositors via facsimile or SWIFT. }\end{array}$ \\
\hline
\end{tabular}


Table 5.12 Links between Securities Depositories (Continued)

\begin{tabular}{|c|c|c|}
\hline Country & Depository & CSDs Links \\
\hline $\begin{array}{l}\text { Mexico } \\
\text { (Continued) }\end{array}$ & & $\begin{array}{l}\text { When receiving instructions via facsimile, INDEVAL executes a prematching } \\
\text { process by telephone with the Mexican counterparty, and enters a free-of-payment } \\
\text { securities delivery instruction in SIDV. Securities are then transferred, and confir- } \\
\text { mations are sent via facsimile to the foreign depositor and the Mexican counter- } \\
\text { party. If the instructions are received through SWIFT, INDEVAL electronically } \\
\text { downloads them from the SWIFT terminal to SIDV. Once the prematching process } \\
\text { has been executed, the instruction entered in SIDV is considered confirmed and } \\
\text { the securities are transferred. Then INDEVAL sends confirmations via SWIFT to } \\
\text { the counterparties. At the end of the day, INDEVAL also sends through SWIFT } \\
\text { information on positions, activity, and pending transactions. }\end{array}$ \\
\hline
\end{tabular}

Settlement of the cash leg occurs bilaterally between the counterparties. Some Mexican eurobonds denominated in U.S. dollars are held in securities accounts in Clearstream, a CSD. For this reason, INDEVAL opened an omnibus account with Clearstream. Some of these securities are listed in BMV and are traded mainly by mutual and pension funds. If a Mexican investor wants to acquire one of these securities, the original owner makes a transfer in Clearstream from its own account to INDEVAL's account, which then credits the account of the Mexican investor. Any further transaction with these same securities inside the Mexican market will be settled through INDEVAL just like any other operation, as long as it is denominated and settled in Mexican pesos.

\begin{tabular}{|c|c|c|}
\hline Netherlands Antilles & BvdNA & No cross-border links. \\
\hline \multirow[t]{2}{*}{ Nicaragua } & CENIVAL & $\begin{array}{l}\text { Currently, the CENIVAL holds accounts for other CSDs in Central America: CEDEVAL, } \\
\text { S.A. (EI Salvador); Caja de Valores (Guatemala); Bolsa Hondureña de Valores; } \\
\text { Central para el Depósito de Valores en la Bolsa Nacional de Valores, S.A. (Costa } \\
\text { Rica); and Central Latinoamericana de Valores, S.A. (Panama). Foreign investors } \\
\text { may buy securities deposited in CENIVAL through the omnibus account that these } \\
\text { other CSDs hold with the former. }\end{array}$ \\
\hline & & $\begin{array}{l}\text { The CENIVAL also offers the custody of securities, both in physical or book-entry } \\
\text { form, for securities issued outside Nicaragua through the same group of Central } \\
\text { American securities depositories. These operations are settled through an } \\
\text { omnibus account open in the name of the CENIVAL in each of this entities. }\end{array}$ \\
\hline OECS & ECSD & No cross-border links. \\
\hline Panama & LATINCLEAR & - \\
\hline Paraguay & - & No cross-border links. \\
\hline Peru & CAVALI & $\begin{array}{l}\text { CAVALI has an account in its name at the U.S. DTCC allowing for foreign securi- } \\
\text { ties that are eligible to be registered at CAVALI and traded simultaneously in the } \\
\text { U.S. market, in other markets, and in the BVL. }\end{array}$ \\
\hline Trinidad and Tobago & TTCD & $\begin{array}{l}\text { Cross-border transactions are facilitated through broker-to-broker arrangements } \\
\text { involving a broker from Trinidad and Tobago and from the broker in the other } \\
\text { country involved in the transaction. For example, a person from another country } \\
\text { who wishes to buy or sell a security in a company listed on the exchange in } \\
\text { Trinidad and Tobago would first contact a broker in that person's country. The } \\
\text { broker in that country would contact a broker operating in Trinidad and Tobago, } \\
\text { who would execute the transactions on the floor of the exchange. Similarly, a } \\
\text { person from another country would deliver funds to settle the transaction through } \\
\text { his broker, who would subsequently forward the funds to the broker in Trinidad } \\
\text { and Tobago. }\end{array}$ \\
\hline
\end{tabular}


Table 5.12 Links between Securities Depositories (Continued)

\begin{tabular}{l|l|l}
\hline Country & \multicolumn{1}{|c}{ Depository } & \multicolumn{1}{c}{ CSDs Links } \\
$\begin{array}{l}\text { Trinidad and Tobago } \\
\text { (Continued) }\end{array}$ & $\begin{array}{l}\text { There is no difference in the process for the clearance and settlement of domestic } \\
\text { trades and cross-border transactions. However, the timetable to complete cross- } \\
\text { border transactions can be longer. In Trinidad and Tobago, foreign investors } \\
\text { wishing to hold 30 percent or more of a domestic company must apply for a license. } \\
\text { The present system does not allow for electronic trading. However, automated } \\
\text { trading will follow after CSDs are established in the region. There is a current } \\
\text { initiative to link stock exchanges in five territories-The Bahamas, Barbados, the } \\
\text { Dominican Republic, Jamaica, and Trinidad and Tobago. }\end{array}$ \\
\hline Uruguay & Stock Exchanges- & No cross-border links. \\
\hline Venezuela, R.B. de & CVV & No cross-border links. \\
\hline
\end{tabular}

Source: Authors' elaboration. 


\section{Transparency, Oversight, and Cooperation in Payments Systems}

he smoothness and reliability of money transfer mechanisms affect the efficiency of the real economy and the financial markets; they also have an impact on central banks' lending of last resort function, the conduct of monetary policy, and liquidity management. Market forces alone may not be able to achieve the objectives of efficiency and reliability of the payments system, because participants and operators may not have adequate incentives to minimize the risk of their own failure, or of the failure or costs they impose on other participants. In addition, the institutional structure of the payments system may not provide incentives or mechanisms for efficient design and operation.

These are reasons why, in all countries, central banks' involvement in the payments system is an integral component of their overall mandate to ensure stability of the financial system and to maintain confidence in the domestic currency. In this context, central banks perform a number of different functions in their national clearance, settlement, and payment arrangements. These functions may include direct involvement in managing clearing and settlement systems and in overseeing the payments system by developing rules, principles, and best practices under which private payment arrangements operate. The oversight role of the central bank is currently at the heart of the international debate, and this function is emerging as key in central bank activity. ${ }^{1}$

${ }^{1}$ Recent examples are the focus on central bank's responsibilities in CPSS (2001), CPSS-IOSCO (2001), and Bank of England (2006). See also Bossone and Cirasino (2001).
The role of the central bank is particularly relevant when the country is engaged in a comprehensive reform of its payments system. In that case, the central bank will have to play a leading role in developing a vision for the reformed system, in coordinating with all stakeholders and in carrying out the reform plan. Direct involvement of the central bank in managing clearing and settlement systems has been, in all countries, the first step to governing the overall structure and operation of a country's payments system, and to ensuring that systemic risk, particularly of large-value payment systems, is adequately minimized. In many cases, this role stems from the need to ensure a widespread adoption of the more advanced technology in the fund transfer mechanisms and to avoid possible discriminations in the access to payment services. In all cases, in order to pursue the public interest in the payments system, central banks should ensure that the systems they operate comply with the principles and guidelines they establish; as overseers, they should ensure the (financial and operational) reliability and efficiency of the clearing and settlement systems they do not operate. The oversight role of the central bank is more likely to emerge in its relevance when the payments reform is complete and the central bank will be called to ensure a proper monitoring of the reliability and efficiency of the domestic system on an ongoing basis.

In recent years, in an increasing number of countries, payments system oversight has been explicitly entrusted to central banks by law. Specifying the objectives in relevant legislation may be the most direct way for providing a well-founded legal basis for the central bank to implement its policies, and to make it accountable in pursuing its goal and mandate in the payments 
system. For countries facing the implementation of reforms in the payments system, it is of utmost importance for the central bank to have a well-founded legal framework that clearly defines its payments system role and objectives.

As for the scope of the oversight function, at the international level there is consensus on the fact that systems posing systemic risks should fall under the direct control of the overseer. Typical examples of these systems are those that handle transactions of a high value at both the individual and aggregate level. For example, the Committee on Payments and Settlement Systems (CPSS) identified four responsibilities of the central bank in applying the core principles for systemically important payment systems (CPSIPS), presented in box 6.1.

In May 2005, the CPSS published a report devoted to payment system oversight in Group of Ten countries.

Increasing attention is being given to securities clearance and settlement systems as relevant components of the

\section{Box 6.1 Oversight Role of the Central Bank}

Responsibilities of the central bank in applying the core principles for systemically important payment systems

- The central bank should define clearly its payment system objectives and should disclose publicly its role and major policies with respect to systemically important payment systems.

- The central bank should ensure that the systems it operates comply with the CPSIPS.

- The central bank should oversee compliance with the CPSIPS by systems it does not operate, and it should have the ability to carry out this oversight.

- The central bank, in promoting payment system safety and efficiency through the CPSIPS, should cooperate with other central banks and with any other relevant domestic or foreign authorities. overall payments system. The oversight of these systems might well be a cooperative effort of two or more regulatory agencies. In some countries, also, retail (low-value) systems fall under control of the oversight agency because of their importance in the overall efficiency of the payments system, their potential impact on the public trust of money, and because of their relevance to sustain the ultimate objective of economic growth. ${ }^{2}$

The evolution toward a new role of the central bank in payment systems calls for a careful consideration of at least three key issues. First, the adequacy of legal enforcement for central bank action in the payments system should be evaluated. The central bank role in payment systems stems from its responsibility for financial market stability and from its monetary policy. In many countries, a clearly stated legal enforcement for the central bank's activity as overseer of the payments system has facilitated the fulfillment of the central bank's objectives.

Second, the internal organization of the central bank as far as the payment system activities are concerned may also be worth evaluating. Experience in many central banks has indicated that significant improvements can be derived by setting up a unit specifically devoted to payments policy issues. Typically, such a unit could develop an appropriate policy framework and the appropriate tools (for example, data collection, periodical inspections, and so on) for use in assessing the appropriateness of individual payments systems. This function could be undertaken in close coordination with the banking supervisory function, for example, which has a high level of competence and experience in examining some of the related issues. In addition, it would be important for those staffing the unit to have appropriate skills. Typical aspects to be analyzed in administering the oversight functions include, among other things, potential risks emerging from the various clearinghouses, the adequacy of risk control measures in place, the potential implications of the resort to unwinding procedures, and efficiency issues.

Third, effective cooperation must be in place between the overseer and market players, among domestic regulators, and among international oversight agencies. In particular, it must be noted that central banks that do not have bank

${ }^{2}$ Many examples can be given on how an inefficient retail system can affect economic activity - for example, by failing to accommodate the needs of customers and merchants in their desire to finalize a transaction, which, as a result, cannot take place. 
supervisory powers may face considerable information limitations, especially in crisis management. The overseer would have to rely on information from the supervisory authorities, or should develop its own independent access to information on payment system participants. Whereas the first option transfers de facto the responsibility for triggering oversight action to the supervisory authority, the second option raises risks of duplication of information collection, inconsistent public action, and additional costs to participants. An effective way to overcome most of these problems is to stipulate rules for granting the overseer with adequate access to supervisory information. The institutionalization of information-sharing arrangements may reduce the risk that the exchange of information will be hampered by frictions in cooperation between different institutions. Various solutions can be adopted for this purpose, from signing a memorandum of understanding that specifies the framework for cooperation, to ensuring contacts between institutions through joint board membership, the establishment of a comprehensive market regulatory and supervisory body where all the institutions with oversight responsibilities are represented and mandated to cooperate. ${ }^{3}$ Cooperation must also be pursued between the overseer and the securities markets regulators, because securities settlement is an integral part of the payments system, and problems in securities markets clearing and settlement may easily spill over to the payments system, and vice versa.

Effective cooperation among market participants, between regulators and market participants, and among regulators is essential for the development of a sound and efficient payments system. In particular, the cross-nature element that characterizes the transfer of money and the systemic nature of the underlying operating procedures make the payments system an institution whose existence

\footnotetext{
${ }^{3}$ See Banca d'Italia (1999) for a description of the institutional arrangements adopted in some leading industrial countries. In the United Kingdom, the Bank of England and the Financial Services Authority, responsible for regulating individual banks, recognize the need to share information about the main payment system members. The two institutions have signed a memorandum of understanding requiring that "the FSA and the Bank [of England] will establish information sharing arrangements, to ensure that all information which is or may be relevant to the discharge of their respective responsibilities will be shared fully and freely. Each will seek to provide the other with relevant information as requested" (see Bank of England 2000). In the European Union, the European Central Bank has issued a protocol for payment system oversight to be adopted by the euroarea national central banks and the European Central Bank.
}

and smooth functioning requires effective cooperation between all participants. On the one hand, the use of payment instruments generates significant externalities on the demand side, because the usefulness of an instrument is strictly linked to the degree of its acceptance and use for transaction purposes (network economies). Consequently, widespread use of new payment instruments and services relies heavily on public confidence in them. On the other hand, within the payments system the supply of services can be affected by coordination failures due to the existence of conflicts of interests (and information costs), as well as the intermediaries' unwillingness to cooperate. This can lead to suboptimal equilibriums in the organizational arrangements as to the system's reliability and efficiency. The payments system overseer is therefore entrusted with making up for a specific type of failure in the market for payment services - that is, the coordination failures. Cooperation problems may be especially relevant within interbank clearing and settlement systems. In fact, in these systems, the risk profiles - both at the system level and at the level of the individual intermediarymay not be fully assessed by participants. In addition, the concern with having to support less reliable intermediaries may lead larger participants to discriminate against smaller ones, even when the latter are technically eligible to participate in the system. Finally, the payment system industry also depends on agreements between producers to ensure that different components of the system are compatible. Most recently, the emergence of new types of nonbank intermediaries and payment instruments has strengthened the need for a comprehensive level of cooperation in the payments system.

With regard to the cooperation among regulators, the safety and efficiency objectives of payment and securities settlement systems may be pursued by a variety of public sector authorities, in addition to the central bank and the securities commission. Examples of these regulators include legislative authorities, ministries of finance, and competition authorities. There are also complementary relationships between oversight, bank supervision, and market surveillance. Appropriate cooperation among supervisors can be achieved in a variety of ways - for example, exchanges of views and information between relevant authorities may be conducted by holding regular or ad hoc meetings. Agreements on the sharing of information may be useful for such exchanges. Table 6.1 presents oversight and cooperative arrangements in LAC. 


\section{STATUS IN THE REGION}

\section{Table 6.1 Oversight and Cooperative Arrangements in Latin America and the Caribbean}

\begin{tabular}{l|l}
\hline Country & \multicolumn{1}{c}{ Oversight Issues } \\
\hline Argentina & Legal Foundations of the Function \\
The Law of Financial Institutions is the legal framework that governs the financial and banking system as a \\
whole. In particular, it gives the Banco Central de la República Argentina (BCRA) broad enforcement author- \\
ity over entities participating in financial intermediation. BCRA authority over clearinghouses and similar \\
entities that perform payment settlement functions stems indirectly from this law, and is formalized in the \\
charter of the BCRA, the Carta Orgánica. The Carta Orgánica grants the BCRA's board of directors the power \\
to regulate the creation and functioning of clearing organizations for cheques and other operations managed \\
by financial entities (Article 14, Point J).
\end{tabular}

\section{Transparency of the Oversight and Dissemination of Information}

The oversight authority of the BCRA is not articulated in a formal policy document.

There are no regular publications of the BCRA regarding the payments system.

Objectives, Scope, Instruments, Pricing, and Access

The BCRA supervises all clearinghouses.

The main instruments are direct supervision, moral suasion, and cooperation through the Comisión Interbancaria de Medios de Pago de la República Argentina.

Pricing policies are not disclosed.

There is no formal policy regarding access to settlement systems.

\section{Organizational Arrangements and Cooperation}

The BCRA is involved through its banking supervision function in the oversight of the private sector clearinghouses. The control of technical and operational aspects of each clearinghouse, both before it is authorized to operate and subsequently, is managed by the banking supervisor (Superintendencia de Entidades Financieras y Cambiarias). The Superintendencia de Entidades Financieras y Cambiarias is also involved in the management of abnormal situations in the clearinghouse through the Comite de Camaras. The Carta Orgánica gives the Superintendencia de Entidades Financieras y Cambiarias the responsibility to enforce the legal provisions on the functioning of plastic cards and e-money issued by the Congress or by the BCRA.

A cooperative body, the Comisión Interbancaria de Medios de Pago de la República Argentina, in which the central bank and the commercial banks are represented, was formed in 1996 to support payment system reform. No formal cooperation is in place between the central bank and other regulatory authorities in the payments system.

The Banco Central de la República Argentina is a member of the Working Group on Payment System Issues of LAC (WGPS-LAC).

\section{Bahamas, The}

\section{Legal Foundations of the Function}

It is not clear whether the law formally assigns to the central bank responsibility over the payments system.

\section{Transparency of the Oversight and Dissemination of Information}

Oversight function not formally performed.

Objectives, Scope, Instruments, Pricing, and Access

Oversight function not formally performed.

Organizational Arrangements and Cooperation

No unit is in charge of the oversight function.

A national payment system council was recently established.

The Central Bank of the Bahamas is not a member of the WGPS-LAC. 


\section{Table 6.1 Oversight and Cooperative Arrangements in Latin America and the Caribbean (Continued)}

\begin{tabular}{|c|c|}
\hline Country & Oversight lssues \\
\hline \multirow[t]{11}{*}{ Bolivia } & Legal Foundations of the Function \\
\hline & $\begin{array}{l}\text { Central Bank Law } 1670 \text { of October } 31,1995 \text {, states that the Banco Central de Bolivia is empowered to formulate } \\
\text { policies of general application over the payments system to fulfill its overall objectives. The same law in its } \\
\text { Article } 54 \text { (k) states that the board of directors of the Banco Central de Bolivia has the authority to authorize } \\
\text { and regulate the functioning of clearinghouses. }\end{array}$ \\
\hline & $\begin{array}{l}\text { The Banco Central de Bolivia has issued several pieces of regulation over the payments system: for example, } \\
\text { Resolution n. 070/2001 regulates the large-value payments system. Resolution n.138/2003 approves the Rules } \\
\text { of Automated Clearinghouse and other clearing and settlement services; Resolution n. 086/2004 approves } \\
\text { and regulates the electronic system. }\end{array}$ \\
\hline & Transparency of the Oversight and Dissemination of Information \\
\hline & Oversight function not formally performed. \\
\hline & Objectives, Scope, Instruments, Pricing, and Access \\
\hline & Oversight function not formally performed. \\
\hline & Organizational Arrangements and Cooperation \\
\hline & No unit is in charge of the oversight function. \\
\hline & No national payment system council exists. \\
\hline & The Banco Central de Bolivia is a member of the WGPS-LAC. \\
\hline
\end{tabular}

Brazil Legal Foundations of the Function

The Payment System Law (10214, March 2001) clearly defines the Banco Central do Brasil (BACEN) major payment system objectives. The BACEN's role, objectives, and policies with respect to the payment system have been publicly disclosed through policy statements. Generally, the BACEN's action during the implementation process has encompassed widely announced objectives and permanent conversation and partnership with interested parties.

The BACEN issued general regulation-setting minimum requirements for clearinghouses' risk-control devices. The Conselho Monetário Nacional's (CMN's) Resolution 2,882 strictly follows the CPSIPS except for Principle 6, which is placed in the Circular 3,057. The resolution includes the delivery versus payment principle for securities settlement. Finally, the resolution expands on the objectives of payments system oversight.

Also, Circular 3,060/2001 enforces the BACEN to offer funds transfer mechanisms operating under a real-time gross settlement (RTGS) mode by April 2002. Being the regulator, supervisor, and lender of the system, that norm rules the functioning of banks' reserve accounts, and a schedule of implementation of the restructuring project that covers communications network and participants' access; optional tests on the communication network, messages exchange system, security system, and prototypes system; mandatory tests; and rules to overdrafts allowance.

\section{Transparency of the Oversight and Dissemination of Information}

Publicly disclosed policy statements are available at the BACEN Web site, such as a technical note on monetary policy that deals with operational characteristics of banks' reserve account; the Sistema de Transferência de Reservas; intraday and interday repo and rediscount operations; the Servico Especial de Liquidação e Custodia, that operates under a gross settlement mode in the securities leg and under an RTGS mode in the payment leg; and considerations about reserves requirements on all eligible assets, which can be used for intraday needs.

The above-mentioned note also contains the key policy decisions taken by the BACEN concerning the payment system. These include systems operated by the BACEN will settle on RTGS mode (reserves balances and government securities book-entry system); banks' reserves account will be monitored in real-time; no overdraft at the reserves account will be allowed; interest-free intraday credit will be granted by the BACEN through repo operations; financial institutions must authorize all debits on their reserves account; the communication network used by Sistema de Transferência de Reservas will be message driven. 


\section{Table 6.1 Oversight and Cooperative Arrangements in Latin America and the Caribbean (Continued)}

\begin{tabular}{|c|c|}
\hline Country & Oversight Issues \\
\hline \multirow[t]{6}{*}{$\begin{array}{l}\text { Brazil } \\
\text { (Continued) }\end{array}$} & $\begin{array}{l}\text { Abundant information on payment system structure and data is available regularly from the BACEN and } \\
\text { other sources. }\end{array}$ \\
\hline & Objectives, Scope, Instruments, Pricing, and Access \\
\hline & $\begin{array}{l}\text { By law and by regulation, the BACEN is committed to apply the CPSIPS to the systems it operates and to } \\
\text { systems it does not operate. }\end{array}$ \\
\hline & $\begin{array}{l}\text { The existing legal and regulatory framework gives the BACEN authority to perform its oversight function, } \\
\text { also, through moral suasion, which means that the BACEN has a broad range of oversight tools, including } \\
\text { discretionary powers. }\end{array}$ \\
\hline & $\begin{array}{l}\text { Rules to sanction abnormal behavior of intermediaries in each system have been produced, and are considered } \\
\text { a crucial element to enforce risk management measures to be taken by the system's participants because well- } \\
\text { defined sanctions are viewed as important to ensure that adequate action is taken to remedy noncompliance } \\
\text { with BACEN rules. }\end{array}$ \\
\hline & $\begin{array}{l}\text { There is no disclosed policy for pricing and access, although these policies are carried out in the context of } \\
\text { the oversight framework described in this table. }\end{array}$ \\
\hline
\end{tabular}

\section{Organizational Arrangements and Cooperation}

The oversight function is performed by the department in charge of the RTGS and banking operations.

A memorandum of understanding, signed on July 5, 2002, sets forth the exchange of information and previous consultation between the BACEN and the Comissão de Valores Mobiliários concerning issues related to entities dealing with settlement of financial assets. The memorandum of understanding is available on the BACEN Web site.

Although the BACEN has a clear policy of cooperation with other stakeholders and system participants, no national payment system council exists.

The Banco Central do Brasil is a member of the WGPS-LAC and cooperates with G-10 central banks in the context of the CPSS.

Chile Legal Foundations of the Function

Article 1 of the Legal Statute of the Central Bank (Banco Central de Chile, BCCH) of 1989 establishes its main responsibilities and powers, among which the $\mathrm{BCCH}$ is responsible "for safeguarding currency stability and the smooth functioning of domestic and foreign payments." This sets up an indirect basis for the establishment of the BCCH oversight policy.

\section{Transparency of the Oversight and Dissemination of Information}

Beyond the objectives explicitly mentioned in the BCCH legal statute, the central bank has defined policy objectives for payment systems in Chile. These have been published. They disclose publicly the BCCH's role and major policies with respect to BCCH payment systems. In particular, the BCCH has recently published a description of the modernization reforms coming with the introduction of a RTGS system and the replacement of outdated payment mechanisms.

\section{Objectives, Scope, Instruments, Pricing, and Access}

The RTGS was designed on the basis that it would meet the CPSIPS. The BCCH is overseeing the observance with the CPSIPS by the Sistema de Pagos de Alto Valor (the commercial banks' net large-value payment system) project proposed by the banks. For the moment, the BCCH does not oversee the observance with the CPSIPS for other payment systems such as the clearinghouse, which nets all retail and card payments, and the Redbanc automated teller machine network, which clears the automated teller machine payments of some banks. However, the BCCH regulates the retail payments systems.

\section{Organizational Arrangements and Cooperation}

The BCCH is working with the supervsion authorities' Superintendencia de Bancos e Instituciones Financieras and Superintendencia de Valores y Seguros to define a framework for collaboration on promoting the payment systems' safety and efficiency. 
Table 6.1 Oversight and Cooperative Arrangements in Latin America and the Caribbean (Continued)

\begin{tabular}{l|l}
$\begin{array}{l}\text { Country } \\
\text { Chile }\end{array}$ & $\begin{array}{l}\text { Oversight Issues } \\
\text { (Continued) }\end{array}$ \\
$\begin{array}{l}\text { The BCCH cooperates with other central banks, in particular through its active participation in the Western } \\
\text { Hemisphere Payments and Securities Clearance and Settlement Forum and the Asociacion Latinoamericana } \\
\text { de Integracion. } \\
\text { The Banco Central de Chile is a member of the WGPS-LAC }\end{array}$
\end{tabular}

Colombia Legal Foundations of the Function

The central bank (Banco de la República, BR) does not have a clear empowerment over the payment system oversight function. The legal foundation for central bank intervention in the system is included in Article 16 of Central Bank Law 31 of 1992 (Ley Orgánica del Banco de la República). In describing the central bank functions, the article states that the central bank should study and adopt monetary, credit, and foreign exchange measures to regulate monetary circulation and, in general, the liquidity of the financial system, and the smooth functioning of the payment system both domestically and internationally. When the central bank directly provides payment services, it meets its regulatory objectives by means of subscription by participants of bilateral contracts in which all obligations and responsibilities of participants are established, as well as the rules for their operations, service pricing, and the sanctions for noncompliance. Law 795/2003 (Estatuto Orgánico del Sistema Financiero) states that the Superintendencia de Bancos "will regulate the payments systems and related activities that are not under the responsibility of the central bank." This activity will be executed with prior consultation to the BR board of directors (Article 6j). In addition, Article 71, paragraph 1, indicates that the Superintendencia de Bancos "will supervise, monitor and inspect, following general guidelines issued by the national Government, the entities administering credit and debit cards or payment and settlement systems."

\section{Transparency of the Oversight and Dissemination of Information}

The central bank plays a significant role in the payments reform because it is the main service provider in the country. BR communications on payment systems (to the congress and public in general) indicate objectives for the payment systems operated by the BR

\section{Objectives, Scope, Instruments, Pricing, and Access}

No formal objectives are in place for the oversight function. The main instruments for carrying out the function are the bilateral contracts and moral suasion. The BR collects and publishes (through the BR Web page) statistics of the systems it manages, and has mechanisms in place to consult with system participants in case of changes of system operations. The BR does not issue authorization to provide payment services. Consumer protection is under the control of the Superintendencia de Industria y Comercio. No explicit provision exists to regulate the pricing of payment services. However, for payment services offered by the central bank, the BR has issued a directive that mandates the full recovery of the production costs, including the opportunity cost of the invested capital. The BR approved a new pricing policy in 2003 (which has been applied since April 2004) for the systems it operates. The BR board determines the access requirements to the systems managed by the central bank.

\section{Organizational Arrangements and Cooperation}

Payments system issues are dealt with by several departments under the Subgerencia de Operaciones Bancarias. Focus is on operations, and no formal unit is in charge of monitoring the payment system as a whole.

At the domestic level, mechanisms exist for ad hoc cooperation between different authorities involved in the financial sector-namely the central bank, the banking supervision authority, the securities regulator, and the deposit guarantee fund - to monitor the payments system. However, there is no formal framework for such cooperation.

No national payment system council exists.

The Banco de la República is a member of the WGPS-LAC and cooperates with G-10 central banks in the context of the CPSS. 


\section{Table 6.1 Oversight and Cooperative Arrangements in Latin America and the Caribbean (Continued)}

Country Oversight lssues

\section{Costa Rica}

Legal Foundations of the Function

Law 7558 of 1995 (Organic Law of the Banco Central de Costa Rica, BCCR), Article 2.

Transparency of the Oversight and Dissemination of Information

The operation of systemically important payment systems are detailed in a set of documents known as the Blue Book.

The BCCR does not have any regular publications covering payment system developments.

Statistical information on the payments system is not available on a regular and structured basis.

Objectives, Scope, Instruments, Pricing, and Access

BCCR has played a significant role in the payments system reform.

BCCR's objectives in the payment system have not been publicly disclosed.

Currently, instruments of oversight can be summarized as the operational involvement, its specific regulations, and moral suasion.

Explicit provision exists to regulate the pricing of payment services in both the central bank law and the Sistema de Negociación y Pagos Electrónicos regulation.

The BCCR determines access requirements to the systems it manages. As of yet, there is no general provision to regulate access to payment systems managed by the private sector.

\section{Organizational Arrangements and Cooperation}

Several departments under the Dirección de Servicios Financieros deal with payments system issues. Some aspects related to foreign exchange and cross-border payments are dealt with by another department (especially management of international reserves).

No formal unit is in charge of monitoring the payment system as a whole.

At the top level, coordination exists through Consejo Nacional de Supervision del Sistema Financiero. However, at the working level, no formal framework exists to enhance cooperation on a continuous basis.

No national payments system council exists.

The Banco Central de Costa Rica is a member of the WGPS-LAC.

\section{Dominican Republic}

A monetary and financial law (Ley Monetaria y Financiera, No. 182-2002, Articles 15 and 27) indicates that the final settlement of payments and clearing systems, and interbank market operations is the responsibility of the Banco Central de la República Dominicana. Article 27 also mentions that payments and cheques settlement systems, as well as other payment media, are a public service under the exclusive competence of the Banco Central de la República Dominicana. The article explicitly prohibits the organization of alternative multilateral settlement systems for the settlement of these instruments, although the service can be provided by a private institution if determined by the monetary board (junta monetaria).

\section{Transparency of the Oversight and Dissemination of Information}

Oversight function not formally performed.

The central bank does not have any regular publications on payment system developments. Statistical information on the payments system is not available on a regular and structured basis.

Objectives, Scope, Instruments, Pricing, and Access

Oversight function not formally performed.

Payment system services are provided free of charge. 


\section{Table 6.1 Oversight and Cooperative Arrangements in Latin America and the Caribbean (Continued)}

\begin{tabular}{l|ll} 
Country & Oversight lssues
\end{tabular}

Dominican Republic (Continued)
The central bank determines the access requirements to the systems it manages. As of yet, there is no general provision to regulate access to payment systems managed by the private sector.

\section{Organizational Arrangements and Cooperation}

The technology and systems department manages the central bank-operated systems. No unit is formally in charge of the oversight function.

No cooperation framework exists among authorities.

No national payment system council exists.

The Banco Central de la República Dominicana is not a member of the WGPS-LAC.

Ecuador Legal Foundations of the Function

The Banco Central del Ecuador (BCE) does not formally perform oversight over the payments system nor has the statutory authority to perform the function. Article 261 of the constitution defines the BCE function as the execution and monitoring of the monetary, financial, credit, and exchange policy. This article is replicated in the legal statute of the BCE (Article 70 of Ley de Régimen Monetario y Banco del Estado). The empowerment for payments systems stems from its role in the financial policy. There are also other specific references in the BCE legal statute, such as cheques clearing (Article 13) or the current accounts of financial institutions at the BCE.

Transparency of the Oversight and Dissemination of Information

Oversight function not formally performed.

The central bank does not have any regular publications covering payment system developments. Only limited statistical information on the payments system is available on a regular and structured basis.

Objectives, Scope, Instruments, Pricing, and Access

Oversight function not formally performed.

For payment services offered by the central bank, the policy of the central bank is that of full recovery of the production costs, including the opportunity cost of the invested capital.

The central bank determines the access requirements to the systems it manages. As of yet, there is no general provision to regulate access to payment systems managed by the private sector.

Organizational Arrangements and Cooperation

Management of the central bank-operated systems is performed by the national banking services division. No unit is formally in charge of the oversight function.

Payments systems issues are coordinated by two committees approved by the BCE regulations (Chapter I, Article 1): an internal committee of the BCE (Comité del Sistema de Pagos) and an interinstitutional committee (Comité Interinstitucional del Sistema de Pagos). However, the securities regulator is not included in the interinstitutional committee.

No national payment system council exists.

The Banco Central de Ecuador is a member of the WGPS-LAC.

El Salvador

No legal clarity on the authority empowered to regulate and oversee payment systems.

Transparency of the Oversight and Dissemination of Information

Oversight function not formally performed.

Objectives, Scope, Instruments, Pricing, and Access

Oversight function not formally performed. 


\section{Table 6.1 Oversight and Cooperative Arrangements in Latin America and the Caribbean (Continued)}

\begin{tabular}{|c|c|}
\hline Country & Oversight lssues \\
\hline $\begin{array}{l}\text { El Salvador } \\
\text { (Continued) }\end{array}$ & $\begin{array}{l}\text { Organizational Arrangements and Cooperation } \\
\text { Oversight function not formally performed } \\
\text { No national payments system council exists. } \\
\text { The Banco Central de El Savador is a member of the WGPS-LAC. }\end{array}$ \\
\hline \multirow[t]{16}{*}{ Guatemala } & Legal Foundations of the Function \\
\hline & $\begin{array}{l}\text { The Legal Statute of the Banco de Guatemala (BANGUAT) (Ley Orgánica del Banco de Guatemala) of } \\
\text { May 2002, Article } 4 .\end{array}$ \\
\hline & Transparency of the Oversight and Dissemination of Information \\
\hline & The BANGUAT does not have any regular publications covering payment system developments. \\
\hline & Statistical information on the payments system is not available on a regular and structured basis \\
\hline & Objectives, Scope, Instruments, Pricing, and Access \\
\hline & $\begin{array}{l}\text { The BANGUAT plays a leading role in the reform of payment arrangements in the country, in particular } \\
\text { through the launch of the new RTGS system. }\end{array}$ \\
\hline & The objectives and scope of the oversight function are not clearly defined. \\
\hline & $\begin{array}{l}\text { In absence of secondary legislation or any central bank document on payments system oversight, the } \\
\text { available instruments are regulation and moral suasion in the context of the central bank's activities. }\end{array}$ \\
\hline & $\begin{array}{l}\text { The BANGUAT has not yet defined a coherent pricing policy for the payment systems it operates, or guide- } \\
\text { lines for the payment systems it does not operate. }\end{array}$ \\
\hline & There is no statement that clarifies BANGUAT objectives and policies related to access. \\
\hline & Organizational Arrangements and Cooperation \\
\hline & No unit is in charge of the oversight function. \\
\hline & $\begin{array}{l}\text { No formal cooperation exists between the BANGUAT and other regulators on payment system issues. Only } \\
\text { recently, the BANGUAT has become more active in international and regional fora on payments and } \\
\text { securities settlement issues. }\end{array}$ \\
\hline & No national payments system council exists. \\
\hline & The Banco Central de Guatemala is a member of the WGPS-LAC. \\
\hline
\end{tabular}

The general empowerment of the central bank regarding payment systems emanates from article 2 of the Banco Central de Honduras (BCH) Law. It indicates that the $\mathrm{BCH}$ is responsible for the stability of the internal and external value of the domestic currency and the normal functioning of the payment systems. Article 16 includes as one of the functions of the $\mathrm{BCH}$ Board the responsibility over the adequate functioning of the financial and payments systems in the country.

Transparency of the Oversight and Dissemination of Information

Oversight function not formally performed.

Objectives, Scope, Instruments, Pricing, and Access

The Banco Central de Honduras plays a leading role in the reform of payment arrangements in the country, in particular through the launch of the new RTGS system.

Oversight function not formally performed.

Organizational Arrangements and Cooperation

No unit is in charge of the oversight function.

A national payments system council was recently established.

Only recently, the $\mathrm{BCH}$ has become more active in international and regional fora on payments and securities settlement issues. However, BCH is not a member of the WGPS-LAC. 


\section{Table 6.1 Oversight and Cooperative Arrangements in Latin America and the Caribbean (Continued)}

\begin{tabular}{|c|c|}
\hline Country & Oversight Issues \\
\hline \multirow[t]{18}{*}{ Jamaica } & Legal Foundations of the Function \\
\hline & $\begin{array}{l}\text { The only reference is Article } 27 \text { of the Bank of Jamaica (BOJ) Act ("The Bank may promote the establishment } \\
\text { of bank clearing systems and provide facilities for the clearance and settlement of transactions between } \\
\text { commercial banks"). }\end{array}$ \\
\hline & Transparency of the Oversight and Dissemination of Information \\
\hline & $\begin{array}{l}\text { The BOJ does not formally perform oversight of the payments system nor does it have the statutory authority } \\
\text { to perform the function. }\end{array}$ \\
\hline & $\begin{array}{l}\text { The central bank does not have any regular publications on payment system developments. Statistical } \\
\text { information on the payments system is not available on a regular and structured basis. }\end{array}$ \\
\hline & Objectives, Scope, Instruments, Pricing, and Access \\
\hline & $\begin{array}{l}\text { The cheque clearinghouse is operated by the Jamaica Clearing Bankers Association but its oversight falls } \\
\text { under the BOJ. The BOJ also participates in the governance arrangements of the Automated Clearing House }\end{array}$ \\
\hline & $\begin{array}{l}\text { For the payment services offered by the central bank, the policy of the central bank is that of full recovery of } \\
\text { the production costs, including the opportunity cost of the invested capital. }\end{array}$ \\
\hline & $\begin{array}{l}\text { The central bank determines the access requirements to the systems it manages. As of yet, there is no } \\
\text { general provision to regulate access to payment systems managed by the private sector. }\end{array}$ \\
\hline & Organizational Arrangements and Cooperation \\
\hline & $\begin{array}{l}\text { The banking and market operations division manages the central bank-operated systems. No unit is formally } \\
\text { in charge of the oversight function on both systems operated by the central bank and other operators. }\end{array}$ \\
\hline & $\begin{array}{l}\text { The BOJ is establishing its oversight function. The draft policy statement will include recommendations for } \\
\text { the organizational structure of the oversight department. }\end{array}$ \\
\hline & $\begin{array}{l}\text { The payments system oversight function is to be carried out by an autonomous department. The department } \\
\text { is currently staffed with a manager, one graduate member of staff, and an administrative assistant. The } \\
\text { department is currently engaged in internal and external system implementation activities as they relate to } \\
\text { payments system reform. The detailed staffing arrangements for oversight are to be determined on completion } \\
\text { of the reforms. }\end{array}$ \\
\hline & A national payment system council was established in 2005 . \\
\hline & $\begin{array}{l}\text { Domestically, at the top level forms of coordination exist between authorities (in particular, the BOJ, the Min- } \\
\text { istry of Finance, and the financial services commission). However, at the working level no formal framework } \\
\text { seems to exist to enhance cooperation on a continuous basis. }\end{array}$ \\
\hline & $\begin{array}{l}\text { There is not yet a clear distinction between the banking supervision and the payments system oversight } \\
\text { tasks within the BOJ. }\end{array}$ \\
\hline & No formal agreement is in place with other central banks or international institutions. \\
\hline & The Bank of Jamaica is a member of the WGPS-LAC. \\
\hline
\end{tabular}

The Banco de México law contains several articles dealing with the specific powers of the Banco de México for payment systems. Among these, the most relevant follow:

- Article 3 defines the central bank's functions as being to regulate the issuance and circulation of currency and of the payments system, and to operate with credit institutions as the reserve bank and as lender of last resort.

- Article 15 details the requirements and exceptions for financing that Banco de México may grant to credit institutions in order to avoid problems in the payments system and the operations Banco de México can make as the lender of last resort. 


\section{Table 6.1 Oversight and Cooperative Arrangements in Latin America and the Caribbean (Continued)}

\begin{tabular}{|c|c|}
\hline Country & Oversight Issues \\
\hline $\begin{array}{l}\text { Mexico } \\
\text { (Continued) }\end{array}$ & $\begin{array}{l}\text { - Article } 24 \text { establishes the central bank's ability to issue regulations for the payments system and to impose } \\
\text { sanctions on entities that do not follow these dispositions. }\end{array}$ \\
\hline
\end{tabular}

Moreover, in November 2002, the Mexican congress enacted the Payment System Law, granting Banco de México full powers to oversee all systemically important payment systems in the country, whether operated by itself or by any other entity or entities, and to impose sanctions.

Transparency of the Oversight and Dissemination of Information

The oversight authority of the Banco de México is not articulated in a formal policy document.

Banco de México regularly publishes on its Web site statistics on fees charged by commercial banks for payment services, general information on the different products commercial banks offer to their clients, and statistics on the use of the major payment systems in the country.

In January each year, Banco de México must disclose, by means of a publication in its official newspaper, the systems it deems as systemically important and, thus, that it is entitled to oversee.

Objectives, Scope, Instruments, Pricing, and Access

Banco de México formally oversees all systemically important payment systems in the country as well as the Sistema Interactivo para el Depósito de Valores, the securities settlement system operated by Instituto para el Depósito de Valores. In practice, it also oversees some retail systems, such as those operated by the Centro de Compensación Bancaria.

The main instruments are direct supervision, moral suasion, and cooperation.

The main criteria underlying the pricing policies are disclosed on Banco de México's Web site.

There is no formal policy regarding access to settlement systems.

Organizational Arrangements and Cooperation

No national payment system council exists.

No formal unit is in charge of payment system oversight within the Banco de México.

There is no specific memorandum of understanding on settlement issues between the Banco de México and the Comisión Nacional Bancaria y de Valores.

The Banco de México is a member of the WGPS-LAC and cooperates with G-10 central banks in the context of the CPSS.

\section{Legal Foundations of the Function}

The Bank van de Nederlandse Antillen (BvdNA) does not have clear legislative authority for the oversight of clearance and settlement systems. The only available regulation for the payments system is the 2001 rulebook for the Netherlands Antilles Clearing System (NACS). Appropriate secondary legislation (bylaws, circulars, and so on) does not exist.

\section{Transparency of the Oversight and Dissemination of Information}

Oversight function not formally performed.

The BvdNA does not have any regular publications covering payment system developments. Statistical information on the payments system is not available on a regular and structured basis.

\section{Objectives, Scope, Instruments, Pricing, and Access}

Oversight function not formally performed.

The NACS was developed jointly by the BvdNA and commercial banks; the investments to develop the system and implementing it were shared. Each participant had contributed the same amount and no differentiation has been made to the future use of the system. Maintenance costs are yearly divided among the 


\section{Table 6.1 Oversight and Cooperative Arrangements in Latin America and the Caribbean (Continued)}

\section{Country \\ Oversight Issues}

Netherlands Antilles (Continued) participants according to the same formula. Staff costs to operate the system are at the expense of the BvdNA. Under this arrangement, for individual transactions processed through the NACS no fee is charged to the participants. Moreover, NACS pricing policies are neutral with regard to less-efficient payment instruments (for example, cheques).

Banks and the government have access to the NACS system operated by the central bank. There is no statement that clarifies BvdNA's objectives and policies related to access.

\section{Organizational Arrangements and Cooperation}

Only informal cooperation exists between the department in charge of operating the NACS system and the banking supervision department.

No national payment system council exists.

The BvdNA is not very active in international and regional fora on payments and securities settlement issues.

The Bank van de Nederlandse Antillen is not a member of WGPS-LAC.

Nicaragua Legal Foundations of the Function

The Banco Central de Nicaragua has legislative authority for the oversight of clearance and settlement systems. The Organic Law (Article 3) states that one of the functions of the central bank is to regulate international and domestic payment. Other articles of the organic law mention more specifically its role for the payment system clearinghouse and could be interpreted as applicable to other payment systems, as well. Other available regulation for the payments system are the rulebooks for both the Transferencias Telefónicas Segura and the cheque clearinghouse.

Transparency of the Oversight and Dissemination of Information

Oversight function not formally performed.

Objectives, Scope, Instruments, Pricing, and Access

Oversight function not formally performed.

Organizational Arrangements and Cooperation

No unit is in charge of the oversight function.

No national payment system council exists.

The Banco Central de Nicaragua is not a member of the WGPS-LAC.

OECS Legal Foundations of the Function

Under the 1983 agreement, the central bank "may at a suitable time in conjunction with other banks organize clearinghouses in such places as may be desirable" (Article 36); no other provision contained in both the agreement and the Banking Act specifically addresses payment system issues, so the role played and the objectives pursued in the payment system are not disclosed.

Transparency of the Oversight and Dissemination of Information

Oversight function not formally performed.

Objectives, Scope, Instruments, Pricing, and Access

Oversight function not formally performed.

Organizational Arrangements and Cooperation

No unit is in charge of the oversight function.

No national payment system council exists.

The Eastern Caribbean Central Bank is a member of the WGPS-LAC. 


\section{Table 6.1 Oversight and Cooperative Arrangements in Latin America and the Caribbean (Continued)}

\begin{tabular}{l|l}
\hline Country & \multicolumn{1}{c}{ Oversight lssues } \\
\hline Panama & Legal Foundations of the Function \\
No central bank. & Transparency of the Oversight and Dissemination of Information \\
Oversight function not formally performed. \\
Objectives, Scope, Instruments, Pricing, and Access \\
Oversight function not formally performed. \\
Banco Nacional de Panamá performs some regulatory and administrative responsibilities related to cheques \\
and other payment instruments and settlement. \\
Organizational Arrangements and Cooperation \\
No unit is in charge of the oversight function. \\
No formal cooperative arrangements are in place, but banks have reached important agreements in relevant \\
areas. \\
No national payment system council exists. \\
Panama authorities are not members of the WGPS-LAC.
\end{tabular}

Paraguay Legal Foundations of the Function

Article 45 of the Central Bank Organic Law 489 of June 29, 1995, states that it is a Banco Central de Paraguay's objective to guarantee the smooth functioning of payment systems, including clearinghouses. Article 5 of the Organic Law empowers the Banco Central de Paraguay to issue any regulations it deems appropriate to carry out its functions, including payment system oversight. Another piece of legislation for the payments system is the central bank resolution number $01 / 1999$, which based on Law N. 1292/1943, regulates the cheque clearinghouse. Moreover, the Cheque Law 805/1996 gives the Banco Central de Paraguay the authority to regulate the modalities of issuance of the instrument. The Banco Central de Paraguay's Interbank Transfer System is regulated by Article 64 of the Organic Law (opening of current account) and several internal provisions of the Banco Central de Paraguay.

Transparency of the Oversight and Dissemination of Information

Oversight function not formally performed.

Objectives, Scope, Instruments, Pricing, and Access

Oversight function not formally performed.

Organizational Arrangements and Cooperation

No unit is in charge of the oversight function.

No national payment council exists.

The Banco Central de Paraguay is a member of the WGPS-LAC.

The central bank does not have a clear empowerment over the payment system oversight function. At present, there is no explicit legal mandate for the central bank to be in charge of the oversight of the payment system, although it is indirectly hinted in the central bank bylaw, in its Article 68, whereby the central bank is empowered to regulate the operation of clearinghouses. The Banco Central de Reserva del Perú (BCRP) develops its oversight function through pieces of regulation called circulares.

Transparency of the Oversight and Dissemination of Information

The objectives of the payments system reform are not formally disclosed, nor is there a policy statement. 


\section{Table 6.1 Oversight and Cooperative Arrangements in Latin America and the Caribbean (Continued)}

Country $\quad$ Oversight Issues

Peru

(Continued)

\section{Objectives, Scope, Instruments, Pricing, and Access}

The main objectives of the payment systems reform and their general guidelines are provided by the BCRP board. The central bank's credit and financial regulation division permanently supervises the performance of the financial sector. In that sense, the payment system department is in charge of payment system oversight, and the monetary and exchange operations department supervises the banks liquidity level and the financial support, if necessary. Finally, the financial system analysis department monitors and evaluates banking sector performance. All these functions are related, and there is feedback among the departments in charge of them.

\section{Organizational Arrangements and Cooperation}

The relationships between the Central Bank and the Superintendency of Banking and Insurance, in the framework of the payment system reform, are based on an Understanding Agreement. It guarantees cooperation and the coordination of common actions to issue regulations regarding the clearing of cheques and other payment instruments. The Superintendency of Banking and Insurance controls and supervises all financial institutions (main users of the Sistema de Liquidación Bruta en Tiempo Real and the clearinghouse). The Superintendency of Banking and Insurance, based on a memorandum of understanding (Acta de Entendimiento) with the BCRP, is empowered to grant the organization and functioning approvals to the electronic clearinghouse. The BCRP also subscribed another memorandum of understanding with the securities commission, Comisión Nacional Supervisora de Empresas y Valores, in August 2002. In the latter, it was agreed on to set up a new securities settlement system based on a delivery versus payment system based on Model 2 of the CPSS (Bank for International Settlements) with final funds transfer through the RTGS.

The BCRP established a cooperative framework through the Payment System Inter-bank Commission in 1998 to spearhead change in the payment systems. The Payment System Inter-bank Commission has provided a forum for developing a consensus on payments system reform, assisting the central bank in the development of an RTGS system, and providing leadership for the planned electronic clearinghouse. Currently, this committee meets occasionally to deal with specific topics. It functions as a forum whereby the central bank and the banking association interchange opinions on various matters of interest, the opinions being nonbinding.

The Banco Central de Reserva del Perú is a member of the WGPS-LAC.

\section{Trinidad and Tobago}

The Central Bank of Trinidad and Tobago undertook an upgrade of existing laws and the introduction of laws specific to payment systems. This legal reform will include a formal empowerment to the Central Bank of Trinidad and Tobago to exercise its payment system oversight function.

\section{Transparency of the Oversight and Dissemination of Information}

A draft policy statement, which includes the objectives, policy stance, and instruments of the oversight function, has been prepared by the payments system council.

Payment system oversight is considered an autonomous regulatory function. The function has developed largely as a result of increasing international debate. It is deemed necessary to bring improvements to the payments clearance and settlement arrangements in the financial system.

Objectives, Scope, Instruments, Pricing, and Access

The following are according to the plan being implemented by the Central Bank of Trinidad and Tobago:

- The objectives of payments system oversight will be efficiency, reliability, safety, and protection of public interest. The participants are free to offer new products and services.

- The instruments for oversight will include moral suasion, rules, agreements, sanctions, and on-site inspection. When the reforms, including legal reform, have been completed, the regulation will be an important instrument. The rules governing the operation of the RTGS, which is operated by the central bank, cover issues of sanctions and penalties for noncompliance.

The plan is to carry out both on- and off-site assessment of systemically important payment systems. On-site assessment will be done in coordination with the supervision function. The oversight department will develop returns to be submitted by participants for analysis. 


\section{Table 6.1 Oversight and Cooperative Arrangements in Latin America and the Caribbean (Continued)}

\begin{tabular}{l|l} 
Country & Oversight Issues
\end{tabular}

Trinidad and Tobago (Continued)

\section{Organizational Arrangements and Cooperation}

The payments system oversight function is to be carried out by an autonomous department. The department is currently staffed with a manager, one graduate member of staff, and an administrative assistant. The department is currently engaged in internal and external system implementation activities as they relate to payments system reform. The detailed staffing arrangements for oversight are to be determined on completion of the reforms.

A national payment system council was established in 2003.

The Central Bank of Trinidad and Tobago is a member of the WGPS-LAC.

\section{Legal Foundations of the Function}

According to its legal statute (Central Bank Law 16.696) dated March 30, 1995, the Banco Central del Uruguay (BCU) has overall legislative authority for the oversight of clearance and settlement systems. The basis of this is expressed in Article 3, which includes as one of the purposes of the BCU, "to ensure the normal functioning of domestic and international payments," and also from Article 7, which empowers the BCU to regulate and supervise the activities of financial sector institutions to accomplish its main purposes, as expressed in Article 3.

\section{Transparency of the Oversight and Dissemination of Information}

In practice, the payment system oversight function is not formally performed within the BCU.

The BCU does not have any regular publications covering payment system developments. Statistical information on the payments system is not available on a regular and structured basis.

Objectives, Scope, Instruments, Pricing, and Access

In absence of secondary legislation or any BCU document on payments system oversight, the available instruments are regulation and moral suasion in the context of the central bank's activities.

At present, the BCU does not charge for the payment and settlement services it provides to institutions that hold a current account with it. Fees were applied in the past, however, and once the migration to the new technological platform is accomplished, the BCU intends to resume the application of fees. However, the pricing policy targets solely a general cost recovery, and no other objectives are sought through this means.

Financial institutions participate in the Sistema Electrónico de Comunicaciones under the legal basis provided by Article 29 of the Central Bank Law. Having a current account at the BCU is required for being able to operate in the Sistema Electrónico de Comunicaciones, but is not sufficient. Institutions without access to the Sistema Electrónico de Comunicaciones can transfer funds by means of paper-based instructions (cartas).

There is no statement that further clarifies BCU objectives and policies related to access.

\section{Organizational Arrangements and Cooperation}

In practice, the payment system oversight function is not formally performed within the BCU.

The BCU does not have any regular publications covering payment system developments. Statistical information on the payments system is not available on a regular and structured basis.

Domestically, there is regular coordination with the Ministry of Finance for issues related to the issuance of government securities. The banking supervisory and securities regulatory functions are performed by the BCU through a banking superintendence and a specialized department (Gerencia del Mercado de Valores). There are no other formal or informal cooperation schemes with other authorities.

No national payment system council exists.

The Banco Central del Uruguay is a member of the WGPS-LAC. 


\section{Table 6.1 Oversight and Cooperative Arrangements in Latin America and the Caribbean (Continued)}

\section{Country \\ Oversight lssues}

Venezuela, R.B. de

Legal Foundations of the Function

The Ley del Banco Central de Venezuela (BCV), October 3, 2001, states, “To achieve adequately its objective(s), the BCV will carry out the following functions ... to oversee the smooth functioning of the payments system and establish its operating rules" (Article 7, \#7). Similarly, Article 21 (\#17) states that among the powers of the board of directors of the BCV is to exercise oversight and dictate rules for the different payment systems in the country, operated or not by the BCV, to ensure they operate efficiently and with the highest level of safety. The BCV is the only entity authorized to establish operating rules for bilateral and international payment systems. The BCV's resolution 99-07-01 expands on general considerations and objectives of the payments reform. The BCV has issued the rules and regulations for the cheque clearinghouse (Reglamento del Sistema del Sistema de Cámara de Compensación, Resolution \#96 08-01). There is no other bylaw or secondary legislation available in the field of payment systems.

Transparency of the Oversight and Dissemination of Information

A public policy statement on oversight is being prepared by the BCV.

The BCV does not have any regular publications covering payment system developments. Statistical information on the payments system is not available on a regular and structured basis.

\section{Objectives, Scope, Instruments, Pricing, and Access}

The central bank's charter mentions explicitly efficiency and safety as the main BCV objectives in the area of payment systems. The scope is wide because all payment systems in the country are covered by Article 21 of the BCV charter.

In the absence of secondary legislation or any BCV document on payments system oversight, the available instruments are regulation and moral suasion in the context of the central bank's activities.

Organizational Arrangements and Cooperation

Coordination among the BCV, the securities regulator, the National Banking Committee (Consejo Bancario Nacional) and the banking supervision exists at the level of the steering committee.

A national payment system council was established in 2004.

The Banco Central de Venezuela is a member of the WGPS-LAC.

Source: Authors' elaboration.

\section{OBSERVATIONS}

- In most Latin America and Caribbean (LAC) countries the law gives some authority to the central bank over the payments system. However, the legal foundation of oversight of clearance and settlement systems is not always solid. For example, the law is often not clear about the scope of application of the function and the relative roles of the central bank and other authorities. To overcome these problems, it is of paramount importance that central banks prepare and encourage approval of a primary or secondary legislation to complete the legal framework and ensure the secure foundation of payment mechanisms that effectively contribute to the integrity, efficiency, and safety of all financial markets and the operation of monetary policy, especially in the area of securities settlement systems. Legislation should clarify in detail the empowerment and enforcement of the central bank as payment system overseer.

- In the context of establishing the oversight function, each LAC central bank should disclose publicly its objectives relating to all significant payment system matters along with its implementation strategies. To this end, it is suggested that central banks develop a comprehensive policy statement. This policy statement should provide sufficient guidance to private sector organizations for all payment systems on matters relating to governance, day-to-day management, risk mitigation, and on the policies that must be satisfied by all transactions that are ultimately settled on its books. 
- With regard to policy objectives, it is recommended that LAC central banks broaden the focus beyond the two traditional main objectives of efficiency and reliability of payment systems to a wider set of issues including the promotion of competition in the payment services market and the protection of consumer interests. These objectives might be pursued by the central banks, as overseer on the payment system, especially in those cases not embraced by other regulatory or supervisory authorities. With regard to the scope of its oversight role, it is recommended that the central bank apply its oversight authority over all payments and securities settlement systems in the country, both systemically important and retail systems, because the latter are especially important in supporting economic activity and the public trust in money.

- LAC central banks, in exercising their oversight role, should have the ability to carry out this function effectively, as follows:

- Central banks should establish appropriate organizational arrangements and staffing. This includes forming a small unit in charge of payments system oversight to be separated to the extent possible from the units in charge of operating the systems offered by the central bank. Skills of human resources involved in the function should be as wide as possible and include legal, operational, and technical expertise as well as policy and economics.

- Central banks should ensure that an adequate degree of participant cooperation exists, and that it is sufficient to promote and realize the desired organizational and operational arrangements (see below in this section).

- Central banks should verify that individual payment systems satisfy user needs, as well as risk and efficiency requirements, through appropriate interventions both at the development stage and during the ongoing system implementation and operational phases.

- Central banks should define and implement appropriate actions in case participants do not comply with published rules and regulations (for example, the application of predetermined penalties and sanctions for compliance failures).

- Central banks should collect and distribute relevant statistical information to demonstrate the use being made of each system and the extent to which the systems are satisfying end user and other market needs. Information and public policy statements relating to all substantial payment system matters should be disclosed in a manner that ensures wide dissemination among payment system stakeholders and the general public (for example, in a payment system chapter of the annual report or other appropriate publication).

- LAC central banks should move toward compliance of all systemically important payment systems in the countries with international standards, as a matter of urgency. In particular, central banks will continue to be direct providers - owners and operators - of clearing and settlement services. With regard to such services, care should be taken to ensure that appropriate service and performance levels are routinely achieved, and that these services and performance levels adequately cover all critical safety and efficiency requirements. To this end, central banks should continuously review and seek to improve the design and operation of the systems they operate (for example, along the lines that the CPSS CPSIPS envisage for payment systems operated by private entities).

- In performing the oversight function, LAC central banks should ensure that transparency of policies and conditions for payment services offered be available to the population of their countries at all times. In each country, the central bank, commercial banks, and other financial institutions should be encouraged to provide information to the public on the services they offer in the payments system and the fees they charge. Moreover, arrangements for the resolution of conflicts should be disclosed and understood by providers, users, and regulators of payment systems and services. The public should be able to resort to any consumers' protection agencies (for example, a bank ombudsman) for resolution of conflicts related to payment services. The central bank should cooperate with the banking supervisor and other relevant authorities to ensure that payment instrument services and instruments are appropriately covered by the new arrangements.

- Cooperation among regulators is an essential component of the oversight function and is lacking in most LAC countries. The payments system overseer (central bank), the Ministry of Finance, the banking supervisor, the securities commission, and other relevant authorities should identify and implement procedure and process changes to address any weaknesses or inconsistencies in the regulatory arrangements and to ensure 
a high level of cooperation in the way that policies are implemented. Consideration should be given to the need for joint task forces to address problems of common interest or the preparation of appropriate memoranda of understanding. At the international level, central banks are invited to become more and more involved in the efforts of harmonization at the subregional level - for example, within MERCOSUR, in Central America and in the Caribbean, and in the activities of the WGPS-LAC.

- In sum, regarding the oversight function and its transparency, many central banks in LAC are in the process of establishing the payment system oversight function. However, many central banks do not fully observe Responsibilities A, B, C, and D of the CPSIPS and, therefore, need to give more solid foundation to the practice.

- Cooperation among regulators and stakeholders is an essential element to ensure safety and efficiency of the payments system. No formal cooperative arrangements for the payments system as a whole exist in LAC countries. It is strongly recommended that, in each country, the central bank establish as a matter of urgency a formal national payment system council. The new body to be formed should include representatives from all major stakeholders with an interest in payments and securities clearance and settlement systems improvements. This new body should be used as the main tool, also, to secure a constructive dialogue between regulators and market participants. The central bank should provide strong leadership and the secretariat of such a body. Payment system councils in the different LAC countries could establish some forms of interaction among them, in particular to move forward the harmonization and integration agenda.

- Binding interbank agreements are equally important to enhance cooperation within the banking sector. It is understood that cooperation at the interbank level has not always been satisfactory in LAC countries. Evidence of this lack of interbank cooperation can be seen in the area of retail payment circuits, the development of the interbank market, and the slowness to reduce the dependency of some countries on cheques. In light of possible market concerns about the potential loss of competitive advantages - which are, however, lower than the social benefit of taking these actions - the central bank and the banks are urged to work together toward the implementation of some agreements in the area of payment systems, which could enhance efficiency for the banking sector as a whole.

- In sum, cooperative arrangements in payment systems should be enhanced in LAC, as a matter of urgency. 



\section{Implementing Payments and Securities Settlement Systems Reforms}

he implementation of a payments and securities settlement system (PSSS) reform is an important undertaking that will involve an effort from all stakeholders over a number of years. Thus, it will constitute a medium-term process normally led by public authorities, but with the important involvement of the private sector. This chapter is based mainly on the experience of the PSSS reforms in which the Western Hemisphere Payments and Securities Clearance and Settlement Initiative team has been involved, but also on other experiences of the World Bank payments unit in helping to reform PSSSs around the world. Two of the authors of this book have also participated in the CPSS working group that developed guidelines for national payment system (NPS) ${ }^{1}$ development, and some of the ideas included in this chapter have been integrated in the final working group document (CPSS 2006a). This chapter is, thus, complementary with the document of the working group.

The starting point of a reform should be a comprehensive assessment of PSSSs based on international standards (see chapter 3 on assessment tools). This chapter is divided into five sections. The first section deals with the issue of how to use the international standards for a review or reform of PSSSs. The second section analyzes the role of a national payment system (NPS), its scope, components, and conceptual framework. The third section explains the different institutional roles. The fourth

${ }^{1}$ References to NPS in this book cover both payments and securities settlement systems. section presents an approach to engage the private sector in a reform program. Finally, the fifth section indicates the main elements of an action plan.

\section{THE ASSESSMENT AS A STARTING POINT OF A PSSS REFORM}

In assessing PSSSs, the assessors - that is, the national authorities in cooperation with the stakeholders or the external assessors - might identify the need for a major reform of the PSSSs, which goes beyond the application of specific measures to overcome existing deficiencies relative to individual settlement systems. Sound and efficient PSSSs are essential in guaranteeing a smooth functioning of the country's financial markets and, ultimately, of the economy in general. In carrying out a reform of settlement systems, the domestic authorities and the stakeholders, with support from assessors, have to face several challenges, some of which are dealt with in the current section of this report. In this exercise, authorities and assessors can also find some guidance in section 10 of the core principles report of the Committee on Payment and Settlement Systems (CPSS 2001), which expands on the importance of a strategic vision in reforming the payments systems, especially in emerging markets. In case of any doubt, authorities and assessors can seek assistance from external specialists, such as those from the International Monetary Fund and the World Bank, organizations that count with staff experienced in reforming payments systems.

An NPS architecture should be considered as an important element in the safety and stability of the financial system as a whole. A consensus on a strategic and 
collaborative approach is crucial, in that it would take a holistic view of all aspects of the nation's payment system needs and satisfy them in an orderly and cost-efficient manner. A collaborative approach, with the active participation of all stakeholders, is highly desirable because of the complexity of the required changes, which will involve inputs relating to service providers; users; technologies; legal and regulatory matters; and contributions from several professional disciplines. A wellstructured collaborative approach will create synergy, stimulate learning, and provide a basis for optimizing benefits through cooperation and consensus building. Finally, the strategic approach would be able to address all the critical issues present in the current payments arrangements.

The central bank or other regulators (in particular the securities regulators), or both, are well positioned to take the lead in formulating and implementing the strategy for payments system modernization. As neutral agents, they are less likely to trigger competitive concerns that could slow progress, and are more able to support the creation of a comprehensive vision for the future NPS.

The scope and difficulty of developing and carrying out a strategy for a successful modernization of the payments system should not be underestimated. This will be a new process, and the projects that will be designed and carried out under the umbrella of the overall strategy will present new challenges to all parties involved. The major risks are that (1) the systems developed could not be used, (2) the resulting system changes will not satisfy the needs of all users, and (3) the systems will not be cost efficient and affordable. However, a collaborative and cooperative approach is the only way in which these risks can be minimized. In order to have an efficient cooperative approach, appropriate human resources, in number and expertise, should be made available by the different stakeholders.

Important issues to be considered are described below.

\section{Legal Foundation}

A sound legal foundation for the PSSSs is essential, and it is something that may take a long time to achieve depending on a country's legislative framework. The assessor should preferably discuss the outstanding legal issues - not only with the authorities, but also with the major participants in the settlement system - in order to find out the needs of a revised or upgraded legal and regulatory framework for the PSSSs. Important issues include the enforceability of contract law and its possible incompatibilities between contractual arrangements and various legislative provisions - for example, provisions of insolvency and competition laws. Finality of a payment or settlement and the possible implications of an existing zero-hour rule will need to be clearly defined.

If need be, the assessor would also have to recommend actions to improve the legal safety in collateral transactions, which is typically subject to three main bodies of law: the law of secured interests, insolvency law, and contract law. The law of secured interests governs the establishment and realization of collateral, and is the law that determines the conditions under which a pledge (or possibly also a repurchase agreement) would be valid. It also determines the procedures that have to be followed if the transferor defaults and the collateral has to be realized by the transferee. The most likely reason for a default by the transferor is insolvency, which would mean that the realization of collateral could be directly affected by the relevant insolvency law. Moreover, some countries may have different types of insolvency schemes depending, for example, on the type of entity that is insolvent. Contract law is also likely to be relevant to the terms of the agreement between the transferee and transferor governing the collateral transaction. In addition to these laws, other bodies of law can sometimes be relevant-for example, banking law, securities law, consumer protection law, and criminal law.

There exist no clearly defined standards for what kind of legislative or regulatory framework should be in place for a payment system. As a consequence, different models exist - from specific payments system acts and laws on central bank oversight, to more general laws, sometimes including provisions in the banking law and in the central bank law. In some countries, the laws are very detailed, whereas in others, the authorities - be it the central bank or other supervisors - have the power to decide on the regulatory framework of the payment system.

It could be debated which one of the models would be the best to choose. It is important to remember, while taking into account the need for the NPS, that the NPS is under constant development and that we do not know 
today what kind of developments we will see tomorrow. This suggests that PSSSs would benefit from a regulatory framework that includes less-detailed regulation in the form of a law, giving the overseer the power to regulate the system in more detail. This is not to say that there cannot be situations where a more-detailed regulation has to be included in the law, but that this should be the exception rather than the rule. There are also certain areas that are better suited to be covered in a law-for example, netting and finality issues.

\section{Monetary Policy, Liquidity Management, and Interbank Money Market}

A safe and efficient PSSS is important for the development of the financial markets. The fact that it is mainly through transactions involving securities - in particular government securities - that a central bank conducts its monetary policy operations gives the PSSS a central role in the financial market infrastructure. Well-functioning PSSSs are thus prerequisites for a modern way of conducting monetary policy. The assessor would have to make sure that the interrelationship between the payment system used for settling the cash side of securities transactions, and the securities settlement system (SSS) is safe and efficient and that delivery versus payment is achieved. Should the assessor find that settlement of securities transactions could be improved, the assessor should discuss such issues with central bank officials responsible for monetary policy operations and with their counterparts in some of the major banks, before making recommendations to that effect.

A safe and efficient PSSS is also important for achieving an efficient market for short-term liquidity based on collateral. Thus, an adequate functioning of the interbank money market supports the liquidity management within the financial sector. Efficient PSSS mechanisms will allow for the improvement of the liquidity management in the system, and thus will introduce better conditions for broker-dealers in the credit lines that they negotiate with banks. A smooth functioning of the money market is also of key interest for the functioning of large-value payment systems. This is especially true of the delivery of collateral to the central bank in order to obtain intraday or overnight credit, which is important in a developed financial market. For this reason, it should be possible to settle transactions with intraday finality.

\section{Level of Sophistication in the Financial Sector and the Infrastructure in the Country}

Recommendations on how to reform a PSSS should take into account the level of development in the financial sector and the sector's actual needs. Furthermore, any recommendations that an assessor makes should take into account the level of development of the infrastructure in the country, in particular the reliability of electrical power and telecommunication installations. In making recommendations, the assessor would need to emphasize that - regardless of the simplicity of a system that sometimes may be best suitable for a developing country-the system should observe the recommendations. Care should also be given to recommended actions that could form a base for easily upgrading to higher standards, when deemed appropriate and cost-effective.

\section{Development Priorities}

Within the financial sector, a safe and efficient payment system for systemically important payment systems (SIPS) would have the highest priority, because most sectors of a country's economy and the country's population would engage in payment system transactions that are finally settled in a SIPS. An SSS that settles large values is likely to come next in the priority list, and its development should be carefully integrated with the SIPS through which the cash side of securities transactions should settle in the form of delivery versus payment. As with SIPS, an SSS that settles on a deferred net settlement basis has to be protected, so that it manages to settle even if the participant with the largest debtor position cannot deliver the required securities. The protection could take several forms - for example, counterpart limits, insurance, automatic securities lending, and liquidity funds built up by the participants and controlled by the operator of the SSS or the central bank.

In defining the various activities that would need to be undertaken, it is clear that the legal or regulatory framework constitutes normally a first priority, and that work should start early in the reform process. The reason is that it could take a considerable amount of time to put in place, or make necessary changes in the legal framework. Therefore, these are activities in a PSSS project that need to start early in the process. 
In certain circumstances, it might also be important to take into account a regional or subregional perspective, in particular if actions to consolidate systems at these levels are in place.

\section{The Need to Increase the Knowledge Base of Payment and Securities Settlement Issues}

Competence within the area of PSSSs is scarce in many countries, because this area has only recently come into focus. There are many ways in which the knowledge base could be increased, which the assessor should stress. An important way would be to study the various reports that have been published by the Committee on Payment and Settlement Systems and International Organization of Securities Commissions, as well as other institutions and organizations - for example, the Group of Thirty and the European Central Bank. Participation in international seminars and workshops should be encouraged. The authorities (regulators and overseers) should be encouraged to pay visits to foreign regulators and overseers that have developed a substantial knowledge base in this area. It is recommended that the authorities take steps to make sure that major stakeholders engage in studying all aspects of settlement systems, thus facilitating the discussions about the possible needs to make existing settlement systems safer or more efficient, or to embark on a reform program.

\section{THE ROLE OF AN NPS}

It is widely accepted that an NPS consists of a set of instruments, banking procedures, and - typically - funds transfer systems that ensure the circulation of money; as well as the full set of institutional arrangements for the confirmation, clearance, and settlement of securities trades and safekeeping of securities. Any country's economy can be viewed as a series of layers in an inverted pyramid, in which each layer is supported by the layers beneath it. The broadest layer of the pyramid represents the real economy and the financial markets - the buying and selling of goods and services throughout the nation. It is supported by the country's banking systemthe next level of the pyramid — which provides payment services to all sectors of the economy. The third level consists of a limited number of interbank value transfer systems through which payment and other financial transactions are processed. The final settlement of funds transfers normally takes place across the accounts that approved institutions hold with the central bank, whose pivotal role is vital to the functioning of the economy as a whole.

The NPS is therefore a core component of the broader financial system and can be viewed as the infrastructure that provides the economy with the channels, or circuits, for processing the payments resulting from the many different types of economic transactions that take place on a daily basis.

A well-functioning NPS requires a delicate balance between market-driven competition, cooperation, and public good considerations. In a mature environment, banks and other payment-service providers should compete for payments business and customers, while achieving the benefits and efficiencies that stem from the sharing of noncompetitive infrastructures. In the national interest, it is imperative that economies of scale be achieved and that the national payment service infrastructure allow as many participants as possible to offer their services to the public.

\section{Scope and Components of an NPS}

It is clear from the previous points that a comprehensive NPS comprises not just the funds transfer mechanisms payment processing organizations, communications networks, and computer systems - but also includes the following:

- Institutions providing financial intermediation.

- A legal and statutory framework.

- Rules, regulations, and agreements.

- Appropriate payment instruments.

- Processing systems and procedures.

- A cost-effective technological infrastructure.

- Clearing and settlement mechanisms that adequately balance risk and efficiency requirements.

- Providers of access to payment-related services.

- Carefully selected range of payment-service providers and products that satisfy market needs at acceptable costs.

\section{Conceptual Framework for NPS Development}

Typically, payment services have evolved — over timein an incremental manner, driven both by the need to resolve problems and by the need to take advantage of 
specifically identified improvement opportunities. To avoid a continuation of this ad hoc operational approach to payments system development, several countries have paused and initiated a business-and banking-needsdriven strategic approach to identify and implement a phased series of agreed-on changes - based on stakeholder consensus - to ensure the realization of a welldescribed medium-term vision of the NPS. A smooth and trouble-free implementation of the NPS can best be achieved through development of a vision that characterizes the sought-after arrangements in terms of goals, objectives, primary features, critical success factors, fundamental principles, and strategies.

There is no disagreement that the primary goal of the NPS is to enable the circulation of money. This goal emphasizes the fact that the NPS is an enabler of economic activity. It provides the circuits for effecting payments, both domestic and international. Usually there is no disagreement as to the objectives of the NPS. There are typically three broad objectives:

- To provide effective mechanisms for the exchange of money between transacting parties.

- To ensure finality and irrevocability of both payment and settlement.

- To enable the management, reduction, and containment of systemic and other payment related risks.

Primary features require detailed discussion and agreement with all stakeholders, because they will include a full range of policy, operational, and technical attributes that will characterize the future. A partial list of typical characteristics might be as follows:

- Settlement of domestic interbank obligations is effected on a same-day basis.

- Participants compete on an equal footing in the provision of interbank clearing and settlement services.

- There is healthy competition among customer payment-service providers.

- The NPS is easily accessible.

- The NPS is cost efficient.

- Appropriate subsystems are provided for retail, wholesale, foreign exchange, commodities markets, capital market, and money market transactions.

- The public is aware of NPS features.

- The NPS supports electronic delivery versus payment for securities transactions, and payment versus payment for foreign exchange transactions.
- The NPS is internationally compatible.

- Payment settlement time lags resulting from trading transactions are in line with international practice.

- The NPS makes optimum use of the available liquidity.

- The international community has an appreciation of the effectiveness of the NPS.

The success of the NPS should be measured against achievement of a comprehensive range of factors, such as:

- Adequate risk control measures.

- Irrevocability of settled transactions.

- Synchronization of delivery and payment.

- Facilitation of monetary policy execution.

- Sufficient liquidity.

- Confidentiality and security.

- Sound legal foundation.

- Adherence to national rules, regulations, and procedures.

- Effective fraud-prevention and detection measures in place.

- A suitable variety of payments.

- Service to all the people of the country.

A vital issue in NPS development and implementation relates to reaching consensus on a comprehensive range of fundamental principles. The Committee on Payment and Settlement Systems core principles for SIPS are an example of such principles. However, because the NPS covers all payment systems, the range of agreed-on fundamental principles should also cover all subsystems. Such fundamental principles might include the following:

- The provision of NPS services is not the exclusive domain of banks.

- The evolution of the NPS infrastructure is a cooperative responsibility.

- Participants are liable for the risks that they introduce into the NPS.

- A balance is maintained between risk reduction and cost.

- The central bank response to a problem in the NPS will be in the interest of the system, not in the interest of individual participants.

- Surveillance (oversight) is necessary to ensure the safety and soundness of the NPS.

Finally, a series of strategies should be developed that, following implementation, will align the current payment 
arrangements with the envisaged NPS. These strategies, taken together, will represent an agreed-on set of initiatives that will be cooperatively implemented by all stakeholders. Typically, this program of change is executed under the leadership of the central bank, and includes a number of clusters of activity aimed at, for example, risk reduction, strengthening the legal and regulatory framework, payment practices, interface between trading systems and the NPS, and management of the NPS. Examples of such strategies might include the following:

- Clarification of the roles and responsibilities of all participants in the NPS.

- Introduction of measures to limit credit exposures in bulk clearing processes.

- Revision of the statutory powers of the central bank regarding payment systems.

- Introduction of a regulatory framework for clearing services providers.

- Creation of participation agreements for utilizing common investments in infrastructure.

- Creation of an NPS forum to discuss and resolve relevant issues in the payments field.

- Establishment of NPS standards.

- Liaison with banks and financial authorities in the region.

- Review of cross-border and foreign currency market practices from an NPS perspective.

\section{INSTITUTIONAL ROLES}

A broad range of institutions and entities are involved in PSSSs. Regulatory authorities (mainly central banks, bank regulators, and securities regulators) create the legal and oversight environment within which the procedures are carried out. Sometimes they also provide clearance and settlement services. Participants are those institutions that send and receive orders directly to and from the system, or which are directly bound by the rules governing securities transfer systems. Direct participants directly exchange transfer orders with other participants in the system on behalf of themselves, their customers, or indirect participants. Indirect participants are distinguished from direct participants by their inability to perform certain activities, such as input of transfer orders.
Issuers are institutions that seek financing via the securities markets. Broker-dealers undertake the primary intermediation role in securities market trading. For this reason, they also have a primary role in the clearance and settlement procedures. Custodians are entities that undertake the safekeeping of securities and other financial instruments on behalf of others. They may provide other services such as clearance and settlement, securities lending, and so on. A global custodian provides those services in respect of securities traded and settled, not only in the country where the custodian is located, but also in other countries throughout the world. Central securities depositories (CSDs) provide facilities for holding securities in either immobilized or book-entry form. In addition to providing this safekeeping role, a CSD may provide trade comparison services, and clearing and settlement services. International CSDs are institutions that settle trades in international securities and in various domestic securities. They usually settle the trades in their own books or through direct or indirect links (through local agents) to domestic CSDs. Central counterparties are entities that become the buyer to every seller, and the seller to every buyer of a specified set of contractsfor example, those executed on particular exchanges.

Exchanges and over-the-counter markets are the mechanisms for trading activity carried out by broker-dealers. The key factor from a clearing and settlement perspective is the way trading information is transmitted, rather than on the way trading takes place. The clearing agent is the entity that carries out the procedures of trade capture, matching, confirmation, and calculation of obligations relating to securities transfer instructions prior to settlement. These functions are normally provided by CSDs, which also provide the depository function or the exchange where the trading takes place. A settlement agent manages the settlement process, determines the settlement positions, and monitors the exchange of securities and payments. Again, this function is sometimes provided by CSDs or exchanges. The payment of funds is usually done through a settlement bank (private bank or central bank), although in some situations it is done directly by the broker-dealer or its paying agent through a means of payment such as a cheque or a certified cheque. A correspondent bank provides payments and other services to another bank, and such services are primarily provided across international boundaries. 


\section{ENGAGING THE PRIVATE SECTOR IN A REFORM PROGRAM}

The reform of the PSSSs is a project that would affect most people in a country. That reform would affect, in particular, the major stakeholders - such as the central bank, the treasury, other regulators, banks, financial institutions, corporations, and final customers. It involves relatively large investment costs, which, together with operational costs, would have to be covered by fees to be paid by those that use the service. It is important that the major stakeholders agree as much as possible on the vision for a country's payment system, avoiding the situation that might occur in which the normal participants in such systems choose alternative and less safe and efficient ways of making their transactions. Other issues that are important in a PSSS reform project include ensuring that there is sufficient coordination between various initiatives, and avoiding situations where certain systems cannot communicate with each other. There are also functional and operational complementarities between the systems' oversight, financial institutions' supervision, and financial market surveillance that need to be exploited. This can be achieved in a variety of ways, from exchanging views and information, to ad hoc or regular meetings and joint actions.

A number of countries have created cooperative bodiesfor example, a National Payments and Securities Settlement Council (NPSSC) to address PSSSs policy issues. The objectives of the NPSSC would be to support the achievement of safe and efficient PSSSs. It can also serve as a forum for cooperation to maintain orderly conditions in regional and international payment systems. Authorities should consider the possibility of creating an NPSSC, especially if the country is involved in a major reform.

The NPSSC would work to facilitate the necessary cooperation between all market participants and regulators in the payments and securities settlement area, and promote common initiatives toward the implementation of the PSSS infrastructure. These initiatives, in fact, should foster a healthy competition among market participants. An important part of the NSSPC's work would be to prepare and agree upon a strategic document (vision) for the overall payment system architecture in the country. It should monitor the implementation of PSSS reforms, and improve or endorse the priorities and sched- ules of individual projects to be launched, financed, and implemented. In doing that, the NPSSC's should promote standardization of procedures and systems and facilitate the sharing of information on economic and business requirements of all parties affected by the payment system. It should identify the impact of different options on participants' business and daily operations and on end user interests, and seek to promote cooperation among all institutions active in PSSSs.

The work of the NPSSC would include the preparation of ad hoc reports on PSSS issues. The reports, which should not have a prescriptive nature, would serve as reference for PSSS policies and reforms in the country. An important part of the NPSSC's work would be to promote the general knowledge of PSSS issues in the country. To this end, the NPSSC could use any means it might find appropriate, like workshops, seminars, Web pages, newsletters, and so on.

The organizational structure and the participation in an NPSSC could take different forms based on the level of development in the respective country. Appointed representatives should preferably be at least at the level of director of their respective organization, and it might be advisable to allow them to be assisted by a specialist in the payment system area at council meetings. In an advanced economy, the NPSSC could give representation to all the major stakeholders of payment and clearing systems and SSSs. These include the central bank and the securities regulators; the ministries of finance, treasury, and banking; competition authorities; bankers' association; major banks; representatives of nonbank financial institutions; clearinghouses and payment services providers; the stock exchange; CSDs; representatives of broker-dealers; and the end users (represented, for example, by a producer association). If one does not see a need for a specific organization or institution to be a regular member of the NPSSC, such entities and individual experts could be invited on a case-by-case basis to participate in its meetings.

The council should have an internal governance structure with a chairperson and a deputy, an executive body, formal rules to determine the terms and conditions for the appointment of the executive positions, and formal rules to govern the activity of the executive body. The central bank would normally be chairing the NPSSC, in close cooperation with the securities regulator, and would 
be responsible for its secretariat. An important part of the NPSSC's responsibilities would be to report on its activities to the top management of the constituting institutions.

Working groups should preferably support the NPSSC, including working groups for legal, technological, and business issues. The working groups could, depending on the composition of these groups or the NPSSC, or both, report directly to the NPSSC, or to a group consisting of senior managers from the institutions or organizations participating in the council; this latter group would then have the role of preparing material for the NPSSC.

The NPSSC should decide about the priorities in the reform project, and who should be responsible for various issues. These issues could fruitfully be divided between representatives from the private sector and the public sector, depending on the issues at stake. The private sector could take the lead in developments that would need to be handled by the users and infrastructure providers, for example. The public sector would take the lead in the areas of legislative and regulatory issues, supervisory or oversight issues, and possible competition issues. In economies where the involvement of the private sector in the payments system is still limited, or where public confidence in the safety of privately run settlement systems is not strong enough, the public sector might play a direct role in providing settlement services.

\section{PREPARING AN ACTION PLAN}

Based on the above elements, authorities and the stakeholders (that is, the payments council), with support from eventual external assessors, should prepare a realistic action plan to address any shortfalls that emerge in the assessment. The action plan should be prepared in modular form and should reflect the priorities agreed on by the council. Depending on the degree of development of the PSSSs, the action plan will be comprehensive or targeted toward a specific development in the system. Guidelines for the potential elements and steps to be included in a comprehensive action plan are described below.

\section{Table 7.1 Potential Pillars for Payments System Reform}

\section{Pillar I}

Payment systems work in a sound and robust legal environment that supports settlement finality.

Pillar II

SIPS are safe and efficient and comply fully with the CPSS core principles for SIPS.

Pillar III

Interbank money markets are fully developed and closely integrated with settlement systems.

\section{Pillar IV}

Retail payment systems are efficient, sound, and interoperable. They support the offer of a wide range of payments instruments and services.

Pillar V

Government collections and disbursements are fully and efficiently integrated with the NPS, and support its smooth functioning.

\section{Pillar VI}

Securities clearance, settlement, and depository systems are safe and efficient, fully comply with international standards, and contribute to support the development of capital markets.

\section{Pillar VII}

The oversight and supervisory framework for PSSSs is clearly defined, and the central bank exercises effectively its oversight authority in cooperation with other regulators and supervisors.

\section{Pillar VIII}

Effective, structured, and fruitful cooperation is in place within the NPS. 


\section{Starting Point: Assessment and Recommendations}

The action plan should be based on the previous assessments and recommendations suggested in the assessment of the PSSSs in the country in terms of international standards. It is important that the assessments of both payments systems and securities settlement systems be taken into account when preparing the action plan.

\section{The Scope of the Reform}

The elaboration of the strategic document (vision) with the input of the assessments and recommendations of external assessors should be the first task of the NPSSC; it is important that the members of the NPSSC subscribe to that document. The strategy should be based on basic pillars to be achieved. Table 7.1 presents an example of potential pillars for a payments system reform.

\section{Organizational Arrangements}

Although the reform of PSSSs should be driven by the NPSSC, many reform projects start with the establishment of temporary task forces to establish the NPSSC, a core project team, committees, ad hoc working groups, and, sometimes, the hiring of external consultants.

\section{Implementation Plan}

Other important elements that an action plan should include are an implementation plan, estimation of the cost of the reform, and immediate actions to be taken. The implementation plan should include the detailed and dated sequence of the necessary steps included in the action plan, and it should be reviewed and updated regularly by the consultants or core team, or both, and presented to the NPSSC for its approval.

\section{Estimates of the Cost of the Reform}

This exercise is aiming to provide country authorities with a credible range for the total cost of the reform, based on similar experiences in other parts of the world. Many cost items are a direct function of ongoing decisions and will need to be revised and approved accordingly by the NPSSC. The estimates should include at least the following (explicit and implicit) costs: cost of long-, medium-, and short-term consultants; internal staff; training; implementation (equipment purchase, software, and so on); and monitoring of the reform.

\section{Immediate Actions}

It is normally very helpful for the reform process to identify a set of four to six immediate actions necessary to take, and to initiate these as a matter of urgency. 



\section{Concluding Remarks}

$\mathrm{n}$ his closing address at a seminar sponsored by the European Central Bank and the Committee on Payment and Settlement Systems in 2003, Tommaso Padoa-Schioppa, the "dean" of the central bank payment system experts, half-jokingly suggested that "the fundamental function of a central bank is payments and monetary policy is just a perversion of it" (PadoaSchioppa 2003). This indicates how prominent payment systems have become among the functions of central banks. Others, more graphically, say "that payment systems, domestically and internationally, are the lifeblood of banking" (Pattinson 2003). Equally, as indicated at the beginning of this book, payment systems moved from the backroom to the boardroom of all financial institutions due to the potentially very serious operational risks posed by a poorly structured or functioning payment system, in addition to the increasing attention bank boards need to pay to the large IT investments required by the progress automation of banking operations and services. It can also be said that payment systems are moving from being a narrow channel for transferring funds to being a much wider integrated network for transferring value (funds and securities).

For these reasons, the World Bank has paid increasing attention to payment systems development as a key component of the financial infrastructure of a country. The World Bank's activities in the Latin America and the Caribbean (LAC) region started in mid-1995, and received a significant impulse with the launching of the Western Hemisphere Payments and Securities Clearance and Settlement Initiative.
The Western Hemisphere Payments and Securities Clearance and Settlement Initiative helped create momentum for reforms throughout the region. In most cases, the reforms were comprehensive and included improvements not only to the systems, but also to the legal, regulatory, and oversight frameworks. In other cases, the approach has been much narrower, focusing on the upgrade of a particular system or merely a revision of operational issues to achieve greater compliance with the international standards.

This last chapter highlights and synthesizes the main findings of the work carried out through the Western Hemisphere Payments and Securities Clearance and Settlement Initiative. The conclusions below are intended to provide a picture of national payments and securities settlement systems in the LAC region as a whole. The statements are therefore of a general nature, and not all of them are necessarily reflective of the situation in each individual country.

\section{Comprehensive reforms to the legal and regulatory framework are still lagging behind the improvements already achieved in other areas, particularly those areas of a technological nature.}

In LAC as a whole, important progress has been made on issues such as the legal validation of electronic signatures and documents. However, many other key legal areas still need to be addressed, including, in particular, the irrevocability of final settlement, adequate protection of the systems against the effects of bankruptcy proceedings, the legal definition of a repo operation, the legal recognition of multilateral netting arrangements, and the legal definition and regulation of oversight 
powers of the central bank. Some other issues more closely related to securities settlement include improvements to the legal basis for custody arrangements, and the legal definition of immobilization and dematerialization of securities, especially for public securities. Other legal issues that could be considered from a developmental point of view include the legal basis for the collateral pledge, and securities lending.

Due to the variety and extreme importance of these legal aspects, countries should consider if the level of the changes required would justify designing a specific law for payment and settlement systems. In any case, these topics should be dealt with at the level of a law.

Throughout the region, there is a clear trend toward the adoption of real-time gross settlement (RTGS) systems for large-value and time-critical payments. More work is needed, however, to make these new systems more efficient so that all relevant market participants use them intensively.

In some countries, the use of the RTGS system is expensive because no sources of liquidity are readily available at a low cost for system participants. RTGS system operators and regulators have been recommended to introduce or improve the facilities to handle the distribution of intraday liquidity. These measures are even more important considering that the central bank's reliance on high reserve requirements to enable the daily functioning of the RTGS system is clearly decreasing as the region's banking systems strive to become competitive in the global marketplace.

These facilities should include modern queuing mechanisms and the provision of fully collateralized intraday credit by the central bank. Additional initiatives include the system's operator providing timely and complete information to enable a thorough liquidity analysis, and the introduction of incentives (for example, pricing) so that a larger share of payments are passed early during the operational day. To better visualize the effects of policy actions that aim at addressing these concerns, central banks can use a variety of methodologies, including the processing and analysis of intraday account balances and flow of transactions in the RTGS system. ${ }^{1}$

\footnotetext{
${ }^{1}$ An example of applying this analysis to the case of Colombia is described in Bernal and Merlano (2006). The article also discusses the interrelation between payment systems and monetary policy as regards liquidity and policy alternatives or actions to achieve the final goal of smoothing the functioning of the RTGS system.
}

In any case, to better understand the real needs of each particular market the creation of a so-called target users' group is recommended.

In some countries, the cheque clearinghouse remains systemically important because many large-value payments are still settled through it, or because it remains the main payment system in the country, or both.

In most cases, the cheque clearinghouse does not have appropriate or even basic settlement assurance mechanisms. Because it is difficult and costly for cheque systems to substantially reduce systemic risk and comply with international standards, the launch of RTGS systems has been recommended as a better option than focusing efforts on creating guarantee funds or other risk-management tools for systemically important cheque clearinghouses.

Because large-value systems represent the backbone of the national payments system, the implementation of an RTGS system in those countries that still do not have one - along the guidelines discussed in this book - will result in a major improvement to the safety and efficiency to those countries' financial infrastructures.

In the retail arena, most LAC countries are still heavily dependent on the use of cash and cheques. Migration to electronic payment alternatives is still slow, in many cases.

Factors behind this aspect include the lack of an appropriate infrastructure to process efficiently electronic payment instruments such as direct credits and direct debits; insufficient interoperability of payment card circuits, which reduces their convenience and accessibility and raises the cost for end users; the lack of an appropriate strategy to induce change in customers' habits, including price incentives; and proper customer education, among other factors.

Central banks and the commercial banks have a role to play to ensure that retail payment circuits support businesses' and customers' needs, and that such arrangements are safe, convenient, and efficient for the economy as a whole.

Public sector institutions that are major players in the payments system have not been sufficiently integrated in the efforts to reform the national payments system. 
While in some particular cases the integration has been successful, in most other cases the procedures for the payment or collection of government and social security payments are generally not integrated, hence straightthrough processing (STP) is not achieved.

It has been noted that in many cases the gains in efficiency and cost reductions for government payments have been the main result of the reform effort. Ensuring a proper integration of public sector institutions in the national payments system can also ensure that the benefits of new payment alternatives be accrued by all segments in the country by inducing a higher use of banking services by the public in general. Moreover, as public sector payment and collection operations can greatly influence the liquidity for the banking system, an effective coordination of operating hours and procedures can also facilitate the smooth functioning of RTGS systems.

With few exceptions, central banks in the LAC region do not carefully monitor the risks deriving from the settlement of foreign exchange transactions in the local market.

A more activist agenda in this area has been recommended. Central banks and banking supervisors should be able to use their regulatory and supervisory powers to introduce appropriate measures to mitigate associated risks. Attention should also be given to correspondent arrangements (of domestic banks) abroad.

In particular, central banks should evaluate the risks in this market, taking as a reference the reports and questionnaires published by the Committee on Payment and Settlement Systems, and analyze together with the financial community the implications of recent major developments, such as the Continuous Linked Settlement Bank.

For the most part, attention to retail cross-border payments, including international remittances, is still limited to balance of payments and money laundering considerations.

In general, there are no standards for aspects such as transparency of fees and other charges, or the timing of accreditation of funds to end beneficiaries. It has therefore been recommended that the regulatory and payment system oversight perspectives be widened to cover these arrangements from a payment system angle to include issues related to efficiency, service level, transparency, and risks.
The development of the interbank money market has become crucial in a new environment in which large value payments are to be settled in a gross system. This, together with the general trend of decreasing reserve requirements, makes liquidity management an increasingly relevant issue.

It is in this market where the majority of domestic interbank funds transfers among financial institutions takes place, and where the central bank implements its monetary policy, impacting the overall liquidity of financial markets. Its adequate functioning is important not only for the smooth operation of a country's payments and securities settlement, but also for the effective transmission of monetary policy signals.

Two key elements for the development of interbank money markets are the existence of a special purpose system for large-value payments to provide secure electronic interbank transfers with immediate settlement and its interconnection to an electronic book-entry securities system to register and record changes in ownership of securities. Authorities and market participants should also discuss in detail the organizational and regulatory arrangements that allow for an adequate development of this market.

Large-value payment systems and SSSs should work in tandem to increase efficiency and reduce settlement risk.

To settle payment obligations, borrow funds, collateralize securities, and achieve delivery versus payment, the large-value payment settlement systems and SSSs must be perfectly synchronized. For these reasons, in planning reforms it is critical to take a holistic view of all the various networks that are likely to interact, looking, in detail, at the infrastructure; the legal and regulatory aspects; the operation of the trading systems, registration, and custody arrangements; and operation of the depositories, in conjunction with a review of the SSSs and the large-value payment system.

Improved clearing and settlement processes in SSS are necessary in most securities markets in the region.

Efforts in this area should aim at achieving trade confirmation on the same day of the trade, reducing market fragmentation, increasing the standardization of settlement cycles, accommodating different settlement needs, operating with shorter settlement cycles, avoiding extensions 
of the settlement cycles due to inadequate risk management tools, improving markets' liquidity through automatic securities lending, and introducing international communication standards.

True delivery versus payment is still not achieved in many securities markets throughout the region.

The settlement of securities and funds should be linked for securities transactions to eliminate principal risk by establishing and duly enforcing delivery versus payment procedures. The main aspects to be improved include the full dematerialization and immobilization of securities, upgrade of current risk management tools, mitigation of credit and liquidity risk in the cash leg (including elimination of the use of cheques as a cash asset), better access to liquidity for SSS participants, careful follow-up of short-selling (when used), and-in general - a comprehensive approach for the reform of SSSs versus technology-driven and exclusively operational reform projects.

There is room for important efficiency gains of the securities settlement infrastructure.

Straight-through processing is not the rule for the processing of securities transactions throughout the region. In particular, physical handling of securities should be eliminated to increase the safety and efficiency of SSSs. The various plans for backup sites and disaster recovery facilities should be accelerated or established when nonexistent. External audit of the systems should be undertaken, especially when the systems have been developed in-house. The latter is especially important when the supervisory framework for operational issues is weak.

\section{Additional measures are necessary to guarantee the protection of customers' assets in the event of bankruptcy of the depository holding its titles or insolvency of a custodian.}

Country authorities should make sure that the segregation of accounts for securities and funds under custody have a clear legal basis under all circumstances, and that customer assets are legally protected against the insolvency of custodians, whatever the nature of the custodian may be. Moreover, authorities must also ensure that all customer assets are appropriately accounted for as beneficial owners in the depository or in the custodian's omnibus accounts.
Strong, capitalized, autonomous, and independent securities depositories, with reliable and flexible systems to expedite settlement of transactions and accessory rights, are crucial for the development of the securities markets.

If important conflicts of interest emerge that could lead to a standstill situation or eventually to the creation of a weak central securities depository, the authorities should take the lead in their resolution. This is even more important if arrangements for a central counterparty are to be introduced.

The importance of cross-border links among central securities depositories is growing throughout the region.

Particular attention should be devoted to the multiple jurisdiction profile of these transactions, especially from the legal and operational perspective. Authorities, service providers, and market participants should further involve themselves in the discussions to build a consensual internationally accepted principle on the arrangements governing the cross-border pledge of securities as collateral.

Central banks throughout the region are beginning to establish formally their payment system oversight function. In order for this function to be implemented effectively, adequate legal empowerment and proper organization arrangements are needed.

It is of paramount importance that central banks prepare and encourage the approval of a primary or secondary legislation to clarify in detail the empowerment and enforcement of the central bank as payment system overseer.

To perform their payment system oversight function effectively, central banks should have appropriate staffing, preferably in a small independent unit to be separatedto the extent possible - from the units in charge of operating the systems offered by the central bank. Staff should have broad skills and experience in a variety of relevant disciplines.

Enhanced transparency is needed throughout the region, both regarding the responsibilities of the payment system overseer and regarding the general conditions of payment services offered.

Central banks should develop a comprehensive policy statement regarding their oversight function to provide 
the necessary guidance to private sector organizations on matters relating to governance, day-to-day management, risk mitigation, and on the policies that must be satisfied by all transactions that are ultimately settled on central bank books.

Central banks together with banks and other financial institutions should also ensure that transparency of policies and conditions for payment services offered be available to the population of their countries at all times.

\section{Central banks in LAC should broaden the focus of the oversight function beyond efficiency and reliability of payment systems, and apply these powers over all major settlement systems in their countries.}

It has been recommended that central banks include as part of their oversight objectives a wider set of issues such as the promotion of competition in the payment services market and the protection of consumer interests. These objectives might be pursued especially in those cases not embraced by other regulatory or supervisory authorities.

Central banks have been recommended to apply their oversight authority not only to systemically important payment systems, but also to SSSs. This is especially important in those cases in which the entity in charge of securities regulation is weak or does not perform any regulatory or oversight role over securities settlement.

\section{Cooperation among regulators should be an essen- tial component of the oversight function in LAC countries.}

It has been recommended that cooperation take place through a formal framework (for example, a memorandum of understanding) to minimize the potential conflicts between the roles of the various authorities. This is especially important for SSSs, because in many cases the oversight function is divided among several regulators.

At the international level, central banks and other relevant regulators should increase their presence in international fora. In particular, an active participation in the Western Hemisphere Payments and Securities Settlement Forum and the Working Group on Payment System Issues of LAC has been recommended, because these have become important mechanisms for the exchange of information, learning, and coordination within the region among all stakeholders, as well as a forum to cooperate with Group of Ten central banks and securities commissions, and other multilateral institutions.

\section{Cooperation between regulators and market partici- pants has proven equally important for the effective achievement of the objectives of the oversight func- tion and should be improved in LAC countries.}

To secure a constructive dialogue, it has been strongly recommended that central banks establish a formal mechanism for cooperation such as a national payments and securities settlement system council (NPSSC) that includes representatives from all major stakeholders with an interest in payments and securities clearance and settlement systems improvements.

\section{MOVING FORWARD WITH THE SUGGESTED REFORMS}

The reform of the National Payments System (NPS) is an important undertaking. The output will affect most citizens in a country, and in particular will affect major stakeholders, such as the central bank, the treasury, other regulators, banks and other financial institutions, corporations, and final customers. It also involves relatively large investment costs. The scope and difficulty of developing and carrying out a strategy for a successful modernization of the payments system should not be underestimated. This will be a new process, and the projects will present new challenges to all parties involved. The major risks of inadequate planning or implementation are that the systems developed could not be used, that the resulting system changes will not satisfy the needs of all users, and that the systems will not be cost efficient and affordable.

A collaborative and cooperative approach is the only way in which these risks can be minimized. A well-structured collaborative approach will create synergy, stimulate learning, and provide a basis for optimizing benefits through cooperation and consensus building. The NPSSC shall work to facilitate the necessary cooperation.

The planned reform to the NPS should take into account the level of development in the financial sector and the actual needs of the various stakeholders. The first task of the NPSSC's work should therefore be to prepare and agree on a strategic document (vision) for the overall payment system architecture in the country, including SSSs. The document will represent an agreed-on set of 
initiatives that will be cooperatively implemented by all stakeholders, and it is therefore important that it be subscribed to by all members of the NPSSC.

Countries throughout the region should proceed rapidly to reforming their payments systems following these guidelines. By adopting a broad approach based on international standards and best practices, and with support from international organizations, other central banks, and payment system experts, each country will be able to count on a set of payment arrangements, services, and circuits able to serve safely and efficiently the needs of all users in the economy.
Reforming appropriately each NPS in the region will also create the conditions for increased harmonization, which will serve as a basis for an eventual integration among different payment systems. It is important to stress that any integration of payment systems should be based on the existence of common features in all relevant areas (legal, risk control mechanisms, liquidity provision, access policies, governance, organizational arrangements, operational aspects, reliability, and business continuity). Any integration agenda should therefore start from comprehensive reforms of the domestic payments systems of the countries involved. 


\section{Main Statistics of Payments and Securities Settlement Systems in Selected Latin America and the Caribbean Countries}

\section{GENERAL NOTES FOR APPENDIX 1}

The tables included in appendix 1 were prepared on the basis of the country statistics provided by Working Group on Payment System Issues of Latin America and the Caribbean (LAC) member central banks. The compilation work was coordinated by Ana Laura Sibaja (Center for Latin American Monetary Studies). All country statistics are produced following a standardized methodology developed by the core team that manages the Western Hemisphere Payments and Securities Clearance and Settlement Initiative. Both this methodology and the full Working Group on Payment System Issues of LAC statistics reports (full country + comparative tables) are available at the Western Hemisphere Payments and Securities Clearance and Settlement Forum's Web site: www.whpaymentsforum.org. These statistics are updated regularly.

Throughout appendix 1, the following symbols are used:

\section{General:}

n.a. data not available

... data not applicable

Neg very small data relative to other relevant data in the table concerned

ECCU Eastern Caribbean Currency Union

M1 currency in circulation plus demand deposits

M1A broad money supply

Other:

BM\&F

BVL

BVN
Brazilian Mercantile \& Futures Exchange Bolsa de Valores de Lima

Bolsa de Valores Nacional (Guatemala)
CBLC

CCE

$\mathrm{CD} / \mathrm{DD}$

CEDEC

CENIT

CETIP

CLC

COMPE

CUD

CVV

DCV

DECEVAL

ECCSD

LBTR

LINX

MEP

Merval

MIT
Companhia Brasileira de Liquidacao e Custodia (Brazil)

Cámara de Compensación Electronica (Peru)

Créditos Directos/Débitos Directos (Costa Rica)

Cámara Electrónica de Compensación (Colombia)

Sistema de Compensación Electrónica Nacional Interbancaria (Colombia)

Central de Custódia e de Liquidação Financeira de Títulos (Brazil)

Compensación y Liquidación de Cheques y Otros Valores (Costa Rica)

Centralizadora da Compensação de Cheques e Outros Papéis (Brazil)

Sistema Electrónico de Cuentas de Depósito (Colombia)

Caja Venezolana de Valores S.A.

Depósito Central de Valores (Colombia)

Depósito Centralizado de Valores de Colombia S.A.

Eastern Caribbean Central Securities Depository

Sistema de Liquidación Bruta en Tiempo Real (Chile and Peru)

Infolink Services Limited (Trinidad and Tobago)

Medio Electrónico de Pagos (Argentina)

Mercado de Valores de Buenos Aires S.A.

Mecasismo Interbancario de Transferencias (Guatemala) 


\begin{tabular}{|c|c|c|c|}
\hline SELIC & Servico Especial de Liquidacao e & SITRAF & Sistema de Transferência de Fundos (Brazil) \\
\hline & Custodia (Brazil) & SPEI & Sistema de Pagos Electrónicos Inter- \\
\hline SIAC & Sistema de Atención a Cuentahabientes & & bancarios (Mexico) \\
\hline & (Mexico) & SPEUA & Sistema de Pagos Electrónicos de Uso \\
\hline SICET & Sistema de Custodia Electrónica de & & Ampliado (Mexico) \\
\hline & Títulos (Venezuela) & STR & Sistema de Transferência de Reservas \\
\hline SIDV & $\begin{array}{l}\text { Sistema Interactivo para el Depósito de } \\
\text { Valores (Mexico) }\end{array}$ & TEBEL & $\begin{array}{l}\text { (Brazil) } \\
\text { online trading system (Costa Rica) }\end{array}$ \\
\hline SILOC & $\begin{array}{l}\text { Sistema de Liquidação Diferida de } \\
\text { Ordens de Crédito Interbancárias } \\
\text { (Brazil) }\end{array}$ & $\begin{array}{l}\text { Tecban } \\
\text { TEF }\end{array}$ & $\begin{array}{l}\text { Technología Bancária (Brazil) } \\
\text { Transferencia Electrónica de Fondos de } \\
\text { Bajo Valor (Mexico) }\end{array}$ \\
\hline SIPAV & Sistema de Pagos de Alto Valor (Bolivia) & TI & $\begin{array}{l}\text { Sistema de Transferencias Interbancarias } \\
\text { (Costa Rica) }\end{array}$ \\
\hline Sistema & Depósito Central de Valores (Chile) & TT & Transferencia de Terceros (Costa Rica) \\
\hline $\begin{array}{l}\text { valore } \\
\text { DCV }\end{array}$ & & TTS & Transferencia Telefónica Segura \\
\hline SITE & $\begin{array}{l}\text { Sistema de Transferencias Electrónicas } \\
\text { (Costa Rica) }\end{array}$ & TTSE & Trinidad and Tobago Stock Exchange \\
\hline
\end{tabular}

Table A.1 Institutional Framework, year-end 2004

\begin{tabular}{|c|c|c|c|c|c|c|}
\hline & $\begin{array}{l}\text { Number of } \\
\text { Institutions }^{1}\end{array}$ & $\begin{array}{c}\text { Inhabitants } \\
\text { per Institution }\end{array}$ & $\begin{array}{l}\text { Number of } \\
\text { Branches }\end{array}$ & $\begin{array}{l}\text { Inhabitants } \\
\text { per Branch }\end{array}$ & $\begin{array}{l}\text { Number of } \\
\text { Accounts } \\
\text { (millions) }\end{array}$ & $\begin{array}{c}\begin{array}{c}\text { Number of } \\
\text { accounts } \\
\text { per Inhabitant }\end{array}\end{array}$ \\
\hline Argentina & 104 & 359,913 & 4,010 & 9,334 & 16.70 & 0.45 \\
\hline Bolivia & 59 & 156,743 & 512 & 18,062 & 1.50 & 0.16 \\
\hline Brazil & 138 & $1,315,942$ & 17,269 & 10,516 & 89.90 & 0.50 \\
\hline Chile $^{3}$ & 33 & 483,333 & 1,614 & 9,882 & 1.70 & 0.11 \\
\hline Colombia ${ }^{4}$ & 84 & 539,286 & 4,557 & 9,941 & 31.20 & 0.69 \\
\hline Costa Rica & 57 & 74,535 & 527 & 8,062 & n.a. & n.a. \\
\hline ECCU & 39 & 14,930 & 92 & 6,329 & n.a. & n.a. \\
\hline Guatemala & 31 & 383,871 & 1,344 & 8,854 & 6.60 & 0.55 \\
\hline Jamaica & n.a. & n.a. & n.a. & n.a. & n.a. & n.a. \\
\hline Mexico $^{5}$ & 52 & $2,019,231$ & 8,524 & 12,318 & 33.70 & 0.32 \\
\hline Nicaragua & 10 & 562,600 & 210 & 26,790 & 0.60 & 0.11 \\
\hline Paraguay ${ }^{4}$ & 21 & 271,508 & 156 & 36,549 & n.a. & n.a. \\
\hline Peru $^{6}$ & 47 & 586,098 & 1,049 & 26,260 & n.a. & n.a. \\
\hline Trinidad and Tobago & 24 & 53,775 & n.a. & n.a. & n.a. & n.a. \\
\hline Uruguay ${ }^{6}$ & 46 & 73,901 & 216 & 15,738 & 0.36 & 0.10 \\
\hline Venezuela, R.B. de & 40 & 652,500 & 2,680 & 9,739 & 12.50 & 0.48 \\
\hline
\end{tabular}

Source: Working Group on Payment System Issues of Latin America and the Caribbean.

1. Includes all those institutions that make noncash payments on behalf of their clients.

2. Checking, savings, and term accounts.

3. The figure for number of accounts does not include the central bank.

4. The figure for number of accounts includes checking accounts only.

5. The figure for number of accounts is as of September 2005.

6. The figure for branches does not include the branches of state-owned banks.

7. The figure for branches and number of accounts does not include the numbers of state-owned banks and branches of foreign banks. 
Table A.2 Banknotes and Coins in Circulation, 2000-04

U.S. dollars and percentages

\begin{tabular}{|c|c|c|c|c|c|c|c|c|c|c|c|}
\hline & 2000 & 2001 & 2002 & 2003 & 2004 & & 2000 & 2001 & 2002 & 2003 & 2004 \\
\hline $\begin{array}{l}\text { Argentina } \\
\text { per inhabitant }\end{array}$ & 350.00 & 250.20 & 132.90 & 245.40 & 303.50 & $\begin{array}{l}\text { Jamaica } \\
\text { per inhabitant }\end{array}$ & 149.30 & 151.90 & 152.90 & 145.40 & 163.60 \\
\hline as $\%$ of GDP & 4.50 & 3.40 & 6.50 & 10.60 & 12.20 & as $\%$ of GDP & 4.90 & 4.90 & 4.80 & 4.70 & 4.90 \\
\hline as $\%$ of $\mathrm{M} 1$ & 63.30 & 57.30 & 58.10 & 62.00 & 60.50 & as $\%$ of $\mathrm{M} 1$ & 36.80 & 34.70 & 34.30 & 36.80 & 35.70 \\
\hline Bolivia & & & & & & Mexico & & & & & \\
\hline per inhabitant & 41.10 & 42.50 & 40.60 & 45.20 & 52.00 & per inhabitant & 194.40 & 217.90 & 219.20 & 227.40 & 257.30 \\
\hline as $\%$ of GDP & 4.10 & 4.30 & 4.50 & 5.00 & 5.50 & as $\%$ of GDP & 3.70 & 3.80 & 4.00 & 4.20 & 4.00 \\
\hline as $\%$ of $\mathrm{M} 1$ & 55.30 & 50.90 & 52.30 & 51.70 & 65.70 & as $\%$ of $\mathrm{M} 1$ & 35.30 & 33.30 & 34.00 & 33.60 & 35.40 \\
\hline Brazil & & & & & & Nicaragua & & & & & \\
\hline per inhabitant & 85.50 & 80.90 & 67.90 & 83.30 & 107.90 & per inhabitant & 26.50 & 27.10 & 26.80 & 29.30 & 33.90 \\
\hline as $\%$ of GDP & 2.40 & 2.80 & 2.60 & 2.90 & 3.20 & as $\%$ of GDP & 3.40 & 3.40 & 3.60 & 3.90 & 4.10 \\
\hline as $\%$ of $\mathrm{M} 1$ & 38.50 & 39.00 & 39.30 & 39.30 & 40.70 & as $\%$ of $\mathrm{M} 1$ & 52.70 & 46.00 & 47.40 & 45.70 & 44.90 \\
\hline Chile & & & & & & Paraguay & & & & & \\
\hline per inhabitant & 122.00 & 113.00 & 112.60 & 117.90 & 161.30 & per inhabitant & 70.60 & 54.00 & 36.90 & 53.60 & 59.70 \\
\hline as $\%$ of GDP & 2.60 & 2.70 & 2.70 & 2.20 & 2.60 & as $\%$ of GDP & 5.30 & 4.50 & 4.00 & 5.40 & 4.90 \\
\hline as $\%$ of $\mathrm{M}^{1}{ }^{1}$ & 28.50 & 27.50 & 25.90 & 23.40 & 21.70 & as $\%$ of $\mathrm{M} 1$ & 53.60 & 51.00 & 53.20 & 48.30 & 45.40 \\
\hline Colombia & & & & & & Peru & & & & & \\
\hline per inhabitant & 77.10 & 84.60 & 79.60 & 96.50 & 127.80 & per inhabitant & 49.60 & 50.60 & 59.60 & 67.80 & 88.90 \\
\hline as $\%$ of GDP & 3.90 & 4.40 & 4.30 & 5.40 & 5.90 & as $\%$ of GDP & 2.40 & 2.70 & 2.80 & 3.00 & 3.60 \\
\hline as $\%$ of $\mathrm{M} 1$ & 43.50 & 44.60 & 46.20 & 48.00 & 47.50 & as $\%$ of $\mathrm{M} 1$ & 64.00 & 65.90 & 68.50 & 68.40 & 64.70 \\
\hline $\begin{array}{l}\text { Costa Rica } \\
\text { per inhabitant }\end{array}$ & 114.70 & 115.50 & 111.00 & 108.30 & 107.60 & $\begin{array}{c}\text { Trinidad and Tobago } \\
\text { per inhabitant }\end{array}$ & 160.10 & 172.00 & 186.90 & 211.60 & 240.70 \\
\hline as $\%$ of GDP & 2.80 & 2.80 & 2.70 & 2.60 & 2.50 & as $\%$ of GDP & 2.50 & 2.50 & 2.70 & 2.60 & 2.70 \\
\hline as $\%$ of $\mathrm{M} 1$ & 32.30 & 32.50 & 28.80 & 26.90 & 29.60 & as $\%$ of $\mathrm{M} 1$ & 26.00 & 20.50 & 20.50 & 23.40 & 23.40 \\
\hline $\begin{array}{c}\text { Dominican Republic } \\
\text { per inhabitant }\end{array}$ & 110.40 & 116.50 & 120.10 & 89.90 & 125.10 & $\begin{array}{l}\text { Uruguay } \\
\text { per inhabitant }\end{array}$ & 175.20 & 142.90 & 83.90 & 95.30 & 120.60 \\
\hline as $\%$ of GDP & 4.60 & 4.50 & 4.70 & 4.70 & 5.90 & as $\%$ of GDP & 2.90 & 2.60 & 2.30 & 2.90 & 3.10 \\
\hline as $\%$ of $\mathrm{M} 1$ & 42.50 & 40.30 & 41.70 & 41.10 & 42.70 & as $\%$ of $M 1$ & 50.20 & 50.20 & 52.10 & 47.90 & 48.50 \\
\hline ECCU & $?$ & $200-0$ & 25 & 0 & 0 & Venezuela, R.B. de & 11550 & 12090 & מ 10 & 1570 & 1201 \\
\hline as $\%$ of GDP & 7.70 & $\begin{array}{r}240.50 \\
7.50\end{array}$ & $\begin{array}{r}202.50 \\
7.90\end{array}$ & 8.30 & $\begin{array}{r}30.40 \\
9.10\end{array}$ & as $\%$ of GDP & 2.50 & $\begin{array}{r}1<0.00 \\
2.60\end{array}$ & 3.50 & 3.50 & 3.10 \\
\hline as $\%$ of $\mathrm{M} 1$ & 32.10 & 30.10 & 29.90 & 28.50 & 25.80 & as $\%$ of $\mathrm{M} 1$ & 24.50 & 25.10 & 34.80 & 25.10 & 23.30 \\
\hline \multicolumn{12}{|l|}{ Guatemala } \\
\hline per inhabitant & 82.50 & 88.90 & 99.40 & 113.50 & 121.20 & & & & & & \\
\hline as $\%$ of GDP & 4.90 & 5.00 & 4.80 & 5.30 & 5.40 & & & & & & \\
\hline as $\%$ of $\mathrm{M} 1$ & 40.80 & 41.50 & 40.30 & 40.70 & 40.10 & & & & & & \\
\hline
\end{tabular}

Source: Working Group on Payment System Issues of Latin America and the Caribbean.

1. Figures estimated with the M1A. 
Table A.3 Banknotes and Coins in Circulation, 2000-04

U.S. dollars and percentages

\begin{tabular}{|c|c|c|c|c|c|c|c|c|c|c|c|}
\hline & 2000 & 2001 & 2002 & 2003 & 2004 & & 2000 & 2001 & 2002 & 2003 & 2004 \\
\hline $\begin{array}{l}\text { Argentina } \\
\text { per inhabitant }\end{array}$ & 203.00 & 186.70 & 96.00 & 150.30 & 197.90 & $\begin{array}{l}\text { Jamaica } \\
\text { per inhabitant }\end{array}$ & 256.90 & 286.00 & 292.50 & 250.10 & 294.40 \\
\hline as $\%$ of GDP & 2.60 & 2.60 & 4.70 & 6.50 & 7.90 & as $\%$ of GDP & 8.50 & 9.20 & 9.10 & 8.10 & 8.90 \\
\hline as $\%$ of $\mathrm{M} 1$ & 36.70 & 42.70 & 41.90 & 38.00 & 39.50 & as $\%$ of $\mathrm{M} 1$ & 63.20 & 65.30 & 65.70 & 63.20 & 64.30 \\
\hline Bolivia & & & & & & Mexico & & & & & \\
\hline per inhabitant & 33.20 & 41.10 & 37.10 & 42.30 & 27.10 & per inhabitant & 356.80 & 435.40 & 424.80 & 448.70 & 468.60 \\
\hline as $\%$ of GDP & 3.30 & 4.20 & 4.10 & 4.70 & 2.90 & as $\%$ of GDP & 6.70 & 7.50 & 7.80 & 8.30 & 7.30 \\
\hline as $\%$ of $\mathrm{M} 1$ & 44.70 & 49.10 & 47.70 & 48.30 & 34.30 & as $\%$ of $\mathrm{M} 1$ & 64.70 & 66.70 & 66.00 & 66.40 & 64.60 \\
\hline Brazil & & & & & & Nicaragua & & & & & \\
\hline per inhabitant & 136.50 & 123.60 & 105.10 & 128.70 & 157.50 & per inhabitant & 23.70 & 31.70 & 29.70 & 34.80 & 41.70 \\
\hline as $\%$ of GDP & 3.90 & 4.20 & 4.00 & 4.50 & 4.70 & as $\%$ of GDP & 3.10 & 4.00 & 3.90 & 4.70 & 5.10 \\
\hline as $\%$ of $\mathrm{M} 1$ & 61.50 & 59.50 & 60.70 & 60.70 & 59.30 & as $\%$ of $\mathrm{M} 1$ & 47.30 & 54.00 & 52.60 & 54.30 & 55.10 \\
\hline Chile $^{1}$ & & & & & & Paraguay & & & & & \\
\hline per inhabitant & 306.70 & 297.70 & 322.50 & 385.80 & 580.30 & per inhabitant & 61.30 & 51.90 & 32.50 & 57.40 & 71.70 \\
\hline as $\%$ of GDP & 6.60 & 7.00 & 7.60 & 7.20 & 9.30 & as $\%$ of GDP & 4.60 & 4.40 & 3.50 & 5.80 & 5.90 \\
\hline as $\%$ of M1 & 71.50 & 72.50 & 74.10 & 76.60 & 78.30 & as $\%$ of $\mathrm{M} 1$ & 46.40 & 49.00 & 46.80 & 51.70 & 54.60 \\
\hline Colombia & & & & & & Peru & & & & & \\
\hline per inhabitant & 100.10 & 105.20 & 92.80 & 104.60 & 141.10 & per inhabitant & 27.90 & 26.20 & 27.40 & 31.30 & 48.50 \\
\hline as $\%$ of GDP & 5.10 & 5.50 & 5.00 & 5.80 & 6.50 & as $\%$ of GDP & 1.40 & 1.40 & 1.30 & 1.40 & 1.90 \\
\hline as $\%$ of $\mathrm{M} 1$ & 56.50 & 55.40 & 53.80 & 52.00 & 52.50 & as $\%$ of $\mathrm{M} 1$ & 36.00 & 34.10 & 31.50 & 31.60 & 35.30 \\
\hline $\begin{array}{l}\text { Costa Rica } \\
\text { per inhabitant }\end{array}$ & 240.70 & 240.00 & 274.10 & 295.00 & 256.00 & $\begin{array}{l}\text { Trinidad and Tobago } \\
\text { per inhabitant }\end{array}$ & 455.40 & 667.00 & 725.40 & 693.40 & 789.70 \\
\hline as $\%$ of GDP & 8.70 & 8.70 & 9.40 & 9.60 & 8.40 & as $\%$ of GDP & 7.00 & 9.50 & 10.40 & 8.40 & 8.90 \\
\hline as $\%$ of $\mathrm{M} 1$ & 67.70 & 67.50 & 71.20 & 73.10 & 70.40 & as $\%$ of $\mathrm{M} 1$ & 74.00 & 79.50 & 79.50 & 76.60 & 76.60 \\
\hline $\begin{array}{l}\text { Dominican Republic } \\
\text { per inhabitant }\end{array}$ & 149.10 & 172.50 & 167.70 & 128.60 & 167.60 & $\begin{array}{l}\text { Uruguay } \\
\text { per inhabitant }\end{array}$ & 173.90 & 141.70 & 77.00 & 103.70 & 128.10 \\
\hline as $\%$ of GDP & 6.20 & 6.70 & 6.60 & 6.70 & 8.00 & as $\%$ of GDP & 2.90 & 2.60 & 2.10 & 3.10 & 3.30 \\
\hline as $\%$ of $\mathrm{M} 1$ & 57.50 & 59.70 & 58.30 & 58.90 & 57.30 & as $\%$ of $\mathrm{M} 1$ & 49.80 & 49.80 & 47.90 & 52.10 & 51.50 \\
\hline $\begin{array}{l}\text { ECCU } \\
\text { per inhabitant }\end{array}$ & 533.50 & 558.20 & 590.60 & 687.30 & 890.90 & $\begin{array}{l}\text { Venezuela, R.B. de } \\
\text { per inhabitant }\end{array}$ & 355.90 & 360.60 & 200.40 & 345.60 & 424.70 \\
\hline as $\%$ of GDP & 16.30 & 17.50 & 18.50 & 20.90 & 26.10 & as $\%$ of GDP & 7.60 & 7.60 & 6.60 & 10.60 & 10.30 \\
\hline as $\%$ of $\mathrm{M} 1$ & 67.90 & 69.90 & 70.10 & 71.50 & 74.20 & as $\%$ of $\mathrm{M} 1$ & 75.50 & 74.90 & 65.20 & 74.90 & 76.70 \\
\hline \multicolumn{12}{|l|}{ Guatemala } \\
\hline per inhabitant & 120.00 & 125.40 & 146.90 & 165.20 & 180.70 & & & & & & \\
\hline as $\%$ of GDP & 7.10 & 7.00 & 7.10 & 7.70 & 8.00 & & & & & & \\
\hline as $\%$ of $\mathrm{M} 1$ & 59.20 & 58.50 & 59.70 & 59.30 & 59.90 & & & & & & \\
\hline
\end{tabular}

Source: Working Group on Payment System Issues of Latin America and the Caribbean.

1. Figures estimated with M1A. 
Table A.4 Payment Media Used by Deposit-Taking Entities, year-end 2004

\begin{tabular}{|c|c|c|c|c|c|c|}
\hline & \multicolumn{2}{|c|}{$\begin{array}{l}\text { Reserves at the Central } \\
\text { Bank (US\$ millions) }\end{array}$} & \multicolumn{2}{|c|}{$\begin{array}{l}\text { Reserves at the Central } \\
\text { Bank as } \% \text { of M1 }\end{array}$} & \multicolumn{2}{|c|}{$\begin{array}{l}\text { Transferable Deposits } \\
\text { in Other Entities } \\
\text { (US\$ millions) }\end{array}$} \\
\hline & $\begin{array}{l}\text { Domestic } \\
\text { Currency }\end{array}$ & $\begin{array}{l}\text { Foreign } \\
\text { Currency }\end{array}$ & $\begin{array}{l}\text { Domestic } \\
\text { Currency }\end{array}$ & $\begin{array}{l}\text { Foreign } \\
\text { Currency }\end{array}$ & $\begin{array}{l}\text { Domestic } \\
\text { Currency }\end{array}$ & $\begin{array}{l}\text { Foreign } \\
\text { Currency }\end{array}$ \\
\hline Bolivia & 89 & 285 & 12 & 39 & n.a. & n.a. \\
\hline Brazil & 10,100 & $\ldots$ & 21 & $\ldots$ & $\ldots$ & $\ldots$ \\
\hline Chile $^{2}$ & 1,525 & 619 & 13 & 5 & n.a. & n.a. \\
\hline Colombia & 2,056 & $\ldots$ & 17 & $\ldots$ & $\ldots$ & $\ldots$ \\
\hline Costa Rica & 424 & 330 & 27 & 21 & n.a. & n.a. \\
\hline Guatemala & 1,016 & 120 & 28 & 3 & 15 & $\ldots$ \\
\hline Jamaica & 52 & 125 & n.a. & n.a. & $\ldots$ & $\ldots$ \\
\hline Mexico $^{3}$ & $\cdots$ & $\cdots$ & $\cdots$ & $\cdots$ & $\cdots$ & $\cdots$ \\
\hline Nicaragua & 121 & 236 & 29 & 56 & $\ldots$ & $\ldots$ \\
\hline Paraguay & 241 & 267 & 32 & 36 & $\ldots$ & $\ldots$ \\
\hline Peru & 101 & 2,915 & 3 & 77 & $\ldots$ & $\ldots$ \\
\hline Trinidad and Tobago & 0.4 & $\ldots$ & 16 & $\ldots$ & 0.2 & 0.4 \\
\hline Uruguay & 209 & 56 & 25 & 7 & n.a. & n.a. \\
\hline Venezuela, R.B. de & 3,947 & 19 & 27 & 0.1 & n.a. & n.a. \\
\hline
\end{tabular}

Source: Working Group on Payment System Issues of Latin America and the Caribbean.

1. Includes required reserves + excess reserves.

2. Figures estimated with M1A.

3. In Mexico, deposit-taking institutions are not required to hold reserves at the central bank.

Table A.5 Payment Cards, year-end 2004

per 1,000 inhabitants

\begin{tabular}{l|r|r|r} 
& $\begin{array}{c}\text { Cards with a Cash } \\
\text { Withdrawal } \\
\text { Function }\end{array}$ & Debit Cards & Credit Cards \\
\hline Argentina & 319 & 319 & 222 \\
Bolivia & 63 & 46 & 8 \\
Brazil & 1,018 & 821 & 295 \\
Chile & 455 & 290 & 166 \\
Colombia & 225 & 225 & 62 \\
ECCU & 659 & 10 & 114 \\
Guatemala & 370 & 259 & 111 \\
Jamaica & 409 & 409 & 75 \\
Mexico & 437 & 328 & 111 \\
Peru & 240 & 189 & 120 \\
\hline Trinidad and Tobago & n.a. & n.a. & 138 \\
Uruguay & 213 & 213 & 337 \\
\hline
\end{tabular}

Source: Working Group on Payment System Issues of Latin America and the Caribbean. 
Table A.6 ATMs and Cash Dispensers, 2000-04

\begin{tabular}{|c|c|c|c|c|c|}
\hline & 2000 & 2001 & 2002 & 2003 & 2004 \\
\hline $\begin{array}{l}\text { Argentina } \\
\text { machines per } 1 \text { million inhabitants } \\
\text { transactions per inhabitant per year } \\
\text { average value of transactions (US\$) }\end{array}$ & $\begin{array}{l}146 \\
12.30 \\
\text { n.a. }\end{array}$ & $\begin{array}{l}161 \\
17.00 \\
\text { n.a. }\end{array}$ & $\begin{array}{l}155 \\
\text { n.a. } \\
\text { n.a. }\end{array}$ & $\begin{array}{l}158 \\
\text { n.a. } \\
\text { n.a. }\end{array}$ & $\begin{array}{l}164 \\
\text { n.a. } \\
\text { n.a. }\end{array}$ \\
\hline $\begin{array}{l}\text { Bolivia } \\
\text { machines per } 1 \text { million inhabitants } \\
\text { transactions per inhabitant per year } \\
\text { average value of transactions (US\$) }\end{array}$ & $\begin{array}{r}45 \\
1.20 \\
41.40\end{array}$ & $\begin{array}{r}52 \\
1.50 \\
42.10\end{array}$ & $\begin{array}{r}47 \\
1.40 \\
46.00\end{array}$ & $\begin{array}{r}50 \\
1.10 \\
66.10\end{array}$ & $\begin{array}{r}55 \\
1.10 \\
63.90\end{array}$ \\
\hline $\begin{array}{l}\text { Brazil } \\
\text { machines per } 1 \text { million inhabitants } \\
\text { transactions per inhabitant per year } \\
\text { average value of transactions (US\$) }\end{array}$ & $\begin{array}{l}569 \\
16 \\
42.30\end{array}$ & $\begin{array}{l}641 \\
22 \\
47.80\end{array}$ & $\begin{array}{l}736 \\
26 \\
46.50\end{array}$ & $\begin{array}{l}758 \\
32 \\
40.70\end{array}$ & $\begin{array}{l}768 \\
34 \\
53.00\end{array}$ \\
\hline $\begin{array}{l}\text { Chile } \\
\text { machines per } 1 \text { million inhabitants } \\
\text { transactions per inhabitant per year } \\
\text { average value of transactions (US\$) }\end{array}$ & $\begin{array}{l}173 \\
11 \\
53.50\end{array}$ & $\begin{array}{l}222 \\
12 \\
46.80\end{array}$ & $\begin{array}{l}236 \\
14 \\
45.30\end{array}$ & $\begin{array}{l}240 \\
14 \\
52.90\end{array}$ & $\begin{array}{l}251 \\
15 \\
58.70\end{array}$ \\
\hline $\begin{array}{l}\text { Colombia } \\
\text { machines per } 1 \text { million inhabitants } \\
\text { transactions per inhabitant per year } \\
\text { average value of transactions (US\$) }\end{array}$ & $\begin{array}{l}130 \\
8 \\
30.70\end{array}$ & $\begin{array}{l}125 \\
8 \\
31.20\end{array}$ & $\begin{array}{l}124 \\
8 \\
29.40\end{array}$ & $\begin{array}{l}125 \\
9 \\
28.30\end{array}$ & $\begin{array}{c}130 \\
9 \\
32.90\end{array}$ \\
\hline $\begin{array}{l}\text { Costa Rica } \\
\text { machines per } 1 \text { million inhabitants } \\
\text { transactions per inhabitant per year } \\
\text { average value of transactions (US\$) }\end{array}$ & $\begin{array}{l}184 \\
10 \\
65.80\end{array}$ & $\begin{array}{l}245 \\
15 \\
38.60\end{array}$ & $\begin{array}{l}\text { n.a. } \\
\text { n.a. } \\
\text { n.a. }\end{array}$ & $\begin{array}{l}\text { n.a. } \\
\text { n.a. } \\
\text { n.a. }\end{array}$ & $\begin{array}{l}\text { n.a. } \\
\text { n.a. } \\
\text { n.a. }\end{array}$ \\
\hline $\begin{array}{l}\text { ECCU } 1 \\
\text { machines per } 1 \text { million inhabitants } \\
\text { transactions per inhabitant per year } \\
\text { average value of transactions (US\$) }\end{array}$ & $\begin{array}{l}\text { n.a. } \\
\text { n.a. } \\
\text { n.a. }\end{array}$ & $\begin{array}{l}\text { n.a. } \\
\text { n.a. } \\
\text { n.a. }\end{array}$ & $\begin{array}{l}\text { n.a. } \\
\text { n.a. } \\
\text { n.a. }\end{array}$ & $\begin{array}{l}\text { n.a. } \\
\text { n.a. } \\
\text { n.a. }\end{array}$ & $\begin{array}{c}268 \\
9 \\
173.40\end{array}$ \\
\hline $\begin{array}{l}\text { Guatemala } \\
\text { machines per } 1 \text { million inhabitants } \\
\text { transactions per inhabitant per year } \\
\text { average value of transactions (US\$) }\end{array}$ & $\begin{array}{c}16 \\
1 \\
22.80\end{array}$ & $\begin{array}{c}19 \\
1 \\
23.50\end{array}$ & $\begin{array}{l}23 \\
2 \\
24.80\end{array}$ & $\begin{array}{l}67 \\
2 \\
26.50\end{array}$ & $\begin{array}{l}\text { n.a. } \\
\text { n.a. } \\
\text { n.a. }\end{array}$ \\
\hline $\begin{array}{l}\text { Jamaica }^{2} \\
\text { machines per } 1 \text { million inhabitants } \\
\text { transactions per inhabitant per year } \\
\text { average value of transactions (US\$) }\end{array}$ & $\begin{array}{l}\text { n.a. } \\
\text { n.a. } \\
\text { n.a. }\end{array}$ & $\begin{array}{l}\text { n.a. } \\
\text { n.a. } \\
\text { n.a. }\end{array}$ & $\begin{array}{l}\text { n.a. } \\
\text { n.a. } \\
\text { n.a. }\end{array}$ & $\begin{array}{l}\text { n.a. } \\
\text { n.a. } \\
\text { n.a. }\end{array}$ & $\begin{array}{l}114 \\
8 \\
58.30\end{array}$ \\
\hline $\begin{array}{l}\text { Mexico } \\
\text { machines per } 1 \text { million inhabitants } \\
\text { transactions per inhabitant per year } \\
\text { average value of transactions (US\$) }\end{array}$ & $\begin{array}{l}\text { n.a. } \\
\text { n.a. } \\
\text { n.a. }\end{array}$ & $\begin{array}{l}168 \\
9 \\
62.40\end{array}$ & $\begin{array}{l}168 \\
11 \\
76.50\end{array}$ & $\begin{array}{l}172 \\
11 \\
70.90\end{array}$ & $\begin{array}{l}194 \\
12 \\
74.70\end{array}$ \\
\hline $\begin{array}{l}\text { Nicaragua } \\
\text { machines per } 1 \text { million inhabitants } \\
\text { transactions per inhabitant per year } \\
\text { average value of transactions (US\$) }\end{array}$ & $\begin{array}{l}8 \\
\text { n.a. } \\
\text { n.a. }\end{array}$ & $\begin{array}{r}11 \\
0.20 \\
40.30\end{array}$ & $\begin{array}{r}19 \\
0.40 \\
40.40\end{array}$ & $\begin{array}{r}19 \\
0.40 \\
48.90\end{array}$ & $\begin{array}{l}20 \\
0.60 \\
49.20\end{array}$ \\
\hline $\begin{array}{l}\text { Peru } \\
\text { machines per } 1 \text { million inhabitants } \\
\text { transactions per inhabitant per year } \\
\text { average value of transactions (US\$) }\end{array}$ & $\begin{array}{l}41 \\
\text { n.a. } \\
\text { n.a. }\end{array}$ & $\begin{array}{l}\text { n.a. } \\
\text { n.a. } \\
\text { n.a. }\end{array}$ & $\begin{array}{l}\text { n.a. } \\
\text { n.a. } \\
\text { n.a. }\end{array}$ & $\begin{array}{r}\text { n.a. } \\
3.15 \\
81.20\end{array}$ & $\begin{array}{r}\text { n.a. } \\
3.14 \\
86.30\end{array}$ \\
\hline
\end{tabular}


Table A.6 ATMs and Cash Dispensers, 2000-04 (Continued)

\begin{tabular}{|c|c|c|c|c|c|}
\hline & 2000 & 2001 & 2002 & 2003 & 2004 \\
\hline $\begin{array}{l}\text { Trinidad and Tobago } \\
\text { machines per } 1 \text { million inhabitants } \\
\text { transactions per inhabitant per year } \\
\text { average value of transactions (US\$) }\end{array}$ & $\begin{array}{l}218 \\
16 \\
26.80\end{array}$ & $\begin{array}{l}234 \\
20 \\
27.90\end{array}$ & $\begin{array}{l}236 \\
21 \\
31.90\end{array}$ & $\begin{array}{l}\text { n.a. } \\
24 \\
34.60\end{array}$ & $\begin{array}{l}240 \\
29 \\
37.60\end{array}$ \\
\hline $\begin{array}{l}\text { Uruguay } \\
\text { machines per } 1 \text { million inhabitants } \\
\text { transactions per inhabitant per year } \\
\text { average value of transactions (US\$) }\end{array}$ & $\begin{array}{l}103 \\
5 \\
43.90\end{array}$ & $\begin{array}{l}115 \\
6 \\
57.60\end{array}$ & $\begin{array}{l}107 \\
6 \\
52.70\end{array}$ & $\begin{array}{l}185 \\
7 \\
46.80\end{array}$ & $\begin{array}{l}207 \\
8 \\
51.60\end{array}$ \\
\hline $\begin{array}{l}\text { Venezuela, R.B. de }{ }^{2} \\
\text { Machines per } 1 \text { million inhabitants } \\
\text { transactions per inhabitant per year } \\
\text { average value of transactions (US\$) }\end{array}$ & $\begin{array}{l}166 \\
4 \\
21.50\end{array}$ & $\begin{array}{l}168 \\
7 \\
14.50\end{array}$ & $\begin{array}{l}171 \\
6 \\
15.40\end{array}$ & $\begin{array}{l}172 \\
6 \\
17.00\end{array}$ & $\begin{array}{c}172 \\
2 \\
18.70\end{array}$ \\
\hline
\end{tabular}

Source: Working Group on Payment System Issues of Latin America and the Caribbean.

1. Figures as of July 2004.

2. Information for number of machines corresponds to the interconnected network only, Suiche B and Conexus. All other information is only for Conexus.

Table A.7 Indicators of Use of Cashless Payment Instruments, 2000-04

volume of transactions, in millions

\begin{tabular}{|c|c|c|c|c|c|}
\hline & 2000 & 2001 & 2002 & 2003 & 2004 \\
\hline \multicolumn{6}{|l|}{ Argentina } \\
\hline Cheques, local currency & 111.00 & 100.80 & 91.10 & 68.70 & 77.80 \\
\hline Card payments & n.a. & n.a. & n.a. & n.a. & n.a. \\
\hline Credit transfers & 4.90 & 7.10 & n.a. & 3.40 & 4.50 \\
\hline Direct debits & 2.20 & 8.00 & n.a. & n.a. & 7.70 \\
\hline \multicolumn{6}{|l|}{ Bolivia } \\
\hline Cheques, local currency & 1.50 & 2.30 & n.a. & n.a. & n.a. \\
\hline Card payments & n.a. & 1.90 & 2.40 & 2.60 & 3.30 \\
\hline Credit transfers & neg & n.a. & n.a. & n.a. & n.a \\
\hline Direct debits & $\cdots$ & $\cdots$ & $\cdots$ & $\cdots$ & $\cdots$ \\
\hline \multicolumn{6}{|l|}{ Brazil } \\
\hline Cheques, local currency & $2,847.40$ & $2,855.90$ & $2,616.10$ & $2,731.60$ & $2,494.10$ \\
\hline Card payments & 911.70 & $1,151.20$ & $1,420.90$ & $1,745.10$ & $2,164.70$ \\
\hline Credit transfers & 697.60 & 767.80 & 849.10 & 907.30 & $1,016.20$ \\
\hline Direct debits & 322.50 & 385.80 & 438.20 & 626.80 & 657.40 \\
\hline \multicolumn{6}{|l|}{ Chile } \\
\hline Cheques, local currency & 305.10 & 293.20 & 285.10 & 291.90 & 284.30 \\
\hline Card payments & 41.80 & 53.50 & 62.90 & 79.40 & 92.00 \\
\hline Credit transfers & 81.90 & 158.40 & 247.30 & 345.30 & 506.70 \\
\hline Direct debits & n.a. & n.a. & n.a. & n.a. & n.a. \\
\hline \multicolumn{6}{|l|}{ Colombia } \\
\hline Cheques, local currency & 130.00 & 106.70 & 104.60 & 93.20 & 85.80 \\
\hline Card payments & 87.60 & 95.60 & 115.80 & n.a. & n.a. \\
\hline Credit transfers & 3.30 & 5.10 & n.a. & n.a. & n.a. \\
\hline Direct debits & n.a. & n.a. & n.a. & n.a. & n.a. \\
\hline \multicolumn{6}{|l|}{ Costa Rica } \\
\hline Cheques, local currency & 11.40 & 11.10 & 10.70 & 10.20 & 10.00 \\
\hline Card payments & 15.30 & 17.70 & n.a. & n.a. & n.a. \\
\hline Credit transfers & n.a. & n.a. & n.a. & n.a. & n.a. \\
\hline Direct debits & n.a. & n.a. & n.a. & n.a. & n.a. \\
\hline
\end{tabular}


Table A.7 Indicators of Use of Cashless Payment Instruments, 2000-04 (Continued)

volume of transactions, in millions

\begin{tabular}{|c|c|c|c|c|c|}
\hline & 2000 & 2001 & 2002 & 2003 & 2004 \\
\hline \multicolumn{6}{|l|}{ ECCU } \\
\hline Cheques, local currency & n.a. & n.a. & n.a. & n.a. & 8.80 \\
\hline Card payments & n.a. & n.a. & n.a. & n.a. & 1.00 \\
\hline Credit transfers & n.a. & n.a. & n.a. & n.a. & 0.10 \\
\hline Direct debits & n.a. & n.a. & n.a. & n.a. & n.a. \\
\hline \multicolumn{6}{|l|}{ Guatemala } \\
\hline Cheques, local currency & 36.10 & 34.00 & 30.80 & 29.60 & 40.10 \\
\hline Card payments & n.a. & n.a. & n.a. & n.a. & n.a. \\
\hline Credit transfers & 0.01 & 0.01 & 0.01 & 0.01 & 0.01 \\
\hline Direct debits & n.a. & n.a. & n.a. & n.a. & n.a. \\
\hline \multicolumn{6}{|l|}{ Jamaica } \\
\hline Cheques, local currency & n.a. & n.a. & n.a. & n.a. & 11.10 \\
\hline Card payments & n.a. & n.a. & n.a. & n.a. & 30.60 \\
\hline Credit transfers & n.a. & n.a. & n.a. & n.a. & n.a. \\
\hline Direct debits & n.a. & n.a. & n.a. & n.a. & n.a. \\
\hline \multicolumn{6}{|l|}{ Mexico } \\
\hline Cheques, local currency & n.a. & 609.60 & 597.10 & 588.40 & 595.10 \\
\hline Card payments & n.a. & 152.60 & 169.80 & 200.20 & 242.20 \\
\hline Credit transfers & n.a. & 130.60 & 146.10 & 149.90 & 169.40 \\
\hline Direct debits & n.a. & 5.30 & 9.10 & 25.10 & 31.40 \\
\hline \multicolumn{6}{|l|}{ Nicaragua } \\
\hline Cheques, local currency & 3.70 & 3.30 & 2.90 & 2.80 & 2.70 \\
\hline Card payments & n.a. & n.a. & n.a. & n.a. & n.a. \\
\hline Credit transfers $^{1}$ & 0.00 & 0.00 & 0.00 & 0.00 & 0.00 \\
\hline Direct debits & n.a. & n.a. & n.a. & n.a. & n.a. \\
\hline \multicolumn{6}{|l|}{ Peru } \\
\hline Cheques, local currency & 5.10 & 4.90 & n.a. & 32.60 & 32.60 \\
\hline Card payments & 37.00 & 41.00 & n.a. & 45.80 & 54.60 \\
\hline Credit transfers ${ }^{2}$ & 0.30 & 0.30 & 0.30 & 0.40 & 0.50 \\
\hline Direct debits & n.a. & n.a. & n.a. & 11.20 & 7.50 \\
\hline \multicolumn{6}{|l|}{ Trinidad and Tobago } \\
\hline Cheques, local currency & 5.90 & 6.70 & n.a. & n.a. & n.a. \\
\hline Card payments & n.a. & n.a. & n.a. & n.a. & n.a. \\
\hline Credit transfers & n.a. & n.a. & n.a. & n.a. & n.a. \\
\hline Direct debits & n.a. & n.a. & n.a. & n.a. & n.a. \\
\hline \multicolumn{6}{|l|}{ Uruguay } \\
\hline Cheques, local currency & 16.00 & 14.30 & 11.40 & 9.70 & 9.90 \\
\hline Card payments ${ }^{3}$ & 13.60 & 15.10 & 13.80 & 17.30 & 19.00 \\
\hline Credit transfers & n.a. & n.a. & n.a. & n.a. & n.a. \\
\hline Direct debits & n.a. & n.a. & n.a. & n.a. & n.a. \\
\hline \multicolumn{6}{|l|}{ Venezuela, R.B. de } \\
\hline Cheques, local currency & 107.60 & 107.00 & 79.10 & 65.80 & 74.90 \\
\hline Card payments 3 & 42.00 & 39.00 & n.a. & n.a. & n.a. \\
\hline Credit transfers ${ }^{1}$ & 0.12 & 0.13 & 0.19 & 0.17 & 0.37 \\
\hline Direct debits & n.a. & n.a. & n.a. & n.a. & n.a. \\
\hline
\end{tabular}

Source: Working Group on Payment System Issues of Latin America and the Caribbean.

Note: Unless otherwise noted, the information includes both intrabank (on us) and interbank items.

1. The information includes only that of the large-value transfer system.

2. Includes interbank credit transfers only.

3 . Includes credit card information only. 
Table A.8 Indicators of Use of Cashless Payment Instruments, 2000-04

value of transactions, US\$ million

\begin{tabular}{|c|c|c|c|c|c|}
\hline & 2000 & 2001 & 2002 & 2003 & 2004 \\
\hline \multicolumn{6}{|l|}{ Argentina } \\
\hline Cheques, local currency & 287,928 & 240,003 & 69,509 & 85,752 & 117,406 \\
\hline Card payments & n.a. & n.a. & n.a. & n.a. & n.a. \\
\hline Credit transfers & n.a. & n.a. & n.a. & n.a. & n.a. \\
\hline Direct debits & 1,383 & 2,597 & n.a. & n.a. & 473 \\
\hline \multicolumn{6}{|l|}{ Bolivia } \\
\hline Cheques, local currency & 4,386 & 3,985 & n.a. & n.a. & n.a. \\
\hline Card payments & n.a. & 93 & 155 & 216 & 255 \\
\hline Credit transfers ${ }^{1}$ & 22,649 & n.a. & n.a. & n.a. & n.a. \\
\hline Direct debits & n.a. & n.a. & n.a. & n.a. & n.a. \\
\hline \multicolumn{6}{|l|}{ Brazil } \\
\hline Cheques, local currency & $1,100,500$ & 917,700 & 673,200 & 650,200 & 665,600 \\
\hline Card payments & 30,000 & 29,500 & 28,800 & 34,700 & 46,000 \\
\hline Credit transfers & $1,053,200$ & $1,049,300$ & $14,936,100$ & $17,846,800$ & $21,307,600$ \\
\hline Direct debits & 29,800 & 30,400 & 26,300 & 31,700 & 40,500 \\
\hline \multicolumn{6}{|l|}{ Chile } \\
\hline Cheques, local currency & 961,230 & 862,269 & 824,513 & 740,537 & 873,072 \\
\hline Card payments & 1,762 & 1,869 & 2,019 & 2,655 & 3,901 \\
\hline Credit transfers & n.a. & n.a. & n.a. & n.a. & n.a. \\
\hline Direct debits & n.a. & n.a. & n.a. & n.a. & n.a. \\
\hline \multicolumn{6}{|l|}{ Colombia } \\
\hline Cheques, local currency & 212,226 & 173,493 & 164,514 & 140,746 & 160,172 \\
\hline Card payments & 2,976 & 3,034 & 3,325 & 3,578 & 4,804 \\
\hline Credit transfers & 228,562 & 598,648 & 783,615 & 827,084 & $1,342,976$ \\
\hline Direct debits & n.a. & n.a. & n.a. & n.a. & n.a. \\
\hline \multicolumn{6}{|l|}{ Costa Rica } \\
\hline Cheques, local currency & 23,389 & 20,136 & 17,976 & 15,579 & 14,696 \\
\hline Card payments & 608 & 740 & n.a. & n.a. & n.a. \\
\hline Credit transfers ${ }^{2}$ & 19,498 & 27,458 & 32,860 & 40,930 & 48,555 \\
\hline Direct debits ${ }^{3}$ & 0 & neg & 95 & 236 & 505 \\
\hline \multicolumn{6}{|l|}{ ECCU } \\
\hline Cheques, local currency & n.a. & n.a. & n.a. & n.a. & 12,534 \\
\hline Card payments & n.a. & n.a. & n.a. & n.a. & 228 \\
\hline Credit transfers & n.a. & n.a. & n.a. & n.a. & 3,278 \\
\hline Direct debits & n.a. & n.a. & n.a. & n.a. & n.a. \\
\hline \multicolumn{6}{|l|}{ Guatemala } \\
\hline Cheques, local currency & 45,852 & 43,389 & 41,640 & 45,108 & 50,948 \\
\hline Card payments & n.a. & n.a. & n.a. & n.a. & n.a. \\
\hline Credit transfers & 9,957 & 10,167 & 9,457 & 7,631 & 11,388 \\
\hline Direct debits & n.a. & n.a. & n.a. & n.a. & n.a. \\
\hline \multicolumn{6}{|l|}{ Jamaica } \\
\hline Cheques, local currency & n.a. & n.a. & n.a. & n.a. & 30,113 \\
\hline Card payments & n.a. & n.a. & n.a. & n.a. & 1,632 \\
\hline Credit transfers & n.a. & n.a. & n.a. & n.a. & n.a. \\
\hline Direct debits & n.a. & n.a. & n.a. & n.a. & n.a. \\
\hline \multicolumn{6}{|l|}{ Mexico } \\
\hline Cheques, local currency & n.a. & $1,083,365$ & 912,594 & 822,311 & 840,052 \\
\hline Card payments & n.a. & 10,713 & 9,942 & 11,061 & 13,334 \\
\hline Credit transfers & $7,875,127$ & $10,720,101$ & $11,469,437$ & $9,600,505$ & $10,891,446$ \\
\hline Direct debits & n.a. & 429 & 922 & 3,042 & 4,415 \\
\hline
\end{tabular}


Table A.8 Indicators of Use of Cashless Payment Instruments, 2000-04 (Continued)

value of transactions, US\$ million

\begin{tabular}{|c|c|c|c|c|c|}
\hline & 2000 & 2001 & 2002 & 2003 & 2004 \\
\hline \multicolumn{6}{|l|}{ Nicaragua } \\
\hline Cheques, local currency & 5,517 & 4,364 & 3,824 & 4,042 & 4,227 \\
\hline Card payments & n.a. & n.a. & n.a. & n.a. & n.a. \\
\hline Credit transfers $^{1}$ & 1,757 & 1,423 & 1,339 & 1,493 & 1,717 \\
\hline Direct debits & n.a. & n.a. & n.a. & n.a. & n.a. \\
\hline \multicolumn{6}{|l|}{ Peru } \\
\hline Cheques, local currency & 32,621 & 32,199 & n.a. & 30,045 & 29,881 \\
\hline Card payments & 1,760 & 1,992 & n.a. & 1,621 & 1,784 \\
\hline Credit transfers ${ }^{2}$ & 168,087 & 147,493 & 169,709 & 165,914 & 167,306 \\
\hline Direct debits & 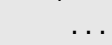 & $\ldots$ & n.a. & 4,812 & 4,241 \\
\hline \multicolumn{6}{|l|}{ Trinidad and Tobago } \\
\hline Cheques, local currency & 3,943 & 4,603 & n.a. & n.a. & n.a. \\
\hline Card payments & n.a. & n.a. & n.a. & n.a. & n.a. \\
\hline Credit transfers & n.a. & n.a. & n.a. & n.a. & n.a. \\
\hline Direct debits & n.a. & n.a. & n.a. & n.a. & n.a. \\
\hline \multicolumn{6}{|l|}{ Uruguay } \\
\hline Cheques, local currency & 18,739 & 18,043 & 10,734 & 9,447 & 10,595 \\
\hline Card payments ${ }^{3}$ & 715 & 717 & 455 & 771 & 951 \\
\hline Credit transfers & n.a. & n.a. & n.a. & 4,816 & 5,731 \\
\hline Direct debits & n.a. & n.a. & n.a. & n.a. & n.a. \\
\hline \multicolumn{6}{|l|}{ Venezuela, R.B. de } \\
\hline Cheques, local currency & 160,953 & 177,218 & 79,003 & 75,439 & 101,029 \\
\hline Card payments ${ }^{3}$ & 1,434 & 1,542 & 905 & 831 & n.a. \\
\hline Credit transfers & n.a. & n.a. & n.a. & n.a. & n.a. \\
\hline Direct debits & n.a. & n.a. & n.a. & n.a. & n.a. \\
\hline
\end{tabular}

Source: Working Group on Payment System Issues of Latin America and the Caribbean.

Note: Unless otherwise noted, the information includes both intrabank (on us) and interbank items.

1. The information includes only that of the large-value transfer system.

2. Includes interbank credit transfers only.

3. Includes credit card information only. 
Table A.9 Features of Selected Interbank Funds Transfer Systems, year-end 2004

\begin{tabular}{|c|c|c|c|c|c|c|c|}
\hline & Type & $\begin{array}{l}\text { Owner or } \\
\text { Manager }\end{array}$ & $\begin{array}{l}\text { Number of } \\
\text { Participant }\end{array}$ & Direct & Processing & Settlement & Membership \\
\hline \multicolumn{8}{|l|}{ Argentina } \\
\hline Cheque clearinghouse & $\mathrm{R}$ & AS & n.a. & n.a. & $\mathrm{ACH}$ & $\mathrm{N}$ & 0 \\
\hline Retail credit transfers & $\mathrm{R}$ & AS & n.a. & n.a. & $\mathrm{ACH}$ & $\mathrm{N}$ & 0 \\
\hline MEP & $L+R$ & $\mathrm{CB}$ & n.a. & n.a. & $\mathrm{RTT}$ & RTGS & 0 \\
\hline \multicolumn{8}{|l|}{ Bolivia } \\
\hline Cheque clearinghouse & $\mathrm{R}$ & AS & n.a. & n.a. & $\mathrm{ACH}$ & $\mathrm{N}$ & n.a. \\
\hline SIPAV & $\mathrm{L}$ & $\mathrm{CB}$ & n.a. & n.a. & $\mathrm{RTT}$ & RTGS & n.a. \\
\hline \multicolumn{8}{|l|}{ Brazil } \\
\hline STR & $\mathrm{L}$ & CB & 144 & 144 & RTT & RTGS & 0 \\
\hline SITRAF & $\mathrm{L}$ & AS & 119 & 119 & RTT & HYBRID & 0 \\
\hline COMPE & $\mathrm{R}$ & $B$ & 137 & 137 & $\mathrm{ACH}$ & MN & 0 \\
\hline SILOC & $\mathrm{R}$ & AS & 117 & 117 & $\mathrm{ACH}$ & MN & 0 \\
\hline Tecban & $\mathrm{R}$ & AS & 45 & 45 & $\mathrm{ACH}$ & MN & 0 \\
\hline \multicolumn{8}{|l|}{ Chile } \\
\hline LBTR & $\mathrm{L}$ & CB & 26 & 26 & RTT & RTGS & 0 \\
\hline Cheque clearinghouse & $\mathrm{R}$ & $B+A S$ & n.a. & 26 & $\mathrm{ACH}$ & $\mathrm{N}$ & 0 \\
\hline \multicolumn{8}{|l|}{ Colombia } \\
\hline CUD & $\mathrm{L}$ & CB & 152 & 152 & RTT & RTGS & RM \\
\hline CEDEC & $\mathrm{R}$ & CB & 28 & 28 & $\mathrm{ACH}$ & $\mathrm{N}$ & $\mathrm{RM}$ \\
\hline CENIT & $\mathrm{R}$ & $\mathrm{CB}$ & 25 & 25 & $\mathrm{ACH}$ & $\mathrm{N}$ & RM \\
\hline ACH Colombia & $\mathrm{R}$ & AS & 19 & 19 & $\mathrm{ACH}$ & $\mathrm{N}$ & $\mathrm{RM}$ \\
\hline \multicolumn{8}{|l|}{ Costa Rica } \\
\hline CLC & $L+R$ & CB & 20 & 20 & $\mathrm{ACH}$ & $\mathrm{N}$ & $\mathrm{RM}$ \\
\hline $\mathrm{TI}$ & $L+R$ & CB & 57 & 57 & RTT & RTGS & RM \\
\hline $\mathrm{TT}$ & $L+R$ & CB & 57 & 57 & RTT & RTGS & RM \\
\hline $\mathrm{CD} / \mathrm{DD}$ & $L+R$ & CB & 37 & 37 & $\mathrm{ACH}$ & $\mathrm{N}$ & $\mathrm{RM}$ \\
\hline \multicolumn{8}{|l|}{ ECCU } \\
\hline Large-value system & $\mathrm{L}$ & CB & 39 & 39 & M & RTGS & $\mathrm{RM}$ \\
\hline \multicolumn{8}{|l|}{ Guatemala } \\
\hline MIT & $\mathrm{L}$ & CB & 49 & 49 & $M$ & RTGS & RM \\
\hline Cheque clearinghouse & $L+R$ & CB & 28 & 28 & M & $\mathrm{MN}$ & $\mathrm{RM}$ \\
\hline \multicolumn{8}{|l|}{ Mexico } \\
\hline Cheque clearinghouse & $\mathrm{R}$ & AS & n.a. & n.a. & $\mathrm{ACH}$ & MN & RM \\
\hline TEF & $\mathrm{R}$ & AS & n.a. & n.a. & $\mathrm{ACH}$ & $\mathrm{MN}$ & RM \\
\hline SIAC & $\mathrm{L}$ & CB & 86 & 86 & RTT & RTGS & $\mathrm{RM}$ \\
\hline SPEUA & $\mathrm{L}$ & CB & 36 & 36 & RTT & RTGS & 0 \\
\hline SPEI ${ }^{1}$ & $\mathrm{~L}$ & CB & n.a. & n.a. & $\mathrm{RTT}$ & RTGS & 0 \\
\hline \multicolumn{8}{|l|}{ Nicaragua } \\
\hline Cheque clearinghouse & $L+R$ & CB & 17 & 17 & $\mathrm{ACH}$ & MN & RM \\
\hline TTS & $L+R$ & CB & 17 & 17 & $\mathrm{RTT}$ & RTGS & 0 \\
\hline \multicolumn{8}{|l|}{ Peru } \\
\hline LBTR & $\mathrm{L}$ & CB & 31 & 16 & RTT & RTGS & RM \\
\hline CCE & $\mathrm{R}$ & $\mathrm{B}$ & 15 & 15 & $\mathrm{ACH}$ & $\mathrm{N}$ & 0 \\
\hline \multicolumn{8}{|l|}{ Trinidad and Tobago } \\
\hline Safe-tt & $\mathrm{L}$ & CB & 21 & 7 & $\mathrm{RTT}$ & RTGS & 0 \\
\hline LINX & $\mathrm{R}$ & AS & 4 & 4 & RTT & $\mathrm{N}$ & 0 \\
\hline \multicolumn{8}{|l|}{ Venezuela, R.B. de } \\
\hline Cheque clearinghouse & $L+R$ & CB & 38 & 36 & $\mathrm{ACH}$ & MN & RM \\
\hline SWIFT DC & $L+R$ & CB & 832 & 832 & RTT & RTGS/GS & \\
\hline
\end{tabular}


Table A.9 Features of Selected Interbank Funds Transfer Systems, year-end 2004 (Continued)

\begin{tabular}{|c|c|c|c|c|c|c|}
\hline & $\begin{array}{c}\text { Degree of } \\
\text { Centralization }\end{array}$ & Pricing & $\begin{array}{l}\text { Closing } \\
\text { Time for } \\
\text { Same-Day } \\
\text { Transactions }\end{array}$ & $\begin{array}{l}\text { Number of } \\
\text { Transactions } \\
\text { (thousands) }\end{array}$ & $\begin{array}{l}\text { Value of } \\
\text { Transactions } \\
\text { (US\$ billions) }\end{array}$ & $\begin{array}{l}\text { Ratio of } \\
\text { Transactions } \\
\text { Value to } \\
\text { Annual GDP } \\
\text { (times) }\end{array}$ \\
\hline \multicolumn{7}{|l|}{ Argentina } \\
\hline Cheque clearinghouse & C & $\mathrm{F}$ & NO & 77,764 & n.a. & n.a. \\
\hline Retail credit transfers & C & $\mathrm{F}$ & NO & 4,511 & 5,154 & 0.20 \\
\hline MEP & C & $\mathrm{N}$ & $20: 00$ & 1,097 & n.a. & n.a. \\
\hline \multicolumn{7}{|l|}{ Bolivia } \\
\hline Cheque clearinghouse & n.a. & n.a. & n.a. & 1,860 & 7 & 2.30 \\
\hline SIPAV & n.a. & n.a. & n.a. & 69 & 24 & 7.70 \\
\hline \multicolumn{7}{|l|}{ Brazil } \\
\hline STR & C & $\mathrm{F}$ & $18: 30$ & 13,400 & 24,548 & 40.60 \\
\hline SITRAF & C & $\mathrm{F}$ & $17: 00$ & 25,400 & 629 & 1.00 \\
\hline COMPE & C & $\mathrm{F}$ & NO & $3,003,400$ & 708 & 1.20 \\
\hline SILOC & C & $\mathrm{F}$ & NO & 94,200 & 31 & 0.10 \\
\hline Tecban & C & $\mathrm{F}$ & NO & 88,900 & 3 & 0.00 \\
\hline \multicolumn{7}{|l|}{ Chile } \\
\hline LBTR & C & V & $17: 30$ & 197 & 1,282 & 12.90 \\
\hline Cheque clearinghouse & C & V & NO & n.a. & n.a. & n.a. \\
\hline \multicolumn{7}{|l|}{ Colombia } \\
\hline CUD & C & V & $21: 00$ & 1,547 & 1,365 & 14.00 \\
\hline CEDEC & C & V & $21: 00$ & 59,770 & 113 & 1.20 \\
\hline CENIT & C & V & $16: 00$ & 792 & 18 & 0.20 \\
\hline ACH Colombia & C & $\mathrm{F}$ & $17: 15$ & 13,774 & 28 & 0.30 \\
\hline \multicolumn{7}{|l|}{ Costa Rica } \\
\hline CLC & C & $\mathrm{F}$ & NO & 10,901 & 21 & 1.10 \\
\hline $\mathrm{TI}$ & C & $\mathrm{F}$ & $17: 00$ & 43 & 34 & 1.80 \\
\hline TT & C & $\mathrm{F}$ & $17: 00$ & 78 & 13 & 0.70 \\
\hline CD/DD & C & $\mathrm{F}$ & NO & 5,442 & 3 & 0.20 \\
\hline \multicolumn{7}{|l|}{ ECCU } \\
\hline Large-value system & C & $\mathrm{N}$ & 1 & 26 & 5 & 2.80 \\
\hline \multicolumn{7}{|l|}{ Guatemala } \\
\hline MIT & C & $\mathrm{N}$ & NO & 8.30 & 52 & 2.00 \\
\hline Cheque clearinghouse & C & $\mathrm{N}$ & NO & $40,261.90$ & 11 & 0.40 \\
\hline \multicolumn{7}{|l|}{ Mexico } \\
\hline Cheque clearinghouse & C & $\mathrm{F}$ & NO & 163,479 & 252 & 0.40 \\
\hline TEF & C & $\mathrm{F}$ & NO & 12,599 & 45 & 0.10 \\
\hline SIAC & C & $\mathrm{F}$ & $19: 30$ & 315 & 2,244 & 3.30 \\
\hline SPEUA & C & $\mathrm{F}$ & 18:00 & 4,314 & 6,317 & 9.40 \\
\hline SPEI & C & $\mathrm{F}$ & $18: 00$ & 212 & 1,551 & 2.30 \\
\hline \multicolumn{7}{|l|}{ Nicaragua } \\
\hline Cheque clearinghouse & C & $\mathrm{N}$ & NO & 2,966 & 6 & 1.40 \\
\hline TTS & C & $S$ & $16: 00$ & 4 & 2 & 0.40 \\
\hline \multicolumn{7}{|l|}{ Peru } \\
\hline LBTR & C & $\mathrm{F}$ & $17: 00$ & 312 & 161 & 2.30 \\
\hline CCE & n.a. & n.a. & $17: 00$ & 8,051 & 30 & 0.40 \\
\hline
\end{tabular}


Table A.9 Features of Selected Interbank Funds Transfer Systems, year-end 2004 (Continued)

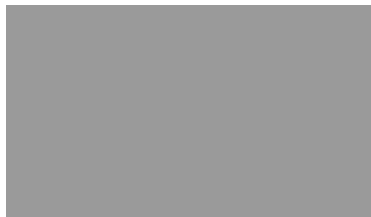

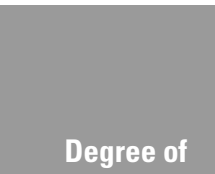

Centralization

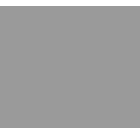

Pricing

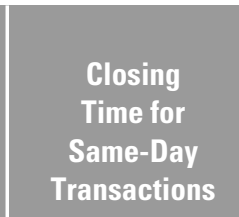

Time for

Same-Day

Transactions

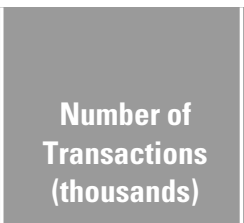

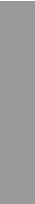

Ratio of

Transactions

Value to

Annual GDP (times)
Trinidad and Tobago Safe-tt LINX
Venezuela, R.B. de Cheque clearinghouse SWIFT DC

C
C
C

$\begin{array}{cc}\mathrm{F} & 14: 45 / 15: 15^{1} \\ \mathrm{~F} & 19: 00 \\ & \\ \mathrm{~V} & \mathrm{NO} \\ \mathrm{N} & 14: 00\end{array}$

Value of

Transactions

(US\$ billions)

Source: Working Group on Payment System Issues of Latin America and the Caribbean.

Note: $\mathrm{L}=$ large value payments system, $\mathrm{R}=$ retail payments system, $\mathrm{L}+\mathrm{R}=$ large value and retail payments system.

Owner/operator: $C B=$ central bank, $B=$ commercial bank, $A S=$ services firm owned by the participating banks.

Processing: $\mathrm{M}=$ manual, $\mathrm{ACH}=$ automated clearinghouse, $\mathrm{RTT}=$ real time transmissions.

Membership: 0 = open membership, $\mathrm{RM}=$ restricted membership.

Settlement: RTGS = real time gross settlement, $\mathrm{GS}=$ other gross settlement, $\mathrm{MN}=$ multilateral netting, $\mathrm{BN}=$ bilateral netting

Degree of Centralization: $C=$ centralized access.

Pricing: $\mathrm{F}=$ full costs (including investments), $\mathrm{V}=$ variable costs, $\mathrm{S}=$ symbolic costs (below variable costs), $\mathrm{N}=$ no charge.

Closing Time for Same-Day Transactions: NO = no same-day transactions.

1. Closing time for consumer transactions and interbank transactions, respectively. 
Table A.10 Operating Hours of Selected Interbank Funds Transfer Systems, year-end 2004

\begin{tabular}{|c|c|c|c|c|c|c|}
\hline & $\begin{array}{l}\text { Gross (G) } \\
\text { or Net (N) }\end{array}$ & $\begin{array}{l}\text { Opening and } \\
\text { Closing Times } \\
\text { for Same-Day } \\
\text { Value } \\
\text { (local time) }\end{array}$ & $\begin{array}{l}\text { Settlement } \\
\text { Finality } \\
\text { (local time) }\end{array}$ & $\begin{array}{l}\text { Cutoff } \\
\text { for All } \\
\text { Third-Party } \\
\text { Payment } \\
\text { Orders }\end{array}$ & $\begin{array}{l}\text { Cutoff for } \\
\text { International } \\
\text { Correspondent } \\
\text { Payment } \\
\text { Orders }\end{array}$ & $\begin{array}{l}\text { Memo: } \\
\text { Standards } \\
\text { Money } \\
\text { Market } \\
\text { Hours } \\
\text { (local time) }\end{array}$ \\
\hline $\begin{array}{l}\text { Argentina } \\
\text { MEP }\end{array}$ & G & n.a. & n.a. & n.a. & n.a. & n.a. \\
\hline $\begin{array}{l}\text { Brazil } \\
\quad \text { STR } \\
\text { SITRAF }\end{array}$ & $\begin{array}{c}G \\
G / N\end{array}$ & $\begin{array}{l}6: 30-18: 30 \\
7: 30-17: 00\end{array}$ & $\begin{array}{l}\text { Real time } \\
\text { Real time }\end{array}$ & $\begin{array}{l}17: 30 \\
17: 30\end{array}$ & $\begin{array}{l}\cdots \\
\cdots\end{array}$ & $\begin{array}{l}6: 30-18: 30 \\
6: 30-18: 30\end{array}$ \\
\hline $\begin{array}{l}\text { Chile } \\
\text { LBTR }\end{array}$ & B & 9:00-18:15 & Real time & $15: 45$ & & $9: 00-18: 00$ \\
\hline $\begin{array}{l}\text { Colombia } \\
\text { CUD }\end{array}$ & G & 8:00-21:00 & Real time & 21:00 & $\ldots$ & 8:00-21:00 \\
\hline $\begin{array}{l}\text { Costa Rica } \\
\text { TI }\end{array}$ & G & 8:00-17:00 & Real time & $17: 00$ & $17: 00$ & 8:00-17:00 \\
\hline $\begin{array}{l}\text { ECCU } \\
\text { Large-value system }\end{array}$ & G & 8:00-15:00 & $3: 00$ & $13: 30$ & $15: 00$ & 8:00-15:00 \\
\hline $\begin{array}{l}\text { Guatemala } \\
\text { MIT }\end{array}$ & G & 9:00-16:00 & Real time & $\ldots$ & $\ldots$ & $8: 00-16: 00$ \\
\hline $\begin{array}{l}\text { Mexico } \\
\text { SIAC } \\
\text { SPEUA }\end{array}$ & $\mathrm{G}$ & $\begin{array}{l}\text { 9:00-19:30 } \\
\text { 9:00-18:00 }\end{array}$ & $\begin{array}{l}\text { Real time } \\
\text { Real time }\end{array}$ & $\begin{array}{l}19: 30 \\
18: 00\end{array}$ & $\begin{array}{l}\cdots \\
\cdots\end{array}$ & $\begin{array}{l}9: 00-19: 30 \\
9: 00-19: 30\end{array}$ \\
\hline $\begin{array}{l}\text { Nicaragua } \\
\text { TTS }\end{array}$ & $\mathrm{N}$ & $8: 30-16: 00$ & $16: 00$ & $\ldots$ & $16: 00$ & $\ldots$ \\
\hline $\begin{array}{l}\text { Peru } \\
\text { Sistema LBTR }\end{array}$ & G & $9: 30-17: 00^{1}$ & Real time & $17: 00$ & 1 & $9: 30-16: 30$ \\
\hline $\begin{array}{l}\text { Trinidad and Tobago } \\
\text { Safe-tt }\end{array}$ & G & $8: 30-15: 15$ & Real time & $14: 45$ & $\cdots$ & n.a. \\
\hline $\begin{array}{l}\text { Venezuela, R.B. de } \\
\text { Cuenta corriente }\end{array}$ & G & 8:00-14:00 & Real time & $14: 00$ & $14: 00$ & $8: 00-14: 00$ \\
\hline
\end{tabular}

Source: Working Group on Payment System Issues of Latin America and the Caribbean.

1. Operating hours can be extended until 18:00 to cover debit positions. 
Table A.11 Features of Selected Securities Settlement Systems, year-end 2004

\begin{tabular}{|c|c|c|c|c|c|c|}
\hline & Type & $\begin{array}{l}\text { Owner or } \\
\text { Operator }\end{array}$ & $\begin{array}{l}\text { Number of } \\
\text { Participants }\end{array}$ & Direct & $\begin{array}{l}\text { Settlement } \\
\text { of Cash Leg }\end{array}$ & Delivery \\
\hline $\begin{array}{l}\text { Argentina } \\
\text { Merval } \\
\text { Argenclear }\end{array}$ & $\begin{array}{c}G+E+0 \\
G\end{array}$ & $\begin{array}{l}\text { SE } \\
\text { SE }\end{array}$ & $\begin{array}{r}\text { n.a. } \\
78\end{array}$ & $\begin{array}{r}\text { n.a. } \\
78\end{array}$ & $\begin{array}{l}\mathrm{N} \\
\mathrm{N}\end{array}$ & $\begin{array}{l}\mathrm{N} \\
\mathrm{N}\end{array}$ \\
\hline $\begin{array}{l}\text { Brazil } \\
\text { SELIC } \\
\text { CETIP } \\
\text { CBLC } \\
\text { BM\&F Activos } 2\end{array}$ & $\begin{array}{c}G \\
G+0^{1} \\
E \\
G\end{array}$ & $\begin{array}{c}A S+C B \\
A S \\
A S \\
S E\end{array}$ & $\begin{array}{r}5,170 \\
4,931 \\
264 \\
92\end{array}$ & $\begin{array}{r}5,170 \\
4,931 \\
264 \\
92\end{array}$ & $\begin{array}{c}\mathrm{G} \\
\mathrm{G} / \mathrm{N} \\
\mathrm{N} \\
\mathrm{N}\end{array}$ & $\begin{array}{c}G \\
G / N \\
N \\
N\end{array}$ \\
\hline $\begin{array}{l}\text { Chile } \\
\text { Sistema valores DCV }\end{array}$ & $\mathrm{G}+\mathrm{E}+\mathrm{O}$ & $B+S E$ & 149 & 149 & $\mathrm{G} / \mathrm{N}$ & $\mathrm{G} / \mathrm{N}$ \\
\hline $\begin{array}{l}\text { Colombia } \\
\text { DCV } \\
\text { DECEVAL }\end{array}$ & $\stackrel{G}{G}+\stackrel{E}{E}+0$ & $\begin{array}{c}\mathrm{CB} \\
\mathrm{B}+\mathrm{SE}\end{array}$ & $\begin{array}{l}\text { n.a. } \\
\text { n.a. }\end{array}$ & $\begin{array}{l}\text { n.a. } \\
\text { n.a. }\end{array}$ & $\begin{array}{l}G \\
G\end{array}$ & $\begin{array}{l}G \\
G\end{array}$ \\
\hline $\begin{array}{l}\text { Costa Rica } \\
\text { TEBEL } \\
\text { Mercado de liquidez } \\
\text { SITE }\end{array}$ & $\begin{array}{c}E+0 \\
G \\
E+0\end{array}$ & $\begin{array}{l}\text { SE } \\
\text { SE } \\
\text { SE }\end{array}$ & $\begin{array}{l}\text { n.a. } \\
\text { n.a. } \\
\text { n.a. }\end{array}$ & $\begin{array}{l}\text { n.a. } \\
\text { n.a. } \\
\text { n.a. }\end{array}$ & $\begin{array}{l}\mathrm{N} \\
\mathrm{N} \\
\mathrm{N}\end{array}$ & $\begin{array}{l}G \\
G \\
G\end{array}$ \\
\hline $\begin{array}{l}\text { ECCU } \\
\text { ECCSD }\end{array}$ & $\mathrm{G}+\mathrm{E}+\mathrm{O}$ & SE & 8 & 8 & $\mathrm{~N}$ & G \\
\hline $\begin{array}{l}\text { Guatemala } \\
\text { BVN }\end{array}$ & $\mathrm{G}+\mathrm{E}+\mathrm{O}$ & SE & 25 & 25 & G & G \\
\hline $\begin{array}{r}\text { Mexico } \\
\text { SIDV }\end{array}$ & $G+E$ & $\mathrm{CB}+\mathrm{B}+\mathrm{SE} / \mathrm{AS}$ & 495 & 495 & $\mathrm{G} / \mathrm{N}^{3}$ & $\mathrm{G} / \mathrm{N}^{4}$ \\
\hline $\begin{array}{l}\text { Peru } \\
\text { BVL }\end{array}$ & $G+E+0$ & SE & 21 & 21 & $\mathrm{~N}$ & G \\
\hline $\begin{array}{l}\text { Trinidad and Tobago } \\
\text { TTSE }\end{array}$ & G & CB & 18 & 18 & $\mathrm{~N}$ & $\mathrm{~N}$ \\
\hline $\begin{array}{l}\text { Venezuela, R.B. de } \\
\text { SICET }\end{array}$ & G & $\mathrm{CB}$ & 113 & 108 & G & G \\
\hline CVV & $\mathrm{G}+\mathrm{E}+0$ & AS & 91 & 91 & G & $\mathrm{N}$ \\
\hline & Delivery & $\begin{array}{l}\text { Central } \\
\text { Securities } \\
\text { Depository }\end{array}$ & $\begin{array}{l}\text { Cash } \\
\text { Settlement } \\
\text { Agent }\end{array}$ & $\begin{array}{l}\text { Number of } \\
\text { Transactions } \\
\text { (thousands) }\end{array}$ & $\begin{array}{l}\text { Value of } \\
\text { Transactions } \\
\text { (US\$ billions) }\end{array}$ & $\begin{array}{l}\text { Ratio of } \\
\text { Transactions } \\
\text { Value to } \\
\text { Annual GDP } \\
\text { (times) }\end{array}$ \\
\hline $\begin{array}{l}\text { Argentina } \\
\text { Merval }^{2} \\
\text { Argenclear }^{2}\end{array}$ & $\begin{array}{c}\mathrm{T}+3 \\
\text { n.a. }\end{array}$ & $\begin{array}{l}\text { Caja valores } \\
\text { Caja valores }\end{array}$ & $\begin{array}{l}B \\
B\end{array}$ & $\begin{array}{l}49 \\
55\end{array}$ & $\begin{array}{l}21 \\
19\end{array}$ & $\begin{array}{l}0.20 \\
0.20\end{array}$ \\
\hline $\begin{array}{l}\text { Brazil } \\
\text { SELIC } \\
\text { CETIP } \\
\text { CBLC } \\
\text { BM\&F activos }{ }^{4}\end{array}$ & $\begin{array}{l}\text { Real time } \\
\begin{array}{l}\mathrm{T}+1^{5} \\
\mathrm{~T}+3^{6} \\
\mathrm{~T}+1\end{array}\end{array}$ & $\begin{array}{l}\text { CB } \\
\text { CETIP } \\
\text { CBLC } \\
\text { CB }\end{array}$ & $\begin{array}{l}C B \\
C B \\
C B \\
C B\end{array}$ & $\begin{array}{r}2.20 \\
0.80 \\
18.80 \\
0.10\end{array}$ & $\begin{array}{r}33,693 \\
1,260 \\
117 \\
458\end{array}$ & $\begin{array}{r}55.80 \\
2.10 \\
0.20 \\
0.80\end{array}$ \\
\hline $\begin{array}{l}\text { Chile } \\
\text { Sistema valores DCV }\end{array}$ & $T+1 / T+2^{7}$ & DCV & B & 1,735 & 349 & 3.50 \\
\hline
\end{tabular}


Table A.11 Features of Selected Securities Settlement Systems, year-end 2004 (Continued)

\begin{tabular}{|c|c|c|c|c|c|c|}
\hline & Delivery & $\begin{array}{l}\text { Central } \\
\text { Securities } \\
\text { Depository }\end{array}$ & $\begin{array}{l}\text { Cash } \\
\text { Settlement } \\
\text { Agent }\end{array}$ & $\begin{array}{l}\text { Number of } \\
\text { Transactions } \\
\text { (thousands) }\end{array}$ & $\begin{array}{l}\text { Value of } \\
\text { Transactions } \\
\text { (US\$ billions) }\end{array}$ & $\begin{array}{l}\text { Ratio of } \\
\text { Transactions } \\
\text { Value to } \\
\text { Annual GDP } \\
\text { (times) }\end{array}$ \\
\hline $\begin{array}{l}\text { Colombia } \\
\text { DCV } \\
\text { DECEVAL }\end{array}$ & $\begin{array}{l}T+0 \\
T+0\end{array}$ & $\begin{array}{c}\text { CB } \\
\text { DECEVAL }\end{array}$ & $\begin{array}{c}C B \\
C B+B\end{array}$ & $\begin{array}{c}4,555 \\
\text { n.a. }\end{array}$ & $\begin{array}{r}1,668 \\
\text { n.a. }\end{array}$ & $\begin{array}{c}17.10 \\
\text { n.a. }\end{array}$ \\
\hline $\begin{array}{l}\text { Costa Rica } \\
\text { TEBEL } \\
\text { Mercado de liquidez } \\
\text { SITE }\end{array}$ & $\begin{array}{l}T+1 \\
T+0 \\
T+3\end{array}$ & $\begin{array}{l}\text { CEVAL } \\
\text { CEVAL } \\
\text { CEVAL }\end{array}$ & $\begin{array}{l}\text { CB } \\
\text { CB } \\
\text { CB }\end{array}$ & $\begin{array}{l}\text { n.a. } \\
\text { n.a. } \\
\text { n.a. }\end{array}$ & $\begin{array}{l}\text { n.a. } \\
\text { n.a. } \\
\text { n.a. }\end{array}$ & $\begin{array}{l}\text { n.a. } \\
\text { n.a. } \\
\text { n.a. }\end{array}$ \\
\hline $\begin{array}{l}\text { ECCU } \\
\text { ECCSD }\end{array}$ & $\mathrm{T}+1$ & ECCSD & B & 352 & 0.20 & 0.10 \\
\hline $\begin{array}{l}\text { Guatemala } \\
\text { BVN }\end{array}$ & $\mathrm{T}+2$ & Caja de valores & n.a. & n.a. & n.a. & n.a. \\
\hline $\begin{array}{r}\text { Mexico } \\
\text { SIDV }\end{array}$ & $\mathrm{T}+2^{4}$ & INDEVAL & CB & 1,509 & 25,804 & 38.30 \\
\hline $\begin{array}{l}\text { Peru } \\
\text { BVL }\end{array}$ & $\mathrm{T}+3$ & CAVALI & B & n.a. & n.a. & n.a. \\
\hline $\begin{array}{l}\text { Trinidad and Tobago } \\
\text { TTSE }\end{array}$ & $\mathrm{T}+0$ & GSS & & 50 & n.a. & \\
\hline $\begin{array}{l}\text { Venezuela, R.B. de } \\
\text { SICET } \\
\text { CVV }\end{array}$ & $\begin{array}{l}\text { Real time } \\
\mathrm{T}+3\end{array}$ & $\begin{array}{l}\text { CB } \\
\text { BVC }\end{array}$ & $\begin{array}{l}\text { CB } \\
\text { CB }\end{array}$ & $\begin{array}{l}94 \\
73\end{array}$ & $\begin{array}{l}113 \\
\text { n.a. }\end{array}$ & $\begin{array}{l}0.90 \\
\text { n.a. }\end{array}$ \\
\hline
\end{tabular}

Source: Working Group on Payment System Issues of Latin America and the Caribbean.

Type: $\mathrm{G}=$ government securities, $\mathrm{E}=$ equities, $\mathrm{O}=$ other

Owner/operator: $\mathrm{CB}=$ central bank, $\mathrm{B}=$ commercial bank, $\mathrm{SE}=$ stock exchange, $\mathrm{AS}=$ services firm owned by the participating banks

Settlement: $\mathrm{G}=$ gross, $\mathrm{N}=$ net

1. Mainly corporate bonds.

2. Started operations in May 17, 2004.

3. For stock exhange transactions, both cash and securities are settled on a net basis. For over-the-counter transactions, both legs are settled gross.

4. For stock exchange transactions settlement occurs in $T+2$. For over-the-counter transactions settlement generally occurs on real time or on $T+1$.

5. For some types of securities, settlement occurs in real time.

6. Stands for spot markets. In the options market, settlement occurs in $\mathrm{T}+1$.

7. $T+2$ is used for shares and $T+1$ for all other types of securities. 
Table A.12 SWIFT Message Flows from and to Domestic Users, 2004

\begin{tabular}{|c|c|c|c|c|c|c|c|}
\hline & \multicolumn{3}{|c|}{ Total Messages Sent } & \multicolumn{3}{|c|}{ Total Messages Received } & \multirow[b]{2}{*}{$\begin{array}{l}\text { Total Traffic } \\
\text { to and } \\
\text { from the } \\
\text { Country }\end{array}$} \\
\hline & Total & Category I & Category II & Total & Category I & Category II & \\
\hline Argentina & $1,271,547$ & 569,087 & 190,297 & $1,584,537$ & 460,885 & 30,263 & $2,856,084$ \\
\hline Bahamas, The & 785,891 & 322,694 & 156,265 & $1,144,665$ & 168,370 & 61,959 & $1,930,556$ \\
\hline Bolivia & 162,906 & 102,399 & 13,546 & 246,207 & 99,777 & 4,937 & 409,113 \\
\hline Brazil & $4,085,545$ & $1,479,989$ & 431,013 & $5,005,631$ & $1,688,508$ & 283,977 & $9,091,176$ \\
\hline Chile & $1,784,603$ & 482,564 & 510,261 & $1,809,650$ & 340,663 & 356,416 & $3,594,253$ \\
\hline Colombia & 866,041 & 374,496 & 196,169 & $1,034,495$ & 389,475 & 67,425 & $1,900,536$ \\
\hline Costa Rica & 275,504 & 195,218 & 18,795 & 427,068 & 211,365 & 5,110 & 702,572 \\
\hline Dominican Republic & 171,799 & 95,229 & 22,635 & 298,064 & 109,263 & 6,531 & 469,863 \\
\hline ECCU & 310,913 & 173,972 & 23,261 & 378,110 & 127,101 & 11,154 & 689,023 \\
\hline Ecuador & 762,912 & 308,001 & 127,655 & $1,338,800$ & 706,436 & 125,316 & $2,101,712$ \\
\hline El Salvador & 163,735 & 103,517 & 19,878 & 201,576 & 74,983 & 5,734 & 365,311 \\
\hline Guatemala & 203,099 & 127,260 & 12,782 & 187,485 & 59,530 & 2,926 & 390,584 \\
\hline Jamaica & 170,311 & 134,972 & 15,999 & 232,984 & 119,375 & 6,224 & 403,295 \\
\hline Mexico & $4,238,655$ & $1,566,086$ & 562,387 & $5,168,479$ & $1,869,045$ & 865,645 & $9,407,134$ \\
\hline Netherlands Antilles & 605,050 & 371,825 & 68,159 & 765,481 & 256,315 & 31,929 & $1,370,531$ \\
\hline Nicaragua & 61,179 & 36,135 & 3,572 & 65,281 & 25,878 & 2,013 & 126,460 \\
\hline Paraguay & 3,943 & n.a. & n.a. & 16,950 & n.a. & n.a. & 20,893 \\
\hline Peru & 656,424 & 353,204 & 59,523 & $1,015,137$ & 486,453 & 12,095 & $1,671,561$ \\
\hline Trinidad and Tobago & 263,328 & 182,510 & 35,292 & 268,772 & 111,477 & 9,949 & 532,100 \\
\hline Uruguay & 559,862 & 335,656 & 49,656 & 831,420 & 360,609 & 19,366 & $1,391,282$ \\
\hline Venezuela, R.B. de & $1,984,293$ & $1,394,734$ & 149,717 & $2,119,590$ & $1,446,095$ & 106,853 & $4,103,883$ \\
\hline Total & & & & & & & $43,527,922$ \\
\hline Global SWIFT traffic & & & & & & & $2,299,074,199$ \\
\hline
\end{tabular}

Source: Working Group on Payment System Issues of Latin America and the Caribbean. 



\section{Scope, Elements, Participants, and Processes of Securities Settlement Systems ${ }^{1}$}

A payment system can be defined as the collection of institutions, instruments, rules, procedures, standards, and technical means used to exchange financial value between two parties discharging an obligation (Listfield and Montes-Negret 1994). A securities clearance and settlement system can be considered as part of the overall payment mechanisms of a country, in that it satisfies the main features of this overall definition. In this case, the exchange of financial value consists both of the exchange of securities (equity, fixed income, or derivatives) and the exchange of liquid funds (usually cash or sight deposits).

The key attributes of a securities clearance and settlement system can best be illustrated by examining each of the elements contained in the definition of a payments system presented above - that is, institutions, instruments, rules, procedures, standards, and technical means.

Institutions provide the infrastructure to clear and settle securities transactions. Two types of institutions are involved: participants that participate directly or indirectly in the clearance and settlement process (clearinghouses, settlement agents, service providers), and regulatory bodies that provide the regulatory framework to clear and settle securities in an orderly and safe way, and to provide oversight for the entire system.

Instruments are the vehicles used for transferring value. Two types of instruments are used: securities that, in a broad sense, include equity, fixed income, and derivatives; and the payments instrument that is used to transfer funds from the buyer of the securities to the seller of the securities. ${ }^{2}$ The specific instrument used to dis- charge the payment leg of the obligation varies; the instrument is dependent on the participants of the transaction and the value of the associated payment. This relationship underscores the importance of an efficient and safe payments clearance and settlement system, and its interconnectivity with the efficiency and safety of the securities clearance and settlement system.

Rules refer to the required legal and administrative framework, and include statutory, regulatory, and contractual rules that govern the rights and obligations of parties to a transaction. A fundamental ingredient of any efficient clearance and settlement system is a clear, comprehensible, sensible, and enforceable (at low cost) legal regime. Technological innovation is having a major impact on the legal, regulatory, and administrative arrangements - for example, on the need to ensure that the judicial system accept electronic records as evidentiary material and that digital signatures have the same attached rights and obligations as physical written signatures.

The securities clearance and settlement procedures vary significantly from one country to another. In some cases, the domestic procedures will differ depending on the specific nature of the securities that are being traded. Typically, procedures have evolved over time and reflect market practices, conditions, traditions, and culture. Today, there is a clear trend toward the use of electronic clearance and settlement mechanisms. A cornerstone of

${ }^{1}$ For more detailed information, see Guadamillas and Keppler (2001). ${ }^{2}$ For a detailed analysis of derivatives clearance and settlement, see BIS (1998). 
such systems is the role played by central securities depositories (CSDs). Establishing a CSD results in increases in efficiency and safety through the immobilization of securities and their safe storage in the CSD, as contrasted with the old arrangements in which the scrip was actually held by the investor. Another benefit usually relates to the issue of securities in a dematerialized or book-entry form. Despite this common evolutionary path, there are many variations in the ways CSDs operate at the detailed level.

The most recent factor that has been introduced into the world of clearance and settlement concerns the role of standards. Standards are required to facilitate the efficient exchange of data between computer systems, and underpin the drive toward straight-through processing in which the entire end-to-end or customer-to-customer transaction flow can be computerized. The use of a common set of standards is also essential in facilitating the integration of national systems into efficient and closely integrated international systems. Today, a wide variety of international institutions and organizations are involved with the development of standards. In some cases, these standards have been established to realize specific purposes and relate primarily to a specific system or group of systems, and thus may not be applicable to all systems. In addition, it should be noted that not every system, especially during the early evolution of securities markets in a country, can or must satisfy all of the standards that have been promulgated. From a practical perspective, the primary need is the availability of a set of standards and implementation guidelines that have applicability to securities markets at different stages of development in mature, transitional, and developing economies. To achieve this end, substantial work has been undertaken at the international level regarding standards development. It is worth noting that this work, quite appropriately, reflects the close interrelationship between securities transfer systems and funds transfer systems.

Finally, the technical means provide the tools and operational infrastructure for transmitting financial value between participants and intermediaries throughout the processing cycle. As mentioned above, technological innovation is providing significant opportunities to reduce operational costs and improve the speed and the security with which information can be processed. However, technological innovation is also introducing new challenges, especially with regard to the need for appropriate legislative changes.

\section{PARTICIPANTS IN SECURITIES CLEARANCE AND SETTLEMENT SYSTEMS}

A broad range of institutions and entities are involved in securities clearance and settlement systems. Regulatory authorities (mainly central banks, superintendencies of banks, and securities regulators) create the legal and oversight environment within which the procedures are carried out. Sometimes they also provide clearance and settlement services, mainly in the case of government securities. Participants are those institutions that send or receive orders directly to or from the system, or that are directly bound by the rules governing securities transfer systems. Participants directly exchange transfer orders with other participants in the system on behalf of themselves, their customers, or on behalf of indirect participants. Indirect participants are distinguished from direct participants by their inability to perform certain activities such as inputting transfer orders or acting as a settlement agent. The typical participants, the functions they perform, and the services they provide are described below. However, as will be noted, the roles of participants are not unique and vary from country to country and from system to system. For example, some of the services or functions undertaken by a specific participant could be provided or performed by separate entities, or some of the services or functions provided or performed by several participants could be provided or performed by a single participant.

Final investors are the individual economic agents in an economy (households and firms) that invest surplus funds or savings with the objective of earning an attractive return on their investment. They normally trade in securities markets through an intermediary, brokerdealer, or institutional investor.

Institutional investors (mainly banks, mutual funds, pension funds, and insurance companies) are playing an increasingly important role in securities markets. The high volume and value of transactions carried out by these institutions place them in a pivotal role in the clearing and settlement processes. International standards recognize the importance of their role and recommend that, although they usually are not direct participants in the trading mechanisms, they should 
have direct participation in the confirmation, comparison, or affirmation processes.

Both final and institutional investors are customers of the securities clearance and settlement system. They are buyers, sellers, or holders of securities and funds. However, they do not participate directly in the clearance and settlement arrangements.

Issuers are institutions that seek financing via the securities markets, thus are obliged to pay interest or dividends and redeem the principal on securities issued by them. They are normally classified as public or private issuers. This distinction is important because countries often have different systems for processing trades in the public and private securities markets. In addition, the public securities market is normally regulated by the central bank, whereas private securities markets are regulated by a separate securities regulatory authority. However, in some countries, where securities regulators do not exist, central banks typically assume the overall regulatory responsibility.

Broker-dealers undertake the primary intermediation role in securities market trading. For this reason, they also have a primary role in the clearance and settlement procedures. It is worth mentioning that the evolution and automation of the securities clearance and settlement systems deeply affects this segment of the industry. In particular, the design of the system, especially the design's impact on the liquidity needs that must be funded by these institutions, can constitute a significant operational constraint. This can present particular difficulties for broker-dealers that focus on the retail sector.

Custodians are entities that undertake the safekeeping of securities and other financial instruments on behalf of others. They may provide other services such as clearance and settlement, securities lending, and so on. A global custodian provides those services with respect to securities that are traded and settled not only in the country where the custodian is located, but also in other countries throughout the world.

CSDs provide facilities for holding securities in either immobilized or book-entry form. In addition to providing this safekeeping role, a CSD may provide trade comparison services, and clearing and settlement services.

International central securities depositories are institutions that settle trades in international securities and in various domestic securities. They usually settle the trades in their own books or through direct or indirect links (through local agents) to domestic CSDs.

Exchanges and over-the-counter (OTC) markets are the mechanisms for trading activity carried out by brokerdealers. Prices are determined by auction bidding on the floor of an exchange or by negotiation (through telephone communications, computer-controlled networks of quotation terminals, and so on) between buying and selling broker-dealers, in the case of OTC markets. The key factor from a clearing and settlement perspective is the way in which trading information is transmitted, rather than the way in which trading takes place.

The clearing agent is the entity that carries out the procedures of trade capture, matching, confirmation, and calculation of obligations relating to securities transfer instructions prior to settlement. These functions are normally provided by CSDs in addition to the depository function, or they are provided by the exchange where the trading takes place. Sometimes the clearing agent assumes counterparty risk by netting the aggregate positions of the participants in a process referred to as novation. In this case, the clearing agent also performs the settlement function.

A settlement agent manages the settlement process, determines the settlement positions, and monitors the exchange of securities and payments. Again, this function is sometimes provided by CSDs or exchanges. The payment of funds is usually done through a settlement bank (private bank or central bank), although in some situations is directly done by the broker-dealer or its paying agent through a means of payment such as a cheque or a certified cheque.

A correspondent bank provides payments and other services to another bank. Such services are primarily provided across international boundaries. It is included in this list because of its relevance to cross-border securities transactions and especially with regard to the role it plays in the payments leg of the transaction.

\section{PROCESSES IN SECURITIES CLEARANCE AND SETTLEMENT SYSTEMS}

After a trade is executed in an exchange or an OTC market, there are still a number of stages to be followed to achieve an effective transfer of value (securities versus 
payment) between the counterparties. These procedures can be quite different from one system to another. This section describes the key aspects of this process. An exhaustive treatment of the many variations and local conditions embedded in such systems around the world is not attempted. The primary purpose is to illustrate the key issues that authorities should consider when striving to achieve an appropriate balance between safety and efficiency.

Box A.1 presents the typical procedures that are undertaken in a securities clearance and settlement system. The life cycle of a securities transaction involves three phases: trade execution, trade clearance, and trade settlement (Stehm 1996). These procedures should be designed and developed to work within a specific legal and operating environment and thus take account of local regulatory and oversight arrangements. An understanding of these latter factors is essential, because they influence the way in which the procedures are used, and thus contribute to any inherent risks embedded in the system. The nature of the operational environment is assuming increasing importance in most countries because technological innovation is changing the way that information is processed and managed; thus technological innovation has an impact on all other factors. The way the authorities adapt to the new operational conditions is critical to maintaining efficient and safe systems. It is thus clear that both the legal and regulatory oversight arrangements need to evolve in line with technologydriven changes in operational procedures.

The process begins with the trade execution phase. The two parties agree to exchange a certain amount of securities for a certain amount of funds on a particular settlement date. The transaction details could be agreed directly between the two counterparties. Transactions between broker-dealers are normally carried out in an exchange or OTC market. ${ }^{3}$ Box A.1 (steps 1 to 3 ) illustrates the case of a transaction processed through an exchange. The fact that a trade is executed in an exchange

${ }^{3}$ It is difficult to have disclosure of off-market transactions, those dealt outside the rules and mechanisms of recognized stock exchanges or other recognized self-regulation markets and bodies. This creates a difficulty in the performance of securities clearance and settlement systems due to the inability to monitor minimum capital requirements, adequacy standards on the behavior in line with the code of conduct, and so on. or OTC market is not significant for clearance and settlement purposes.

Trade clearance refers to the procedures necessary to determine the obligations of direct market participants (broker-dealers and so on) to deliver securities and funds following trade execution. ${ }^{4}$ It includes trade capture, matching, confirmation, comparison, and affirmation procedures (steps 4 to 6 in box A.1) and the calculation of settlement obligations (step 7 in box A.1). Once a trade is executed, the next step is to record (capture) the key information relating to the trade and to ensure that the counterparties agree on all of the terms of the transaction and are able to review and confirm these trade details (matching and confirmation). If the exchange or OTC market transmits locked-in trades, trade matching is done jointly with trade execution; all these procedures occur simultaneously with the delivery of the information by the exchange. If foreign investors participate in the trading, custodian banks normally act as agents for these investors in the clearance and settlement process. In some cases, indirect market participants (institutional investors and custodians), due to the high volume of their operations, participate in a trade comparison system with positive affirmation of trade details.

The calculation of settlement obligations can be done on a gross (the settlement occurs individually on an orderby-order basis), bilateral net (the debits and credits between any two participants are set off), or multilateral net (each participant's total debit and credits to the entire system are set off, leaving the participant with a single net position in relation to the entire system) basis for both the securities balances and the funds balances. The choice is not irrelevant. On the contrary, the choice has an important impact on the efficiency and risk exposure of the system. In addition, this choice is influenced by market characteristics, especially those relating to the availability of liquidity. The main strengths and weaknesses of the two methods require careful study and always result in trade-offs between liquidity requirements and risk mitigation, especially those risks relating to settlement failure. Gross settlement systems eliminate risk, but require more liquidity than net settlement systems. However, net settlement systems have increased risk due to the deferred nature of the settlement process.

${ }^{4}$ This phase is sometimes referred to as trade processing. 


\section{Box A.1. Securities Clearance and Settlement Procedures}

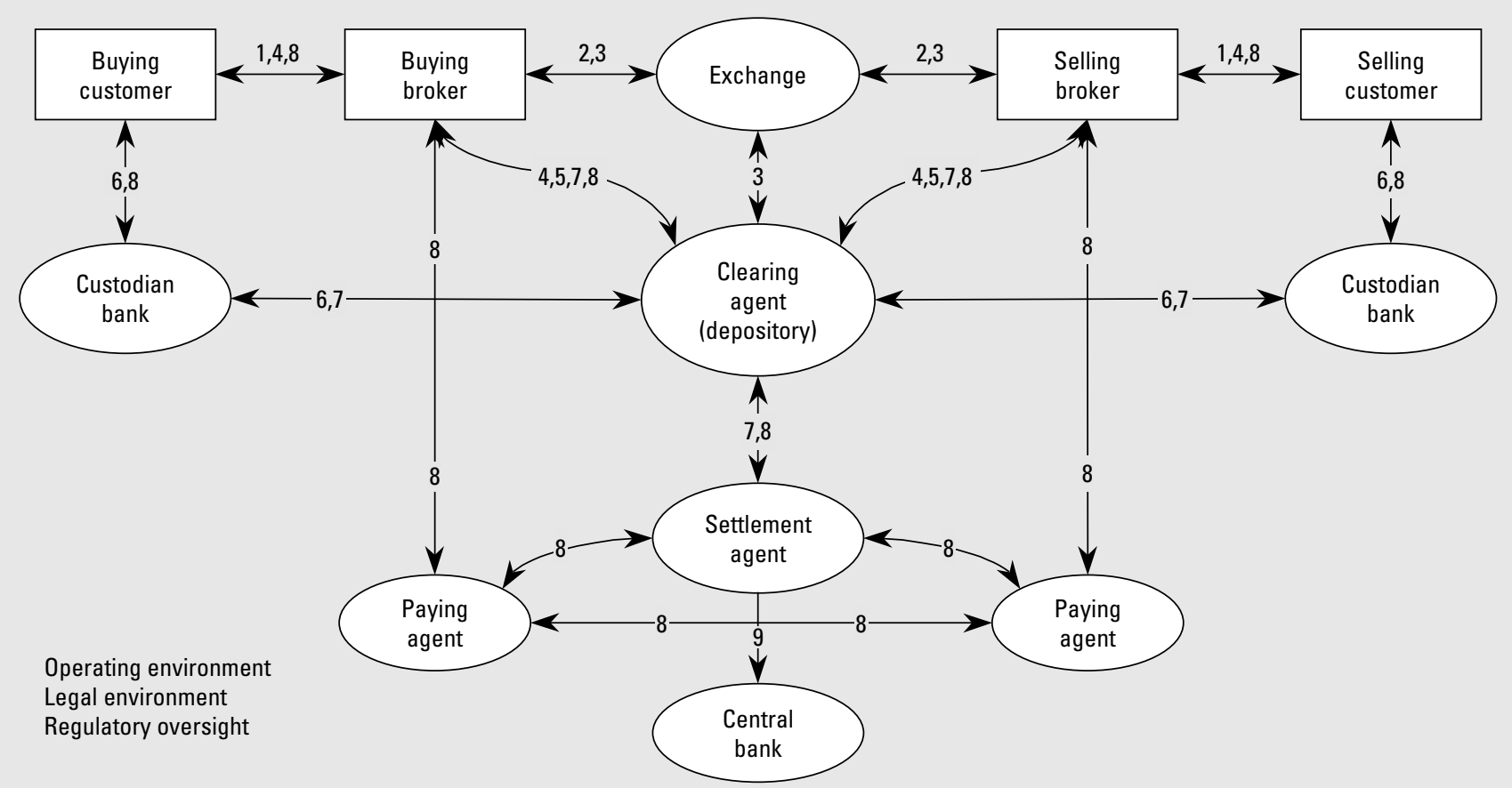

\section{TRADE EXECUTION}

1. Buying and selling customers place their orders with their respective brokers.

2. Brokers executes clients' orders at the exchange.

3. The exchange sends to the clearing agent and brokers the detail of transactions executed.

The trade execution could be done directly between the counterparties. Transactions between broker-dealers are normally carried over an exchange or over-the-counter market. The procedures could be paper based or electronic, processed through the communications systems. It is common that depositories also perform the function of clearing agents. Usually, trading details are sent from the exchange to the clearing agent on $\mathrm{T}$.

\section{TRADE CLEARANCE}

\section{Trade Capture, Matching, Confirmation, Comparison, and Affirmation}

4. Brokers, both buying and selling, send trade details to the clearing agent. Brokers deliver a confirmation to their customers containing the details of the customer's executed orders.

5. The clearing agent compares each side of the trade and provides a report to each broker.

6. For large institutional investors, the confirmation is normally directed to an intermediary such as a custodian acting as agent for the investor in the clearing process.

During this phase, the information flow continues until there are no mistakes in trade details. In some cases, those processes may occur outside the clearing agent as part of the trade execution process. When the trades are transmitted as locked-in transactions by the computer systems of the exchanges or over-the-counter markets, the details of the trades have already been matched. Ideally, all comparison of trades between market participants should be accomplished by $T+1$.

\section{Calculation of Settlement Obligations}

7. The clearing agent sends to the brokers, custodians, and settlement agent the securities balances (gross, bilateral net, or multilateral net) and the fund balances (gross, bilateral net, or multilateral net). In case of mistakes, the information flow continues until the balances are correct. 


\section{Box A.1. Securities Clearance and Settlement Procedures (Continued)}

The selling broker must provide availability of securities before the settlement time, and the buying broker must provide availability of funds before the settlement time.

\section{Availability of Securities}

- Securities in book-entry form: Immobilized and dematerialized securities are available through the broker's accounts in the depository. Normally, the value of securities traded are blocked until the trade is settled, and cannot be used for other trades in subsequent days.

- Securities in physical form: The broker should make them available on the settlement day.

\section{Availability of Funds}

- Payment through a settlement agent: In this case brokers or its paying agents have an account at the settlement agent (usually a bank) and the clearing agent communicates the balances to the settlement agent before settlement day. Broker's paying agents (usually banks) or custodians send the funds before settlement time.

- Direct payment by the broker: In this case, buying brokers directly provide the funds at settlement time by a means of payment (for example, a cheque or certified cheque) or instruct a direct payment through its paying agent to the selling broker.

In some occasions the clearing agent guarantees the trade netting the delivery and receipt of settlement obligations. This is referred to as "novation" or the substitution of one party for another (the clearing agent becomes the buyer to every seller and the seller to every buyer). In most markets trade clearance typically ranges from $T+1$ to $T+5$.

\section{TRADE SETTLEMENT}

8. Securities are delivered in exchange of funds.

\section{Delivery of Securities}

- Through a depository (securities are previously immobilized in the depository or issued in a dematerialized form)

- Directly between the brokers (physical form of securities)

\section{Payment}

- Through a settlement agent

- Directly between the brokers by a means of payment (for example, cheque or certified cheque)

9. The funds are finally registered in the central bank accounts. These funds will be final unless intercepted by judicial resolution.

Securities are transferred through the clearing agent with physical delivery or through a book-entry system. In the latter case, if the depository is a different institution, the clearing agent instructs the depository, and the movement of the securities takes place through the depository accounts. Funds settlement could be done directly by the broker-dealers by a means of payment or through its payment agent, or funds settlement could be centralized in a settlement agent that receives and pay the funds directly through the brokers or its paying agents that pay or receive the money on the participant's behalf. Sometimes, mainly in the case of public securities, for both securities and funds, the settlement is done through Central Bank accounts. Ideally, securities should be delivered if, and only if, there is payment and vice versa, that is, on a delivery versus payment basis.

Finally, settlement involves the discharge of settlement obligations through the final transfer of securities from the seller to the buyer, and the final transfer of funds from the buyer to the seller. Again, this could be done by a variety of procedures, but two elements represented by the concept of delivery versus payment are critical. ${ }^{5}$ This means that securities should be delivered if, and

${ }^{5}$ This concept is referred sometimes as true or real delivery versus payment. 


\section{Box A.2 Trade Confirmation, Comparison, and Affirmation}

Trade comparison type

Locked-in

Matched

\section{Description}

The exchange or over-the-counter market delivers its participants' trades on a locked-in basisthat is, the trades are already matched.

The information on securities traded by its participants is submitted to the clearing agent by the exchange or over-the-counter market, which compares and matches the buy and sell sides of the trades. Comparison members submit the trade data, and the clearing agent sends confirmation reports to comparison members that validate the comparison of the trade data. only if, there is payment, and vice versa - that is, on a delivery versus payment basis. But as important as the previous concept is that transactions are final-that is, that the securities and funds legs cannot be reversedit should also be noted that finality is affected by the particularities of legal and judicial systems. Thus, legal issues such as the concept of nominee or the provisions embedded in bankruptcy laws should be seriously considered by the authorities to ensure consistency with securities laws, regulations, and operational procedures.

A gross settlement system requires a critical mass of marketable securities and systemwide liquidity for its efficient operation. Systemic risk in gross settlement systems is low, because transactions are not executed unless there are securities and funds in the accounts of the counterparties. The relatively recent and rapidly growing use of real-time gross settlement (RTGS) systems (that is, a gross settlement system in which processing and settlement take place in real time, continuously) reduces credit and liquidity risk in comparison with batch processing systems (that is, processing of a group of securities transfer instructions or payment orders at a set of discrete intervals of time). However, the associated liquidity needs may represent a significant constraint to the adoption of these systems in securities markets, because participants are mainly broker-dealers that typically lack the amount of liquidity required for the smooth operation of such systems, unless they are owned by or have a close relationship with a commercial bank. For this reason, the choice of settlement mechanism is not straightforward. It could affect the evolution of the market in terms of the dominant institutions (banks versus nonbank dependent broker-dealers) and the pattern of the market toward a retail or wholesale dominance. ${ }^{6}$ As a consequence, gross settlement systems are more frequently used to remove the risks embedded in large-value funds transfers systems, in which the main participants are banks that have access to intraday liquidity provided by the central bank within carefully controlled arrangements. Well-designed gross settlement systems typically include queue management procedures and other mechanisms such as bilateral and multilateral offset arrangements to mitigate the impact of so-called gridlock in the system. ${ }^{7}$

Net systems, because of the deferred nature of settlement, avoid the need for large amounts of intraday liquidity; the specific volume and value of transactions flows should be studied to determine the potential for risk, however. By reducing the overall value of the final funds transfers that have to be made between participating financial institutions, netting can enhance the efficiency of national payments systems, but netting can also contribute to an increase in systemic risk. This may be the case if, instead of achieving reductions in participants' true exposures, it merely obscures the level of these exposures. The true position becomes apparent only when the net positions are identified at the end of the clearing cycle. At this point, shortages of either securities or funds are identified. Should appropriate cover not be available, then - in the simple case - transactions have to be unwound with the obvious negative impact on sys-

\footnotetext{
${ }^{6}$ The debate about this issue is broader and covers other areas, such as equal regulatory treatment.

${ }^{7}$ Gridlock is a situation in which the failure of some transfer instructions to be executed prevents a substantial number of instructions from other participants from being executed.
} 
tem participants and market confidence. Well-designed netting systems can mitigate these implications by invoking previously agreed settlement assurance procedures. Such procedures can be costly and are sometimes difficult to put in place. In some system arrangements, the clearing agent guarantees settlement, and in effect becomes the counterparty to each trade. This mechanism is referred to as novation, and requires a supporting legal environment.

Operational systems, especially those in transition, often exhibit a combination of gross and net schemes. For example, it is not uncommon to see systems that combine securities gross settlement with funds net settlement. The Bank for International Settlements made an effort to categorize the range of existing systems using different flavors of the concept of delivery versus payments, already mentioned (CPSS 1992). It should also be noted that the boundaries between RTGS systems and net settlement systems are becoming blurred. An increasing number of net settlement systems now settle periodically during the day rather than solely at the end of the day. This reduces the potential for settlement failure by reducing the progressive build-up of credit exposures between participants. Also, as noted earlier, gridlock-busting routines in gross settlement arrangements make use of embedded net settlement offset concepts. This trend is continuing, and it is likely that some form of final convergence between these mechanisms will take place. 


\section{CPSS Core Principles for Systemically Important Payment Systems}

I. The system should have a well-founded legal basis under all relevant jurisdictions.

II. The system's rules and procedures should enable participants to have a clear understanding of the system's impact on each of the financial risks they incur through participation in it.

III. The system should have clearly defined procedures for the management of credit risks and liquidity risks, which specify the respective responsibilities of the system operator and the participants and which provide appropriate incentives to manage and contain those risks.

IV. The system should provide prompt final settlement on the day of value, preferably during the day and at a minimum at the end of the day.

V. A system in which multilateral netting takes place should be, at a minimum, capable of ensuring the timely completion of daily settlements in the event of an inability to settle by the participant with the largest single settlement obligation.

VI. Assets used for settlement should preferably be a claim on the central bank; where other assets are used, they should carry little or no credit risk and little or no liquidity risk.

VII. The system should ensure a high degree of security and operational reliability and should have contingency arrangements for timely completion of daily processing.

VIII. The system should provide a means of making payments, which is practical for its users and efficient for the economy.

IX. The system should have objective and publicly disclosed criteria for participation, which permit fair and open access.

$\mathrm{X}$. The system's governance arrangements should be effective, accountable, and transparent.

\section{RESPONSIBILITIES OF THE CENTRAL BANK IN APPLYING THE CORE PRINCIPLES}

A. The central bank should define clearly its payment system objectives and should disclose publicly its role and major policies with respect to systemically important payment systems.

B. The central bank should ensure that the systems it operates comply with the Core Principles.

C. The central bank should oversee compliance with the Core Principles by systems it does not operate and it should have the ability to carry out this oversight.

D. The central bank, in promoting payment system safety and efficiency through the Core Principles, should cooperate with other central banks and with any other relevant domestic or foreign authorities. 



\section{CPSS-IOSCO Recommendations for Securities Settlement Systems}

Recommendation 1. Securities settlement systems should have a well-founded, clear, and transparent legal basis in the relevant jurisdictions.

Recommendation 2. Confirmation of trades between direct market participants should occur as soon as possible after trade execution, but no later than trade date $(\mathrm{T}+0)$. Where confirmation of trades by indirect market participants (such as institutional investors) is required, it should occur as soon as possible after trade execution, preferably on $\mathrm{T}+0$, but no later than $\mathrm{T}+1$.

Recommendation 3. Rolling settlement should be adopted in all securities markets. Final settlement should occur no later than $\mathrm{T}+3$. The benefits and costs of a settlement cycle shorter than $\mathrm{T}+3$ should be evaluated.

Recommendation 4. The benefits and costs of a central counterparty should be evaluated. Where such a mechanism is introduced, the central counterparty should rigorously control the risks it assumes.

Recommendation 5. Securities lending and borrowing (or repurchase agreements and other economically equivalent transactions) should be encouraged as a method for expediting the settlement of securities transactions. Barriers that inhibit the practice of lending securities for this purpose should be removed.

Recommendation 6. Securities should be immobilized or dematerialized and transferred by book entry in CSDs to the greatest extent possible.

Recommendation 7. CSDs should eliminate principal risk by linking securities transfers to funds transfers in a way that achieves delivery versus payment.
Recommendation 8. Final settlement should occur no later than the end of the settlement day. Intraday or realtime finality should be provided where necessary to reduce risks.

Recommendation 9. CSDs that extend intraday credit to participants, including CSDs that operate net settlement systems, should institute risk controls that, at a minimum, ensure timely settlement in the event that the participant with the largest payment obligation is unable to settle. The most reliable set of controls is a combination of collateral requirements and limits.

Recommendation 10. Assets used to settle the ultimate payment obligations arising from securities transactions should carry little or no credit or liquidity risk. If central bank money is not used, steps must be taken to protect CSD members from potential losses and liquidity pressures arising from the failure of the cash settlement agent whose assets are used for that purpose.

Recommendation 11. Sources of operational risk arising in the clearing and settlement process should be identified and minimized through the development of appropriate systems, controls, and procedures. Systems should be reliable and secure, and have adequate, scalable capacity. Contingency plans and backup facilities should be established to allow for timely recovery of operations and completion of the settlement process.

Recommendation 12. Entities holding securities in custody should employ accounting practices and safekeeping procedures that fully protect customers' securities. It is essential that customers' securities be protected against the claims of a custodian's creditors. 
Recommendation 13. Governance arrangements for CSDs and central counterparties should be designed to fulfill public interest requirements and to promote the objectives of owners and users.

Recommendation 14. CSDs and central counterparties should have objective and publicly disclosed criteria for participation that permit fair and open access.

Recommendation 15. While maintaining safe and secure operations, securities settlement systems should be costeffective in meeting the requirements of users.

Recommendation 16. Securities settlement systems should use or accommodate the relevant international communication procedures and standards in order to facilitate efficient settlement of cross-border transactions.
Recommendation 17. CSDs and central counterparties should provide market participants with sufficient information for them to accurately identify and evaluate the risks and costs associated with using the CSD or central counterparty services.

Recommendation 18. Securities settlement systems should be subject to transparent and effective regulation and oversight. Central banks and securities regulators should cooperate with each other and with other relevant authorities.

Recommendation 19. CSDs that establish links to settle cross-border trades should design and operate such links to reduce effectively the risks associated with crossborder settlements. 


\section{CPSS-IOSCO Recommendations for Central Counterparties}

\section{Legal risk}

A central counterparty (CCP) should have a well-founded, transparent, and enforceable legal framework for each aspect of its activities in all relevant jurisdictions.

\section{Participation requirements}

A CCP should require participants to have sufficient financial resources and robust operational capacity to meet obligations arising from participation in the CCP. A CCP should have procedures in place to monitor that participation requirements are met on an ongoing basis. A CCP's participation requirements should be objective, publicly disclosed, and permit fair and open access.

\section{Measurement and management of credit exposures}

A CCP should measure its credit exposures to its participants at least once a day. Through margin requirements, other risk control mechanisms or a combination of both, a CCP should limit its exposures to potential losses from defaults by its participants in normal market conditions so that the operations of the CCP would not be disrupted and nondefaulting participants would not be exposed to losses that they cannot anticipate or control.

\section{Margin requirements}

If a CCP relies on margin requirements to limit its credit exposures to participants, those requirements should be sufficient to cover potential exposures in normal market conditions. The models and parameters used in setting margin requirements should be risk-based and reviewed regularly.

\section{Financial resources}

A CCP should maintain sufficient financial resources to withstand, at a minimum, a default by the participant to which it has the largest exposure in extreme but plausible market conditions.

\section{Default procedures}

A CCP's default procedures should be clearly stated, and they should ensure that the CCP can take timely action to contain losses and liquidity pressures and to continue meeting its obligations. Key aspects of the default procedures should be publicly available.

\section{Custody and investment risk}

A CCP should hold assets in a manner whereby risk of loss or of delay in its access to them is minimized. Assets invested by a CCP should be held in instruments with minimal credit, market, and liquidity risk.

\section{Operational risk}

A CCP should identify sources of operational risk and minimize them through the development of appropriate systems, control, and procedures. Systems should be reliable and secure, and have adequate, scalable capacity. Business continuity plans should allow for timely recovery of operations and fulfillment of a CCP's obligations.

\section{Money settlements}

A CCP should employ money settlement arrangements that eliminate or strictly limit its settlement bank risks, that is, its credit and liquidity risks from use of banks to effect money settlements with its participants. Funds transfers to the CCP should be final when effected.

\section{Physical deliveries}

A CCP should clearly state its obligations with respect to physical deliveries. The risks from these obligations should be identified and managed. 


\section{Risks in links between CCPS}

CCPs that establish links either cross-border or domestically to clear trades should evaluate the potential sources of risks that can arise, and ensure that the risks are managed prudently and on an ongoing basis. There should be a framework for cooperation and coordination between the relevant regulators and overseers.

\section{Efficiency}

While maintaining safe and secure operations, CCPs should be cost-effective in meeting the requirements of users.

\section{Governance}

Governance arrangements for a CCP should be clear and transparent to fulfill public interest requirements and to support the objectives of owners and users. In particular, they should promote the effectiveness of the CCP's risk management procedures.

\section{Transparency}

A CCP should provide market participants with sufficient information for them to identify and evaluate accurately the risks and costs associated with using its services.

\section{Regulation and oversight}

A CCP should be subject to transparent and effective regulation and oversight. In both a domestic and international context, central banks and securities regulators should cooperate with each other and with other relevant authorities. 


\section{CPSS General Guidance for National Payments System Development}

\section{A. BANIKING SYSTEM}

Guideline 1. Keep the central bank at the centre: Due to its overall responsibility for a sound currency, the central bank has a central role in the development of the use of money as an effective means of payment.

Guideline 2. Promote the role of a sound banking system: Payment accounts, instruments, and services available to end users are provided by banks and other similar financial institutions, which compete individually but often need to act cooperatively as a system.

\section{B. PLANNING}

Guideline 3. Recognize complexity: Planning should be based on a comprehensive understanding of all the core elements of the national payment system and the principal factors influencing its development.

Guideline 4. Focus on needs: Identify, and be guided by, the payment needs of all users in the national payment system and by the capabilities of the economy.

Guideline 5. Set clear priorities: Plan and prioritize development of the national payment system strategically.

Guideline 6. Implementation is key: Ensure effective implementation of the strategic plan.

\section{INSTITUTIONAL FRAMEWORK}

Guideline 7. Promote market development: The expansion and strengthening of market arrangements for payment services are key aspects of the evolution of the national payment system.
Guideline 8. Involve relevant stakeholders: Encourage the development of effective consultation among relevant stakeholders in the national payment system.

Guideline 9. Collaborate for effective oversight: Effective payment system oversight by the central bank often requires collaborative arrangements with other authorities.

Guideline 10. Promote legal certainty: Develop a transparent, comprehensive and sound legal framework for the national payment system.

\section{INFRASTRUCTURES}

Guideline 11. Expand availability of retail payment services: Extend the availability and choice of efficient and secure noncash payment instruments and services available to consumers, businesses, and government by expanding and improving retail payment infrastructures.

Guideline 12. Let the business case guide the large-value payment system: Develop a large-value payment system based primarily on the needs of financial markets and the growth in time-critical interbank payments.

Guideline 13. Align development of payment and securities systems: Coordinate the development of securities and large-value payment systems for safety and efficiency in the financial system.

Guideline 14. Coordinate settlement of retail, largevalue and securities systems: The settlement processes for the core systems should be operationally coordinated to efficiently manage the interrelated liquidity needs and settlement risks among them. 



\section{Recommendations of the Financial Action Task Force on Money Laundering}

The 40 Recommendations of the Financial Action Task

Force on Money Laundering (FATF)

\section{A. GENERAL FRAMEWORK OF THE RECOMMENDATIONS}

1. Each country should take immediate steps to ratify and to implement fully, the 1988 United Nations Convention against Illicit Traffic in Narcotic Drugs and Psychotropic Substances (the Vienna Convention).

2. Financial institution secrecy laws should be conceived so as not to inhibit implementation of these recommendations.

3. An effective money laundering enforcement program should include increased multilateral cooperation and mutual legal assistance in money laundering investigations and prosecutions and extradition in money laundering cases, where possible.

\section{B. ROLE OF NATIONAL LEGAL SYSTEMS IN COMBATING MONEY LAUNDERING}

\section{Scope of the Criminal Offense of Money Laundering}

4. Each country should take such measures as may be necessary, including legislative ones, to enable it to criminalize money laundering as set forth in the Vienna Convention. Each country should extend the offense of drug money laundering to one based on serious offenses. Each country would determine which serious crimes would be designated as money laundering predicate offenses.
5. As provided in the Vienna Convention, the offense of money laundering should apply at least to knowing money laundering activity, including the concept that knowledge may be inferred from objective factual circumstances.

6. Where possible, corporations themselves - not only their employees - should be subject to criminal liability.

\section{Provisional Measures and Confiscation}

7. Countries should adopt measures similar to those set forth in the Vienna Convention, as may be necessary, including legislative ones, to enable their competent authorities to confiscate property laundered, proceeds from, instrumentalities used in or intended for use in the commission of any money laundering offense, or property of corresponding value, without prejudicing the rights of bona fide third parties. Such measures should include the authority to (1) identify, trace and evaluate property that is subject to confiscation; (2) carry out provisional measures, such as freezing and seizing, to prevent any dealing, transfer or disposal of such property; and (3) take any appropriate investigative measures. In addition to confiscation and criminal sanctions, countries also should consider monetary and civil penalties, and/or proceedings including civil proceedings, to void contracts entered into by parties, where parties knew or should have known that as a result of the contract, the State would be prejudiced in its ability to recover financial claims, e.g., through confiscation or collection of fines and penalties. 


\section{ROLE OF THE FINANCIAL SYSTEM IN COMBATING MONEY LAUNDERING}

8. Recommendations 10 to 29 should apply not only to banks, but also to nonbank financial institutions. Even for those nonbank financial institutions which are not subject to a formal prudential supervisory regime in all countries, for example bureaux de change, governments should ensure that these institutions are subject to the same anti-money laundering laws or regulations as all other financial institutions and that these laws or regulations are implemented effectively.

9. The appropriate national authorities should consider applying Recommendations 10 to 21 and 23 to the conduct of financial activities as a commercial undertaking by businesses or professions that are not financial institutions, where such conduct is allowed or not prohibited. Financial activities include, but are not limited to, those listed in the attached annex. It is left to each country to decide whether special situations should be defined where the application of anti-money-laundering measures is not necessary, for example, when a financial activity is carried out on an occasional or limited basis.

\section{Customer Identification and Recordkeeping Rules}

10. Financial institutions should not keep anonymous accounts or accounts in obviously fictitious names: they should be required (by law, by regulations, by agreements between supervisory authorities and financial institutions or by self-regulatory agreements among financial institutions) to identify, on the basis of an official or other reliable identifying document, and record the identity of their clients, either occasional or usual, when establishing business relations or conducting transactions (in particular opening of accounts or passbooks, entering into fiduciary transactions, renting of safe deposit boxes, performing large cash transactions). In order to fulfill identification requirements concerning legal entities, financial institutions should, when necessary, take measures: (1) to verify the legal existence and structure of the customer by obtain- ing either from a public register or from the customer or both, proof of incorporation, including information concerning the customer's name, legal form, address, directors, and provisions regulating the power to bind the entity; (2) to verify that any person purporting to act on behalf of the customer is so authorized and identify that person.

11. Financial institutions should take reasonable measures to obtain information about the true identity of the persons on whose behalf an account is opened or a transaction conducted if there are any doubts as to whether these clients or customers are acting on their own behalf, for example, in the case of domiciliary companies (i.e., institutions, corporations, foundations, trusts, etc. that do not conduct any commercial or manufacturing business or any other form of commercial operation in the country where their registered office is located).

12. Financial institutions should maintain, for at least five years, all necessary records on transactions, both domestic or international, to enable them to comply swiftly with information requests from the competent authorities. Such records must be sufficient to permit reconstruction of individual transactions (including the amounts and types of currency involved if any) so as to provide, if necessary, evidence for prosecution of criminal behavior. Financial institutions should keep records on customer identification (e.g., copies or records of official identification documents like passports, identity cards, driving licenses, or similar documents), account files, and business correspondence for at least five years after the account is closed. These documents should be available to domestic competent authorities in the context of relevant criminal prosecutions and investigations.

13. Countries should pay special attention to money laundering threats inherent in new or developing technologies that might favor anonymity, and take measures, if needed, to prevent their use in money laundering schemes.

\section{Increased Diligence of Financial Institutions}

14. Financial institutions should pay special attention to all complex, unusual large transactions, and all 
unusual patterns of transactions, which have no apparent economic or visible lawful purpose. The background and purpose of such transactions should, as far as possible, be examined, the findings established in writing, and be available to help supervisors, auditors, and law enforcement agencies.

15. If financial institutions suspect that funds stem from a criminal activity, they should be required to report promptly their suspicions to the competent authorities.

16. Financial institutions, their directors, officers, and employees should be protected by legal provisions from criminal or civil liability for breach of any restriction on disclosure of information imposed by contract or by any legislative, regulatory, or administrative provision, if they report their suspicions in good faith to the competent authorities, even if they did not know precisely what the underlying criminal activity was, and regardless of whether illegal activity actually occurred.

17. Financial institutions, their directors, officers, and employees, should not, or, where appropriate, should not be allowed to, warn their customers when information relating to them is being reported to the competent authorities.

18. Financial institutions reporting their suspicions should comply with instructions from the competent authorities.

19. Financial institutions should develop programs against money laundering. These programs should include, as a minimum (1) the development of internal policies, procedures and controls, including the designation of compliance officers at management level, and adequate screening procedures to ensure high standards when hiring employees; (2) an ongoing employee training program; (3) an audit function to test the system.

\section{Measures to Cope with the Problem of Countries with No or Insufficient Anti-Money-Laundering Measures}

20. Financial institutions should ensure that the principles mentioned above are also applied to branches and majority owned subsidiaries located abroad, especially in countries which do not or insufficiently apply these Recommendations, to the extent that local applicable laws and regulations permit. When local applicable laws and regulations prohibit this implementation, competent authorities in the country of the mother institution should be informed by the financial institutions that they cannot apply these Recommendations.

21. Financial institutions should give special attention to business relations and transactions with persons, including companies and financial institutions, from countries that do not or insufficiently apply these Recommendations. Whenever these transactions have no apparent economic or visible lawful purpose, their background and purpose should, as far as possible, be examined, the findings established in writing, and be available to help supervisors, auditors, and law enforcement agencies.

\section{Other Measures to Avoid Money Laundering}

22. Countries should consider implementing feasible measures to detect or monitor the physical crossborder transportation of cash and bearer negotiable instruments, subject to strict safeguards to ensure proper use of information and without impeding in any way the freedom of capital movements.

23. Countries should consider the feasibility and utility of a system where banks and other financial institutions and intermediaries would report all domestic and international currency transactions above a fixed amount, to a national central agency with a computerized data base, available to competent authorities for use in money laundering cases, subject to strict safeguards to ensure proper use of the information.

24. Countries should further encourage in general the development of modern and secure techniques of money management, including increased use of cheques, payment cards, direct deposit of salary cheques, and book entry recording of securities, as a means to encourage the replacement of cash transfers.

25. Countries should take notice of the potential for abuse of shell corporations by money launderers and should consider whether additional measures are required to prevent unlawful use of such entities. 


\section{Implementation, and Role of Regulatory and other Administrative Authorities}

26. The competent authorities supervising banks or other financial institutions or intermediaries, or other competent authorities, should ensure that the supervised institutions have adequate programs to guard against money laundering. These authorities should cooperate and lend expertise spontaneously or on request with other domestic judicial or law enforcement authorities in money laundering investigations and prosecutions.

27. Competent authorities should be designated to ensure an effective implementation of all these Recommendations, through administrative supervision and regulation, in other professions dealing with cash as defined by each country.

28. The competent authorities should establish guidelines which will assist financial institutions in detecting suspicious patterns of behavior by their customers. It is understood that such guidelines must develop over time, and will never be exhaustive. It is further understood that such guidelines will primarily serve as an educational tool for financial institutions' personnel.

29. The competent authorities regulating or supervising financial institutions should take the necessary legal or regulatory measures to guard against control or acquisition of a significant participation in financial institutions by criminals or their confederates.

\section{STRENGTHENING OF}

\section{INTERNATIONAL COOPERATION}

\section{Administrative Cooperation}

\section{Exchange of general information}

30. National administrations should consider recording, at least in the aggregate, international flows of cash in whatever currency, so that estimates can be made of cash flows and reflows from various sources abroad, when this is combined with central bank information. Such information should be made available to the International Monetary Fund and the Bank for International Settlements to facilitate international studies.

31. International competent authorities, perhaps Interpol and the World Customs Organisation, should be given responsibility for gathering and disseminating information to competent authorities about the latest developments in money laundering and money laundering techniques. Central banks and bank regulators could do the same on their network. National authorities in various spheres, in consultation with trade associations, could then disseminate this to financial institutions in individual countries.

\section{Exchange of information relating to suspicious transactions}

32. Each country should make efforts to improve a spontaneous or "upon request" international information exchange relating to suspicious transactions, persons, and corporations involved in those transactions between competent authorities. Strict safeguards should be established to ensure that this exchange of information is consistent with national and international provisions on privacy and data protection.

\section{Other Forms of Cooperation}

\section{Basis and means for cooperation in confiscation, mutual assistance, and extradition}

33. Countries should try to ensure, on a bilateral or multilateral basis, that different knowledge standards in national definitions - i.e., different standards concerning the intentional element of the infraction - do not affect the ability or willingness of countries to provide each other with mutual legal assistance.

34. International cooperation should be supported by a network of bilateral and multilateral agreements and arrangements based on generally shared legal concepts with the aim of providing practical measures to affect the widest possible range of mutual assistance.

35. Countries should be encouraged to ratify and implement relevant international conventions on money laundering such as the 1990 Council of Europe Convention on Laundering, Search, Seizure and Confiscation of the Proceeds from Crime. 


\section{Focus of improved mutual assistance on money laundering issues}

36. Cooperative investigations among countries' appropriate competent authorities should be encouraged. One valid and effective investigative technique in this respect is controlled delivery related to assets known or suspected to be the proceeds of crime. Countries are encouraged to support this technique, where possible.

37. There should be procedures for mutual assistance in criminal matters regarding the use of compulsory measures including the production of records by financial institutions and other persons, the search of persons and premises, seizure and obtaining of evidence for use in money laundering investigations and prosecutions, and in related actions in foreign jurisdictions.

38. There should be authority to take expeditious action in response to requests by foreign countries to identify, freeze, seize, and confiscate proceeds or other property of corresponding value to such proceeds, based on money laundering or the crimes underlying the laundering activity. There should also be arrangements for coordinating seizure and confiscation proceedings which may include the sharing of confiscated assets.

39. To avoid conflicts of jurisdiction, consideration should be given to devising and applying mechanisms for determining the best venue for prosecution of defendants in the interests of justice in cases that are subject to prosecution in more than one country. Similarly, there should be arrangements for coordinating seizure and confiscation proceedings which may include the sharing of confiscated assets.

40. Countries should have procedures in place to extradite, where possible, individuals charged with a money laundering offense or related offenses. With respect to its national legal system, each country should recognize money laundering as an extraditable offense. Subject to their legal frameworks, countries may consider simplifying extradition by allowing direct transmission of extradition requests between appropriate ministries, extraditing persons based only on warrants of arrests or judgments, extraditing their nationals, and/or introducing a simplified extradition of consenting persons who waive formal extradition proceedings. 



\section{Systemically Important Payment Systems in Latin America and the Caribbean Results of the Self-Assessment Exercises}

The Committee on Payment and Settlement Systems' core principles for systemically important payment systems (CPSIPS) has become a key component in the assessments of financial systems aimed at identifying potential weaknesses. Following up on the international debate, in 2002 and 2003 the Working Group on Payment System Issues of LAC promoted among its members carrying out a self-assessment exercise of the region's systemically important payment systems (SIPS) versus the Committee on Payment and Settlement Systems' CPSIPS.

The general results of these exercises, together with an accompanying analysis of the current situation and the potential future written by Arango C. and J. Bernal, were published in June 2003 in the Western Hemisphere Payments and Securities Clearance and Settlement Initiative's research series (Arango and Bernal 2003). This appendix summarizes the main outcome of this effort, to which the central banks of the following 15 countries contributed: Argentina, Belize, Bolivia, Brazil, Colombia, Costa Rica, Chile, Ecuador, El Salvador, Guyana, Mexico, Organization of Eastern Caribbean States, Peru, Trinidad \& Tobago, and the República Bolivariana de Venezuela.

\section{GENERAL ASSESSMENT OF THE CURRENT SITUATION OF SIPS IN THE LATIN AMERICA AND THE CARIBBEAN REGION}

Table A.13 summarizes the grades given by participating central banks regarding the degree of their compliance with the 10 core principles and the four central bank responsibilities. It should be noted that out of 29 payment systems identified as SIPS, in nine the corre- sponding central banks did not assign a specific grade, either because such systems are currently being reformed or because these central banks abstained from providing such grades.

At first glance, grades assigned by self-assessors tend to be high. In most cases, countries report either an "observed" or "broadly observed" grade. Nevertheless, participating central banks recognize deficiencies particularly as regards to CPs I, II, and X, as well as in responsibilities $\mathrm{A}, \mathrm{B}$, and $\mathrm{C}$.

These grades neither fully coincide with the opinions of the authors (see figures A.1 and A.2), nor with some shortcomings expressed by the own self-assessors.

Additionally, when these grades are compared to those obtained from financial sector assessment program missions to developing countries worldwide, which include LAC as well as other regions, it may be concluded that grades assigned by self-assessors tend to be more optimistic than those assigned by the international experts comprising the financial sector assessment program team.

In an attempt to show a simplified picture of the relative positions of national SIPS throughout the region, the authors conceived a risk versus efficiency matrix and grouped those countries for which the combination of risk and efficiency, according to the relative weights given by the authors, produces a similar overall result. The number of countries whose SIPSs fall under each risk-efficiency category is plotted on figure A.1. ${ }^{1}$

${ }^{1}$ In this context, "risk" refers to credit risks being faced by the central bank. In this matrix, the desired stages are those characterized by increased efficiency and diminished risk (that is, the bottom right corner). 
Table A.13 Observance of the Core Principles in the Latin America and the Caribbean Region According to the Self-Assessment Exercise

\begin{tabular}{|c|c|c|c|c|c|c|c|c|c|c|c|c|c|c|}
\hline \multirow{2}{*}{$\begin{array}{l}\text { Level of } \\
\text { Observance }\end{array}$} & \multicolumn{14}{|c|}{ Observance of Each Core Principle and Central Bank Responsibility } \\
\hline & I & II & III & IV & v & VI & VII & VIII & IX & $\mathrm{x}$ & A & B & C & D \\
\hline Observed & $25 \%$ & $55 \%$ & $35 \%$ & $60 \%$ & $35 \%$ & $85 \%$ & $60 \%$ & $42 \%$ & $70 \%$ & $42 \%$ & $50 \%$ & $50 \%$ & $8 \%$ & $75 \%$ \\
\hline Broadly observed & $35 \%$ & $10 \%$ & $20 \%$ & $35 \%$ & $5 \%$ & $15 \%$ & $30 \%$ & $37 \%$ & $15 \%$ & $26 \%$ & $14 \%$ & $14 \%$ & $17 \%$ & $8 \%$ \\
\hline Partially observed & $40 \%$ & $35 \%$ & $30 \%$ & $5 \%$ & $20 \%$ & $0 \%$ & $10 \%$ & $21 \%$ & $15 \%$ & $32 \%$ & $36 \%$ & $36 \%$ & $42 \%$ & $17 \%$ \\
\hline Not observed & $0 \%$ & $0 \%$ & $15 \%$ & $0 \%$ & $10 \%$ & $0 \%$ & $0 \%$ & $0 \%$ & $0 \%$ & $0 \%$ & $0 \%$ & $0 \%$ & $0 \%$ & $0 \%$ \\
\hline Not applicable & $0 \%$ & $0 \%$ & $0 \%$ & $0 \%$ & $30 \%$ & $0 \%$ & $0 \%$ & $0 \%$ & $0 \%$ & $0 \%$ & $0 \%$ & $0 \%$ & $33 \%$ & $0 \%$ \\
\hline Total & 20 & 20 & 20 & 20 & 20 & 20 & 20 & 19 & 20 & 19 & 14 & 14 & 12 & 12 \\
\hline
\end{tabular}

Source: Working Group on Payment System Issues of Latin America and the Caribbean member central banks self-assessment reports.

In figure A.1, countries whose SIPS are located in the upper-left-hand section are generally those in which deferred net settlement systems based on cheques are predominant. Although probably fulfilling, at present, the majority of needs in smaller economies, these systems nevertheless possess significant shortcomings, including the lack of appropriate mechanisms to ensure the timely completion of daily settlements in the event of an inability to settle by one or more participants, and lengthy settlement cycles (one and even two weeks, in some cases).

Countries whose SIPS are more in the center of the spectrum (that is, less risk and more efficiency) have made greater efforts to increase efficiency-for exam-

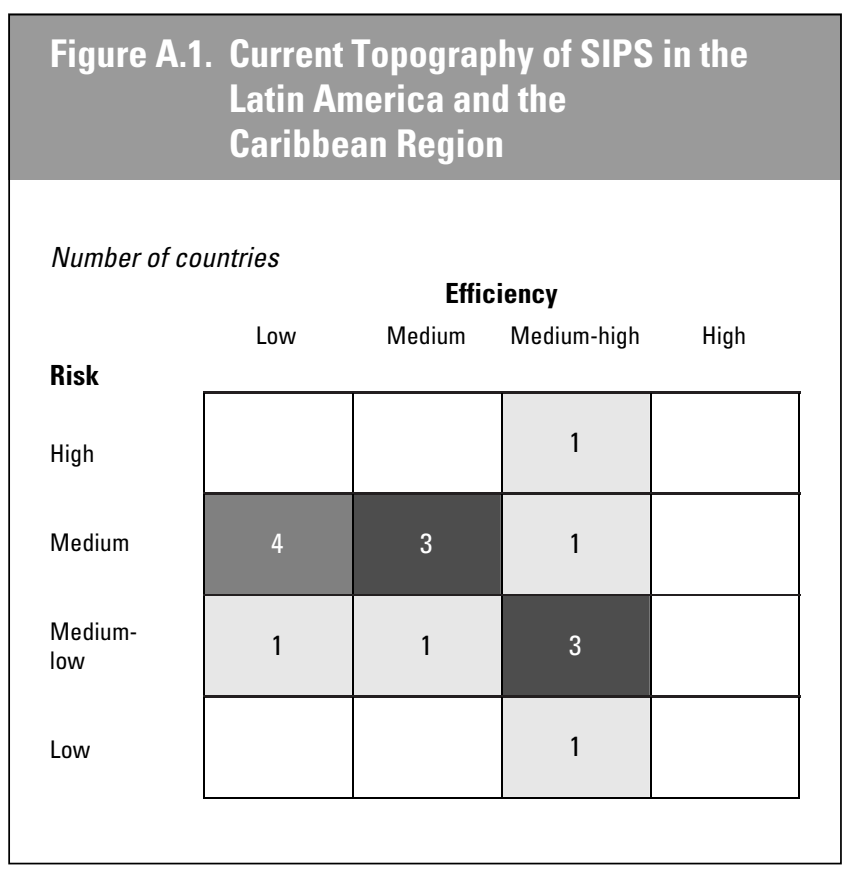

ple, by implementing an early session for large-value cheques, but most important, by introducing RTGS systems for time-critical, large-value payment transactions. This is particularly true for medium-sized economies. In this context, their relative position would move to the right (that is, more efficiency) as they develop efficient intraday liquidity facilities secured with liquid collaterals.

The group of the larger countries shows a significant heterogeneity. In one case, the system may well be considered efficient, but it is characterized by high moral hazard and credit risk for the central bank because it is compelled to ensure settlement finality by authorizing current account overdrafts. Within this group, there is also the case of a deferred net settlement system considered safe, due to the existence of "sound loss sharing guarantees." Finally, there is the case of a remarkably safe and very efficient system, which, in the authors' opinion, may even be seen as a reference point for payment systems worldwide.

\section{REFORM PROCESSES CURRENTLY UNDER WAY}

Along with their self-assessment exercises, the majority of the participating central banks, recognizing the existence of shortcomings in their SIPS and their effort toward achieving compliance with the CPSIPS, provided information on reforms currently under way regarding their SIPS.

In general, the most relevant aspects of the reforms being proposed throughout the LAC region are:

- Enhanced operational efficiency

- Technological upgrades 
- Improved legal framework, including (1) further clarification of the regulatory and oversight roles of the central bank, (2) assurance of settlement finality, and (3) in fewer cases, the protection of netting arrangements.

Therefore, those countries that at present are highly dependent on cheques for large-value interbank payment transactions are moving toward increasing the operational efficiency of the cheque clearinghouse. For this purpose, some are introducing magnetic ink character recognition (MICR) technology to enable the electronic transmission of data that will facilitate the interbank exchange. Some countries are also introducing tools to enable participants to have better control over their balances at the central bank (for example, real-time balances provided over the telephone). Some others are introducing basic, low-cost (including semimanual) RTGS systems.

Nevertheless, it must be stressed that some inefficiencies and risks will persist even after the reforms for the countries located in the upper-left-hand section of the matrix. No major changes are being considered so far in aspects such as prevailing high-reserve requirements and continued risk exposure of the central bank as lender of last resort, which is supposed to guarantee the finality of the cheque clearing arrangements.

In addition, some of these countries have migrated to RTGS systems but their reform processes appear incomplete because they do not seem to have given sufficient consideration to the need for an efficient liquidity provisioning mechanism for such systems, which in turn requires an efficient interface with the securities settlement system (SSS).

Countries at the center of the risk-efficiency spectrum are mainly focusing their efforts in the following aspects:

- Countries in which deferred net settlement is the prevailing SIPS are focusing on improving the soundness of their legal framework, including the clarification of the regulatory and oversight roles of the central bank.

- Countries that already have implemented RTGS systems with no intraday liquidity facilities are focusing on the upgrade of their SSSs in order to achieve effective interoperability between the two, and to reduce liquidity risks and costs.

- Countries that already have RTGS systems with intraday liquidity facilities are paying more attention to increasing the efficiency of their SIPS through, for example, the implementation of algorithms for liquidity optimization (for example, offsetting queues to produce an effect similar to that of hybrid systems), or in providing price incentives to the system's participants to reduce risks and to have the system functioning more smoothly.

Finally, larger countries are focusing their efforts on the approval of a payments system law that, among other features, would give certainty to settlement finality, protect netting arrangements, protect obligations in SIPS from insolvency procedures, clarify the regulatory and oversight powers of the central bank regarding payment systems, and allow for a better allocation of risks among the system's participants and operators. The authors believe that, from the information that was received, these countries will be the first to arrive at the preferred risk-efficiency scenarios.

Figure A.2 shows the new relative positions given by the authors to participating countries, having considered the expected outcomes of the reforms in a period of two years or less. The authors believe that, although some legal risks and other risks for the central bank will persist, the reforms under way will greatly improve the observance with the CPs for most SIPS in the LAC region. Nevertheless, according to the information available, there are reasons to conclude that most of the countries will still face shortcomings in their legal framework and that much more has to be done to improve the risk balance for cheque-based SIPS.

\section{Figure A.2. Possible Risk-Efficiency Topography after Completion of Reforms}

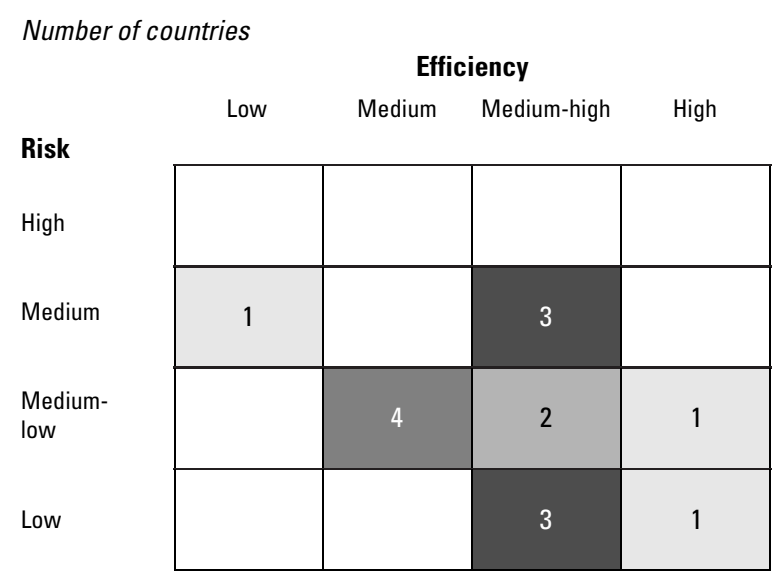





\section{References}

Adams, R. M., P. W. Bauer, and R. C. Sickles. 2004. "Scale Economies, Scope Economies and Technical Change in Federal Reserve Payment Processing." Journal of Money Credit and Banking 36 (5).

Arango, C., and J. Bernal. 2003. Systemically Important Payment Systems in Latin America and the Caribbean: Results of Self-Assessment Exercises. Center for Latin American Monetary Studies-World Bank Payments and Securities Clearance and Settlement Systems Research Series. Mexico City: Center for Latin American Monetary Studies, June.

Balto, D., and J. McAndrews. 1998. "Joint Venture Payment Networks and Public Policy." In Payment Systems in the Global Economy: Risk and Opportunities. Prepared for the 34th Annual Conference on Bank Structure and Competition, Federal Reserve Bank of Chicago, Chicago, May.

Banca d'Italia. 1997. Guiding Principles for the Performance of the Function. White paper on payment system oversight. Rome, May.

1999. Objectives, Methods, Areas of Interest. White paper on payment system oversight. Rome, November.

Bank of England. 2005. Payment System Oversight Report 2004. London, January.

Basel Committee on Banking Supervision. 1999. "Enhancing Corporate Governance in Banking Organizations." Bank for International Settlements, Basel, Switzerland, September.

Bernal, J., and C. Merlano. 2006. Políticas de Sistema de Pagos y Liquidez Intradía en un Sistema de Liquidación Bruta en Tiempo Real: El Caso Colombiano. Center for Latin American Monetary Studies-World Bank Payments and Securities Clearance and Settlement Systems Research Series. Mexico City: Center for Latin American Monetary Studies.
Bhala, R. 1994a. "Legal Foundations of Large-Value Transfer Systems." In The Payment System: Design, Management and Supervision, ed. B J Summers. Washington, DC: International Monetary Fund.

1994b. "Paying for the Deal: An Analysis of Wire Transfer Law and International Financial Market Interest Groups." Kansas Law Review 42 (667), The University of Kansas School of Law, Lawrence, KS.

1995. "Towards a Payments System Law for Developing Countries.” World Bank Discussion Paper 299. World Bank, Washington, DC, September.

BIS (Bank for International Settlements). 1990. Report of the Committee on Interbank Netting Schemes of the Central Banks of the Group of Ten Countries (The Lamfalussy Report). Bank for International Settlements, Basel, Switzerland, November.

1997. "Clearing Arrangements for ExchangeTraded Derivatives." Bank for International Settlements, Basel, Switzerland, March.

1998. "OTC Derivatives: Settlement Procedures and Counterparty Risk Management." Bank for International Settlements, Basel, Switzerland, September.

2000. "Supervisory Guidance for Managing Settlement Risk in Foreign Exchange Transactions." Basel Committee on Banking Supervision, Bank for International Settlements, Basel, Switzerland, September.

Bloomstein, H. J., and B J Summers. 1994. "Banking and Payment Systems." In The Payment System: Design, Management and Supervision, ed. B J Summers. Washington, DC: International Monetary Fund.

Bossone, B. 1998. "A Central Bank Perspective on Reducing FX Settlement Risk, Payment Systems Worldwide." World Bank, Washington, DC. 
Bossone, B., and L. Promisel. 1998. "Strengthening Financial Systems in Developing Countries. The Case for Incentives-Based Financial Sector Reforms." World Bank, Washington, DC.

1999. "The Role of Financial Self-Regulation in Developing Economies." Unpublished paper, World Bank, Washington, DC.

Bossone, B., and M. Cirasino. 2001. The Oversight of Payments Systems: A Framework for the Development and Governance of Payment Systems in Emerging Economies. Center for Latin American Monetary Studies-World Bank Payments and Securities Clearance and Settlement Systems Research Series. Mexico City: Center for Latin American Monetary Studies, July.

Bossone, B., P. Honohan, and M. Long. 2000. "Policy for Small Financial Systems.” World Bank, Washington, DC, May.

Bradford T., M. Davies, and S. Weiner. 2003. Nonbanks in the Payment System. Kansas City, MO: Federal Reserve Bank of Kansas City, November.

Calomiris, C. W., and C. M. Khan. 1996. "The Efficiency of Self-Regulated Payments Systems: Learning from the Suffolk System." Journal of Money, Credit and Banking 28 (4, part 2): 766-97.

CEMLA (Center for Latin American Monetary Studies). 2000. "Payments and Securities Clearance and Settlement in Argentina." Center for Latin American Monetary Studies, Mexico City, August.

Cirasino, M. 2002. "Cooperation within Payment System: Terms of Reference for Payments Council." Western Hemisphere Payments and Securities Clearance and Settlement Initiative Working Paper 4, April. Also available on http://www.forodepagos.org/pdf/wp-04.pdf.

Cirasino, M., and M. Guadamillas. 2000. "The Western Hemisphere Payments and Securities Clearance and Settlement Initiative." Payments System Worldwide (Winter 2000-1). Also available on http://www.forodepagos.org/ pdf/2001/sp-PSWW-ing.pdf.

COSRA (Council of Securities Regulators of the Americas). 1996. "COSRA Principles of Clearance and Settlement." Unpublished paper.

CPSS (Committee on Payment and Settlement Systems). 1992. "Delivery versus Payment in Securities Settlement Systems." Bank for International Settlements, Basel, Switzerland, September.
1995. "Cross-Border Securities Settlements." Bank for International Settlements, Basel, Switzerland, March.

1996a. "Settlement Risk in Foreign Exchange Transactions." Bank for International Settlements, Basel, Switzerland, March.

1996b. "Security of Electronic Money." Bank for International Settlements, Basel, Switzerland, August.

1997a. "Clearing Arrangements for ExchangeTraded Derivatives.” Bank for International Settlements, Basel, Switzerland, March.

1997b. "Real-Time Gross Settlement Systems." Bank for International Settlements, Basel, Switzerland, March.

1998a. "Reducing Foreign Exchange Settlement Risk: A Progress Report by the Committee on Payment and Settlement Systems." Bank for International Settlements, Basel, Switzerland, July.

1998b. "OTC Derivatives, Settlement Procedures and Counterparty Risk Management." Bank for International Settlements, Basel, Switzerland, September.

1999a. "Retail Payments in Selected Countries: A Comparative Study." Bank for International Settlements, Basel, Switzerland, September.

1999b. "Securities Lending Transactions: Market Development and Implications." Bank for International Settlements, Basel, Switzerland, July.

2000a. "Survey of Electronic Money Developments." Bank for International Settlement. Basel, Switzerland, May.

2000b. "The Contribution of Payment Systems to Financial Stability." Paper presented at a workshop on payment systems at Center for Latin American Monetary Studies, Mexico City, May.

2000c. "Clearing and Settlement Arrangements for Retail Payments in Selected Countries." Bank for International Settlements, Basel, Switzerland, September.

. 2001. "Core Principles for Systemically Important Payment Systems." Bank for International Settlements, Basel, Switzerland, January.

2003a. "Policy Issues for Central Banks in Retail Payments.” Bank for International Settlements, Basel, Switzerland, March.

2003b. "The Role of Central Bank Money in Payment Systems." Bank for International Settlements, Basel, Switzerland, August. 
.2003c. "A Glossary of Terms Used in Payments and Settlement Systems." Bank for International Settlements, Basel, Switzerland, March.

2005a. "New Developments in Large-Value Payment Systems." Bank for International Settlements, Basel, Switzerland, April.

2005b. "Central Bank Oversight of Payment and Settlement Systems.” Bank for International Settlements, Basel, Switzerland, April.

2006a. "General Guidance for National Payment System Development." Bank for International Settlements, Basel, Switzerland, January.

2006b. "Cross-Border Collateral Arrangements." Bank for International Settlements, Basel, Switzerland, January.

CPSS-IOSCO (Committee on Payment and Settlement Systems - International Organization of Securities Commissions). 2001. "Recommendations for Securities Settlement Systems." Bank for International Settlements, Basel, Switzerland, November.

2002. "Assessment Methodology for Recommendations for Securities Settlement Systems." Bank for International Settlements, Basel, Switzerland, November.

2004. "Recommendations for Central Counterparties." Bank for International Settlements, Basel, Switzerland, November.

Crawford, B. 2002. Payment, Clearing and Settlement in Canada. Aurora, Ont., Canada: Canada Law Book Inc.

ECB (European Central Bank). 1998. "Assessment of EU Securities Settlement Systems against the Standards for their Use in ESCB Credit Operations." European Central Bank, Frankfurt, September.

1999. "Improving Cross-Border Retail Payment Services in the Euro Area - The Eurosystem's View." European Central Bank, Frankfurt, September.

2000. "Role of the Eurosystem in the Field of Payment Systems Oversight." European Central Bank, Frankfurt, June.

2001. "Toward an Integrated Infrastructure for Credit Transfers in Euro.” European Central Bank, Frankfurt, November.

2003a. "Oversight Standards for Euro Retail Payment Systems." European Central Bank, Frankfurt, June. 2003b. "Toward a Single Euro Payments AreaProgress Report.” European Central Bank, Frankfurt, June.

2004a. "The Use of Central Bank Money for Settling Securities Transactions." European Central Bank, Frankfurt, May.

2004b. "Assessment of Euro Large-Value Payment Systems against the Core Principles." European Central Bank, Frankfurt, May.

2004c. "Standards for Securities Clearing and Settlement in the European Union." European Central Bank, Frankfurt, September.

2004d. "Standards for Securities Clearing and Settlement in the European Union." European Central Bank, Frankfurt, November.

Economides, N., and C. Himmelber. 1995. "Critical Mass and Network Size with Application to the U.S. Fax Market.” Discussion paper EC-95-11, New York University Stern School of Business, New York.

European Parliament. 1998. "Directive 98/26/EC on Settlement Finality in Payment and Securities Settlement Systems." Official Journal L 166, pp. 0045-0050. Brussels, May.

FIBV (International Federation of Stock Exchanges). 1989. "Improving International Settlement." FIBV Secretariat, Paris, June.

1999. "Clearing and Settlement Best Practices." FIBV Secretariat, Paris, September.

Geva, B. 2003. The Law of Electronic Funds Transfers. Toronto: Matthew Bender \& Co.

Godeffroy, J-M. 2001. "The Effects of Consolidation on Payment and Settlement Systems." Report on Consolidation in the Financial Sector. R. W. Ferguson, Jr., Chair, Group of Ten, January.

Good, B. A. 1997. "Electronic Money.” Working Paper 9716, Federal Reserve Bank, Cleveland, August.

Group of Eight (G-8). 2004. "G8 Action Plan: Applying the Power of Entrepreneurship to the Eradication of Poverty." Sea Island, GA, June 9.

Group of Thirty (G-30). 1989. "Group of Thirty Recommendations Regarding Securities Clearance and Settlement." Group of Thirty, Washington, DC.

2003. "Global Clearing and Settlement: A Plan of Action." Group of Thirty, Washington, DC, January. 
Guadamillas, M. 2001. "WHI Methodology for the Assessment of Securities Clearance and Settlement Systems." Western Hemisphere Initiative Working Paper, 2, April. Also available on http://www.forodepagos.org/pdf/2001/ sp-methodology.pdf.

Guadamillas, M., and R. Keppler. 2001. "Securities Clearing and Settlement Systems: A Guide To Best Practices." Policy Research Working Paper 2581, World Bank, Washington DC, April.

Hancock, D., D. B. Humphrey, and J. A. Wilcox. 1999. "Cost Reductions in Electronic Payments: The Roles of Consolidation, Economies of Scale, and Technical Change." Journal of Banking and Finance 23: 391-421.

Heller, S. 2002-3. "The New CHIPS: Intraday Finality: Revolutionary or Evolutionary?" Banking and Finance Law Review 18, Toronto.

Humphrey, D. B. 1995. "Payments Systems: Principles, Practice, and Improvements." World Bank Technical Paper 260, Washington, DC, February.

Humphrey, D. B., and L. Pulley. 1998. "Retail Payments Instruments: Costs, Barriers and Future Use." Paper presented at the 34th Annual Conference on Bank Structure and Competition, "Payment Systems in the Global Economy: Risk and Opportunities." Federal Reserve Bank of Chicago, Chicago, May.

Humphrey, D. B., R. H. Keppler, and F. Montes-Negret. 1997. "Cost Recovery and Pricing of Payment Systems." Policy Research Working Paper 1833, World Bank, Washington, DC, October.

Humphrey, D. B., L. Pulley, and J. Vesala. 1996. "Cash, Paper and Electronic Payments: A Cross-Country Analysis.” Journal of Money, Credit and Banking 28 (4).

Humphrey, D. B., S. Sato, M. Tsurumi, and J. M. Vesala. 1996. "The Evolution of Payments in Europe, Japan, and the United States: Lessons for Emerging Economies." Policy Research Working Paper 1676. World Bank, Washington, DC, October.

IOSCO (International Organization of Securities Commissions). 1990. "Clearing and Settlement." Report of the Technical Committee, IOSCO, Madrid, July.

1992. "Clearing and Settlement in Emerging Markets: A Blueprint." Report of the Development Committee (now called the Emerging Markets Committee), IOSCO, Madrid, October. 1997a. "Short Selling and Securities Lending: Issues for Consideration." A Report by the Emerging Markets Committee, IOSCO, Madrid, May.

1997b. "Toward a Legal Framework for Clearing and Settlement in Emerging Markets.” Report of the Emerging Markets Committee, IOSCO, Madrid, November.

1998. "Objectives and Principles of Securities Regulation.” Report of IOSCO, IOSCO, Madrid, September.

2001. "Recommendations for Securities Settlement Systems." IOSCO, Madrid, November.

ISSA (International Services Securities Association). 1992a. "Report on Cross-Border Trade Comparison." ISSA, Zurich, Switzerland, April.

1992b. "Report on Cross-Border Settlement and Custody." ISSA, Zurich, Switzerland, April.

1992c. "Report on Cross-Border Proxy Voting and Corporate Actions." ISSA, Zurich, Switzerland, April.

1992d. "Report on Global Custody.” ISSA, Zurich, Switzerland, April.

1997. "G-30/ISSA Recommendations: 1997 Status Review.” ISSA, Zurich, Switzerland, November.

. 2000. "Recommendations 2000." ISSA, Zurich, Switzerland, June.

Johnson, O.E.G. 2000. "Verifying Compliance with the Core Principles for Systemically Important Payment Systems." Unpublished paper, International Monetary Fund, Washington, DC.

Kane, E. J. 1987. “Competitive Financial Regulation: An International Perspective." In Threats to International Financial Stability, ed. R. Portes and A. Swoboda. 1994. Cambridge, UK: Cambridge University Press, 111-47.

Kemppainen, K. 2003. "Competition and Regulation in European Retail Payment Systems." Bank of Finland Discussion Paper 16/2003, Helsinki, June.

Keppler, R. H. 1999. "Transforming Payment Systems: The Building Blocks and the World Bank's Role." World Bank-Federal Reserve of New York (FRBNY) Seminar, New York, April 13-16.

Lacker, J. M., and J. A. Weinberg. 1998. "Can the Fed be a Payment System Innovator?” Economic Quarterly (Federal Reserve Bank, Richmond, VA) 84 (2): 1-25. .

Large, A. 2003. "Global Clearing and Settlement: A Plan of Action.” Group of Thirty, Washington, DC. 
Leinonen, H. 2000. "Re-Engineering Payment Systems for the E-World." Bank of Finland Discussion Paper 17/2000, Helsinki, November.

Levahri, D., and D. Patinkin. 1972. "The Role of Money in A Simple Growth Model." In Studies in Monetary Economics, D. Patinkin, ed. New York: Harper \& Row.

Listfield, R., and F. Montes-Negret. 1994. "Modernizing Payment Systems in Emerging Economies." Policy Research Working Paper 1936, Financial Sector Development Department, World Bank, Washington, DC, August.

McAndrews, J. J. 1997. "Banking and Payment System Stability in an Electronic Money World." Working Paper 97-9, Federal Reserve Bank, Philadelphia.

Millard, S., and M. Willison. 2004. "The Welfare Benefits of Stable and Efficient Payment Systems.” Working Paper, Bank of England, London, May.

Montes-Negret, F. 2006. "The Changing Landscape: An Overview of the Forces Pushing for a Rapid Change in Payment Systems.” WHF Paper, July.

Montes-Negret, F., and R. Keppler. 1995. "Project Design for Payment Systems, Public Project for the Private Sector." FPD Note 37, World Bank, Washington, DC, March.

Northcott, C A. 2002. "Estimating Settlement Risk and the Potential for Contagion in Canada's Automated Clearing Settlement System." Bank of Canada Working Paper 2002-41, Ottawa, Canada, December.

O'Connor, S. 2003. "Developments, Issues and Initiatives in Retail Payments." Bank of Canada Review (Autumn).

OECD (Organisation for Economic Co-operation and Development). 1991. "Systemic Risks in Securities Markets." OECD Publication Service, Paris.

Padoa-Schioppa, T. 1992. "La Moneta e il Sistema de Pagamenti.” Banca d'Italia, Rome.

. 1999. "Payments and the Eurosystem." Proceedings from SIBOS Conference, Munich, September 13.

_.2003. "Closing Address." Global Conference on Private and Public Sector Challenges. European Central Bank-Committee on Payment and Settlement Systems, Frankfurt, June 12-13).

Parkinson, P., and J. Stehm. 1992. "Clearance and Settlement in U.S. Securities Markets.” Staff Study 163, Board of Governors of the Federal Reserve System, Washington, DC, March.
Pattinson, R. 2003. "Liquidity Management in a Cross-Border Context." Global Conference on Private and Public Sector Challenges. European Central Bank-Committee on Payment and Settlement Systems, Frankfurt, June 12-13.

Payne, M. 1999. "Risks in Payments Systems." Paper presented at the Thomas Murray Global Custody Conference on Minimizing Risk in Clearing, Payment and Settlement Systems, New York, May 24-25.

Rivlin, A. 1998. "Risks and opportunities in payment systems." In Payment Systems in the Global Economy: Risk and Opportunities. Proceedings of the 34th Annual Conference on Bank Structure and Competition, Federal Reserve Bank of Chicago, Chicago, May.

Ryser, M. 1997. "Sanctions without Law: The Japanese Financial Clearinghouse Guillotine and Its Impact on Default Rates." In Reputation. Studies in the Voluntary Elicitation of Good Conduct, D. B. Kein, ed. Ann Arbor, MI: University of Michigan Press, 225-40.

SEC (U.S. Securities and Exchange Commission). 2002. "Sound Practices to Strengthen the Resilience of the U.S. Financial System." SEC, Washington, DC, August 30. Draft interagency White Paper.

Sendrovic, I. 1994. "Technology and the Payment System." In The Payment System: Design, Management and Supervision, B J Summers, ed. Washington, DC: International Monetary Fund.

Shaffer, S. 1997. "Network Diseconomies and Optimal Structure.” Working Paper 97-19, Federal Reserve Bank, Philadelphia, July.

Snellman, J. 2000. "Evolution of Retail Payments in Finland in the 1990s." Discussion Paper 19/2000, Bank of Finland, Helsinki, December.

Snellman, J., J. Vesala, and D. B. Humphrey. 2000. "Substitution of Noncash Payment Instruments for Cash in Europe." Discussion Paper 1/2000, Bank of Finland, Helsinki, March.

Solomon, E. H. 1997. Virtual Money: Understanding the Power and Risks of Money's High-Speed Journey into Electronic Space. New York: Oxford University Press.

Spindler, J. A., and B J Summers. 1994. "The Central Bank and the Payments System." In The Payment System: Design, Management and Supervision, B J Summers, ed. Washington, DC: International Monetary Fund.

Stehm, J. 1996. "Clearance and Settlement Systems for Securities: Critical Design Choices in Emerging Market 
Economies.” World Bank Discussion Paper 321, Washington, DC, April.

Summers, B J. 1994. "The Payment System in A Market Economy." In The Payment System: Design, Management and Supervision, B J Summers, ed. Washington, DC: International Monetary Fund.

Sundararajan, V., and G. Sensenbrenner. 1994. "Linkages between Payment System Reform and Monetary Policy: The Recent Experience in Russia and Other Former Soviet Union Countries." In Framework for Monetary Stability, ed. T. J. Balino, and C. Cottarelli. Washington, DC: International Monetary Fund.

Tresoldi, C. 2000. "European Retail Payments: A Task for Central Banks?" Kreeditwesen 14 (July).
Van den Bergh, P., and J. M. Veale. 1994. "Payment System Risk and Risk Management." In The Payment System. Design, Management, and Supervision, B J Summers, ed. Washington, DC: International Monetary Fund, 89-105.

Vesala, J. 1998. "Delivery Networks and Pricing Behaviour in Banking: An Empirical Investigation Using Finnish Data." Bank of Finland Discussion Paper 18/98, Helsinki, August.

Weinberg, J. A. 1997. "The Organization of Private Payment Networks." Economic Quarterly (Federal Reserve Bank, Richmond, VA) 83 (2): 25-43.

Whitehill, R. 1999. "Evaluating Local Market Custody Arrangements." Presented at the Thomas Murray Global Custody Conference on Minimizing Risk in Clearing, Payment, and Settlement Systems, New York, May 24-25. 
Argentina

clearing and settlement processes, 136

cross-border payments, 94

CSDs' organizational arrangements, 174

custody arrangements, 159

FX transactions, 94

government payments and collections, 85

interbank money market, 99

legal issues, 28-29

LVPS

features, 46

operational risk management, 60

pricing policies, 63

oversight and cooperative arrangements, 188

retail settlement systems, 67-68

risk management tools and settlement asset, 144

securities

dematerialization and immobilization, 141

depositories, links between, 182

market, 106

SSSs, 114

legal issues, 124

operational issues, 151

regulatory and oversight issues, 166

Asociación Latinoamericana de Integración, 93

assessment, SSSs

counterparts, 24

criteria, 23

expert, 23

methodology, 24-25

obstacles, 24

preparation, 23-24

process, 22-23

tools, 21-26

ATMs and cash dispensers, 84, 226-227

automated clearing houses (ACHs),

83-84, 85
The Bahamas

clearing and settlement processes, 136

cross-border payments, 94

CSDs' organizational arrangements, 174

custody arrangements, 159

FX transactions, 94

government payments and collections, 85

legal issues, 29

LVPS features, 46

oversight and cooperative arrangements, 188

retail settlement systems, 68

risk management tools and settlement asset, 144

securities

dematerialization and immobilization, 141

depositories, links between, 182

market, 106

SSSs, 114

legal issues, 124

operational issues, 151

regulatory and oversight issues, 166

banknotes and coins in circulation,

$$
\text { 223-224 }
$$

Bolivia

clearing and settlement processes, 136

cross-border payments, 94

CSDs' organizational arrangements, 174

custody arrangements, 159

FX transactions, 94

government payments and collections, 86

legal issues, 29-30

LVPS features, 47

oversight and cooperative arrangements, 189

retail settlement systems, 68-69
Index

risk management tools and settlement asset, 144

securities

dematerialization and immobilization, 141

depositories, links between, 182

market, 106

SSSs, 114-115

legal issues, 124

operational issues, 151

regulatory and oversight issues, 166

Brazil

clearing and settlement processes, 136

cross-border payments, 94

CSDs' organizational arrangements,

174-176

custody arrangements, 159

FX transactions, 94

government payments and collections, 86

interbank money market, 99

legal issues, 30-31

LVPS

features, $47-48$

operational risk management, 60

pricing policies, 63

oversight and cooperative arrangements, 189-190

retail settlement systems, 69-70

risk management tools and settlement asset, 144-145

securities

dematerialization and immobilization, 141

depositories, links between, 182

market, 107

SSSs, 115

legal issues, 124-125

operational issues, 151-152

regulatory and oversight issues, 166

broker-dealers, 149, 241 
capital, demand and supply, 17

Caribbean Common Market, 93

cash, 7

banknotes and coins in circulation, 223-224

money settlements, CCP, 251

payments, 11

cashless payment instruments, indicators of use, 227-230

central banks, 22, 98, 217

internal organization, 186

money, 7

oversight function, 18-19, 202, 218, 219

responsibilities, 18-19

role/function, 148-149, 186, 215

central counterparties (CCPs), 249

CPSS-IOSCO recommendations, 15-16, 25-26, 251-252

risk, 139,252

trades, 139

central securities depositories (CSDs), 210, 241, 249, 250

context, 173

cross-border links, 181

cross-border trade, 250

observations, 173, 181

SSSs, 173-181

status in the regions, 173, 174-180

cheques

clearinghouse, 216

settlements, 64, 147

use, 83

Chile

clearing and settlement processes, 136

cross-border payments, 94

CSDs' organizational arrangements, 176

custody arrangements, 159-160

FX transactions, 94

government payments and collections, 86

interbank money market, 99

legal issues, 31

LVPS

features, 48-49

pricing policies, 63

oversight and cooperative arrangements, 190-191

retail settlement systems, 70-71

risk management tools and settlement asset, 145

securities

dematerialization and immobilization, 141

depositories, links between, 182

market, 107

SSSs, 115-116

legal issues, 125

operational issues, 152

regulatory and oversight issues, 166

clearing and settlement, 17

context, 134-135 infrastructure, 17-18

key issues, 18

observations, 135, 138-139

processes, 134-139

status in the region, 135-138

"Clearing and Settlement Best Practices Report," 14

Colombia

clearing and settlement processes, 136

cross-border payments, 95

CSDs' organizational arrangements, 176-177

custody arrangements, 160

FX transactions, 95

government payments and collections, 86

interbank money market, 100

legal issues, 31-32

LVPS

features, 49-50

operational risk management, 60

pricing policies, 63

oversight and cooperative arrangements, 191

retail settlement systems, 71

risk management tools and settlement asset, 145

securities

dematerialization and immobilization, 141

depositories, links between, 182

market, 107-108

SSSs, 116

legal issues, 125-126

operational issues, 152-153

regulatory and oversight issues, 166-167

Committee of Wise Men, 16

Committee on Payment and Settlement

Systems (CPSS), vii, 261

core principles, 22, 64, 247

guidance for NPS development, 253

integrated approach, 5-7

remittance services, 92-93

Committee on Payment and Settlement Systems-International Organization of Securities Commissions

(CPSS-IOSCO) recommendations, 249-250

central counterparties, 25-26, 251-252

clearing and settlement processes, 134

SSSs, 24, 149

concentration risk, 149

consumers. See customers

Continuous Link Settlement Bank (CLS

Bank), 6, 11-12

correspondent bank, 241

Costa Rica

clearing and settlement processes, 136

cross-border payments, 95

CSDs' organizational arrangements, 177 custody arrangements, 160

FX transactions, 95

government payments and collections, 86

interbank money market, 100

legal issues, 32-33

LVPS

features, 50

operational risk management, 60

oversight and cooperative arrangements, 192

retail settlement systems, 71-72

risk management tools and settlement asset, 145

securities

dematerialization and immobilization, 141

depositories, links between, 182

market, 108

SSSs, 117

legal issues, 126

operational issues, 153-154

regulatory and oversight issues, 167

counterparties. See central counterparties

credit, 16

exposures, CCP, 251

risk, 139, 249

cross-border settlement and transactions,

$$
\text { 11-12, 181-184 }
$$

categories, 11

clearing and settlement barriers, 16

context, 181

CSDs and, 250

observations, 181

payments, 6,93

status in the region, 181, 182-184

custodians, 133, 158, 241, 249

custody risk, SSSs, 157-158

CCP, 251

context, 157-158

observations, 158

status in the region, 158, 159-165

customers

assets, bankruptcy and, 218

identification, 256

message flows, from and to domestic users, 237

needs, 84-85

securities services, 16

Declaration of Nuevo León, 8

default procedures, CCP, 251

deferred net settlement systems, 6

delivery vs. payment (DvP), 139, 140, 147, 218

dematerialization and immobilization, securities, 140, 149

development priorities, PSSSs, 207

digital signatures, 123

see also electronic technologies

disaster preparedness, 9 
Dominican Republic

clearing and settlement processes, 137

cross-border payments, 95

CSDs' organizational arrangements, 177

custody arrangements, 160

FX transactions, 95

government payments and collections, 87

interbank money market, 100

legal issues, 33

LVPS features, 50

oversight and cooperative arrangements, 192-193

retail settlement systems, 72-73

risk management tools and settlement asset, 145

securities

dematerialization and immobilization, 142

depositories, links between, 182

market, 108

SSSs, 117

legal issues, 126

operational issues, 154

regulatory and oversight issues, 167

Ecuador

clearing and settlement processes, 137

cross-border payments, 95

CSDs' organizational arrangements, 177

custody arrangements, 160

FX transactions, 95

government payments and collections, 87

interbank money market, 100

legal issues, 33-34

LVPS features, 51

oversight and cooperative arrangements, 193

retail settlement systems, 73

risk management tools and settlement asset, 145-146

securities

dematerialization and immobilization, 142

depositories, links between, 182

market, 108-109

SSSs, 117

legal issues, 126-127

operational issues, 154

regulatory and oversight issues, 167

El Salvador

clearing and settlement processes, 137

cross-border payments, 95

CSDs' organizational arrangements, $177-178$

custody arrangements, 161

FX transactions, 95 government payments and collections,

87

interbank money market, 100

legal issues, 34-35

LVPS

features, 51

pricing policies, 63

oversight and cooperative arrangements, 193-194

retail settlement systems, 74

risk management tools and settlement asset, 146

securities

dematerialization and immobilization, 142

depositories, links between, 182

market, 109

SSSs, 117

legal issues, 127

operational issues, 154

regulatory and oversight issues, 168

electronic technologies, 158, 240

communication networks, 12

digital signatures, 45, 123

documents, 45

payment, 84,216

systems, 2

Emerging Markets Committee, 14

financial systems

diligence, 256-257

market liberalization, 2

money laundering, combating, 256

payment system and, vii

resources, CCP, 251

sophistication, PSSSs, 207

Financial Stability Forum, 14

fraud, reduction, 158

funds transfer systems, 2

features, 232-233

interbank, 231

operating hours, 234

fungible securities, 140, 147

FX transactions, 11-12, 91-98

context, 91-92

by country, 94-97

observations, 98

wholesale, 98

Giovannini Group, 16

Global Equity Market, 12

globalization, SSSs and, 16-18

governance, 250

CCP, 252

CSDs, 173,181

remittance systems, 93

government payments, 85-91

context, 85 observations, 90-91

status in the region, 85-90

Guatemala

clearing and settlement processes, 137

cross-border payments, 95

CSDs' organizational arrangements, 178

custody arrangements, 161

FX transactions, 95

government payments and collections, 87

interbank money market, 100

legal issues, 35

LVPS

features, 51-52

operational risk management, 60

oversight and cooperative arrangements, 194

retail settlement systems, 74-75

risk management tools and settlement asset, 146

securities

dematerialization and immobilization, 142

depositories, links between, 182

market, 109

SSSs, 117-118

legal issues, 127

operational issues, 154

regulatory and oversight issues, 168

Honduras

clearing and settlement processes, 137

cross-border payments, 96

CSDs' organizational arrangements, 178

custody arrangements, 161

FX transactions, 96

government payments and collections, 88

legal issues, 35-36

LVPS features, 52

oversight and cooperative arrangements, 194

retail settlement systems, 75-76

risk management tools and settlement asset, 146

securities

dematerialization and immobilization, 142

depositories, links between, 182

market, 109

SSSs, 118

legal issues, 127

operational issues, 154

regulatory and oversight issues, 168

infrastructure

economic development and, 1

PSSSs, 207 
infrastructure (continued) retail settlement systems, 67

securities settlement, 218

interbank money market, 98-103, 217

context, 98-99

observations, 102-103

PSSSs, 207

status in the region, 99-102

interbank payment obligations, 2

International Monetary Fund-World Bank, core principles for SIPS, 22-23

International Organization of Securities Commissions (IOSCO), 13, 14

CPSS-IOSCO recommendations, 15-16, 25-26, 251-252

International Securities Services Association, 13-14

International Standards for Securities Settlement Systems, evolution of, 15

intervention trigger, 44

Jamaica

clearing and settlement processes, 137

cross-border payments, 96

CSDs' organizational arrangements, 178

custody arrangements, 161

FX transactions, 96

government payments and collections, 88

interbank money market, 100

legal issues, 36

LVPS

features, 53

operational risk management, 61

oversight and cooperative arrangements, 195

retail settlement systems, 76

risk management tools and settlement asset, 146

securities

dematerialization and immobilization, 142

depositories, links between, 182

market, 110

SSSs, 118

legal issues, 128

operational issues, 154

regulatory and oversight issues, 168

knowledge base, increasing, PSSSs, 208

Lamfalussy Recommendations, vii, 14

large-value payment systems (LVPs), 6-7, 45-65, 217

context, 45

interbank money market, 102-103

observations, 64-65 operational risk management, 60-62, 65

pricing policies, 63-64

status in the region, 45-59

legal and regulatory framework, 28-43, 215-216

context, 113, 123

by country, $28-43,124-132$

CSDs, 181

custody risk, 158

definitions, 132

enforceability, 134

issues, 44-45

money laundering, combating, 255

observations, 44-45, 132-134

PSSSs, 206-207

remittance systems, 93

retail payment systems, 66

risk, CCP, 251

SSSs, 115-134

updating, 134

liquidity, 10, 12

clearing and settlement processes, 135

constraints, 148

interbank money market, 102

PSSSs, 207

risk, 249

margin requirements, $\mathrm{CCP}, 251$

markets

infrastructure, 10

investors, clearing and settlement processes, 134

performance, 66

remittance systems, 93

securities, 106-113

SSSs and, 16-18

Mexico

clearing and settlement processes, 137

cross-border payments, 96

CSDs' organizational arrangements, 178-179

custody arrangements, 161-162

FX transactions, 96

government payments and collections, 88

interbank money market, 101

legal issues, 36-37

LVPS

features, 53-54

operational risk management, 61

pricing policies, 63

oversight and cooperative arrangements, 195-196

retail settlement systems, 76-77

risk management tools and settlement asset, 146

securities

dematerialization and immobilization, 142 depositories, links between, 182-183

market, 110

SSSs, 118-119

legal issues, 128

operational issues, 154

regulatory and oversight issues, 168-169

migrant workers, remittances, 8-9

monetary policy, vii, 2, 207

money laundering, 10, 217

international cooperation, 258-259

measures to avoid, 257

problem countries, 257

provisional measures and confiscation, 255

recommendations of the Financial Action Task Force, 255-259

regulatory and administrative authorities' roles, 258

scope, 255

money settlements, CCP, 251

national payment systems (NPS), 2-3, 208-210, 219-220

CPSS guidance for development, 253 principles, 209

National Payments and Securities Settlement Council (NPSSC), 211-212

Netherlands Antilles clearing and settlement processes, 137 cross-border payments, 96

CSDs' organizational arrangements, 179 custody arrangements, 163

FX transactions, 96

government payments and collections, 88

interbank money market, 101

legal issues, 37-38

LVPS

features, 54-55

operational risk management, 61

pricing policies, 63

oversight and cooperative arrangements, 196-197

retail settlement systems, 77-78

risk management tools and settlement asset, 146

securities

dematerialization and immobilization, 143

depositories, links between, 183

market, 110

SSSs, 119

legal issues, 128-129

operational issues, 155

regulatory and oversight issues, 170

Nicaragua

clearing and settlement processes, 137

cross-border payments, 96 
CSDs' organizational arrangements, 179 custody arrangements, 163

FX transactions, 96

government payments and collections, 88

interbank money market, 101

legal issues, 38

LVPS

features, 55

operational risk management, 61

pricing policies, 63

oversight and cooperative arrangements, 197

retail settlement systems, 78

risk management tools and settlement asset, 146

securities

dematerialization and immobilization, 143

depositories, links between, 183

market, 110-111

SSSs, 119

legal issues, 129

operational issues, 155

regulatory and oversight issues, 170

"Objectives and Principles of Securities Regulation," 14

operational issues, SSSs, 149-157

context, 149-150

observations, 150,157

status of the region, $150,151-157$

operational risk, 10, 249

CCP, 251

Organization of Eastern Caribbean States (OECS)

clearing and settlement processes, 137

cross-border payments, 96

CSDs' organizational arrangements, 179

custody arrangements, 163

FX transactions, 96

government payments and collections, 89

legal issues, 38-39

LVPS

features, 56

operational risk management, 61

pricing policies, 63

oversight and cooperative arrangements, 197

retail settlement systems, 78-79

risk management tools and settlement asset, 146

securities

dematerialization and immobilization, 143

depositories, links between, 183

market, 111

SSSs, 120 legal issues, 129

operational issues, 155

regulatory and oversight issues, $170-171$

oversight, 18-19, 44, 165, 173, 185,

186-203, 218, 219, 250

CCP, 252

central bank's role, 186

legal foundation, 201

over-the-counter markets, 138, 210, 241

Panama

clearing and settlement processes, 137

cross-border payments, 97

CSDs' organizational arrangements, 179

custody arrangements, 163

FX transactions, 97

government payments and collections, 89

interbank money market, 101

legal issues, 39-40

LVPS features, 56

oversight and cooperative arrangements, 198

retail settlement systems, 79

risk management tools and settlement asset, 146

securities

dematerialization and immobilization, 143

depositories, links between, 183

market, 111

SSSs, 120

legal issues, 129

operational issues, 155

regulatory and oversight issues, 171

Paraguay

clearing and settlement processes, 137

cross-border payments, 97

CSDs' organizational arrangements, 179

custody arrangements, 163

FX transactions, 97

government payments and collections, 89

legal issues, 40

LVPS features, 57

oversight and cooperative arrangements, 198

retail settlement systems, 79-80

risk management tools and settlement asset, 146

securities

dematerialization and immobilization, 143

depositories, links between, 183

market, 111-112

SSSs, 120

legal issues, 130

operational issues, 155 regulatory and oversight issues, 171

participation requirements, $\mathrm{CCP}, 251$

payments

cards, 225

circuits, 84

cross-border nature, 11

media, deposit-taking entities, 225

payment settlement systems (PSSs), 13

payment systems, 1, 2

1970s and 1980s, vii

assessment, 27-103

country assessments and date, 27

infrastructure, remittance systems, 92

objectives, 201-202

reform, pillars of, 212

scope, 5

systemically important, 261-263

payments and securities settlement systems

(PSSSs) reforms

action plan, 212-213

assessment, 205-208

implementing, 205-213

institutional roles, 210

NPS role, 208-210

pillars of reform, 212

private sector, engaging, 211-212

statistics, 221-237

Peru

clearing and settlement processes, 137

cross-border payments, 97

CSDs' organizational arrangements, $179-180$

custody arrangements, 163

FX transactions, 97

government payments and collections, 89

interbank money market, 101

legal issues, 41

LVPS

features, $57-58$

operational risk management, 62

pricing policies, 63

oversight and cooperative arrangements, 198-199

retail settlement systems, $80-81$

risk management tools and settlement asset, 146

securities

dematerialization and immobilization, 143

depositories, links between, 183

market, 112

SSSs, 121

legal issues, 130

operational issues, 155-156

regulatory and oversight issues, 171

physical delivers, CCP, 251

prime savers, 17,18

public policy goals, retail payment sys-

tems, 66-67 
public sector

institutions, 216-217

payment systems and, 90-91

real-time gross settlements (RTGS), 6, 14, $64-65,140,216$

interbank money market, 103

SSSs, 132

recordkeeping rules, 256

reforms, 219-220

currently under way, 262-263

possible risk-efficiency topography after completion, 263

regulatory and oversight issues

agencies, securities, 165

authorities, NPS, 210

response, 10

SSSs, 98, 158-173

context, 158, 165

observations, 165,173

status in the region, 165, 166-172

remittances, 217

growing flows, 8-9

specialized institutions, 98

remittance services

costs, 8

CPSS principles, 92-93

international policy coordination, 9

providers, role, 93

task force on, 9

repo, definition, 133

retail cross-border payments, 91, 216, 217

retail payment instruments and services, 84 unclear directions, 7

retail settlement systems

context, 65-66

legal and regulatory framework, 66

observations, 83-85

standards and infrastructure, 66-67

status in the region, 67-83

risk, 44

CCP, 251

concentration, 149

operational, 10, 249

settlement, 139-149

risk management, 93, 147, 249

clearing and settlement processes, 135

cross-border payments, 98

FX transactions, 98

securities

automatic lending and borrowing facilities, 138

dematerialization and immobilization, 149,158

lending and borrowing, 133, 138-139, 249

ownership transfer, finality, 140 regulators, role, 165

services value chain, 17

securities clearance and settlement sys-

tems, 1, 2, 239

participants, $240-241$

procedures, 239-240, 241-242, 243

securities depositories, 140, 147, 148-149, 218

cross-border links, 218

securities markets, 106-113

by country, 106-113

confirmation of trades, 135

interbank money market, 103

laws, 132

mature and liquid, 135

securities settlement systems (SSSs),

13-14, 14-15, 105-184, 217

assessment methodology, 24-25

clearing and settlement process, 134-139, 217-218

by country, 114-123

country assessments and date, 105

CPSS-IOSC recommendations, 24

cross-border settlement, 181-184

CSDs' organizational arrangements, 173-181

custody risk, 157-158

features, 235-236

infrastructure, 157

integration, 148

legal issues, 113-134

market infrastructure, globalization and, $16-18$

operational issues, 149-157

regulatory and oversight issues, 158-173

scope, elements, participants, and processes, 239-246

settlement risk, 139-149

settlement

agent, 241

arrangements, 14

final, 249

finality, concept of, 44, 45

obligations, calculation, 242-245

procedure, 138

rolling, 249

systems

gross, 245

net, 245-246

operational reliability, resilience, and integrity, 9-10

settlement risk, SSSs, 139-149

context, 139-140

observations, 140, 147-149

status in the region, 140, 141-147

short-selling, 149

signatures, digital, 123

Single European Payment Area, 12

standards, vii, 240, 250 clearing and settlement processes, 134

international, 13-14, 15

retail settlement systems, 66-67

settlement cycle, 135, 138

system operators, 173

stock exchanges, clearing and settlement processes, 135,138

SWIFT message flows, from and to domestic users, 237

systematically important payment systems (SIPS)

core principles, 22-23

self-assessment and, 261, 262, 263

trade

affirmation, 245

clearance, 242, 243-244

clearing and settlement processes and, 134-135

comparison, 245

confirmation, 245, 249

execution phase, 242, 243

matching, 134-135

settlement, 244

Trans-European Automated Real-Time Gross Settlement Express Transfer System 2 (TARGET 2), 12

transparency, 218-219, 250

arrangements, 188-201

CCP, 252

observations, 201-203

oversight and cooperation, 185-204

remittance systems, 92

Trinidad and Tobago

clearing and settlement processes, 137

cross-border payments, 97

CSDs' organizational arrangements, 180 custody arrangements, 163-164

FX transactions, 97

government payments and collections, 89

interbank money market, 101-102

legal issues, 41-42

LVPS

features, 58

operational risk management, 62

pricing policies, 64

oversight and cooperative arrangements, 199-200

retail settlement systems, 81

risk management tools and settlement asset, 146

securities

dematerialization and immobilization, 143

depositories, links between, 183-184

market, 112

SSSs, 121-122

legal issues, 130-131 
operational issues, 156

regulatory and oversight issues,

171-172

\section{Uruguay}

clearing and settlement processes, 138

cross-border payments, 97

CSDs' organizational arrangements, 180

custody arrangements, 164

FX transactions, 97

government payments and collections, 90

interbank money market, 102

legal issues, 42

LVPS

features, 58-59

operational risk management, 62

pricing policies, 64

oversight and cooperative arrangements,

$$
200
$$

retail settlement systems, 82

risk management tools and settlement asset, 147

securities dematerialization and immobilization, 143

depositories, links between, 184

market, 112-113

SSSs, 122

legal issues, 131

operational issues, 156

regulatory and oversight issues, 172

Venezuela, R.B. de

clearing and settlement processes, 138

cross-border payments, 97

CSDs' organizational arrangements, 180

custody arrangements, 164-165

FX transactions, 97

government payments and collections, 90

interbank money market, 102

legal issues, 43

LVPS

features, 59

operational risk management, 62

pricing policies, 64

oversight and cooperative arrangements, 201 retail settlement systems, $82-83$

risk management tools and settlement asset, 147

securities

dematerialization and immobilization, 143

depositories, links between, 184

market, 113

SSSs, 122-123

legal issues, 131-132

operational issues, 156-157

regulatory and oversight issues, 172

Western Hemisphere Payments and Securities Clearance and Settlement Forum (WHF), vii, 3, 4

assessments, vii

Western Hemisphere Payments and Securities Clearance and Settlement Initiative (WHI), vii, 3, 4, 21

assessments, vii

"Yellow Books," 21 




\section{Eco-Audit}

\section{Environmental Benefits Statement}

The World Bank is committed to preserving Endangered Forests and natural resources. The Office of the Publisher has chosen to print Reforming Payments and Securities Settlement Systems in Latin America and the Caribbean on 30 percent postconsumer recycled paper, processed chlorine free. The World Bank has formally agreed to follow the recommended standards for paper usage set by Green Press Initiative - a nonprofit program supporting publishers in using fiber that is not sourced from Endangered Forests. For more information, visit www.greenpressinitiative.org.

The printing of this book on recycled paper saved the following:

\begin{tabular}{|c|c|c|c|c|}
\hline Trees* & Solid Waste & Waste Water & Net Greenhouse Gases & Energy \\
\hline 12 & 570 & 4,436 & 1,069 & 8 \\
\hline $\begin{array}{l}\text { "404" in height and } \\
6-8)^{\circ \text { i n diameter }}\end{array}$ & Pounds & Gallons & Pounds & BTU \\
\hline
\end{tabular}




safe and effective functioning of a financial system. In Latin America and the Caribbean, efforts to raise the awareness of the importance of modernizing national payments systems were formalized through the 1999 Western Hemisphere Payments and Securities Clearance and Settlement Initiative (WHI).

Reforming Payments and Securities Settlement Systems in Latin America and the Caribbean extracts the main lessons and experiences of the WHI, describing trends in payments and securities settlement systems worldwide and assessing Latin American and Caribbean systems in relation to international standards and best practices. Assessments cover legal and regulatory frameworks, interbank exchange and settlement circuits, retail settlement systems, government payments, foreign exchange and cross-border settlement, the interbank money market, securities settlement systems, and the oversight role of the central bank and its coordination with other authorities and the private sector. 